INSTITUTO DE PESQUISAS ENERGÉTICAS E NUCLEARES

Autarquia associada à Universidade de São Paulo

\title{
DESENVOLVIMENTO DE UMA TÉCNICA DE MEDIDA DE NÍVEL EM VASOS DE PRESSÃO UTILIZANDO SONDAS TÉRMICAS E REDES NEURAIS ARTIFICIAIS
}

WALMIR MAXIMO TORRES

Tese apresentada como parte dos requisitos para obtenção do grau de Doutor em Ciências na Área de Tecnologia Nuclear - Reatores.

Orientador:

Prof. Dr. Benedito Dias Baptista Filho 
Aos meus saudosos e queridos pais, João e Irene, pelo amor, carinho, empenho $\mathrm{e}$ incentivo dedicados à minha formação, e com quem tanto aprendi. À minha esposa Sílvia e meus filhos, Paula e Pedro, pelo amor, carinho e compreensão. 


\section{AGRADECIMENTOS}

Ao Prof. Dr. Benedito Dias Baptista Filho, pela amizade, incentivo e orientação no desenvolvimento deste trabalho.

Ao Conselho Nacional de Desenvolvimento Científico e Tecnológico CNPq pelo apoio financeiro na construção do aparato experimental.

Ao Instituto de Pesquisas Energéticas e Nucleares - IPEN - CNEN/SP pela oportunidade a mim concedida para o desenvolvimento deste trabalho e também pelo apoio ao desenvolvimento científico nacional.

Ao Centro de Engenharia Nuclear - CEN do IPEN-CNEN/SP, nas pessoas, do gerente do centro Prof. Dr. Antonio Teixeira e Silva, e dos gerentes adjuntos Dr. Arivaldo Vicente Gomes e Prof. Dr. Miguel Mattar Neto, pelo incentivo e apoio financeiro.

Aos Professores Dr. José Roberto Simões Moreira, Dr. Jorge Luis Baliño, Dr.Linilson Rodrigues Padovese, Dr. Antonio Carlos de Oliveira Barroso, Dr. Roberto Navarro de Mesquita e Dra. Iraci Martinez Gonçalves Pereira por terem aceitado o convite para a composição da banca examinadora.

Aos meus amigos Luiz Alberto Macedo, Delvonei Alves de Andrade, Pedro Ernesto Umbehaun e Gaianê Sabundjian pelo companheirismo, amizade, sugestões e incentivos constantes.

Aos colegas Orlando Nogueira da Silva pelos serviços de projetista e desenhista; e a Antonio Murilo dos Santos e Thiago Fernando dos Santos, pelos serviços de construção e montagem do aparato experimental. A Antonio Rodrigues de Lima e Marcos Afonso Bissa pelos serviços prestados. Aos colegas Adilson Aboláfio e José Carlos de Almeida pela colaboração na calibração dos instrumentos. A Alfredo José Alvim de Castro pela contribuição na elaboração do programa para aquisição de dados. A Gelson Toshio Otani pela colaboração na área de informática; e a todos aqueles que, de alguma forma, contribuíram para a realização deste trabalho. 


\title{
DESENVOLVIMENTO DE UMA TÉCNICA DE MEDIDA DE NÍVEL EM VASOS DE PRESSÃO UTILIZANDO SONDAS TÉRMICAS E REDES NEURAIS ARTIFICIAIS
}

\author{
Walmir Maximo Torres
}

\begin{abstract}
RESUMO
Foi desenvolvida uma técnica de medida de nível em vasos de pressão usando sondas térmicas resfriadas internamente por um fluido e análise dos dados experimentais com Redes Neurais Artificiais (RNA's). Esse novo conceito de sondas térmicas foi testado em uma Bancada Experimental para Testes de Sondas de Nível (BETSNI) com duas seções de testes, ST1 e ST2. Dois projetos distintos de sondas foram construídos: Sonda de Tubos Concêntricos e Sonda de Tubo U. Um Sistema de Aquisição de Dados (SAD) foi montado para registrar os dados experimentais. Testes foram realizados tanto para condições de nível nas seções de testes em estado estacionário quanto para transientes. Os dados experimentais de temperatura e de nível obtidos foram usados para compor tabelas de treinamento e de verificação usadas para implementar RNA's no programa RETRO-05, que simula um Perceptron de Múltiplas Camadas com Retropropagação. As análises mostraram que a técnica pode ser aplicada para medir o nível em vasos de pressão. As análises mostraram ainda que a técnica é aplicável para um número menor de entradas de temperatura que o inicialmente previsto no projeto das sondas e é robusta, aplicando-se mesmo quando ocorre a perda de alguma informação de temperatura. Dados experimentais disponíveis na literatura referentes a uma sonda térmica aquecida eletricamente também foram usados nas análises com RNA's, produzindo bons resultados. Os resultados das análises indicaram que a técnica é eficaz e robusta, podendo ser aprimorada e aplicada para medidas de nível em vasos de pressão.
\end{abstract}




\title{
DEVELOPMENT OF A TECHNIQUE FOR LEVEL MEASUREMENT IN PRESSURE VESSELS USING THERMAL PROBES AND ARTIFICIAL NEURAL NETWORKS
}

\author{
Walmir Maximo Torres
}

\begin{abstract}
A technique for level measurement in pressure vessels was developed using thermal probes with internal cooling and Artificial Neural Networks (ANN's). This new concept of thermal probes was experimentally tested in an Experimental Facility (BETSNI) with two test sections, ST1 and ST2. Two different thermal probes were designed and constructed: Concentric Tubes Probe and U Tube Probe. A Data Acquisition System (DAS) was assembled to record the experimental data during the tests. Steady state and transient level tests were carried out and the experimental data obtained were used as learning and recall data sets in the ANN's program RETRO-05 that simulate a Multilayer Perceptron with Backpropagation. The results of the analysis show that the technique can be applied for level measurements in pressure vessel. The technique is applied for a less input temperature data than the initially designed to the probes. The technique is robust and can be used in case of lack of some temperature data. Experimental data available in literature from electrically heated thermal probe were also used in the ANN's analysis producing good results. The results of the ANN's analysis show that the technique can be improved and applied to level measurements in pressure vessels.
\end{abstract}




\section{SUMÁRIO}

\section{Página}

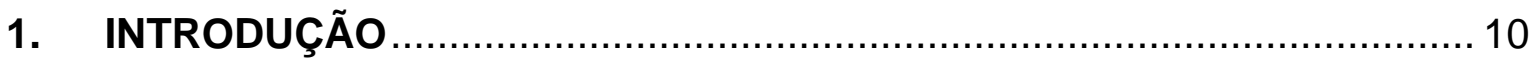

1.1 A retomada mundial da energia nuclear ........................................ 10

1.2 Reatores nucleares avançados e de IV geração ................................ 13

1.3 O acidente de Three Mile Island .................................................... 17

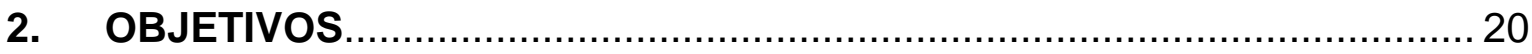

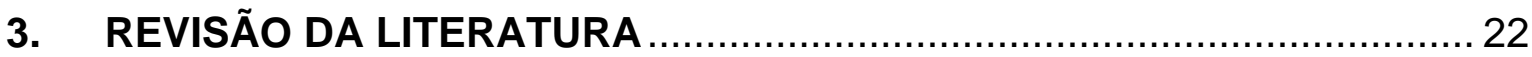

3.1 Sondas de Nível Ultra-Sônicas ....................................................... 24

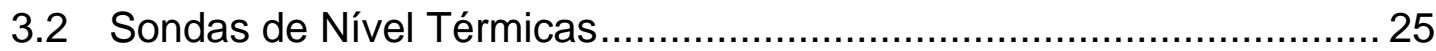

3.3 Outras Sondas de Nível e Técnicas de Medida.................................. 28

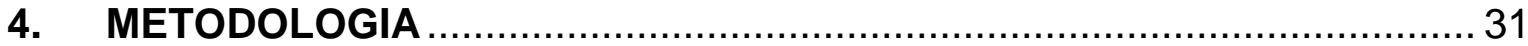

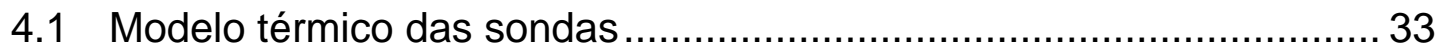

4.2 Bancada Experimental para Testes de Sondas de Nível (BETSNI) .... 35

4.3 Sondas Térmicas de Medida de Nível .............................................. 40

4.3.1 Sonda de Tubos Concêntricos................................................40

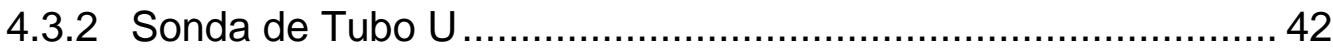

4.3.3 Cálculo do tempo de trânsito do fluido de resfriamento

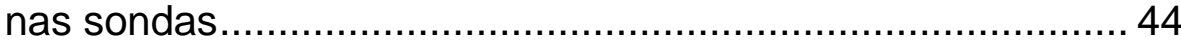

4.4 Calibração dos Instrumentos ......................................................... 46

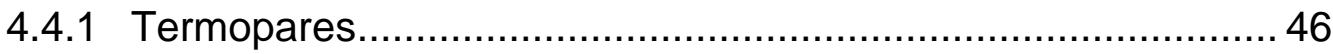


4.4.2 Transmissores de Pressão Diferencial ................................... 48

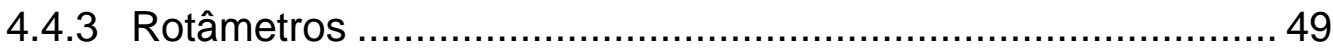

4.5 Sistema de aquisição de dados (SAD) e programação LabView 7 ......50

4.6 Redes Neurais Artificiais - RNA's..................................................... 55

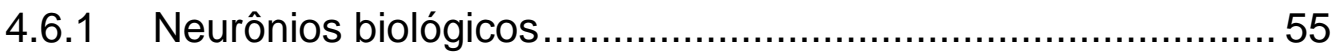

4.6.2 Aspectos históricos das RNA's ............................................ 57

4.6.3 Modelo matemático de McCulloch e Pitts para o

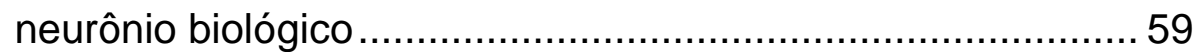

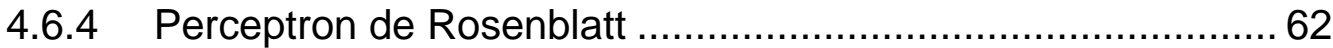

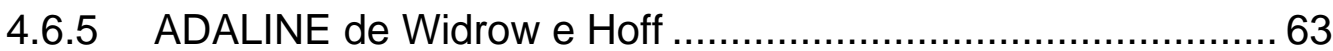

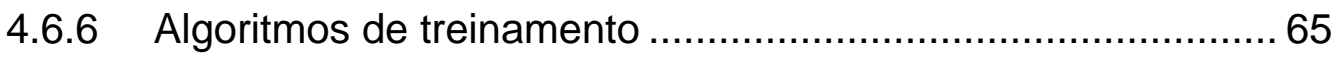

4.6.6.1 Treinamento supervisionado ................................... 65

4.6.6.1.1 Regra de correção de erros ...................................66

4.6.6.1.2 Regra Delta de Widrow-Hoff ou método do gradiente descendente....................................67

4.6.6.1.3 Algoritmo de Retropropagação .............................. 69

4.6.6.2 Treinamento não supervisionado .............................. 70

4.6.6.2.1 Treinamento Hebbiano ........................................ 71

4.6.7 Arquiteturas de redes neurais artificiais .............................. 72 
4.7 Abordagem do Problema e Programa RETRO-05 para análise dos dados com RNA's.

5. TESTES, ANÁLISES E RESULTADOS …............................................... 77

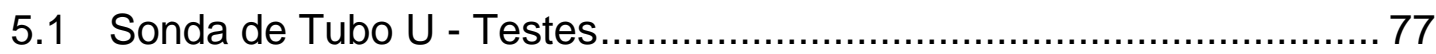

5.1.1 Sonda de Tubo U - Testes preliminares............................... 77

5.1.2 Sonda de Tubo U - Testes em Estado Estacionário ............... 82

5.1.3 Sonda de Tubo U - Testes em Transiente ........................... 105

5.1.3.1 Testes em transiente a frio ...................................... 105

5.1.3.2 Testes em transiente a quente ................................. 107

5.2 Sonda de Tubos Concêntricos - Testes........................................... 120

5.2.1 Sonda de Tubos Concêntricos -

Testes em Transiente a quente ........................................ 120

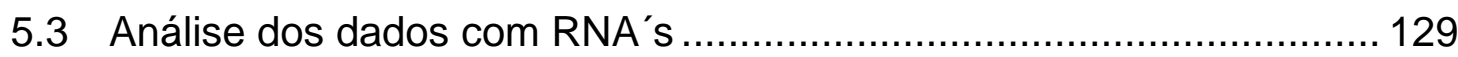

5.3.1 Análise dos dados para a Sonda de Tubo U na ST2 ............. 129

5.3.1.1 Cálculo da incerteza na medida de nível para............... 176 a Sonda de Tubo U

5.3.2 Análise dos dados para a Sonda de Tubos Concêntricos na ST1 .............................................. 181

5.3.3. Análise dos dados com RNA para a Sonda TRICOTH ........... 199

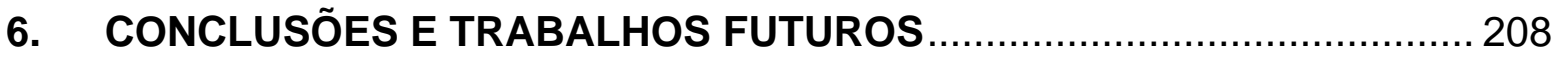




\section{APÊNDICES}

APÊNDICE A - Calibração dos Termopares da Bancada Experimental e e das sondas

APÊNDICE B - Calibração dos Transmissores de Pressão

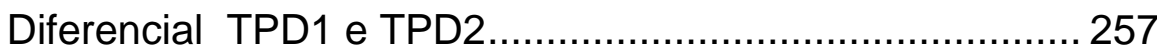

APÊNDICE C - Calibração dos rotâmetros R1 e R2 ................................... 263

APÊNDICE D - Procedimento experimental para ligar o SAD

e o computador PC ........................................................ 266

APÊNDICE E - Procedimento experimental para testes em estado estacionário com nível constante e com variação da vazão de água de resfriamento das sondas

APÊNDICE F - Procedimento experimental para testes em transiente de diminuição de nível em ST1 e ST2 ................................ 269 


\section{$1 \quad$ INTRODUÇÃO}

\subsection{A retomada mundial da energia nuclear}

De acordo com o Conselho Mundial de Energia, o crescimento da população mundial e o desenvolvimento econômico resultarão num aumento de 150\% a 300\% no consumo de energia no mundo até 2050. Ainda segundo as previsões, a eletricidade, terá seu consumo, no mínimo, duplicado no mesmo período. Além disso, todo o crescimento populacional esperado durante os próximos 30 anos será mais concentrado nas áreas urbanas, aumentando o problema de fornecimento de energia (Gauthier, 2002).

A produção e o suprimento de energia levantam questões cruciais na maioria dos países. A preocupação com os impactos ambientais decorrentes das atividades humanas têm aumentado substancialmente. Ao mesmo tempo, objetiva-se minimizar os efeitos de possíveis crises políticas e econômicas nos mercados de energia, administrando os riscos destes mercados para evitar oscilações de preços. A diversificação na utilização das fontes de energia, investimentos e políticas de longo prazo será fundamental para atender à demanda de energia.

Neste contexto, muitos países industrializados ou em desenvolvimento, após análises de suas necessidades energéticas, capacidades de produção e requisitos ambientais, estão reconhecendo as características positivas da energia nuclear como uma fonte de energia capaz de preencher uma parcela significativa em suas matrizes de energia.

$\mathrm{Na}$ Europa, a Alemanha e a Bélgica recentemente ordenaram a interrupção gradual da geração de energia elétrica através de reatores nucleares, porém garantiram o futuro da operação de suas usinas nucleares em funcionamento para os próximos 30 anos. A Finlândia aprovou recentemente a construção de seu quinto reator nuclear, após 
uma análise abrangente e imparcial, visando assegurar o futuro do seu suprimento de energia. Na França, onde aproximadamente $75 \%$ da energia elétrica é de origem nuclear, os desenvolvimentos das usinas nucleares e da indústria do ciclo do combustível consolidaram a política de investimentos feita nos últimos trinta anos. A França exporta o excedente de energia elétrica oriunda de seus reatores nucleares para a Inglaterra, Alemanha, Espanha, Portugal, Bélgica e Itália, muitos desses países contrários ao uso da energia nuclear, tendo rendimentos financeiros da ordem de US\$ 4 a 5 bilhões, sem contar com a economia de US\$20 a 30 bilhões na importação de petróleo.

Nos Estados Unidos, houve uma mudança no clima econômico e político, e com isso o uso da tecnologia nuclear na geração de energia passou a ser considerada necessária, havendo planos para a construção de novos reatores nos próximos dez anos.

$\mathrm{Na}$ Ásia, o desenvolvimento da energia nuclear é contínuo e o apoio à geração de energia através de reatores nucleares é mais forte. Lá existem vários reatores em operação, em construção e em projeto, principalmente no Japão, China, Coréia do Sul e Índia.

Nos países do Oriente Médio, muitos deles grandes produtores de petróleo, para os quais a opção nuclear visa não só ajudar a estender a vida de suas grandes, porém limitadas reservas petrolíferas, mas também, resolver uma grave situação de escassez de água doce, já que uma maneira econômica de dessalinizar a água do mar é através de usinas nucleares. Marrocos, Tunísia, Irã, Bahrein e Arábia Saudita são países que estão analisando a construção de usinas nucleares, (Maisseu, 2001).

No Brasil, atualmente (2008) a produção de energia elétrica é majoritariamente de origem hidrelétrica, contribuindo com cerca de 92\%. Em segundo lugar está a energia nuclear com 3,3\%, proveniente dos reatores PWRs Angra 1 (Westinghouse - $626 \mathrm{MW}_{\mathrm{e}}$ ) e Angra 2 (KWU-Siemens - $1300 \mathrm{MW}_{\mathrm{e}}$ ), (Pinheiro, 2007). 
Essa participação, embora minoritária, é fundamental para o equilíbrio do sistema interligado. Em meados de 2007 foi aprovada pelo Conselho Nacional de Política Energética (CNPE), em seu Plano Nacional de Energia 2030, a construção do reator PWR Angra 3 (KWU-Siemens - $1300 \mathrm{MW}_{\mathrm{e}}$ ), que tem previsão para entrada em operação o ano de 2013. Este Plano tem como base a diversificação da matriz energética brasileira e a adição de $53700 \mathrm{MW}_{\mathrm{e}}$ ao seu parque gerador até 2030, com um aumento da participação termoelétrica (nuclear, gás, carvão, óleo e biomassa), prevendo um crescimento contínuo da energia nuclear com o acréscimo de seis novos reatores. A este panorama favorável, alia-se o fato do Brasil pertencer ao restrito grupo de países que possuem a tecnologia de enriquecimento de urânio e fabricação de elementos combustíveis. Além disso, o país possui a sexta reserva mundial de urânio, tendo apenas 30\% de seu território prospectado, (Dantas, 2007).

Recentemente, mais precisamente em 23 de julho de 2008, o Ministério do Meio Ambiente, por intermédio do Instituto Brasileiro do Meio Ambiente e dos Recursos Renováveis (IBAMA) concedeu à Eletrobrás Termonuclear S.A. Eletronuclear, empresa responsável pela Central Nuclear Almirante Álvaro Alberto, a Licença Prévia no. 279/2008 para início da construção da Unidade 3 (Angra 3) para a geração de $3765 \mathrm{MW}_{t}$ de potência térmica e $1350 \mathrm{MW}$ e potência elétrica, (IBAMA, 2008).

Essa tendência positiva mundial tem contribuído para aumentar o apoio e confiança sobre a energia nuclear originado em seu nascimento. Essa convicção é fortalecida por fatores econômicos, onde as usinas nucleares em operação provaram ser bem sucedidas dentro do novo e competitivo ambiente de geração elétrica mundial. Os progressos operacionais destas usinas resultaram em um drástico aumento da eficiência, menores custos de operação, elevados padrões de desempenho e segurança, os quais permitiram operar com mais rentabilidade, mesmo sob pressão competitiva. O processo de extensão da vida útil de usinas nucleares certamente aumentará ainda mais esses benefícios. Por outro lado, todas as tecnologias para a produção de energia estão aprimorando seu desempenho operacional. A indústria 
nuclear terá que permanecer neste círculo virtuoso para manter sua competitividade e sustentabilidade, além de fornecer respostas técnicas convincentes às dúvidas da população relativas à opção nuclear.

Segundo a World Nuclear Association, baseada em dados de maio de 2008, atualmente existem 439 reatores nucleares em operação distribuídos entre 30 países, fornecendo cerca de $16 \%$ de toda a energia elétrica consumida no planeta, num total aproximado de $372.000 \mathrm{MW}_{\mathrm{e}}$. Outras 36 usinas estão em construção em países como Canadá, China, Coréia do Sul, Finlândia, França, Índia, Japão, Rússia e Taiwan, entre outros, e que adicionarão $30.000 \mathrm{MW}_{\mathrm{e}}$ ao parque elétrico mundial. Outros 93 reatores estão planejados e 218 reatores estão propostos.

\subsection{Reatores nucleares avançados e de IV geração}

No início de 2001, diversas regiões dos Estados Unidos depararam com uma situação de escassez de energia elétrica sem precedentes. Na Califórnia, um dos seus estados mais ricos e onde se concentram as indústrias de alta tecnologia, os apagões

tornaram-se freqüentes, gerando grandes prejuízos. Para enfrentar essa crise, o governo solicitou um plano de política energética para o país, que resultou no relatório "National Energy Policy", de maio de 2001. Uma das principais conclusões desse relatório foi que o país precisa construir entre 1300 e 1900 novas usinas geradoras de energia elétrica, e desse total, uma grande parte proveniente da energia nuclear.

O programa conjunto internacional de cooperação em pesquisa denominado Generation-Four International Forum (GIF) de iniciativa do Department Of Energy (DOE) dos Estados Unidos, coordenado pela Westinghouse, do qual fazem parte Argentina, Brasil, Canadá, França, Japão, Coréia do Sul, África do Sul, Suíça e Inglaterra, e mais recentemente Rússia e China (2006), foi estabelecido desde 2000 para montar as bases da próxima geração de reatores nucleares, denominados reatores de IV Geração. Esse 
programa de cooperação, sem precedentes em pesquisa e desenvolvimento, favorecerá o progresso da energia nuclear, em harmonia com o desenvolvimento sustentável.

O GIF estabeleceu oito metas para os reatores de IV Geração. Primeiramente, uma melhor utilização do combustível nuclear; minimização dos rejeitos; e resistência à proliferação, ou seja, reatores que produzam menor quantidade de plutônio ou que o utilizem como combustível durante a operação. Também são exigidas maior segurança e confiabilidade para os trabalhadores da usina e para a população, drástica redução na probabilidade de ocorrência de acidentes, suficiente para que não haja a necessidade de uso de um plano de emergência fora do sítio do reator. Por outro lado, busca-se um aumento da eficiência de geração da planta e maior atratividade ao investidor, através da redução do prazo de retorno do capital investido, redução dos riscos financeiros e dos custos de capital, (Uranium Information Center, 2007), (World Nuclear Association, 2007) e (Energy Information Administration, 2007).

Após dois anos de deliberações, o GIF anunciou a seleção de seis tecnologias de reatores que acreditam representar o futuro da energia nuclear para aplicação após 2030. As seis tecnologias de reatores escolhidas pelo GIF foram:

Reatores rápidos refrigerados a gás (gás-cooled fast reactors). Estes reatores deverão operar como os reatores refrigerados a Hélio, porém em temperaturas mais elevadas $\left(850^{\circ} \mathrm{C}\right)$, conveniente para a geração de potência, produção termoquímica de hidrogênio ou outros processos térmicos. Para a produção de eletricidade, o gás irá acionar diretamente uma turbina a gás. O combustível para esse reator poderá ser o urânio já utilizado (depleted) ou qualquer outro material físsil e/ou fértil, e o combustível queimado poderá ser reprocessado na usina diminuindo a produção de rejeitos de longa duração.

Reatores rápidos refrigerados a chumbo (lead-cooled fast reactors). Estes reatores deverão operar em circulação natural com refrigeração promovida por metal líquido chumbo $(\mathrm{Pb})$ ou uma liga chumbo-bismuto $(\mathrm{Pb}-\mathrm{Bi})$. O combustível será o urânio 
metálico já utilizado (depleted) e o reprocessamento sendo realizado em unidades regionais ou centrais. Uma larga faixa de tamanhos pode ser vislumbrada para estes reatores, desde pequenas unidades para pequenas demandas ou para países em desenvolvimento, até reatores modulares de 300 - $400 \mathrm{MW}_{\mathrm{e}}$, ou ainda unidades maiores de $1400 \mathrm{MW}_{\mathrm{e}}$. A temperatura de operação é de $550^{\circ} \mathrm{C}$, porém pretende-se atingir $850^{\circ} \mathrm{C}$ com o avanço na tecnologia dos materiais, e com isso possibilitar a produção termoquímica do hidrogênio.

Reatores a sal fundido (molten salt reactors). O urânio combustível é dissolvido no refrigerante (fluoreto de sódio - sal) que circula através de canais de grafite no núcleo para promover alguma moderação e obter um espectro de nêutrons epitérmicos. Os produtos de fissão são removidos continuamente e os actinídeos são plenamente reciclados, enquanto que o plutônio e outros actinídeos podem ser adicionados ao U-238. A temperatura do refrigerante é $700^{\circ} \mathrm{C}$ em pressão muito baixa, com a pretensão de atingir $800^{\circ} \mathrm{C}$. Um sistema de resfriamento secundário é usado para a geração de eletricidade, e a produção termoquímica do hidrogênio.

Reatores rápidos refrigerados a sódio (sodium-cooled fast reactors). Este reator está baseado na experiência adquirida na operação de reatores a nêutrons rápidos em cinco décadas e em oito países. Ele usa urânio usado (depleted) como combustível e a temperatura do refrigerante é de $550^{\circ} \mathrm{C}$ permitindo a geração de eletricidade através de um circuito secundário de sódio, sendo que o circuito primário opera em pressão próxima da atmosférica. São propostas duas opções: reatores de 150 - $500 \mathrm{MW}_{\mathrm{e}}$ com actinídeos incorporados em um combustível metálico, o que exige um processamento pirometalúrgico; e reatores de 500 - $1500 \mathrm{MW}_{\mathrm{e}}$ com combustível convencional MOX reprocessado em plantas convencionais.

Reatores refrigerados a água supercrítica (supercritical water-cooled reactors). Este reator opera com água em alta pressão, mais especificamente em condições acima do ponto triplo da água, para obter um aumento de um terço na eficiência comparado com os reatores a água leve atuais. A água em condições 
supercríticas (25MPa e $510-550^{\circ} \mathrm{C}$ ) aciona diretamente a turbina sem qualquer sistema secundário. Sistemas com características de segurança passiva são similares àqueles de reatores BWR. O combustível é o óxido de urânio, enriquecido no caso da opção de ciclo aberto. Entretanto, ele pode ser construído como um reator rápido com reciclagem plena de actinídeos baseada no reprocessamento convencional. A maioria das pesquisas em projeto com este tipo de reator tem sido realizada no Japão.

Reatores a gás em temperatura muito alta (very high-temperature gas reactors). Estes reatores são refrigerados a Hélio e moderados a grafite, e são baseados na vasta experiência adquirida ao longo dos anos. O núcleo pode ser constituído por blocos prismáticos como nos reatores HTGR do Japão e os reatores GTMHR em desenvolvimento pela General Atomic ou outros na Rússia, ou pode ser de leito fluidizado (peeble bed) como o HTR-10 da China e o PBMR em desenvolvimento na África do Sul. A temperatura do gás atinge $1000^{\circ} \mathrm{C}$ possibilitando a produção termoquímica de hidrogênio através de um trocador de calor intermediário, com cogeração de eletricidade, ou acionamento direto de alta eficiência da turbina a gás em um ciclo termodinâmico de Brayton. Existe alguma flexibilidade quanto ao combustível a ser usado neste reator, mas não permite reprocessamento. Módulos de $600 \mathrm{MW}$ térmicos são pretendidos.

Além dos reatores mencionados anteriormente, o GIF também avaliou projetos de reatores para desenvolvimento em curto prazo, denominados Near Term Deployment, que poderiam começar a ser utilizados entre 2010 e 2015. Entre estes projetos está incluído o reator IRIS (International Reactor Innovative and Secure), que é um projeto coordenado pela Westinghouse, no qual participam várias instituições de ensino, pesquisa e indústria, de vários países, incluindo o Brasil. (Universidade Politécnica de Milão, 2003).

O reator IRIS é um reator tipo PWR (Pressurized Water Reactor) integrado, ou seja, os geradores de vapor, as bombas, o pressurizador e blindagem do núcleo estão contidos em um único vaso de pressão, diferentemente dos PWR's convencionais 
onde estes equipamentos são individualizados e conectados ao vaso do reator por meio de tubulações. A ausência de tubulações é uma das grandes vantagens deste projeto com relação à segurança. Estes reatores deverão ter potência entre 100 e 300 MWe, e um tempo previsto de construção de três anos. Isto propicia ao projeto a característica de modularidade, ou seja, módulos poderão ser incorporados à central nuclear de acordo com as necessidades de energia e as possibilidades financeiras do investidor. Neste reator, a medida de nível de água no vaso de pressão será feita na região do pressurizador onde existe líquido e vapor saturado.

\subsection{O acidente de Three Mile Island}

Em 28 de março de 1979 ocorreu em Three Mile Island (TMI), próximo à Middletown, na Pennsylvania, o mais grave acidente já ocorrido com plantas nucleares comerciais dos Estados Unidos (United States Nuclear Regulatory Commission, 2004). Uma seqüência de eventos que envolveram: mal funcionamento de equipamentos, problemas relacionados com o projeto do sistema e falhas humanas; levaram à fusão parcial do núcleo do reator e à liberação de radioatividade para fora da usina. Embora o acidente não tenha provocado mortes ou ferimentos nos trabalhadores da usina ou nos moradores da comunidade vizinha à planta, ele provocou mudanças no planejamento de respostas às emergências, no treinamento dos operadores com vistas às falhas humanas, no projeto da instrumentação, na proteção radiológica e muitas outras áreas da operação de plantas nucleares. Obviamente, a Nuclear Regulatory Commission (NRC) americana, órgão regulador daquele país, passou a tratar o assunto ainda com maior rigor, resultando em mudanças na indústria nuclear que provocaram o aumento da segurança. Este acidente foi, sem dúvida, um dos motivos para a desaceleração do setor nuclear mundial nos anos seguintes. A seguir é descrito resumidamente a seqüência de eventos ocorridos durante as primeiras horas do acidente. 
$\mathrm{O}$ acidente com o reator PWR da unidade 2 (TMI-2) fabricado pela BabcokWilcox teve início por volta das 4:00 horas do dia 28 de março, quando ocorreu uma falha no circuito secundário dessa planta. As bombas de água de alimentação falharam por motivo elétrico ou mecânico, impedindo a remoção de calor pelos geradores de vapor. A turbina e o reator foram desligados e a pressão no circuito primário começou a subir. Para que a pressão não atingisse valores elevados, foi aberta a válvula de alívio Pilot-Operated Relief Valve (PORV) localizada em uma linha no topo do pressurizador. Esta válvula deveria permanecer aberta até que a pressão diminuísse para um valor préestabelecido em projeto. Após isto, ela deveria ter fechado, fato que não ocorreu. Os sinais da instrumentação, disponíveis aos operadores, não mostraram que a válvula ainda permanecia aberta. Como conseqüência ocorreu a saída de fluido refrigerante do circuito primário, provocando o superaquecimento do núcleo e sua fusão parcial.

Quando o fluido refrigerante saiu do vaso do reator através do pressurizador, as informações dos instrumentos disponíveis aos operadores na sala de controle os induziram a interpretações equivocadas sobre o que realmente estava ocorrendo com a planta. Não havia nenhum instrumento que medisse e indicasse diretamente, aos operadores, o nível de refrigerante no vaso do reator. Os operadores avaliaram o nível de refrigerante no vaso do reator pela informação de nível no pressurizador, e como este nível estava alto, concluíram também que o nível no vaso estava em condições ideais para o resfriamento do núcleo. Enquanto isso a válvula PORV continuava aberta com o fluido do circuito primário saindo através dela.

Análises técnicas realizadas posteriormente indicaram que, após cerca de 130 minutos do início do acidente o topo do núcleo do reator estava exposto e o intenso calor gerado no núcleo provocou uma reação entre o vapor formado no núcleo e a camisa de zircônio do combustível nuclear. Esta reação danificou a camisa do combustível, liberando mais produtos radioativos ao refrigerante do reator, e ainda produziu hidrogênio, que se acumulou no topo do vaso do reator, aumentando ainda mais a gravidade do acidente pela possibilidade de explosões. 
Por volta das 6:00 horas, foi detectado que a temperatura nos tanque de armazenagem, para onde estava sendo enviado o refrigerante primário que saía pelo pressurizador, estava elevada e foi usada a válvula de bloqueio (Block Valve) para impedir a saída de refrigerante do primário pelo pressurizador. Somente após 165 minutos do início do acidente, quando refrigerante contaminado por radiação alcançou os detectores de radiação, é que os alarmes de radiação foram ativados. Neste ponto, o nível de radiação no refrigerante primário era da ordem de 300 vezes o nível esperado e a planta estava seriamente contaminada.

Às 7:00 horas, foi declarado estado de Emergência na Área da Planta (Site Area Emergency), o segundo nível mais alto em condições de acidente, que às 7:24 horas foi elevado para a condição de Emergência Geral (General Emergency), o nível mais elevado. Às 7:45 o escritório regional da NRC em King of Prússia na Pennsylvania foi notificado. Às 8:00, o escritório central da NRC em Washington D.C. foi alertado e o centro de operações da NRC em Bethesda, Maryland, foi ativado. O escritório regional prontamente enviou uma equipe de inspetores ao local, e outras entidades, como o Departamento de Energia (DOE) e a Agência de Proteção Ambiental também mobilizaram suas equipes. Às 9:15 horas, a Casa Branca foi notificada e às 11:00 todos funcionários com tarefas consideradas não essenciais à operação e segurança da planta foram retirados do local.

O objetivo deste breve relato do ocorrido nas primeiras horas do acidente de TMI foi mostrar que, se houvesse um medidor de nível de água no vaso do reator, muito provavelmente este acidente não teria ocorrido, ou ainda, se tivesse ocorrido, suas conseqüências seriam muito menores, pois, de posse de informações sobre o nível baixo de água no vaso, ações teriam sido tomadas pelos operadores da planta para garantir o resfriamento adequado do núcleo do reator. O relato também mostra que tratou-se de um acidente relativamente lento, tendo levado algumas horas até que o núcleo ficasse descoberto causando a fusão de parte do mesmo. 
A obtenção de medidas de nível precisas no interior dos vasos de pressão de reatores nucleares representa um problema ainda sem solução satisfatória e é um desafio a ser superado, tanto para as atuais gerações de reatores a água pressurizada, quanto para as futuras. As severas condições de escoamento, pressão e temperatura existentes no vaso de pressão, aliadas às necessidades de eliminação e/ou redução de probabilidade de ocorrência de acidentes dificultam o desenvolvimento de um sensor de nível capaz de atender aos requisitos de: precisão de medida, robustez, confiabilidade, durabilidade, entre outros.

O objetivo deste trabalho é o desenvolvimento de uma técnica para medida contínua de nível em vasos de pressão operando com água e vapor saturado a partir do tratamento, por Redes Neurais Artificiais (RNA's), dos sinais de temperatura produzidos por termopares instalados em sondas térmicas resfriadas internamente.

Geralmente, as sondas térmicas funcionam com aquecimento interno promovido por resistências elétricas, produzindo um fluxo de calor de dentro para fora da sonda. A diferença entre os coeficientes de transferência de calor (h) que ocorrem na fase líquida (parede da sonda-líquido; h elevado) e na fase vapor (parede da sondavapor; $\mathrm{h}$ baixo) produzem diferenças de temperaturas na parede da sonda, que são medidas por termopares e estão relacionadas com o nível de inserção da sonda. Essas sondas são calibradas com níveis de inserção conhecidos e são medidas as temperaturas, obtendo assim padrões ou "assinaturas" características daquela condição de nível. A medida do nível quando essas sondas são instaladas em um vaso é feita a partir da comparação das temperaturas medidas com os padrões obtidos na calibração. 
Neste trabalho foram concebidas, projetadas e construídas, duas sondas térmicas com termopares instalados na parede, a saber: Sonda de Tubos Concêntricos e Sonda de Tubo U. Diferentemente das sondas térmicas citadas anteriormente, o fluxo de calor ocorre de fora para dentro das sondas. Estas sondas são resfriadas internamente por água, de forma que na região da sonda que está em contato com o vapor ocorrerá preferencialmente o processo condensação de vapor, cujo coeficiente de transferência de calor $\mathrm{h}$ é elevado, enquanto que na região da sonda em contato com o líquido ocorrerá um processo complexo de transferência de calor envolvendo condução e convecção mono e bifásica com h menor. Essa característica das sondas térmicas usadas neste trabalho é inédita, conferindo esse caráter a todo o trabalho, ainda mais associado às Redes Neurais Artificiais. Essas sondas foram testadas em uma Bancada Experimental, obtendo-se dados de temperatura característicos em função do nível nas seções de testes, os chamados padrões ou "assinaturas". Um programa de análise de dados por Redes Neurais Artificiais (RNA's) baseado em Perceptrons de Múltiplas Camadas com Retropropagação chamado RETRO-05 foi usado para o treinamento da rede, tendo as temperaturas como dados de entrada e os níveis como saídas desejadas.

O princípio da técnica de medida de nível proposta é treinar uma RNA com dados de temperatura na sonda e nível na seção de testes e posteriormente verificar a capacidade da RNA treinada em reconhecer níveis genéricos na seção de testes a partir de dados de temperatura na sonda. 


\section{REVISÃO DA LITERATURA}

Antes do acidente de TMI, o inventário de água no circuito primário dos reatores PWR's era medido e controlado pela medida de nível no pressurizador. A ausência de um medidor de nível também no vaso de pressão contribuiu para a ocorrência e o agravamento das conseqüências desse acidente. No caso, enquanto a medida no pressurizador indicava nível de água normal no circuito primário, a realidade mostrava que o núcleo estava descoberto e sem resfriamento, fato que provocou a fusão parcial de elementos combustíveis e suas indesejáveis conseqüências. Após esse acidente, a NRC dos Estados Unidos passou a exigir dos fabricantes, em novos reatores, e dos proprietários das usinas nucleares existentes, a instalação de instrumentação adicional para atenuar as condições de acidentes, incluindo a instalação de medidores de nível também nos vasos de pressão.

No reator integrado IRIS, o nível de água no vaso, ou o inventário de água do primário do sistema, será medido na região do pressurizador, localizado no domo superior do vaso. Uma peça em forma de "chapéu invertido" separa a região do pressurizador do restante do reator. Caminhos de comunicação entre as duas regiões permitem o escoamento durante os transitórios de variação de carga da planta. A função desta peça é possibilitar a manutenção de uma camada de água na condição de saturação mesmo com existência de sub-resfriamento na região abaixo, ou seja, nas condições de saída do núcleo. Para isso, ela possui em seu interior um enchimento do tipo colméia que tem como função diminuir ou até impedir a formação de linhas de convecção e assim aumentar a resistência à transferência de calor entre as regiões. Medidores de nível baseados em medidas de pressão diferencial não são convenientes para essa aplicação porque existe escoamento na região do núcleo, fato que interfere nas medidas. Alguns tipos de medidores de nível usando outras técnicas de medida tais como, ultra-som e temperaturas, estão sendo ou foram desenvolvidos e são brevemente descritos abaixo. Um desenho ilustrativo do vaso do reator integrado IRIS com as linhas de escoamento é mostrado na FIG. 3.1. 


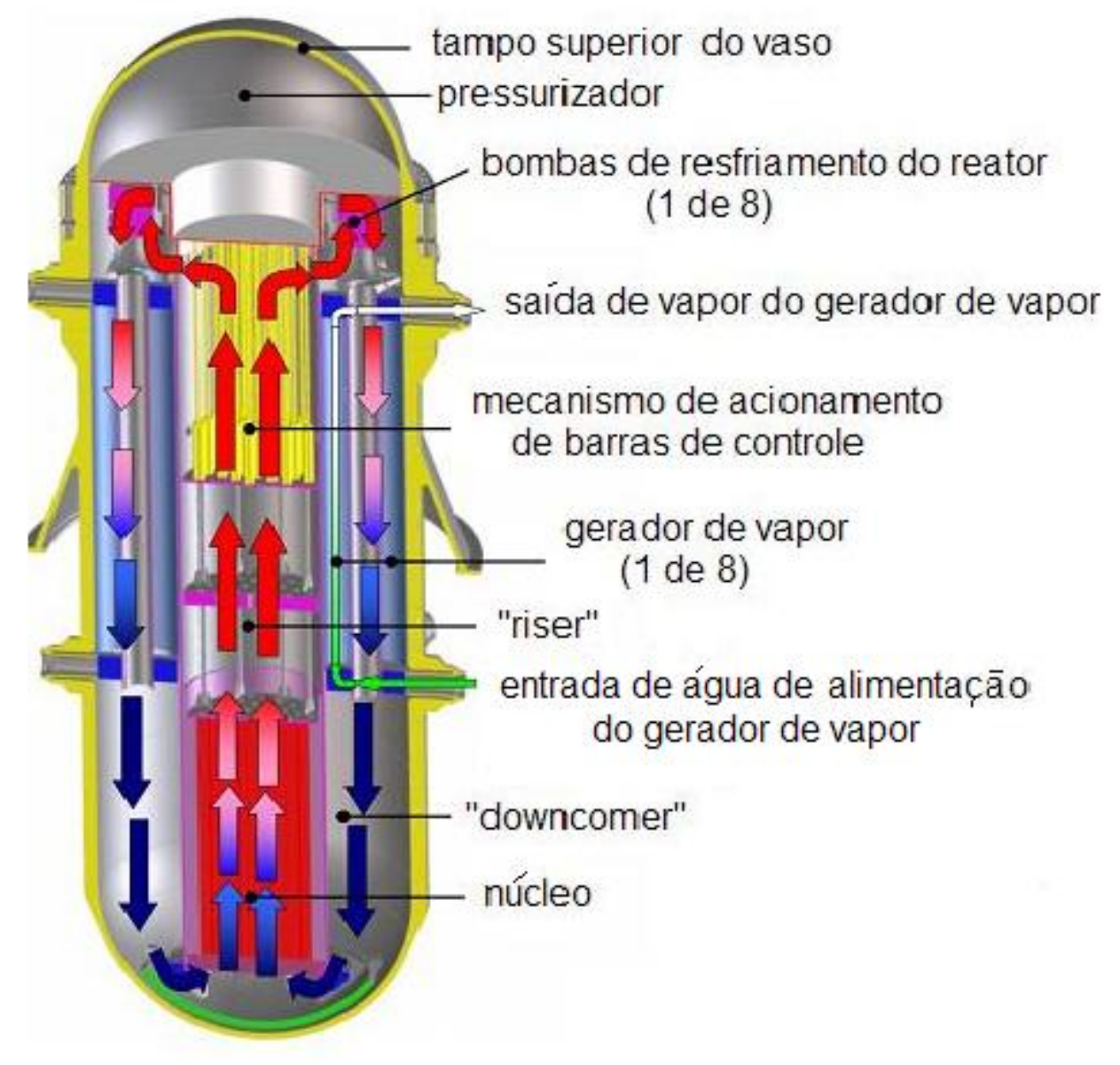

FIGURA 3.1. Desenho ilustrativo do vaso do reator integrado IRIS e seus componentes Referência: Projeto IRIS- Universidade Politécnica de Milão http://www.hulk.cesnef.polimi.it

Dois importantes grupos de sensores de nível para vasos de pressão foram identificados nas pesquisas, além de outros sensores e técnicas de medida de nível menos estudadas. O primeiro grupo engloba sensores que utilizam ondas ultra-sônicas para a determinação do nível, as sondas de nível ultra-sônicas; enquanto que o segundo grupo abrange os sensores que utilizam informações de temperatura para a determinação do nível, as sondas de nível térmicas. Alguns dos trabalhos realizados com esses dois grupos de sensores são descritos a seguir, assim como alguns outros tipos de sensores e técnicas de medida. 


\subsection{Sondas de Nível Ultra-Sônicas}

O princípio de funcionamento deste tipo de sonda é baseado na atenuação de pulsos ultra-sônicos em um elemento sensor posicionado verticalmente e que fica parcialmente imerso na mistura líquido-vapor. A atenuação dos pulsos varia de acordo com o grau de imersão da sonda. Em geral este tipo de sensor é composto por: conversor acústico, guia de ondas ultra-sônicas e elemento sensor.

Arave (1970) apresentou um estudo sobre um medidor de nível ultra-sônico, estudo este que deu origem a uma patente do medidor, Arave (1973). Mais tarde, Arave (1979) desenvolveu um densitômetro para operar nas condições de operação de um reator nuclear PWR $\left(343^{\circ} \mathrm{C}\right.$ e $\left.15 \mathrm{MPa}\right)$ usando a técnica de ondas ultra-sônicas torsionais e como princípio de funcionamento o tempo de propagação que depende da densidade do fluido ao redor do sensor e que indiretamente fornece informação sobre o nível.

Lynnworth (1979) apresentou um artigo sobre a técnica de medida de nível com sondas de nível usando guia de ondas ultra-sônicas longitudinais e torsionais. Dando seqüência aos estudos, Miller et al. (1980) desenvolveram um sensor para medida de nível em alta pressão $(15,2 \mathrm{MPa})$ e temperatura $\left(250^{\circ} \mathrm{C}\right)$ usando o princípio de funcionamento das guia de ondas ultra-sônicas torsionais.

Baseado nos trabalhos de Arave e Lynnworth, Melnikov e Khokhlov (1997) desenvolveram um sensor de nível por guia de ondas ultra-sônicas para medir o nível em um gerador de vapor horizontal da usina nuclear de Zaporozhye, na Rússia. O sensor foi testado em condições de alta pressão (20MPa) e temperatura, e posteriormente instalado no gerador de vapor, sendo testado por 10 meses e apresentando bons resultados.

Mais recentemente Willner e Eisentraudt (2001) apresentaram uma metodologia e um dispositivo para determinação de nível com pulsos ultra-sônicos. 
Kim et al. (2004) apresentaram trabalho onde comparam os resultados de medida de nível em uma mistura bifásica ar-água realizados com uma sonda ultrasônica e com uma sonda tipo capacitiva, com os resultados visuais. Uma série de experimentos com várias vazões de ar foi realizada em pressão atmosférica e temperatura ambiente em uma bancada experimental feita de vidro Pirex transparente com $2 \mathrm{~m}$ de altura e 0,3 m de diâmetro interno. Boa concordância entre os resultados foi obtida para ambas as sondas, com pequena vantagem para a sonda ultra-sônica.

\subsection{Sondas de Nível Térmicas}

Neuschaefer (1982) apresentou artigo onde descreve um sistema para medida de nível usando sondas térmicas. Essas sondas possuem junções de termopares localizadas em regiões aquecidas eletricamente e junções termopares localizadas em regiões sem aquecimento. Os sinais de saída desses termopares foram ligados diferencialmente de forma a medir a diferença de temperatura entre as regiões, que depende do coeficiente de transferência de calor do meio circundante. Foram realizados testes de verificação do princípio de funcionamento, testes em alta pressão e temperatura em uma autoclave do Oak Ridge National Laboratory, para o desenvolvimento do projeto e testes de produção de um protótipo. Finalmente foram realizados testes de desempenho do sistema completo já com o processamento de sinais, alarmes aos operadores e indicações de temperatura.

Ara et al. (1982) publicou artigo onde introduziu o conceito da sonda de nível térmica BICOTH (BInary Coded THermocouple) que ao invés de possuir muitos termopares, ela possui um arranjo de termopares ligados diferencialmente de maneira a fornecer uma saída composta por sinais binários relacionados com o nível. Foram realizados testes de viabilidade da técnica, onde se observou bons resultados. Protótipos foram fabricados usando aquecedor formado por pino rígido e tubo com ranhuras para a soldagem dos termopares, e usando a tecnologia de fabricação de 
termopares para encamisar o aquecedor (fios flexíveis) e os fios dos termopares num mesmo conjunto e um tubo suporte com ranhuras para instalar os conjuntos. Bons resultados foram obtidos, porém alguns pontos ainda deveriam ser resolvidos antes da aplicação real em um vaso de pressão.

Prosseguindo nas pesquisas, Ara et al. $(1988,1989)$ desenvolveram um sistema alternativo para medir nível no reator BWR de Dodewaard de $200 \mathrm{MW}$ da Holanda usando os sensores BICOTH, citado anteriormente. Os termopares do sensor produzem códigos binários 0’s e >0's que correspondem unicamente aos níveis de água no vaso do reator. Um sistema deste tipo foi instalado no reator de Dodewaard, operando satisfatoriamente por 3 anos. Neste mesmo trabalho os autores propõem, baseados na experiência adquirida e nos resultados com o BICOTH, um sensor mais avançado, denominado TRICOTH (TRInary COding THermocouples) que operaria com um número maior de sinais binários $<0^{\prime} s$, 0’s e $>0$ 's, produzindo melhores resultados com relação à medida de nível.

Termaat et al. (1990) estudaram a viabilidade de fabricação do sensor TRICOTH. Um protótipo foi construído usando a tecnologia de fabricação de termopares encamisados e isolados com material cerâmico. O sensor consiste de um tubo de inconel de 3,2 mm de diâmetro, em cujo interior existem dois fios referentes ao aquecedor elétrico e três fios de termopares com multi-junções, todos isolados do tubo externo com óxido de magnésio. Os resultados foram considerados promissores e neste trabalho, os autores também propõem uma versão avançada do TRICOTH, denominada de TRICOTH-III que adota um aquecedor coaxial para evitar interferências de campos elétricos, seis sensores de códigos ternários e um conjunto de termopares padrão, tudo integrado em um tubo com 3,4 mm de diâmetro externo. Os dados experimentais referentes a testes realizados com um protótipo do sensor TRICOTH em uma seção de testes operando em baixa pressão e temperatura foram utilizados para verificar a técnica proposta neste trabalho de uso de RNA's para a medida de nível com os sinais de sondas térmicas. Os resultados são apresentados no capítulo 5. 
Schmidt et al. (1985), para atender aos requisitos da Reactor Safety Commission (RSK) da Alemanha que, após o acidente de TMI também passou a exigir um medidor de nível para o vaso do reator independente do medidor de nível do pressurizador, desenvolveram uma sonda térmica com essa específica finalidade. Um sensor de nível usado no reator Atucha 1 da Argentina, e testado durante vários anos serviu como referência para o desenvolvimento deste medidor, e que tem como princípio de funcionamento as diferenças entre os coeficientes de transferência de calor entre água e vapor. Um elemento aquecedor operando com potência constante fornece calor em excesso com relação às condições externas, promovendo um fluxo de calor. Um termômetro de resistência do tipo RTD (Resistance Temperature Detector) mede as variações de temperatura deste aquecedor e compara com as temperaturas medidas por outro RTD posicionado numa região sem aquecimento. Esses RTD's são ligados em uma ponte de Wheatstone, que realiza a comparação. Numa primeira fase, um protótipo desse medidor foi testado numa bancada experimental desenvolvida para testes de pequenos LOCA's em pressões de até 3,0 MPa. Posteriormente foram realizados testes funcionais em alta pressão 16,0 MPa e em pressões referentes às condições de acidente 9,0 MPa. Vários outros testes foram realizados com o medidor e acessórios, tais como: inspeção visual, envelhecimento térmico, teste de alta voltagem, irradiação, corrosão e testes com os equipamentos eletrônicos. Após todos os testes, 2 medidores foram instalados no vaso do reator Philippsburg 2 (KKP 2) em Karlsruhe na Alemanha para comissionamento.

Wenran et al. (1998) apresentaram estudo de uma sonda térmica para medida de nível, com aquecimento elétrico e termopares instalados na parede da sonda e termopares sem aquecimento, e ligados diferencialmente entre si, e um sistema codificador para os sinais de diferencial de temperatura. O princípio de funcionamento da sonda térmica é baseado na diferença de coeficientes de transferência de calor que ocorrem na região imersa (líquido) e na região não imersa (vapor) da sonda. Testes em laboratório foram realizados em pressões 0,15 - 3,0 MPa, e um sistema codificador denominado GRAY foi desenvolvido para tratar os sinais de temperatura em função do nível. O objetivo deste estudo foi verificar a viabilidade do conjunto sonda e codificador, 
para posterior aplicação e instalação no reator Daqing 200 MW (NHR-200) na China. As análises e os experimentos mostraram a viabilidade e confiabilidade do novo sistema para monitorar o nível de água no reator $\mathrm{NRH}-200$, e dois conjuntos com 8 sensores cada foram instalados no vaso do reator.

\subsection{Outras Sondas de Nível e Técnicas de Medida}

Lewis (1987) propõe a possibilidade de medida de nível em vasos de reatores tipo PWR pela análise da freqüência natural da oscilação pendular do vaso, que depende da quantidade de água neste. A presença dos internos do vaso e a geração de ondas na superfície do fluido quando o vaso está parcialmente cheio complicam o efeito. Para pequenas perdas de água, os efeitos são mensuráveis, porém pequenos. A principal vantagem é que o método mede diretamente a massa de água e é não invasivo. O autor indica que, somente com os testes em vasos propriamente ditos, será possível determinar se a técnica é adequada. Em termos gerais ocorre um decréscimo de $10 \%$ no momento de inércia para uma diminuição de 10\% no inventário.

Mandl e Umminger (1988) demonstraram a influência do termo de aceleração do escoamento nas medidas de nível instantâneas quando se usa transmissores de pressão diferencial com essa finalidade e propuseram um método para a determinação do nível instantâneo verdadeiro. Testes realizados em uma instalação experimental PKL que simula em escala 1:145 um reator PWR de $1300 \mathrm{MW}_{\mathrm{e}}$ mostraram sérias inconsistências no nível instantâneo do "downcomer" e no vaso do reator, fato que levou os autores a investigarem em detalhes o assunto e a propor um método para a correção que considera a medida da velocidade de escoamento em conjunto com as medidas de pressão diferencial para a obtenção do nível instantâneo.

$\mathrm{Na}$ e No (1992), apresentam trabalho onde propõem o projeto de um controlador baseado em um observador adaptativo para controlar o nível em 
geradores de vapor. $\mathrm{Na}$ proposição, o observador adaptativo analisa simultaneamente os parâmetros do gerador de vapor em conjunto e as variáveis de estado. O problema variável no tempo é resolvido estimando os parâmetros a cada time step, por meio de uma função custo, procedimento semelhante ao usado em redes neurais artificiais com aprendizado supervisionado.

Torok et al.(1994) estudaram um sistema para medir nível em reatores BWR's durante as instabilidades que ocorrem em transientes sem desligamento (Antecipated Transient Without SCRAM - ATWS). Dados de testes obtidos em uma bancada experimental foram utilizados para refinar e calibrar o sistema, que usa transmissores de pressão diferencial para medir o nível no vaso de pressão. Os autores concluíram que mudanças rápidas na pressão do vaso do reator podem produzir erros nas oscilações de nível indicadas pelo sistema. Eles concluíram também que os erros estão relacionados com o comprimento das linhas de pressão (alta pressão e baixa pressão).

Jirsa (1997) apresenta um trabalho onde propõe um algoritmo para monitorar o nível nos vasos dos reatores tipo VVER-440/213 da República Tcheca. O algoritmo é baseado na análise computacional das mudanças nas freqüências naturais dos internos do reator como função dos diferentes níveis e foi desenvolvido usando a técnica de elementos finitos. Os dados do sistema de análise de ruídos já existente nas plantas de Dukovany e Jaslovské Bohunice foram usados para comparação com o modelo, e baseado nessa comparação o autor conclui que é possível monitorar o nível pela observação das freqüências naturais do vaso e seus internos.

Kodeli e Bignan (1997) apresentam trabalho onde estudaram a possibilidade de utilização do fluxo de nêutrons atrasados e de radiação gama medidos pela instrumentação nuclear externa ao vaso (ex-core) para obter informações sobre o nível no vaso. O uso da técnica de medida de nível usando os nêutrons atrasados foi descartada por uma série de fatores, principalmente pelo seu rápido decréscimo com o tempo após o desligamento do reator. $O$ uso do fluxo de radiação gama total 
apresentou-se como uma promessa para futuros trabalhos de pesquisa e desenvolvimento.

Hampel et al. (2003) apresentaram estudo para medida de nível em reatores Boiling Water Reactors (BWR's) utilizando dois métodos de medida. Um utiliza as informações de medida de nível hidrostática e métodos modernos de processamento de sinais e o outro usa as medidas de radiação gama provenientes do núcleo com a análise dos dados realizada por Redes Neurais Artificiais e Teoria de Lógica Nebulosa.

Habibiyan et al. (2004) propuseram um controlador de nível para geradores de vapor usando Redes Neurais Artificiais para melhorar o controle de nível. Cerca de $25 \%$ dos desligamentos (shutdowns) em reatores PWR's são causados por controles inadequados do nível nos geradores de vapor. Os parâmetros do gerador de vapor para vários níveis de potência de operação foram usados para o treinamento de redes neurais que posteriormente foram usadas no controlador. 
As sondas térmicas utilizadas para medir nível têm como princípio de funcionamento as diferenças de coeficientes de transferência de calor que ocorrem nas regiões da sonda e que depende do grau de inserção da mesma no fluido cujo nível se deseja medir. Nas sondas térmicas convencionais, que geralmente são aquecidas eletricamente, o fluxo de calor ocorre de dentro para fora da sonda, sendo que os maiores coeficientes de transferência de calor ocorrem na região da sonda em contato

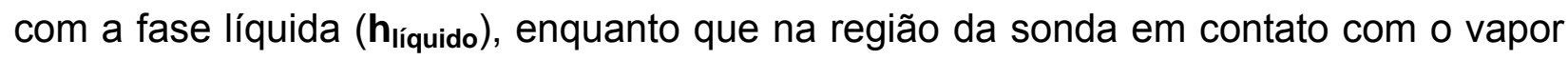
o coeficiente de transferência de calor é menor ( $\mathbf{h}_{\text {vapor }}$ ). Essas diferenças entre coeficientes de transferência de calor produzem diferenças de temperaturas na parede das sondas térmicas, as quais são usadas para medir o nível.

As sondas térmicas propostas para este trabalho são resfriadas internamente por um fluido de resfriamento, no caso a água, produzindo um fluxo de calor que vai da parte externa da parede da sonda para a parte interna da mesma, quando essas estiverem imersas num fluido mais quente. Devido ao fato dessas sondas térmicas serem concebidas para medir nível em vasos onde exista uma mistura saturada bifásica estratificada de água e vapor, ocorrerá preferencialmente o processo de condensação de vapor na região superior das sondas que estiver em contato com o vapor, com elevado coeficiente de transferência de calor ( $\mathbf{h}_{\text {vapor }}$ ), enquanto que na região da sonda em contato com a fase líquida ocorrerá a transferência de calor por um processo complexo de transferência de calor envolvendo condução e convecção ( $\boldsymbol{h}_{\text {líquido), }}$ com coeficientes de transferência de calor relativamente baixos, quando comparados aos do processo de condensação do vapor. Essa diferença também irá produzir diferenças nas temperaturas da parede das sondas que dependerão do nível de água no vaso e conseqüentemente do grau de inserção das sondas. As temperaturas de parede em função do nível de inserção das sondas e as temperaturas de entrada e saída do fluido de resfriamento constituirão "assinaturas de temperatura", as quais serão usadas como entradas conhecidas para o treinamento de Redes Neurais Artificiais (RNA's), que após treinadas deverão adquirir a capacidade 
de determinar o nível no vaso tendo como dados de entrada as informações de temperaturas das sondas.

Com base no exposto acima, foi elaborada uma metodologia para o desenvolvimento do trabalho, que incluiu os seguintes pontos:

- Elaboração de um modelo térmico para as sondas térmicas;

- Concepção, projeto, fabricação e montagem de uma Bancada Experimental para a realização dos testes;

- Concepção, projeto, fabricação e montagem das sondas térmicas;

- Calibração dos instrumentos da Bancada Experimental e das sondas térmicas;

- Montagem de um Sistema de Aquisição de Dados e elaboração de um programa para a aquisição dos dados experimentais;

- Realização dos testes com as sondas e obtenção dos dados experimentais; e

- Estudo das RNA's e aplicação de um programa de RNA's para a análise dos dados experimentais; e

Para a concretização dos objetivos propostos para este trabalho, contou-se com recursos, principalmente, do Projeto de Pesquisa submetido junto ao CNPQ (CTEnerg), aprovado em dezembro de 2003 com o título "Desenvolvimento de um medidor de nível em pressurizadores e vasos de pressão de reatores integrados utilizando sondas de temperatura e técnicas de inteligência artificial". Recursos de menor monta, porém indispensáveis ao andamento do trabalho, também foram disponibilizados pelo Centro de Engenharia Nuclear (CEN) durante a montagem da Bancada Experimental e das Sondas Térmicas. 


\subsection{Modelo térmico das sondas}

Um modelo unidimensional do problema térmico foi desenvolvido com o objetivo de fornecer subsídios para o projeto das sondas, tais como, materiais a serem usados, diâmetros de tubos e fluidos de resfriamento. Dois tipos de sondas foram avaliados pelo modelo, ou seja, Sonda de Tubos Concêntricos e Sonda de Tubo U, como é mostrado na FIG. 4.1. O "software" Engineering Equation Solver (EES) desenvolvido por Klein e Alvarado (2001) foi usado para a resolução do conjunto de equações de conservação de massa e energia do modelo, em regime estacionário. As equações foram programadas no EES de forma a permitir variações em parâmetros tais como: material de construção da sonda, comprimento das sondas, comprimento da sonda imerso na fase líquida, número de nós de discretização nas fases líquida e de vapor, fluido de resfriamento, vazão de fluido de resfriamento, coeficiente de transferência de calor de condensação (fase de vapor) e no coeficiente de transferência de calor de convecção natural (fase líquida). Os resultados de dois casos analisados, um para cada tipo de sonda, são mostrados nas FIG. 4.2 e 4.3. Observa-se a existência de descontinuidades na temperatura da parede das sondas decorrente da diferença entre os coeficientes de transferência de calor. Essas descontinuidades, somadas às demais informações contidas nas temperaturas de entrada e saída do fluido de resfriamento medidas pelos termopares instalados nas sondas serão usadas no treinamento de redes neurais artificiais, que posteriormente serão capazes de identificar o nível, tendo como entrada as informações de temperatura.

Neste modelo térmico utilizaram-se coeficientes de transferência de calor constantes para as regiões de líquido e vapor. Em trabalhos futuros este modelo térmico poderá ser melhorado com a introdução de correlações para coeficiente de transferência de calor mais representativas das condições reais que ocorrem na parede das sondas quando no interior das seções de testes da Bancada Experimental. 


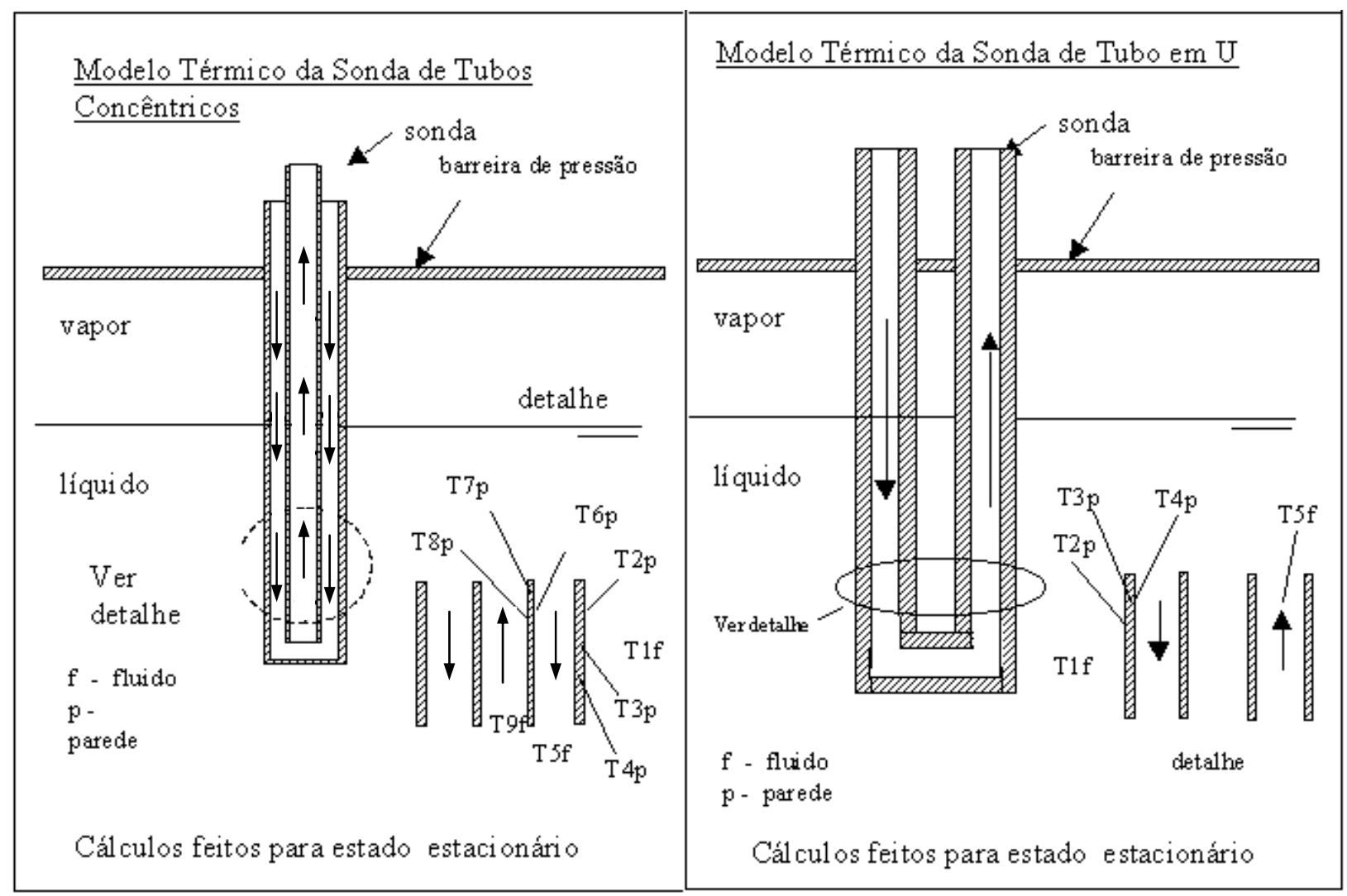

FIGURA 4.1. Modelo térmico para a Sonda de Tubos Concêntricos e Sonda de Tubo U.
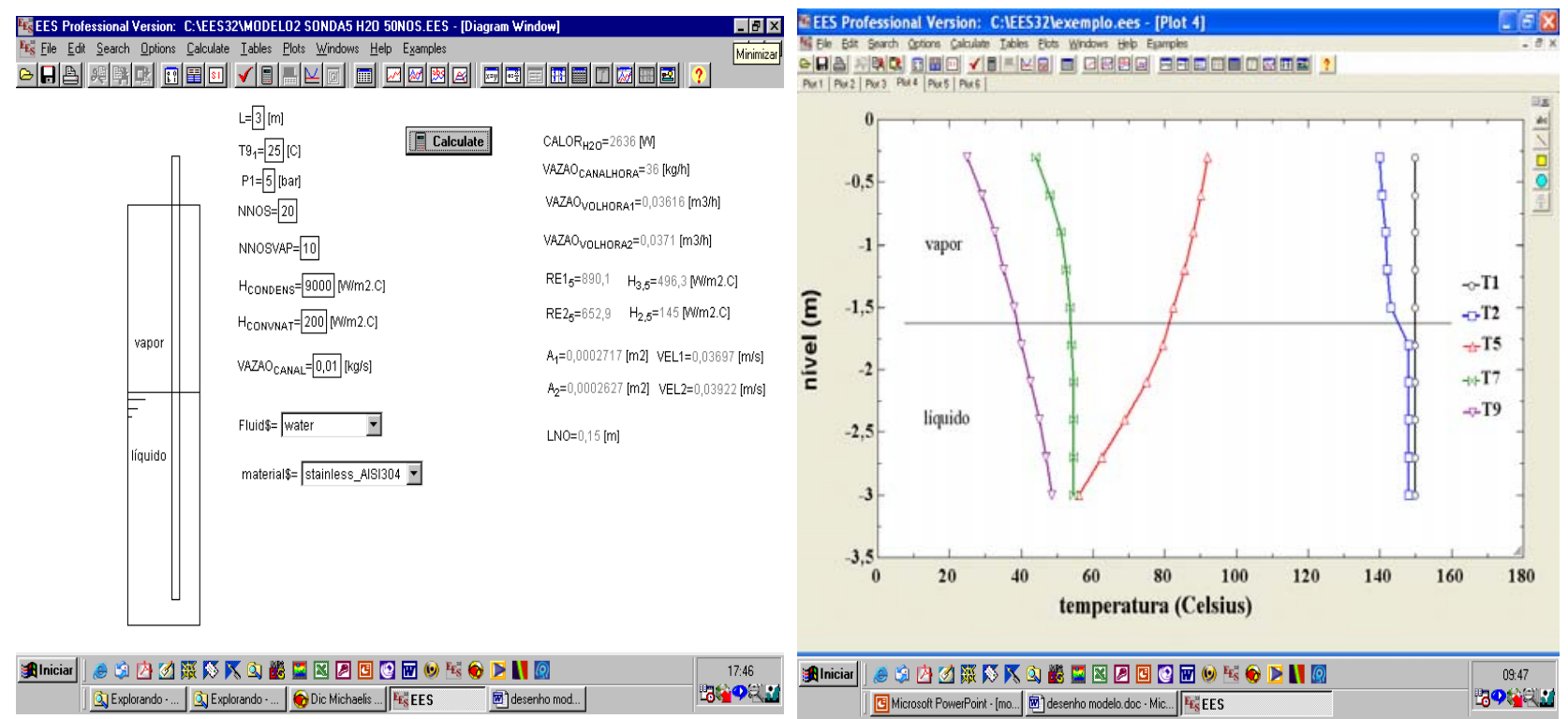

FIGURA 4.2. Temperatura no fluido e na parede da Sonda de Tubos Concêntricos. 


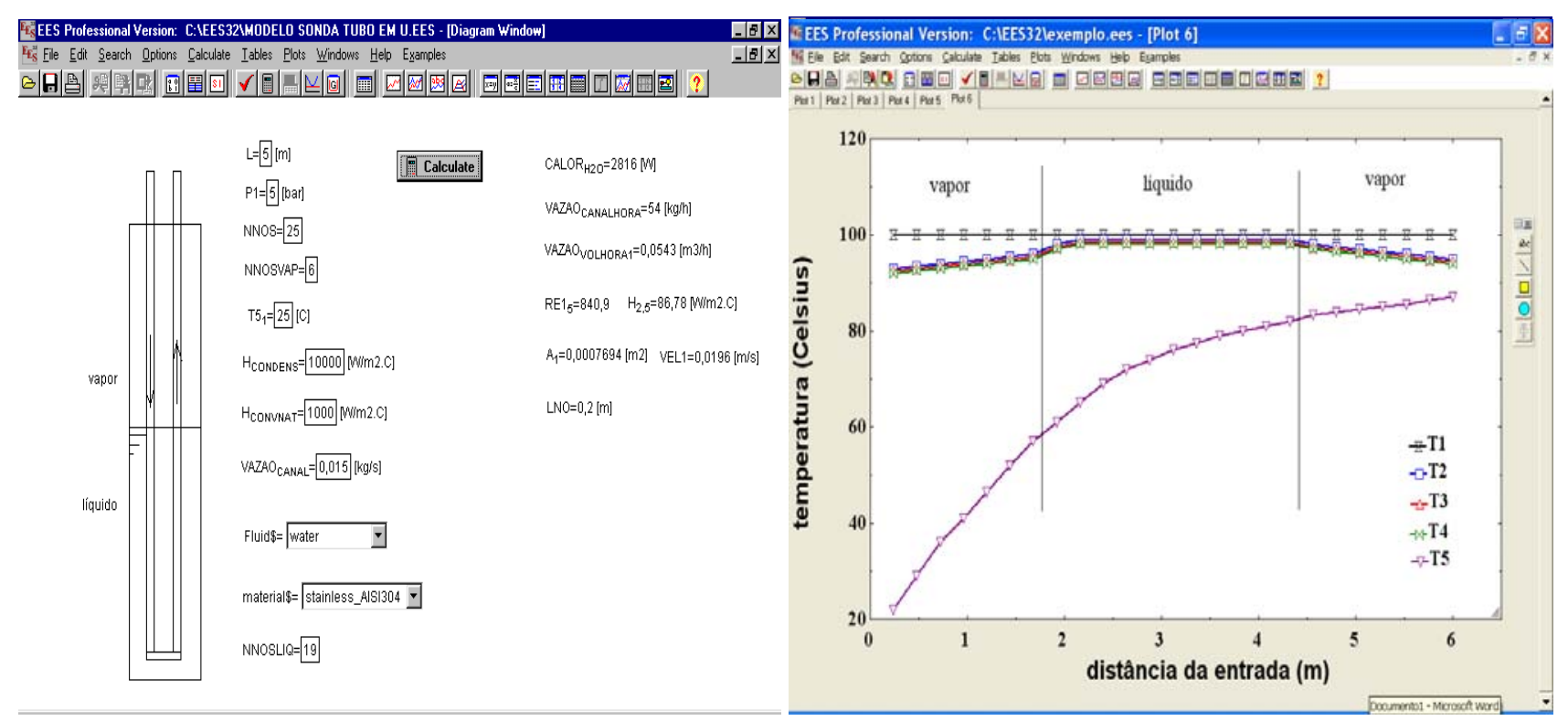

FIGURA 4.3. Temperatura no fluido e na parede da Sonda de Tubo U.

\subsection{Bancada Experimental para Testes de Sondas de Nível (BETSNI)}

A Bancada Experimental para Testes de Sondas de NIvel (BETSNI) foi concebida, projetada e construída para a realização dos testes. Ela permite realizar testes em pressões de até 0,3 MPa (3 bar), e consiste basicamente de duas seções de testes verticais ST1 e ST2 com $5 \mathrm{~m}$ de altura cada. As seções de testes foram fabricadas usando tubos de 4 polegadas e schedule 10S, de aço inoxidável ASTM 312 com costura, cujas dimensões são: diâmetro externo igual a 114,3 mm, diâmetro interno igual a 108,2 $\mathrm{mm}$ e espessura de parede igual a 3,05 mm. As extremidades das seções de testes ST1 e ST2 possuem flanges soldados. Na extremidade inferior, os flanges de fechamento das seções de testes possuem luvas de $1 \frac{1}{4}$ de polegada com rosca NPT para permitir a instalação dos aquecedores elétricos. Na extremidade superior, os flanges de fechamento são parte integrante das sondas. As seções de testes ST1 e ST2 também possuem visores de nível fabricados com vidro de borosilicato resistente à temperatura. Soldadas em cada uma das seções de testes, existem seis luvas de $1 / 2$ 
polegada com rosca NPT para a instalação dos termopares para medir a temperatura de processo. Para medir o nível colapsado de água, cada uma das seções de testes possui um sistema que fornece diretamente a informação de nível durante os testes. Esse sistema é composto por um transmissor de pressão diferencial especialmente calibrado, um pote de condensação dotado de manômetro, tubulações e válvula do tipo "manifold". Cada seção de testes possui ainda uma válvula de alívio/segurança para atuar caso ocorra aumento indesejável na pressão do sistema; possui também outras válvulas agulha de aço inoxidável de $1 / 2$ polegada que permitem a interligação entre elas, funcionam como respiro e dreno, e permitem a alimentação da bancada com água tratada por um deionizador. Tubulações de aço inoxidável com diâmetro externo igual a $12 \mathrm{~mm}$ e espessura de parede de $1 \mathrm{~mm}$, foram utilizadas na interligação das válvulas com a bancada, assim como conexões de aço inoxidável dotadas de anilhas metálicas do mesmo material. As seções ST1 e ST2 foram isoladas termicamente com material isolante (tubos bipartidos de silicato de cálcio) com 4 polegadas de diâmetro interno e $40 \mathrm{~mm}$ de espessura, e posteriormente recobertas com chapas de alumínio com 0,5 $\mathrm{mm}$ espessura. A bancada tem dois rotâmetros, um para cada seção de testes, com capacidade de medida de $0-0,25 \mathrm{~m}^{3} / \mathrm{h}(0-0,069 \mathrm{~kg} / \mathrm{s})$, para medir a vazão de resfriamento das sondas. Os aquecedores são do tipo $U$ invertido com dois elementos cada, sendo que cada elemento contribui com aproximadamente a metade da potência total dissipada nos aquecedores. Eles possuem potência nominal de $9 \mathrm{~kW}$ e $3 \mathrm{~kW}$, e são alimentados pela rede normal de energia com uma tensão nominal de $220 \mathrm{Vac}$. Durante os testes, o valor real da tensão de alimentação variou entre 203 e $217 \mathrm{~V}_{\mathrm{ac}}$ e foi medido com um multímetro digital portátil.

Na FIG. 4.4 é mostrado um desenho simplificado da bancada experimental BETSNI, enquanto que detalhes da bancada experimental durante e após sua montagem são mostrados nas FIG. 4.5 e 4.6. Na FIG. 4.7 são mostrados detalhes da região superior das seções de testes, tais como: os potes de condensação, as válvulas de alívio e segurança, a válvula de equalização, e ainda os rotâmetros e o deionizador de água. 


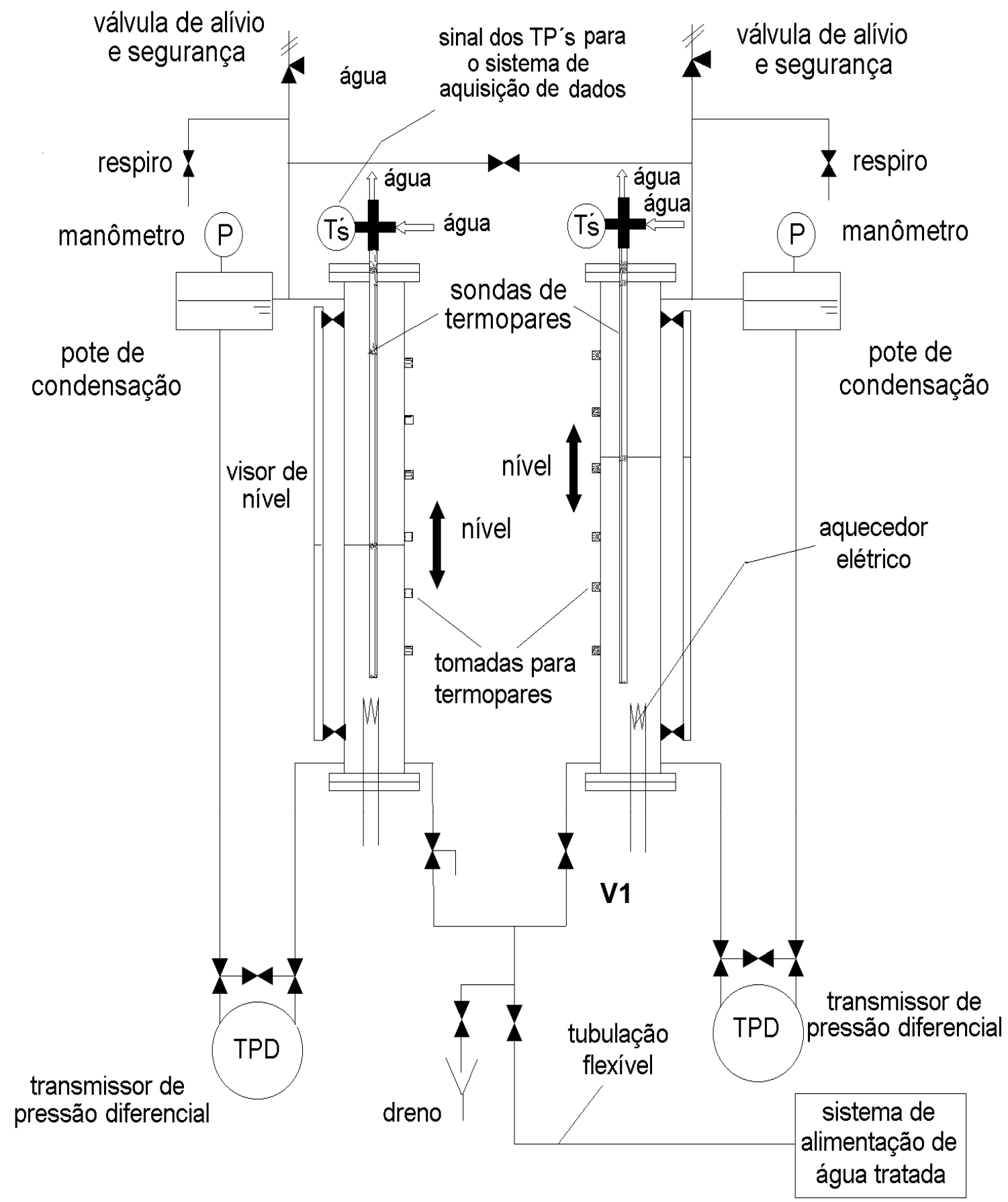

FIGURA 4.4. Bancada Experimental para Testes de Sondas de Nível - BETSNI. 


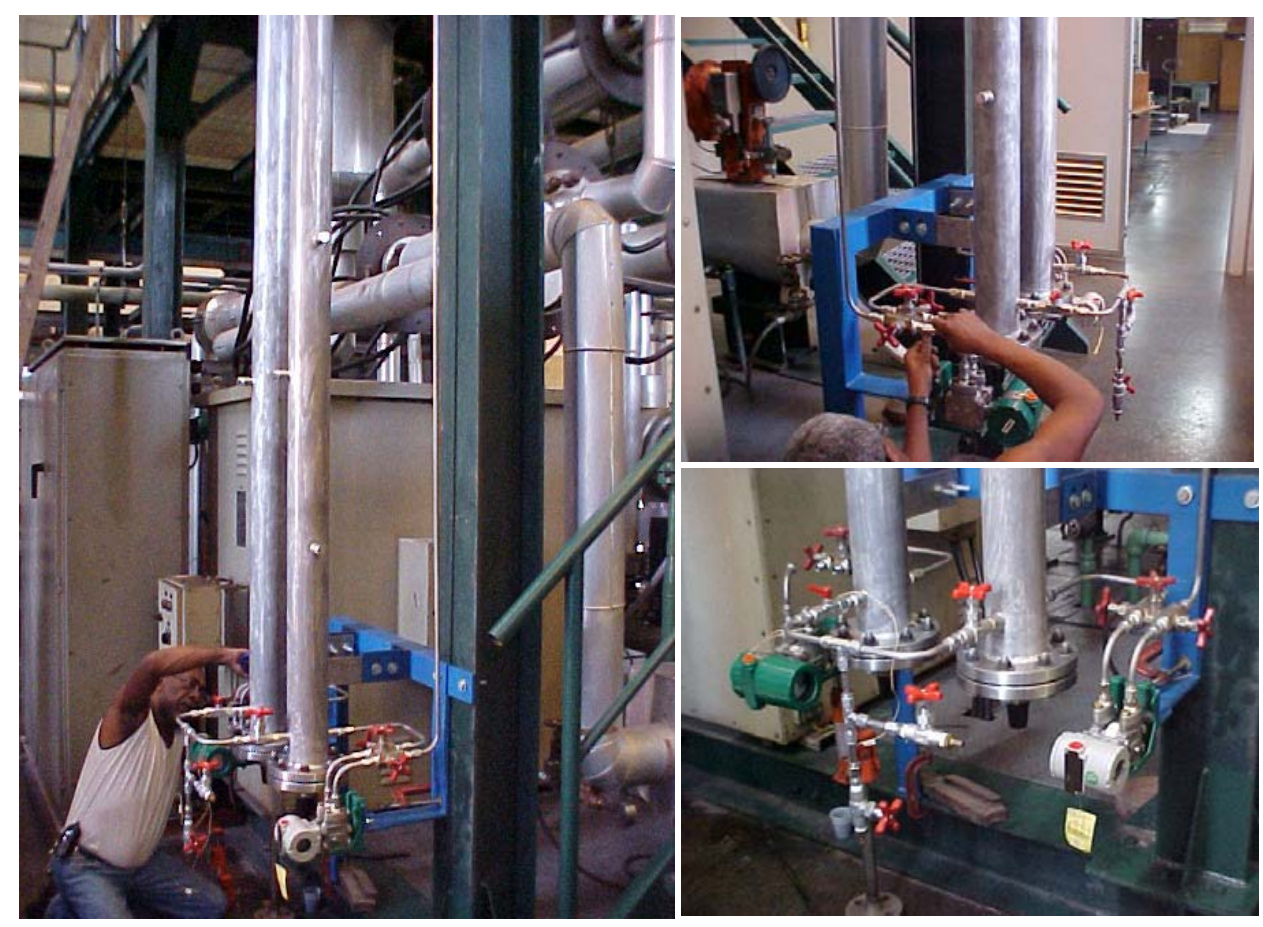

FIGURA 4.5. Bancada Experimental na fase de montagem. Detalhes da região inferior com os transmissores de pressão diferencial, as válvulas e as tubulações.

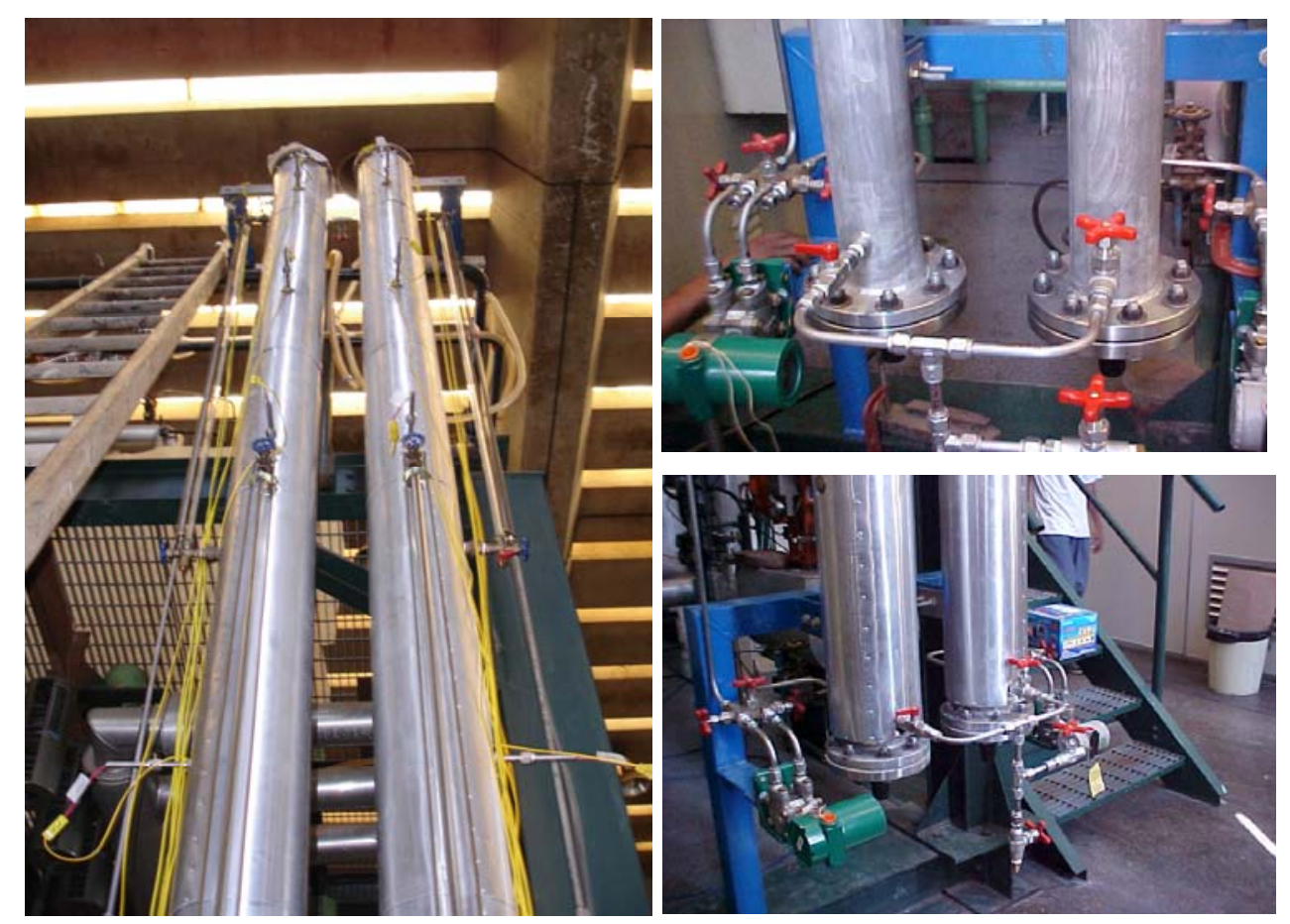

FIGURA 4.6. Bancada experimental após montagem. Detalhes da mostrando os visores de nível e suas válvulas e os termopares de processo; e região inferior. 

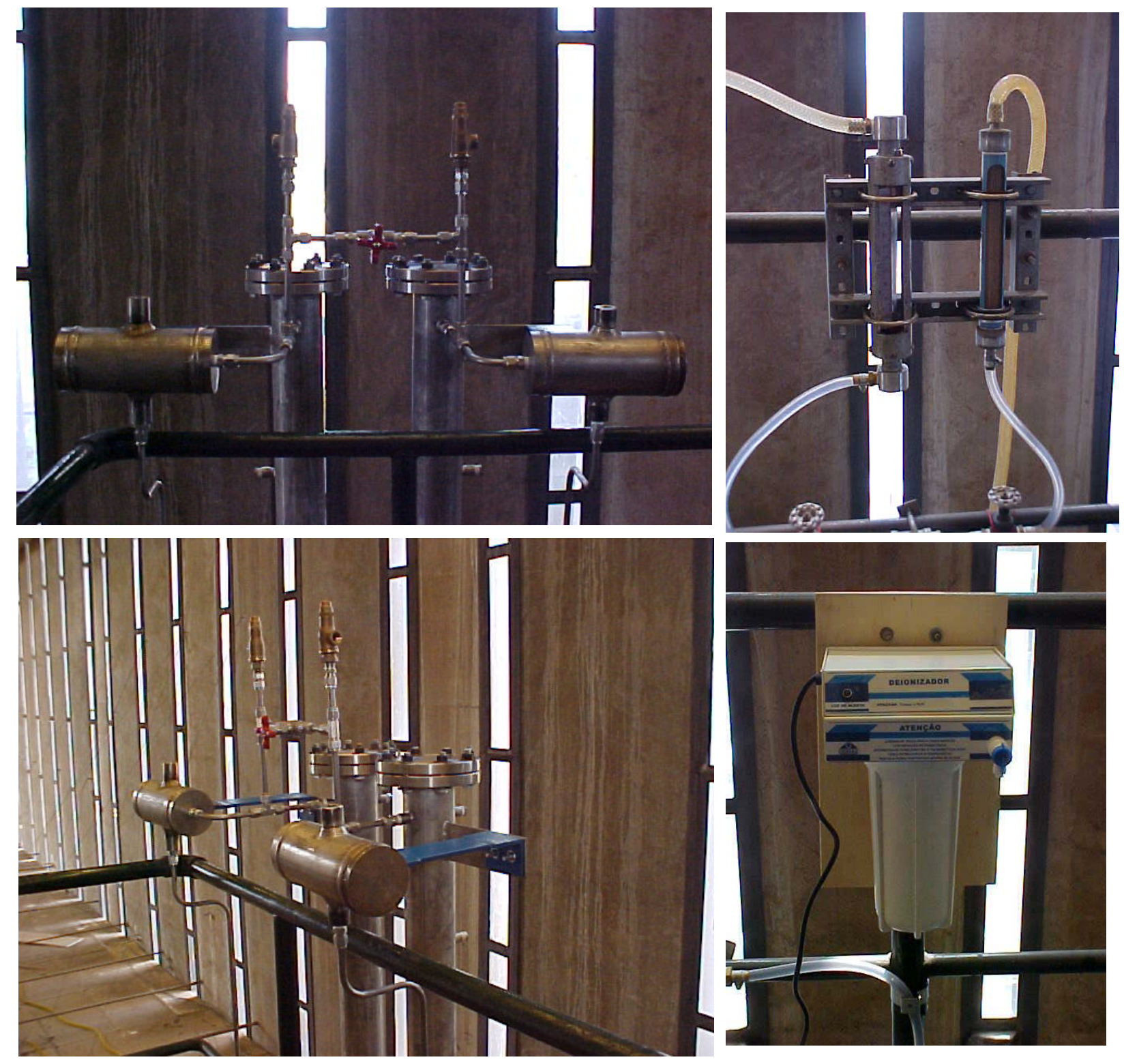

FIGURA 4.7. Bancada experimental. Detalhes da região superior das seções de testes mostrando os potes de condensação, as válvulas de alívio e segurança, a válvula de equalização, os rotâmetros e do deionizador de água. 


\subsection{Sondas Térmicas de Medida de Nível}

Para a realização dos testes de medida de nível foram projetados e construídos dois tipos de sondas térmicas, ou seja, Sonda de Tubos Concêntricos e Sonda de Tubo U, descritas a seguir.

\subsubsection{Sonda de Tubos Concêntricos}

Este tipo de sonda, como o próprio nome indica, consiste de dois tubos concêntricos de aço inoxidável 304 com $3 \mathrm{~m}$ de comprimento, sendo que o tubo externo possui diâmetro externo de $38,1 \mathrm{~mm}$, diâmetro interno de $35,1 \mathrm{~mm}$ e espessura de parede de 1,5 mm. O tubo interno possui diâmetro externo de $19,05 \mathrm{~mm}$, diâmetro interno de 16,65 mm e espessura de parede de 1,2 $\mathrm{mm}$. O fluido de resfriamento entra na sonda através da região anular formada pelos dois tubos, percorre o caminho de descida até a extremidade inferior onde muda de direção retornando através do tubo interno. Na região inferior do tubo externo foi soldada uma peça que tem a função de fechar a extremidade do tubo externo e também servir como guia para manter o tubo interno centralizado. $O$ tubo interno também possui uma peça soldada na extremidade inferior e possui rasgos laterais na extremidade inferior que permitem a passagem e a mudança de direção de escoamento do fluido de resfriamento em seu retorno.

Nesta sonda foram instalados, na parede do tubo externo, 12 termopares do tipo K (Chromel-Alumel) não aterrados de $1 \mathrm{~mm}$ de diâmetro de camisa. Os termopares foram fixados na parede usando abraçadeiras de aço inoxidável de 0,5 mm de espessura e $5 \mathrm{~mm}$ de largura e parafusos também em aço inoxidável. Os termopares foram instalados nas seguintes posições, contadas a partir da extremidade inferior da sonda: $800 \mathrm{~mm}$ (TC1-11), $1000 \mathrm{~mm}$ (TC1-12), $1150 \mathrm{~mm}$ (TC1-13), $1300 \mathrm{~mm}$ (TC1-14), 1400 mm (TC1-15), 1500 mm (TC1-16), 1600 mm (TC1-17), 1700 mm (TC1-18), 1850 mm (TC1-19), 2000 mm (TC1-20), 2200 mm (TC1-21), 2400 mm (TC1-22). Desta forma, essa sonda possui uma região instrumentada com $1600 \mathrm{~mm}$ de comprimento, conforme é mostrado na FIG. 4.8. Outros dois termopares do tipo K (Chromel-Alumel) 
aterrados de $12 \mathrm{~mm}$ de diâmetro de camisa (TC1-07 e TC1-08) foram instalados na sonda para medir as temperaturas de entrada e saída da água de resfriamento. Esta sonda foi instalada na seção de testes ST1.
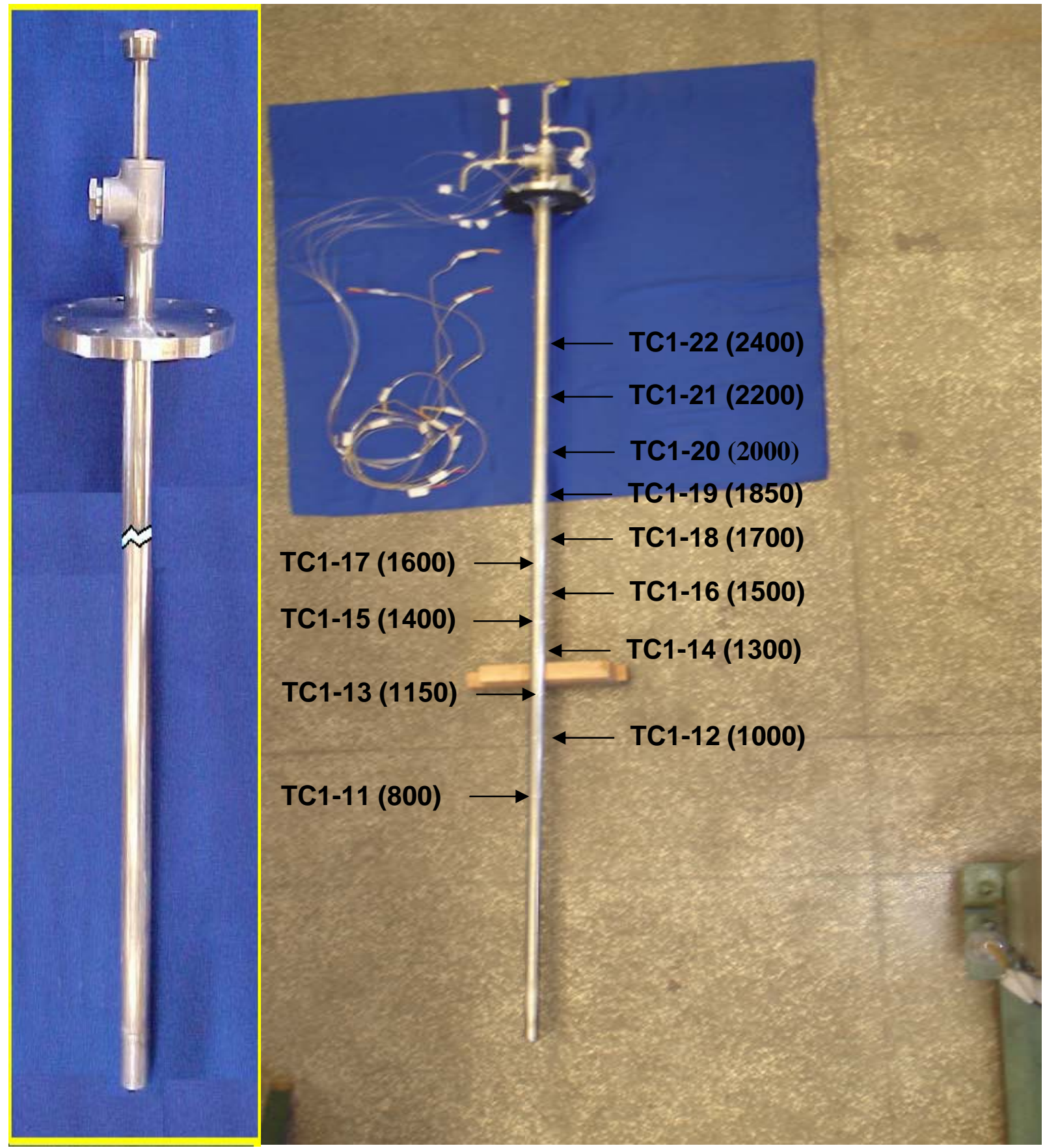

FIGURA 4.8. Sonda de tubos concêntricos e posição dos termopares instalados na parede. 


\subsubsection{Sonda de Tubo U}

Este tipo de sonda consiste de um tubo de aço inoxidável 304 em forma de U, com diâmetro externo de 19,05 mm, diâmetro interno de $16,65 \mathrm{~mm}$ e espessura de parede de 1,2 mm. O comprimento total do tubo é de $6,0 \mathrm{~m}$, sendo $3,0 \mathrm{~m}$ em cada trecho (descendente e ascendente) do $\mathrm{U}$. O fluido de resfriamento entra na sonda, percorre o trecho de descendente até a extremidade inferior onde muda de direção retornando pelo trecho ascendente. Nas extremidades do tubo $U$ existem conexões do tipo $T$ que permitem a alimentação da água de resfriamento da sonda e a instalação de termopares para medir a temperatura de entrada e saída da água. A sonda de tubo $U$ é mostrada na FIG. 4.9, e foi instalada na seção de testes ST2.

Nesta sonda foram instalados, na parede do tubo $\mathrm{U}, 12$ termopares do tipo $\mathrm{K}$ (Chromel-Alumel) não aterrados de $1 \mathrm{~mm}$ de diâmetro. Os termopares foram fixados na parede usando abraçadeiras de aço inoxidável de $0,5 \mathrm{~mm}$ de espessura e $5 \mathrm{~mm}$ de largura e parafusos também em aço inoxidável. Os termopares foram instalados no trecho descendente do tubo $U$ nas seguintes posições, contadas a partir da extremidade inferior da sonda: $800 \mathrm{~mm}$ (TC2-11), $1000 \mathrm{~mm}$ (TC2-12), $1150 \mathrm{~mm}$ (TC213), $1300 \mathrm{~mm}$ (TC2-14), $1400 \mathrm{~mm}$ (TC2-15), $1500 \mathrm{~mm}$ (TC2-16), $1600 \mathrm{~mm}$ (TC2-17), $1700 \mathrm{~mm}$ (TC2-18), $1850 \mathrm{~mm}$ (TC2-19), 2000 mm (TC2-20), $2200 \mathrm{~mm}$ (TC2-21), 2400 mm (TC2-22). Desta forma, essa sonda possui uma região instrumentada com 1600 $\mathrm{mm}$ de comprimento. Outros dois termopares do tipo $\mathrm{K}$ (Chromel-Alumel) aterrados de $12 \mathrm{~mm}$ de diâmetro de camisa (TC2-07 e TC2-08) foram instalados para medir as temperaturas de entrada e saída da água de resfriamento da sonda.

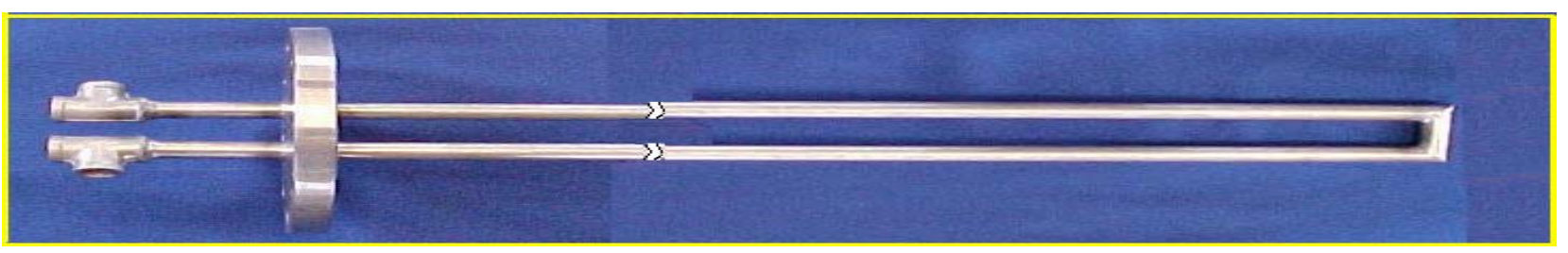

FIGURA 4.9. Sonda de Tubo U. 
A posição relativa dos termopares instalados nas sondas de tubos concêntricos e na sonda de tubo $U$ é apresentada na TAB. 4.1.

TABELA 4.1. Posição relativa dos termopares das sondas nas seções de testes ST1 e ST2.

\begin{tabular}{|c|c|c|c|c|c|}
\hline \multicolumn{3}{|c|}{ Sonda de Tubos Concêntricos } & \multicolumn{3}{|c|}{ Sonda de Tubo U } \\
\hline Termopar & $\begin{array}{l}\text { Posição do } \\
\text { termopar } \\
\text { na sonda }\end{array}$ & $\begin{array}{l}\text { Posição } \\
\text { relativa na } \\
\text { ST1 }\end{array}$ & Termopar & $\begin{array}{l}\text { Posição do } \\
\text { termopar } \\
\text { na sonda }\end{array}$ & $\begin{array}{l}\text { Posição } \\
\text { relativa na } \\
\text { ST2 }\end{array}$ \\
\hline & $(\mathrm{mm})$ & $(\mathrm{mm})$ & & $(\mathrm{mm})$ & $(\mathrm{mm})$ \\
\hline TC1-07 & entrada & & TC2-07 & entrada & \\
\hline TC1-08 & saída & & TC2-08 & saída & \\
\hline TC1-11 & 800 & 2766 & TC2-11 & 800 & 2766 \\
\hline TC1-12 & 1000 & 2966 & TC2-12 & 1000 & 2966 \\
\hline TC1-13 & 1150 & 3166 & TC2-13 & 1150 & 3166 \\
\hline TC1-14 & 1300 & 3266 & TC2-14 & 1300 & 3266 \\
\hline TC1-15 & 1400 & 3366 & TC2-15 & 1400 & 3366 \\
\hline TC1-16 & 1500 & 3466 & TC2-16 & 1500 & 3466 \\
\hline TC1-17 & 1600 & 3566 & TC2-17 & 1600 & 3566 \\
\hline TC1-18 & 1700 & 3666 & TC2-18 & 1700 & 3666 \\
\hline TC1-19 & 1850 & 3816 & TC2-19 & 1850 & 3816 \\
\hline TC1-20 & 2000 & 3966 & TC2-20 & 2000 & 3966 \\
\hline TC1-21 & 2200 & 4166 & TC2-21 & 2200 & 4166 \\
\hline TC1-22 & 2400 & 4366 & TC2-22 & 2400 & 4366 \\
\hline \multicolumn{3}{|c|}{$\begin{array}{c}\text { Obs: A referência (zero) na ST1 é a } \\
\text { posição, na região inferior, onde está a } \\
\text { conexão de tomada de alta pressão do } \\
\text { TPD1 }\end{array}$} & \multicolumn{3}{|c|}{$\begin{array}{l}\text { Obs: A referência (zero) na ST2 é a } \\
\text { posição, na região inferior, onde está a } \\
\text { conexão de tomada de alta pressão do } \\
\text { TPD2 }\end{array}$} \\
\hline
\end{tabular}




\subsubsection{Cálculo do tempo de trânsito do fluido de resfriamento nas sondas}

O tempo de trânsito do fluido nas sondas é função da vazão de resfriamento imposta às sondas e das áreas de escoamento por onde passa o fluido. O tempo de resposta das sondas não será inferior a este tempo.

Para a sonda tipo tubo $U$ temos uma área de escoamento igual a $A_{U}=2,177 \times 10^{-4} \mathrm{~m}^{2}$, e um comprimento medido entre as posições ocupadas pelos termopares que medem as temperaturas de entrada TC2-07 e de saída TC2-08 igual a $L_{U}=6,315 \mathrm{~m}$. O tempo de trânsito do fluido $\Delta t_{U}$ é calculado pela relação entre comprimento $L_{U}$ e velocidade de escoamento $V$. O tempo de trânsito, $\Delta t_{U t p}$, considerando apenas a região onde estão instalados os termopares da parede da sonda é calculado da mesma forma, porém com $L_{U}=1,6 \mathrm{~m}$, que é a distância entre os termopares TC2-11 e TC2-22. A TAB. 4.2 mostra os resultados dos cálculos para a sonda tipo tubo $U$.

TABELA 4.2. Tempo de trânsito $\Delta t_{\cup} e \Delta t_{U t p}$ do fluido na Sonda de Tubo U.

\begin{tabular}{ccccc}
\hline $\begin{array}{c}\text { Vazão } \\
(\mathrm{I} / \mathrm{h})\end{array}$ & $\begin{array}{c}\text { Vazão } \\
\left(\mathrm{m}^{3} / \mathrm{s}\right)\end{array}$ & $\begin{array}{c}\text { Velocidade } \\
(\mathrm{m} / \mathrm{s})\end{array}$ & $\begin{array}{c}\Delta \mathrm{t}_{\mathrm{U}} \\
(\mathrm{s})\end{array}$ & $\begin{array}{c}\Delta \mathrm{t}_{\mathrm{utp}} \\
(\mathrm{s})\end{array}$ \\
\hline 60 & $1,667 \times 10^{-5}$ & 0,0766 & 82,48 & 20,90 \\
70 & $1,944 \times 10^{-5}$ & 0,0893 & 70,73 & 17,92 \\
80 & $2,222 \times 10^{-5}$ & 0,1021 & 61,88 & 15,68 \\
90 & $2,500 \times 10^{-5}$ & 0,1148 & 55,00 & 13,93 \\
100 & & & & \\
& $2,778 \times 10^{-5}$ & 0,1276 & 49,50 & 12,54 \\
\hline
\end{tabular}


Para a sonda tipo tubos concêntricos deve-se separar em dos trechos, ou seja, trecho de descida do fluido (região anular) e trecho de subida (região circular). Para a região anular a área de escoamento é igual $A_{A}=6,826 \times 10^{-4} \mathrm{~m}^{2}$, enquanto que para a região circular, a área de escoamento é igual a $A_{C}=2,177 \times 10^{-4} \mathrm{~m}^{2}$. Os comprimentos das duas regiões são ligeiramente diferentes e iguais a $L_{A}=3,145 \mathrm{~m}$ e $L_{C}=3,270 \mathrm{~m}$, respectivamente para as regiões anular e circular. O tempo de trânsito $\Delta \mathrm{t}_{\mathrm{TC}}$ do fluido na sonda é a soma dos tempos nas duas regiões $\Delta \mathrm{t}_{\mathrm{TCA}}{ }_{\mathrm{e}} \Delta \mathrm{t}_{\mathrm{TCC}}$. O tempo de trânsito, $\Delta \mathrm{t}_{\mathrm{TCtp}}$, considerando apenas a região onde estão instalados os termopares da parede da sonda é calculado da mesma forma, porém com $L_{A}=1,600 \mathrm{~m}$, que é a distância entre os termopares TC1-11 e TC1-22 e com a velocidade de escoamento referente à região anular. A TAB. 4.3 mostra os resultados dos cálculos para a sonda tipo tubos concêntricos.

TABELA 4.3. Tempo de trânsito $\Delta \mathrm{t}_{\mathrm{TC}}$ e $\Delta \mathrm{t}_{\mathrm{TCtp}}$ do fluido na Sonda de Tubos Concêntricos.

\begin{tabular}{|c|c|c|c|c|c|c|c|}
\hline $\begin{array}{c}\text { Vazão } \\
\text { (l/h) }\end{array}$ & $\begin{array}{l}\text { Vazão } \\
\left(\mathrm{m}^{3} / \mathrm{s}\right)\end{array}$ & $\begin{array}{c}\text { Velocidade } \\
V_{\mathrm{A}} \\
(\mathrm{m} / \mathrm{s})\end{array}$ & $\begin{array}{c}\Delta \mathrm{t}_{\mathrm{TCA}} \\
(\mathrm{s})\end{array}$ & $\begin{array}{c}\text { Velocidade } \\
V_{C} \\
(\mathrm{~m} / \mathrm{s})\end{array}$ & $\begin{array}{c}\Delta \mathrm{t}_{\mathrm{TCC}} \\
(\mathrm{s})\end{array}$ & $\begin{array}{c}\Delta \mathrm{t}_{\mathrm{TC}} \\
(\mathrm{s})\end{array}$ & $\begin{array}{c}\Delta \mathrm{t}_{\mathrm{TCtp}} \\
\text { (s) }\end{array}$ \\
\hline 60 & $1,667 \times 10^{-5}$ & 0,0244 & 128,79 & 0,0766 & 42,71 & 171,50 & 65,52 \\
\hline 70 & $1,944 \times 10^{-5}$ & 0,0285 & 110,43 & 0,0893 & 36,63 & 147,06 & 56,18 \\
\hline 80 & $2,222 \times 10^{-5}$ & 0,0326 & 96,62 & 0,1021 & 32,04 & 128,66 & 49,15 \\
\hline 90 & $2,500 \times 10^{-5}$ & 0,0366 & 85,88 & 0,1148 & 28,48 & 114,36 & 43,69 \\
\hline 100 & $2,778 \times 10^{-5}$ & 0,0407 & 77,27 & 0,1276 & 25,63 & 102,90 & 39,31 \\
\hline
\end{tabular}




\subsection{Calibração dos Instrumentos}

O conjunto experimental formado pela Bancada Experimental BETSNI e pelas sondas de tubos concêntricos e de tubo $U$, possui termopares, transmissores de pressão diferencial e rotâmetros, os quais foram previamente calibrados antes de sua utilização nos testes, conforme descrito a seguir.

\subsubsection{Termopares}

Termopares aterrados do tipo $\mathrm{K}$, com camisa de aço inoxidável de $12 \mathrm{~mm}$ de diâmetro e $160 \mathrm{~mm}$ de comprimento, mostrados na FIG. 4.10, foram especialmente montados no IPEN, para a instalação nas seções de testes ST1 e ST2 da bancada experimental, como termopares para medida de temperatura de processo, e nas sondas de tubos concêntricos e de tubo $U$ para a medida das temperaturas de entrada e saída da água de resfriamento. Estes termopares (dezesseis) foram montados utilizando fios de termopares do tipo $\mathrm{K}$ com isolamento de tecido de lã de vidro. Os fios foram acomodados dentro de um tubo de aço inoxidável 304 com $12 \mathrm{~mm}$ de diâmetro externo e $1 \mathrm{~mm}$ de espessura de parede. Foram utilizadas miçangas de material cerâmico para isolar os fios do termopar da parede metálica. A extremidade sensível do termopar foi soldada em uma peça de aço inoxidável que também tem a finalidade de fechar o tubo. A soldagem foi realizada usando o processo TIG (Tungsten Inert Gas).

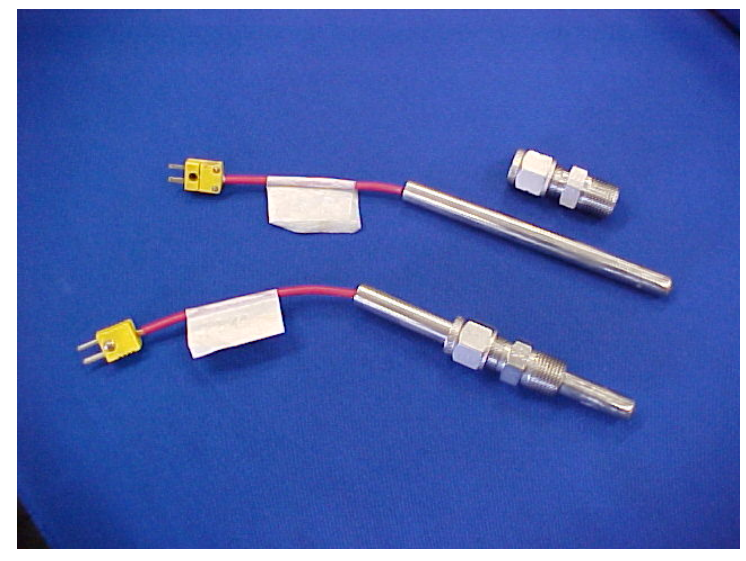

FIGURA 4.10. Termopares do tipo K montados no IPEN. 
Estes termopares foram calibrados no Laboratório de Calibração (LAC) do Centro de Engenharia Nuclear (CEN), na faixa de 35 a $90^{\circ} \mathrm{C}$. Na calibração destes termopares foi usado um forno modelo Isocal 6 Vênus 2125B da Isotech, que produz banho térmico de água com temperatura controlada. Como padrão de comparação foi usado um RTD (PT100) calibrado. Um multímetro digital HP 34401A foi usado para medir a resistência do PT100 e um calibrador microprocessado Cappo 10 da Ecil para medir o sinal de temperatura dos termopares. Os resultados da calibração destes termopares podem ser vistos no APÊNDICE A.

Os termopares usados para medir as temperaturas na parede das sondas também são do tipo K, não aterrados, com camisa de aço inoxidável e diâmetro externo $1 \mathrm{~mm}$, com $4000 \mathrm{~mm}$ de comprimento da IOPE, como mostrado na FIG. 4.11. Estes termopares foram calibrados na faixa de 35 a $150^{\circ} \mathrm{C}$ usando um forno Júpiter $650 \mathrm{~B}$ da Isotech, que produz temperatura controlada num bloco térmico metálico, e como padrão de comparação foi usado um RTD (PT100) calibrado. Um multímetro digital HP 34401A foi usado para medir a resistência do PT100 e um calibrador microprocessado Cappo 10 da Ecil para medir o sinal de temperatura dos termopares. Os resultados da calibração destes termopares podem ser vistos no APÊNDICE A. O conjunto formado pelos equipamentos utilizados na calibração é mostrado na FIG. 4.12.

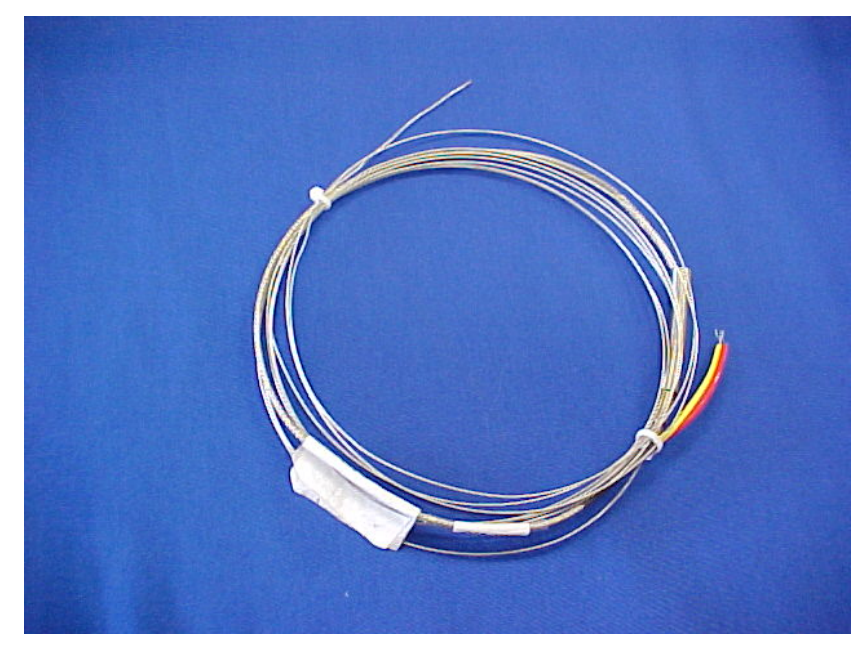

FIGURA 4.11. Termopares do tipo K para medir a temperatura de parede nas sondas. 


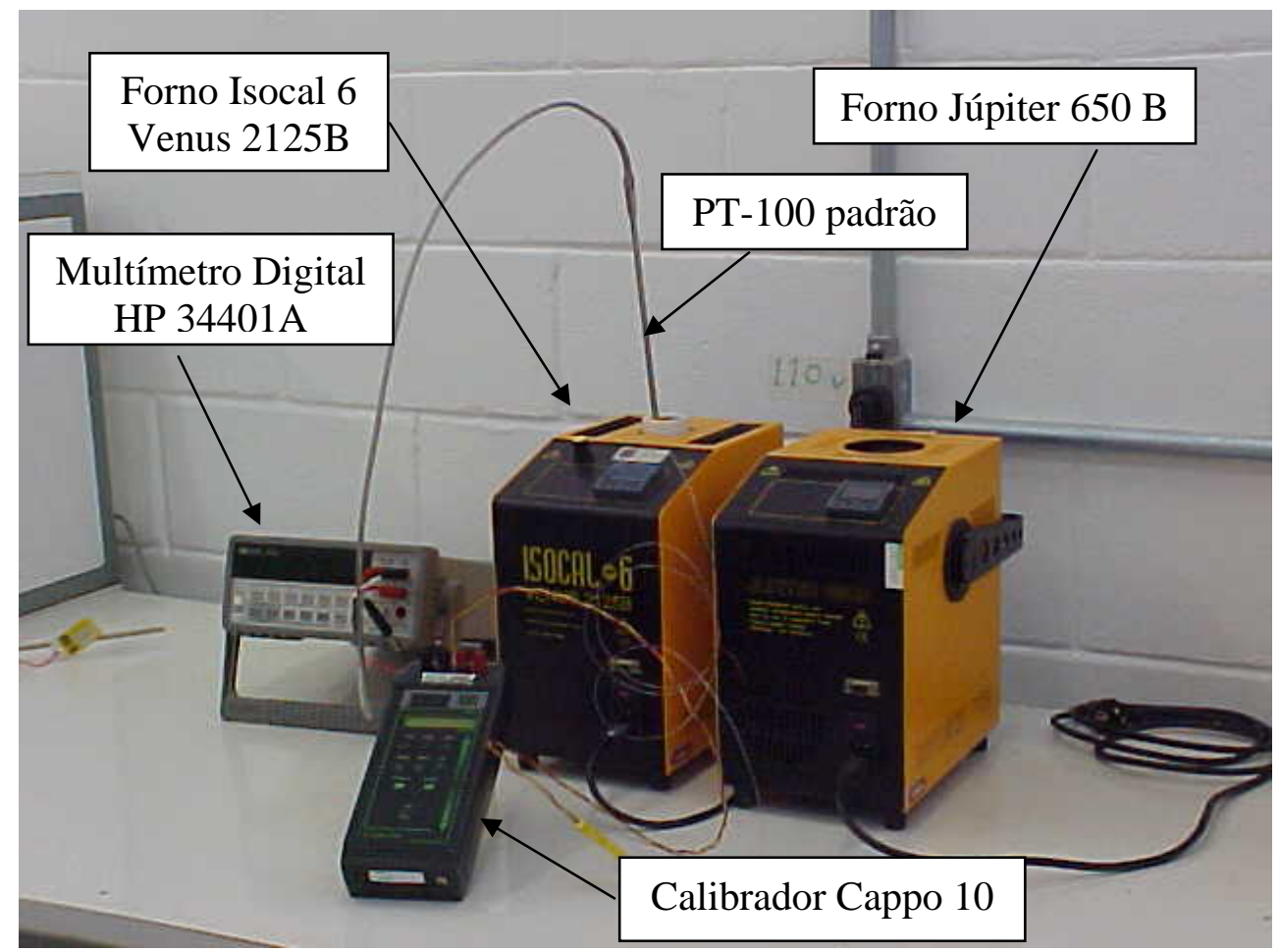

FIGURA 4.12. Conjunto de equipamentos/instrumentos usados na calibração dos termopares. Fornos, multímetro digital, CAPPO 10 e PT-100.

\subsubsection{Transmissores de Pressão Diferencial}

Os dois transmissores de pressão diferencial usados para medir o nível nas seções de testes ST1 e ST2, um da marca Fisher (ST1) e outro da marca SMAR (ST2), foram calibrados na faixa de $0-5000 \mathrm{mmH} 2 \mathrm{O}(0-48980 \mathrm{~Pa})$. Nas calibrações destes instrumentos foram usados: um timoneiro, um calibrador microprocessado Cappo $10 \mathrm{da}$ Ecil e um multímetro HP 34401A para medir o sinal de saída de 4-20 mA produzido pelos transmissores. Esses equipamentos e instrumentos são mostrados na FIG. 4.13. Na calibração, a pressão foi aplicada à câmara de baixa pressão, com a câmara de alta pressão ficando aberta para a atmosfera. Desta forma, estes instrumentos depois de instalados nas respectivas seções de testes fornecerão diretamente a informação de nível. Os resultados da calibração destes transmissores de pressão diferencial podem ser vistos no APÊNDICE B. 


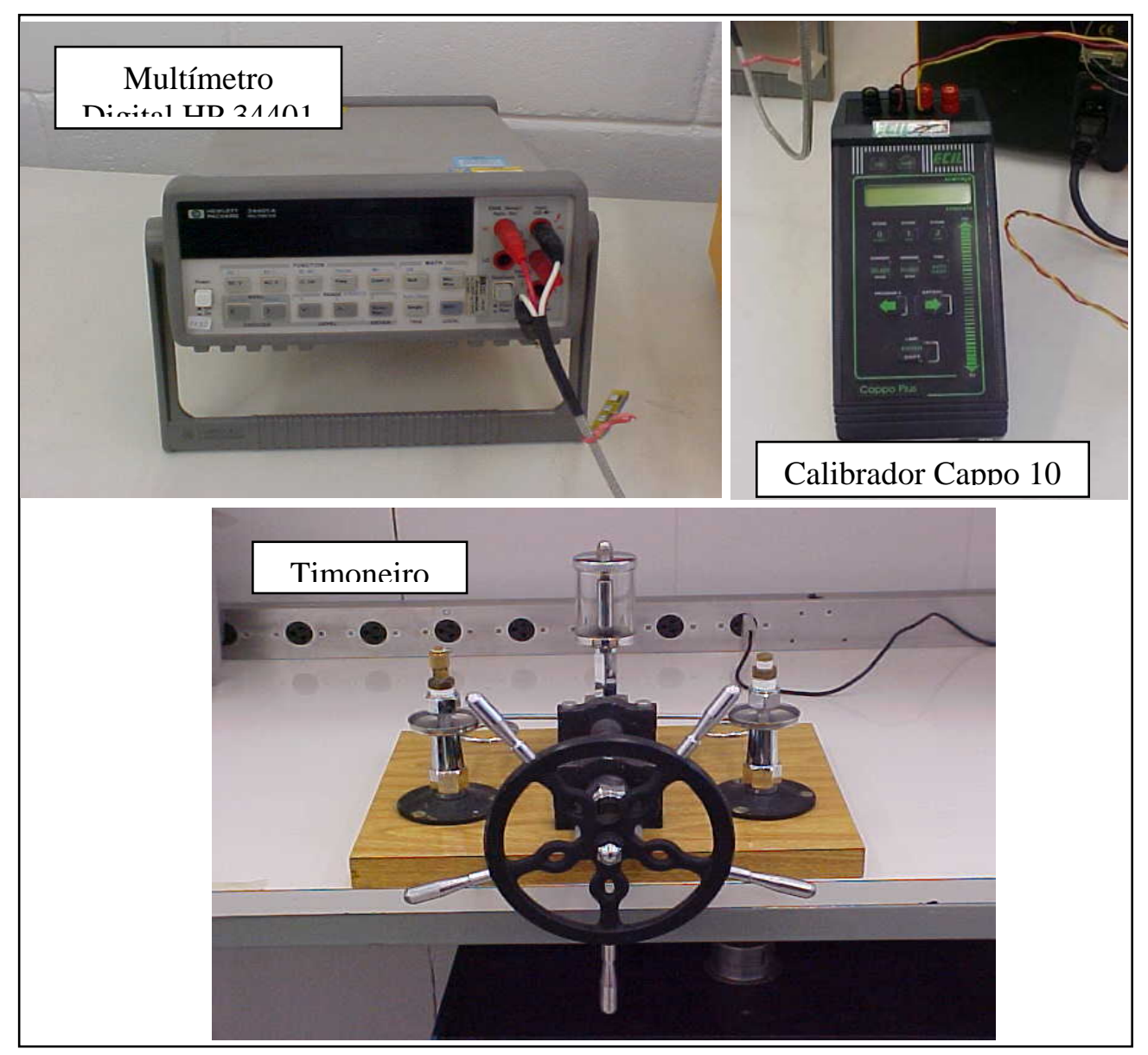

FIGURA 4.13. Conjunto de equipamentos/instrumentos usados na calibração dos transmissores de pressão diferencial. Timoneiro, multímetro digital e calibrador CAPPO 10.

\subsubsection{Rotâmetros}

Os dois rotâmetros foram calibrados usando um balão de vidro com volume conhecido (2 litros) e um cronômetro. Os rotâmetros são da marca Krohne e têm a capacidade de medir vazões na faixa $0-0,25 \mathrm{~m}^{3} / \mathrm{h}(0-0,0691 \mathrm{~kg} / \mathrm{s})$. Os resultados das calibrações destes rotâmetros podem ser vistos no APÊNDICE C. Esses rotâmetros foram utilizados para medir a vazão volumétrica da água de resfriamento das sondas. 


\section{5. $\quad$ Sistema de Aquisição de Dados (SAD) e Programação LabView 7}

Para a aquisição dos dados experimentais foi montado um Sistema de Aquisição de Dados (SAD) usando equipamentos da linha SCXI da National Instruments (2001), e um microcomputador. Este sistema é composto por:

- 1 chassi NI SCXI - 1000 com 4 posições ("slots");

- 2 conjuntos formados por condicionadores de sinais e blocos terminais, assim distribuídos;

conjunto 1 - SCXI NI 1102 (condicionador de sinal)+ SCXI 1303 (bloco terminal);

conjunto 2 - SCXI NI 1100 (condicionador de sinal)+ SCXI 1303 (bloco terminal); e

- 1 placa de aquisição de dados PCI-6031E instalada num computador;

- 1 computador Pentium IV de $3 \mathrm{GHz}, 512$ MBytes de RAM;

- 2 cabos tipo multi-cabo com 12 pares de cabos de extensão cada;

- cabos de extensão individuais para os termopares; e

- 1 fonte de alimentação $V_{d c}$ para os transmissores de pressão diferencial modelo HP 6216 A.

Cada conjunto formado por um condicionador de sinal e um bloco terminal tem capacidade de 32 canais diferenciais (+/-). No conjunto 1 (posição 1 do chassi), que comanda o SAD, foram instalados os termopares que medem a temperatura da parede da Sonda de Tubos Concêntricos e da Sonda de Tubo $U$, mais as temperaturas de entrada e saída da água de resfriamento das duas sondas. No conjunto 2 (posição 2 do chassi) foram instalados os termopares que medem a temperatura da água de processo das seções de testes ST1 e ST2 e os dois transmissores de pressão diferencial. Os transmissores de pressão diferencial são alimentados com $24 \mathrm{~V}_{\mathrm{dc}}$ por uma fonte de tensão contínua modelo HP $6216 \mathrm{~A}$. Para obter sinais de saída dos transmissores de pressão diferencial na forma de sinal de 
tensão (1 - 5V), ao invés de sinal de corrente $(4-20 \mathrm{~mA})$, foram instalados resistores de precisão de 250 Ohms, em série em cada sinal de saída, conforme mostrado na FIG. 4.14.

O programa MAX versão 3.1 (Measurement \& Automation Explorer), do LabView 7 (Laboratory Virtual Instrumentation Engineering Workbench), National Instruments (2003), foi usado para a configuração de todos os instrumentos nos módulos e canais do SAD. No programa MAX são definidos: o chassi, os módulos e os canais para o sistema de aquisição de dados, assim como o tipo de sinal de entrada, tensão ou corrente, e o tipo de termopar que está sendo utilizado.

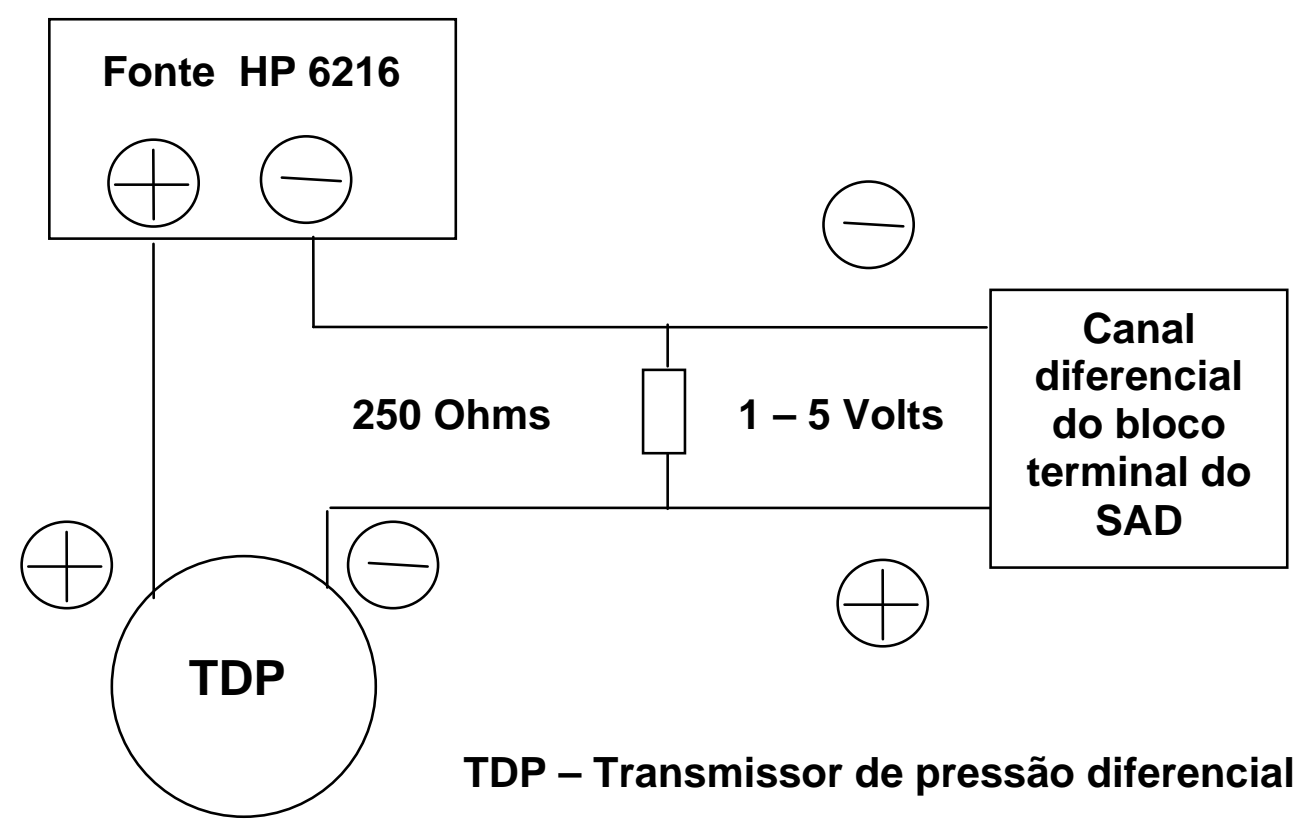

FIGURA 4.14. Esquema de ligação elétrica dos transmissores de pressão diferencial para obtenção de sinal de saída de 1 - 5 Volts para uso no SAD.

O programa BETSNI prog.vi foi desenvolvido com o LabView 7 para a aquisição dos dados, que trabalha com programação por instrumentos virtuais (Virtual Instruments - Vl's). O programa BETSNI prog.vi possui um painel frontal onde é 
possível representar esquematicamente o experimento por meio de desenhos, apresentar os dados do experimento na forma de gráfica e/ou de indicadores, e ainda inserir e/ou alterar dados de entrada; e um painel de controle onde efetivamente é feita a programação.

O SAD recebe, através do programa BETSNI prog.vi, um total de 45 sinais produzidos pelos instrumentos da bancada experimental e das duas sondas de medida de nível, sendo: 43 sinais de termopares e dois sinais de transmissores de pressão diferencial, mais os valores inseridos manualmente através do painel frontal do programa de aquisição de dados, tais como: vazão de resfriamento das sondas, tensão de alimentação dos elementos aquecedores e as resistências elétricas dos aquecedores. Os dados são coletados e podem ser gravados em arquivos do tipo texto (.txt), que posteriormente são trabalhados em planilhas do tipo Excel. O SAD e a fonte de tensão DC para a alimentação dos transmissores de pressão diferencial são mostrados na FIG. 4.15, enquanto que uma parte da tela do painel frontal do programa BETSNI prog.vi é mostrado nas FIG. 4.16 e 4.17.

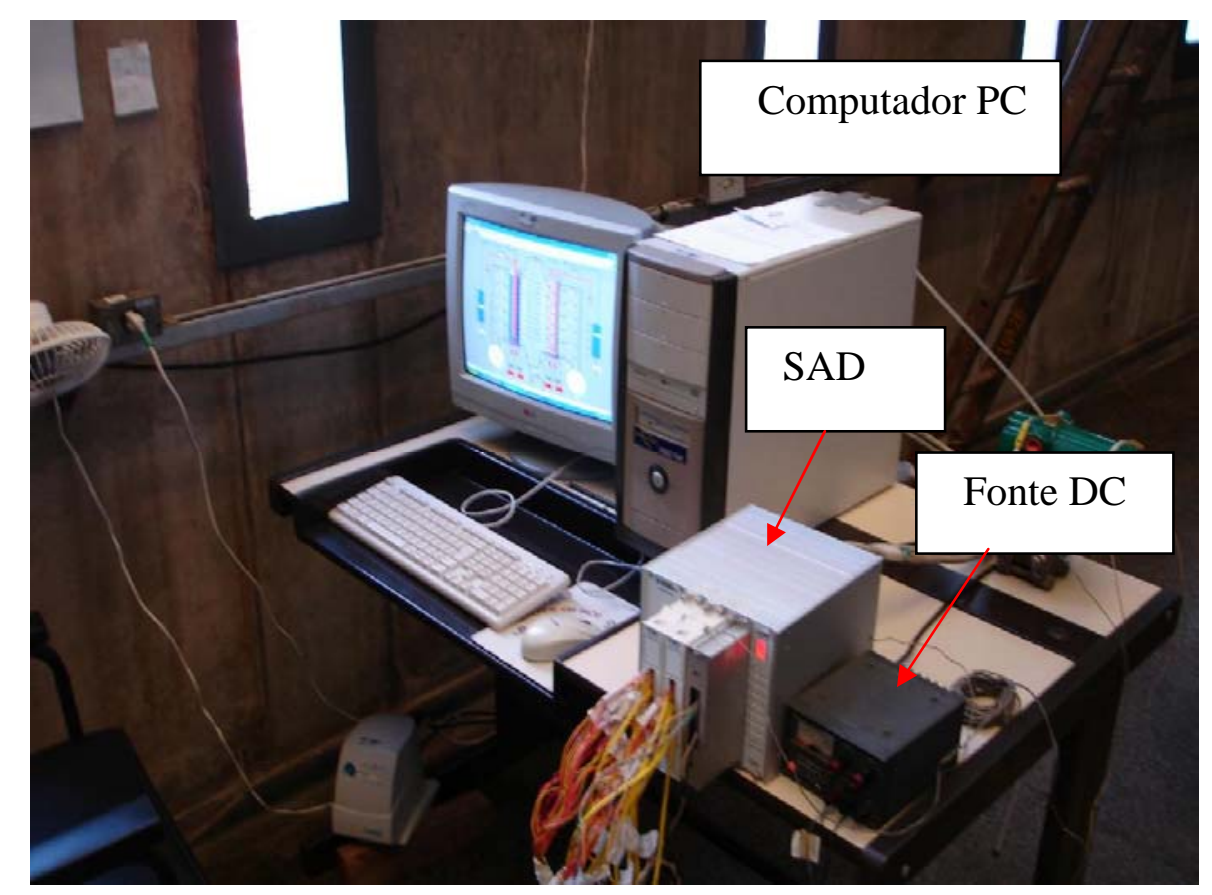

FIGURA 4.15. Sistema de aquisição de dados e fonte de alimentação dos TPD's. 


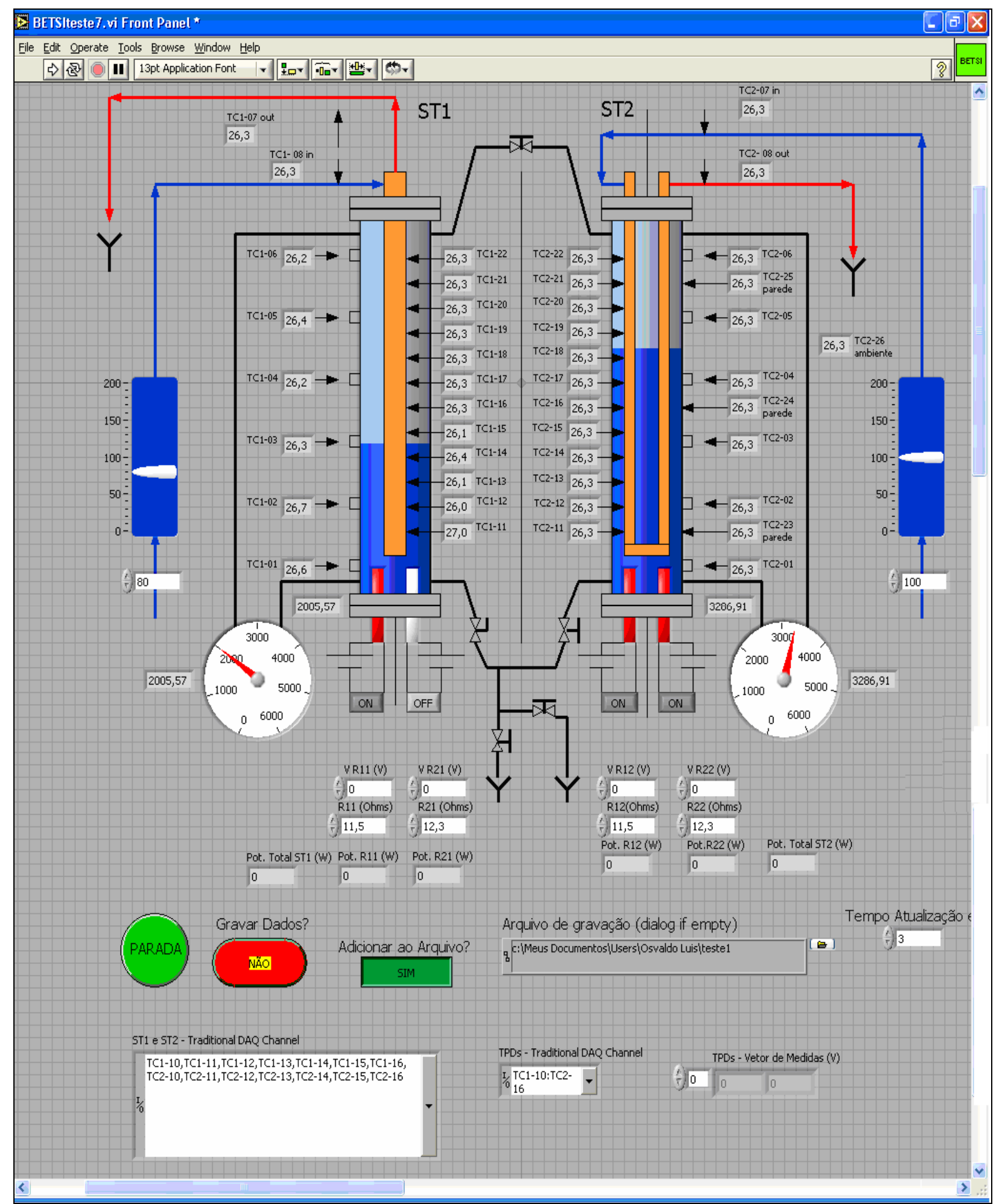

FIGURA 4.16. Parte do painel frontal do programa BETSNI prog.vi em LabView mostrando as Seções de Testes ST1 e ST2 e os instrumentos. 


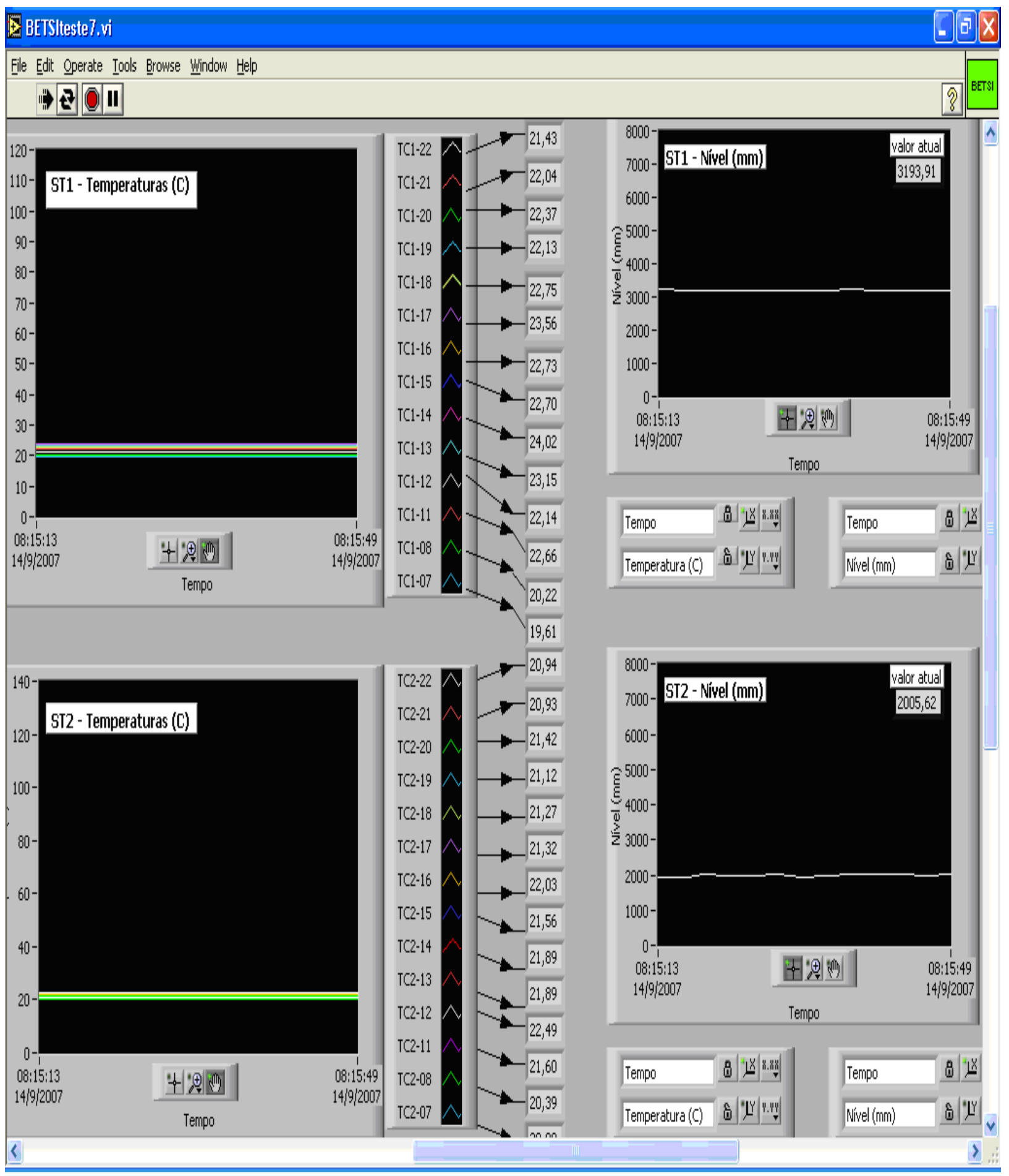

FIGURA 4.17. Parte do painel frontal do programa BETSNI prog.vi em LabView. Temperaturas e níveis nas seções de testes ST1 e ST2. 


\subsection{Redes Neurais Artificiais - RNA's}

As Redes Neurais Artificiais (RNA's) são sistemas paralelos distribuídos formados por unidades de processamento simples, dispostas em camadas e interligadas por um grande número de conexões, baseados no funcionamento do cérebro, e que calculam determinadas funções matemáticas, geralmente não lineares. As RNA's desenvolvem capacidade adaptativa, de aprendizado e armazenam conhecimento, tornando-as capazes de generalização, ou seja, possuem a capacidade de aprender por exemplos e realizar interpolações e extrapolações daquilo que aprenderam. As RNA's tiveram a sua origem nos trabalhos de modelagem biológica dos processos neurofisiológicos, cognitivos e comportamentais.

As RNA's têm se mostrado ao longo dos últimos anos como uma importante ferramenta para a análise de dados onde a modelagem matemática é complexa. $\mathrm{O}$ procedimento usual na solução dos problemas com RNA's passa por uma fase de aprendizagem, onde um conjunto de exemplos é apresentado à rede, que extrai as características daquele conjunto e que são usadas para gerar respostas ao problema quando são apresentados à rede outros dados de entrada. A capacidade de aprender por exemplos e de generalizar a informação aprendida é o principal atrativo das RNA's.

\subsubsection{Neurônios biológicos}

Os neurônios biológicos são divididos em três seções, ou seja, o corpo celular, o axônio e os dendritos. Os dendritos recebem os impulsos nervosos provenientes de outros neurônios e transmitem essas informações, através do axônio, ao corpo celular, onde ocorre o processamento das informações e novos impulsos nervosos são gerados, sendo transmitidos a outros neurônios através do axônio. A sinapse é o ponto de contato entre a terminação axônica de um neurônio e o dendrito de outro neurônio. São as sinapses que promovem a interligação entre os neurônios formando as redes neurais. Os sinais provenientes dos neurônios vizinhos são 
recebidos pelo corpo do neurônio, que os integra e compara com valor limiar, disparando um impulso ao neurônio seguinte. Um desenho de um neurônio motor biológico é apresentado na FIG. 4.18 e o comportamento do potencial pós-sináptico de um neurônio é mostrado na FIG. 4.19.

Estima-se que, quando nasce um bebê, seu cérebro possua cerca de 100 bilhões $\left(10^{11}\right)$ de neurônios. A conectividade neuronal atinge um estágio em que uma única célula, através de seu axônio, forma em média 1000 conexões sinápticas com outras células, recebendo um número equivalente ou maior de conexões de outras células. Um neurônio motor pode receber 10.000 diferentes contactos, enquanto que uma célula de Purkinje do cerebelo pode receber até 150.000 contactos. No total são formadas em torno de $10^{14}$ conexões sinápticas no sistema nervoso humano.

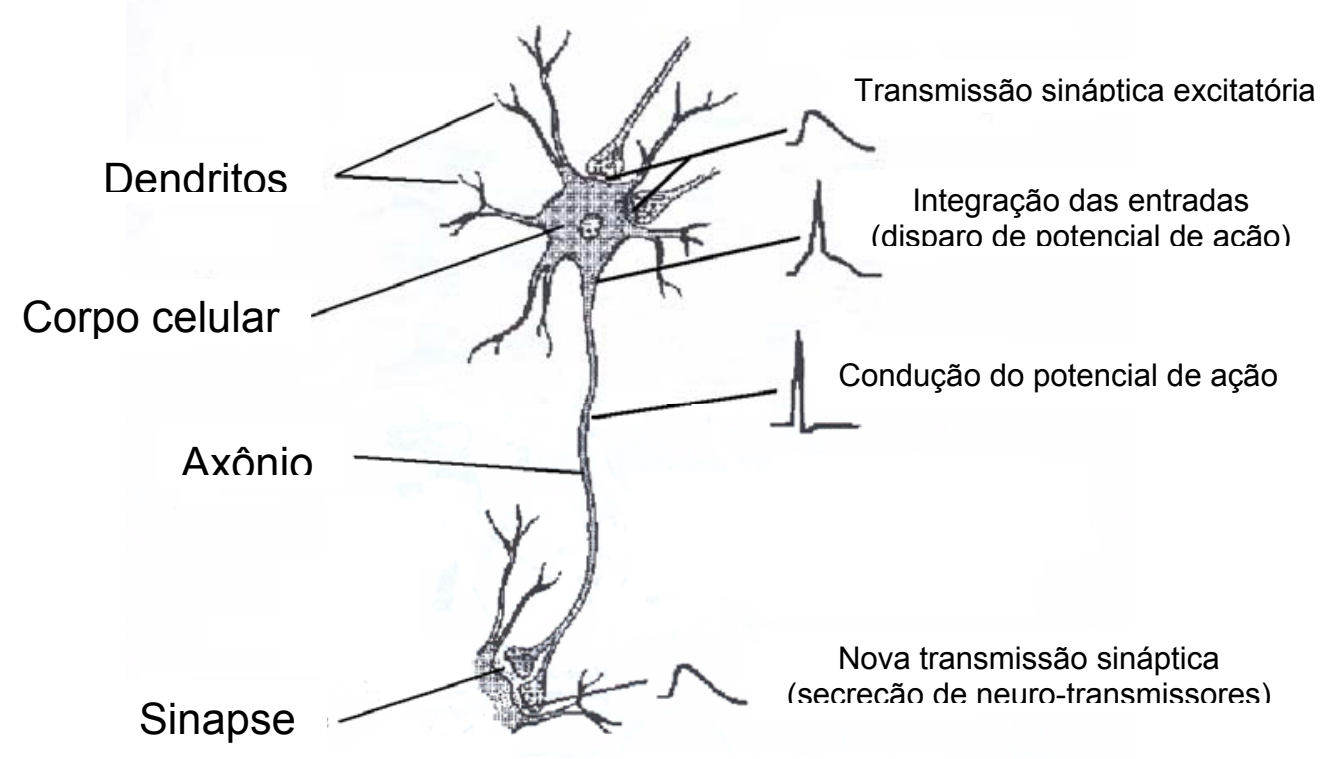

FIGURA 4.18. Neurônio motor biológico. 


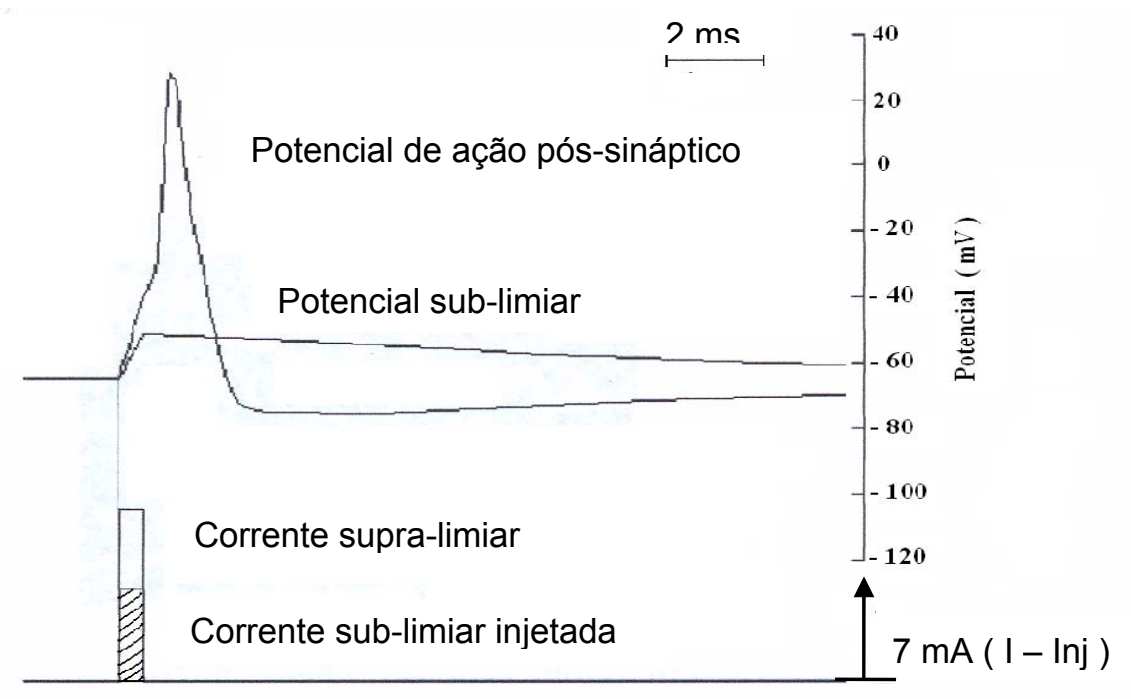

FIGURA 4.19. Potencial de ação pós-sináptico.

\subsubsection{Aspectos históricos das RNA's}

Em 1943, o neurofisiologista e psiquiatra Warren Sturgis McCulloch e o matemático Walter Pitts, escreveram o artigo "A Logical Calculus of the Ideas Immament in Nervous Activity", que é considerado como o pioneiro no desenvolvimento das RNA's, McCulloch e Pitts (1943). Nesse trabalho, os autores apresentaram a primeira modelagem matemática de um neurônio biológico.

Somente em 1949, o psicólogo Donald Olding Hebb publicou o primeiro trabalho sobre o aprendizado de RNA's, (Hebb, 1949). Segundo o pesquisador, o aprendizado de um sistema nervoso estava baseado no reforço das ligações sinápticas entre os nós excitados. A regra de aprendizado de Hebb até hoje é utilizada em algoritmos. 
Frank Rosenblatt um cientista da computação propôs um projeto de "computador neural" usado para classificar certos tipos de padrões, denominado PERCEPTRON, termo utilizado até hoje (Rosemblatt, 1958). O Perceptron descrito por Rosenblatt possuía três camadas, sendo que a primeira camada (retina) recebe as entradas externas e possui conexões fixas; a segunda camada (peso) recebe os impulsos da primeira através de conexões com pesos ajustáveis e envia as saídas para a terceira camada (resposta). O Perceptron de Rosenblatt (retina-peso-resposta) mostrou ser capaz de classificar somente padrões linearmente separáveis.

Paralelamente aos estudos de Rosenblatt, os pesquisadores Widrow e Hoff (1960) propuseram, o conceito de ADALINE (ADAptive LINear Element), posteriormente denominado ADAptive LInear NEuron. O ADALINE, assim como o PERCEPTRON, é baseado na idéia de ter elementos de processamento executando operações de soma ponderada e posterior comparação com um valor limiar. Widrow e Hoff também propuseram uma regra de aprendizado, denominada de regra de WidrowHoff, ou Regra Delta, ou ainda Regra do Gradiente Descendente. Esta regra é baseada no método do gradiente para minimização do erro na saída de um neurônio com resposta linear e deu origem ao algoritmo de retro-propagação (back-propagation) para treinamento de perceptrons de múltiplas camadas. Widrow e Hoff definiram uma rede, denominada de MADALINE (Mulitple ADALINE).

As redes de mapas auto-organizáveis, também conhecidas por SOM (Self Organizing Maps), foram desenvolvidas por Kohonen (1989) e foram inspiradas no mapa topológico do córtex cerebral. Na rede SOM, quando um padrão $\mathbf{p}$ é apresentado, ela procura por outro padrão que seja o mais parecido com $\mathbf{p}$, aumentando a semelhança durante o treinamento da rede. Desta forma, a rede constrói um mapa topológico onde agrupa padrões com características semelhantes. Uma rede SOM típica possui uma única camada com os nodos fortemente interligados lateralmente, formando um reticulado. A rede SOM utiliza um algoritmo de aprendizado competitivo, onde os nodos competem entre si para se tornarem ativos e com maior sinal de saída. 
Isso é feito com a utilização de conexões inibitórias laterais. Maiores detalhes podem ser vistos em Braga et al. (2000).

\subsubsection{Modelo matemático de McCulloch e Pitts para o neurônio biológico}

O primeiro modelo matemático de um neurônio biológico foi proposto por McCulloch e Pitts (1943). O neurônio de McCulloch e Pitts era um modelo matemático binário bastante simples, cuja saída poderia ser pulso (ativo) ou não pulso (não ativo) dependendo de suas várias entradas, que tinham um ganho arbitrário e poderiam ser excitatórias (positivas) ou inibitórias (negativas). A saída do neurônio é calculada pela média ponderada das entradas, pelos ganhos. Se a resposta fosse maior do que um valor limiar, então a saída do neurônio seria pulso (ativo), caso contrário seria não pulso (não ativo). Já neste artigo, McCulloch e Pitts discutiram, sem aprofundamento no assunto, alguns métodos de aprendizagem para que os neurônios pudessem executar determinadas funções. O modelo matemático do neurônio biológico proposto por McCulloch e Pitts é mostrado na FIG. 4.20, enquanto que na FIG. 4.21 é mostrada uma variação para a representação do neurônio de McCulloch e Pitts com a utilização do conceito de "bias" na integração dos sinais, cujo efeito está representado na FIG. 4.22. No modelo de neurônio proposto por McCulloch e Pitts, a ativação é obtida pela aplicação de uma função de ativação, que ativa ou não a saída conforme o valor resultante da integração dos sinais multiplicados pelos respectivos pesos. A função de ativação pode ser simples, do tipo binário, ativo ou não ativo ( 0 ou 1), ou pode assumir de uma função mais complexa, conforme os exemplos mostrados na FIG. 4.23. As funções, tangente hiperbólica e sigmóide, são bastante utilizadas em estudos com RNA's.

A integração dos sinais de entrada (integrador linear) representa a soma dos sinais de entrada do neurônio biológico, enquanto que a função de ativação $(F)$ representa a função disparo do potencial de ação do neurônio. Os pesos $(w)$ representam os processos de transmissão sináptica. 


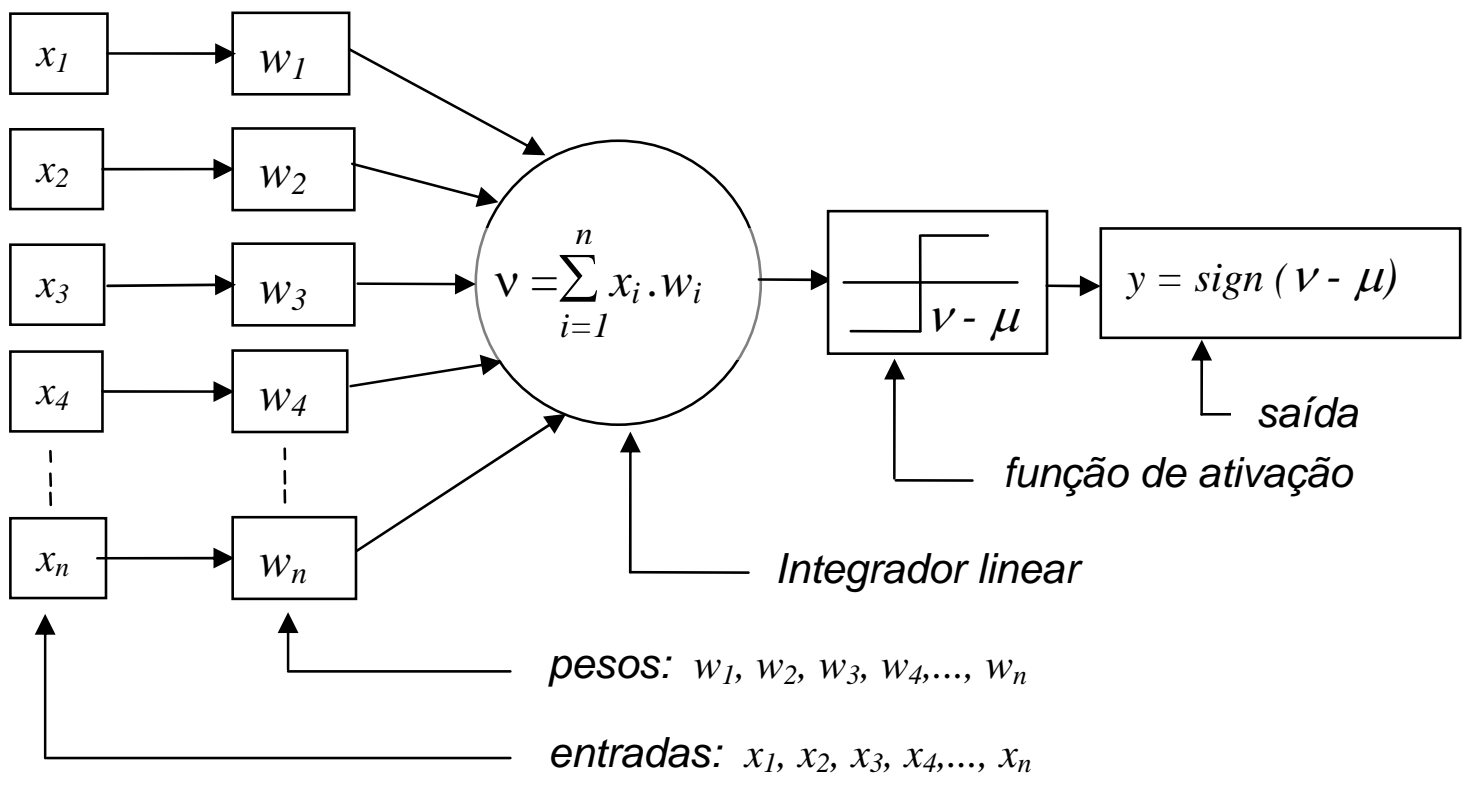

FIGURA 4.20. Modelo matemático do neurônio biológico de McCulloch e Pitts. 


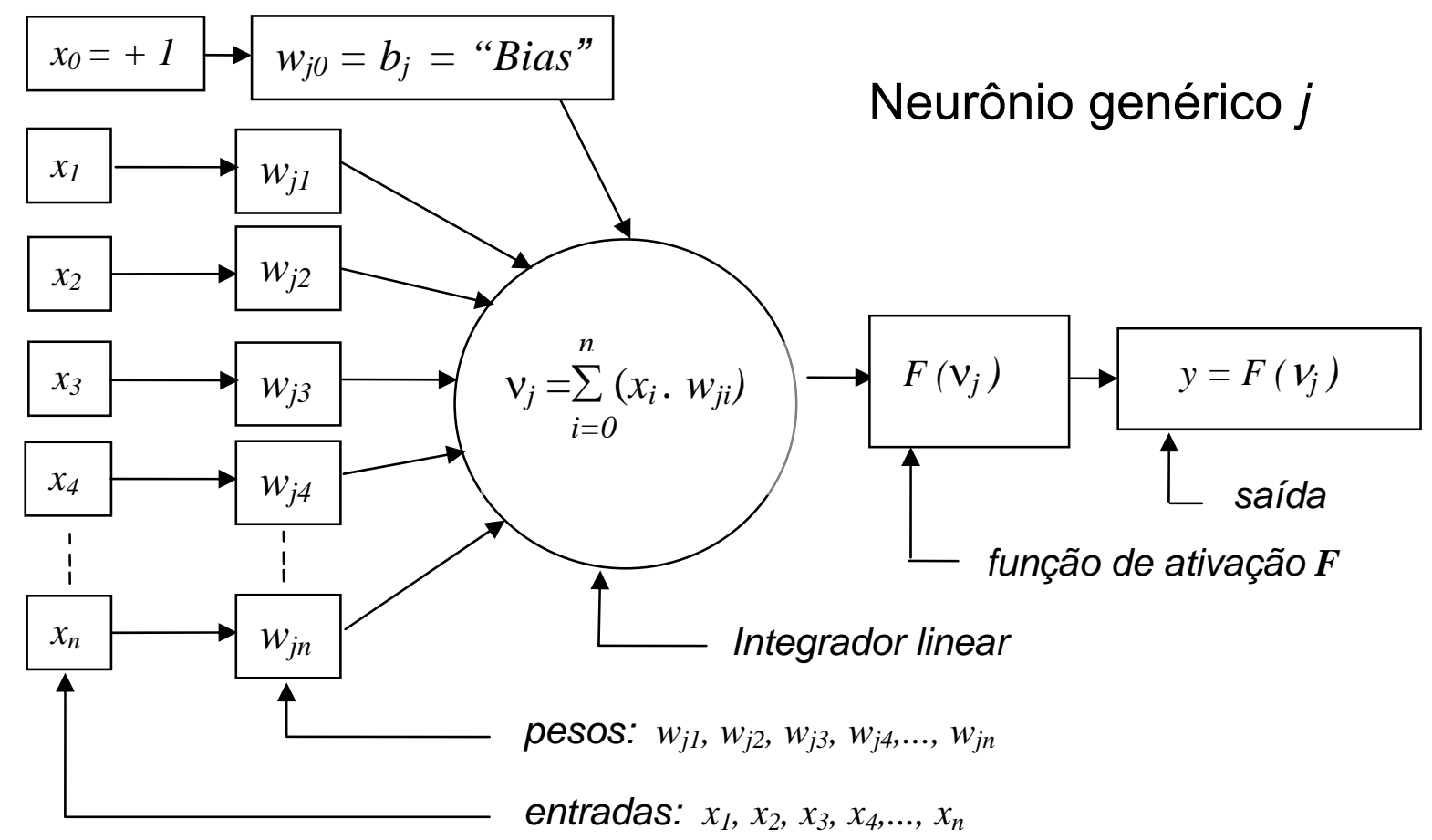

FIGURA 4.21. Modelo matemático do neurônio biológico de McCulloch e Pitts com "bias".

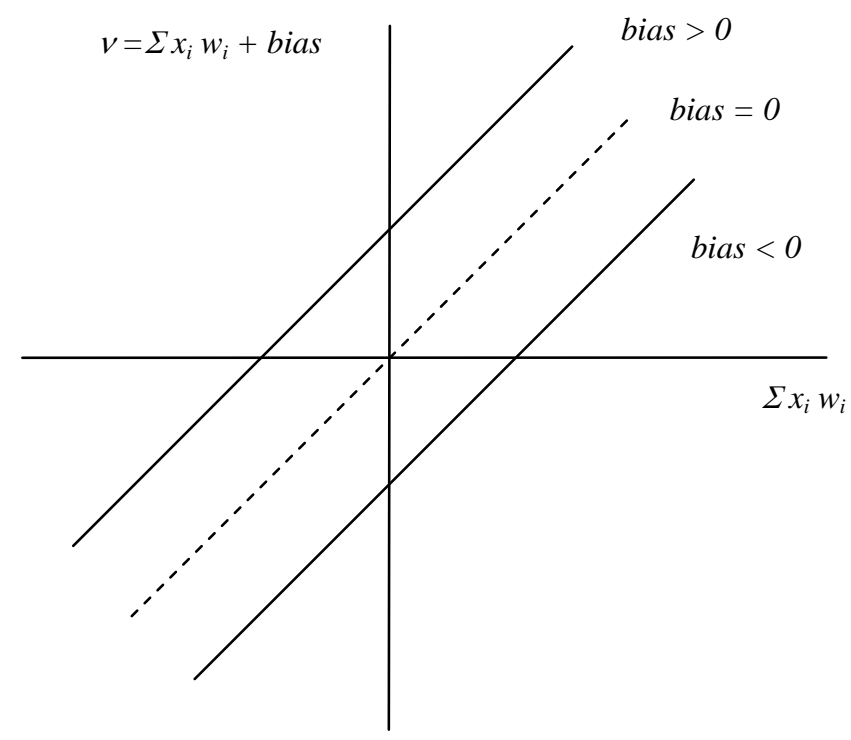

FIGURA 4.22. Efeito do "bias" na integração dos sinais. 

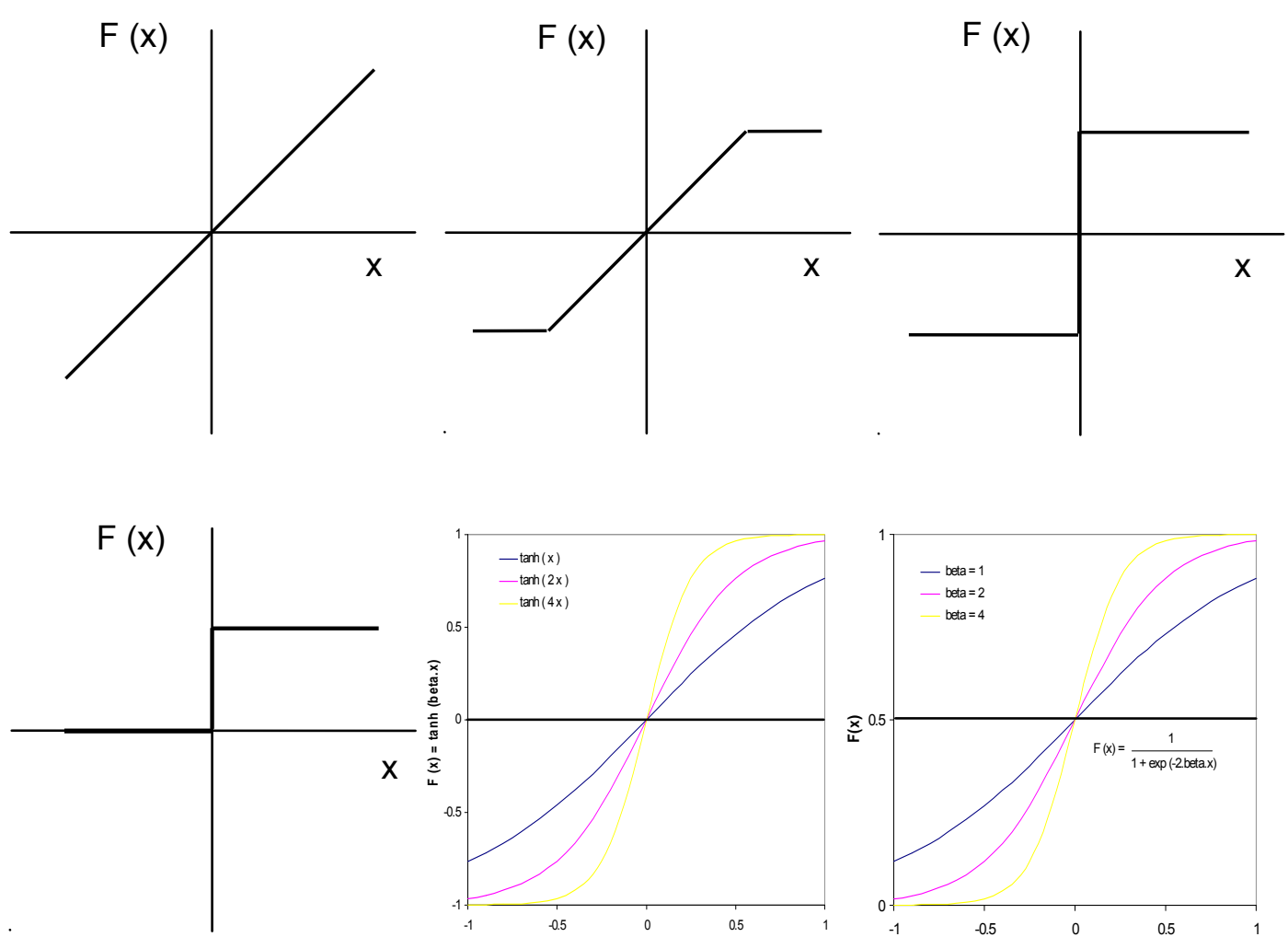

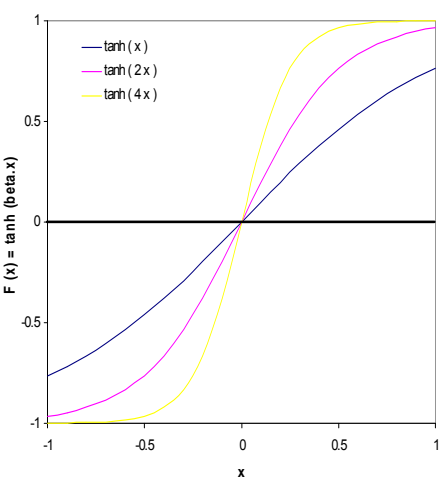

Função tangente hiperbólica

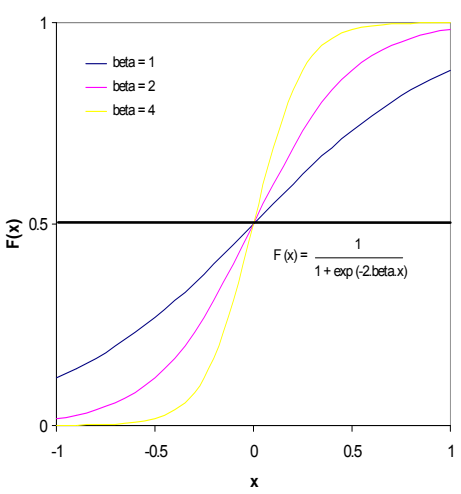

Função sigmóide

FIGURA 4.23. Tipos mais comuns de função de ativação utilizadas em RNA's.

\subsubsection{Perceptron de Rosenblatt}

Rosenblatt propôs o conceito do Perceptron em 1958. O Perceptron consistia de 400 fotocélulas que recebiam estímulos óticos primários (entradas), que estavam interligadas a unidades processadoras que produziam uma determinada saída, dependendo das entradas. Embora possua três níveis, o Perceptron de Rosenblatt é considerado com tendo uma única camada.

Juntamente com o Perceptron, Rosenblatt introduziu o conceito de aprendizado ou treinamento para o seu modelo, que considerava o sinal binário de saída e o sinal de treinamento baseado na saída desejada, conforme mostra a FIG. 4.24 . 


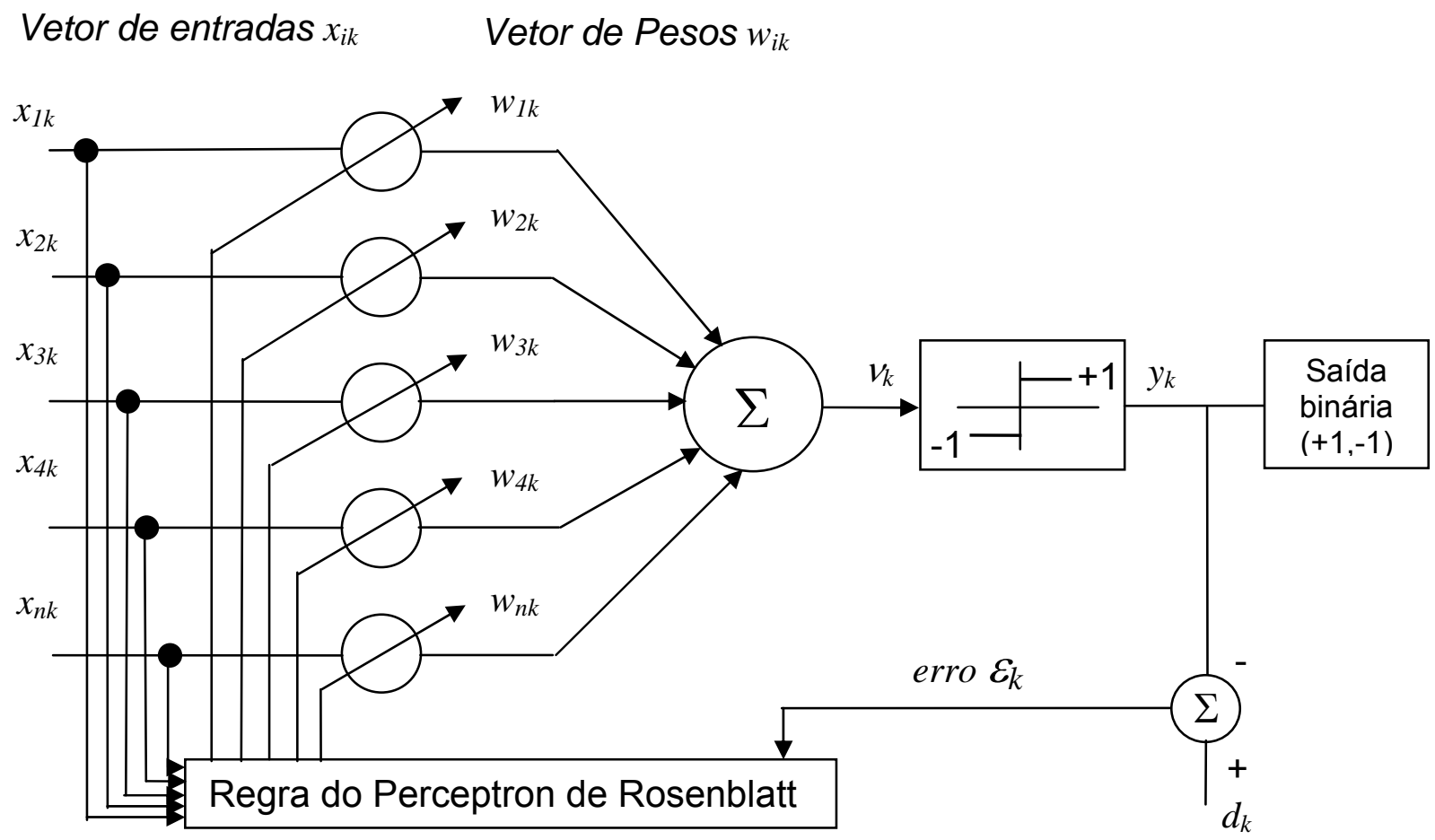

FIGURA 4.24. Treinamento do Perceptron de Rosenblatt.

\subsubsection{ADALINE de Widrow e Hoff}

O conceito de ADALINE (ADAptive LINear Element) foi desenvolvido por Widrow e Hoff em 1960, que mais tarde foi denominado por alguns autores de ADAptive Linear NEuron, quase que simultaneamente com o Perceptron. Eles trabalharam com saídas com valores contínuos e funções de ativação diferenciáveis. $\mathrm{O}$ aprendizado ou treinamento do ADALINE trabalha com um algoritmo de mínimos quadrados para minimização do erro ou diferença entre a saída calculada e a saída desejada, também conhecida como Regra Delta ou de Gradiente Descendente. O uso de múltiplos ADALINE's é conhecido como MADALINE (Multiple ADALINE). Na FIG. 4.25 é mostrado o ADALINE de Widrow e Hoff e seu processo de treinamento. 


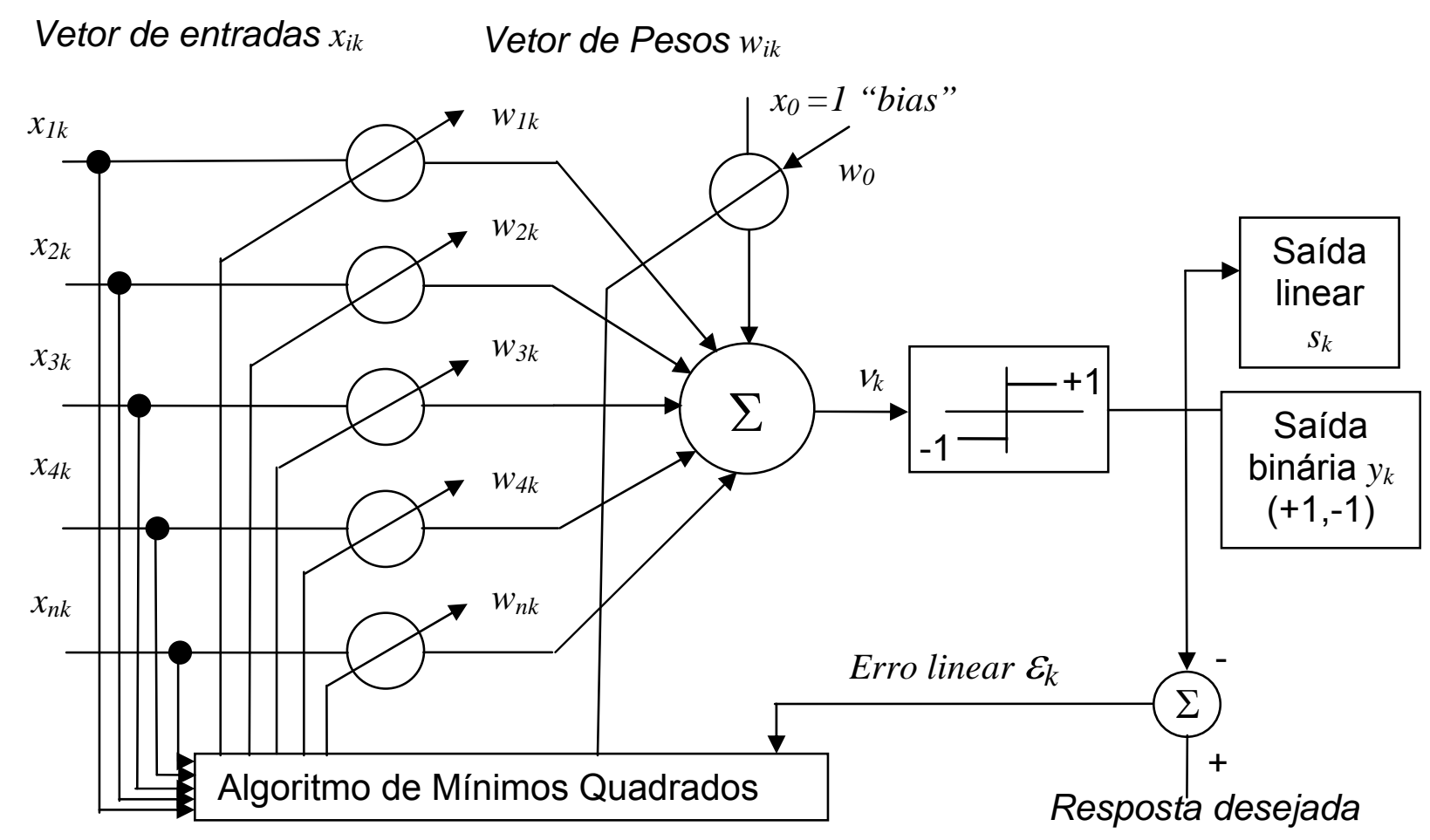

FIGURA 4.25 ADALINE de Widrow e Hoff. 


\subsubsection{Algoritmos de treinamento}

O treinamento ou aprendizagem de uma RNA pode ser definido como um processo através do qual os parâmetros ou pesos da rede são ajustados de forma continuada, influenciada pelo ambiente em que a rede está operando. Um algoritmo de treinamento ou aprendizagem consiste de um conjunto de procedimentos matemáticos para ajustar os parâmetros ou pesos de ligação de uma RNA para que a mesma aprenda uma determinada função.

O treinamento consiste em apresentar um conjunto (vetor) de dados de entrada para a RNA, que depois de treinada irá produzir um conjunto de saídas desejadas. O treinamento pode ser supervisionado, se tiver um "professor", ou não supervisionado.

\subsubsection{Treinamento supervisionado}

O treinamento supervisionado de uma RNA é assim denominado porque utiliza um supervisor ou professor. Neste tipo de treinamento, são fornecidas à rede pelo supervisor, as entradas e as saídas desejadas. O objetivo é ajustar os pesos de forma a obter uma relação entre as entradas e saídas desejadas, tornando mínimas as diferenças entre as saídas calculadas pela rede e as saídas desejadas fornecidas. Baseada nas entradas fornecidas, a rede calcula valores para as saídas (saídas calculadas). Os valores das saídas calculadas são comparados com os valores das saídas desejadas e as diferenças, denominadas de erros, são utilizadas para realimentar a rede e ajustar os pesos. O treinamento visa a diminuição dos erros e a soma dos erros quadráticos, denominada função energia do erro, é usada como parâmetro de desempenho de treinamento da rede. O treinamento por reforço é considerado como um caso particular de treinamento supervisionado. A FIG. 4.26 mostra um diagrama do fluxo de informações e o funcionamento do treinamento supervisionado. 


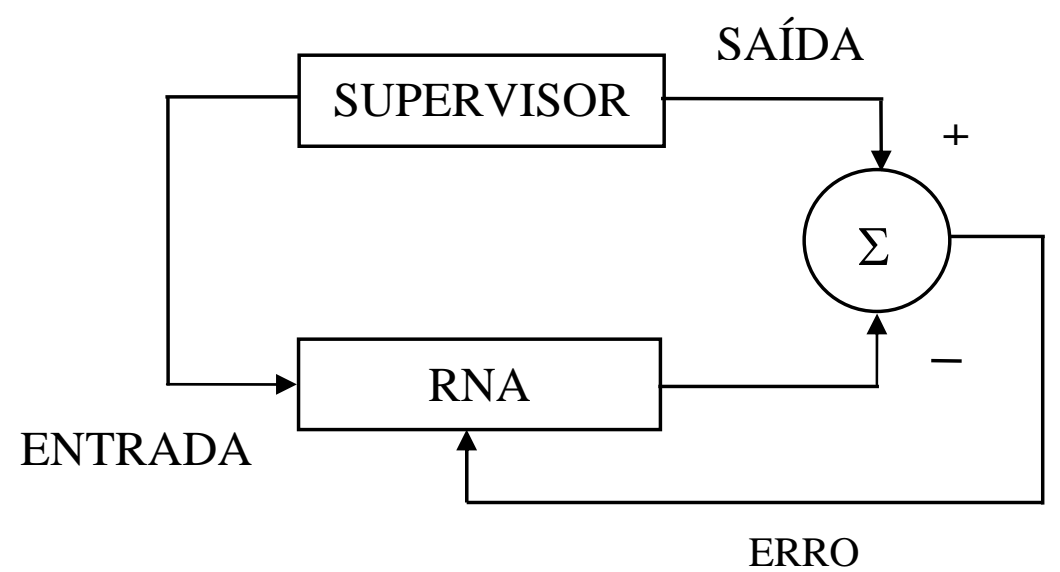

FIGURA 4.26. Treinamento supervisionado.

Exemplos de algoritmos de treinamento supervisionado mais utilizados são: a regra por correção de erros e a regra delta de Widrow-Hoff; e a sua generalização, o algoritmo de retro-propagação, para aplicação em redes de múltiplas camadas.

\subsection{Regra de correção de erros}

O algoritmo de regra de correção de erros, como nos demais algoritmos de treinamento de RNA's, visa minimizar a diferença entre os valores de saídas calculadas pela rede e saídas desejadas através da correção dos pesos sinápticos $w_{i j}$, de acordo com as EQ. 4.1 a 4.3:

$$
\begin{aligned}
& w_{i, j}(t+1)=w_{i, j}(t)+\Delta w_{i, j}(t) \\
& \Delta w_{i, j}=\eta \varepsilon_{j}(\mathrm{t}) x_{i, j} \\
& \varepsilon_{j}=\left(y_{D j}-y_{j}(\mathrm{t})\right)
\end{aligned}
$$


Onde,

$w_{i, j}(\mathrm{t}) \quad$ é o valor do peso da sinapse $i$ do neurônio $j$ no instante $t$;

$w_{i, j}(\mathrm{t}+1) \quad$ é valor do peso da sinapse $i$ do neurônio $j$ no instante $\mathrm{t}+1$;

$\Delta w_{i, j}(\mathrm{t}) \quad$ é o incremento ao peso da sinapse $i$ do neurônio $j$ para o $\mathrm{t}+1$;

$\eta \quad$ é o parâmetro denominado de taxa de aprendizado;

$\varepsilon_{j}(\mathrm{t})$ é a diferença entre a saída desejada e a saída calculada em $\mathrm{t}$;

$x_{i, j} \quad$ é o valor do sinal de entrada através da sinapse $i$ do neurônio $j$;

$y_{D j} \quad$ é o valor do sinal de saída desejado do neurônio j; e

$y_{j}(\mathrm{t})$ é o valor calculado pela rede do sinal de saída do neurônio $j$ em $\mathrm{t}$.

\subsection{Regra Delta de Widrow-Hoff ou método do gradiente descendente}

A regra delta Widrow e Hoff ou método do gradiente descendente é um algoritmo supervisionado que tem como objetivo minimizar uma função erro calculada pela $E Q$. 4.4:

$$
E=\frac{1}{2} \sum_{p=1}^{p}\left(y_{D}^{p}-y^{p}\right)^{2}
$$

Onde,

E é a função erro;

$p \quad$ é o número de neurônios na camada de saída;

$y_{D} \quad$ é o valor da saída desejada; e

y é o valor da saída calculada pela rede.

Dado um vetor inicial de pesos [w(0)], o objetivo é determinar o ajuste necessário para caminhar na direção da solução ótima. Isso pode ser obtido pelo 
gradiente da função erro no ponto $w(0)$. A otimização é feita no sentido contrário ao vetor gradiente, daí o nome de gradiente descendente. A solução, portanto é dada por pelas EQ. 4.5 a 4.10 .

$$
\begin{aligned}
& \Delta w=-\eta \nabla E=-\eta \frac{\partial E}{\partial w} \\
& \frac{\partial E}{\partial w}=\frac{\partial E}{\partial y} \frac{\partial y}{\partial w} \\
& y_{i}^{p}=\sum_{i} w_{i} x_{i} \\
& \frac{\partial E}{\partial y}=-\sum_{p}\left(y_{D}^{p}-y_{i}^{p}\right) \\
& \frac{\partial E}{\partial w_{i}}=-\sum_{p}\left(y_{D}^{p}-y_{i}^{p}\right) x_{i}^{p} \\
& \Delta w_{i}=-\eta \frac{\partial E}{\partial w_{i}}=\eta \sum_{p}\left(y_{D}^{p}-y_{i}^{p}\right) x_{i}^{p},
\end{aligned}
$$

Fazendo as mudanças individuais para cada entrada $x_{i}$, temos:

$$
\Delta w_{i}=\eta\left(y_{D}^{P}-y_{i}^{p}\right) x_{i}^{p}
$$

Se definirmos o parâmetro delta $(\delta)$ para cada saída, como a diferença entre a saída desejada e a saída calculada pela rede, temos:

$$
\delta_{i}^{p}=\left(y_{D}^{P}-y_{i}^{p}\right)
$$




$$
\Delta w_{i}=\eta \delta_{i}^{p} x_{i}^{p}
$$

A correção dos pesos $\left(w_{i}\right.$ 's) na iteração posterior $(n+1)$, portanto é dada pelo seu valor na iteração anterior $(n)$ somado a uma variação $\Delta w_{i}$, por:

$$
w_{i}(n+1)=w_{i}(n)+\Delta w_{i}
$$

\subsection{Algoritmo de Retropropagação}

Este algoritmo é bastante utilizado no treinamento de RNA's do tipo multicamadas ("Multi-Layer Perceptron - MLP") e foi utilizado no programa de treinamento (RETRO_05) para as RNA's usadas neste trabalho. O algoritmo de retropropagação também é um algoritmo supervisionado, no qual o treinamento é feito em duas etapas, ou seja, adiante ("forward") e para trás ("backward"), e a correção dos pesos sinápticos é feita utilizando a regra delta ou do gradiente descendente.

Na primeira iteração da etapa adiante, a rede calcula as saídas com base nas entradas fornecidas e em pesos sinápticos iniciais, geralmente escolhidos de forma aleatória. Os resultados das saídas calculadas são comparados com os valores das saídas desejadas, e a diferença entre esses valores é utilizada para corrigir os pesos sinápticos, usando a regra delta, a partir da última camada da rede até a primeira camada da rede (etapa para trás). Com os novos valores de pesos sinápticos corrigidos, a rede calcula novos valores de saídas calculadas (etapa adiante), que são comparados com as saídas desejadas, e assim por diante. O processo iterativo (épocas de treinamento) continua até que as diferenças entre entradas calculadas e saídas desejadas seja suficientemente pequenas de forma que não haja mudanças significativas nos pesos sinápticos ou que um valor de tolerância pré-estabelecido seja atingido. 


\subsubsection{Treinamento não supervisionado}

Neste caso não existe a figura do supervisor ou professor, e o treinamento da RNA acontece durante a ação da rede. A resposta é baseada na capacidade da rede de se auto-organizar. Para o treinamento da rede é fornecido somente um conjunto de entradas. Durante o treinamento, a rede ajusta estatisticamente os pesos de forma que o conjunto de entradas de treinamento seja separado em grupos com características semelhantes. Na FIG. 4.27 é mostrado um diagrama do fluxo de informações e o funcionamento do treinamento não supervisionado.

Exemplos de algoritmos de treinamento não supervisionado mais utilizados são: o treinamento Hebbiano (Hebb, 1949) e suas variações, tais como, o modelo de Linsker, a regra de Oja e a regra de Yuille; e o treinamento ou aprendizado por competição, usado em aplicações com Mapas Auto Organizados (SOM). Mais detalhes sobre estes algoritmos podem ser vistos em (Braga, 2000).

ESTADO

DO MEIO

EXTERNO

RESPOSTA

MEIO EXTERNO

RNA

FIGURA 4.27. Treinamento não supervisionado. 


\subsection{Treinamento Hebbiano}

Este algoritmo de treinamento não supervisionado foi proposto por Hebb em 1949 , onde o autor estabelece que os pesos das sinapses devam ser ajustados se existir um sincronismo entre as atividades de entradas e saídas de neurônios, ou seja, o ajuste depende das condições pré e pós sinápticas. Se dois neurônios adjacentes são ativados de forma sincronizada, então o peso sináptico tende a aumentar, fortalecendo a sinapse. Caso contrário, ou seja, os neurônios são ativados de forma não sincronizada, então a sinapse se enfraquece podendo até desaparecer. A EQ.4.15 governa a mudança de peso sináptico do algoritmo de treinamento de Hebb.

$$
\Delta w_{i, j}=\eta y_{j}(t) x_{, j}(t)
$$

Onde,

$\eta \quad$ é o parâmetro denominado de taxa de aprendizado ;

$y_{j}(\mathrm{t})$ é a saída do neurônio $j$ da rede no instante t; e

$x_{j}(t)$ é a entrada do neurônio $j$ da rede no instante $t$. 


\subsubsection{Arquiteturas de redes neurais artificiais}

A arquitetura das redes neurais artificiais é um parâmetro muito importante a ser definido. Redes com apenas uma camada somente resolvem problemas linearmente separáveis. A definição do número de camadas, do número de neurônios por camada, o tipo de conexão entre os nodos e a topologia da rede constituem os pontos para o estabelecimento da arquitetura da rede. A FIG. 4.28 apresenta alguns exemplos de arquitetura.
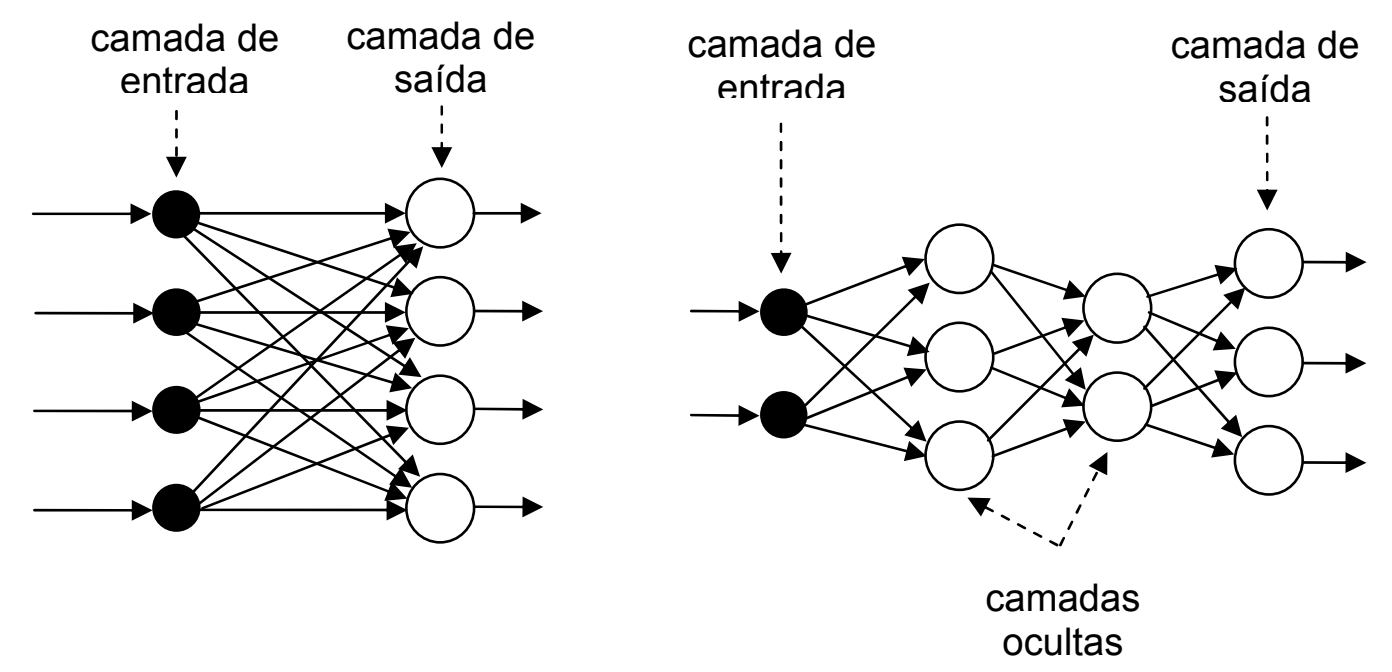

Redes alimentadas adiante (feedforward) ou com propagação para frente.

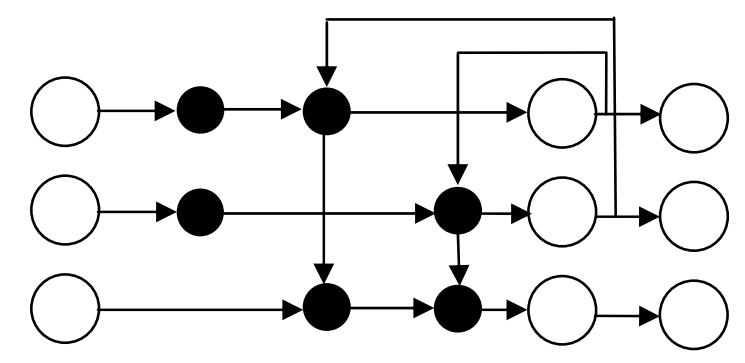

Redes com realimentação (feedback forward) ou com retro-propagação.

FIGURA 4.28. Arquiteturas das redes neurais artificiais. 


\subsection{Abordagem do Problema e Programa RETRO-05 para análise com RNA's}

Os testes foram realizados na Bancada Experimental BETSNI com as sondas de tubos concêntricos e de tubo U. Estes testes produziram dados experimentais de temperatura nas sondas e de nível colapsado nas seções de testes ST1 e ST2. Do conjunto geral de dados experimentais, foram separados os dados de interesse para as análises com RNA's, por exemplo, os dados referentes a uma condição de estado estacionário ou uma condição de transiente. Esses dados separados foram então utilizados para compor tabelas de treinamento e tabelas de verificação para uso nas análises com RNA's, as quais foram realizadas com um programa de Perceptrons de Múltiplas Camadas com Retropropagação, descrito adiante.

Primeiro foi feito um estudo paramétrico com RNA's para verificação de uma configuração de rede adequada a ser usada nas análises, ou seja, uma, duas, três ou quatro camadas. O número de "neurônios" ou elementos por camada da rede também foi verificado, assim como o número de épocas de treinamento e a opção de treinamento com sorteio de exemplos.

Análises com RNA's também foram realizadas considerando um número reduzido de dados de entrada de temperatura de parede, no caso considerando metade dos dados (6 dados) mais as temperaturas de entrada e saída do fluido de resfriamento. As temperaturas foram escolhidas alternadamente entre os termopares que medem a temperatura de parede.

Outras análises com RNA's foram realizadas considerando metade dos dados de temperatura de parede, porém agora considerando as informações de temperatura referentes aos 6 termopares posicionados nas regiões inferior e superior da sonda, além das temperaturas de entrada e saída do fluido de resfriamento. A análise com RNA's considerando a perda de informação de um termopar foi também realizada. 
Os dados experimentais das sondas foram analisados em RNA's usando o programa RETRO-05, que se trata de uma rede de Perceptrons de Múltiplas Camadas com Retropropagação (MLP - Multilayer Perceptron with Backpropagation) foi desenvolvido por (Baptista Filho, 2005), em linguagem BorlandDelphi 7, para aplicação no curso de Redes Neurais Artificiais na Engenharia Nuclear. Este curso é oferecido pelo IPEN aos alunos da Universidade de São Paulo (USP) como disciplina do curso de graduação. O programa possui uma interface amigável que permite inserir e modificar os parâmetros e a arquitetura de RNA's com até quatro camadas. Na tela de interface, FIG. 4.29, o programa apresenta um gráfico com o comportamento das energias ou erros (EQ. 4.4) referentes às tabelas de treinamento $e$ de verificação em função do número de épocas de treinamento. O programa permite interromper o treinamento da rede após um determinado número de épocas, podendo este treinamento ser retomado.

Os arquivos Retro-in.txt ou Retro-tt.txt são usados pelo programa como arquivos de dados entrada para a tabela de treinamento da rede, enquanto que o arquivo Retro-tv.txt é usado como arquivo de dados para a tabela de verificação da rede. O programa fornece quatro arquivos de saída, ou seja:

Retro-ou.txt: arquivo com os dados de entrada, as saídas desejadas e os pesos sinápticos após o treinamento;

Retro-graf.wmf: arquivo com gráfico da energia versus número de épocas de treinamento, semelhante ao gráfico mostrado na interface do programa, referente aos arquivos de dados de treinamento e de verificação;

Retro-re.txt: arquivo com os parâmetros da rede calculados para continuação (Restart) do treinamento; e

Retro-Gr.txt: é o principal arquivo de saída, e contém as entradas fornecidas, tanto para a tabela de treinamento quanto para a tabela de verificação, e as 
saídas desejadas e calculadas pela rede, também para as tabelas de treinamento e verificação.

Neste trabalho foram realizadas várias análises com RNA's usando o programa RETRO-05. Nestas análises variou-se o número de camadas da rede em 2, 3 até o máximo de 4 camadas permitido pelo programa, assim como o número de neurônios por camada e de épocas de treinamento. As temperaturas de entrada e saída da água de resfriamento, e as temperaturas de parede da sonda foram fornecidas para a rede como entradas conhecidas, totalizando 14 valores. O nível colapsado na seção de testes foi fornecido à rede como saída desejada única. Foram realizadas também análises fornecendo um número menor de entradas conhecidas para a rede para verificar sua capacidade de aprendizado e generalização e também para verificar a possibilidade da construção de sondas mais simples com menos termopares.

Nas análises foram usados os parâmetros "default" do programa RETRO-05, ou seja:

Função de transferência (tangente hiperbólica)

$f=a \cdot \tanh (\beta \cdot x)$; $a=1,7159$ e $\beta=0,66666667$

Constantes de treinamento

Taxa de aprendizado inicial $\eta_{0}=0,1$

Meia vida da taxa de aprendizado $c_{\eta}=100.000$

Constante de Momentum $\alpha=0.0$

Tolerância Tol $=0,0001$

Limite dos pesos iniciais $=0,5$

Em algumas análises alteraram-se alguns parâmetros da rede sem modificação significativa dos resultados. Por isso optou-se pelo uso dos parâmetros "default" do programa RETRO-05 em todas as análises. 


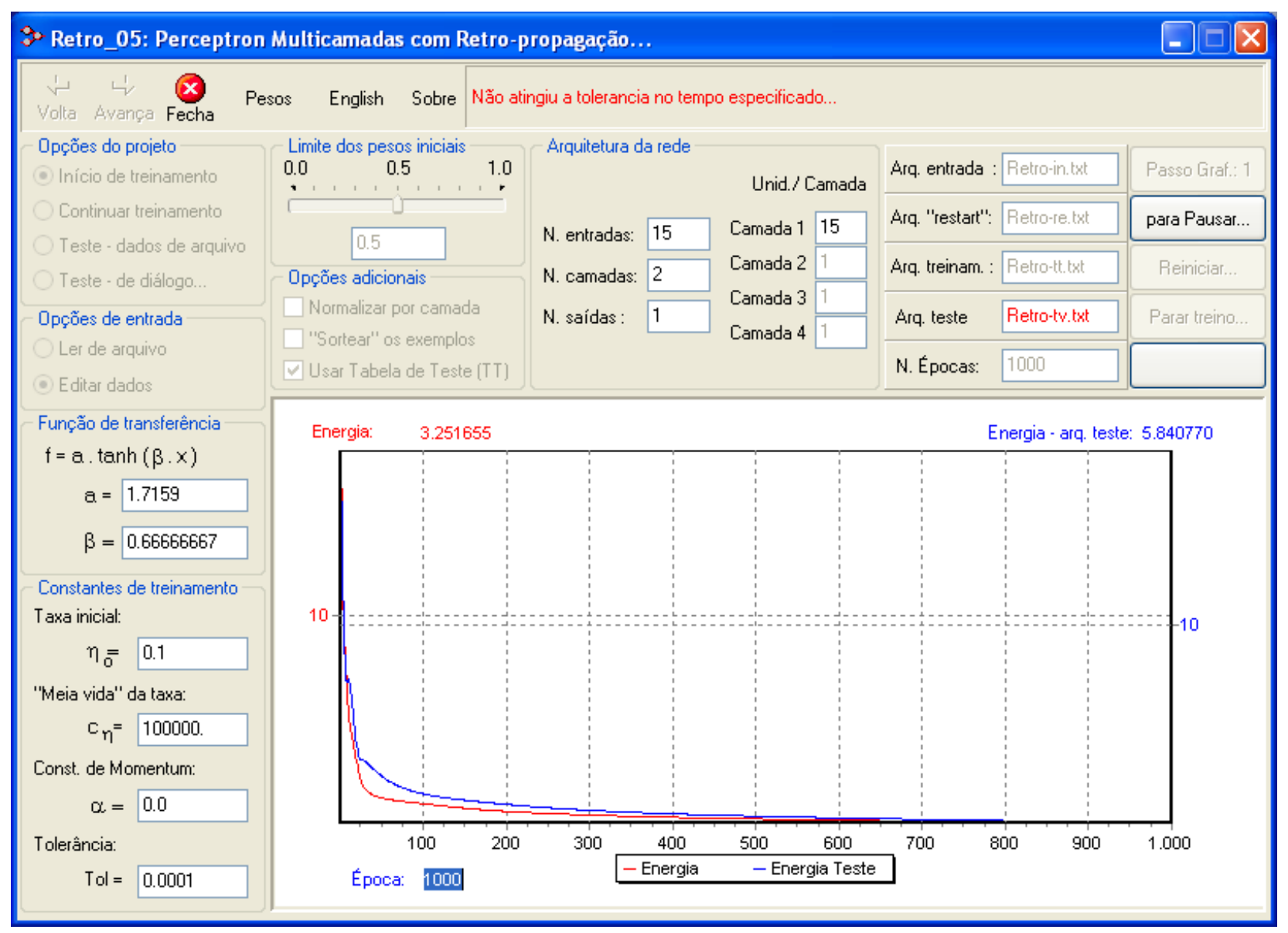

FIGURA 4.29. Interface do programa RETRO-05. 
Neste capitulo são apresentados os dados experimentais obtidos com as Sondas de Tubos Concêntricos e de Tubo U na Bancada Experimental tanto para a condição de estado estacionário quanto para a condição de transiente. Os resultados das análises realizadas com RNA's com esses dados experimentais também são apresentados e discutidos neste capítulo. Também são apresentados alguns resultados da análise por RNA's aplicada a dados experimentais da literatura, obtidos com sondas térmicas aquecidas. Os resultados das análises com RNA's mostraram que a técnica de medida proposta pode ser utilizada para medir nível em vasos de pressão.

\subsection{Sonda de Tubo U - Testes}

\subsubsection{Sonda de Tubo U - Testes preliminares}

Antes da realização de qualquer teste com as sondas na bancada experimental é necessário ligar o computador e o sistema de aquisição de dados, acessando o programa BETSNI prog.vi. O procedimento para a realização desta tarefa está descrito no APÊNDICE D.

Testes preliminares foram realizados com a sonda de tubo $U$ instalada na seção de testes ST2. Nos primeiros testes, os termopares estavam instalados alternadamente tanto no trecho descendente quanto no trecho ascendente do $\mathrm{U}$, porém nas mesmas posições relativas da faixa de medida, ou seja, entre 2766 e $4366 \mathrm{~mm}$, conforme mostrado na TAB. 4.1. Alguns testes foram realizados com essa configuração. Os dados experimentais de temperatura obtidos mostraram que a maior parte do calor trocado ocorria no trecho descendente do $U$, sendo que os termopares instalados no trecho ascendente apresentavam temperaturas praticamente iguais e já estabilizadas, perdendo com isso informações importantes e necessárias para realização da análise com RNA's. Por isso, optou-se pela 
instalação dos termopares somente no trecho descendente do $U$. A sonda de tubo $U$ foi removida da seção de testes ST2 e os termopares foram reposicionados na parte descendente do $U$. A sonda de tubo $U$ foi reinstalada na ST2. Com essa nova configuração de instalação de termopares foram realizados novos testes, ainda preliminares, onde se fixava um valor de nível colapsado de líquido na seção de testes ST2 e um valor de potência de aquecimento, variando-se a vazão de resfriamento da sonda. Para cada vazão de resfriamento aguardava-se até que a condição de estado estacionário fosse atingida, para então alterá-la e assim por diante até que todas as vazões de resfriamento fossem testadas para aquele nível. Após isso, fixava-se um novo nível colapsado e se repetia o procedimento. É conveniente lembrar que uma vazão de resfriamento foi mantida desde o início dos testes.

Os testes foram realizados a uma potência constante, fornecida pelas duas resistências R12 e R22 do aquecedor elétrico instalado na ST2. Este aquecedor elétrico, cuja potência nominal de placa da fábrica é de $9000 \mathrm{~W}$, é formado por duas resistências elétricas de $\mathrm{Ni}$-Cr em forma de $\mathrm{U}$ invertido. Elas são isoladas por material cerâmico e revestidas por uma camisa de aço inoxidável de diâmetro igual a 8,5 mm e $300 \mathrm{~mm}$ de altura. As resistências individuais medidas em temperatura ambiente foram iguais a: $R 12=11,5 \Omega$ e $R 12=12,3 \Omega$. Essas resistências foram ligadas eletricamente em paralelo e se alimentadas com uma tensão de $220 \mathrm{~V}_{\mathrm{ac}}$ forneceriam juntas uma potência de $8143 \mathrm{~W}$. Observou-se durante os testes que a tensão de alimentação sofreu variações da ordem de 5\% em média, consideradas normais para uma rede elétrica sem controlador. Valores médios de tensão de $207 \mathrm{~V}(7210 \mathrm{~W})$ com variações entre aproximadamente $203 \mathrm{e}$ $217 \mathrm{~V}_{\mathrm{ac}}$ foram medidos com multímetro digital durante os testes. Essas variações de tensão foram consideradas como não interferentes de forma significativa nos dados experimentais dos testes. Os 41 testes preliminares realizados são apresentados na TAB. 5.1. Os dados referentes aos testes realizados para o nível colapsado igual a 3000 mm na ST2 (TAB. 5.1 - coluna 7) são mostrados na FIG. 5.1. O procedimento descrito no APÊNDICE E foi utilizado para a realização destes testes. 
Observou-se nestes testes que, para vazões de resfriamento abaixo de $70 \mathrm{l} / \mathrm{h}\left(1,944 \times 10^{-5} \mathrm{~m}^{3} / \mathrm{s}\right.$ ou $\left.0,019 \mathrm{~kg} / \mathrm{s}\right)$, a temperatura do fluido de resfriamento aumentou excessivamente com a formação de vapor na linha de resfriamento, conforme pode ser observado pelas temperaturas mostradas na FIG. 5.1 e confirmado por um balanço térmico entre energia entregue pelo aquecedor (7210 W) e a energia removida pelo fluido de resfriamento. Esse fato foi considerado indesejado aos dados experimentais. Para vazões de resfriamento acima $70 \mathrm{l} / \mathrm{h}$ $\left(1,944 \times 10^{-5} \mathrm{~m}^{3} / \mathrm{s}\right.$ ou $\left.0,019 \mathrm{~kg} / \mathrm{s}\right)$, a formação de vapor diminuiu bastante, sendo que para $100 \mathrm{l} / \mathrm{h}\left(2,777 \times 10^{-5} \mathrm{~m}^{3} / \mathrm{s}\right.$ ou $\left.0,028 \mathrm{~kg} / \mathrm{s}\right)$ não se observou a formação de vapor na linha de resfriamento. Diante desta conclusão, os testes subseqüentes foram todos realizados com a vazão de $100 \mathrm{l} / \mathrm{h}\left(2,777 \times 10^{-5} \mathrm{~m}^{3} / \mathrm{s}\right.$ ou $\left.0,028 \mathrm{~kg} / \mathrm{s}\right)$. Nos testes da FIG. 5.1, os dados foram gravados pelo programa BETSNI prog.vi a cada 3s, de forma que o tempo total dos testes apresentados na FIG. 5.1 é de aproximadamente $8700 \mathrm{~s}$ ou 2:25 horas.

Os demais dados referentes aos testes preliminares apresentados na TAB. 5.1 não serão apresentados, exceto os apresentados na FIG. 5.1. Os dados dos testes da TAB. 5.1 não foram usados nas análises com RNA's.

Devido ao fato das seções de testes ST1 e ST2 possuírem um volume relativamente pequeno, $0,0458 \mathrm{~m}^{3}(45,8 \mathrm{l})$ cada, e também devido à pequena potência do aquecedor utilizado nos testes $(9 \mathrm{~kW})$, com a ocorrência de condensação do vapor durante os testes verificou-se a formação de condições de pressão sub-atmosférica (vácuo parcial) nas ST's. Por isso somente foi possível realizar transientes de nível nas ST's pela transferência de água entre elas, por diferença de pressão hidrostática. Pressões sub-atmosféricas não devem ocorrer no caso de utilização deste tipo de sonda em um vaso de reator, onde a quantidade de energia entregue ao fluido do vaso é muito grande, mesmo com o reator desligado, e também devido aos enormes volumes envolvidos. A quantidade de energia removida pela sonda seria insuficiente para promover alterações na pressão do sistema. 
Observaram-se durante os testes, pelos visores de nível das ST's, oscilações do nível nas seções de testes da ordem de $300 \mathrm{~mm}$ causadas pela movimentação da mistura bifásica no interior das ST's. Para diminuir as oscilações no visor de nível e permitir uma medida do nível expandido da mistura na seção de testes, promoveu-se o estrangulamento (fechamento parcial) da válvula existente na extremidade inferior do visor, diminuindo as oscilações no visor de nível para valores da ordem de $30 \mathrm{~mm}$. O efeito das oscilações nas medidas de temperatura das sondas não pôde ser quantificado com a configuração de instalação testada, porém pode ser avaliado e diminuído com o uso de tubos de acalmação em torno das sondas, em trabalhos futuros.

Foram observadas também diferenças médias da ordem de $800 \mathrm{~mm}$ entre o nível expandido da mistura bifásica no interior das ST's e o nível colapsado medido pelos transmissores de pressão diferencial. Para uma faixa de nível nas ST's entre $2000 \mathrm{~mm}$ e $3200 \mathrm{~mm}$, esse valor representa frações volumétricas de vapor na mistura bifásica estimadas entre 25 e $40 \%$.

Os testes preliminares serviram para aprender a utilizar e para verificar o comportamento e funcionamento da bancada experimental e da sonda de tubo $U$ durante a realização dos testes. As informações e experiência operacional obtidas com esses testes foram úteis na elaboração dos procedimentos experimentais apresentados nos APÊNDICES E e F, juntamente com o aprendizado sobre o comportamento da bancada experimental obtido com os testes posteriores. 
TABELA 5.1. Testes preliminares com a sonda tipo tubo U na seção de testes ST2.

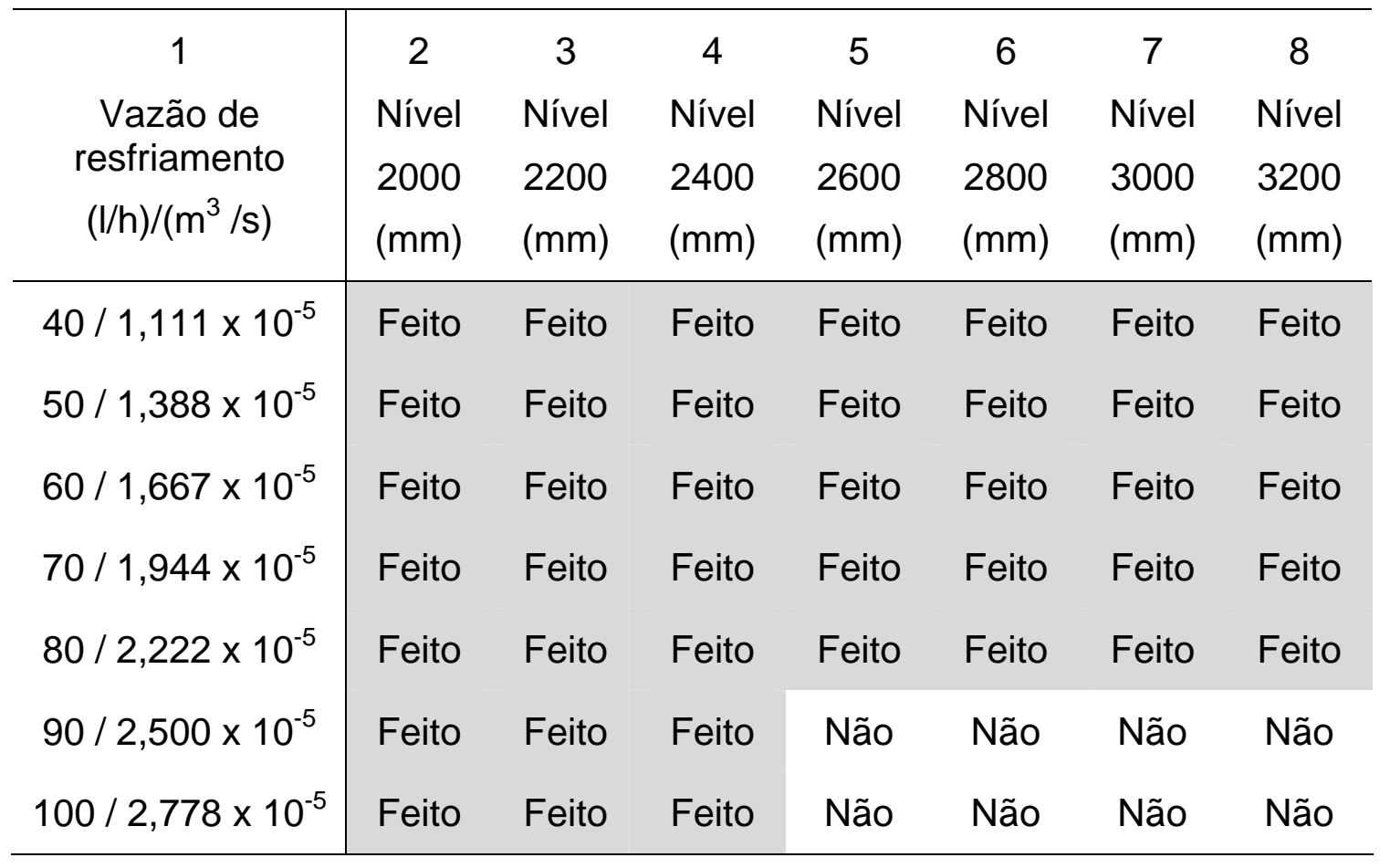

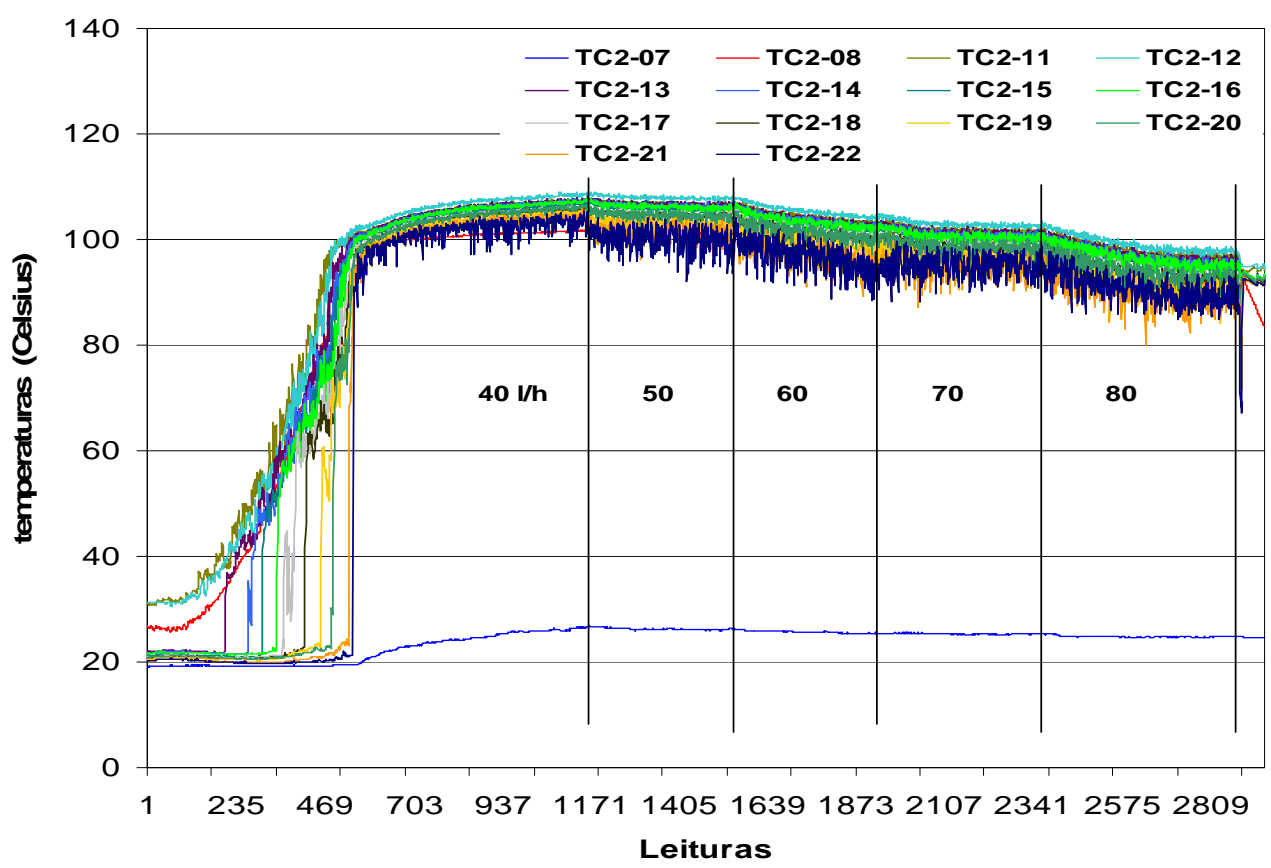

FIGURA 5.1. Resultados dos testes preliminares com sonda tipo tubo U para nível colapsado igual a $3000 \mathrm{~mm}$. 


\subsubsection{Sonda de Tubo U - Testes em Estado Estacionário}

Foram realizados testes com a sonda de tubo $U$ para valores de nível colapsado constante na seção de testes ST2, para a obtenção de dados experimentais representativos da condição de estado estacionário correspondente a cada nível colapsado testado. Os seguintes valores de nível colapsado na ST2 foram testados: 2200, 2400, 2600, 2800, 3000 e 3200 mm. Na realização desses testes foram seguidos os procedimentos experimentais apresentados APÊNDICE D para ligar o SAD e o computador, e o APÊNDICE E para a realização dos testes.

O programa BETSNI prog.vi é ajustado para que os dados sejam adquiridos pelo SAD em intervalos de tempo desejados. A divisão do tempo total do teste por esse intervalo de tempo fornece o número de dados daquele teste. Para estes testes os dados foram gravados a cada 30 s.

O procedimento do APÊNDICE E estabelece que seja mantido um nível colapsado igual a $1200 \mathrm{~mm}$ na seção de testes ST1 e o valor de nível colapsado desejado na seção de testes ST2. Os aquecedores das duas ST's são ligados, aguardando até que a condição de saturação seja atingida em ambas. $O$ ar existente nas ST's e que prejudica o processo de condensação, é então eliminado através das linhas de respiro com o posterior fechamento das válvulas de respiro. A válvula de equalização entre as duas ST's é aberta com apenas 1/4 de volta. A abertura de apenas $1 / 4$ de volta é para evitar a passagem de fluido de ST2 para ST1 pela linha de equalização, fato observado em testes preliminares quando se abria totalmente a válvula de equalização. Após isso, a vazão de resfriamento da sonda é estabelecida em $100 \mathrm{l} / \mathrm{h}\left(2,778 \times 10^{-5} \mathrm{~m}^{3} / \mathrm{s}-0,028 \mathrm{~kg} / \mathrm{s}\right)$ e aguarda-se que a condição de estado estacionário se estabeleça na ST2. Os dados experimentais de temperatura e dos níveis nas ST's referentes aos testes em estado estacionário são apresentados nas FIG. 5.2 a 5.40 . 
No geral, observa-se nas FIG. 5.2 a 5.37 um comportamento semelhante para as temperaturas medidas. Exceção feita aos dados obtidos no testes para 0 nível colapsado de 3000 mm, apresentados nas FIG. 5.26 e 5.27, onde ocorreram interrupções temporárias no fornecimento de energia aos aquecedores.

Numa $\mathbf{1}^{\mathrm{a}}$ fase dos testes acontece o aquecimento do fluido nos vasos das ST's, com as temperaturas atingindo as condições de saturação e com valores por volta de $100^{\circ} \mathrm{C}$. Depois numa $2^{\mathrm{a}}$ fase, que tem início com o estabelecimento da vazão de resfriamento na sonda, observa-se uma diminuição geral nas temperaturas medidas na parede da sonda e no fluido das ST's. Essa diminuição ocorre mais acentuadamente nas temperaturas correspondentes aos termopares instalados na região mais superior da sonda (TC2-20, TC2-21 e TC2-22), ou seja, na região de entrada do fluido de resfriamento. Nesta região da seção de testes ST2, ocupada por vapor, ocorre o processo de condensação do vapor e a diminuição mais acentuada das temperaturas de parede. O sistema formado pelas duas ST's interligadas possui volume constante e a condensação do vapor provoca a formação de vácuo nas ST's, medido por um manovacuômetro instalado no topo do pote de condensação.

Temperaturas de parede na sonda inferiores a $40^{\circ} \mathrm{C}$ foram medidas durante os testes, embora as condições gerais na ST2 fossem de saturação. Nesta fase do teste, ocorre um desbalanceamento entre a remoção de calor pelo resfriamento da sonda e o calor fornecido pelo aquecedor. Após um intervalo de tempo aproximado de uma hora, tem início um processo de recuperação com o aumento nas temperaturas de parede e o estabelecimento da condição de estado estacionário na seção de testes ST2 para aquele nível colapsado específico. Pressões de vácuo da ordem de $50 \mathrm{kPa}$ foram medidas. Considerando esta pressão de vácuo e ainda que a pressão atmosférica medida no galpão de experimentos onde está montada a Bancada Experimental é igual a 91,2 kPa, então a pressão média absoluta atuante na ST2 em estado estacionário é igual a 41,2 kPa, que 
corresponde a uma temperatura de saturação de $76,6^{\circ} \mathrm{C}$. Valores próximos a este podem ser observados nas FIG. 5.2 a 5.37 .

Esses testes foram conduzidos de forma diferente dos testes preliminares descritos no item 5.1.1, onde a vazão de resfriamento da sonda foi mantida durante todos os testes enquanto que para estes testes a vazão de resfriamento da sonda foi estabelecida após as condições de saturação terem sido atingidas nas ST's e a eliminação do ar nas mesmas fosse feita. Por isso o comportamento diferente nas curvas de temperatura versus tempo.

Os dados experimentais (temperatura de entrada e saída da água de resfriamento, temperatura de parede da sonda e nível colapsado) que foram usados nas análises por RNA's, são mostrados nas FIG. 5.2 a 5.37, relativos à região onde as condições de estado estacionário estavam estabelecidas, para cada um dos níveis testados: 2200, 2400, 2600, 2800, 3000 e 3200 mm. Para cada caso escolheu-se um intervalo aproximado de $3000 \mathrm{~s}$, resultando em grupos de aproximadamente 100 dados para cada nível colapsado, perfazendo um total de 617 dados. Os dados experimentais e o intervalo de tempo escolhido são apresentados nas FIG. 5.6, 5.7, 5.12, 5.13, 5.18, 5.19, 5.24, 5.25, 5.30, 5.31, 5.36 e 5.37.

Os dados foram agrupados num conjunto geral e são apresentados nas FIG. 5.38 e 5.39, enquanto que na FIG. 5.40 são mostrados os dados de temperatura de saída do fluido de resfriamento (TC2-08) e de temperatura de parede na sonda (TC2-11 a TC2-22) para o nível colapsado de $2200 \mathrm{~mm}$ em uma escala de temperatura expandida. Com isso é possível verificar com maior clareza a ocorrência de pequenas diferenças nas temperaturas medidas e que existe também um comportamento coerente para estas. Temperaturas maiores são medidas pelos termopares inferiores da sonda (TC2-11 e TC2-12). À medida que se sobe ao longo da sonda observa-se que as temperaturas diminuem como conseqüência do resfriamento, com os menores valores medidos pelo termopar TC2-22 posicionado na região superior da sonda, região onde ocorre a condensação do vapor. 


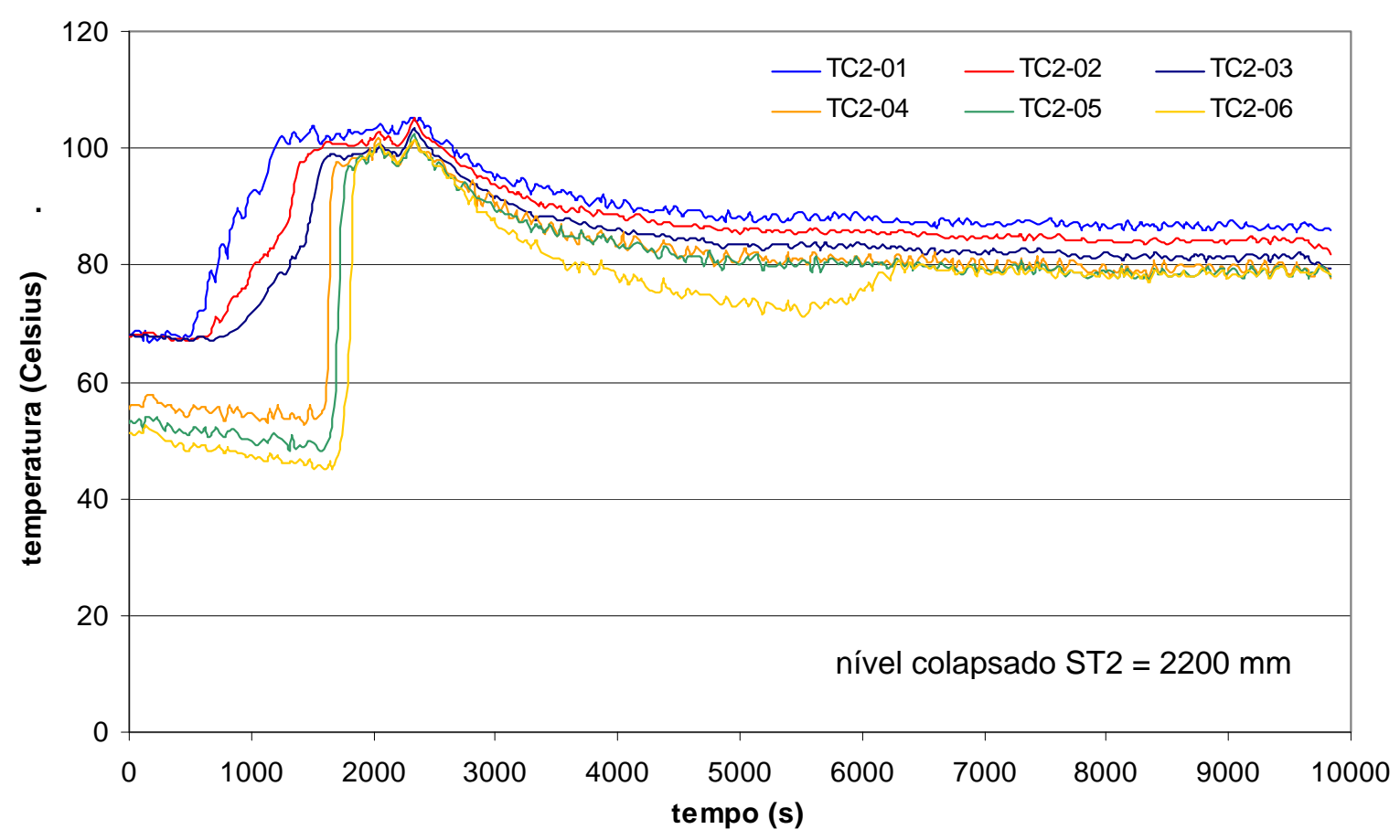

FIGURA 5.2. Temperaturas do fluido (TC2-01 a TC2-06) no vaso da seção de testes ST2 para nível colapsado igual a $2200 \mathrm{~mm}$ na ST2.

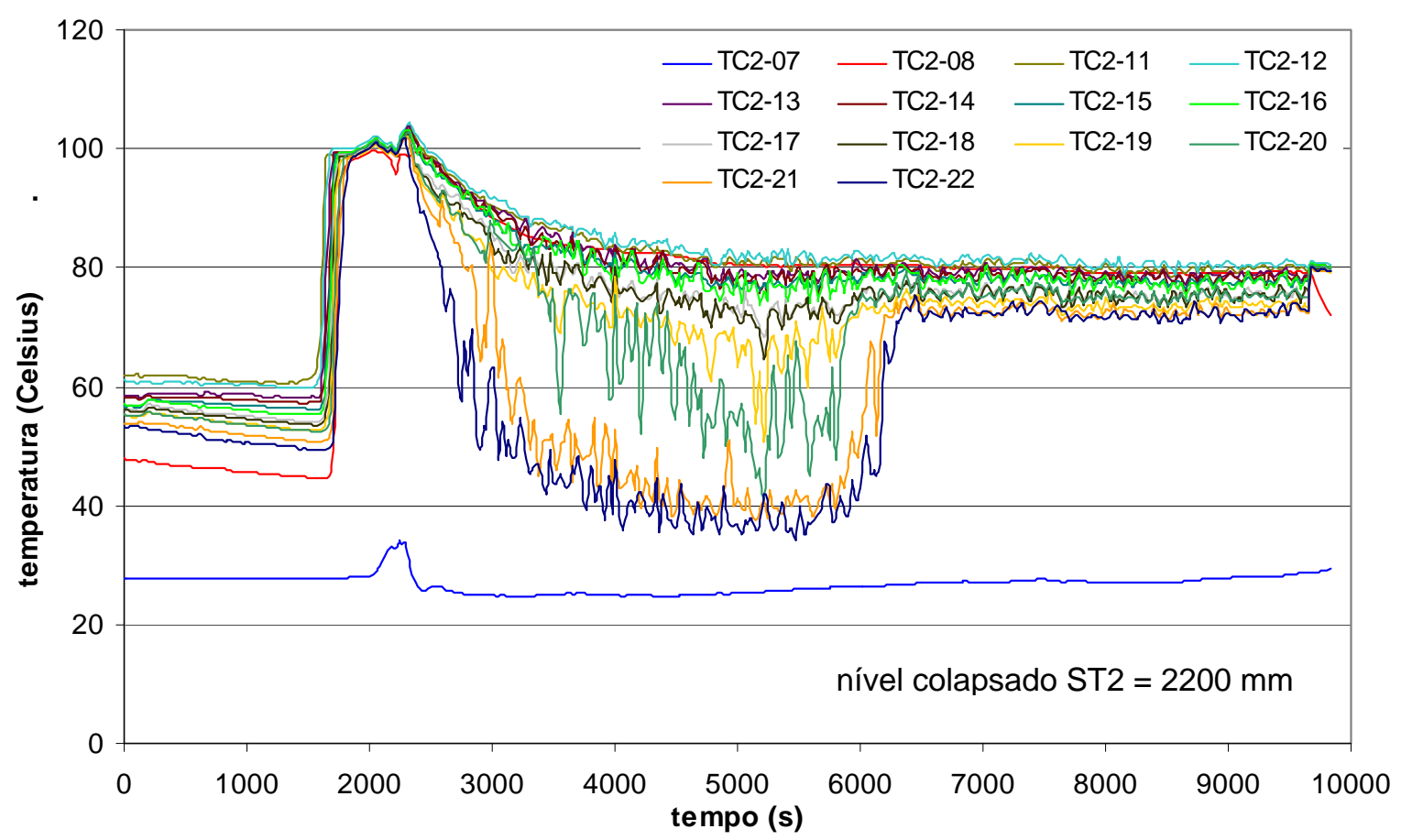

FIGURA 5.3. Temperaturas de entrada (TC2-07) e saída (TC2-08) do fluido de resfriamento e de parede na sonda tipo tubo $U$ (TC2-11 a TC2-22) para nível colapsado igual a 2200 mm na ST2. 


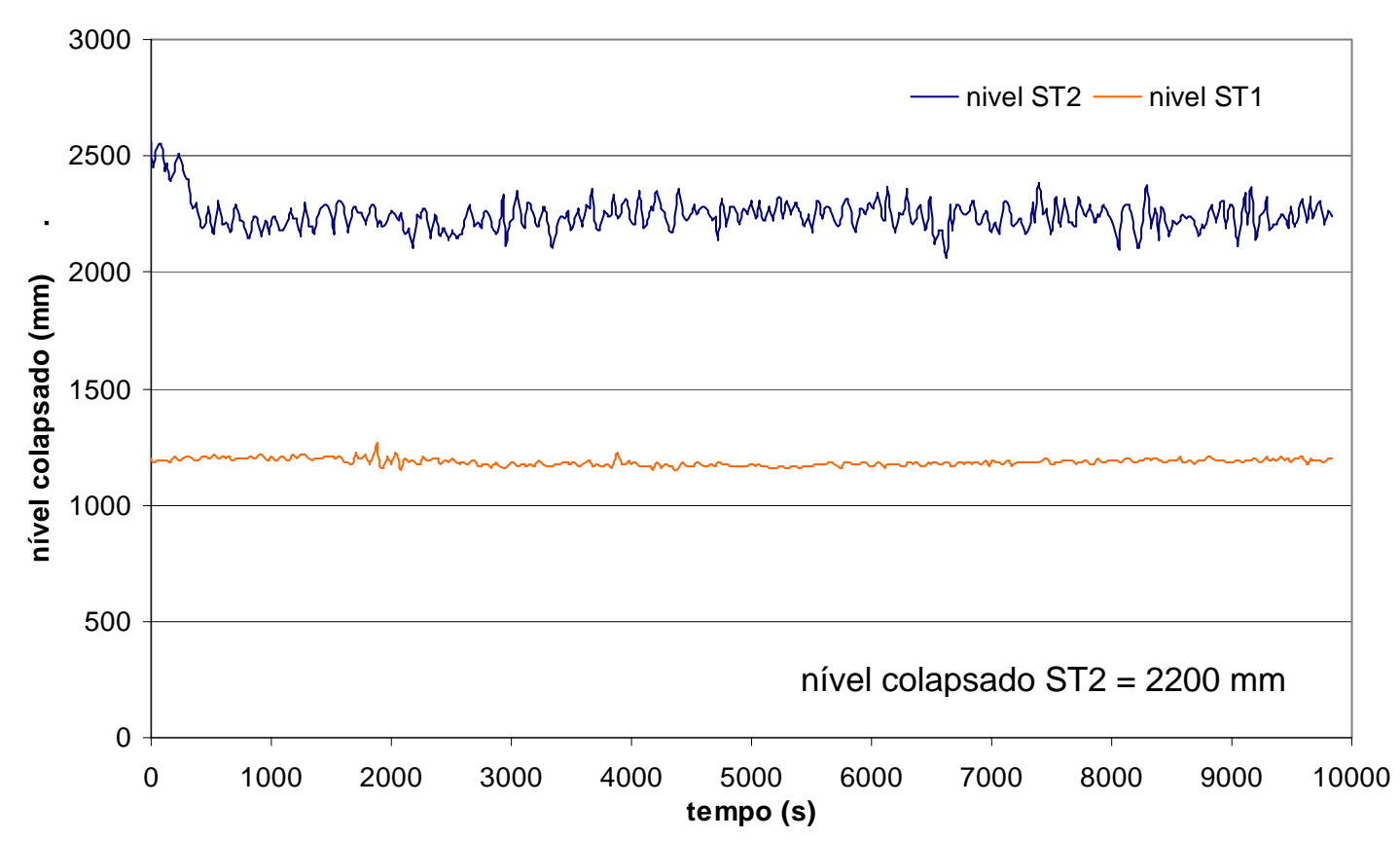

FIGURA 5.4. Nível colapsado nas seções de testes ST1 e ST2 durante o teste para nível colapsado igual a $2200 \mathrm{~mm}$ na ST2.

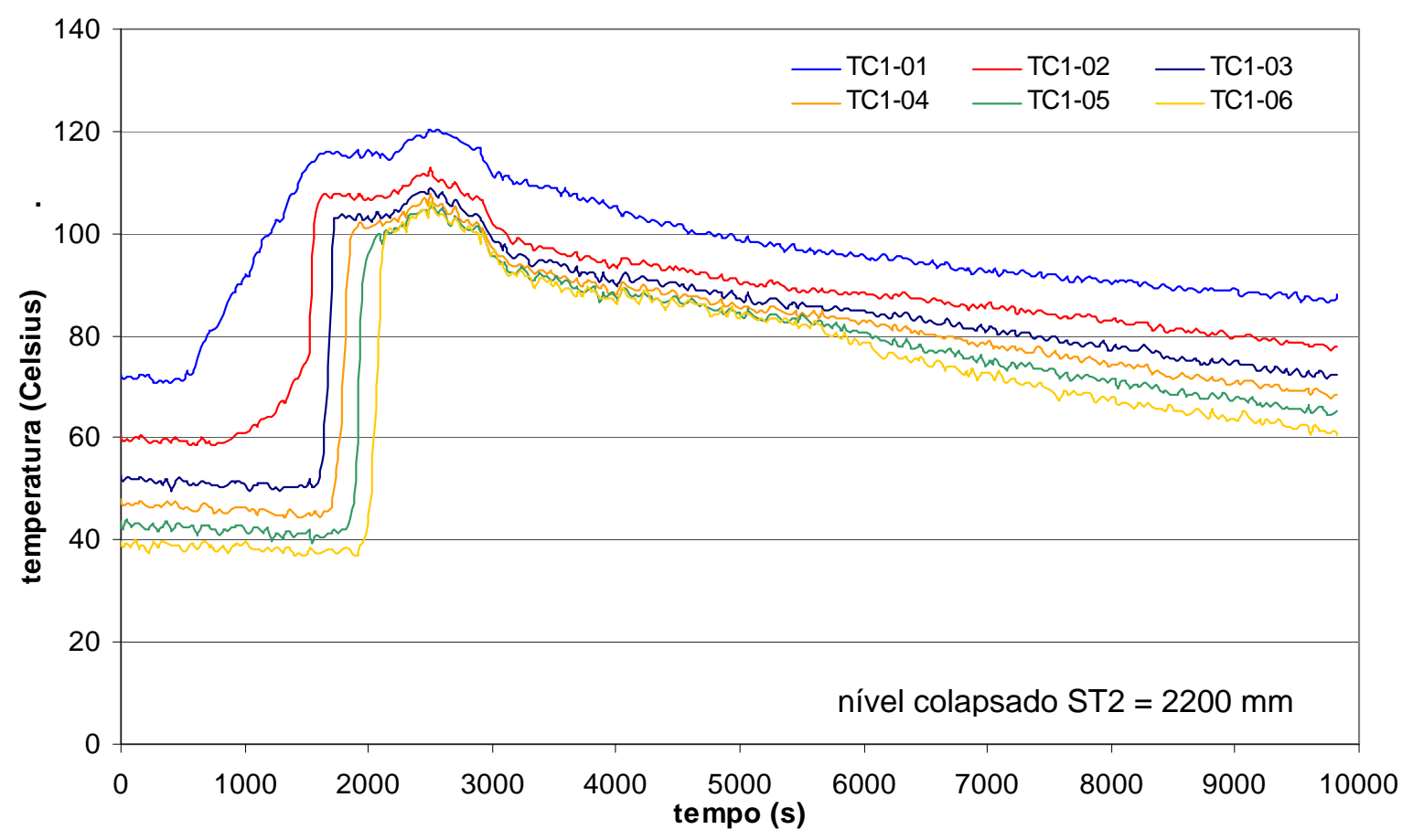

FIGURA 5.5. Temperaturas do fluido (TC1-01 a TC1-06) no vaso da seção de testes ST1 para nível colapsado igual a $2200 \mathrm{~mm}$ na ST2. 


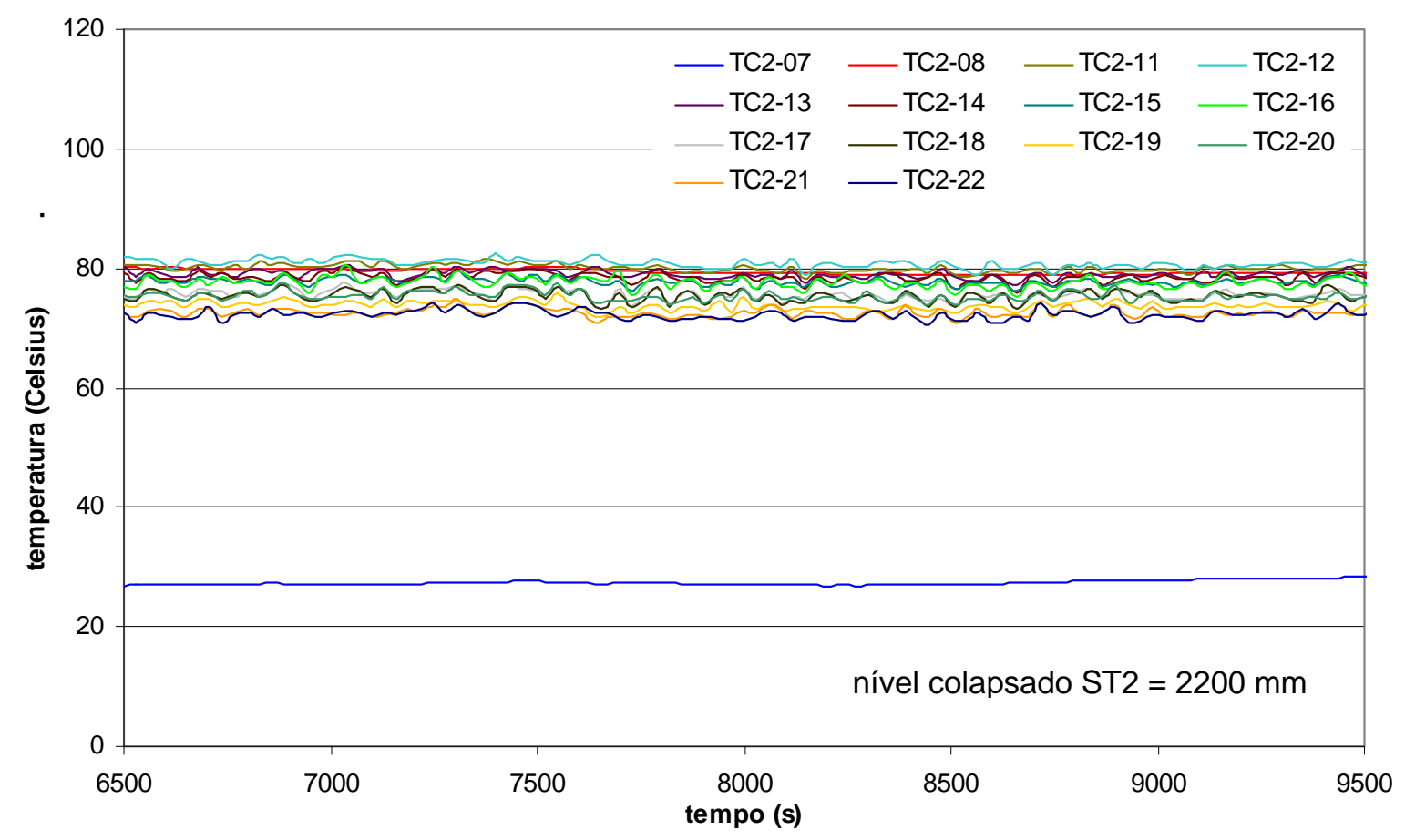

FIGURA 5.6. Dados em estado estacionário utilizados para análise com RNA's. Temperaturas de entrada (TC2-07) e saída (TC2-08) do fluido de resfriamento e de parede na sonda tipo tubo U (TC2-11 a TC2-22) para nível colapsado igual a $2200 \mathrm{~mm}$ na ST2.

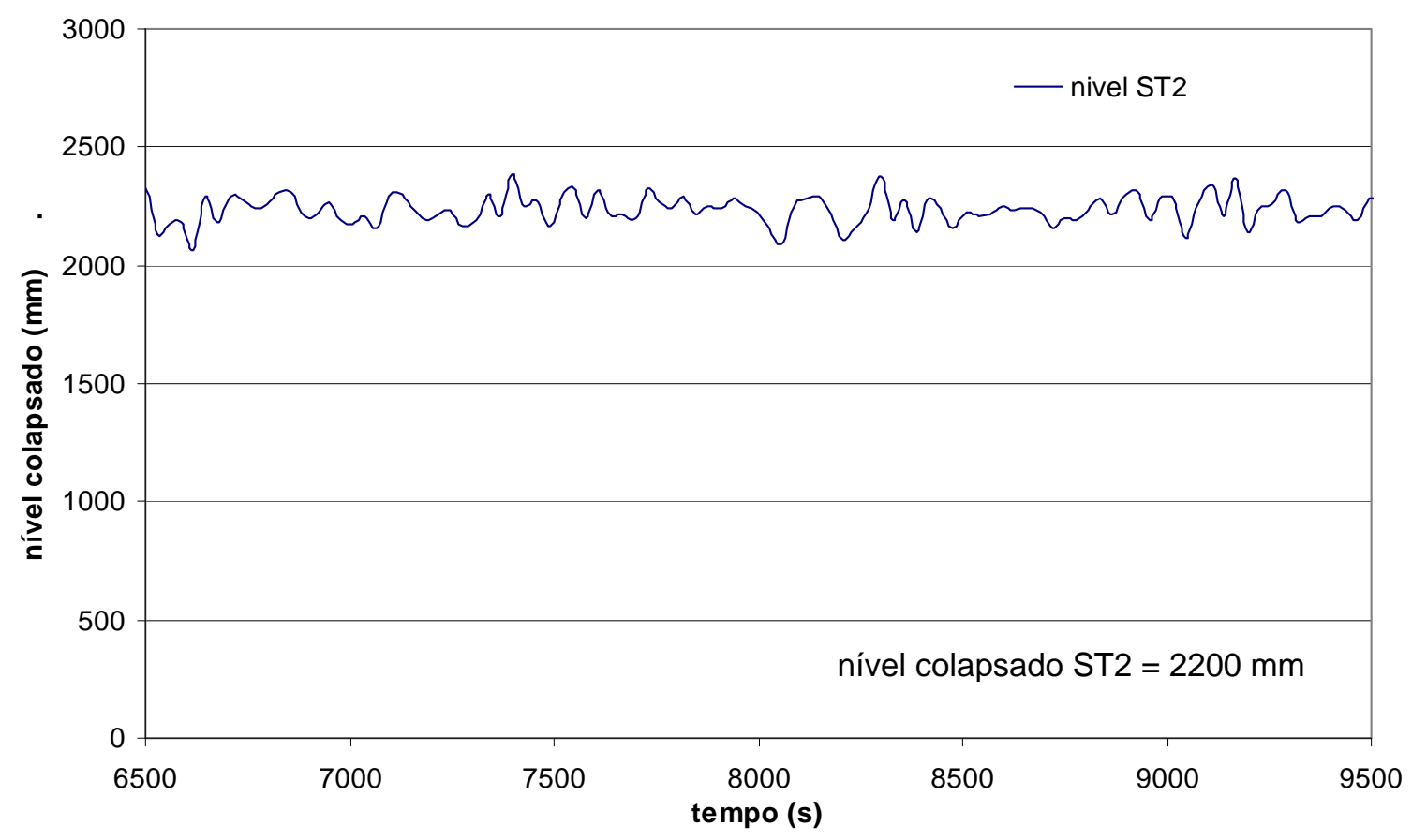

FIGURA 5.7. Dados em estado estacionário utilizados para análise com RNA's. Nível colapsado igual a 2200 mm na seção de testes ST2. 


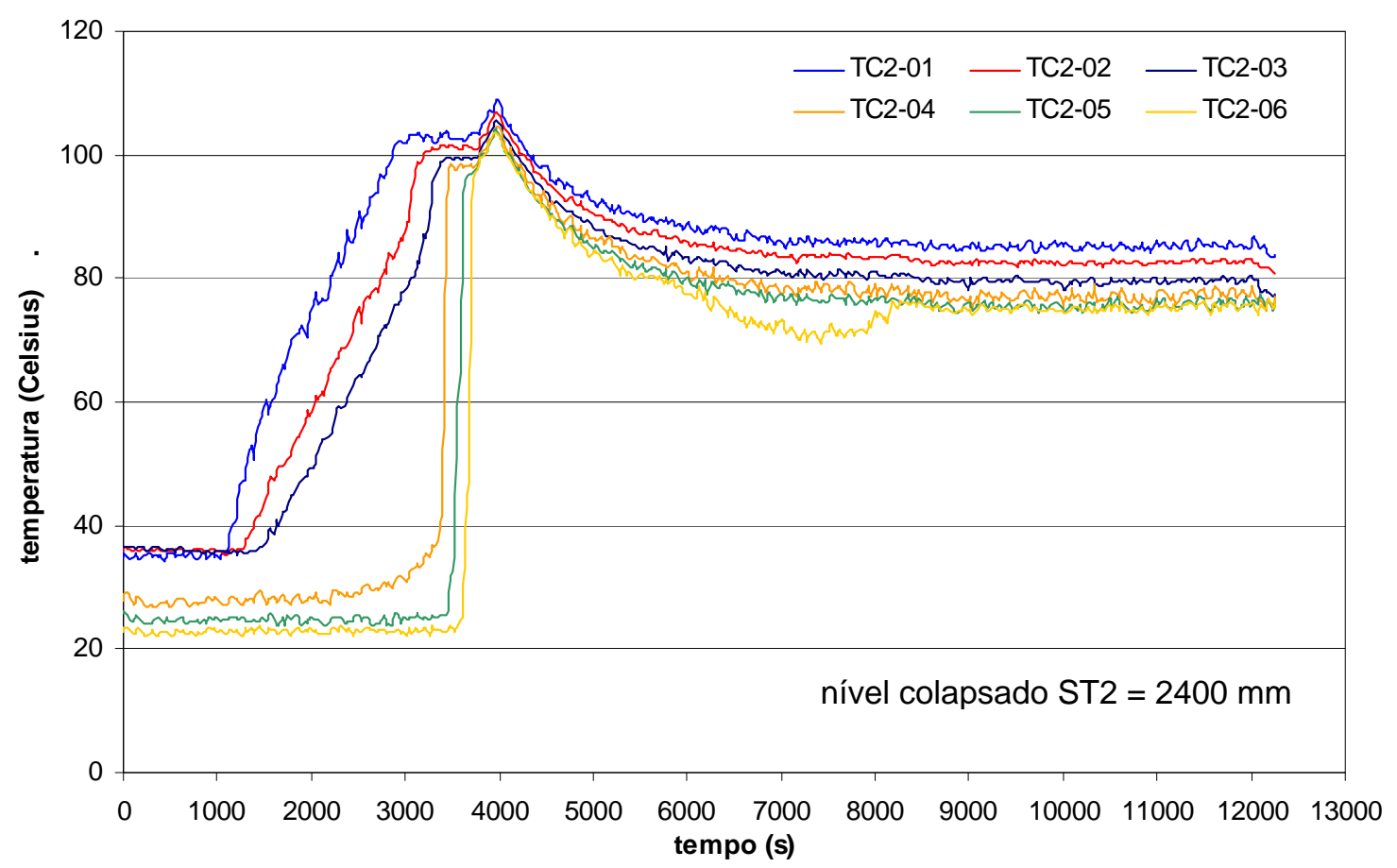

FIGURA 5.8. Temperaturas do fluido (TC2-01 a TC2-06) no vaso da seção de testes ST2 para nível colapsado igual a $2400 \mathrm{~mm}$ na ST2.

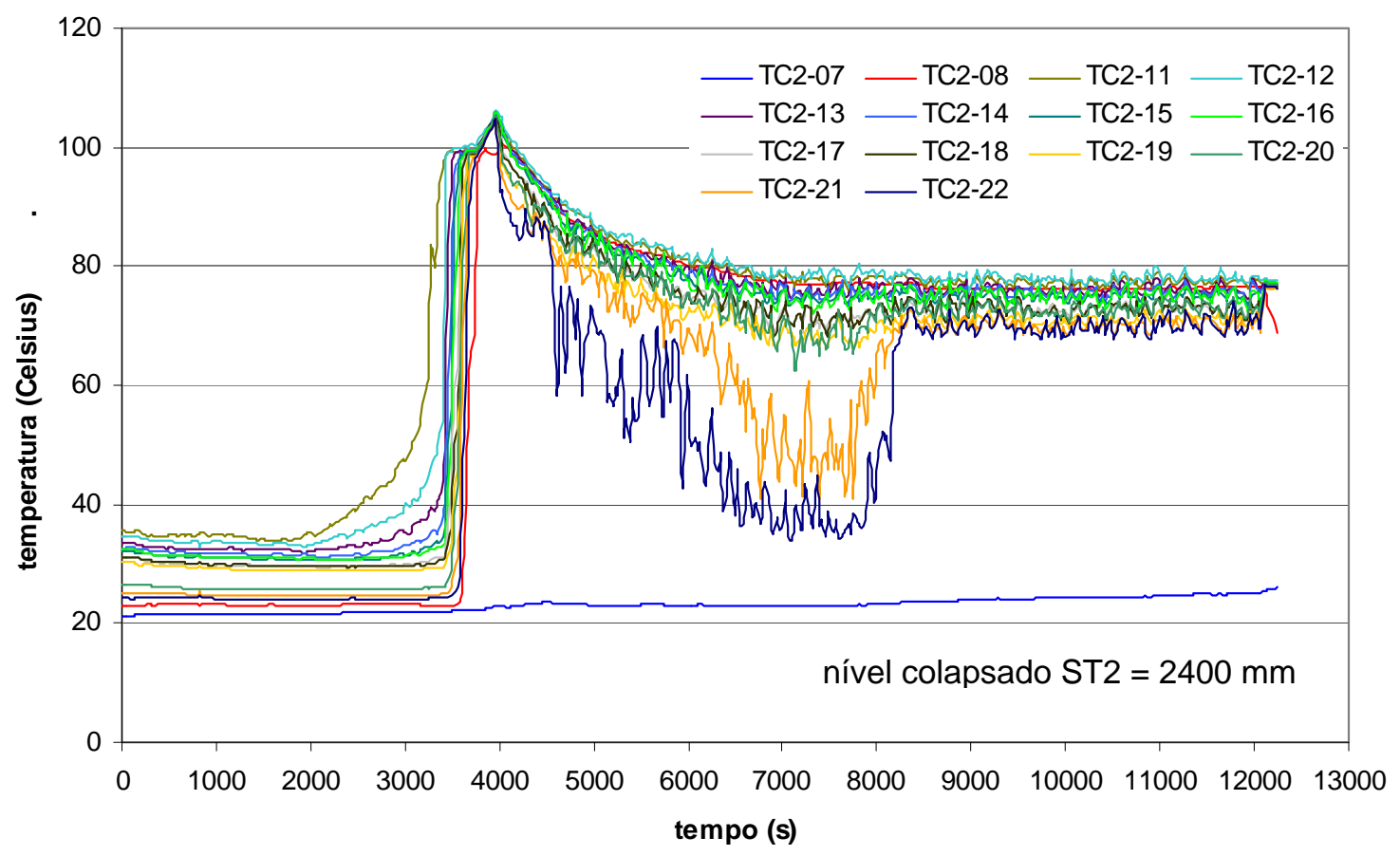

FIGURA 5.9. Temperaturas de entrada (TC2-07) e saída (TC2-08) do fluido de resfriamento e de parede na sonda tipo tubo U (TC2-11 a TC2-22) para nível colapsado igual a $2400 \mathrm{~mm}$ na ST2. 


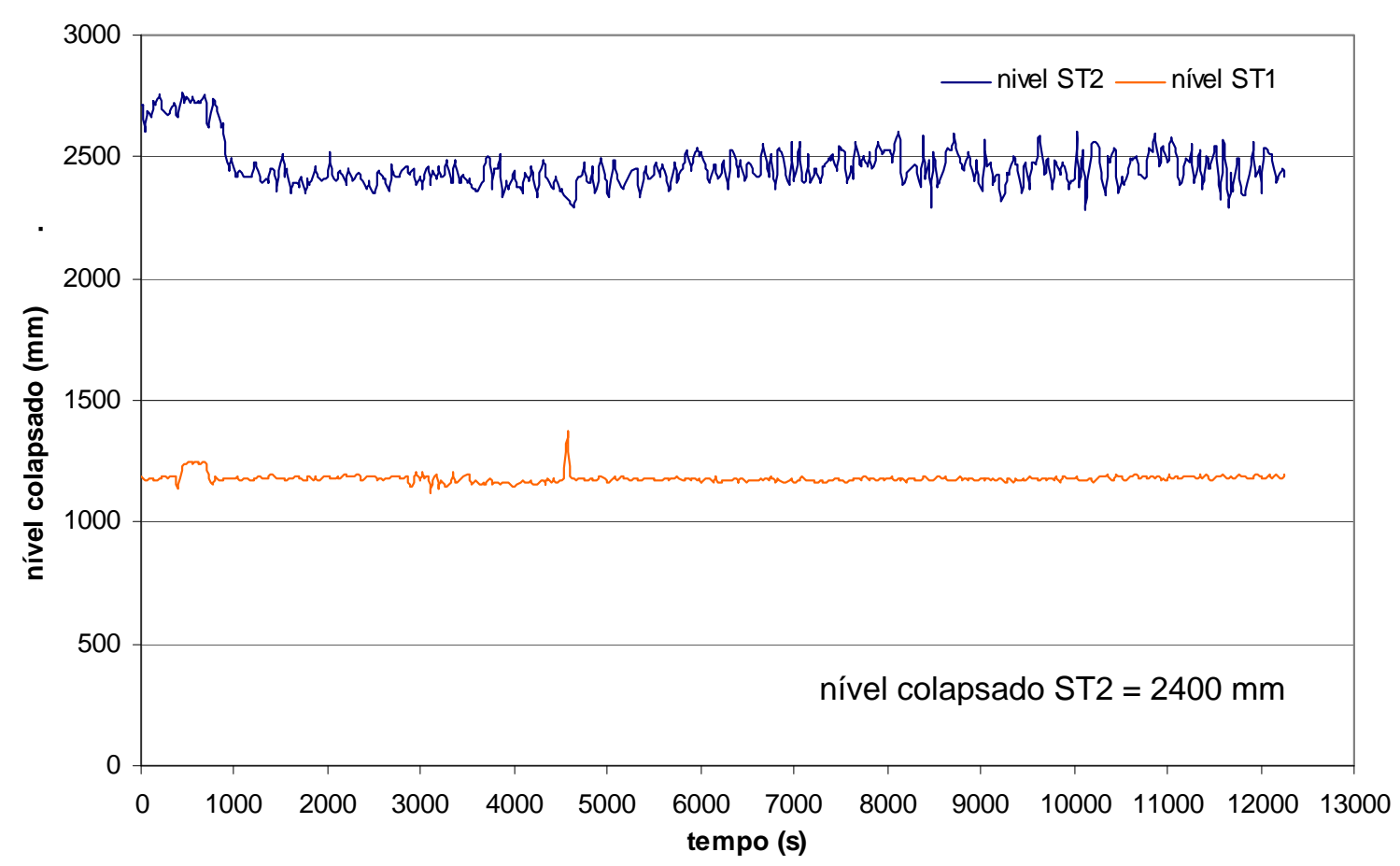

FIGURA 5.10. Nível colapsado nas seções de testes ST1 e ST2 durante o teste para nível colapsado igual a $2400 \mathrm{~mm}$ na ST2.

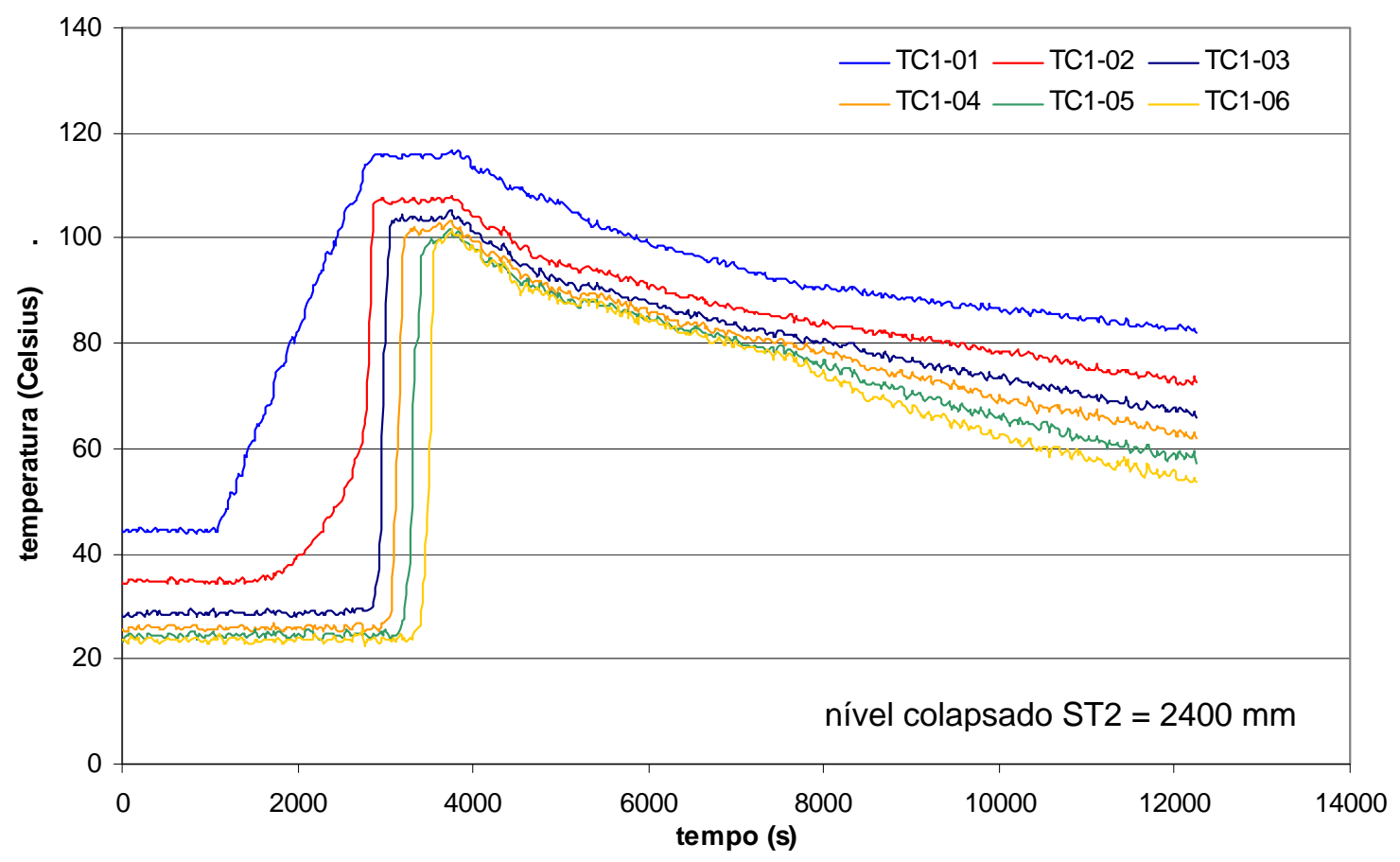

FIGURA 5.11. Temperaturas do fluido (TC1-01 a TC1-06) no vaso da seção de testes ST1 para nível colapsado igual a $2400 \mathrm{~mm}$ na ST2. 


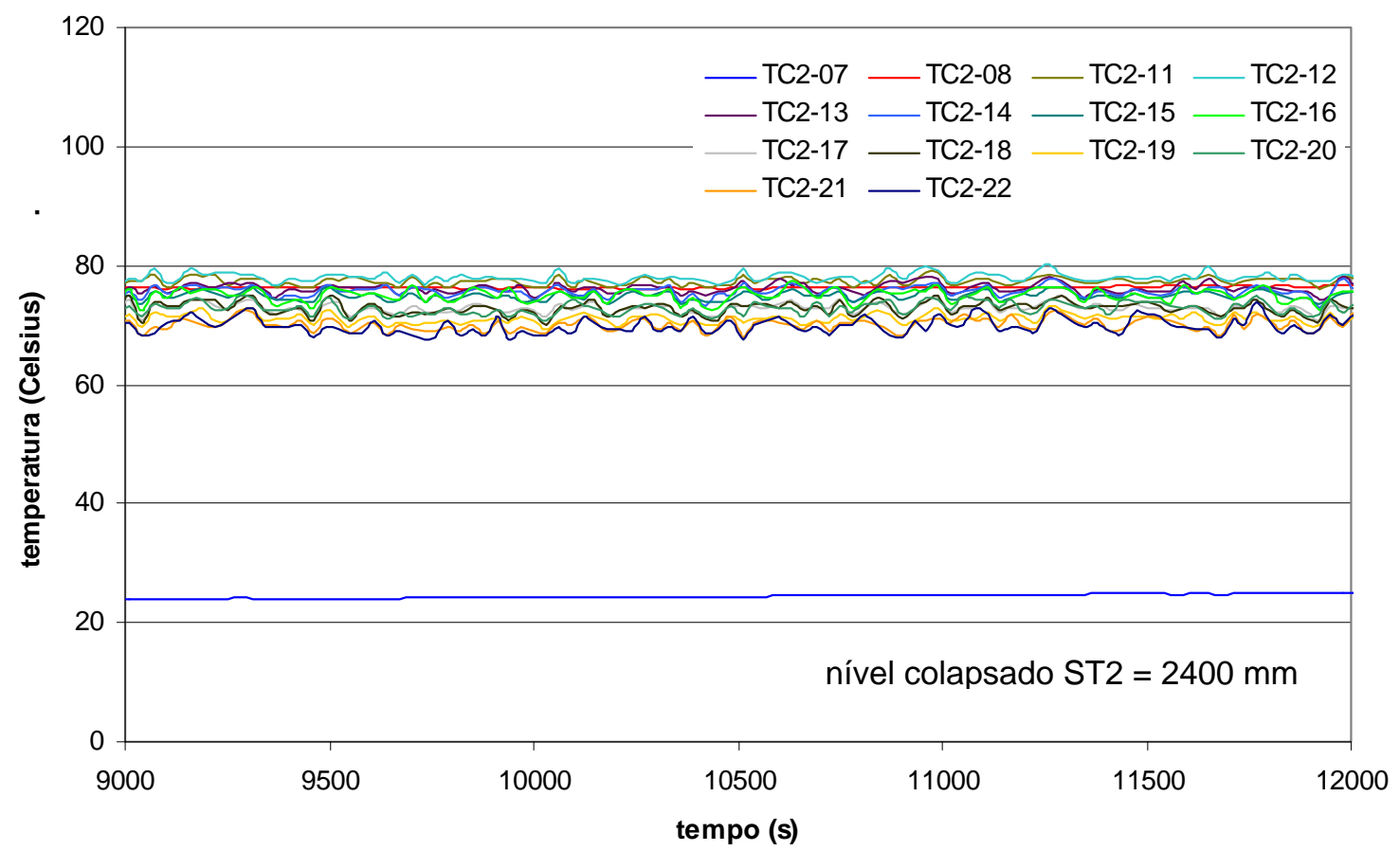

FIGURA 5.12. Dados em estado estacionário utilizados para análise com RNA's. Temperaturas de entrada (TC2-07) e saída (TC2-08) do fluido de resfriamento e de parede na sonda tipo tubo $U$ (TC2-11 a TC2-22) para nível colapsado igual a 2400mm na ST2.

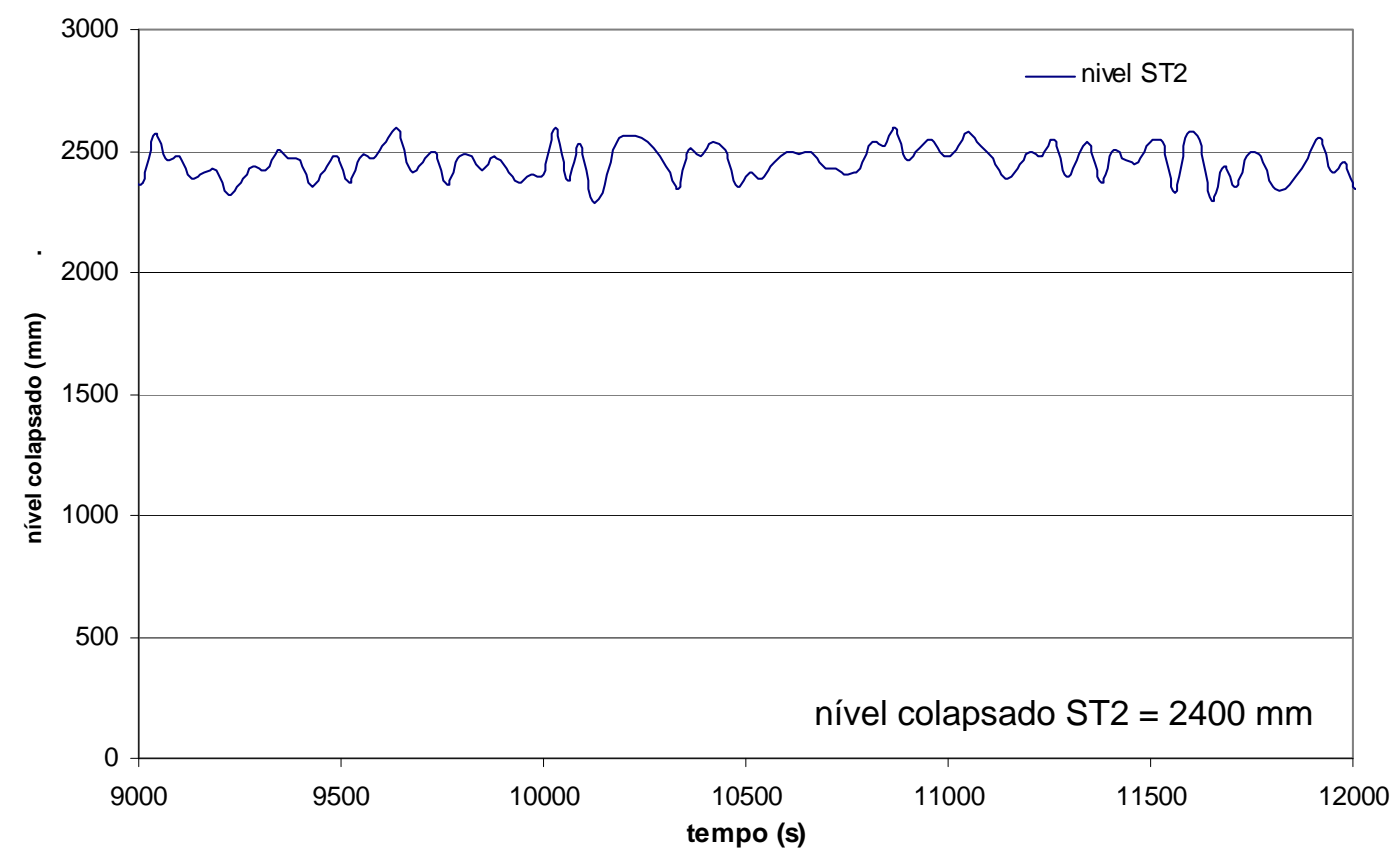

FIGURA 5.13. Dados em estado estacionário utilizados para análise com RNA's. Nível colapsado igual a $2400 \mathrm{~mm}$ na seção de testes ST2. 


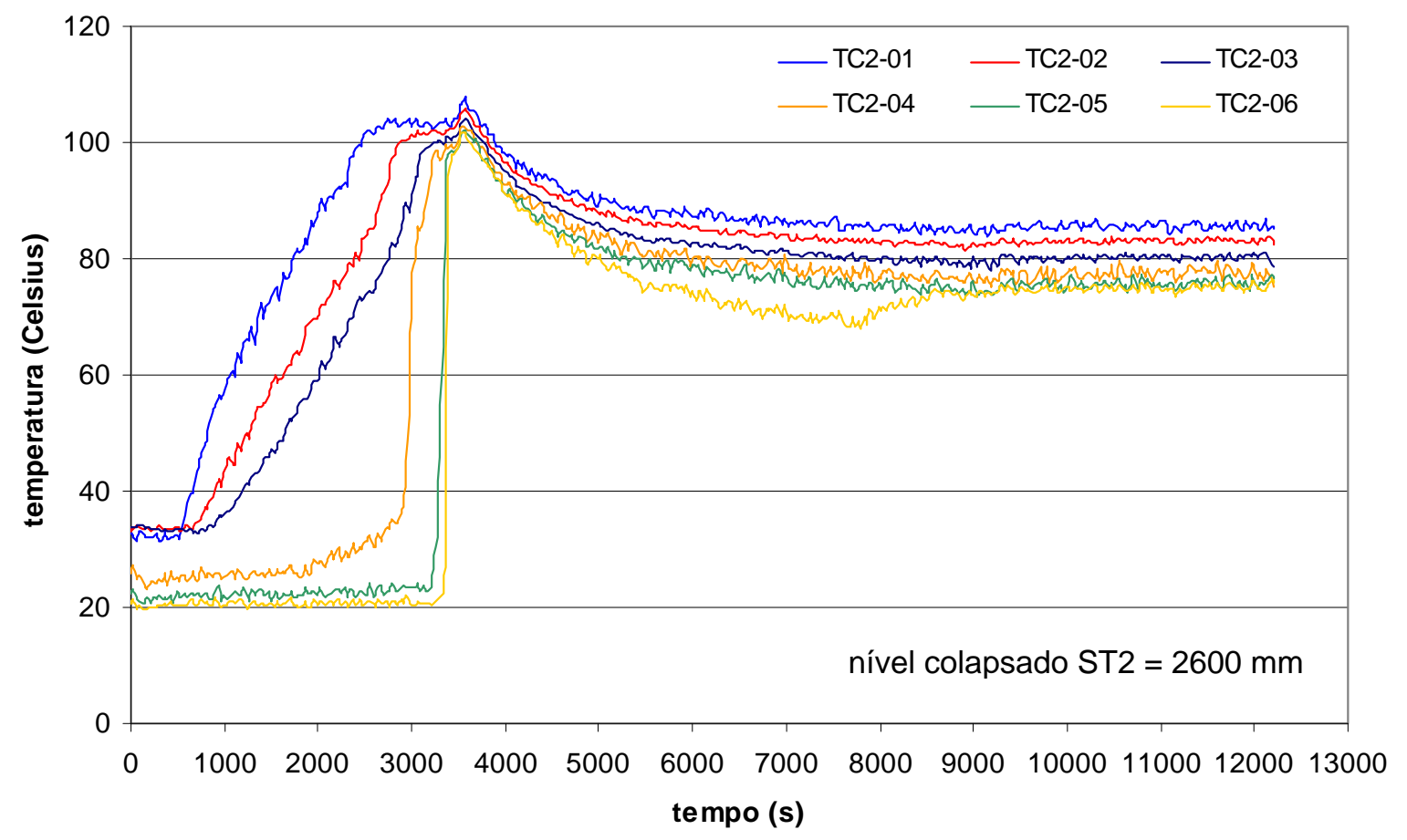

FIGURA 5.14. Temperaturas do fluido (TC2-01 a TC2-06) no vaso da seção de testes ST2 para nível colapsado igual a $2600 \mathrm{~mm}$ na ST2.

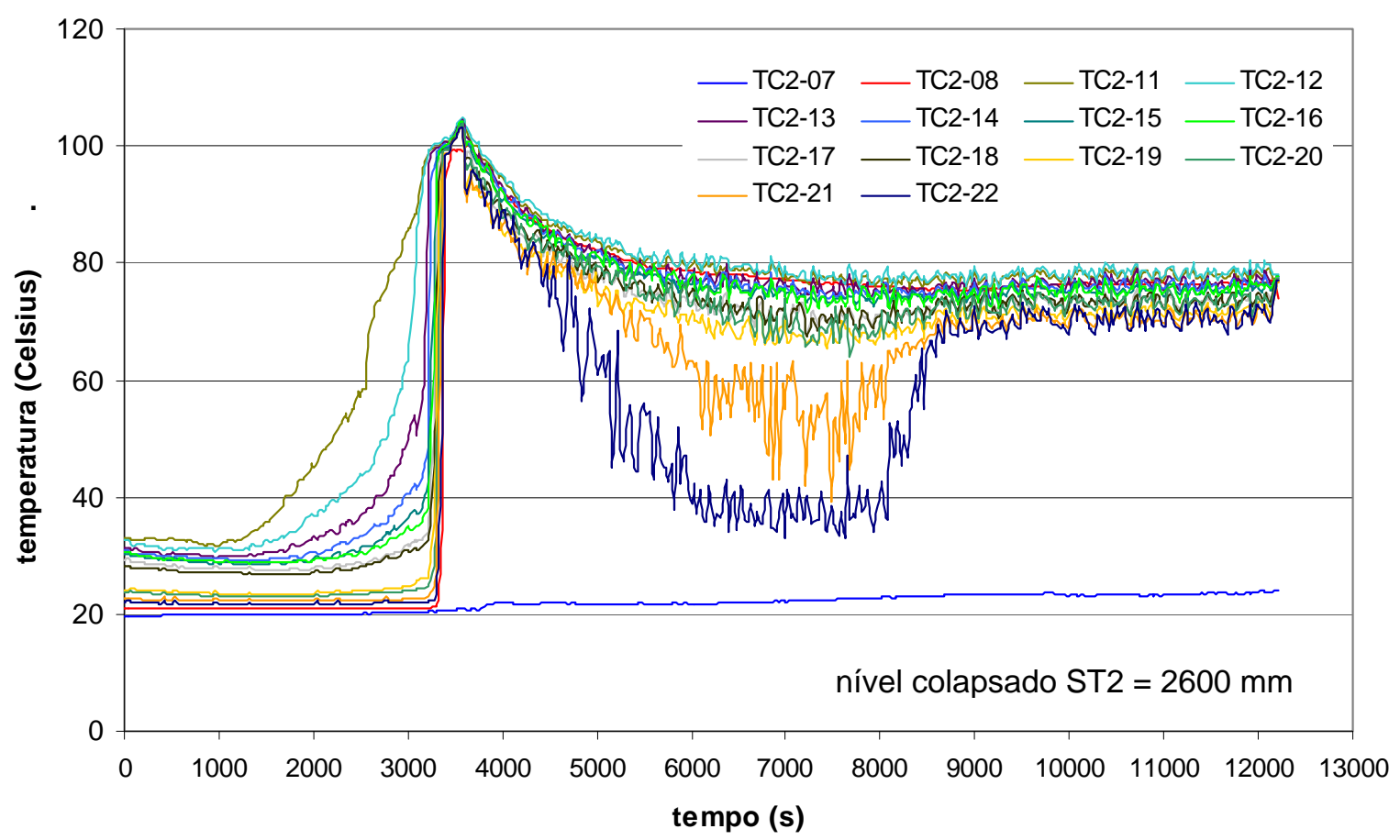

FIGURA 5.15. Temperaturas de entrada (TC2-07) e saída (TC2-08) do fluido de resfriamento e de parede na sonda tipo tubo $U$ (TC2-11 a TC2-22) para nível colapsado igual a $2600 \mathrm{~mm}$ na ST2. 


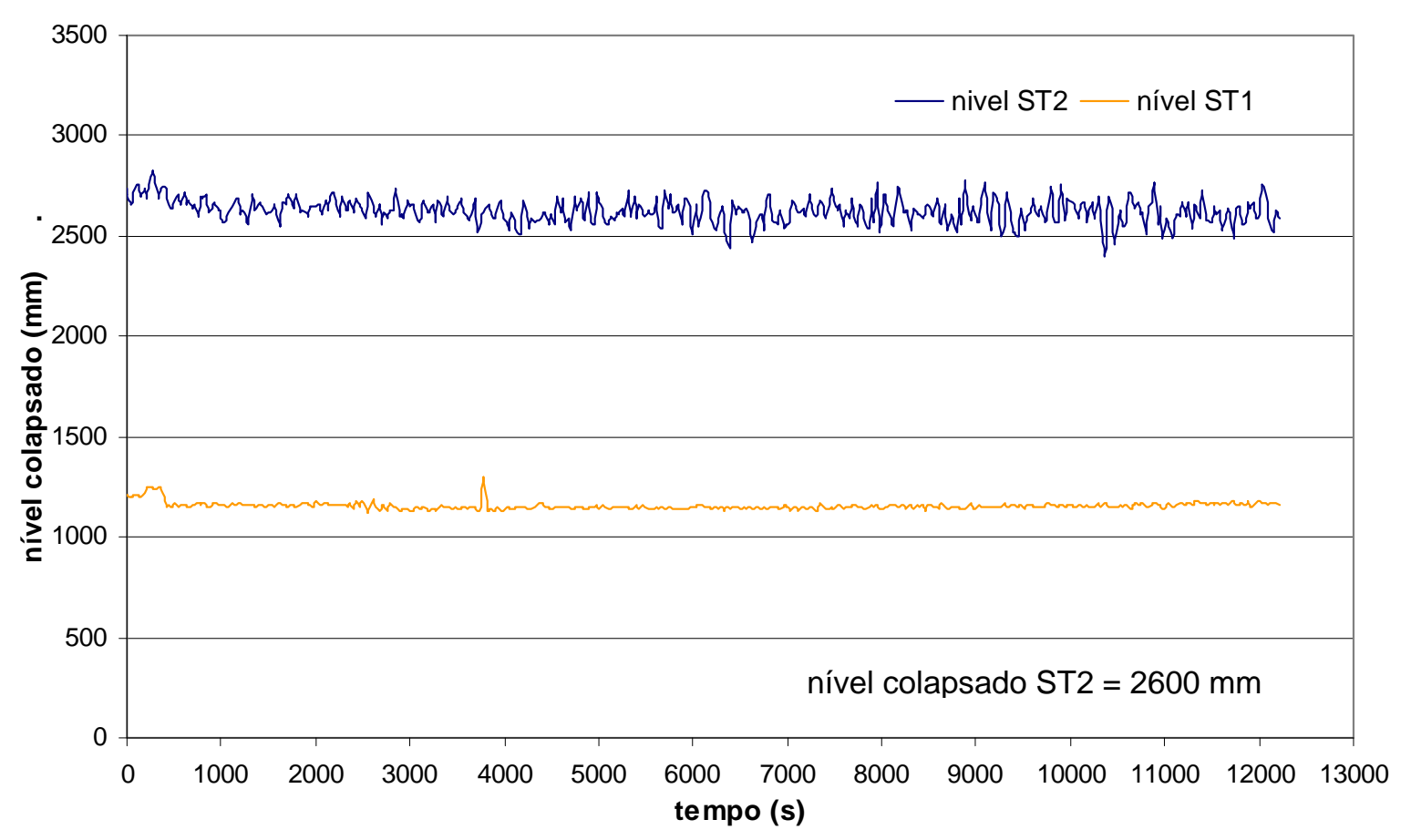

FIGURA 5.16. Nível colapsado nas seções de testes ST1 e ST2 durante o teste para nível colapsado igual a $2600 \mathrm{~mm}$ na ST2.

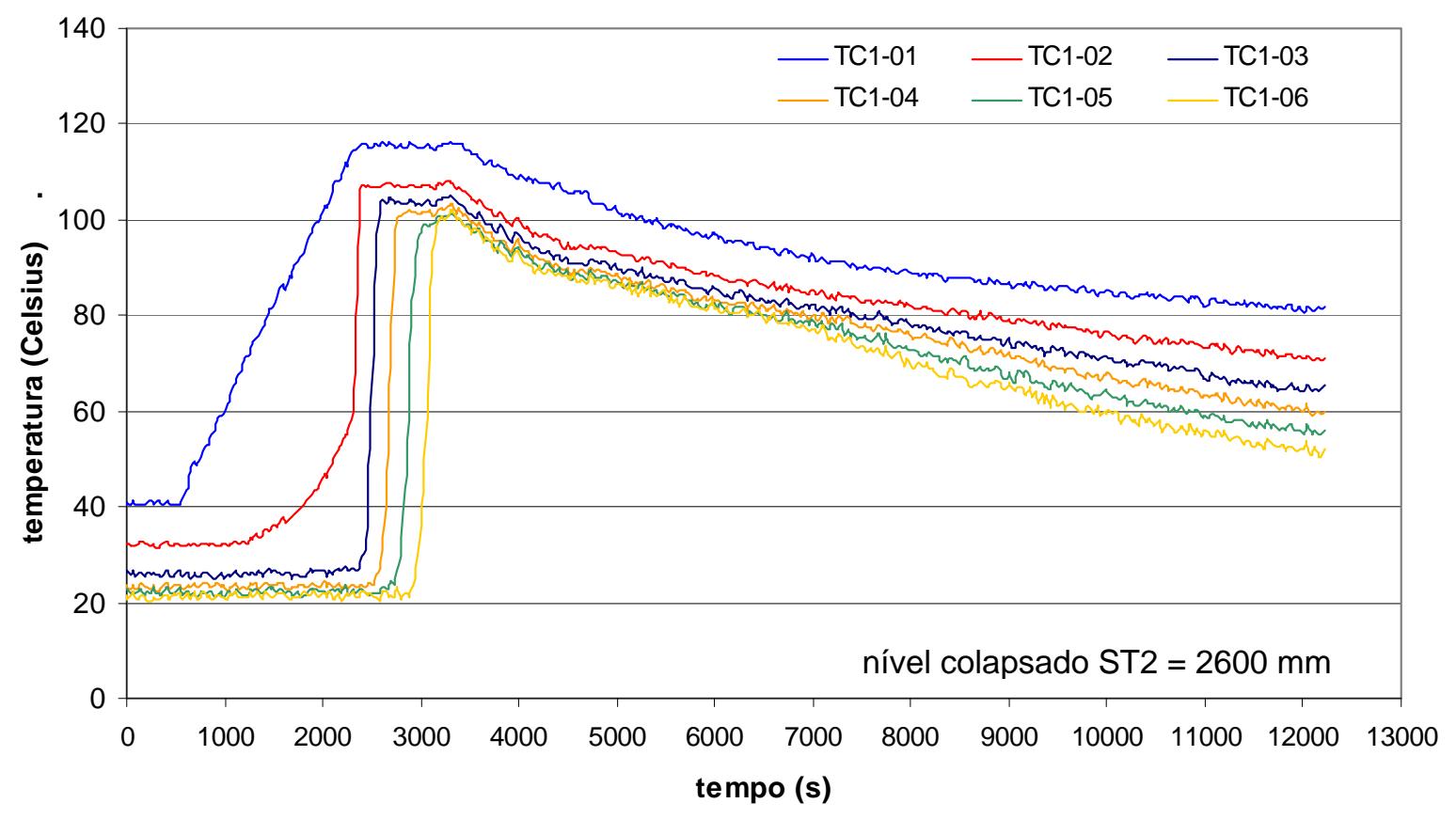

FIGURA 5.17. Temperaturas do fluido (TC1-01 a TC1-06) no vaso da seção de testes ST1 para nível colapsado igual a $2600 \mathrm{~mm}$ na ST2. 


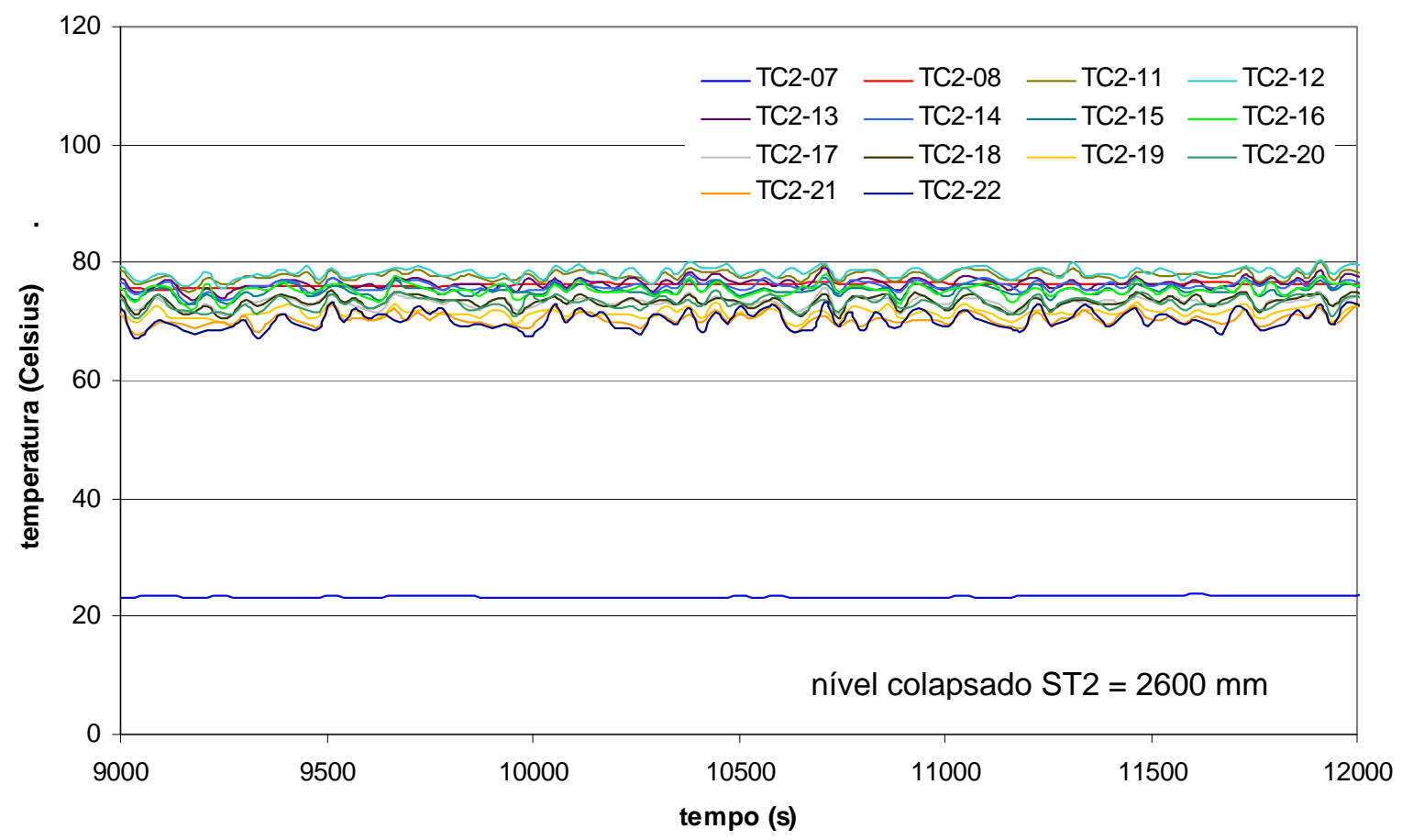

FIGURA 5.18. Dados em estado estacionário utilizados para análise com RNA's. Temperaturas de entrada (TC2-07) e saída (TC2-08) do fluido de resfriamento e de parede na sonda tipo tubo $U$ (TC2-11 a TC2-22) para nível colapsado igual a $2600 \mathrm{~mm}$ na ST2.

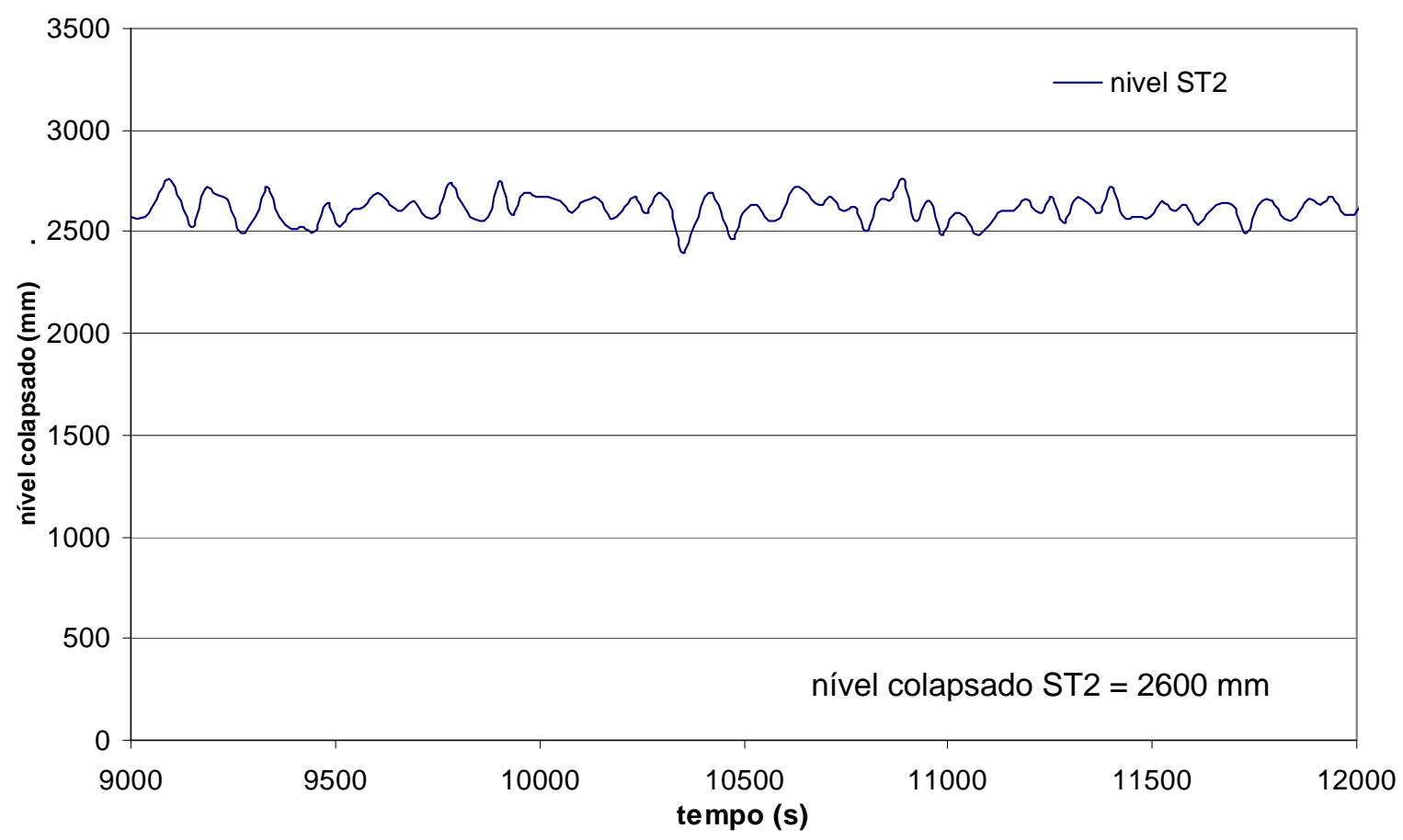

FIGURA 5.19. Dados em estado estacionário utilizados para análise com RNA's. Nível colapsado igual a $2600 \mathrm{~mm}$ na seção de testes ST2. 


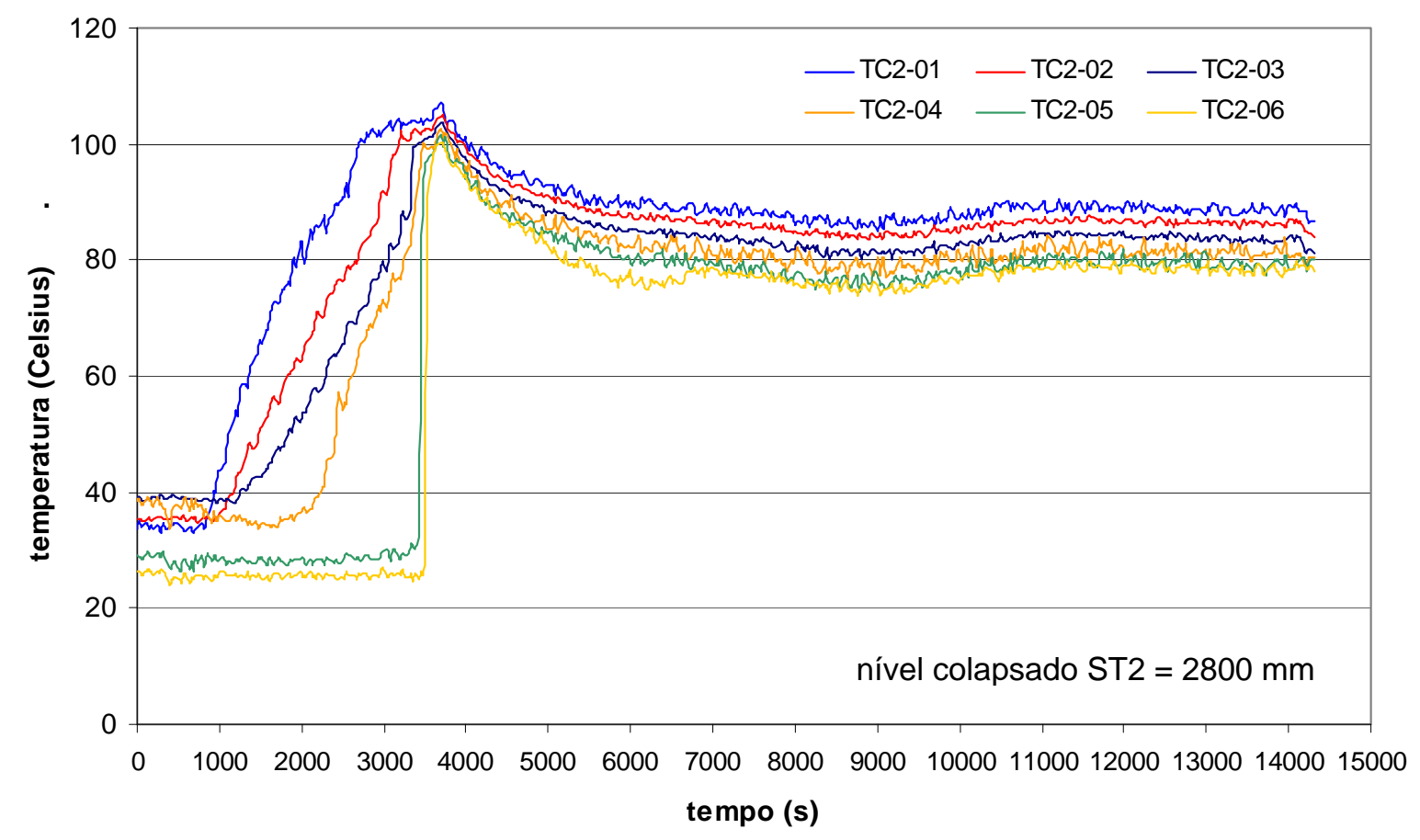

FIGURA 5.20. Temperaturas do fluido (TC2-01 a TC2-06) no vaso da seção de testes ST2 para nível colapsado igual a 2800 mm na ST2.

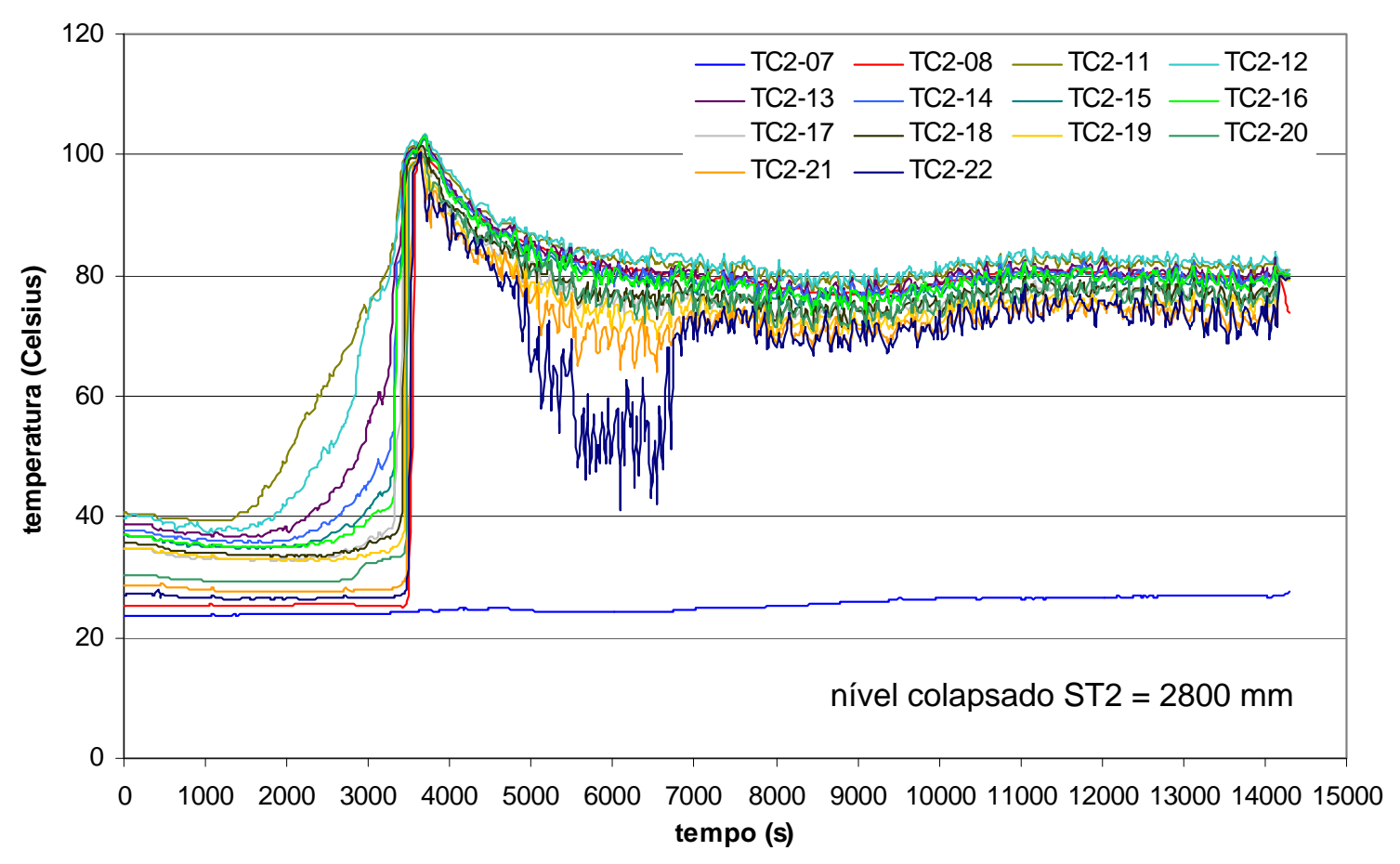

FIGURA 5.21. Temperaturas de entrada (TC2-07) e saída (TC2-08) do fluido de resfriamento e de parede na sonda tipo tubo $U$ (TC2-11 a TC2-22) para nível colapsado igual a 2800 mm na ST2. 


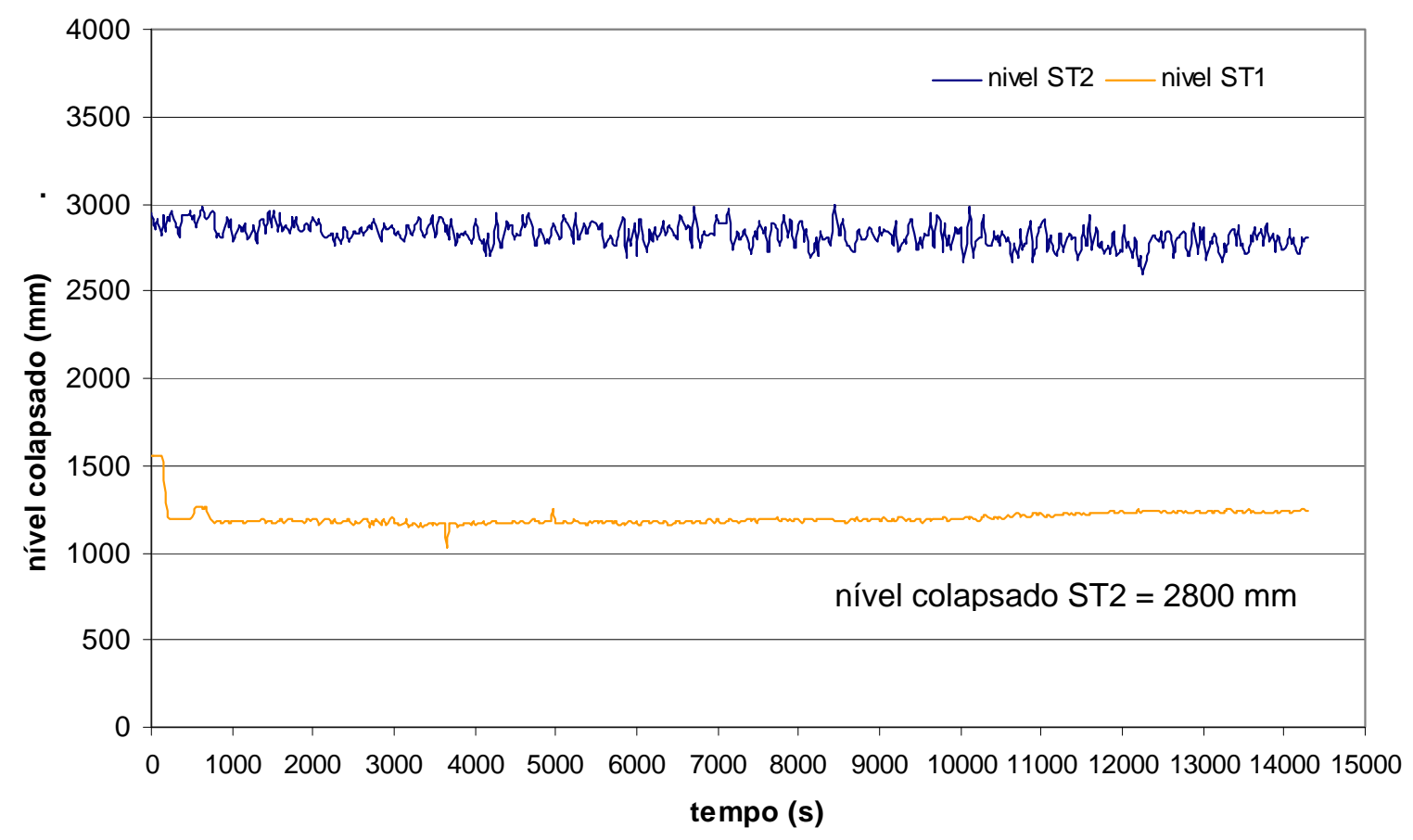

FIGURA 5.22. Nível colapsado nas seções de testes ST1 e ST2 durante o teste para nível colapsado igual a $2800 \mathrm{~mm}$ na ST2.

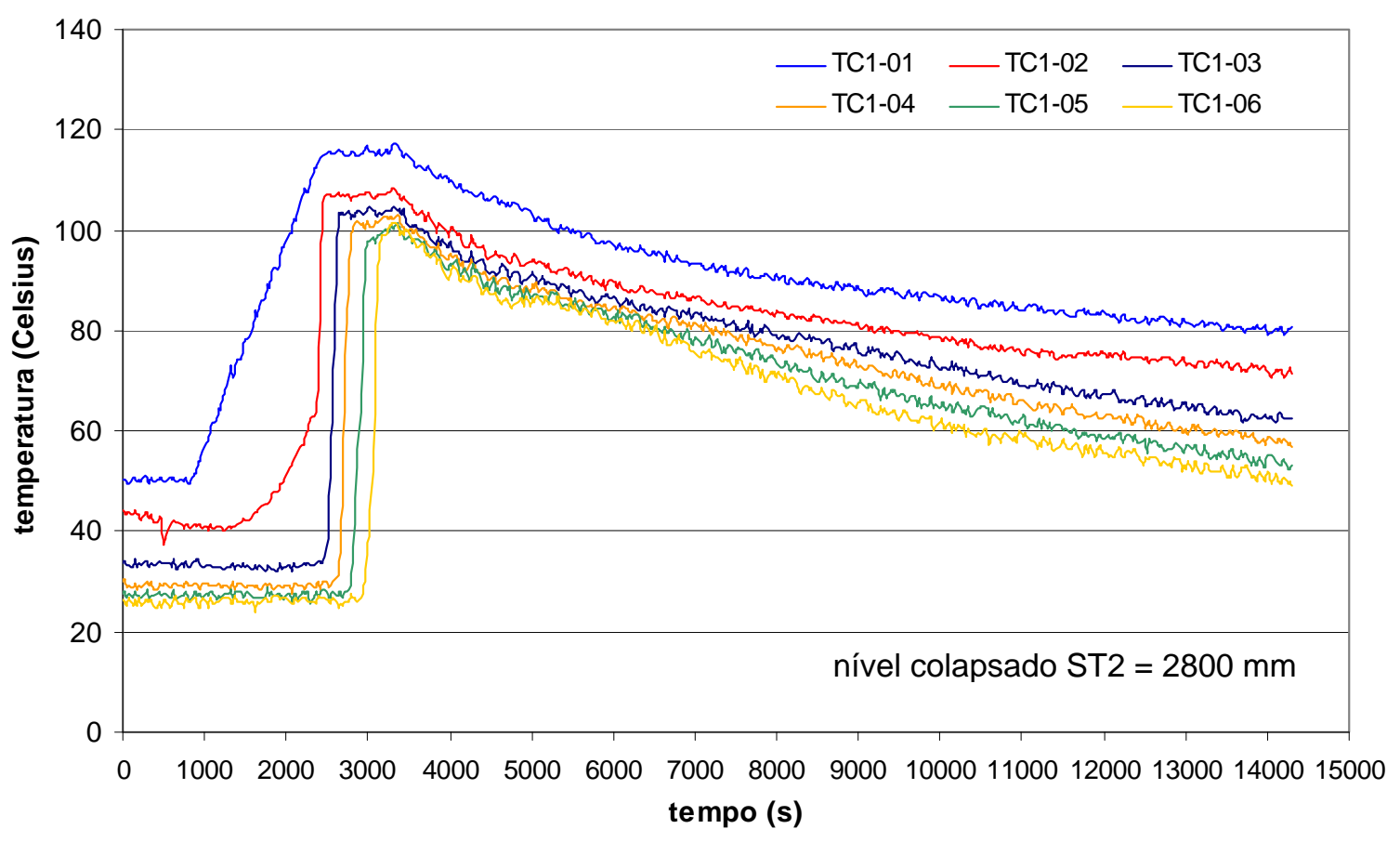

FIGURA 5.23. Temperaturas do fluido (TC1-01 a TC1-06) no vaso da seção de testes ST1 para nível colapsado igual a $2800 \mathrm{~mm}$ na ST2. 


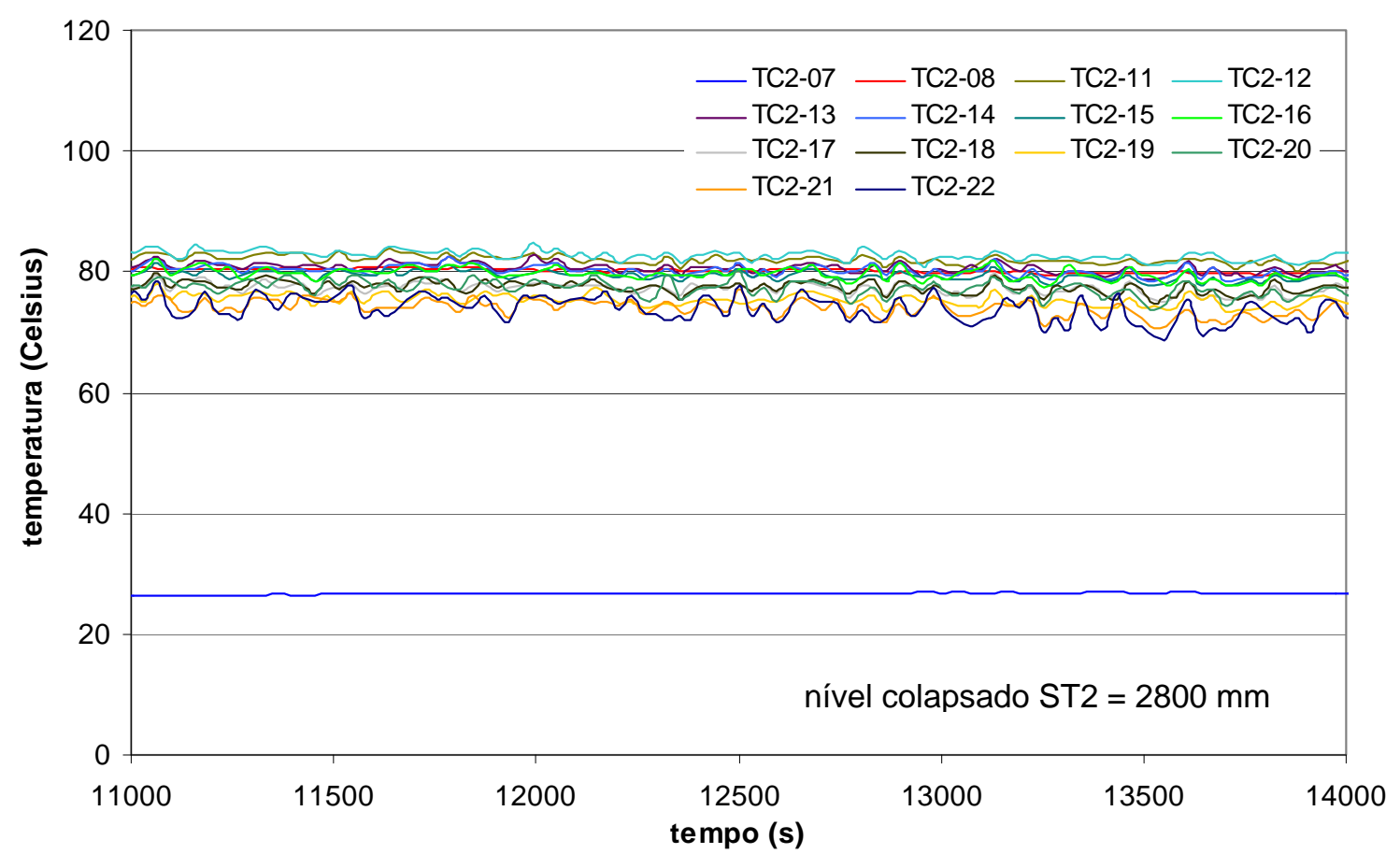

FIGURA 5.24. Dados em estado estacionário utilizados para análise com RNA's. Temperaturas de entrada (TC2-07) e saída (TC2-08) do fluido de resfriamento e de parede na sonda tipo tubo $U$ (TC2-11 a TC2-22) para nível colapsado igual a $2800 \mathrm{~mm}$ na ST2.

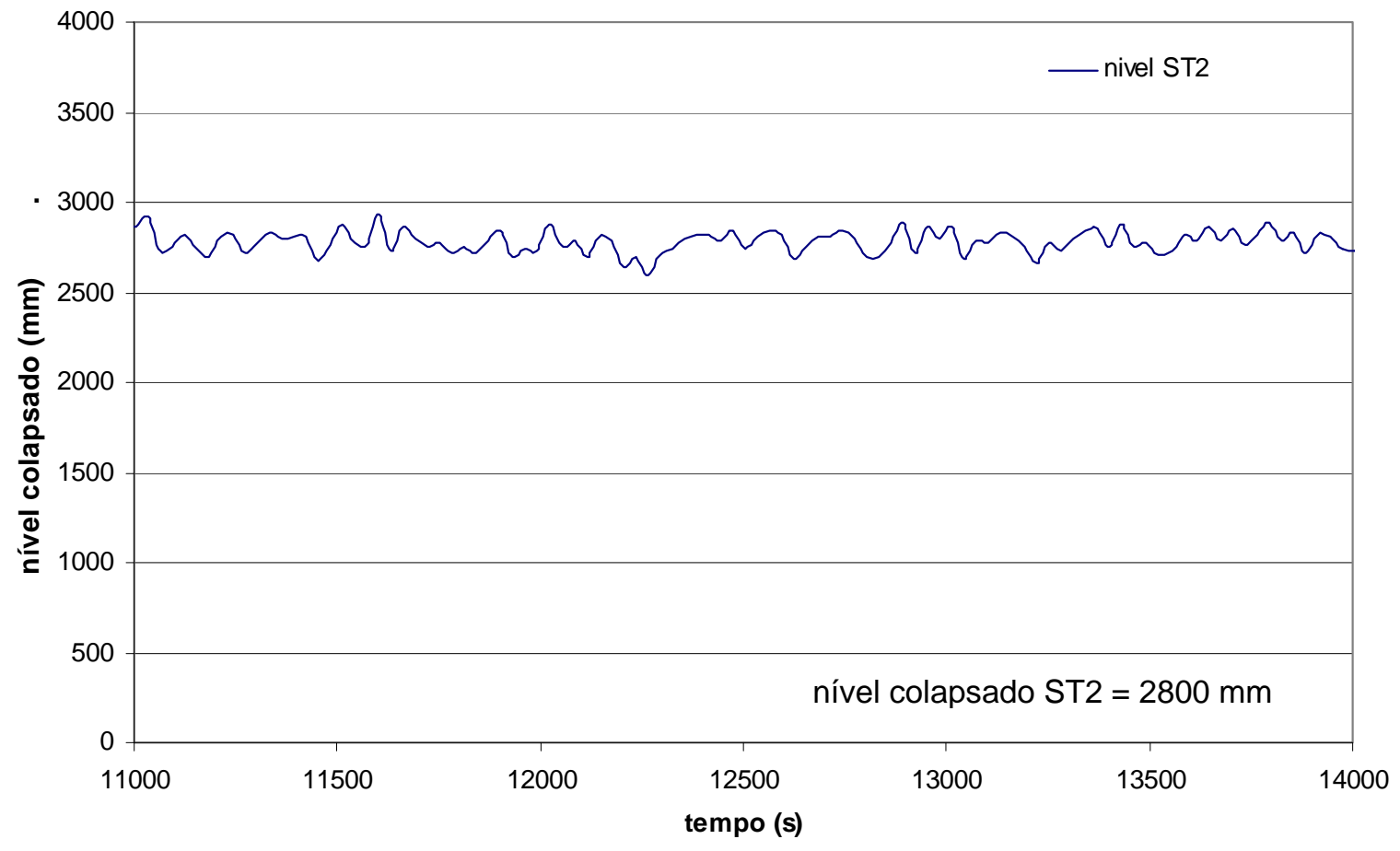

FIGURA 5.25. Dados em estado estacionário utilizados para análise com RNA's. Nível colapsado igual a 2800 mm na seção de testes ST2. 


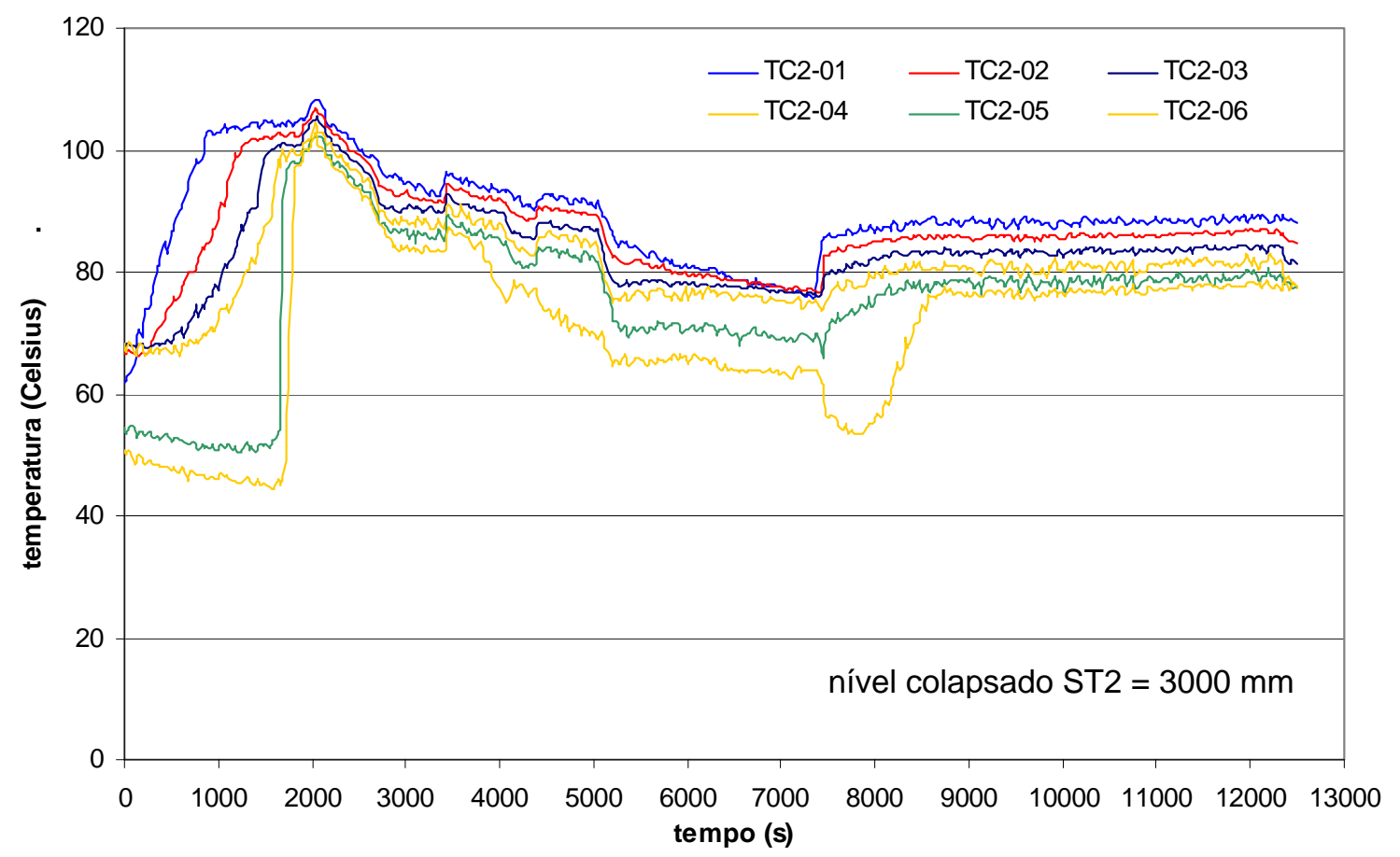

FIGURA 5.26. Temperaturas do fluido (TC2-01 a TC2-06) no vaso da seção de testes ST2 para nível colapsado igual a $3000 \mathrm{~mm}$ na ST2.

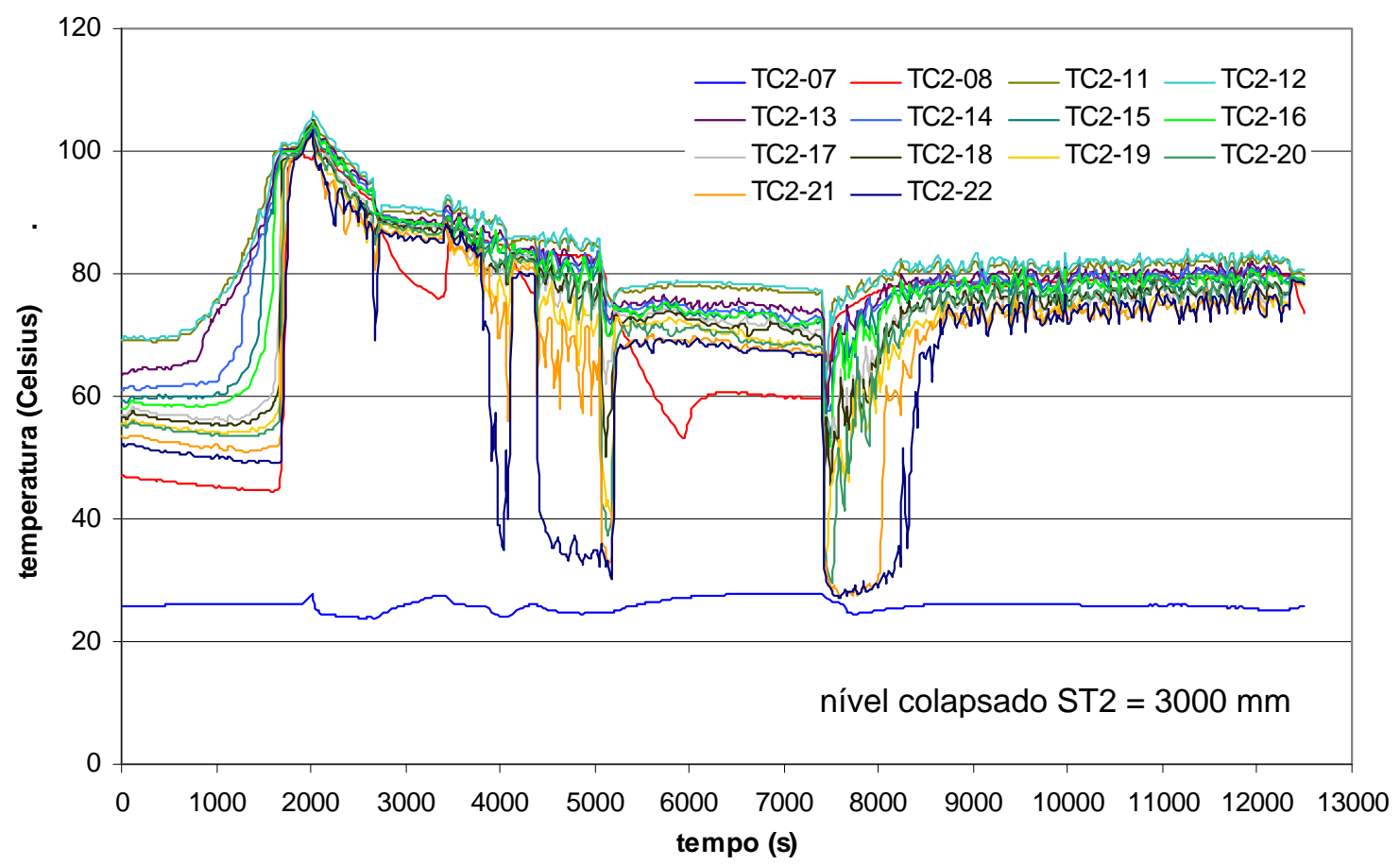

FIGURA 5.27. Temperaturas de entrada (TC2-07) e saída (TC2-08) do fluido de resfriamento e de parede na sonda tipo tubo $U$ (TC2-11 a TC2-22) para nível colapsado igual a 3000 mm na ST2. 


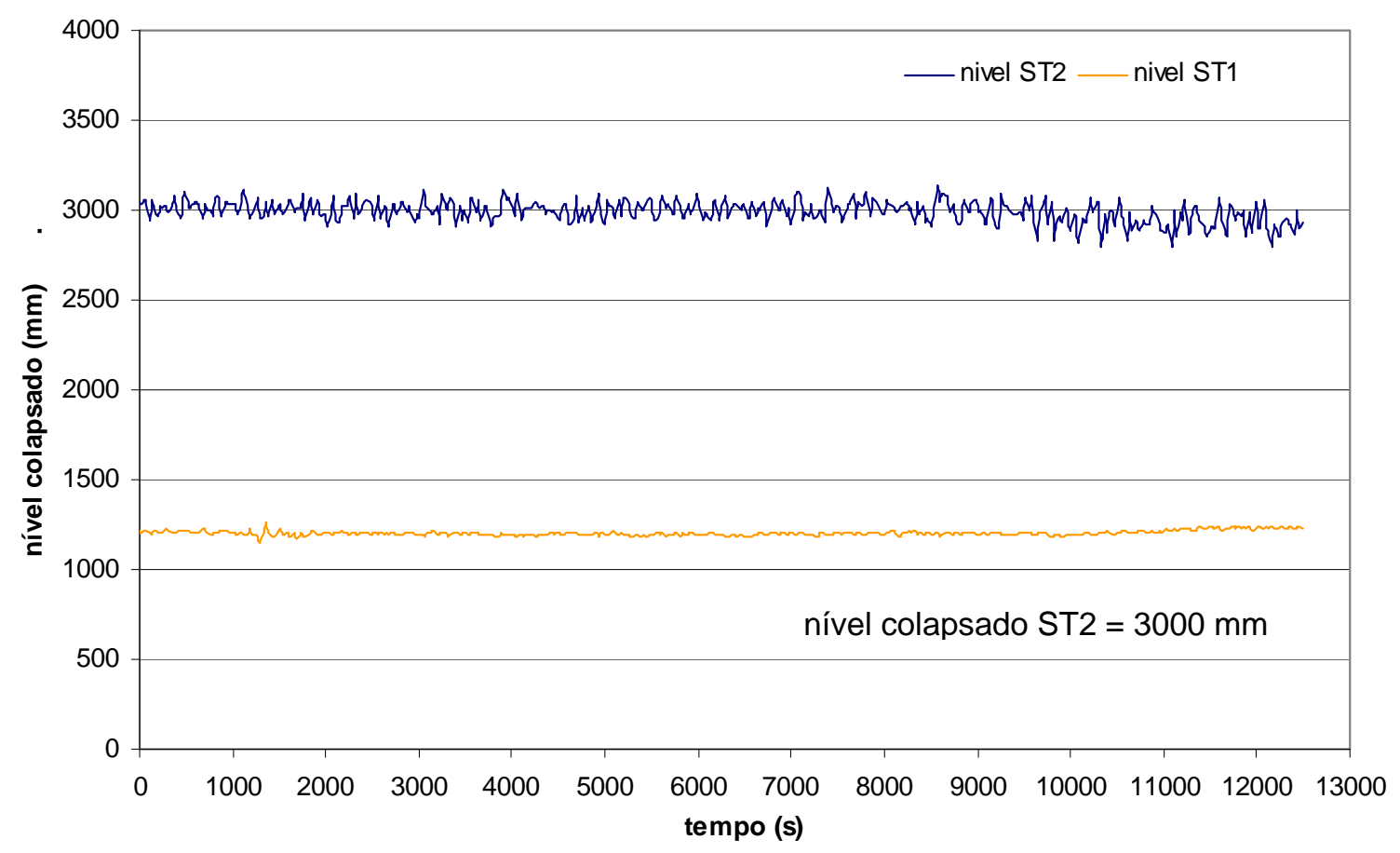

FIGURA 5.28. Nível colapsado nas seções de testes ST1 e ST2 durante o teste para nível colapsado igual a $3000 \mathrm{~mm}$ na ST2.

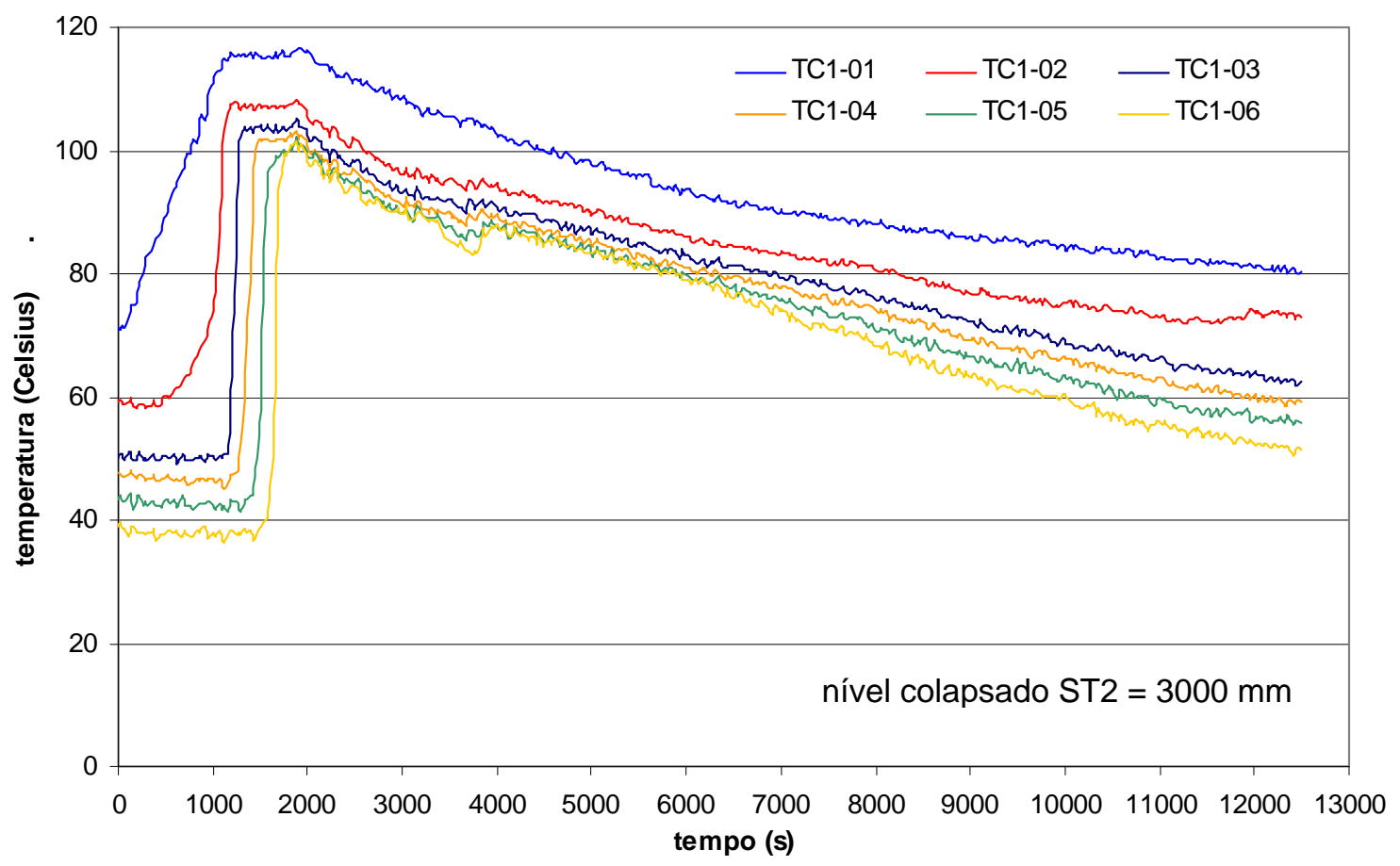

FIGURA 5.29. Temperaturas do fluido (TC1-01 a TC1-06) no vaso da seção de testes ST1 para nível colapsado igual a 3000 mm na ST2. 


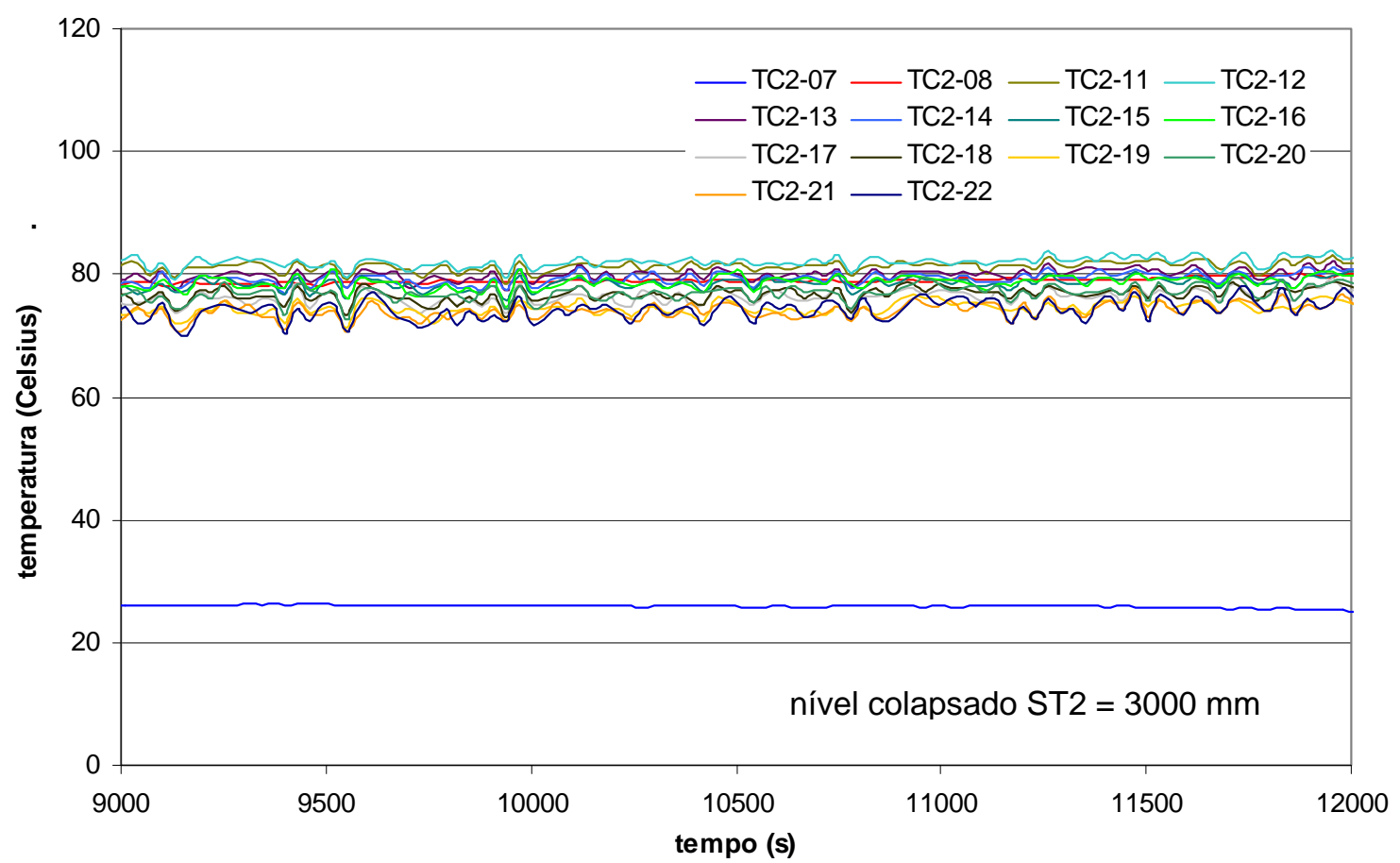

FIGURA 5.30. Dados em estado estacionário utilizados para análise com RNA's. Temperaturas de entrada (TC2-07) e saída (TC2-08) do fluido de resfriamento e de parede na sonda tipo tubo $U$ (TC2-11 a TC2-22) para nível colapsado igual a $3000 \mathrm{~mm}$ na ST2.

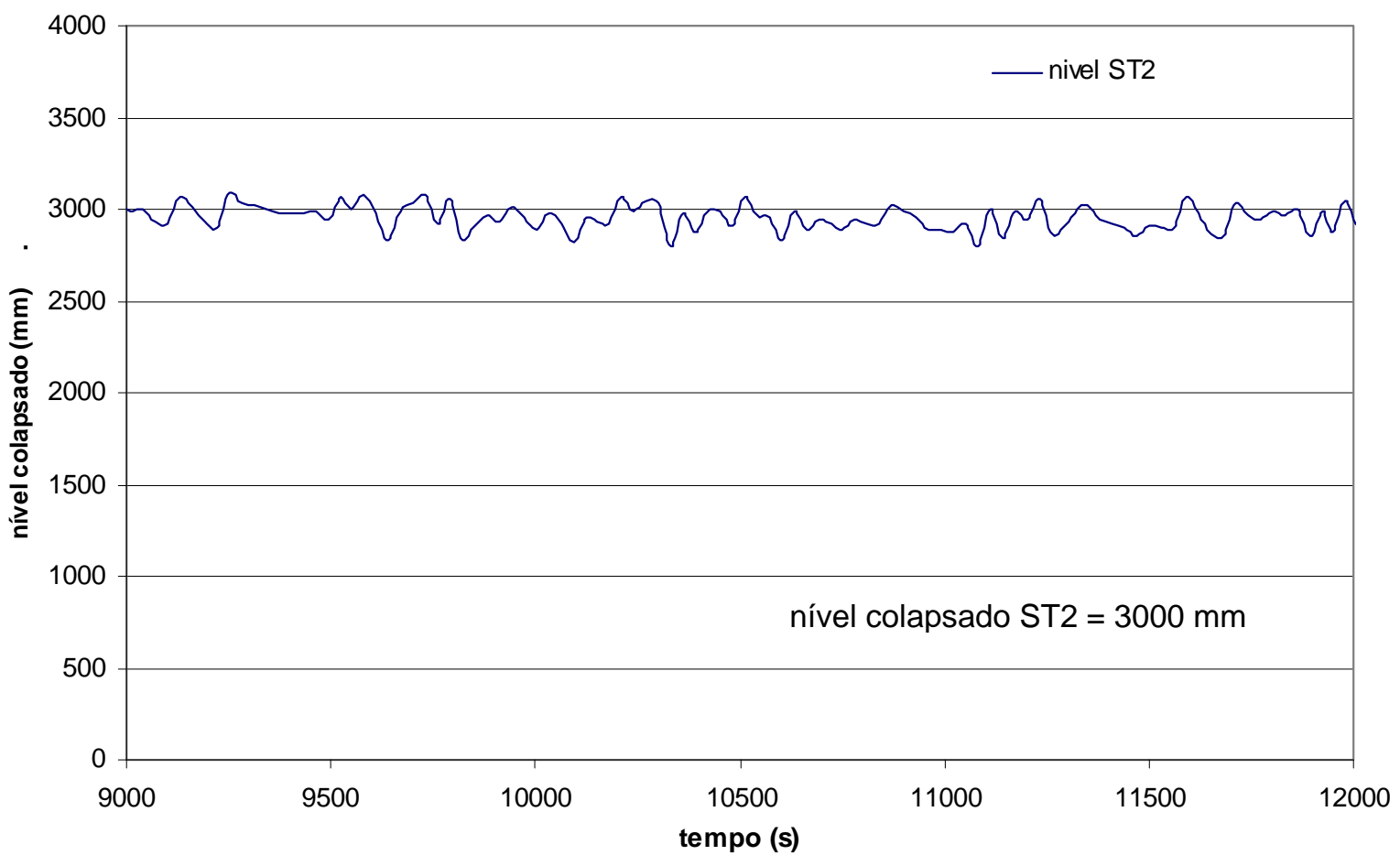

FIGURA 5.31. Dados em estado estacionário utilizados para análise com RNA's. Nível colapsado igual a 3000 mm na seção de testes ST2. 


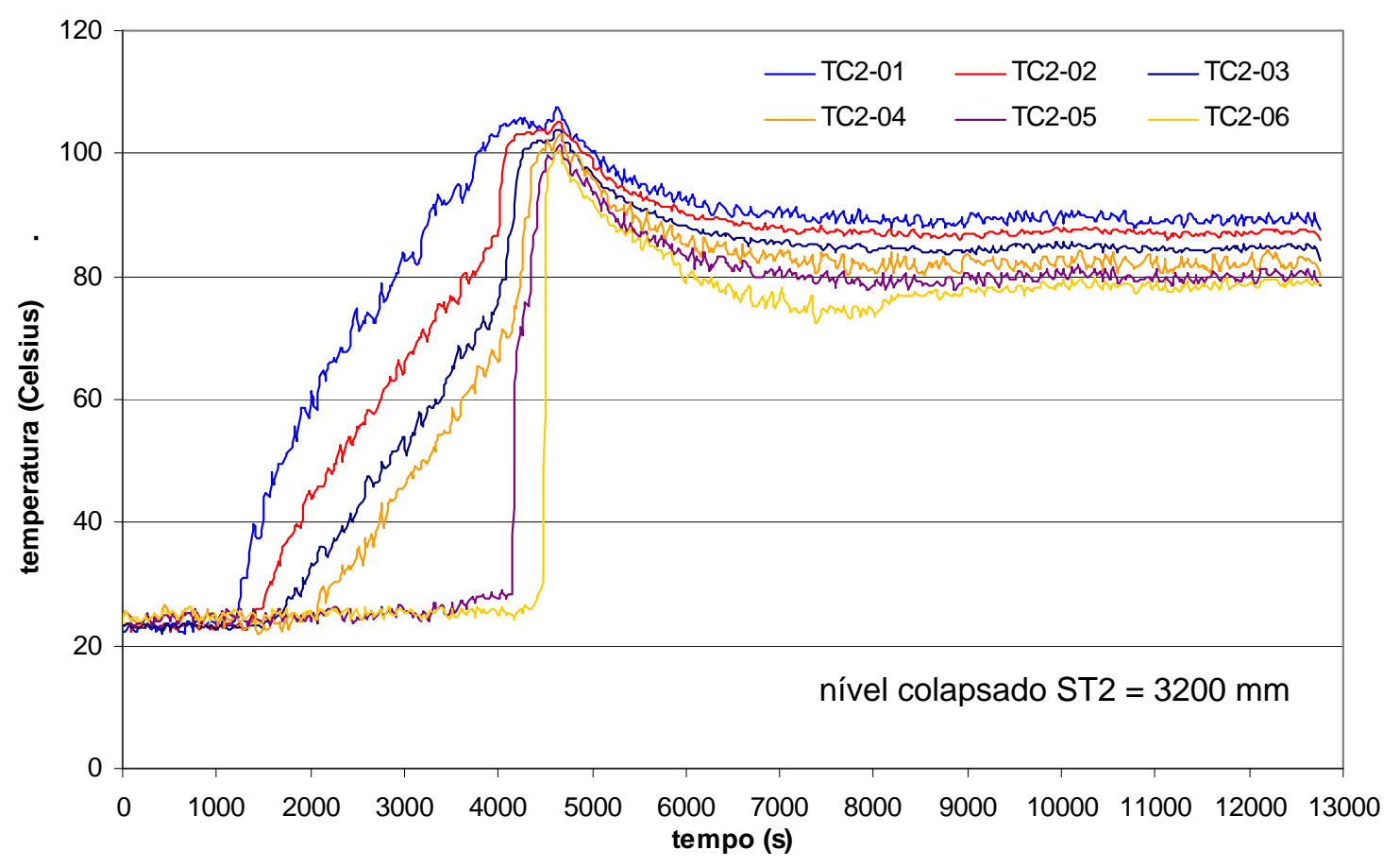

FIGURA 5.32. Temperaturas do fluido (TC2-01 a TC2-06) no vaso da seção de testes ST2 para nível colapsado igual a $3200 \mathrm{~mm}$ na ST2.

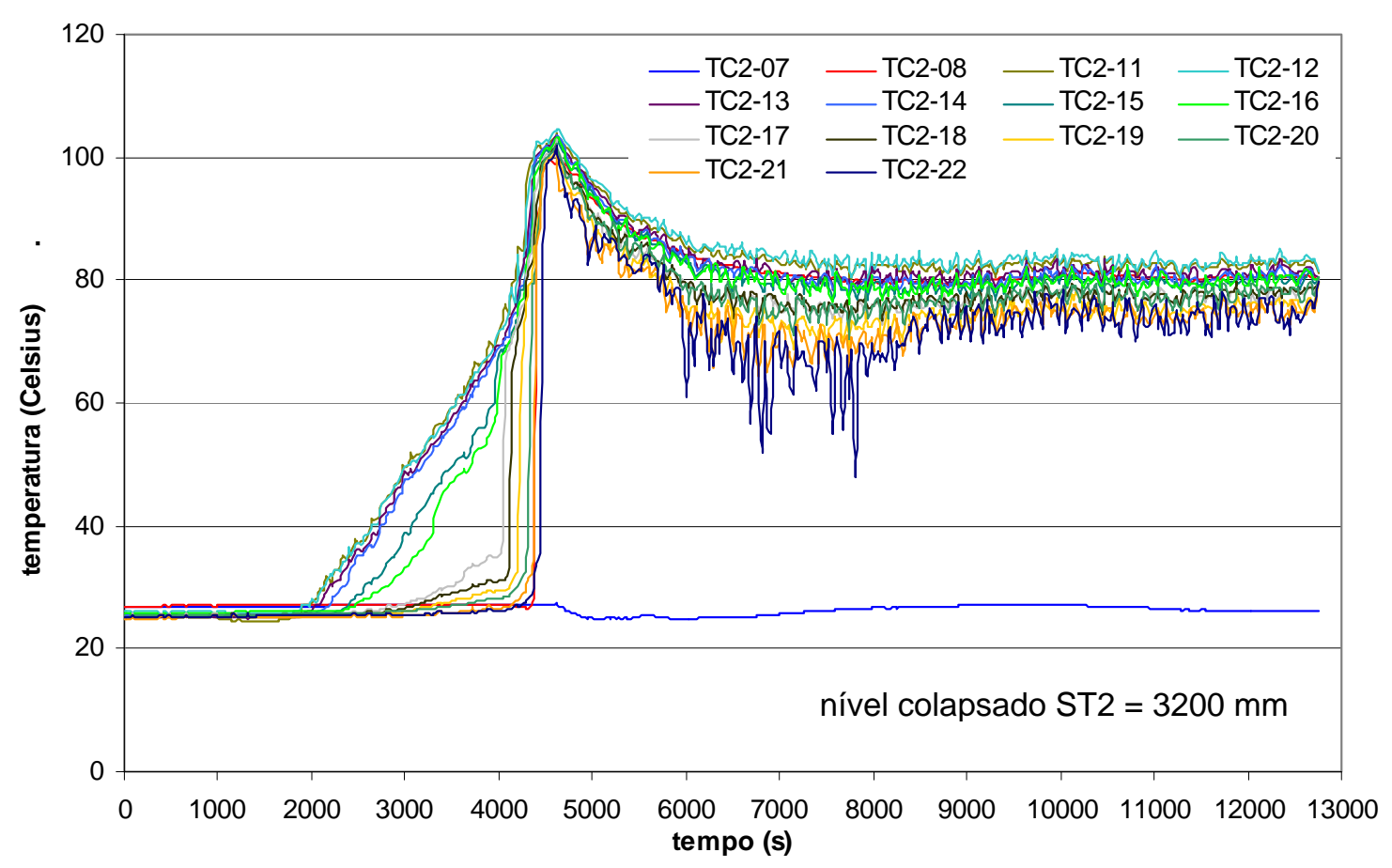

FIGURA 5.33. Temperaturas de entrada (TC2-07) e saída (TC2-08) do fluido de. resfriamento e de parede na sonda tipo tubo $U$ (TC2-11 a TC2-22) para nível colapsado igual a $3200 \mathrm{~mm}$ na ST2. 


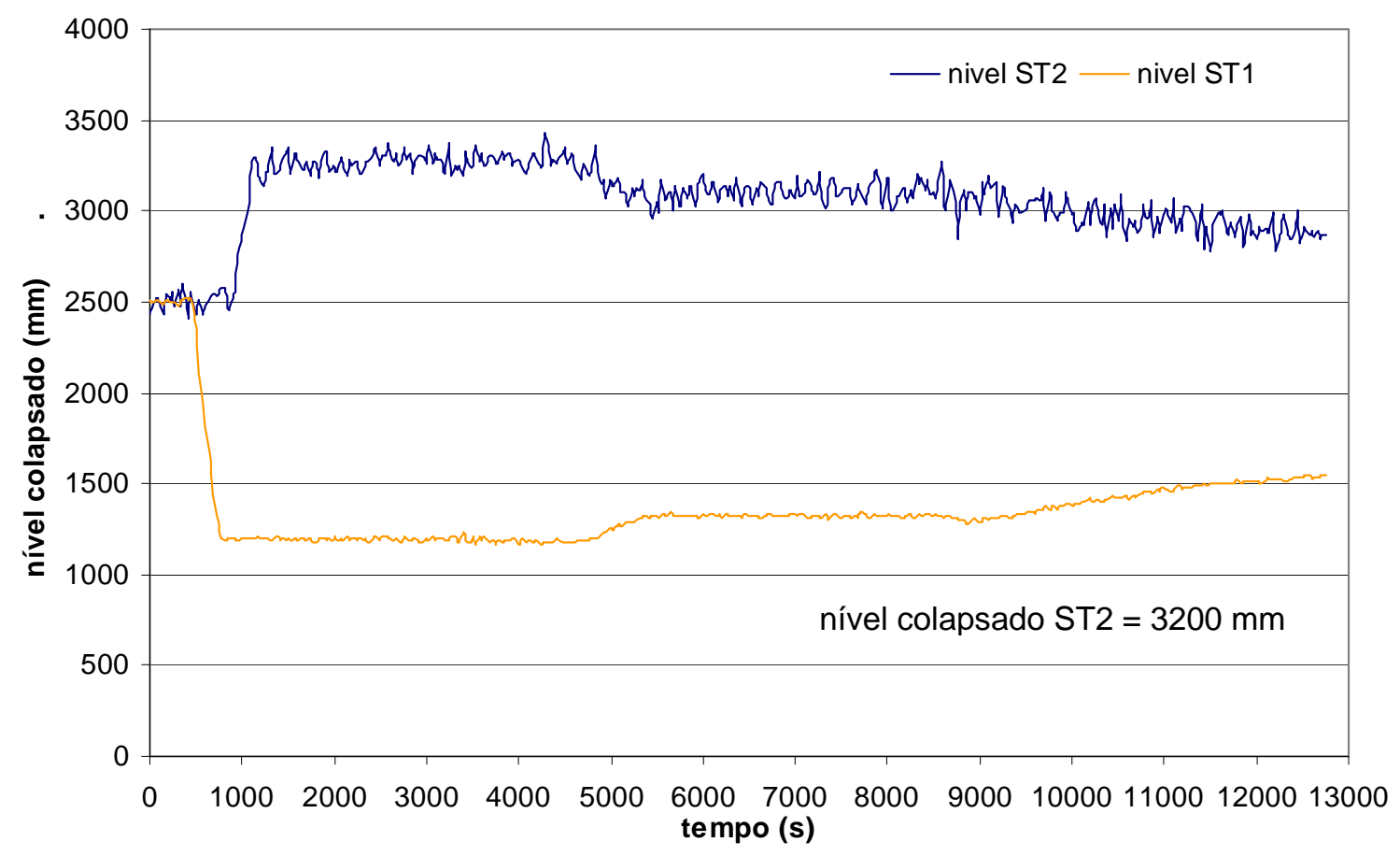

FIGURA 5.34. Nível colapsado nas seções de testes ST1 e ST2 durante o teste para nível colapsado igual a $3200 \mathrm{~mm}$ na ST2.

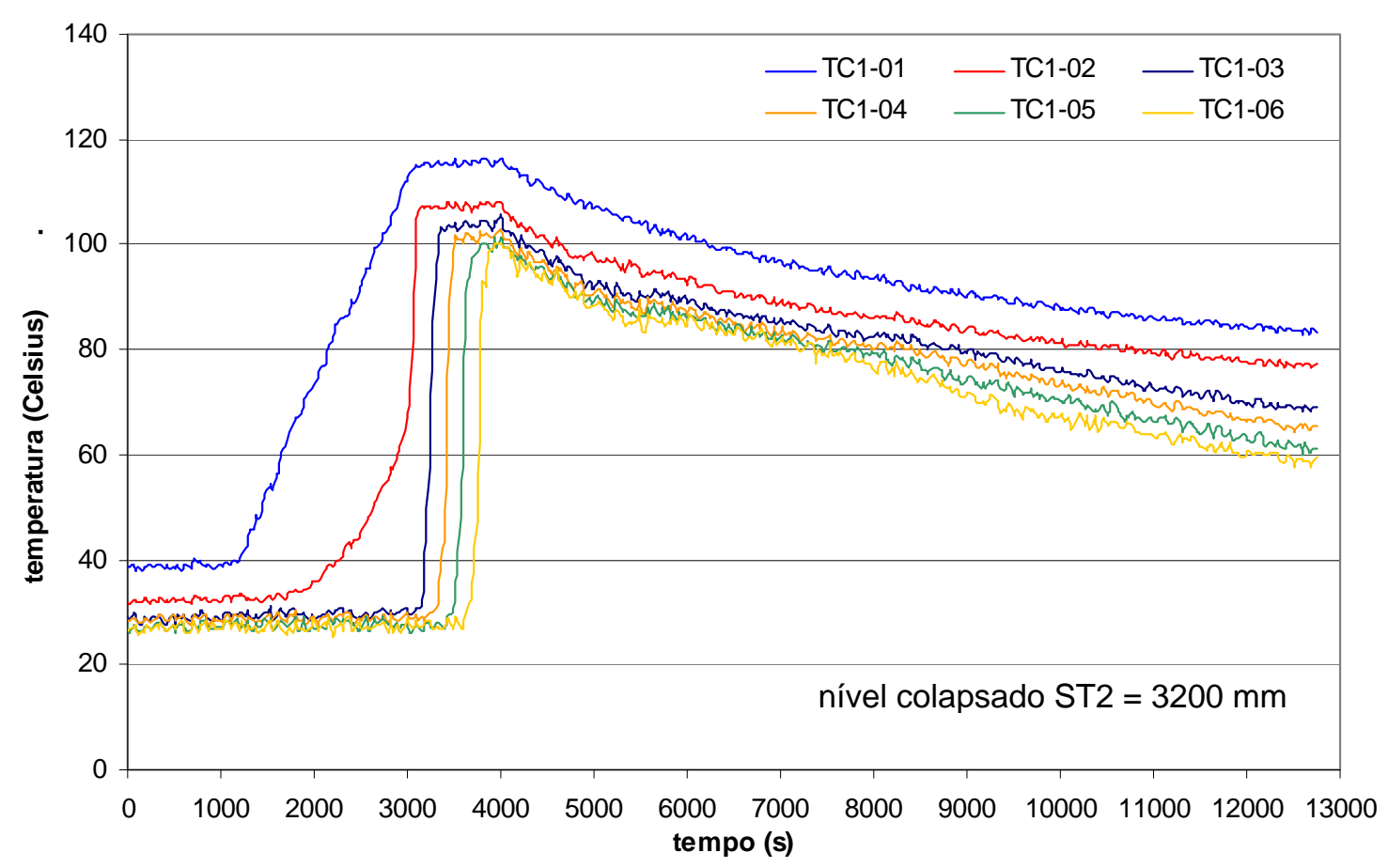

FIGURA 5.35. Temperaturas do fluido (TC1-01 a TC1-06) no vaso da seção de testes ST1 para nível colapsado igual a 3000 mm na ST2. 


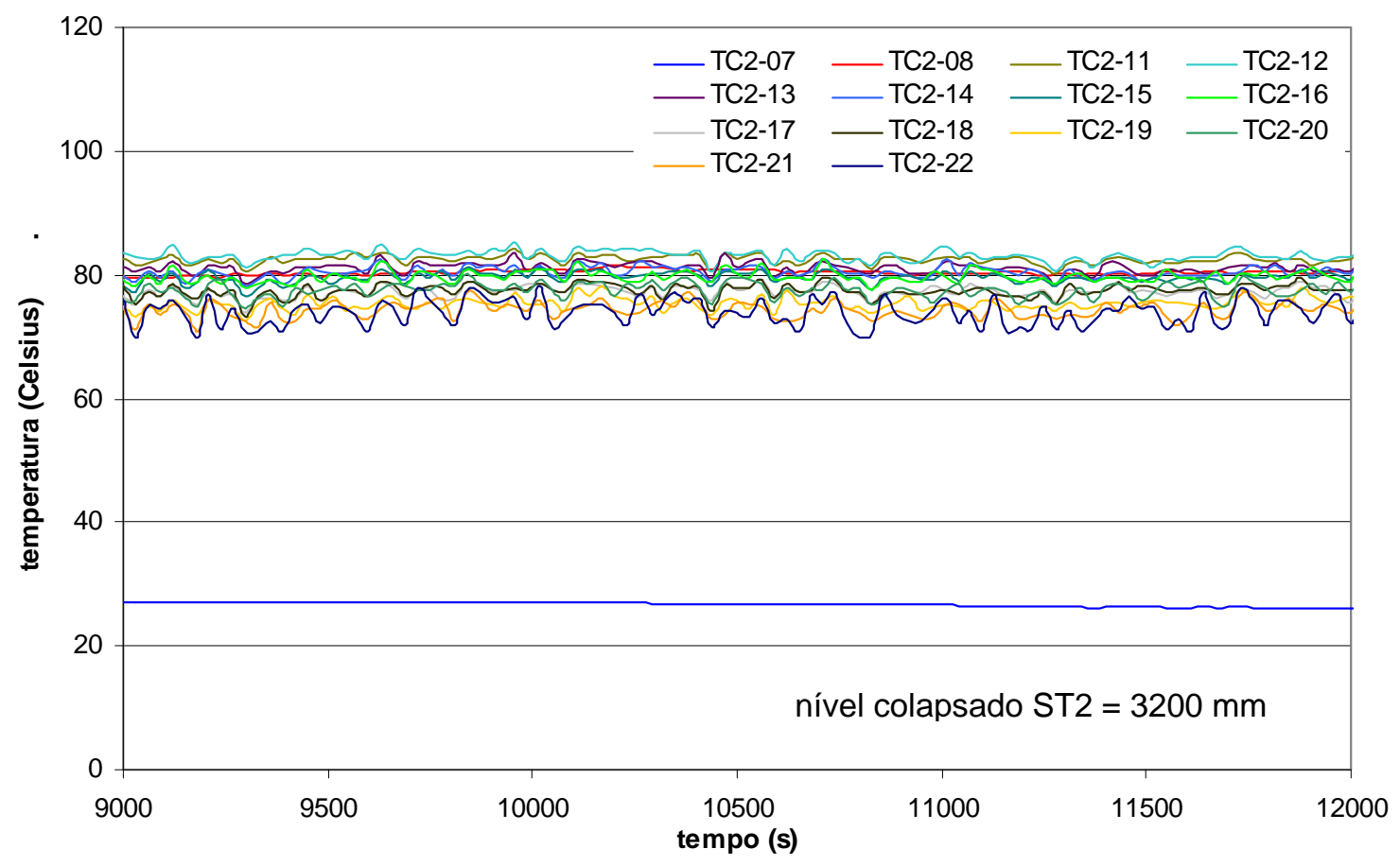

FIGURA 5.36. Dados em estado estacionário utilizados para análise com RNA's. Temperaturas de entrada (TC2-07) e saída (TC2-08) do fluido de resfriamento e de parede na sonda tipo tubo $\mathrm{U}$ (TC2-11 a TC2-22) para nível colapsado igual a 3200mm na ST2.

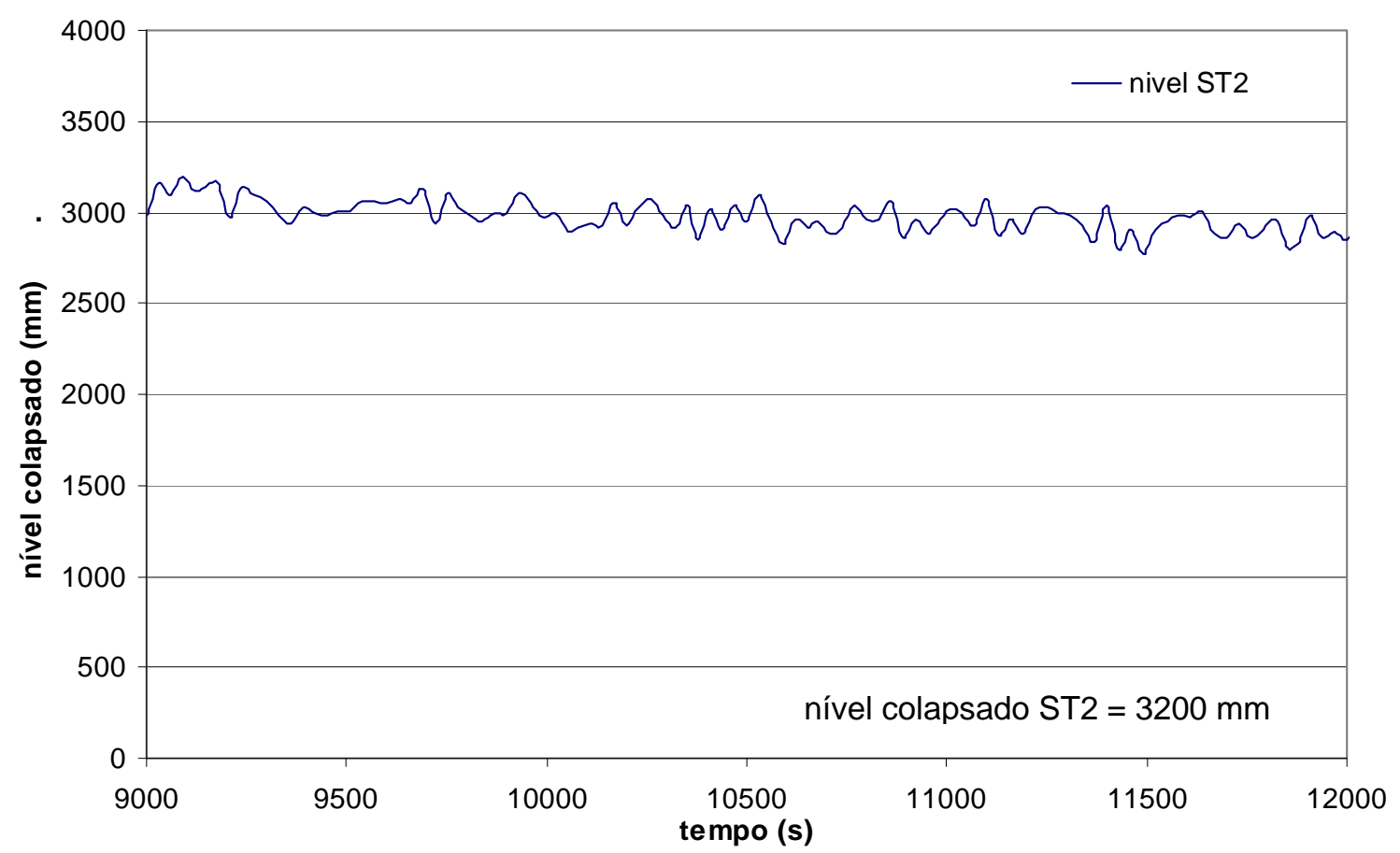

FIGURA 5.37. Dados em estado estacionário utilizados para análise com RNA's. Nível colapsado igual a 3200 mm na seção de testes ST2. 


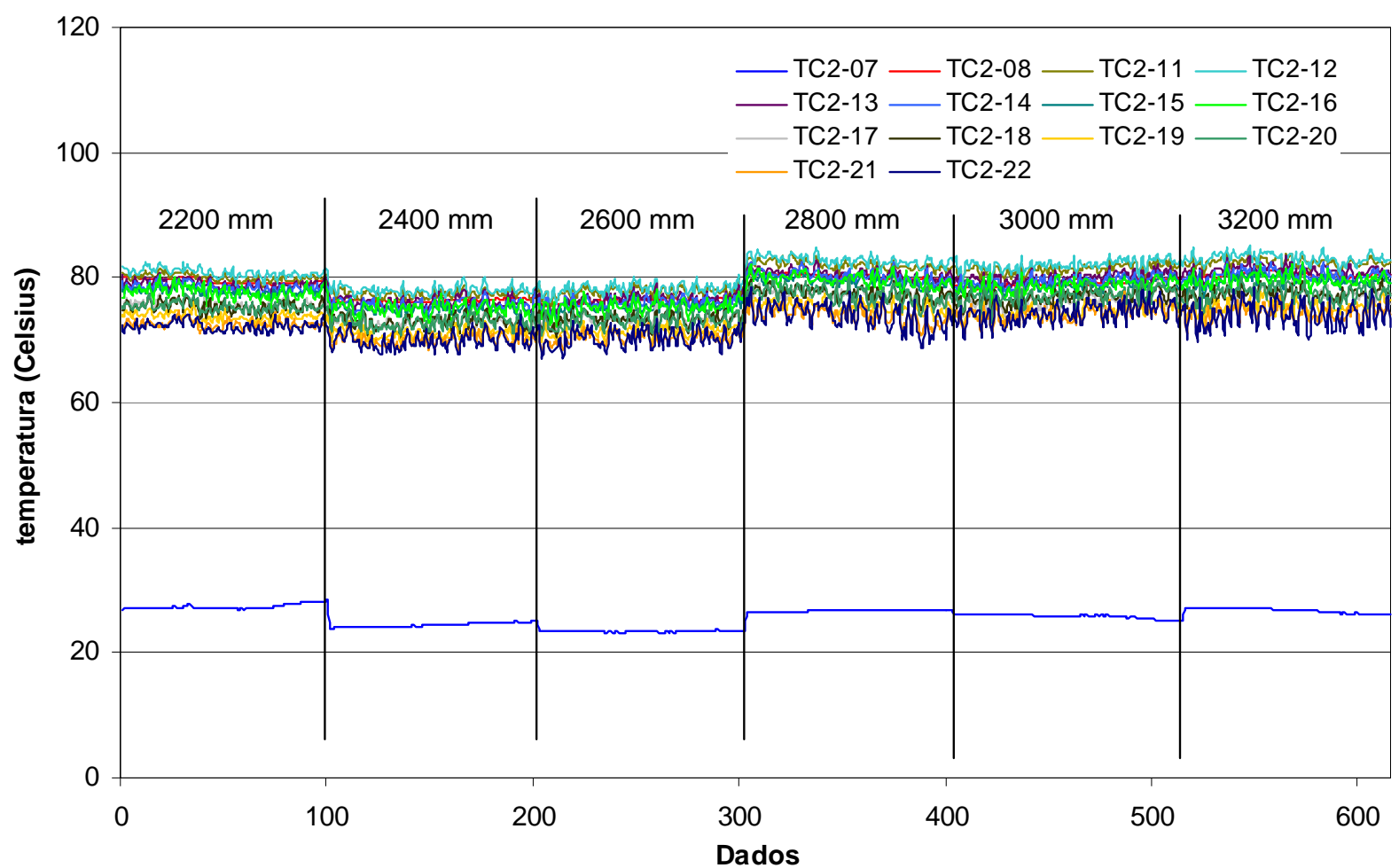

FIGURA 5.38. Dados em estado estacionário utilizados para análise com RNA's. Nível colapsado de 2200 a 3200 mm na seção de testes ST2.

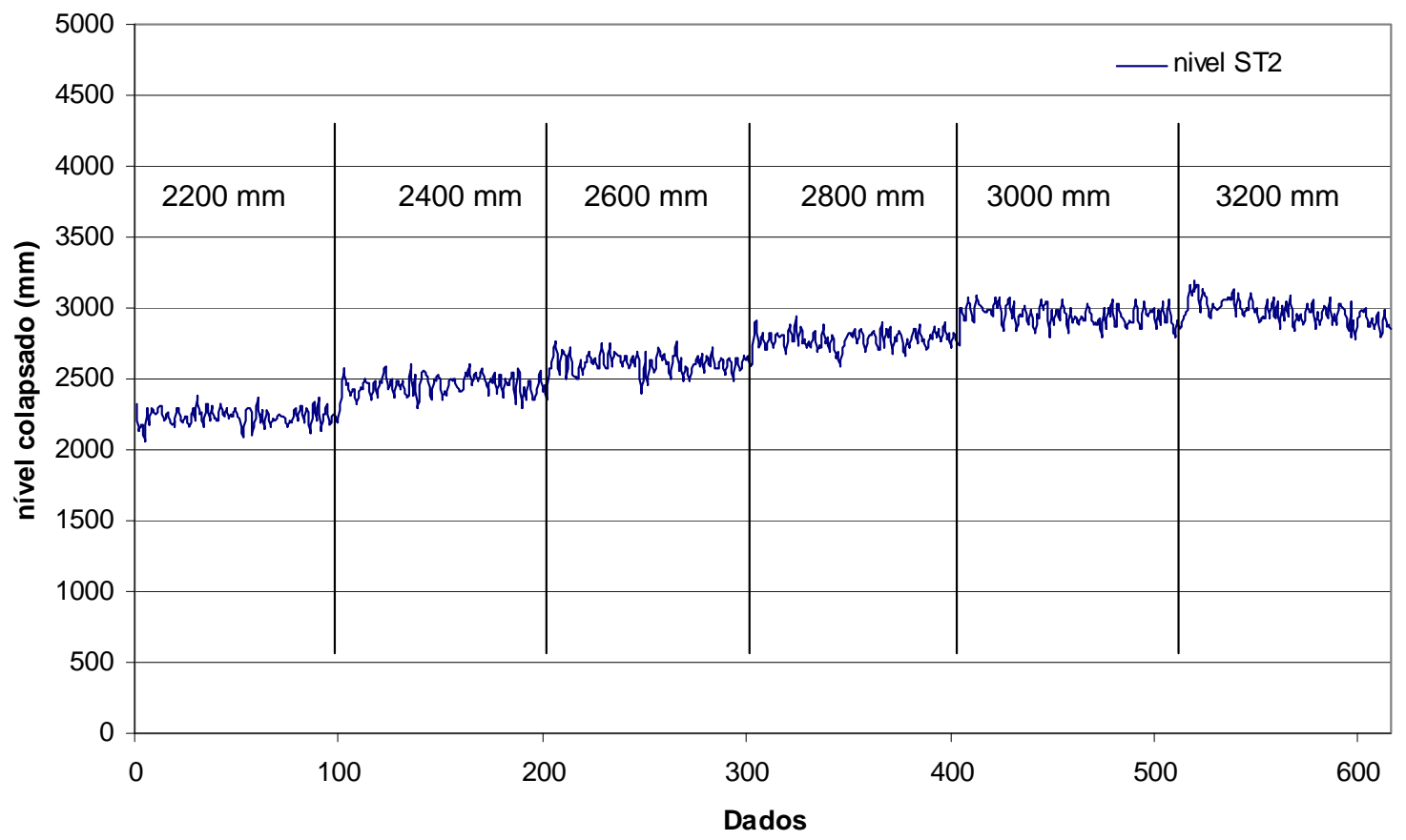

FIGURA 5.39. Dados em estado estacionário utilizados para análise com RNA's. Nível colapsado de 2200 a 3200 mm na seção de testes ST2. 


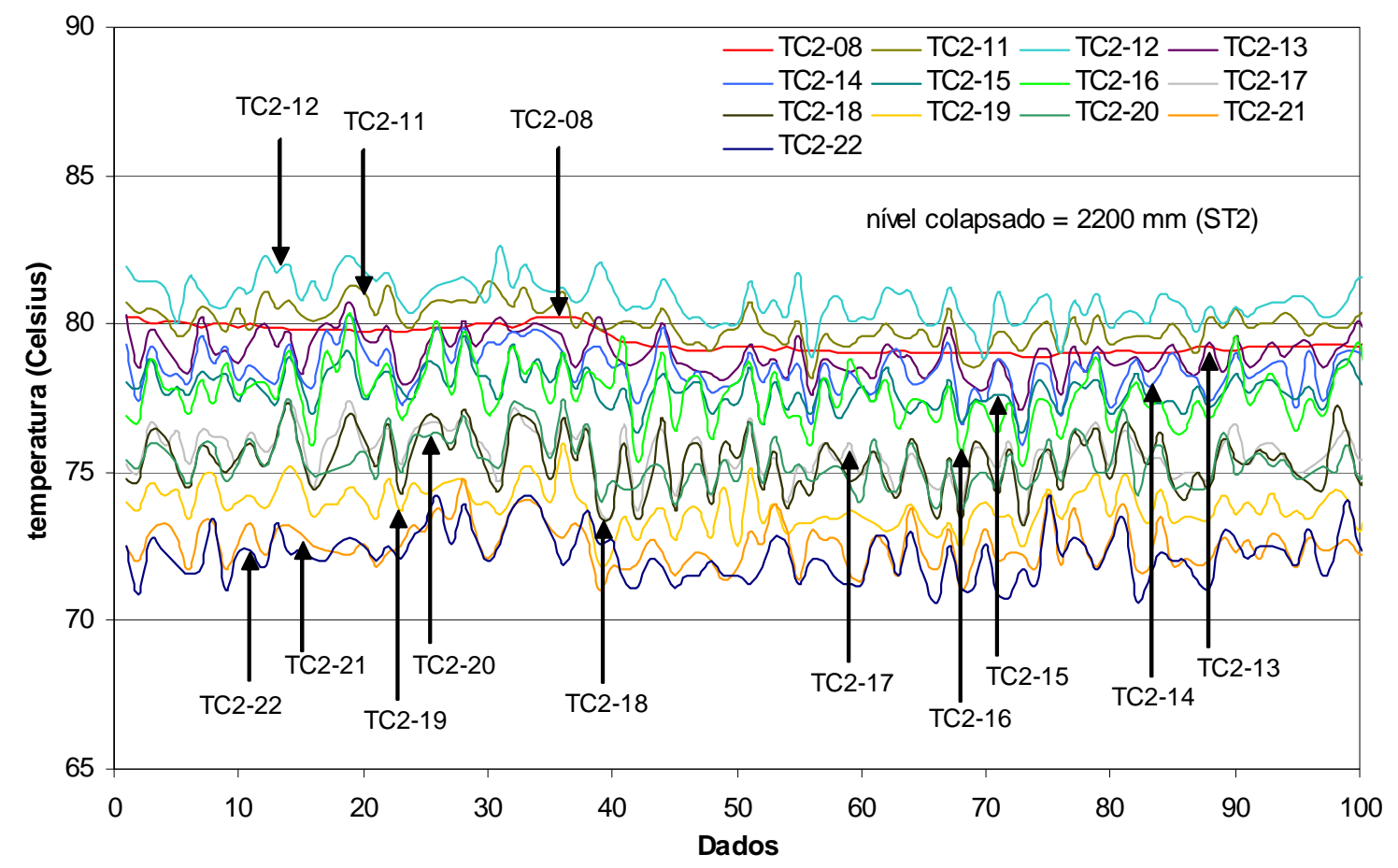

FIGURA 5.40. Dados em estado estacionário utilizados para análise com RNA's. Nível colapsado de $2200 \mathrm{~mm}$ na seção de testes ST2 com escala de temperatura expandida.

Observa-se na FIG. 5.40 a ocorrência de oscilações das temperaturas de parede da sonda. Essas oscilações são decorrentes das condições de transferência de calor no interior da seção de testes que envolvem processos de condução e convecção monofásica e bifásica. Observa-se também esse comportamento oscilatório não ocorre com a temperatura de saída do fluido de resfriamento TC2-08, pois no interior do tubo as condições de transferência de calor são bem definidas. 


\subsubsection{Sonda de Tubo U - Testes em Transiente}

\subsubsection{Testes em Transiente a frio}

Foram realizados testes de aumento e diminuição de nível respectivamente, nas seções de testes ST1 e ST2, em temperatura ambiente. O transiente de mudança de nível foi realizado com a transferência de fluido entre as seções de testes ST1 e ST2. Estes testes tiveram como objetivo verificar o comportamento do nível nas ST's em função do tempo e do número de voltas de abertura na válvula agulha existente na entrada da ST2. O número máximo de voltas para essa válvula específica é de 5,75 voltas. Os testes foram realizados para as aberturas de válvula iguais a: 0,$5 ; 1,0 ; 1,5 ; 2,0 ; 2,5 ; 3,0 ; 4,5$; e 5,75 voltas.

Para os testes de diminuição de nível na ST2 e aumento em ST1 obedeceu-se o seguinte procedimento: estabelecimento de um nível em ST1=1000 mm e ST2=3600 mm; equalização das pressões nas ST's; abertura total da válvula de esfera existente na entrada da ST1; abertura da válvula de agulha da entrada da ST2 com o número de voltas desejado; e aguardar até a estabilização dos níveis nas ST's, que neste caso deve ocorrer em torno de $2300 \mathrm{~mm}$, perfazendo uma faixa de variação de nível igual $1300 \mathrm{~mm}$.

Na FIG. 5.41 são apresentados os resultados de nível em função do tempo em ST1(aumentando) e ST2 (diminuindo) referentes a uma abertura de válvula igual a 0,5 volta. Observa-se um intervalo de tempo aproximado de $4000 \mathrm{~s}$ ( 1:10 horas) entre o início e o término do transiente. A mudança no nível nas ST's não é linear com o tempo. No início deste transiente observa-se uma taxa de diminuição de nível em ST2 da ordem de $0,5 \mathrm{~mm} / \mathrm{s}(1800 \mathrm{~mm} / \mathrm{h})$, que decresce ao longo do tempo. Na FIG. 5.42 são apresentados os resultados dos testes realizados para as outras aberturas de válvula para a variação de nível (diminuição) em ST2. Taxas de diminuição de nível da ordem de 4,35 mm/s $(15660 \mathrm{~mm} / \mathrm{h})$ são observadas para uma abertura de 5,75 voltas. 


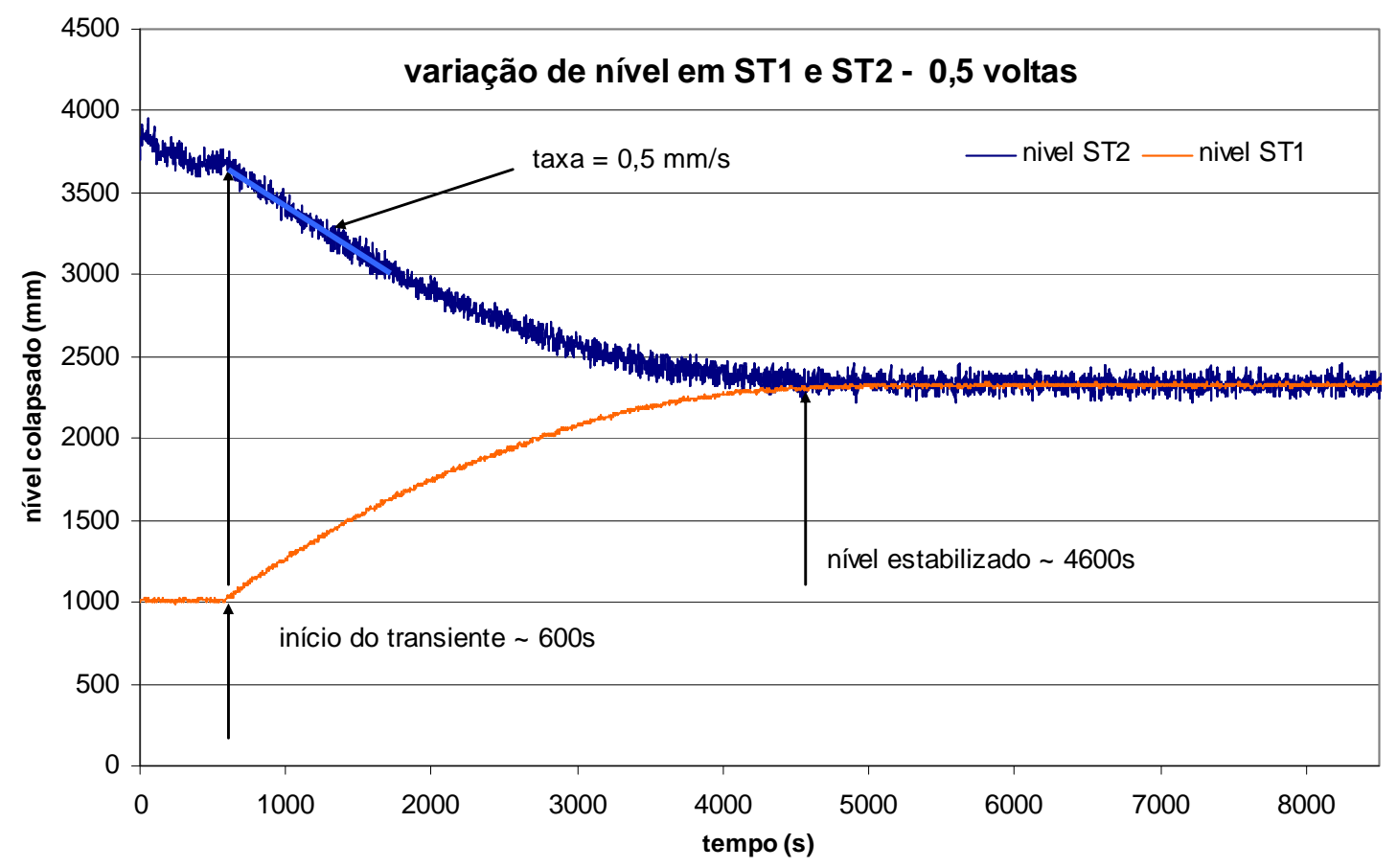

FIGURA 5.41. Variação de nível em ST1 e ST2 para 0,5 voltas de abertura da válvula.

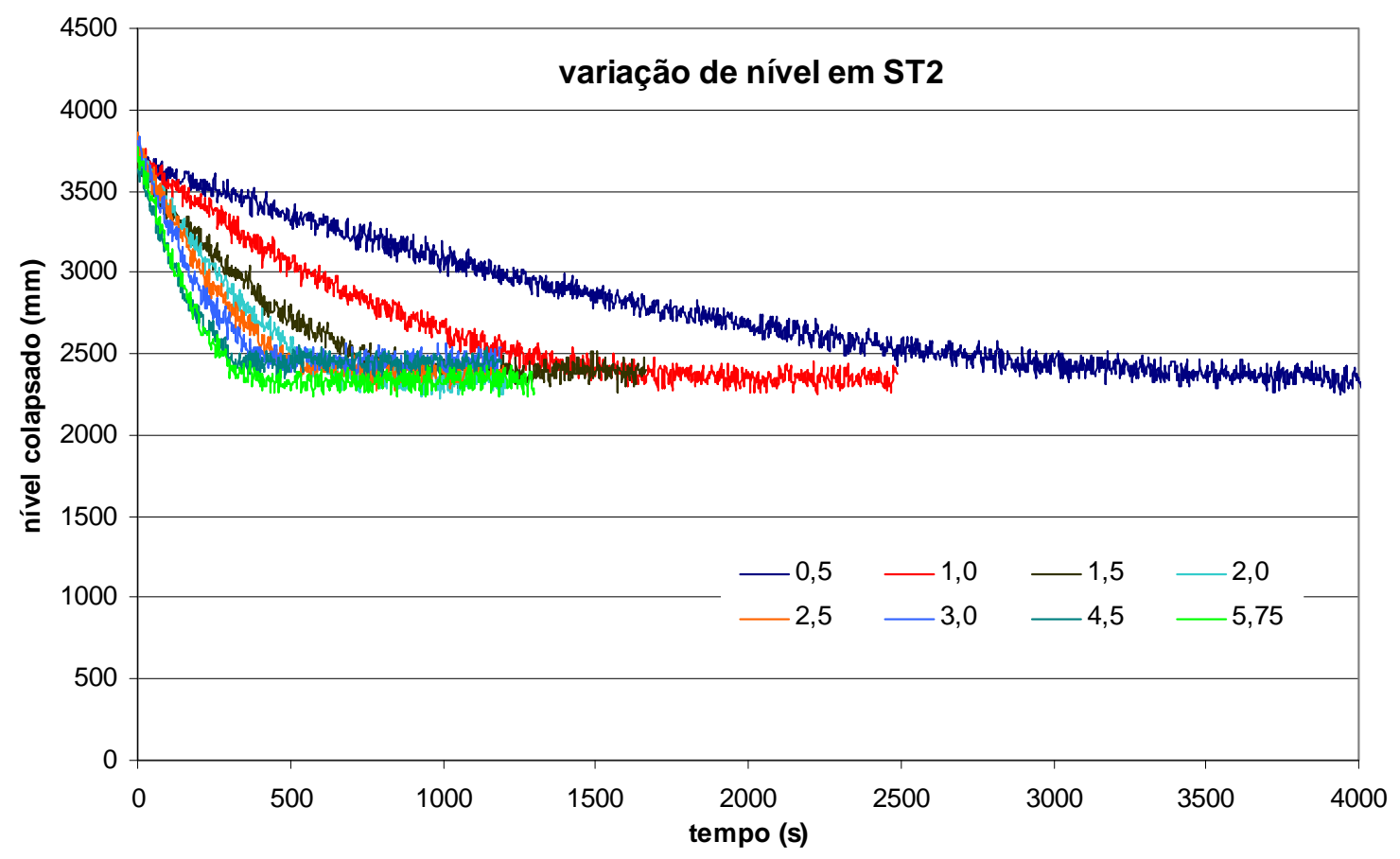

FIGURA 5.42. Variação de nível em ST2 para diversas de aberturas da válvula. 


\subsubsection{Testes em Transiente a quente}

Testes em transiente a quente foram realizados com a sonda tipo tubo $U$ instalada na seção de testes ST2. O transiente de queda de nível na ST2 foi realizado com a transferência de fluido entre as seções de testes ST1 e ST2, conforme apresentado no item anterior.

Um procedimento mais elaborado foi seguido para a realização destes testes a quente, e é apresentado no APÊNDICE F. Resumidamente, este procedimento estabelece que seja fixado um nível igual a 1200 mm em ST1 e 3600 mm em ST2. Após o equilíbrio o nível nas ST's será 2400 mm, perfazendo uma faixa de variação de nível de $1200 \mathrm{~mm}$ entre os níveis inicial e final. O fluido nas ST's é aquecido até atingir a condição de saturação para a pressão atmosférica, deixando que uma pequena parte deste vapor saia pela linha de respiro para a remoção do ar existente na região superior das ST's. As válvulas de respiro são fechadas e a válvula de equalização existente na região superior da bancada é aberta com apenas $1 / 4$ de volta. Experimentos com aberturas maiores que $1 / 4$ de volta mostraram que ocorre a passagem de fluido pela linha de equalização de ST2 para ST1, interferindo no transiente. A vazão de resfriamento da sonda é fixada em $100 \mathrm{l} / \mathrm{h}$, $\left(2,777 \times 10^{-5} \mathrm{~m}^{3} / \mathrm{s}\right.$ ou $\left.0,028 \mathrm{~kg} / \mathrm{s}\right)$ aguardando o equilíbrio na ST2. Com a válvula de esfera da entrada da ST1 totalmente aberta, procede-se a abertura da válvula de agulha da entrada de ST2 com o número de voltas desejado, dando início ao transiente.

Foram realizados testes com 0,5; 1,0 e 2,0 voltas de abertura na válvula. Os dados registrados durante todo o teste de diminuição de nível em ST2 referente a 0,5 volta de abertura na válvula são apresentados nas FIG. 5.43 e 5.44. Na FIG. 5.43 é mostrado o comportamento do nível nas ST's enquanto que na FIG. 5.44 são mostradas as temperaturas de entrada (TC2-07) e saída (TC2-08), e temperaturas de parede ao longo da sonda (TC2-11 a TC2-22). Observa-se na FIG. 5.44 a fase de aquecimento do fluido na ST2 até atingir a condição de saturação e a fase de 
resfriamento decorrente do estabelecimento da vazão de resfriamento. O transiente de diminuição de nível na ST2 foi iniciado após decorridos 4320 s, quando a válvula foi aberta com 0,5 volta.

Observa-se na FIG. 5.45, que neste caso, a taxa inicial de diminuição de nível na ST2 é da ordem de $0,27 \mathrm{~mm} / \mathrm{s}(960 \mathrm{~mm} / \mathrm{h})$, diferente da taxa medida nos testes do item 5.1.3.1, onde se mediu $0,5 \mathrm{~mm} / \mathrm{s}(1800 \mathrm{~mm} / \mathrm{h})$. Essa diferença é decorrente de dois fatores, ou seja, partiu-se de diferentes níveis nas seções de testes para os testes a frio (ST1=1000 mm e ST2=3600 mm) e a quente (ST1=1200 $\mathrm{mm}$ e ST2=3600 mm), e principalmente pela formação de vácuo nas seções de testes nos testes a quente, que interfere na transferência do fluido entre elas.

Para este transiente, os dados foram registrados pelo SAD a cada $30 \mathrm{~s}$, de forma que em $10000 \mathrm{~s}$ tem-se aproximadamente 330 pontos. Os dados experimentais foram escolhidos entre os instantes 4200 s e 10200 s e serão utilizados para treinar as RNA's nas condições de transiente. Para este intervalo de tempo tem-se 198 pontos que foram escolhidos alternadamente na proporção de 4 pontos para formar a tabela de treinamento e 1 ponto para formar a tabela de verificação. Desta forma constituiu-se uma tabela de treinamento com 159 dados e uma tabela de verificação com 39 dados, que estão mostrados na forma de gráficos nas FIG. 5.47, 5.48, 5.49 e 5.50.

Nas FIG. 5.51 e 5.52 são apresentados os resultados do teste de diminuição de nível em ST2 referentes a 1,0 volta de abertura na válvula. Na FIG. 5.51 é mostrado o comportamento do nível nas ST's enquanto que na FIG. 5.52 são mostradas as temperaturas de entrada (TC2-07) e saída (TC2-08), e temperaturas de parede ao longo da sonda (TC2-11 a TC2-22). Observa-se a fase de aquecimento do fluido na ST2 até atingir a condição de saturação e a fase de resfriamento decorrente do estabelecimento da vazão de resfriamento. O transiente foi iniciado depois de decorridos $4882 \mathrm{~s}$, quando a válvula foi aberta com 1,0 volta, 
produzindo uma taxa inicial de diminuição de nível na ST2 da ordem de $0,40 \mathrm{~mm} / \mathrm{s}$ (1440 mm/h).

Para este transiente, os dados foram registrados a cada $15 \mathrm{~s}$ pelo SAD. Os dados experimentais foram escolhidos entre os instantes $4000 \mathrm{~s}$ e $9000 \mathrm{~s}$ serão utilizados em RNA's como dados para compor uma tabela de verificação. Para este intervalo de tempo tem-se 335 pontos, que estão mostrados na forma de gráficos nas FIG. 5.53, 5.54, 5.55 e 5.56.

Nas FIG. 5.57 e 5.58 são apresentados os dados do teste de diminuição de nível em ST2 referentes a 2,0 voltas de abertura na válvula. Na FIG. 5.57 é mostrado o comportamento do nível nas ST's enquanto que na FIG. 5.58 são mostradas as temperaturas de entrada (TC2-07) e saída (TC2-08), e temperaturas de parede ao longo da sonda (TC2-11 a TC2-22). Observa-se a fase de aquecimento do fluido na ST2 até atingir a condição de saturação e a fase de resfriamento decorrente do estabelecimento da vazão de resfriamento na sonda. O transiente foi iniciado depois de decorridos $3090 \mathrm{~s}$, quando a válvula foi aberta com 2,0 volta, produzindo uma taxa inicial de diminuição de nível na ST2 da ordem de $0,1,46 \mathrm{~mm} / \mathrm{s}(5250 \mathrm{~mm} / \mathrm{h})$.

Para este transiente, os dados foram registrados pelo SAD a cada $30 \mathrm{~s}$, sendo escolhidos entre os instantes 3000 s e 10500 s. Eles serão utilizados em RNA's como dados para a tabela de verificação nas condições de transiente. Para este intervalo de tempo tem-se 250 pontos, que estão mostrados na forma de gráficos nas FIG. 5.59, 5.60, 5.61 e 5.62. 


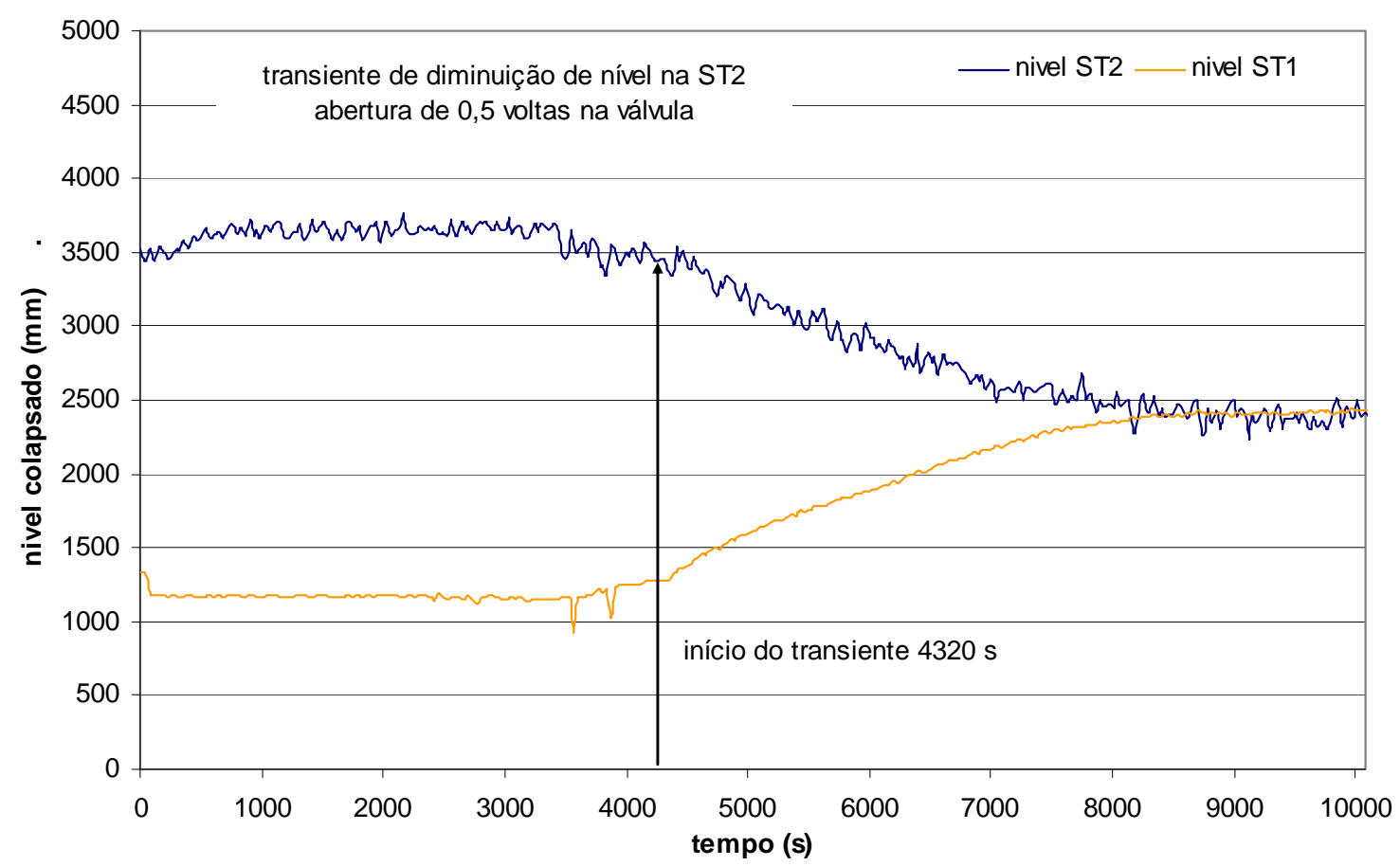

FIGURA 5.43. Nível em ST1 e ST2 versus tempo para 0,5 volta de abertura de válvula.

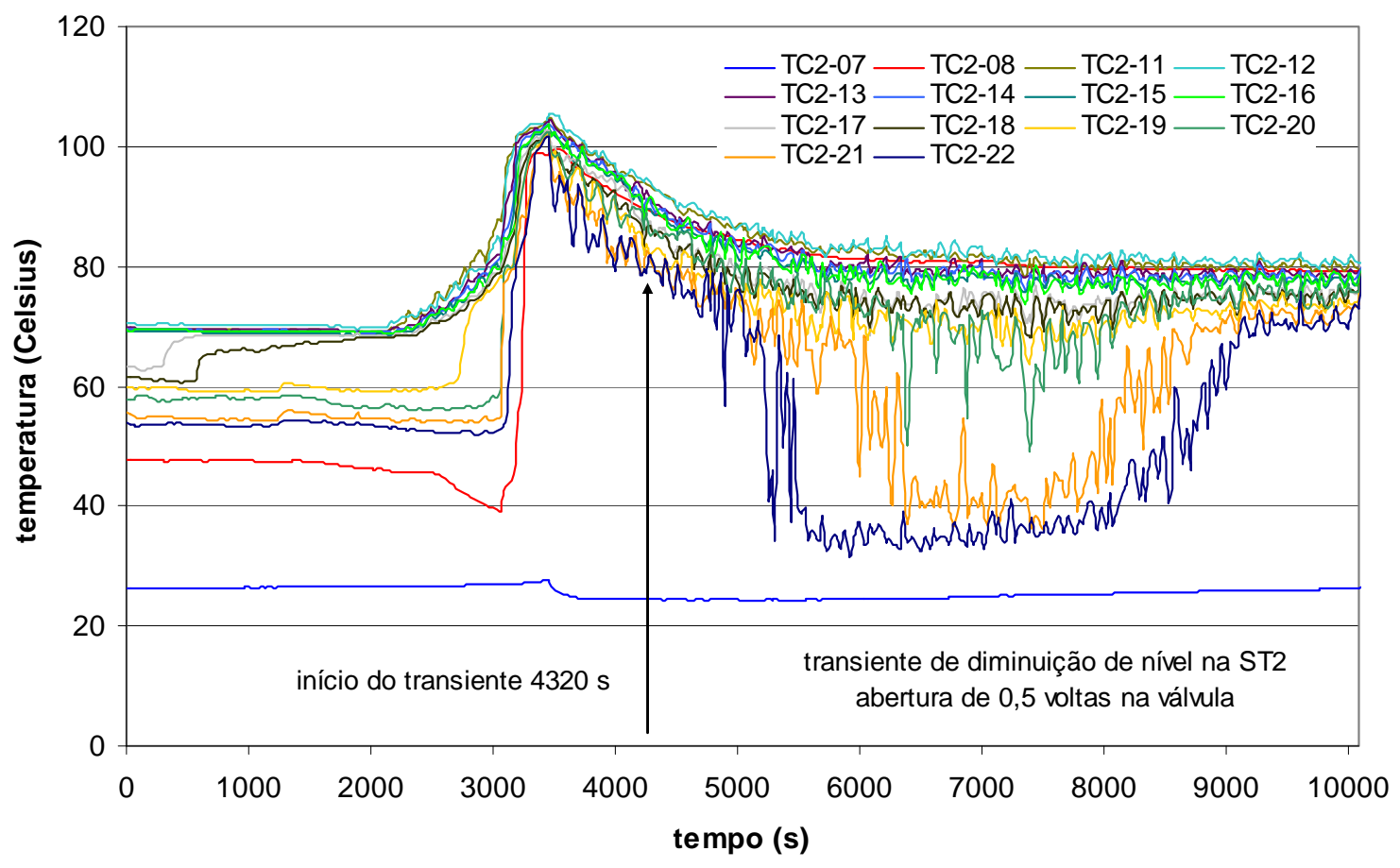

FIGURA 5.44. Temperaturas na sonda tipo tubo $U$ para 0,5 volta de abertura de válvula. 


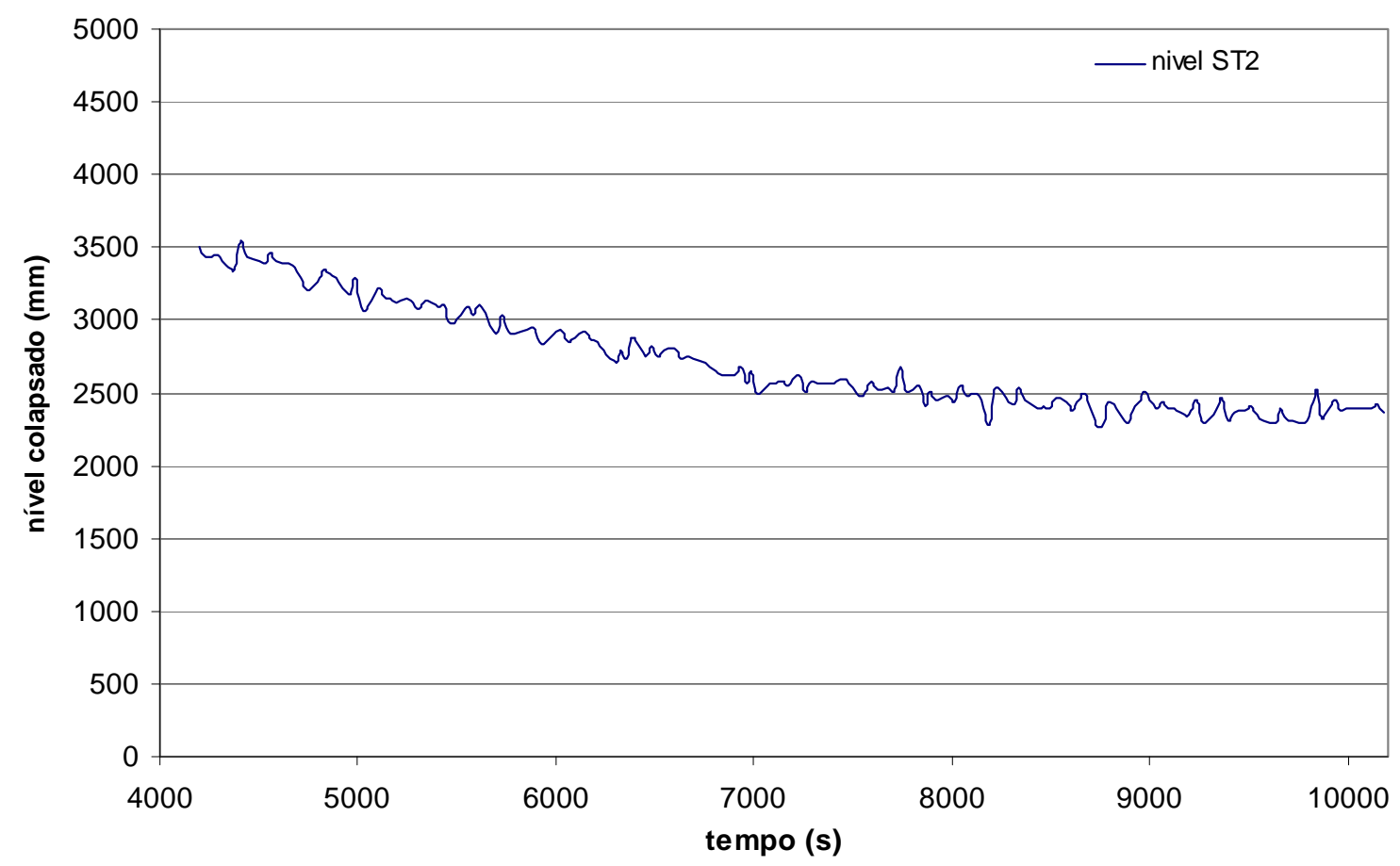

FIGURA 5.45. Nível em ST2 no intervalo de tempo escolhido para representar a condição de transiente para 0,5 volta de abertura da válvula.

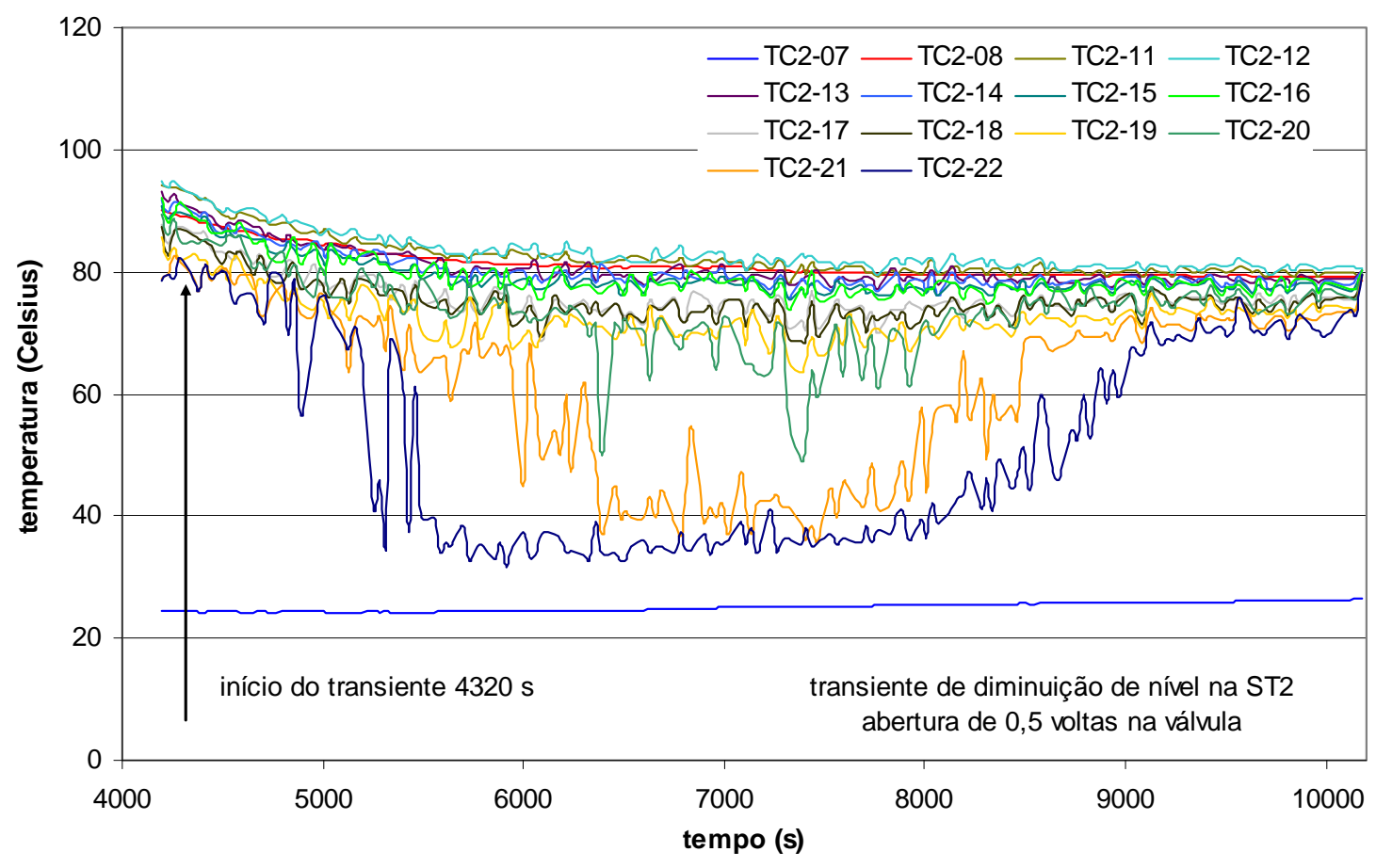

FIGURA 5.46. Temperaturas na sonda tipo tubo $U$ no intervalo de tempo escolhido para representar a condição de transiente para 0,5 volta de abertura da válvula. 


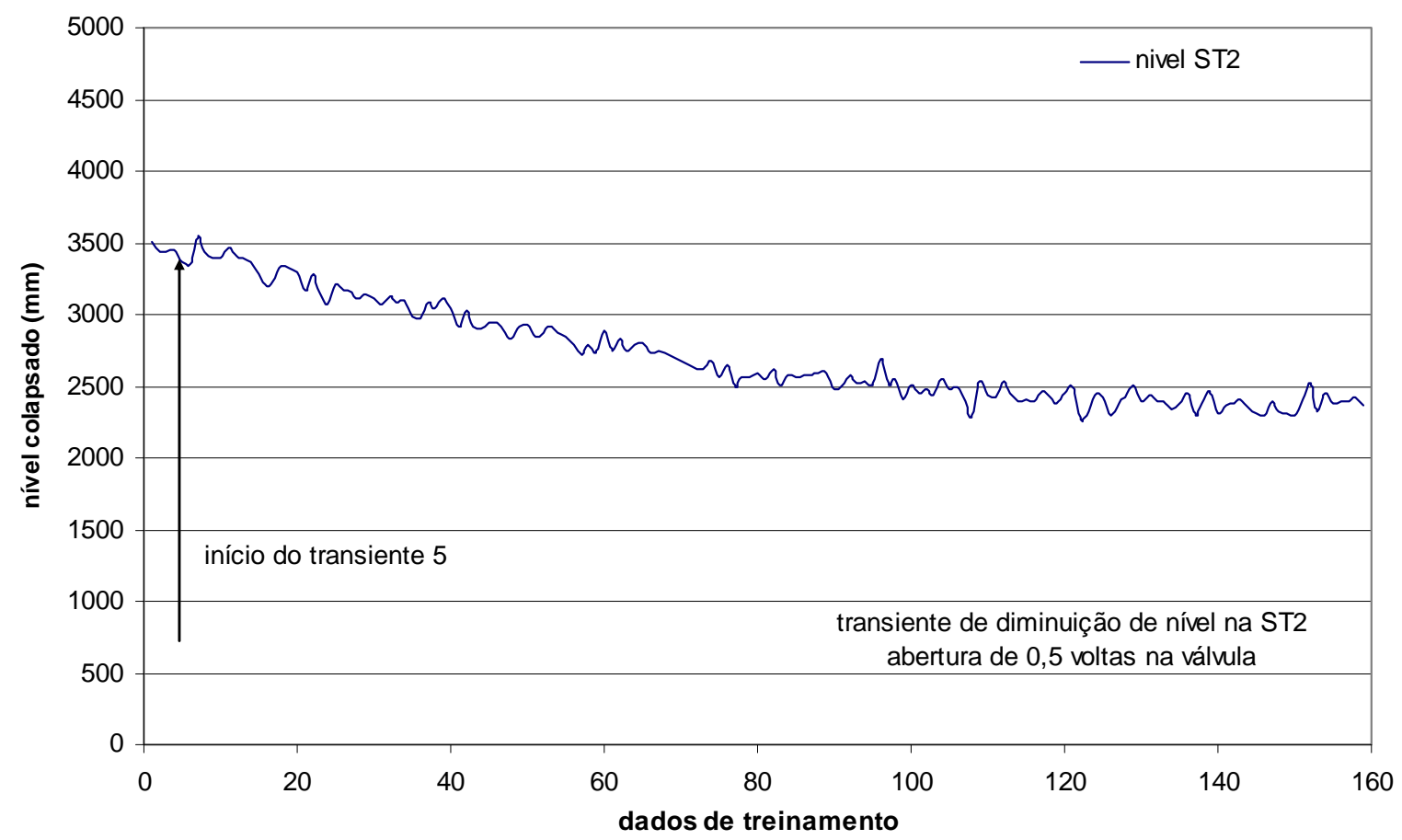

FIGURA 5.47. Nível em ST2 - Dados da tabela de treinamento.

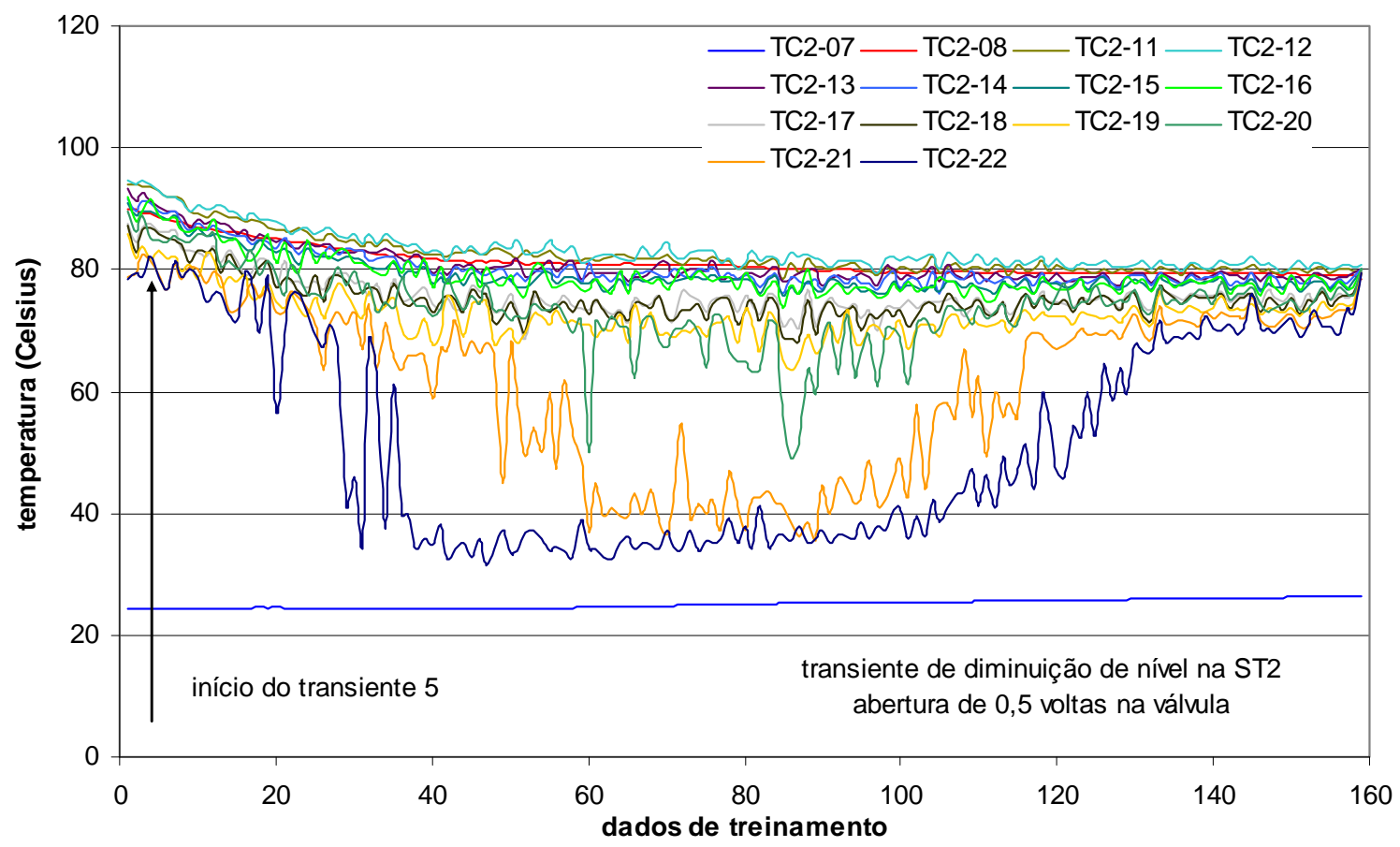

FIGURA 5.48. Temperaturas na sonda de tubo $U$ - Dados da tabela de treinamento. 


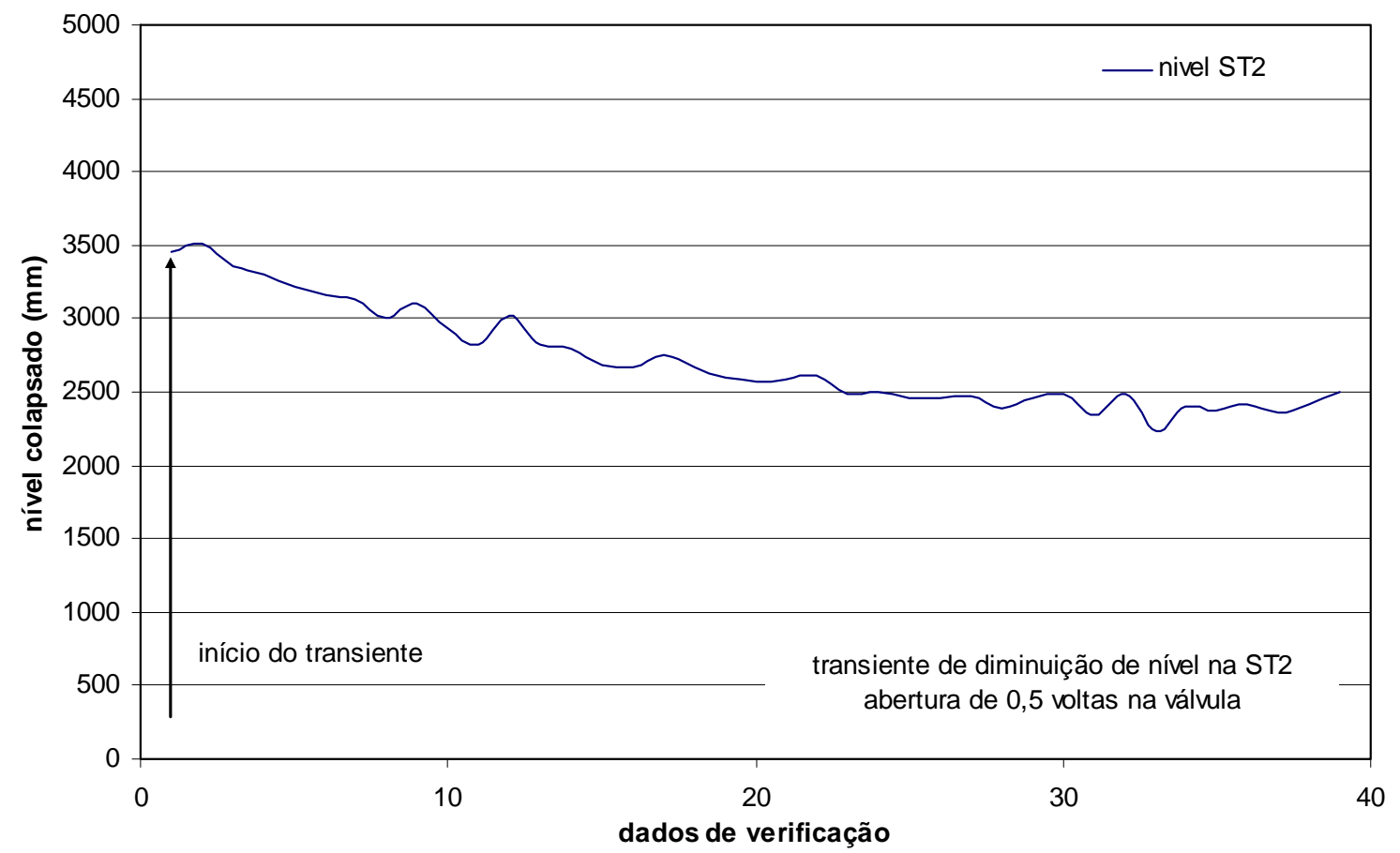

FIGURA 5.49. Nível em ST2 - Dados da tabela de verificação.

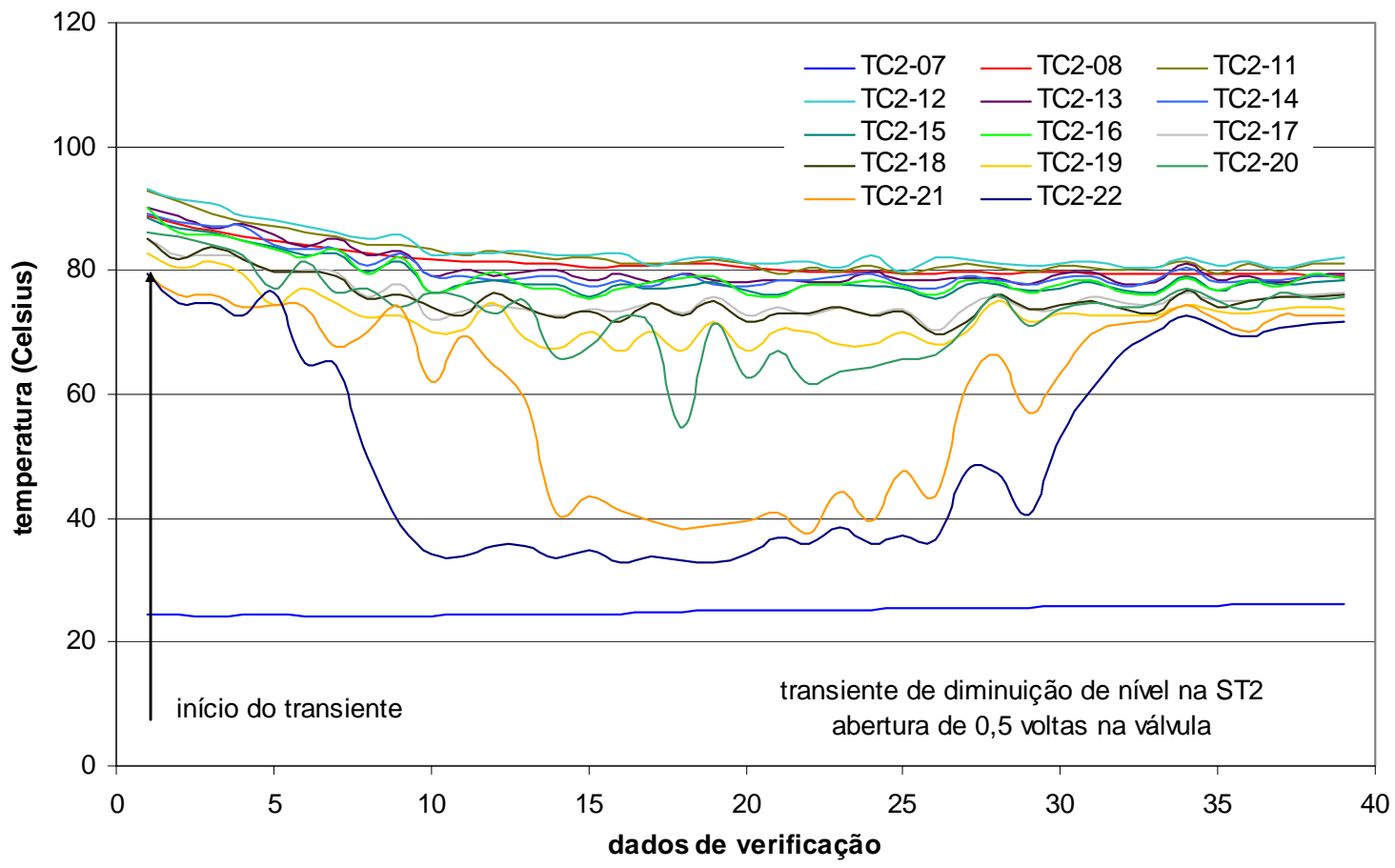

FIGURA 5.50. Temperaturas na sonda de tubo U - Dados da tabela de verificação. 


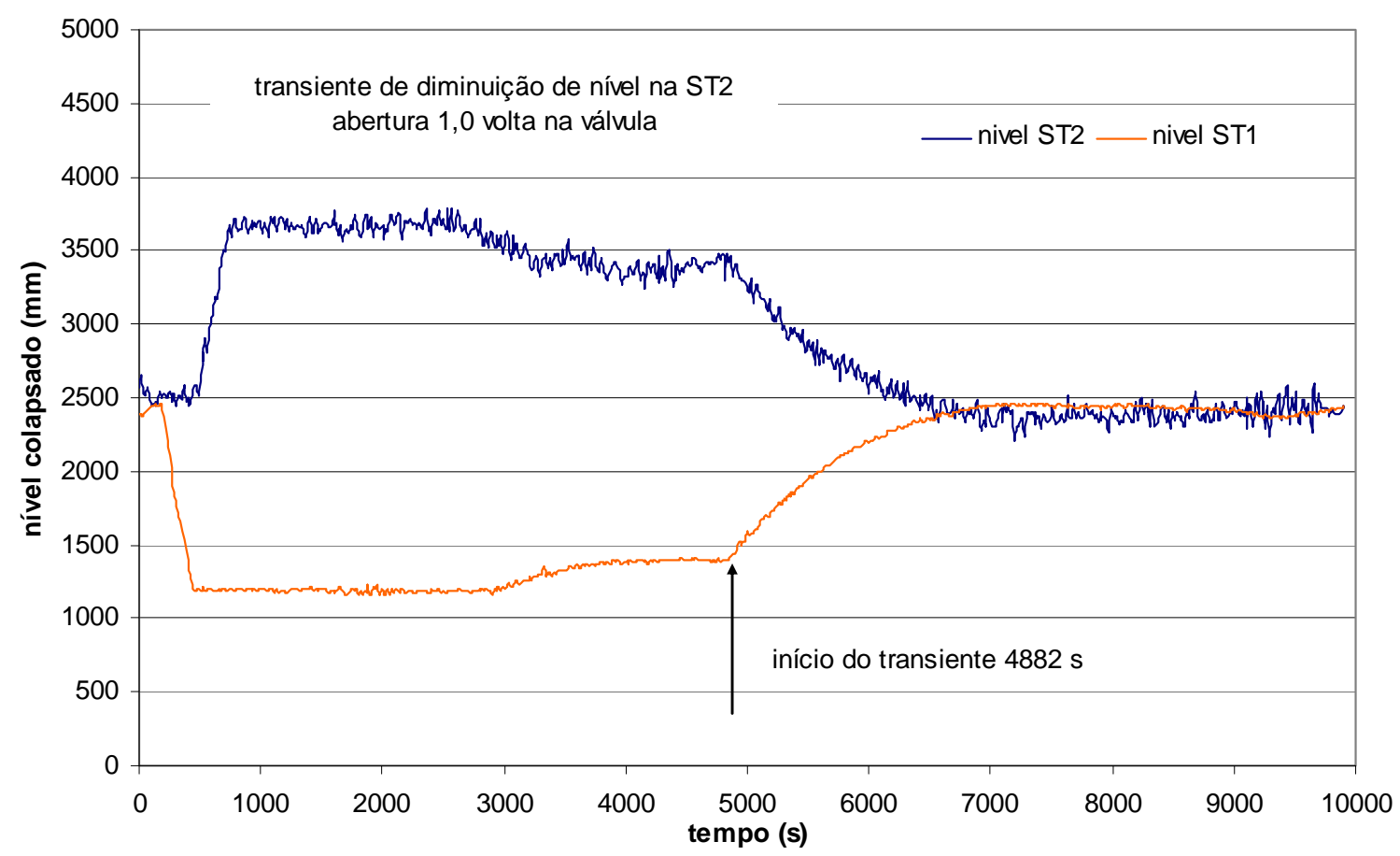

FIGURA 5.51. Nível em ST1 e ST2 versus tempo para 1,0 volta de abertura de válvula.

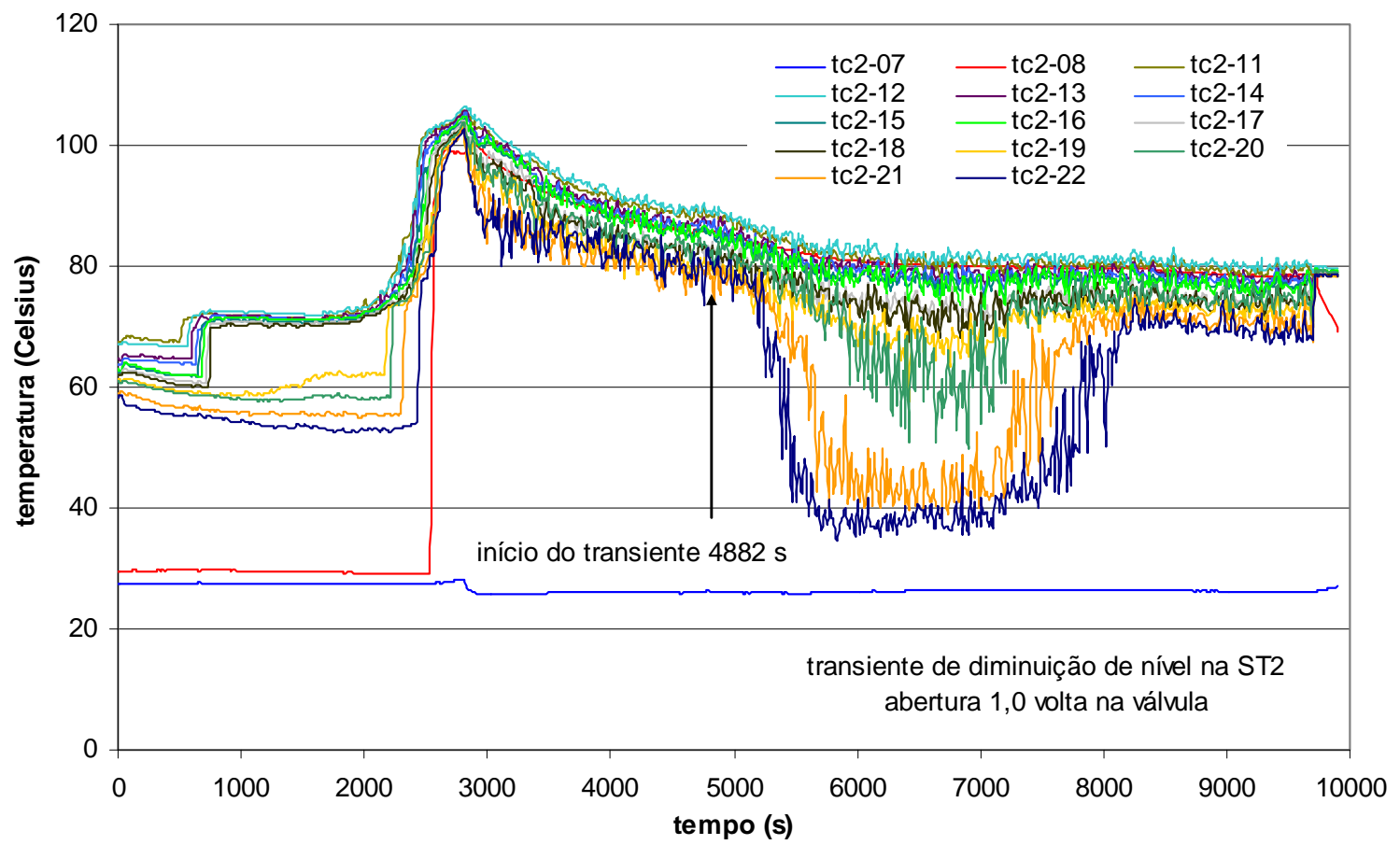

FIGURA 5.52. Temperaturas na sonda tipo tubo $U$ para 1,0 volta de abertura de válvula. 


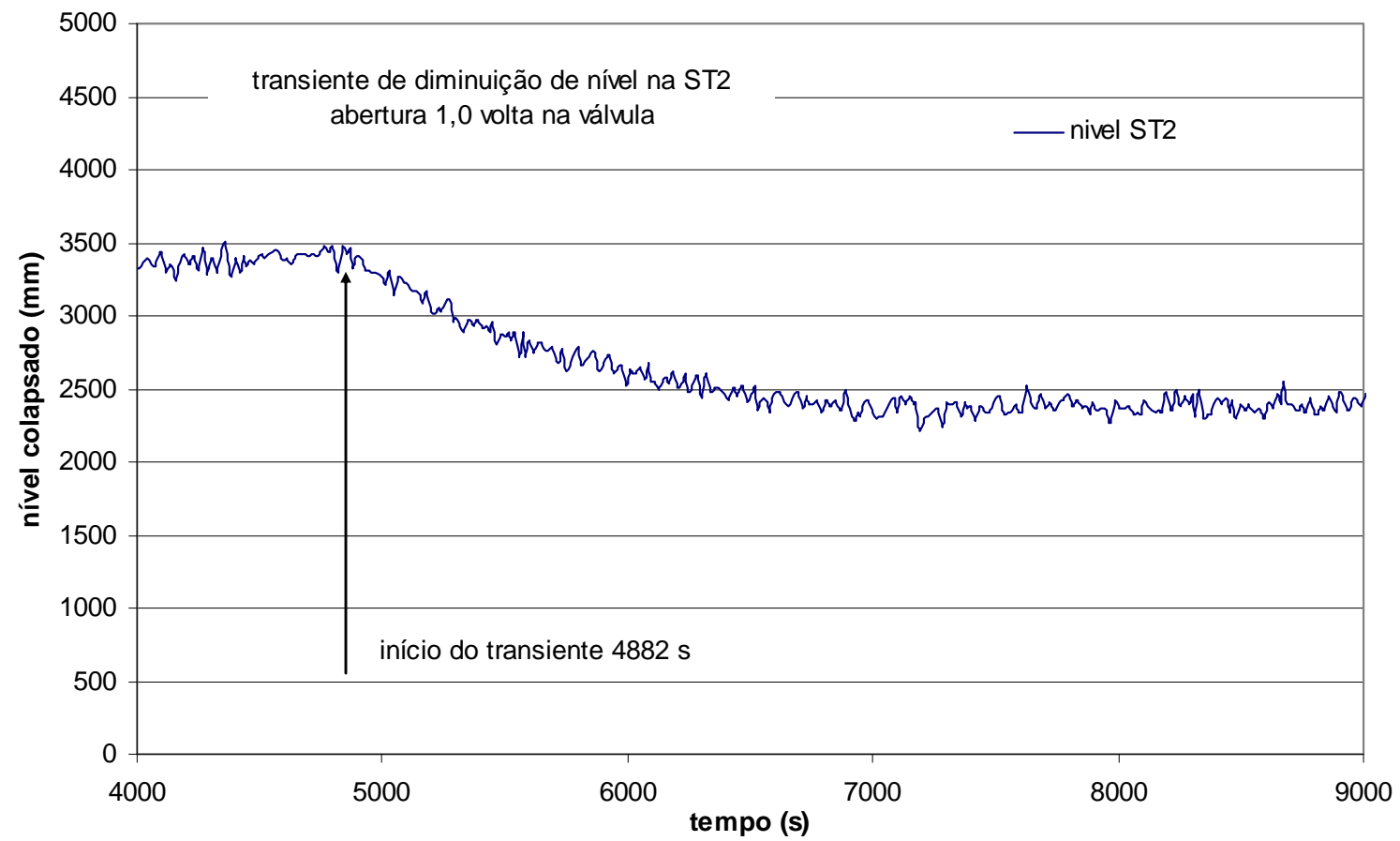

FIGURA 5.53. Nível em ST2 no intervalo de tempo escolhido para representar a condição de transiente para 1,0 volta de abertura de válvula.

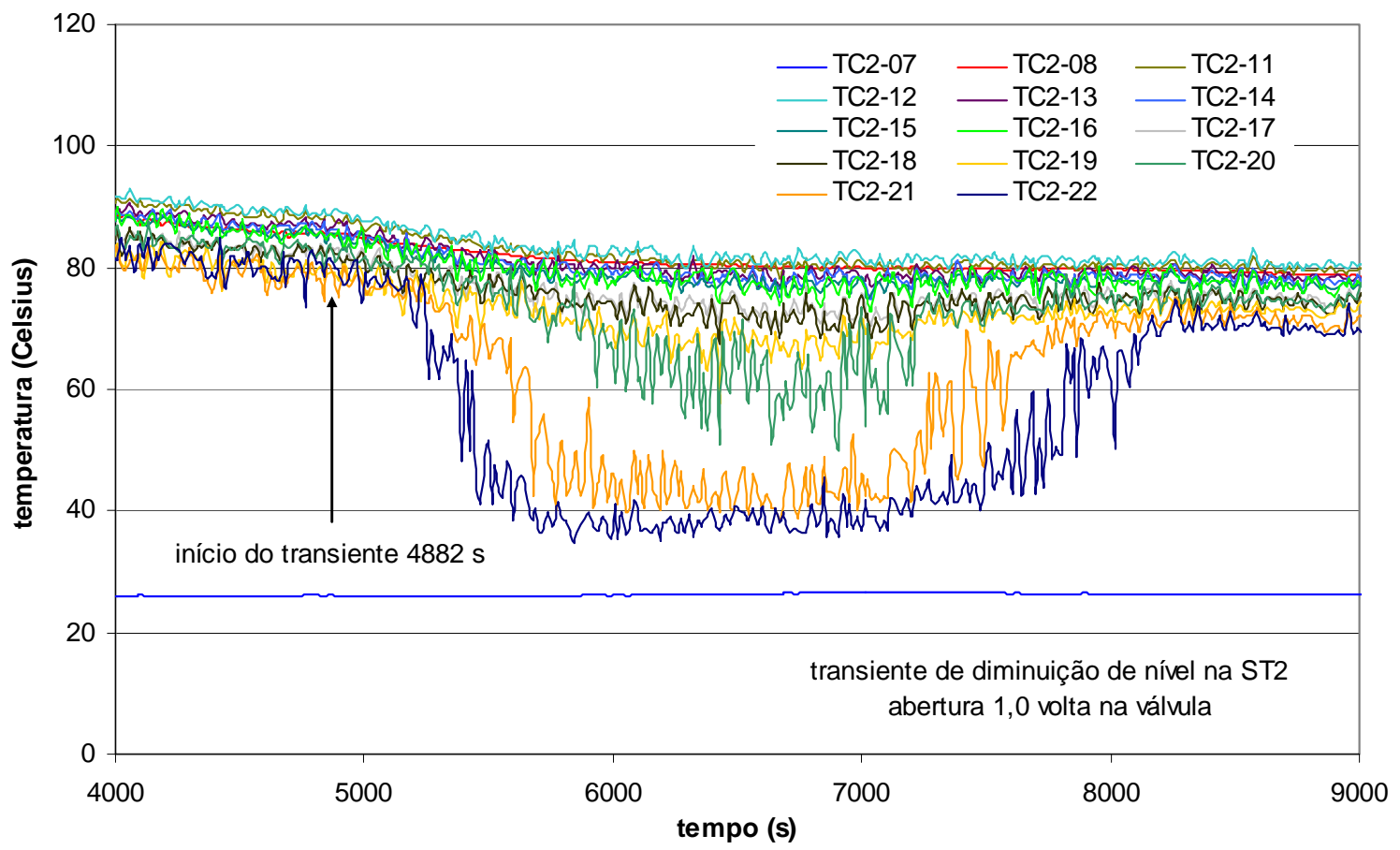

FIGURA 5.54. Temperaturas na sonda tipo tubo $U$ no intervalo de tempo escolhido para representar a condição de transiente para 1,0 volta de abertura de válvula. 


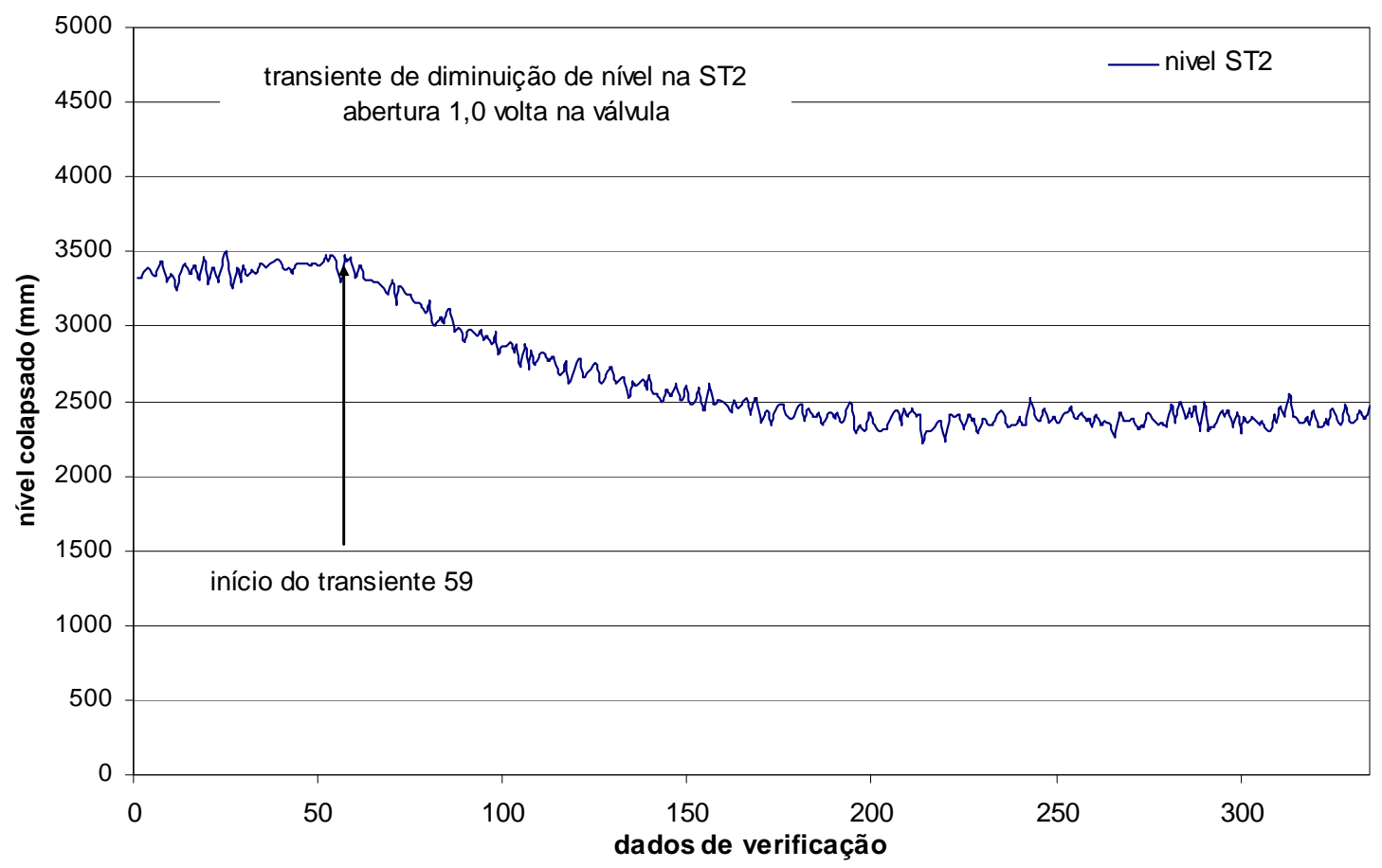

FIGURA 5.55. Nível em ST2 - Dados da tabela de verificação.

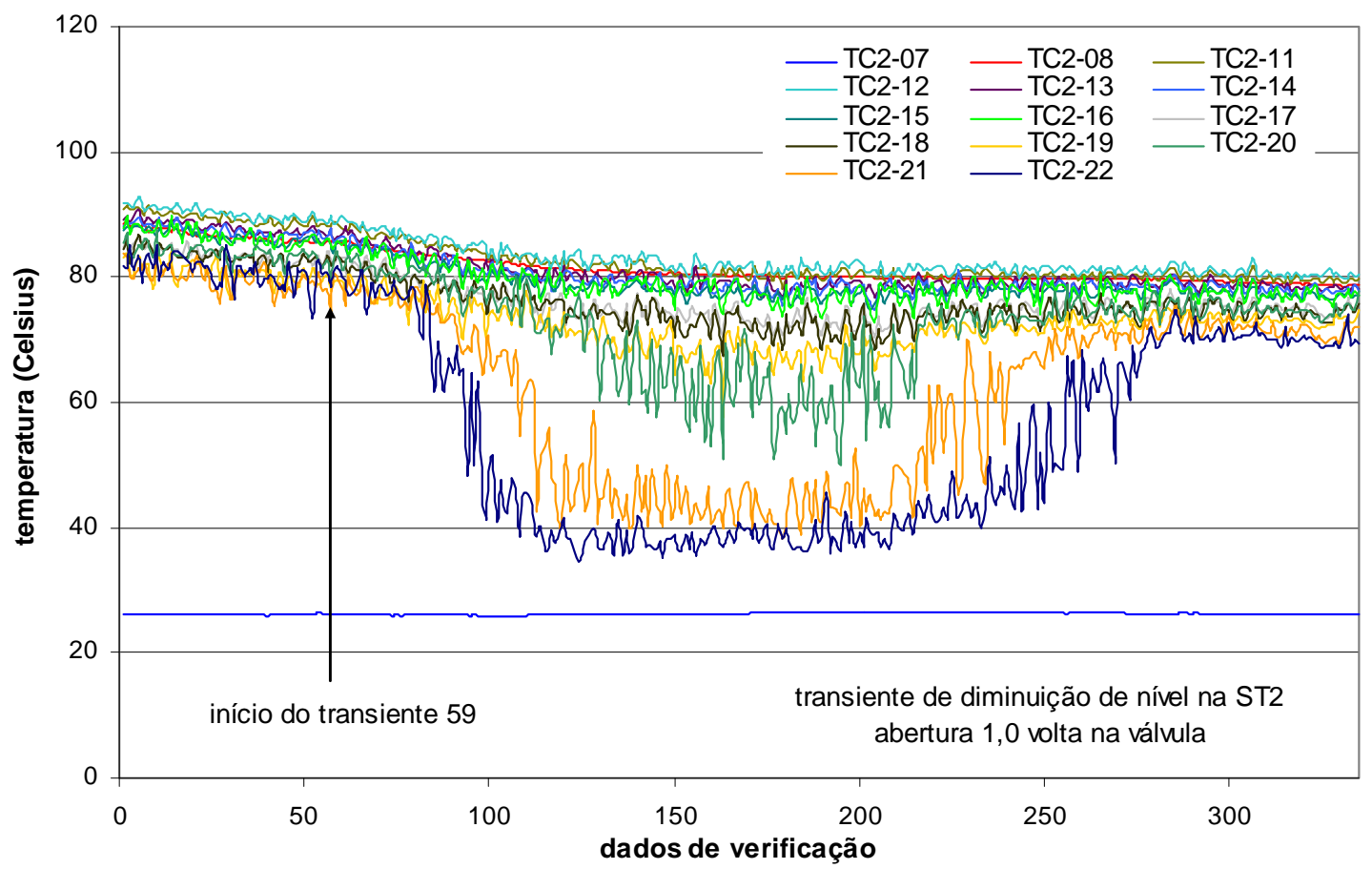

FIGURA 5.56. Temperaturas na sonda tipo tubo U - Dados da tabela de verificação. 


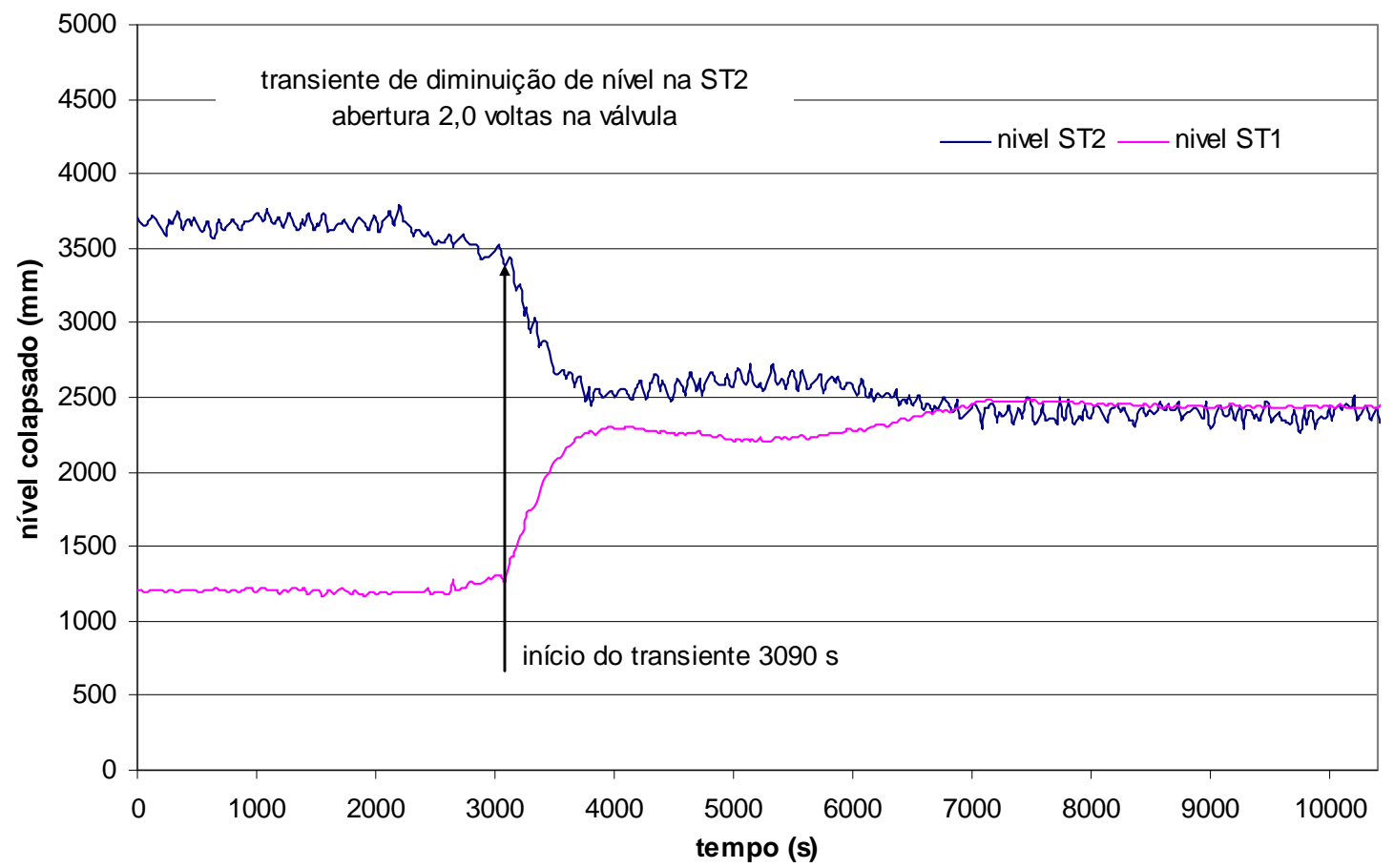

FIGURA 5.57. Nível em ST1 e ST2 versus tempo para 2,0 voltas de abertura de válvula.

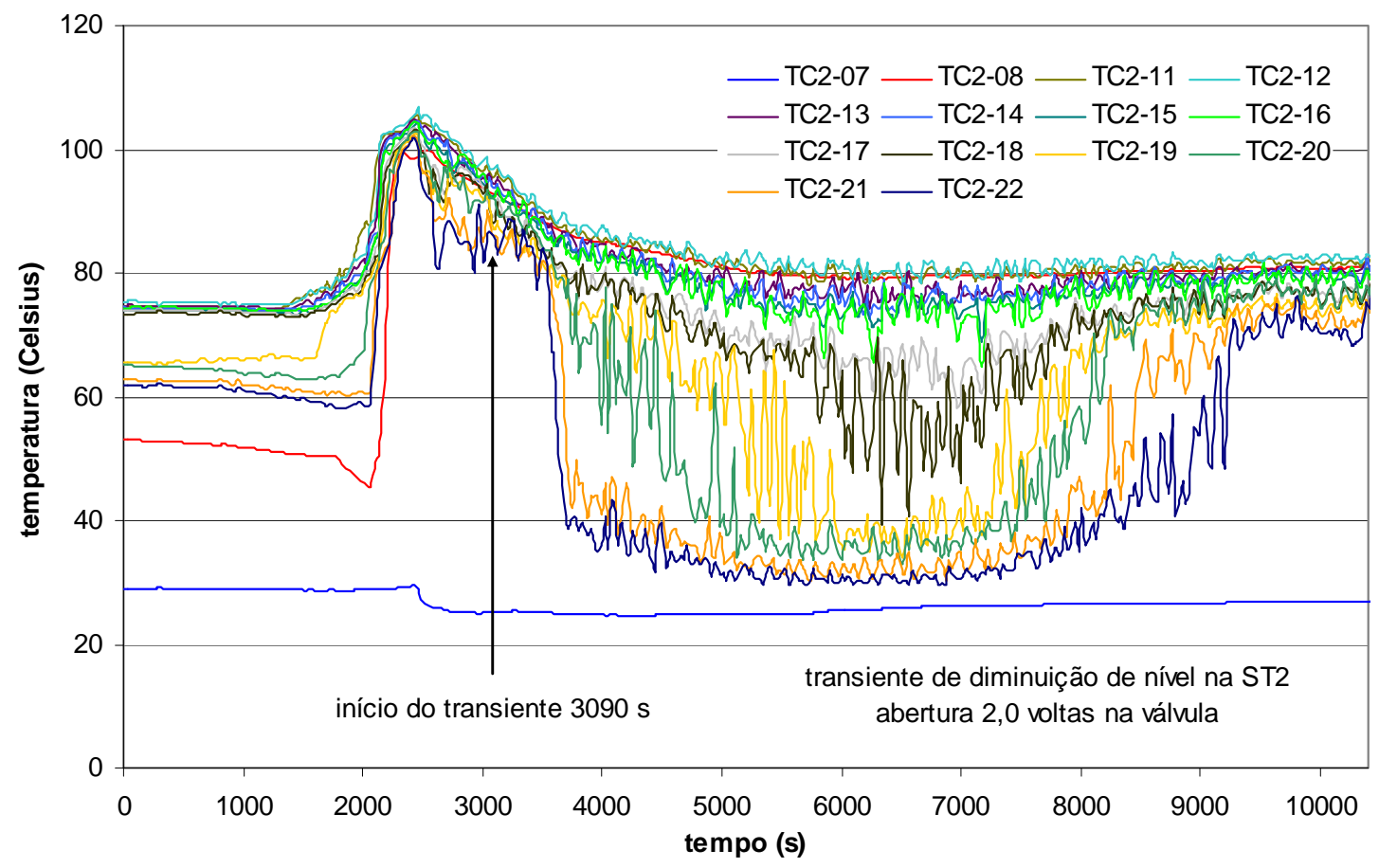

FIGURA 5.58. Temperaturas na sonda tipo tubo $U$ para 2,0 voltas de abertura de válvula. 


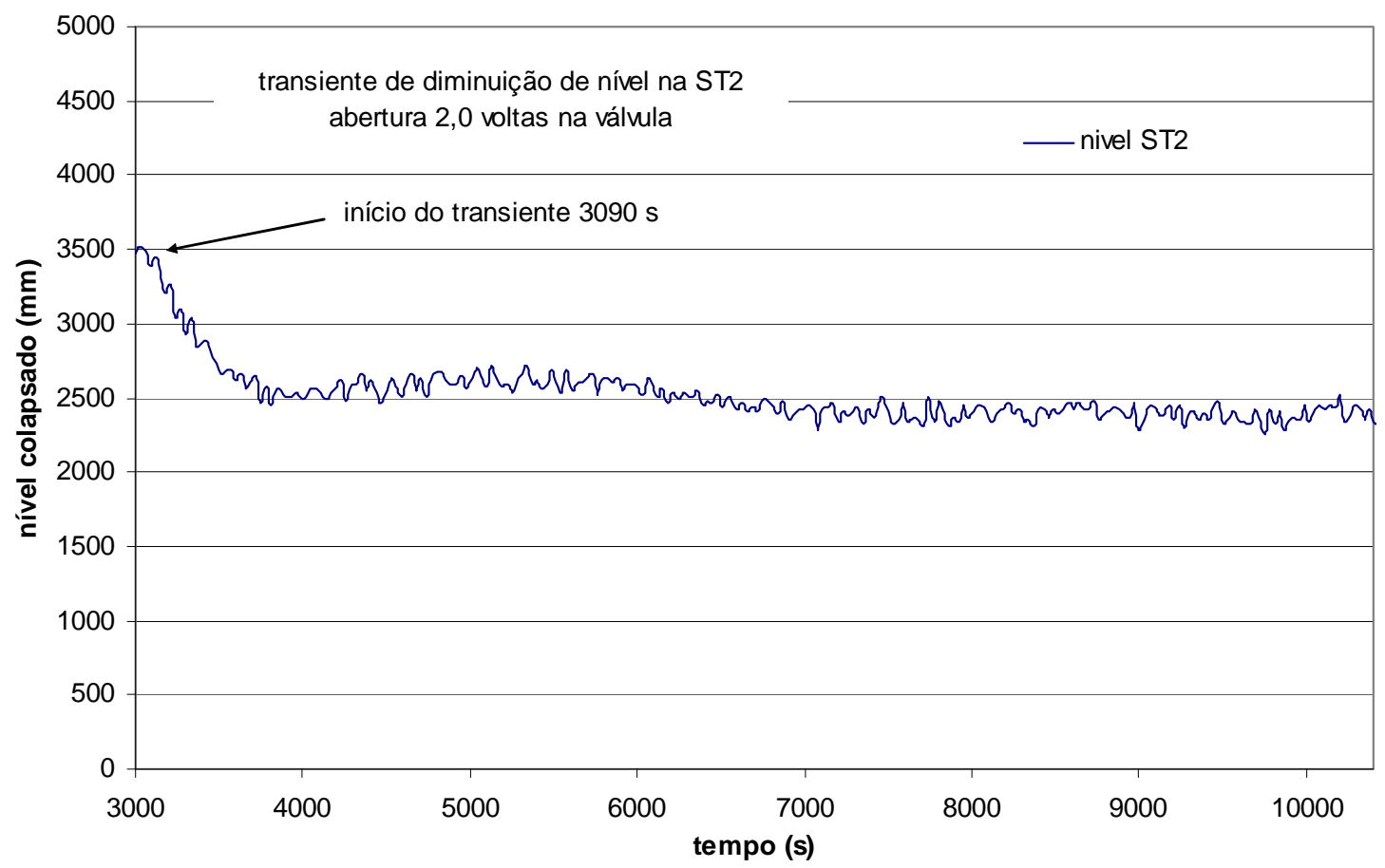

FIGURA 5.59. Nível em ST2 no intervalo de tempo escolhido para representar a condição de transiente para 2,0 voltas de abertura da válvula.

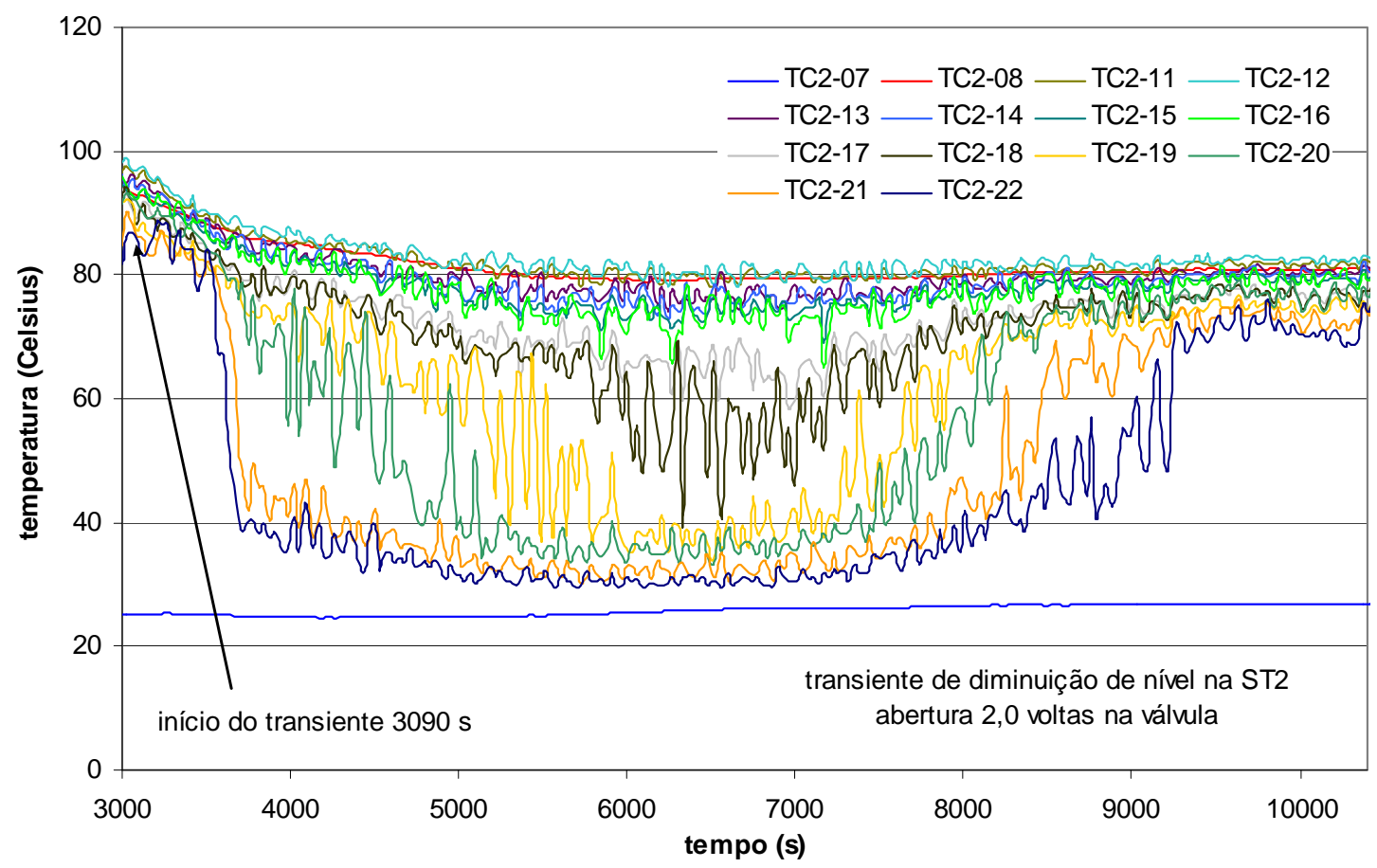

FIGURA 5.60. Temperaturas na sonda tipo tubo $U$ no intervalo de tempo escolhido para representar a condição de transiente para 2,0 voltas de abertura de válvula. 


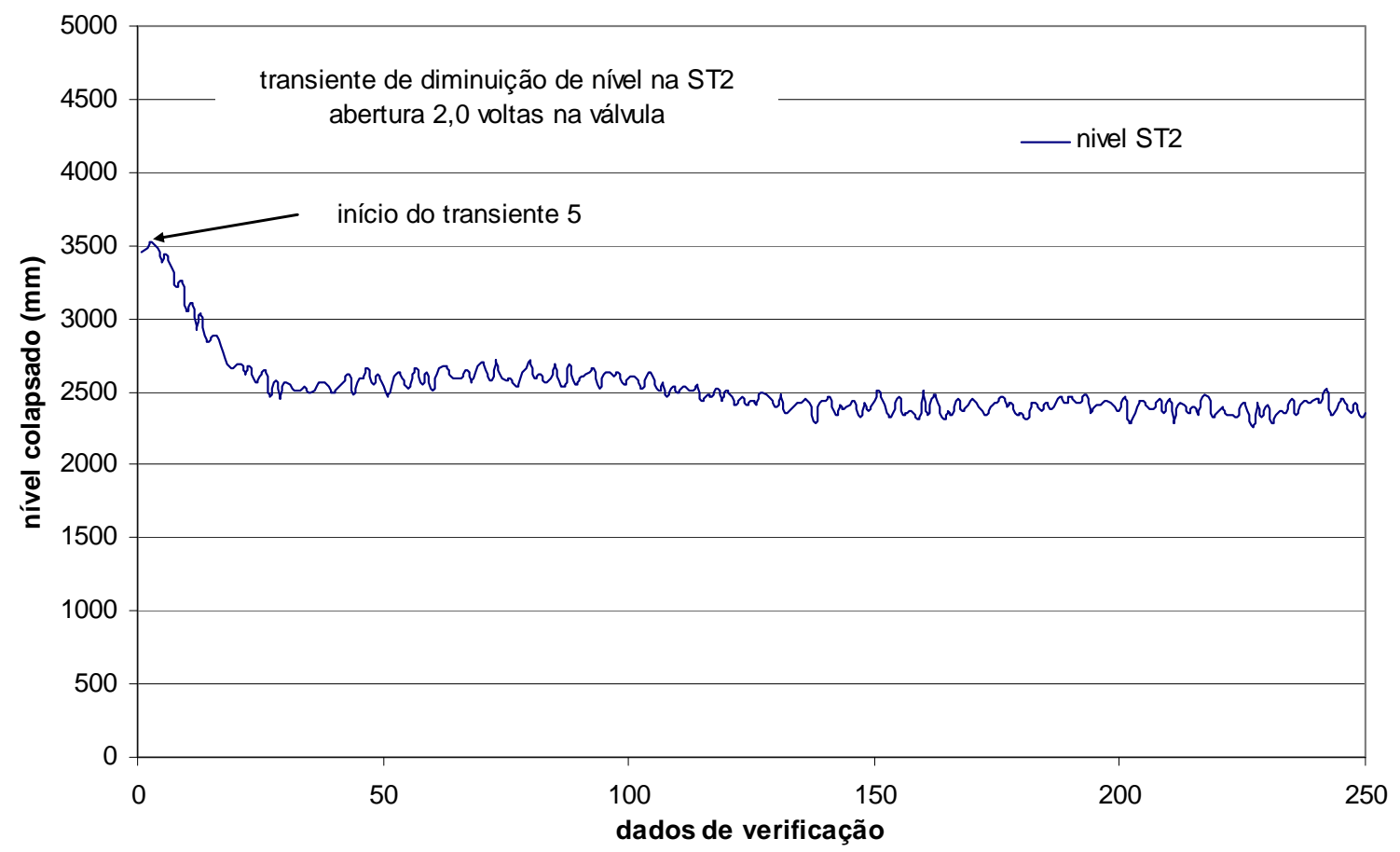

FIGURA 5.61. Nível em ST2, 335 dados de verificação.

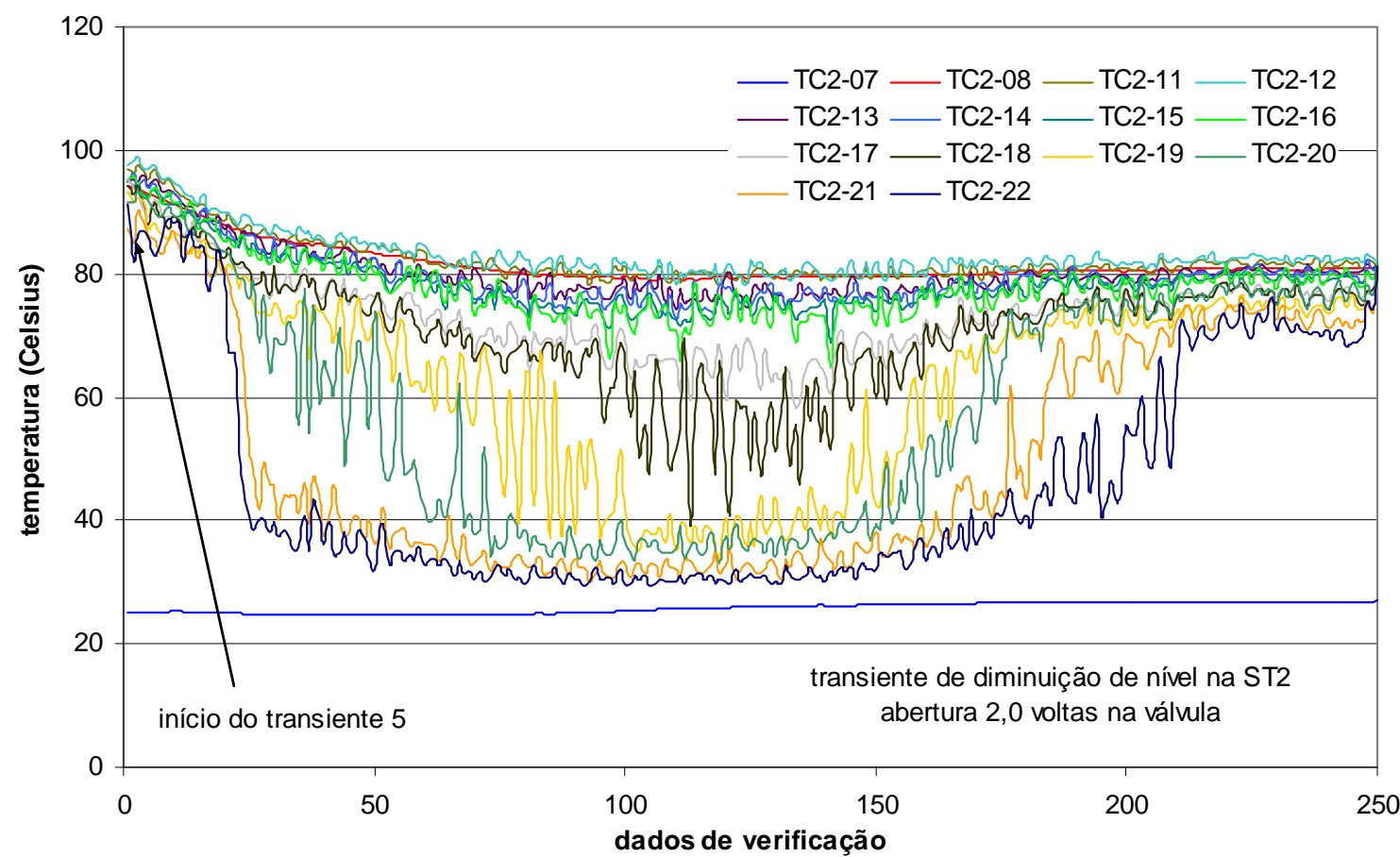

FIGURA 5.62. Temperaturas na sonda tipo tubo $U, 335$ dados de verificação. 


\subsection{Sonda de Tubos Concêntricos - Testes}

Os testes com a sonda do tipo tubos concêntricos foram realizados no vaso da seção de testes ST1. O aquecedor de $9 \mathrm{~kW}$ anteriormente na ST2 foi instalado na ST1, e o aquecedor de $3 \mathrm{~kW}$ da ST1 foi instalado na ST2. Com a sonda de tubos concêntricos foram realizados apenas testes em condições de transiente a quente, apresentados a seguir.

\subsubsection{Sonda de Tubos Concêntricos - Testes em Transiente a quente}

Os testes foram realizados obedecendo ao procedimento apresentado no APÊNDICE F. A vazão de resfriamento da sonda foi igual a $100 \mathrm{l} / \mathrm{h}\left(2,78 \times 10^{-5} \mathrm{~m}^{3} / \mathrm{s}\right.$ ou $0,028 \mathrm{~kg} / \mathrm{s}$ ). A água de resfriamento percorre o caminho de descida da sonda, até a extremidade inferior através do canal anular formado pelos tubos interno e externo, retornando pelo tubo interno até o topo da sonda. Foram realizados testes em condições de transiente para 0,5 e 1,0 volta de abertura da válvula da entrada da ST2.

Os dados referentes ao primeiro teste com a sonda de tubos concêntricos realizado para 0,5 volta de abertura da válvula são apresentados nas FIG. 5.63 e 5.64. A taxa inicial de diminuição de nível foi da ordem de $0,46 \mathrm{~mm} / \mathrm{s}$ $(1656 \mathrm{~mm} / \mathrm{h})$. Os dados foram registrados pelo SAD a cada $3 \mathrm{~s}$ até o instante $5074 \mathrm{~s}$, após o qual foi ajustado para registrar os dados a cada $30 \mathrm{~s}$. Os dados experimentais apresentados na FIG. 5.64 mostram um comportamento para as temperaturas de

parede na sonda de tubos concêntricos diferente daquele observado para a sonda de tubo U. Na FIG. 5.64 as temperaturas nos termopares localizados em posições mais elevadas (TC1-22, TC1-21 e TC1-20) não caem tanto como ocorreu nos testes com a sonda de tubo $\mathrm{U}$, onde valores menores que $40^{\circ} \mathrm{C}$ foram medidos. Os resultados referentes a este teste foram utilizados para formar a tabela de treinamento. 
Um segundo teste foi realizado também para um transiente com 0,5 volta de abertura de válvula. A taxa inicial de diminuição de nível foi da ordem de $0,40 \mathrm{~mm} / \mathrm{s}$ (1440 mm/h). Neste caso, o gráfico mostrando a fase de aquecimento do fluido na seção de testes ST1 foi suprimido, sendo apresentados somente os dados do transiente, nas FIG. 5.69, 5.70, 5.71 e 5.72. Esses dados foram utilizados para compor uma tabela de verificação com 216 dados, que foi usada nas análises com RNA's das condições de transiente.

Da mesma forma, foi realizado um teste em transiente com 1,0 volta de abertura da válvula. A taxa inicial de diminuição de nível foi da ordem de 1,88 mm/s $(6780 \mathrm{~mm} / \mathrm{h})$. Os resultados podem ser vistos nas FIG. 5.73, 5.74, 5.75 e 5.76. Esses resultados foram usados para compor outra tabela de verificação com 190 dados. 


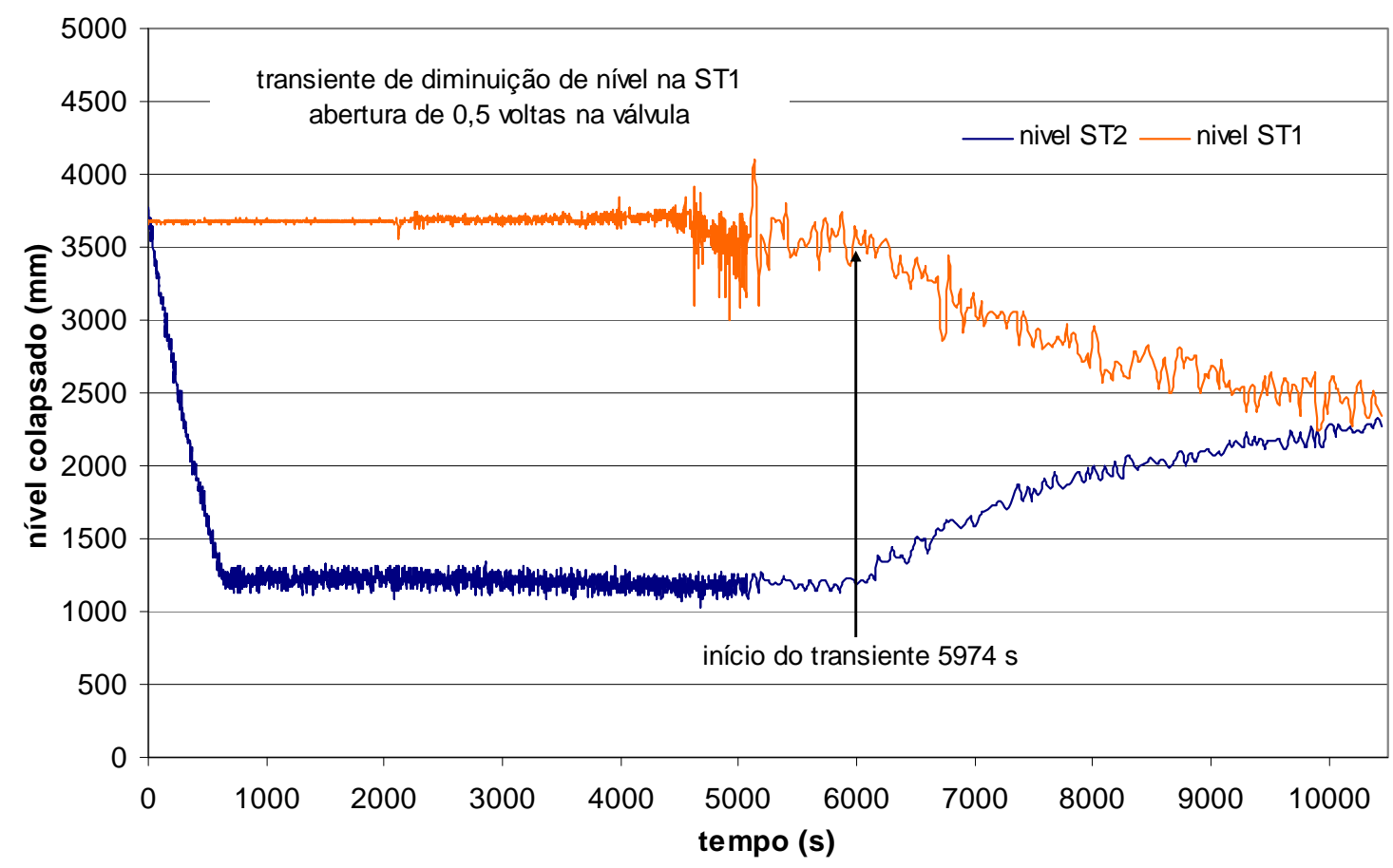

FIGURA 5.63. Nível em ST1 e ST2 versus tempo para 0,5 volta de abertura de válvula.

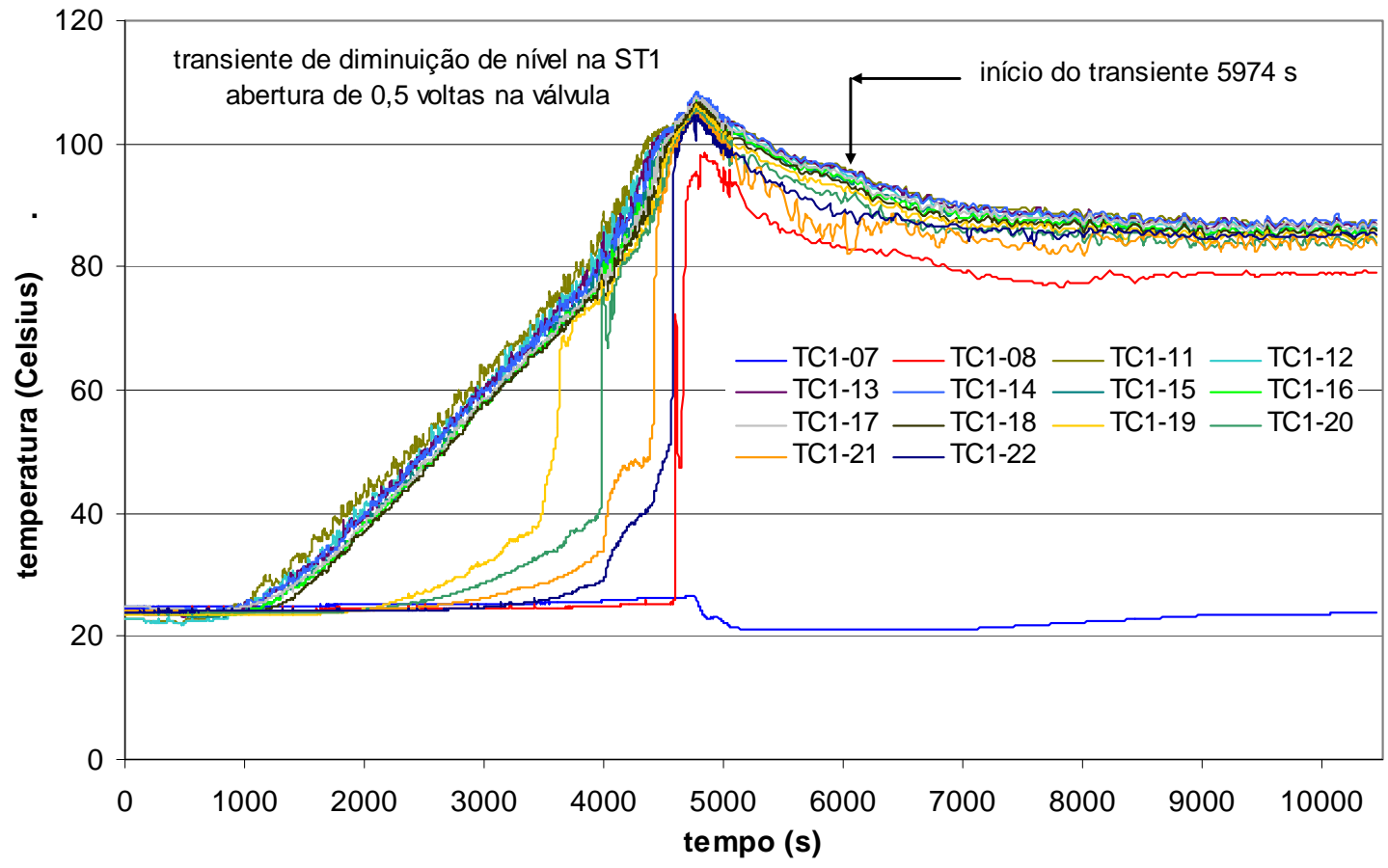

FIGURA 5.64. Temperaturas na sonda tipo tubos concêntricos $U$ para 0,5 volta de abertura de válvula. 


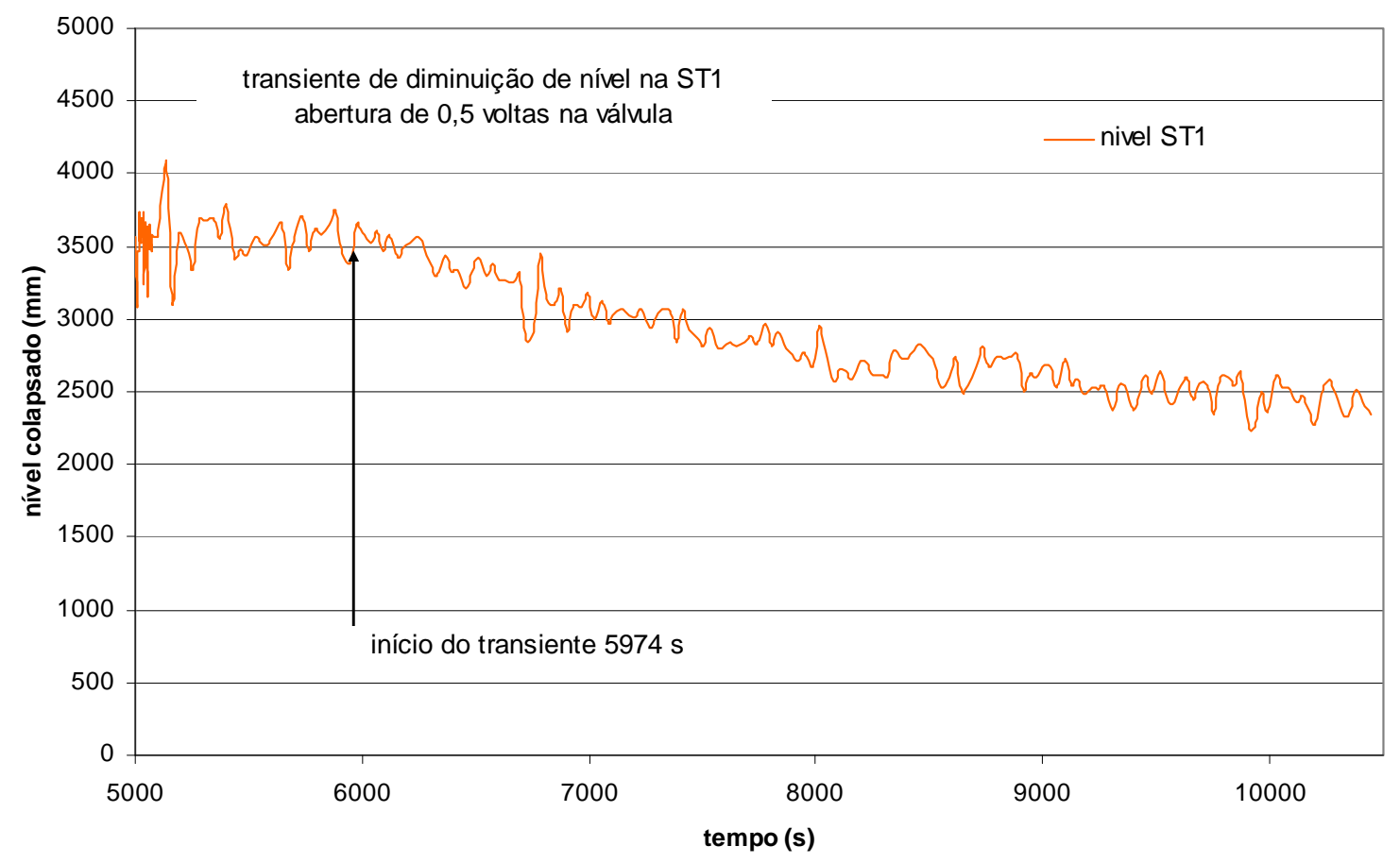

FIGURA 5.65. Nível em ST1 no intervalo de tempo escolhido para representar a condição de transiente para 0,5 volta de abertura da válvula.

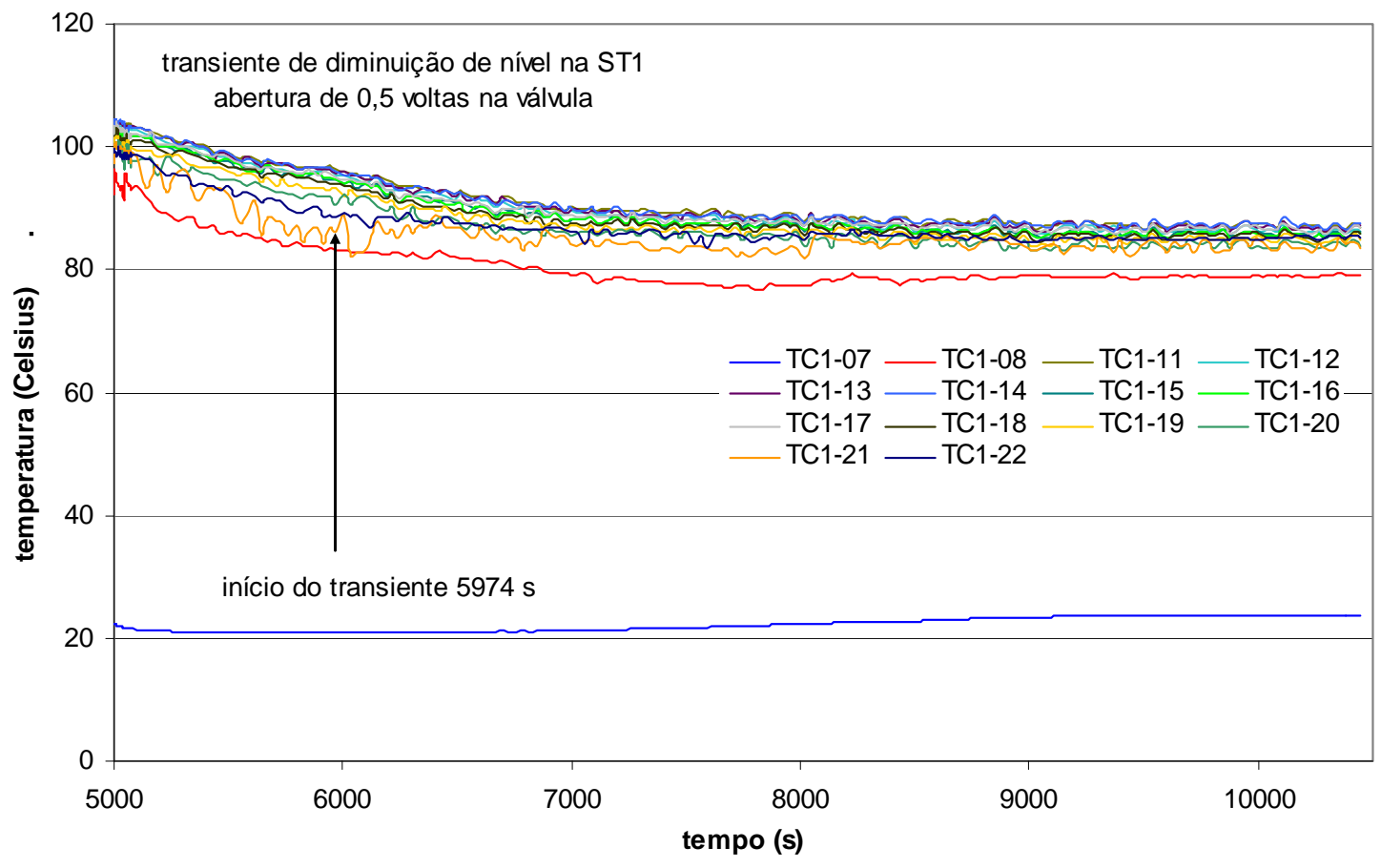

FIGURA 5.66. Temperaturas no intervalo de tempo escolhido para representara condição de transiente para 0,5 volta de abertura da válvula. 


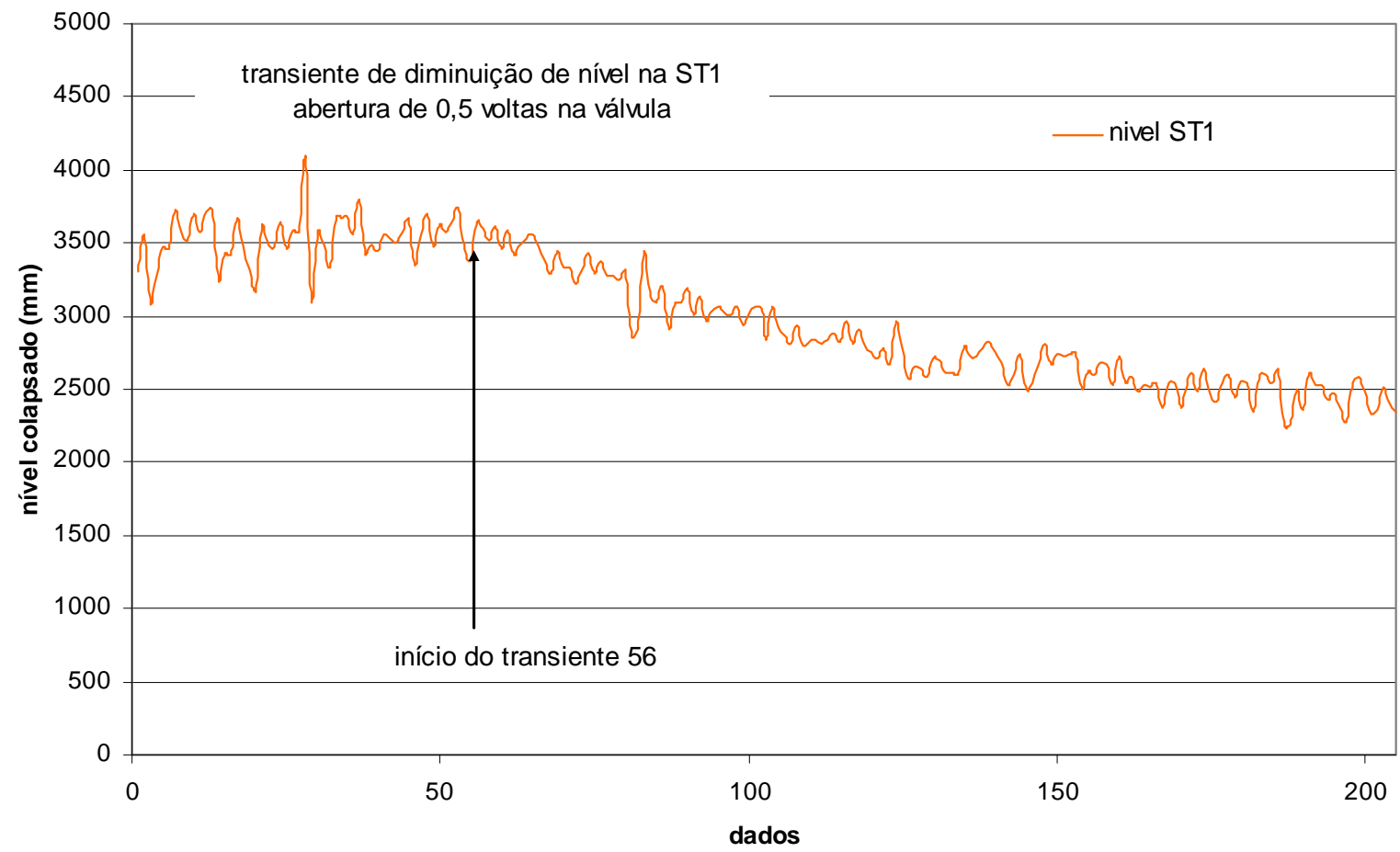

FIGURA 5.67. Nível em ST1, 205 dados de treinamento.

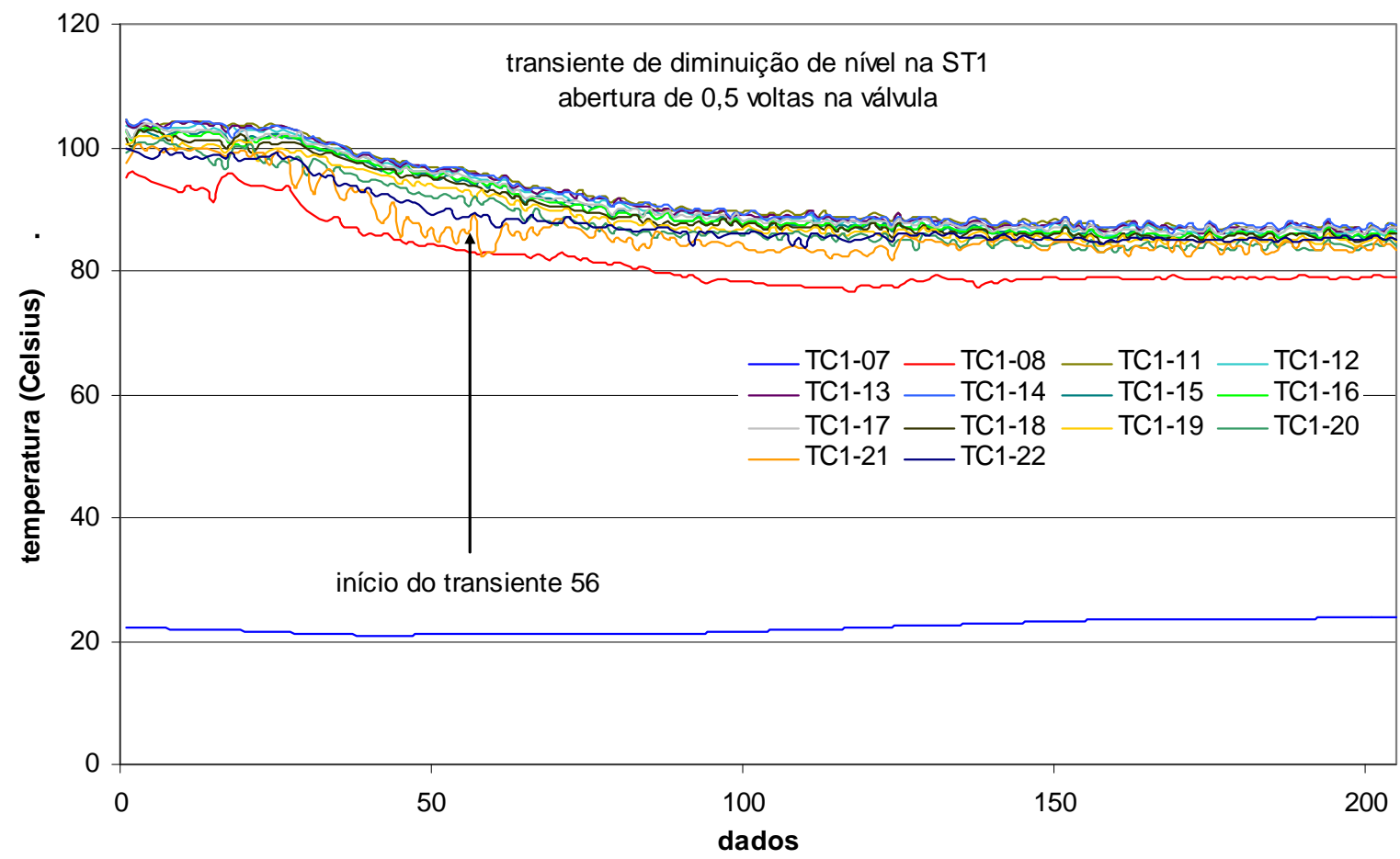

FIGURA 5.68. Temperaturas na sonda de tubos concêntricos, 205 dados de treinamento. 


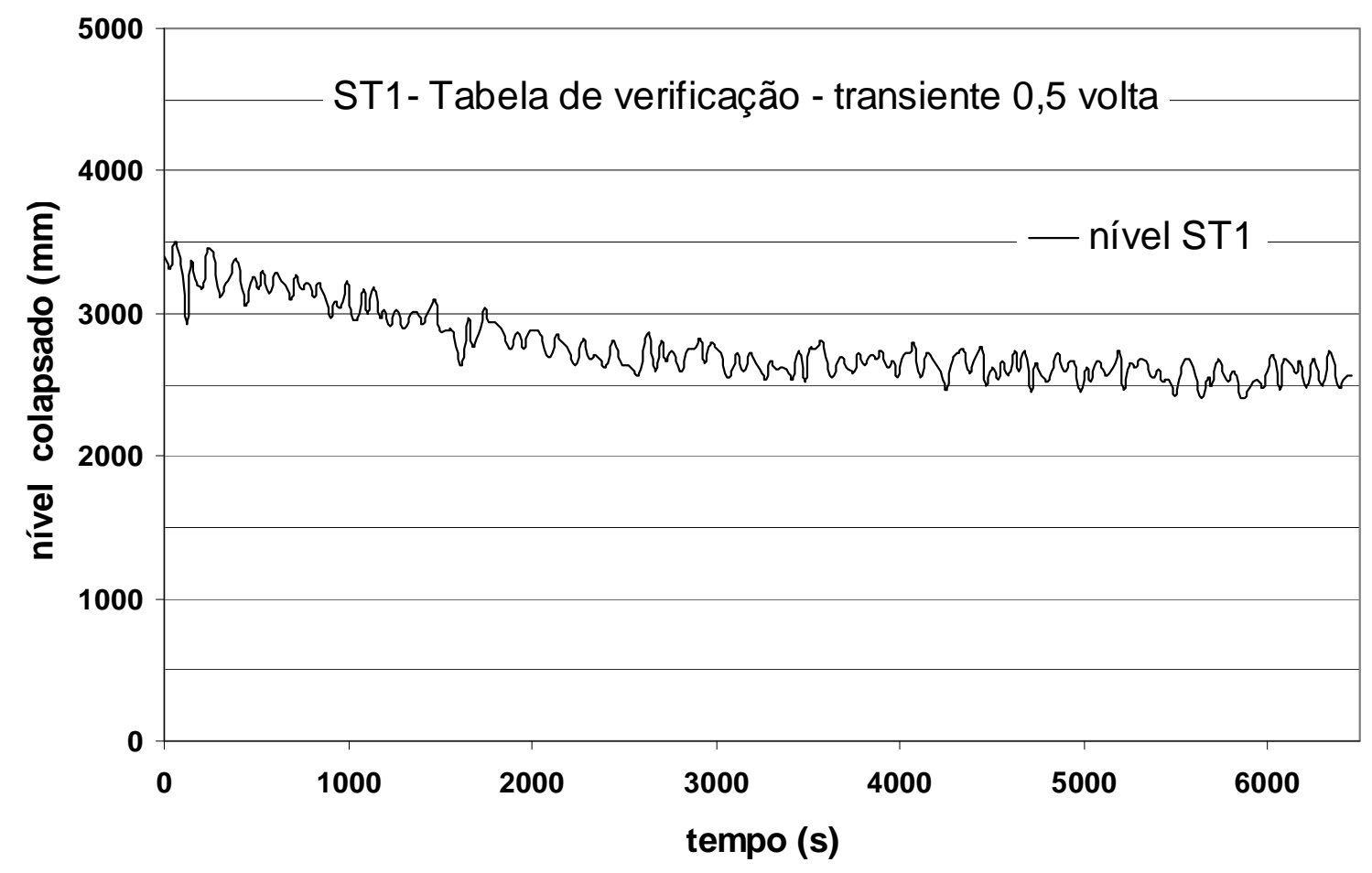

FIGURA 5.69. Nível em ST1 versus tempo - 0,5 volta - tabela de verificação.

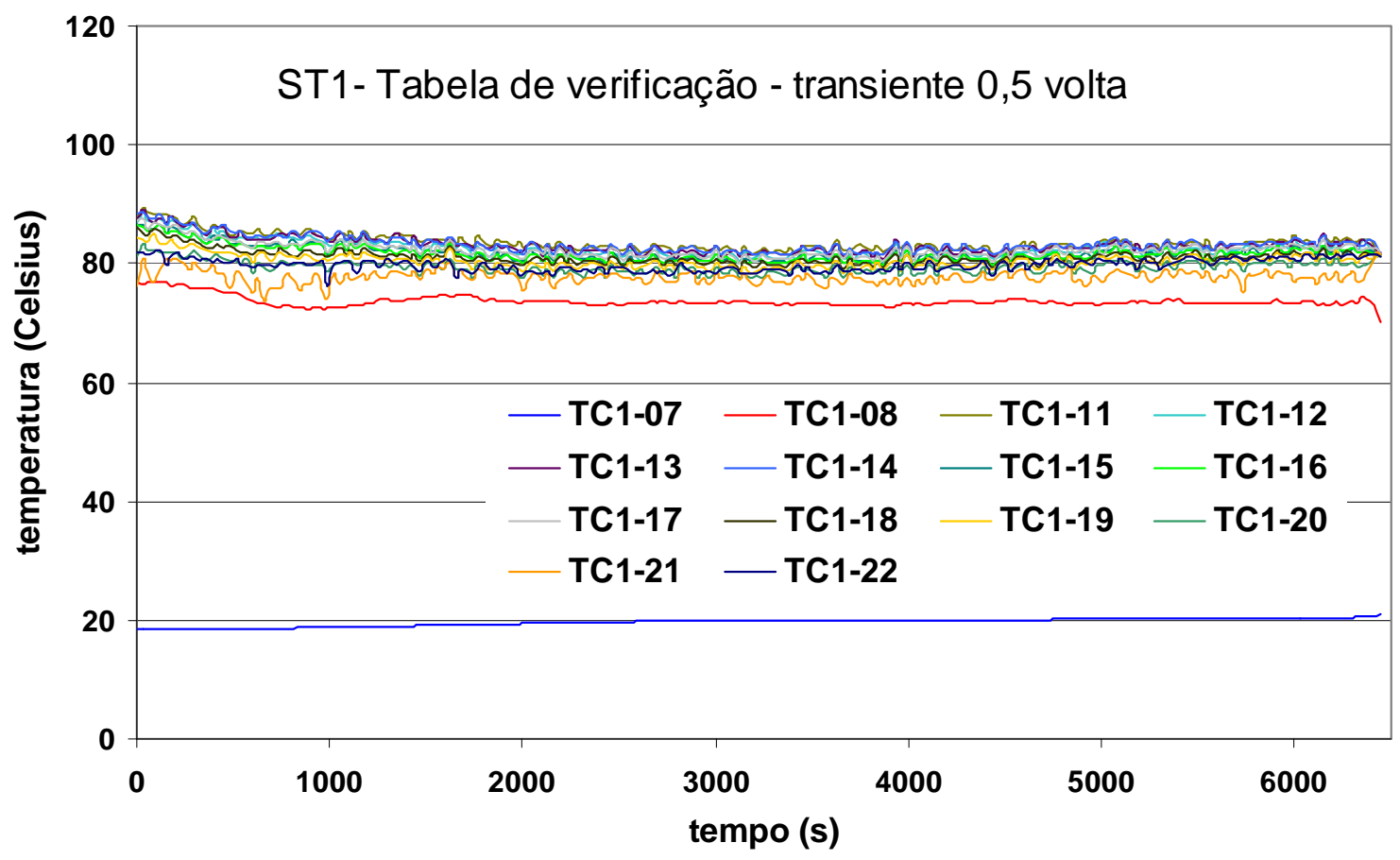

FIGURA 5.70. Temperatura versus tempo - 0,5 volta - tabela de verificação. 


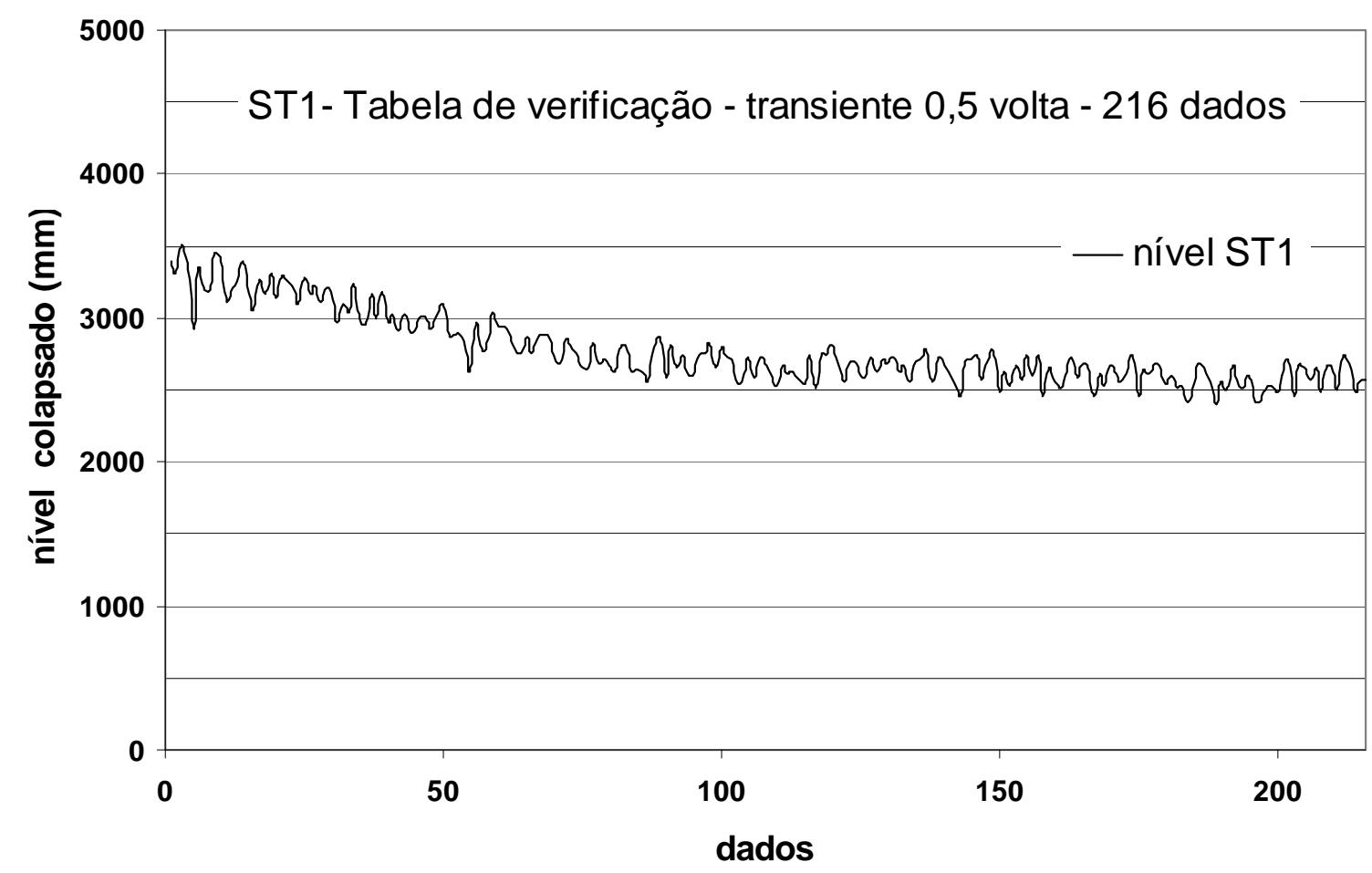

FIGURA 5.71. Nível em ST1 - Dados da tabela de verificação.

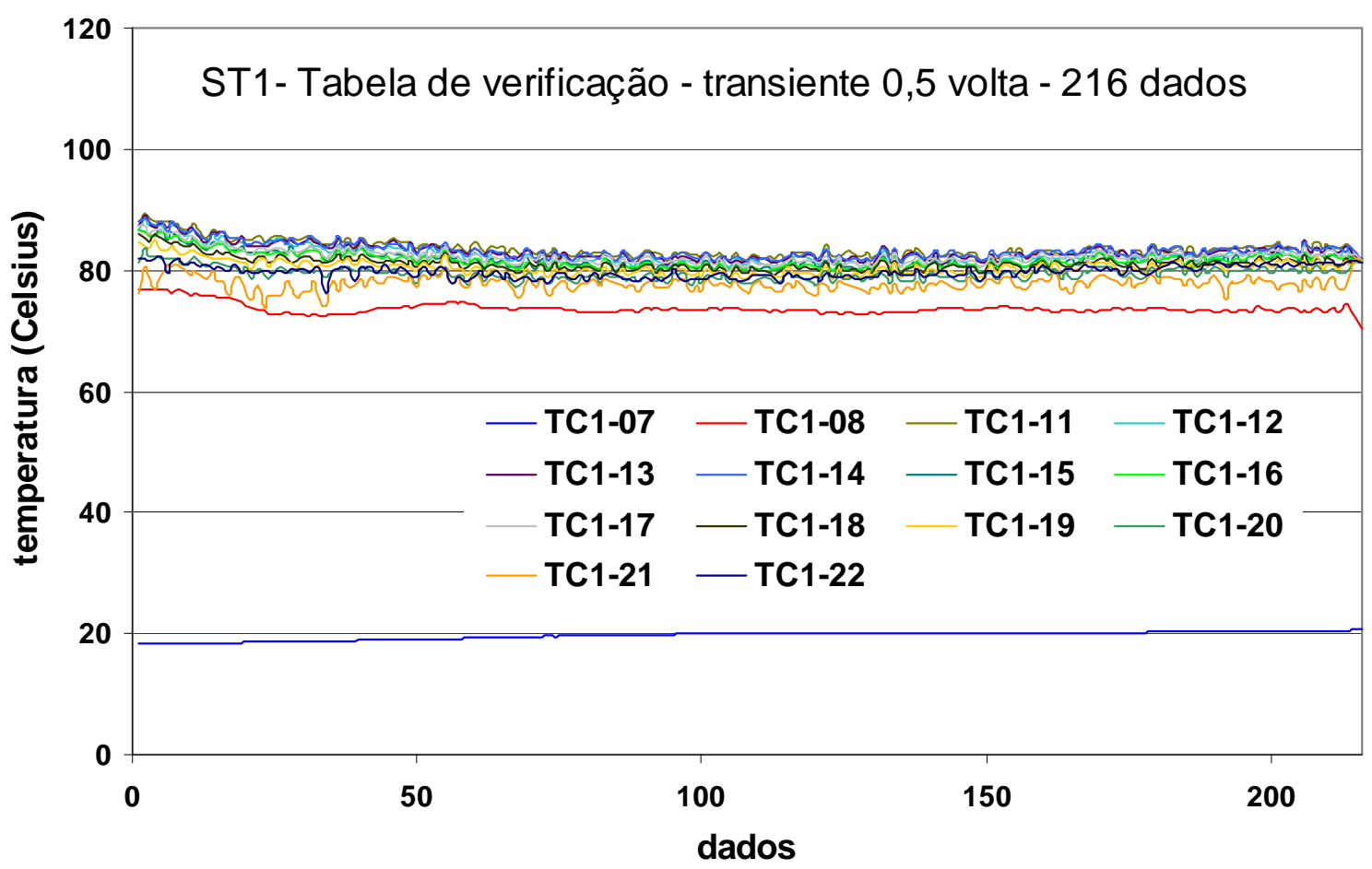

FIGURA 5.72. Temperaturas na sonda de tubos concêntricos - Dados de verificação. 


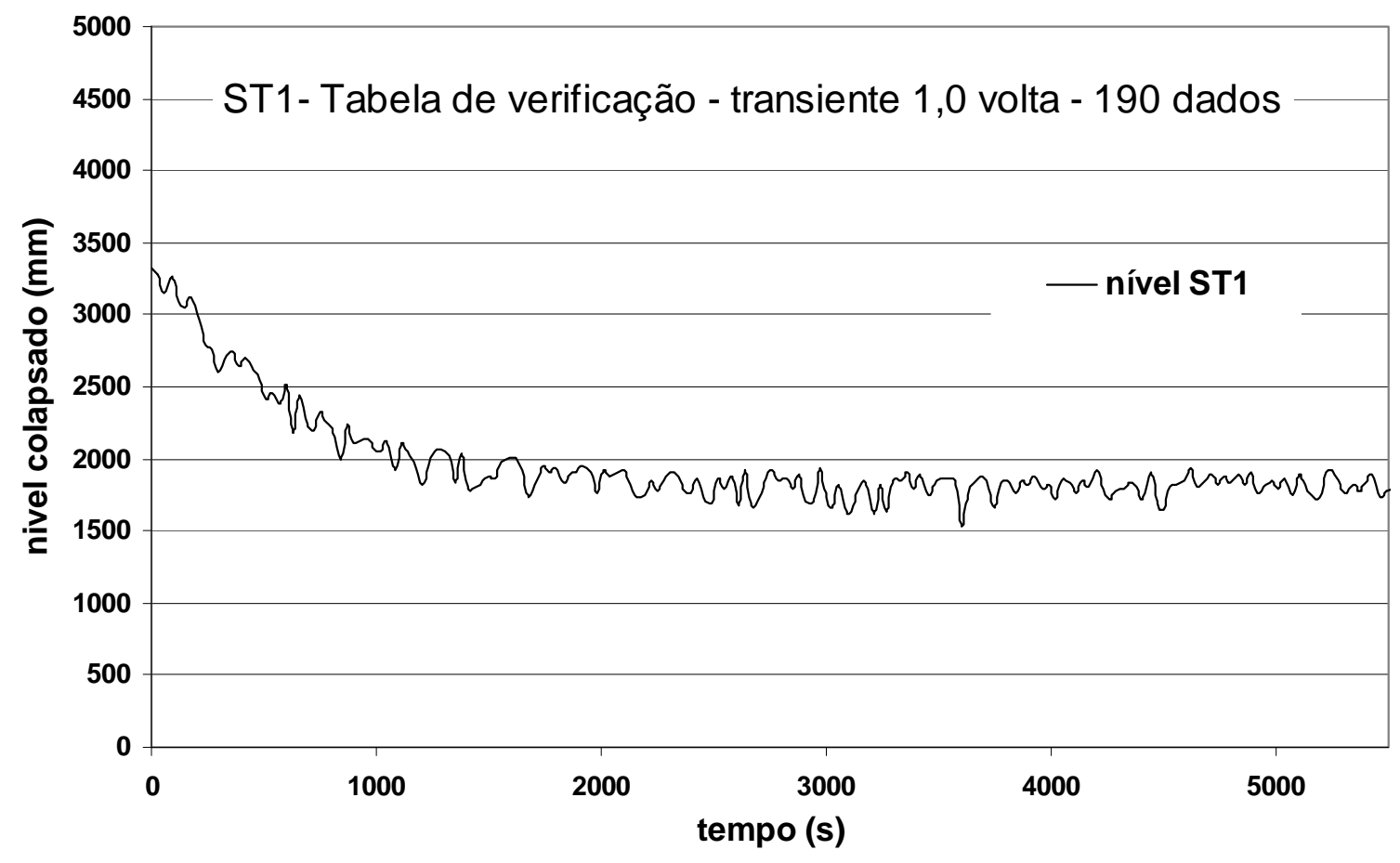

FIGURA 5.73. Nível em ST1 versus tempo - 1,0 volta - tabela de verificação.

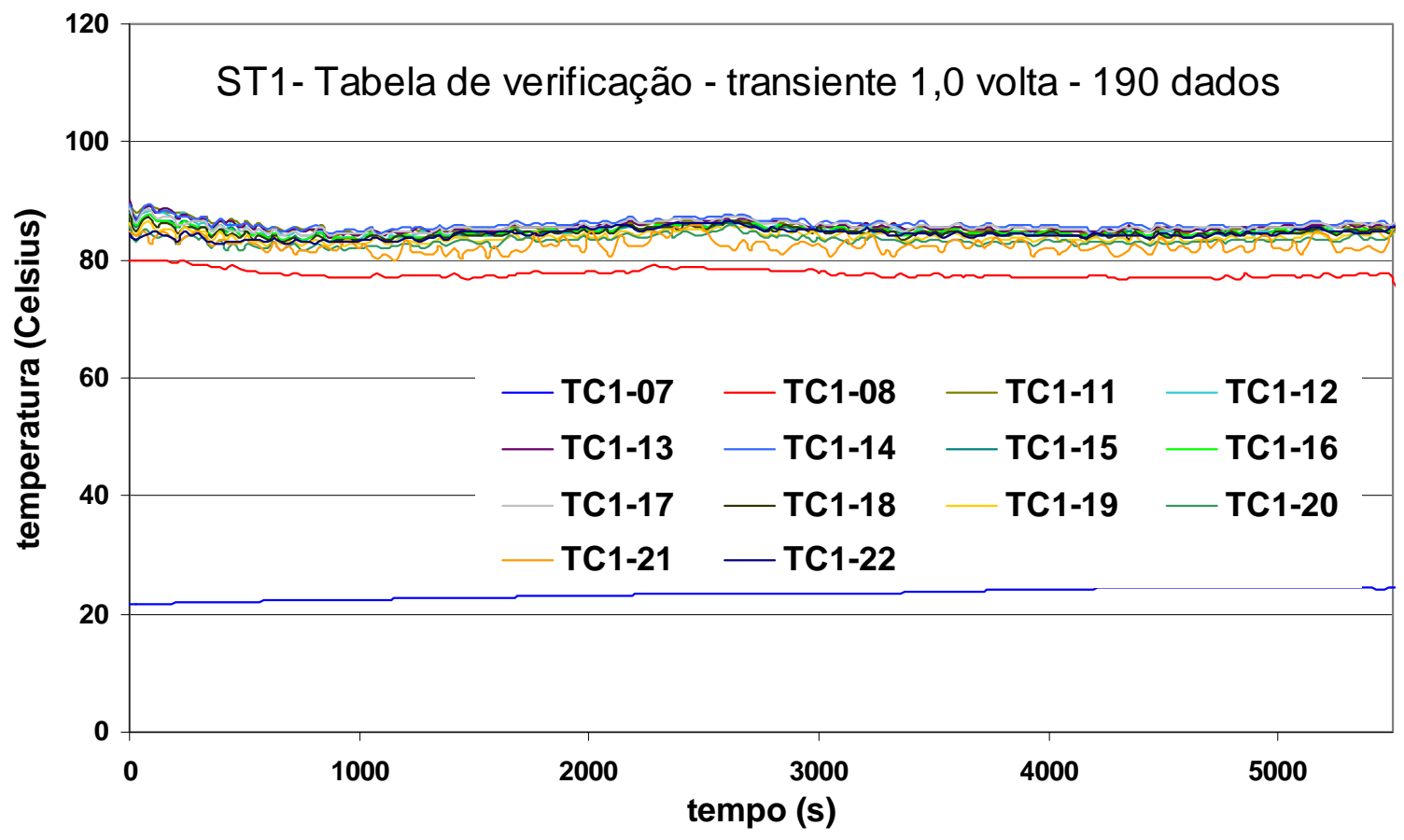

FIGURA 5.74. Temperatura versus tempo - 1,0 volta - tabela de verificação. 


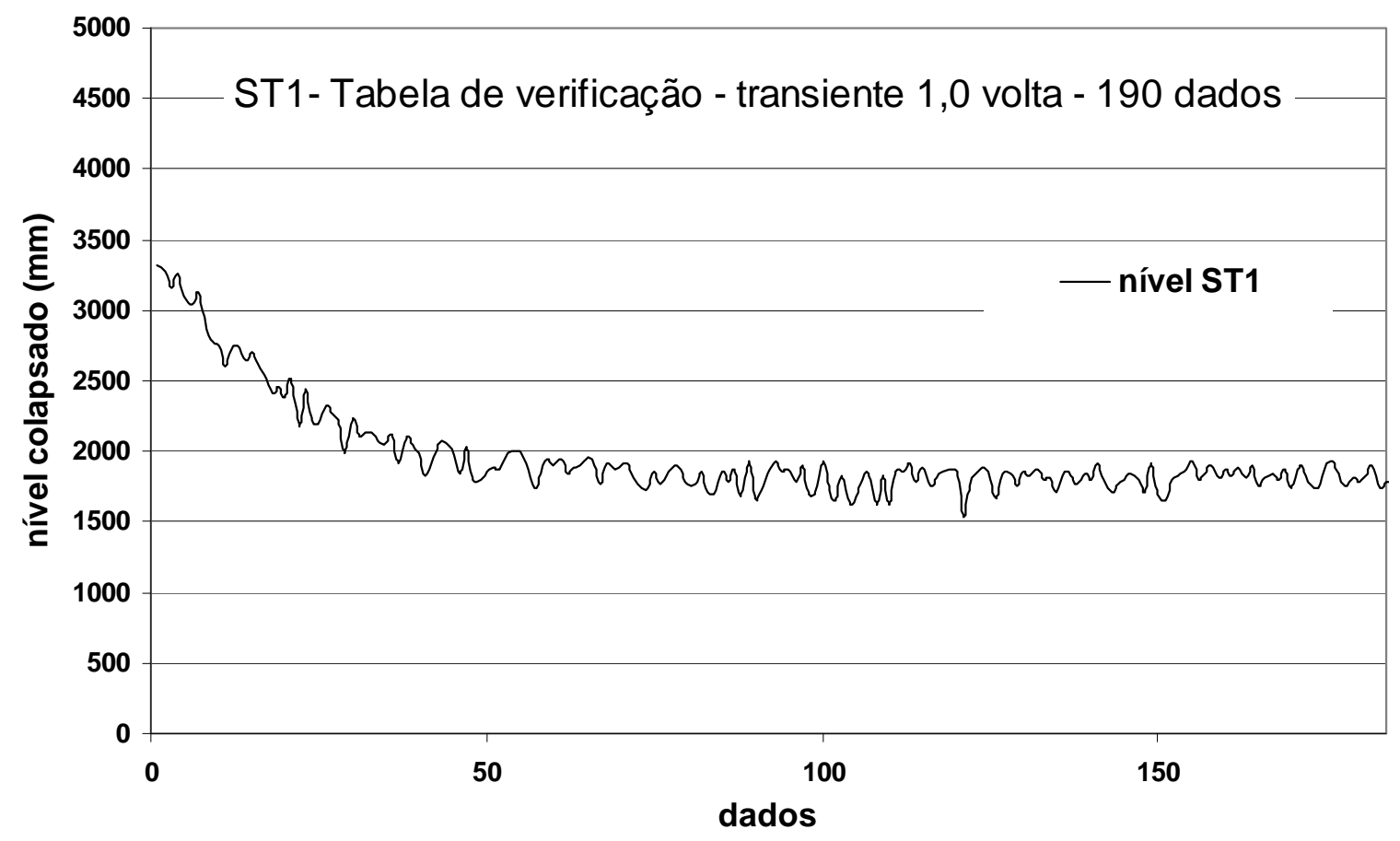

FIGURA 5.75. Nível em ST1 - Dados da tabela de verificação.

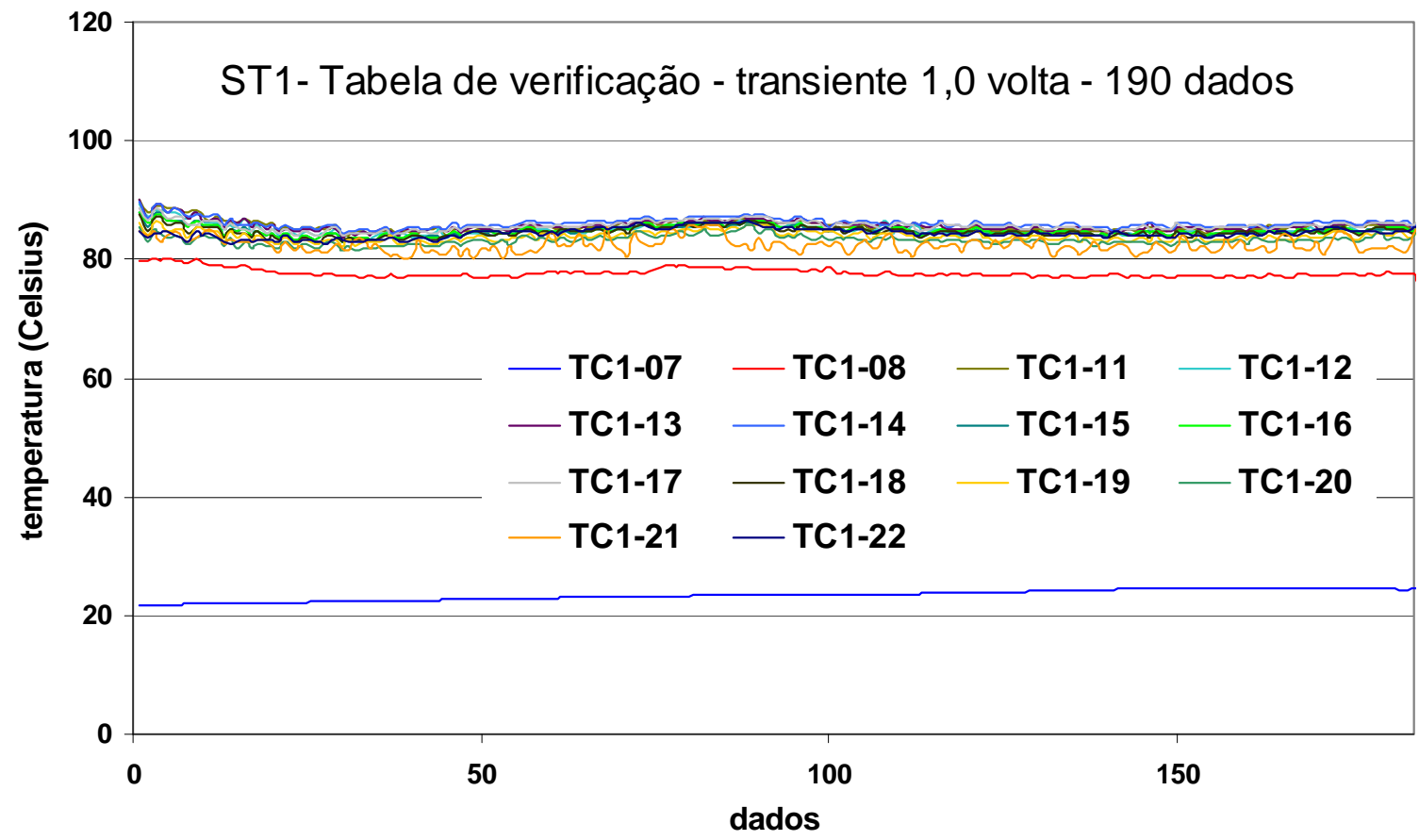

FIGURA 5.76. Temperaturas na sonda de tubos concêntricos - Dados da tabela de verificação. 


\subsection{Análise dos dados com RNA's}

\subsubsection{Análise dos dados para a Sonda de Tubo U na ST2}

Os dados de temperatura e nível referentes às condições de estado estacionário para níveis entre 2200 e $3200 \mathrm{~mm}$ para a sonda tipo tubo U são mostrados nas FIG. 5.38 e 5.39. Esses dados foram utilizados para treinamento de redes neurais artificiais com o programa RETRO-05. Os dados de temperatura foram usados como dados de entrada (14 entradas conhecidas) e os dados de nível foram usados como saída (1 saída desejada) formando um conjunto geral com 617 dados. Com esse conjunto geral de dados foi feito um estudo paramétrico para selecionar as características mais adequadas para a RNA.

A primeira configuração estudada foi uma RNA com duas camadas, com 14 neurônios na primeira camada e 1 neurônio na camada de saída (14x1). Essa rede foi treinada com o programa RETRO-05 com os parâmetros de rede mostrados na FIG. 5.78 para um total de 5000 épocas. Os resultados comparando os valores de nível calculado e nível medido e as linhas de desvio de $+5 \%$ e $-5 \%$ são mostrados na FIG. 5.77. Observa-se que RNA treinada não conseguiu realizar as interpolações com os padrões fornecidos. Na FIG. 5.78 é mostrado o gráfico da energia do conjunto de treinamento versus o número de épocas de treinamento. Ao final de 5000 épocas de treinamento a energia atingiu um valor elevado de 5,956.

Prosseguindo com o estudo paramétrico, aumentou-se o número de camadas da rede para três, com 14 neurônios na primeira camada, 14 na segunda camada e 1 na camada de saída (14×14×1). Essa RNA também foi treinada por 5000 épocas e com os mesmos parâmetros do caso anterior. Os resultados são apresentados nas FIG. 5.79 e 5.80, onde é possível observar uma melhora nos resultados, com os valores calculados se aproximando dos valores de nível medido. Neste caso, a energia após o treinamento de 5000 épocas ficou em torno de 4,280, valor ainda considerado muito elevado. 
Em outra análise, uma RNA com 4 camadas $(14 \times 14 \times 14 \times 1)$ foi treinada por 5000 épocas e os resultados podem ser vistos nas FIG. 5.81 e 5.82. Neste caso, observa-se uma sensível melhora nos resultados do treinamento, indicando que as RNA's com um número maior de camadas conseguem melhorar as interpolações produzindo melhores resultados. O programa RETRO-05 permite análises com RNA's com o máximo de 4 camadas. A energia do conjunto de treinamento após 5000 épocas de treinamento foi 1,487 .

A RNA com 4 camadas $(14 \times 14 \times 14 \times 1)$ foi novamente treinada por 10000 épocas para avaliar o efeito do número de épocas de treinamento nos resultados. Os resultados são apresentados nas FIG. 5.83 e 5.84, mostrando que um maior número de pontos experimentais ficou dentro da faixa de $+5 \%$ e $-5 \%$, quando comparado com o treinamento para 5000 épocas. Essa análise mostrou que treinamentos mais longos produzem melhores resultados.

Uma RNA com 4 camadas $(7 \times 7 \times 7 \times 1)$ também foi treinada por 10000 épocas com o objetivo de verificar o efeito da quantidade de neurônios nas camadas. Os resultados após o treinamento são apresentados na FIG. 5.85 e mostram que a redução do número de neurônios por camada provocou uma piora nos resultados.

Indo na outra direção, ou seja, de aumento do número de neurônios por camada, treinou-se uma RNA com 4 camadas $(20 \times 20 \times 20 \times 1)$ e 10000 épocas. Os resultados após o treinamento são apresentados na FIG. 5.86 e confirmam que RNA's com maior número de neurônios produzem melhores resultados para iguais números de épocas de treinamento.

Outra RNA com 3 camadas $(20 \times 20 \times 1)$ foi treinada por 20000 épocas e os resultados podem ser vistos na FIG. 5.87. Comparando-se os resultados das FIG.

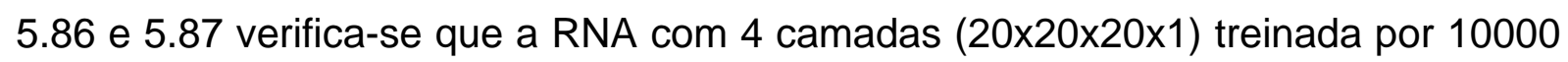
épocas produziu melhores resultados que a RNA com 3 camadas $(20 \times 20 \times 1)$ treinada 
por 20000 épocas. Conclui-se que a diminuição de uma camada na RNA não é compensada por um aumento no número de épocas de treinamento da rede.

A RNA de 4 camadas $(20 \times 20 \times 20 \times 1)$ também foi treinada por 10000 épocas, mas neste caso, usando apenas 8 entradas de temperatura, ou seja, TC207 (temperatura de entrada do fluido de resfriamento), TC2-08 (temperatura de saída do fluido de resfriamento), TC2-11, TC2-13, TC2-15, TC2-17, TC2-19 e TC2-21. Os resultados podem ser vistos na FIG. 5.88, e mostram que a sonda de tubo $U$ pode operar com um número menor de termopares (menor dificuldade de fabricação e montagem) e conseqüentemente com maiores distâncias de separação entre eles.

Uma RNA de 4 camadas $(14 \times 14 \times 14 \times 1)$ foi treinada por 10000 épocas, tendo como entradas apenas as temperaturas de entrada (TC2-07) e de saída (TC208) do fluido de resfriamento. Os resultados podem ser vistos na FIG. 5.89, e mostram que a RNA com apenas essas duas entradas foi incapaz de realizar as interpolações, evidenciando a necessidade e a importância das demais informações contidas nas temperaturas de parede da sonda.

Os dados do conjunto geral (617 dados) utilizados nas análises até aqui foram separados para constituir nova tabela de treinamento (555 dados; 90\%) e tabela de verificação (62 dados; 10\%). A separação foi feita obedecendo a uma seqüência de 9 dados para o treinamento e 1 dado para a verificação.

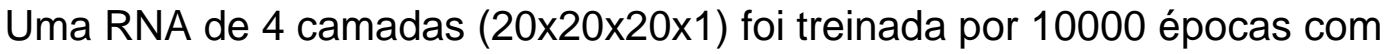
estas tabelas. Os resultados podem ser vistos nas FIG. 5.90 e 5.91, onde é possível observar uma boa concordância para os resultados referentes à tabela de treinamento. Com relação à tabela de verificação, observa-se que aproximadamente $50 \%$ dos pontos se encontram dentro da faixa de $+5 \%$ e $-5 \%$. O treinamento com essa RNA foi feito sem sortear exemplos da tabela de treinamento no programa RETRO-05. Essa mesma RNA foi novamente treinada com as mesmas características e pelo mesmo número de épocas, porém agora sorteando exemplos 
da tabela de treinamento. Os resultados são apresentados nas FIG. 5.92 e 5.93 . Observa-se uma sensível melhora nos resultados, principalmente os resultados referentes à tabela de treinamento onde $100 \%$ dos pontos ficaram dentro da faixa de $+5 \%$ e $-5 \%$. Os resultados melhoraram também para a tabela de verificação, onde $63 \%$ dos pontos ficaram dentro da faixa de $+5 \%$ e $-5 \%$. Diante desta sensível melhora observada nos resultados, as análises com as RNA's passaram a ser feitas sorteando exemplos da tabela de treinamento.

Para verificar o efeito da quantidade de dados nos resultados, tanto da tabela de treinamento quanto da tabela de verificação, os dados foram separados na proporção de $80 \%$ para a tabela de treinamento (495 dados) e $20 \%$ para a tabela de verificação (122 dados). Neste caso, os dados também foram separados obedecendo a uma seqüência de 4 dados para o treinamento e 1 dado para a verificação.

Uma RNA de 4 camadas $(20 \times 20 \times 20 \times 1)$ foi treinada por 10000 épocas com essas novas tabelas e os resultados podem ser vistos nas FIG. 5.94 e 5.95. Cerca de $67 \%$ dos pontos referentes à tabela de verificação ficaram dentro da faixa de $+5 \%$ e $-5 \%$, portanto muito próximo dos resultados obtidos para o caso anterior com a proporção de $90 \%$ e $10 \%$ respectivamente para a tabela de treinamento e de verificação.

Para fins de comparação, são mostrados nas FIG. 5.96 e 5.97, os resultados para a RNA de 4 camadas $(20 \times 20 \times 20 \times 1)$, porém sem sortear exemplos da tabela de treinamento. Nas FIG. 5.98 e 5.99 são mostrados os resultados referentes a uma RNA de 4 camadas $(10 \times 10 \times 10 \times 1)$ sorteando exemplos. Observase que a análise com a opção sorteando exemplos produziu melhores resultados mesmo quando o número de neurônios por camada é menor (metade). 
As tabelas de treinamento (495 dados) e de verificação (122 dados) foram modificadas, removendo-se alternadamente dessas tabelas as informações referentes a 6 termopares que medem a temperatura de parede na sonda. As tabelas modificadas ficaram com 8 entradas (entradas ímpares) de temperatura (TC2-07, TC2-08, TC2-11, TC2-13, TC2-15, TC2-17, TC2-19 e TC2-21) e uma saída de nível.

A RNA de 4 camadas $(20 \times 20 \times 20 \times 1)$ foi treinada por 10000 épocas com essas tabelas modificadas (entradas ímpares) e os resultados são apresentados nas FIG. 5.100 e 5.101. Observa-se que os resultados foram bons, indicando que é possível bom resultado com um número menor de termopares de parede, como já concluído anteriormente.

A RNA de 4 camadas $(10 \times 10 \times 10 \times 1)$ foi treinada por 10000 épocas com essas tabelas modificadas (entradas ímpares) e os resultados são apresentados nas FIG. 5.104 e 5.105. Os resultados também foram bons .

As tabelas de treinamento (495 dados) e de verificação (122 dados) foram modificadas novamente, removendo-se alternadamente dessas tabelas as informações referentes a 6 termopares que medem a temperatura de parede na sonda. As tabelas modificadas ficaram com 8 entradas (entradas pares) de temperatura (TC2-07, TC2-08, TC2-12, TC2-14, TC2-16, TC2-18, TC2-20 e TC2-22) e uma saída de nível.

O mesmo treinamento foi realizado com a RNA de 4 camadas

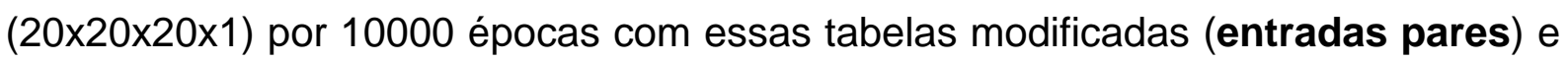
os resultados são apresentados nas FIG. 5.102 e 5.103. Como no caso anterior, os resultados foram bons e a conclusão é a mesma, ou seja, é possível bom resultado com um número menor de termopares de parede. 


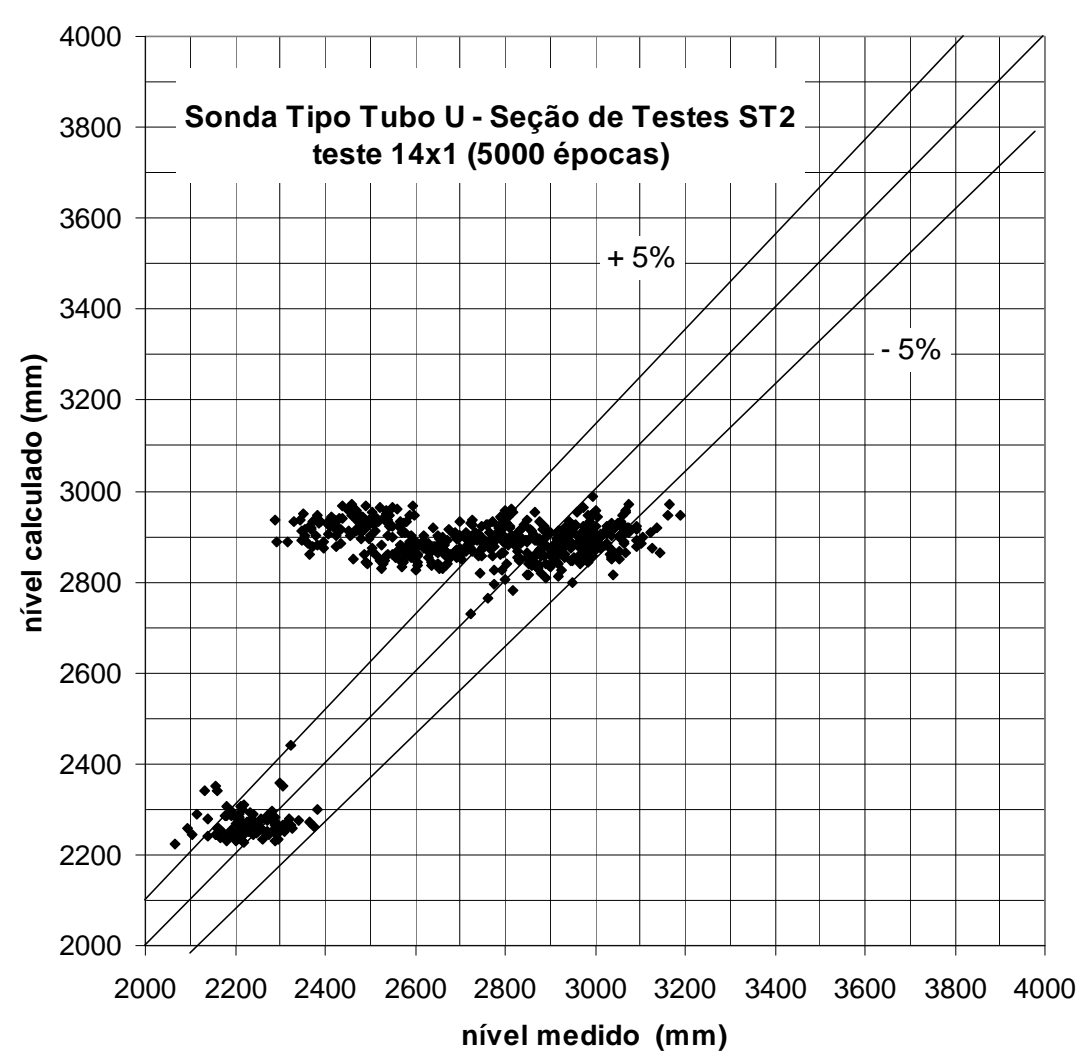

FIGURA 5.77. Análise com RNA 2 camadas (14×1) e 5000 épocas.

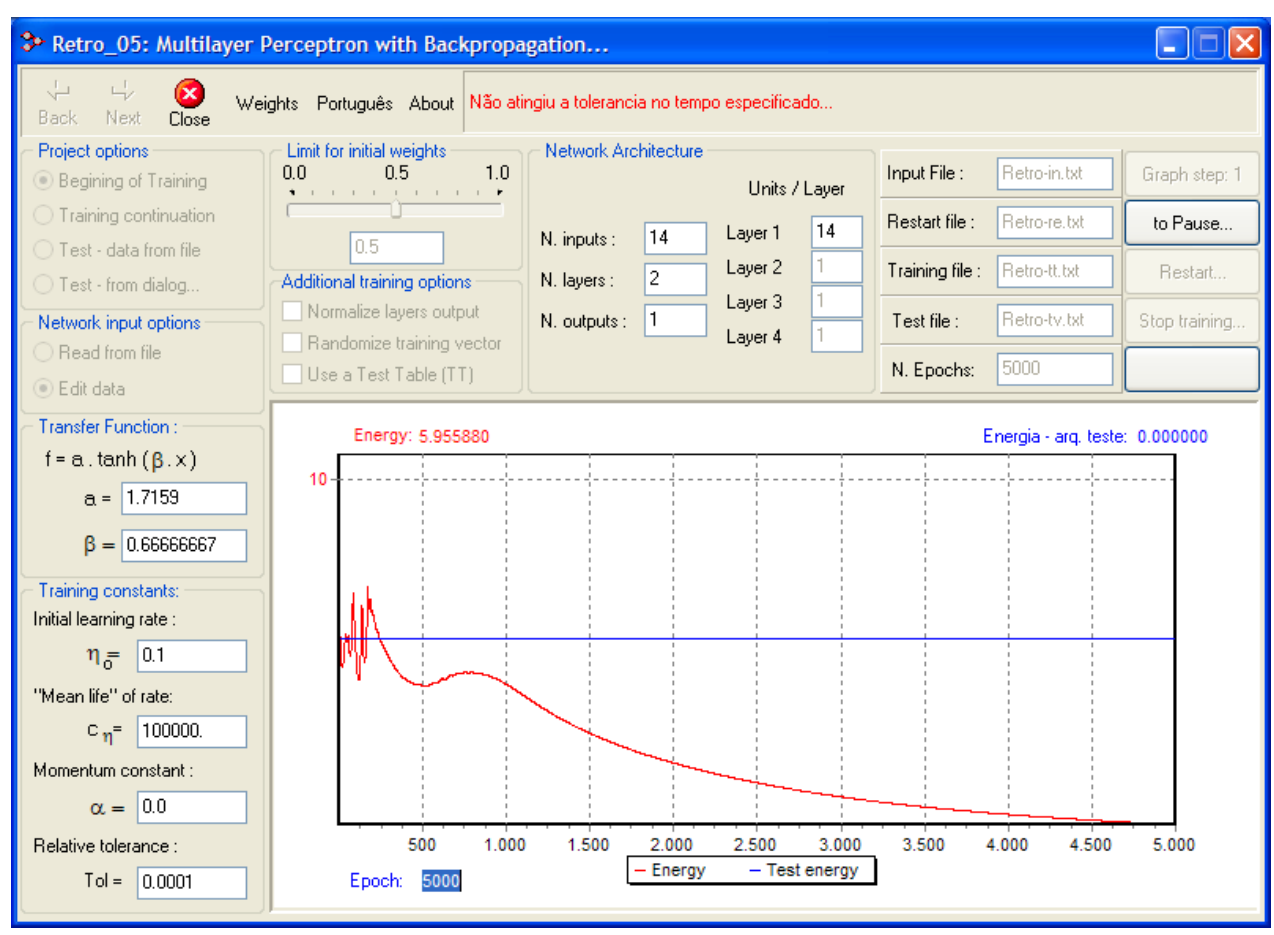

FIGURA 5.78. Energia da tabela de treinamento RNA (14x1) e 5000 épocas. 


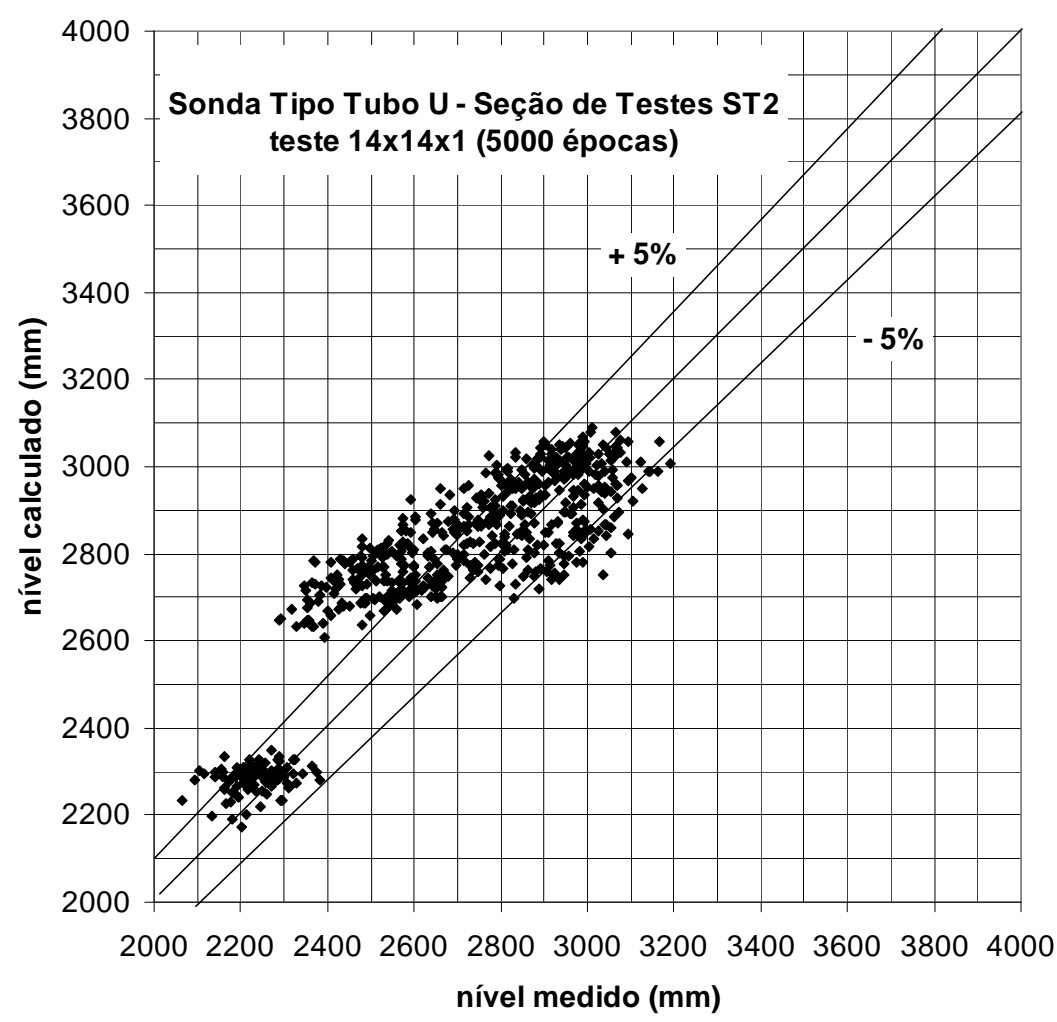

FIGURA 5.79. Análise com RNA 3 camadas (14×14x1) e 5000 épocas.

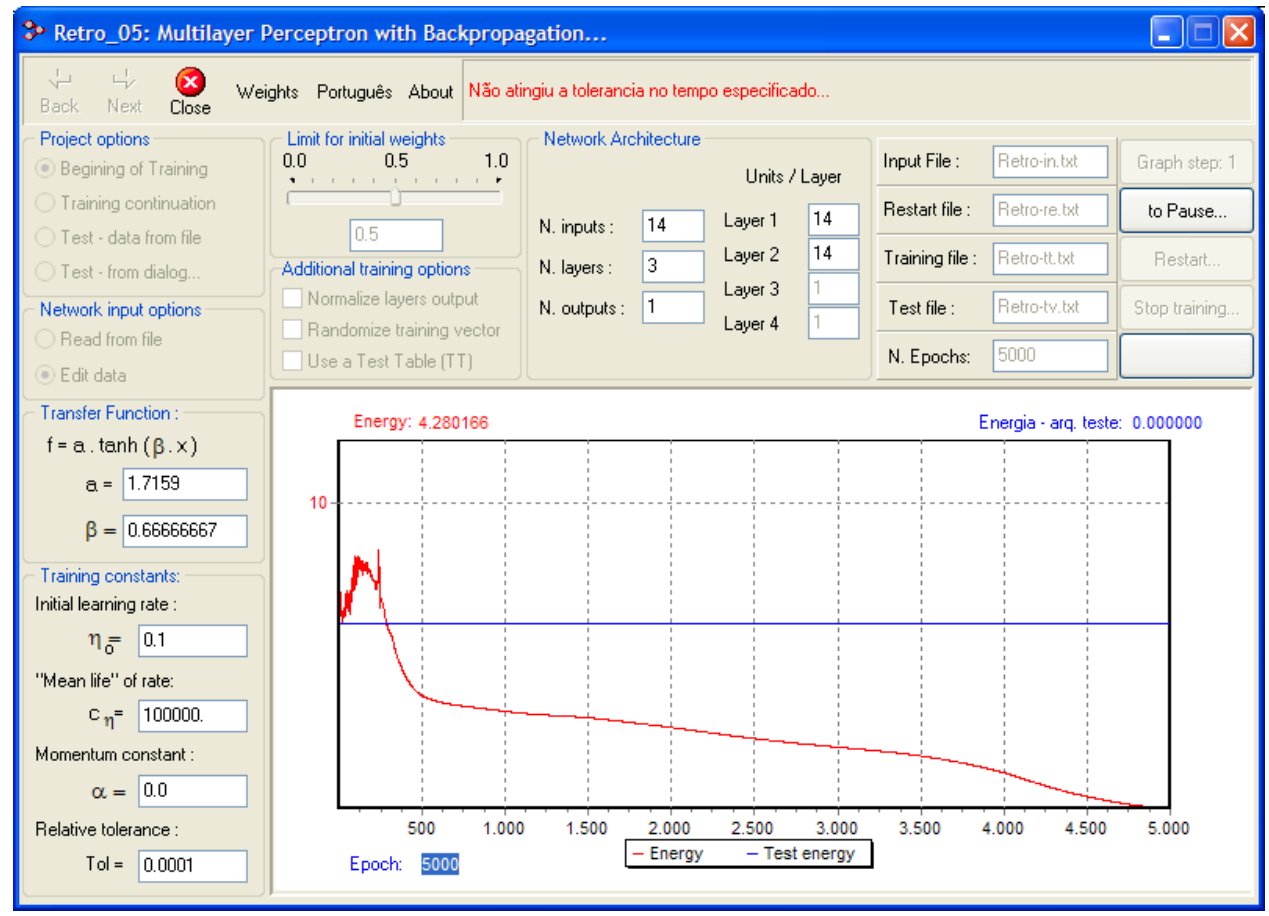

FIGURA 5.80. Energia da tabela de treinamento RNA (14×14x1) e 5000 épocas. 


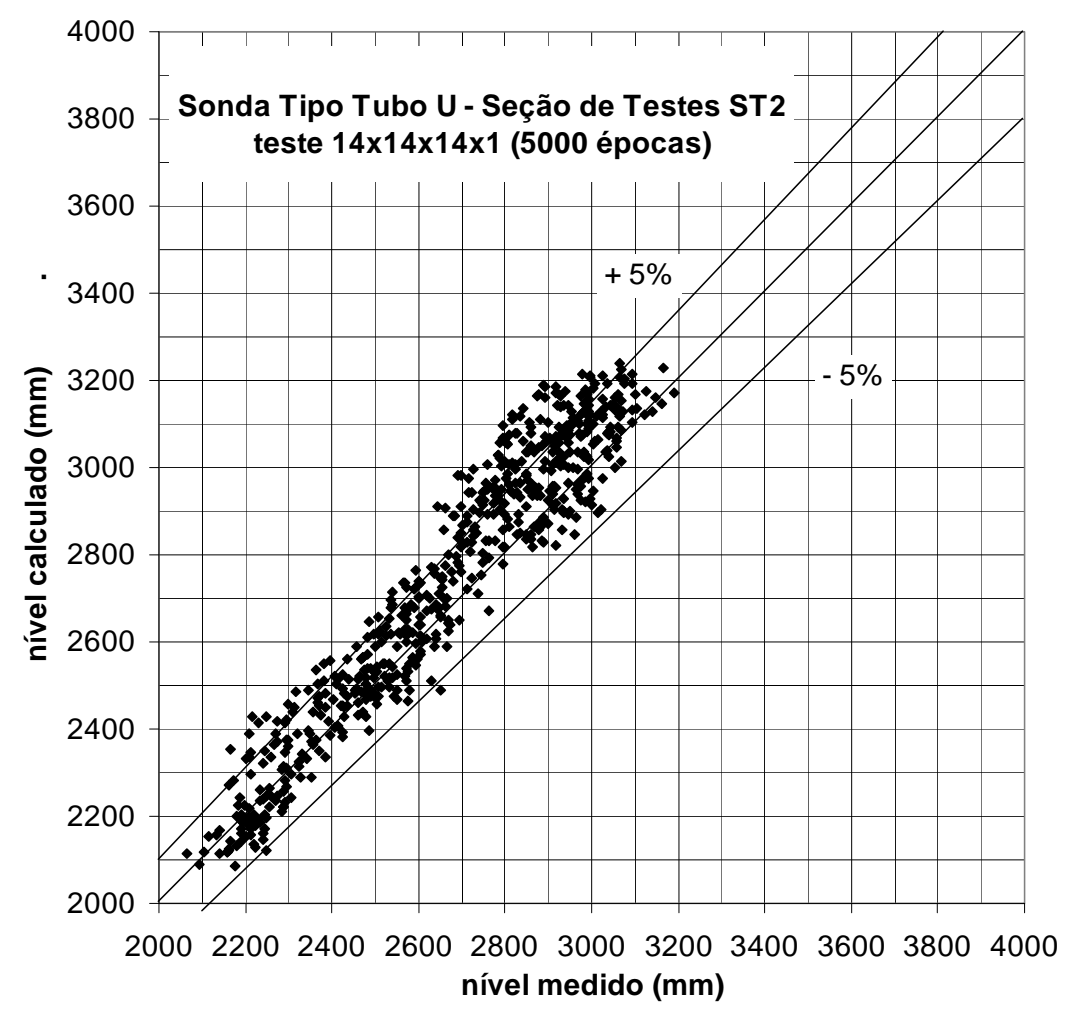

FIGURA 5.81. Análise com RNA 4 camadas (14×14x14x1) e 5000 épocas.

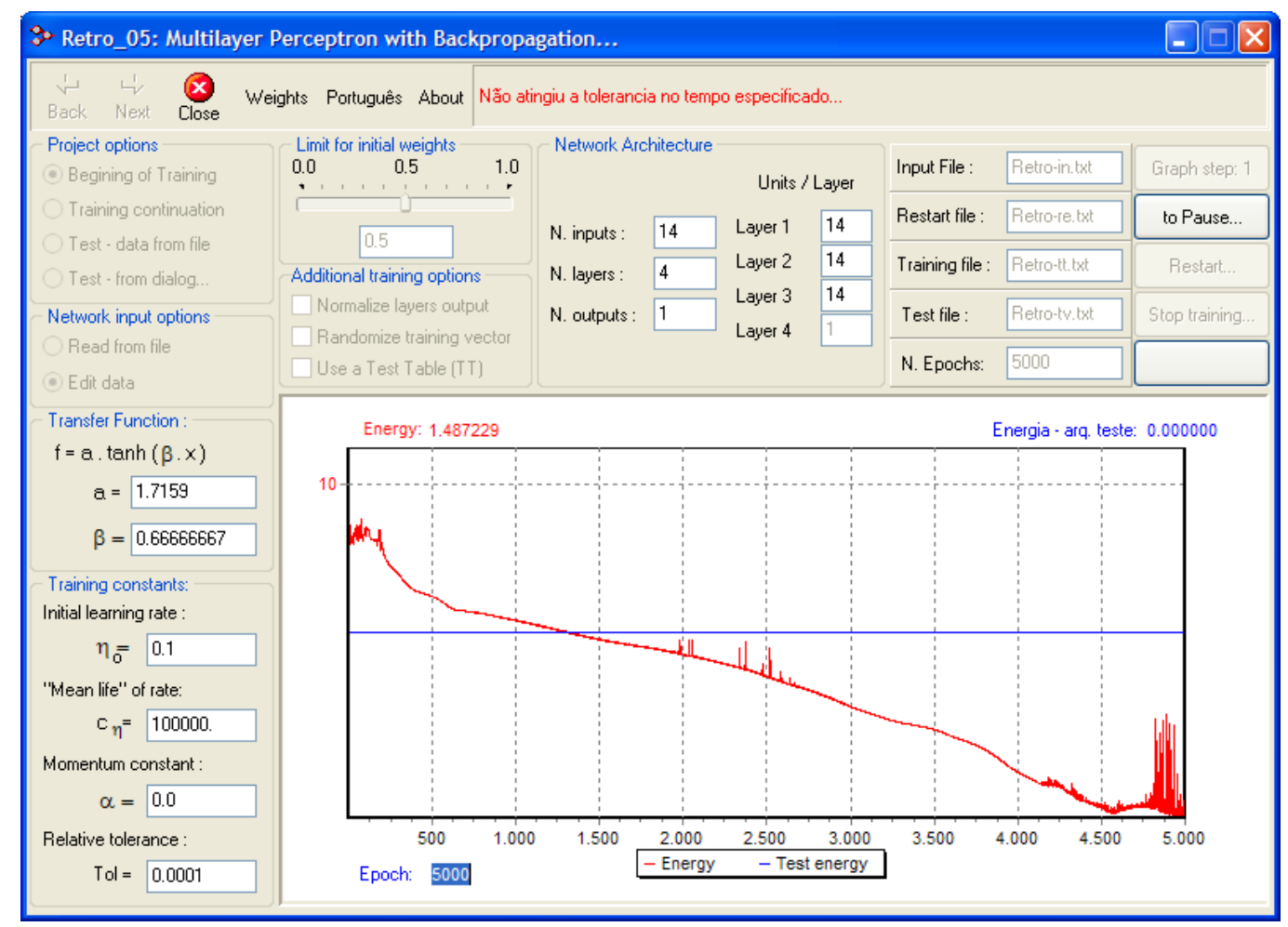

FIGURA 5.82. Energia da tabela de treinamento RNA $(14 \times 14 \times 14 \times 1)$ e 5000 épocas. 


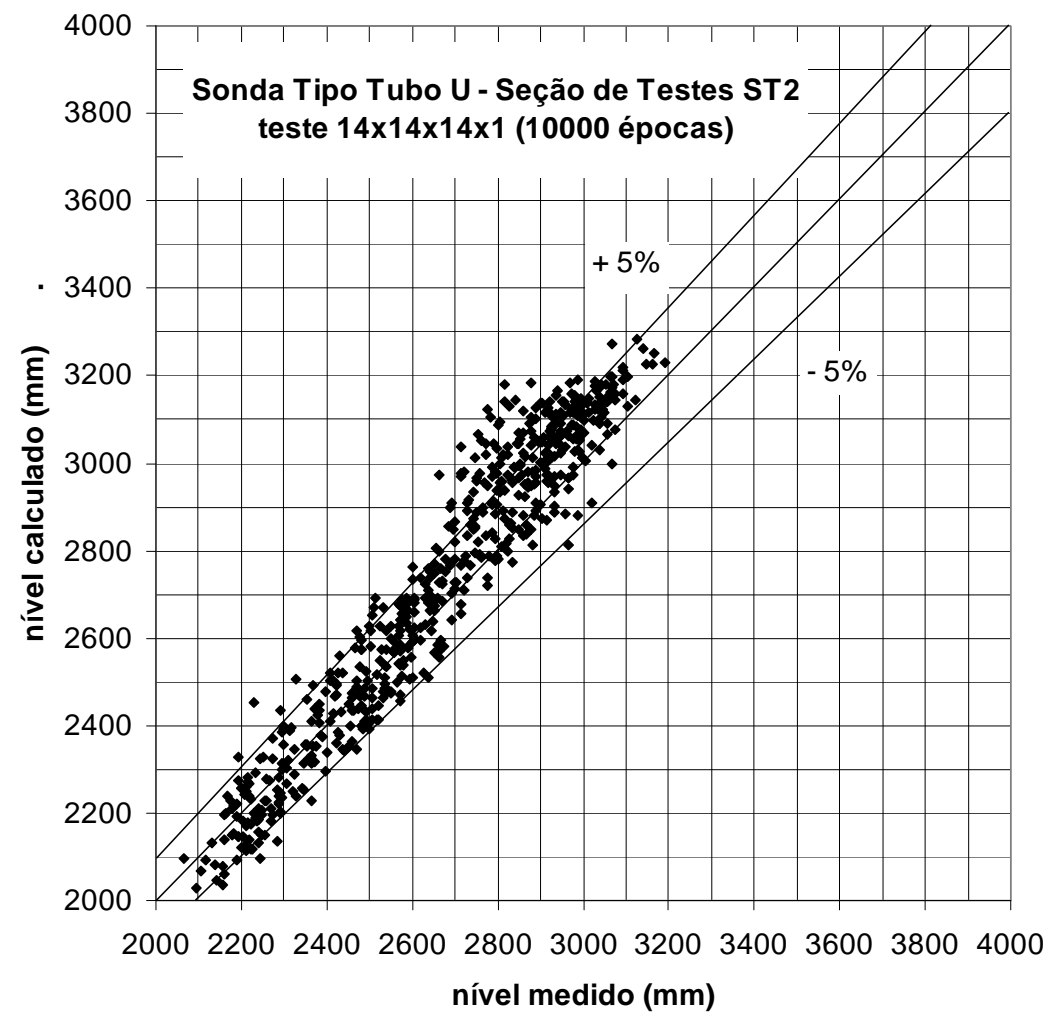

FIGURA 5.83. Análise com RNA 4 camadas (14×14×14×1) e 10000 épocas.

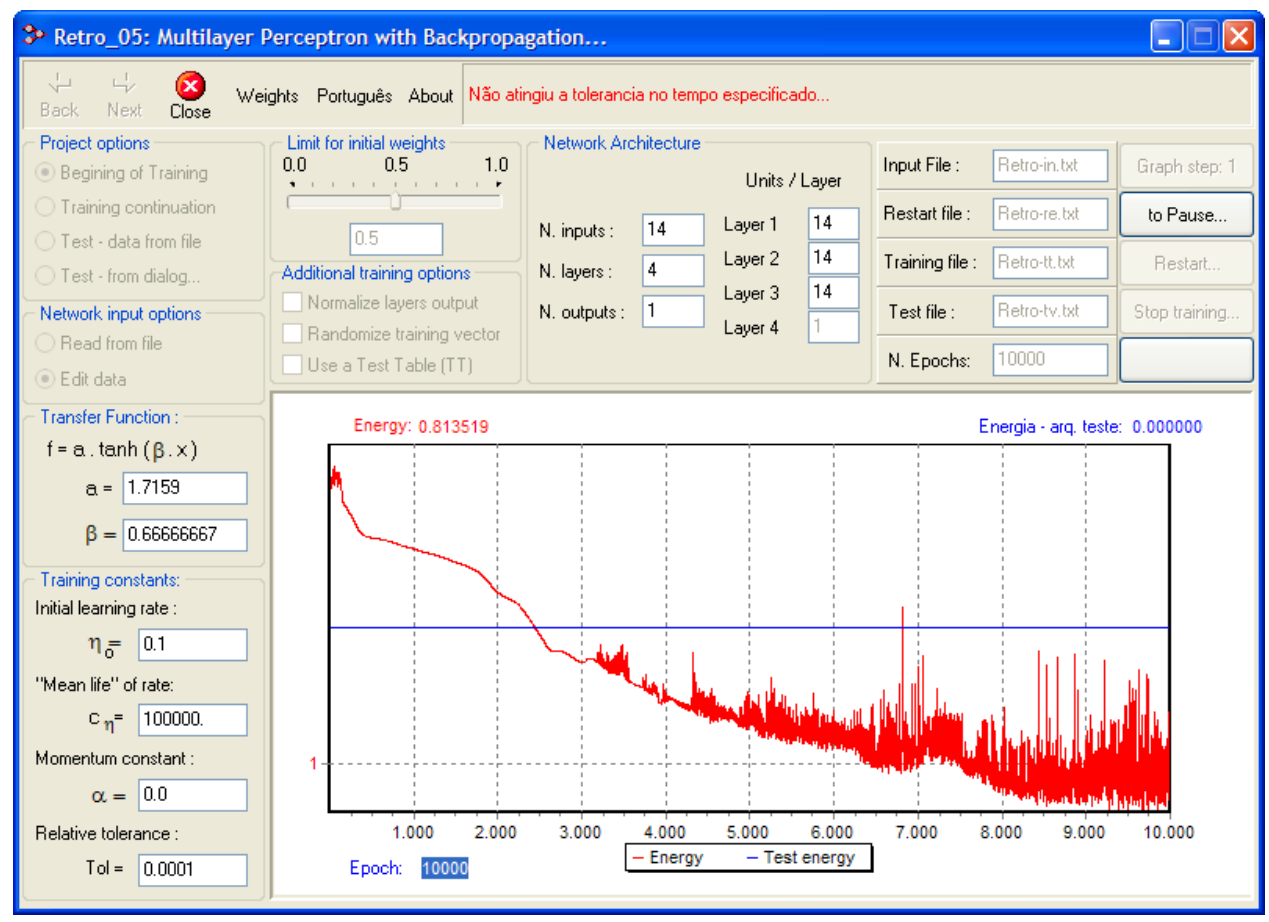

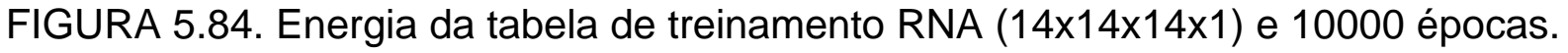




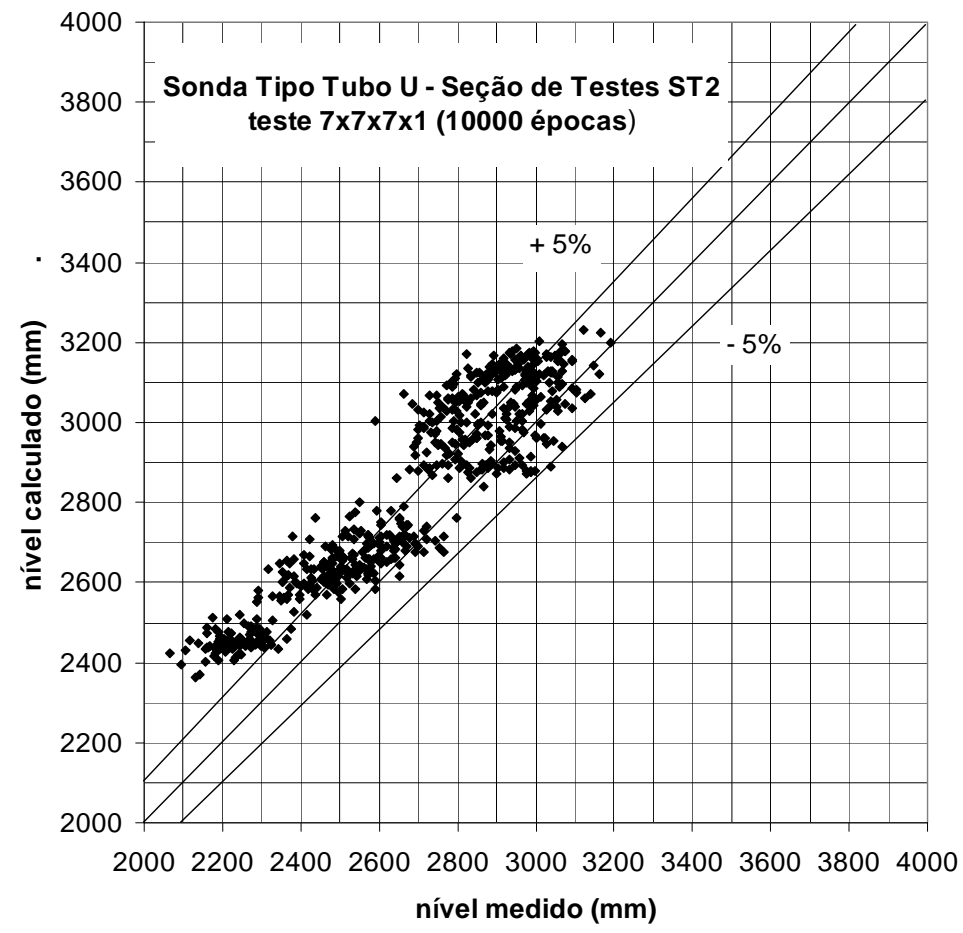

FIGURA 5.85. Análise com RNA 4 camadas (7×7x7×1) e 10000 épocas.

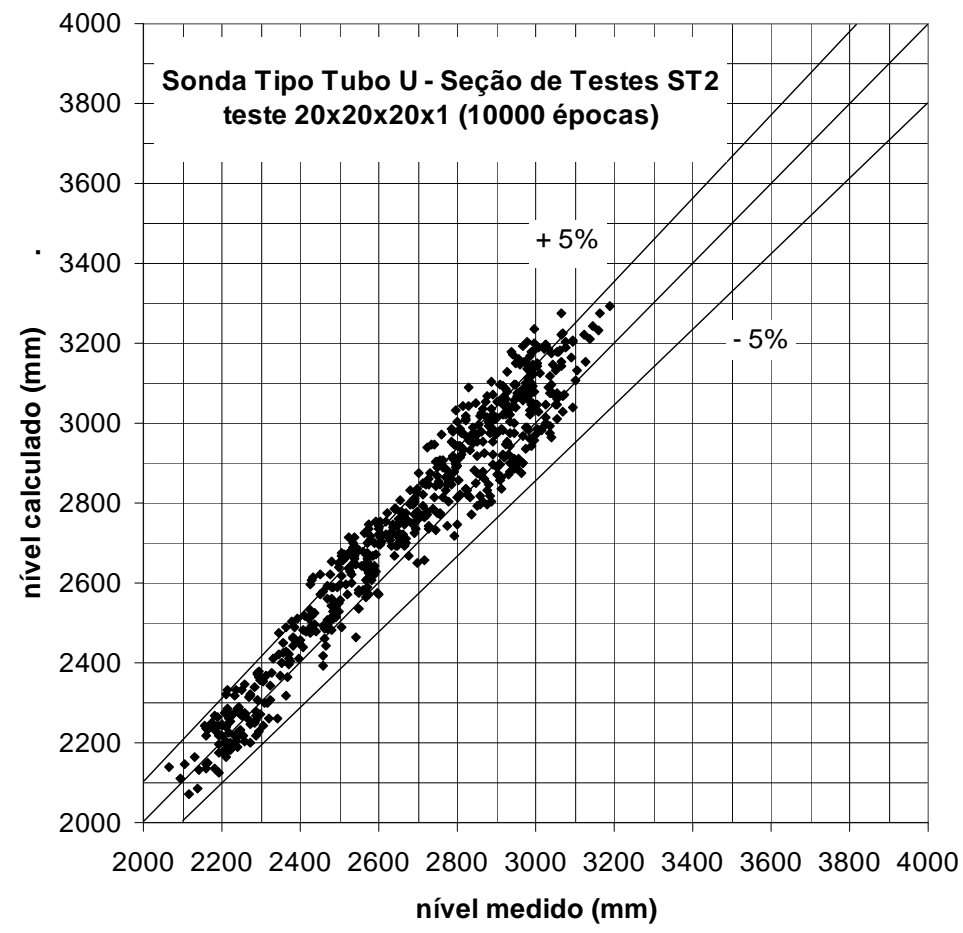

FIGURA 5.86. Teste RNA 4 camadas (20×20×20×1) e 10000 épocas. 


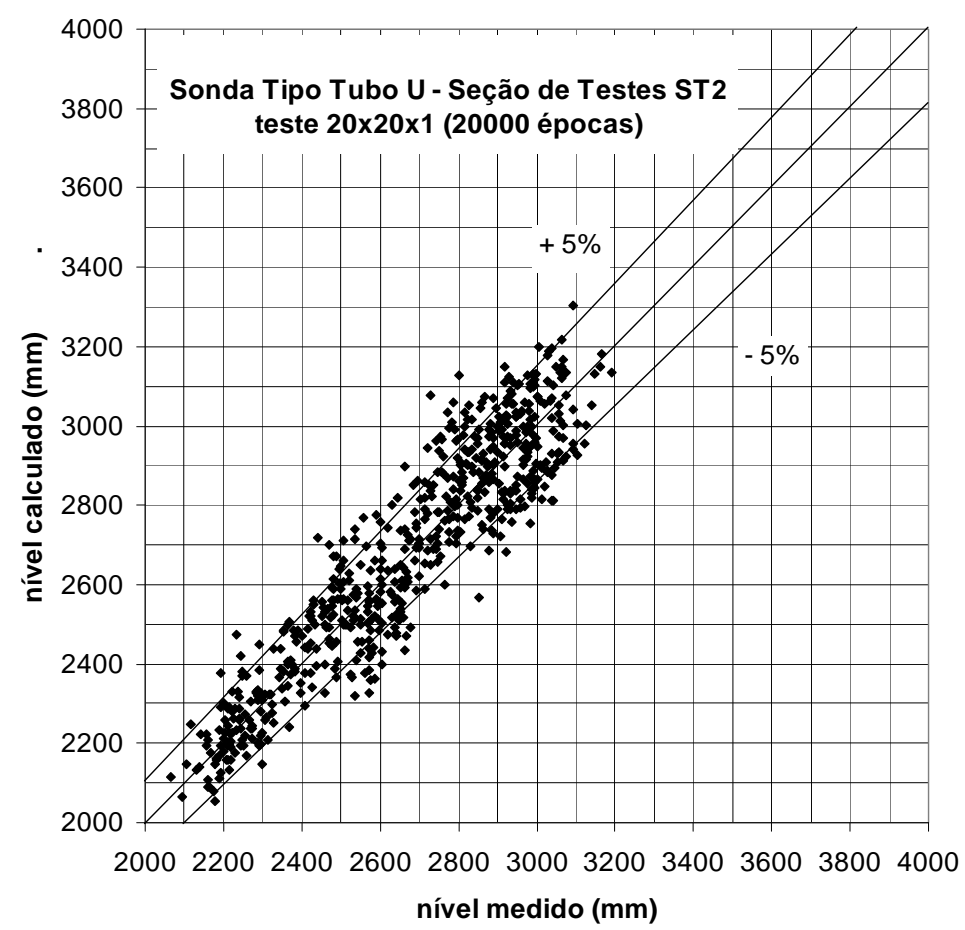

FIGURA 5.87. Análise com RNA 3 camadas (20×20×1) e 20000 épocas.

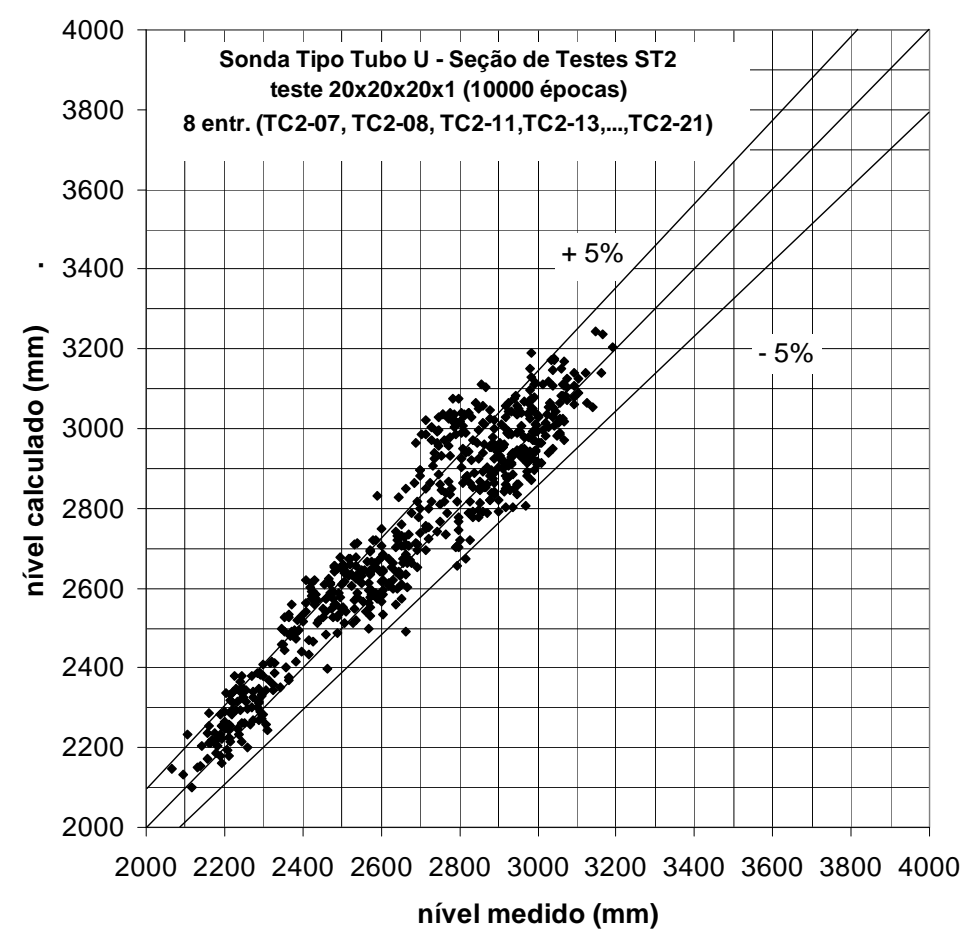

FIGURA 5.88. Análise com RNA 4 camadas $(20 \times 20 \times 20 \times 1)$ e 10000 épocas e 8 entradas: TC2-07, TC2-08, TC2-11, TC2-13, TC2-15, TC2-17, TC2-19 e TC2-21. 


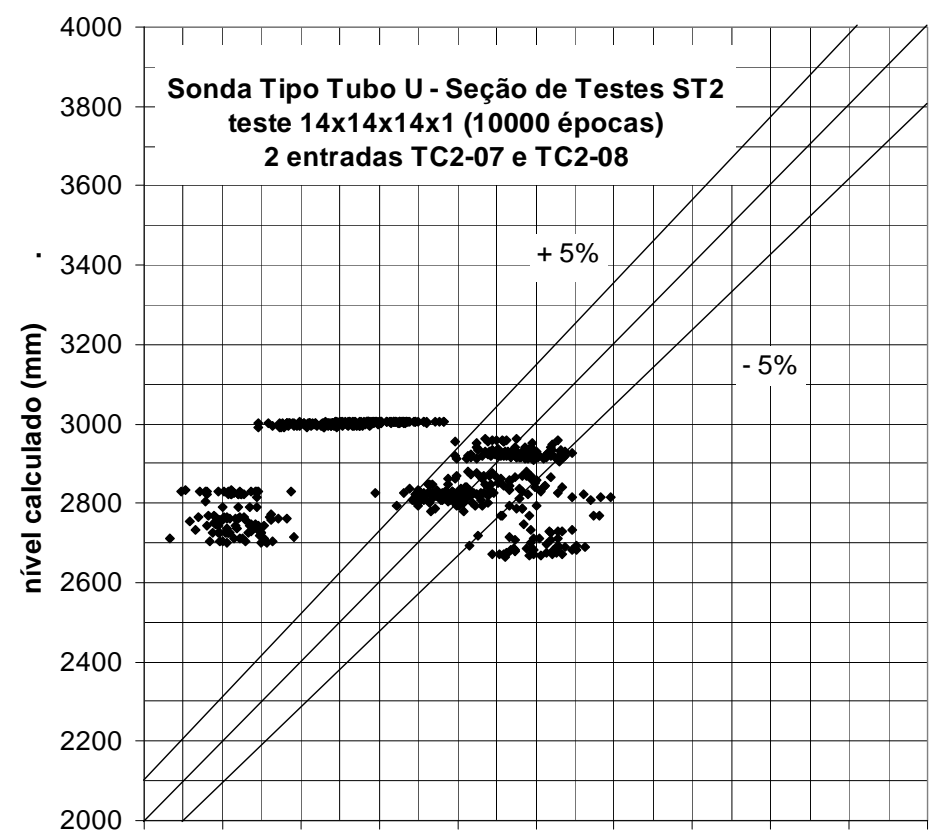

20002200240026002800300032003400360038004000 nível medido $(\mathrm{mm})$

FIGURA 5.89. Análise com RNA 4 camadas $(14 \times 14 \times 14 \times 1)$ e 10000 épocas e 2 entradas: TC2-07 e TC2-08. 


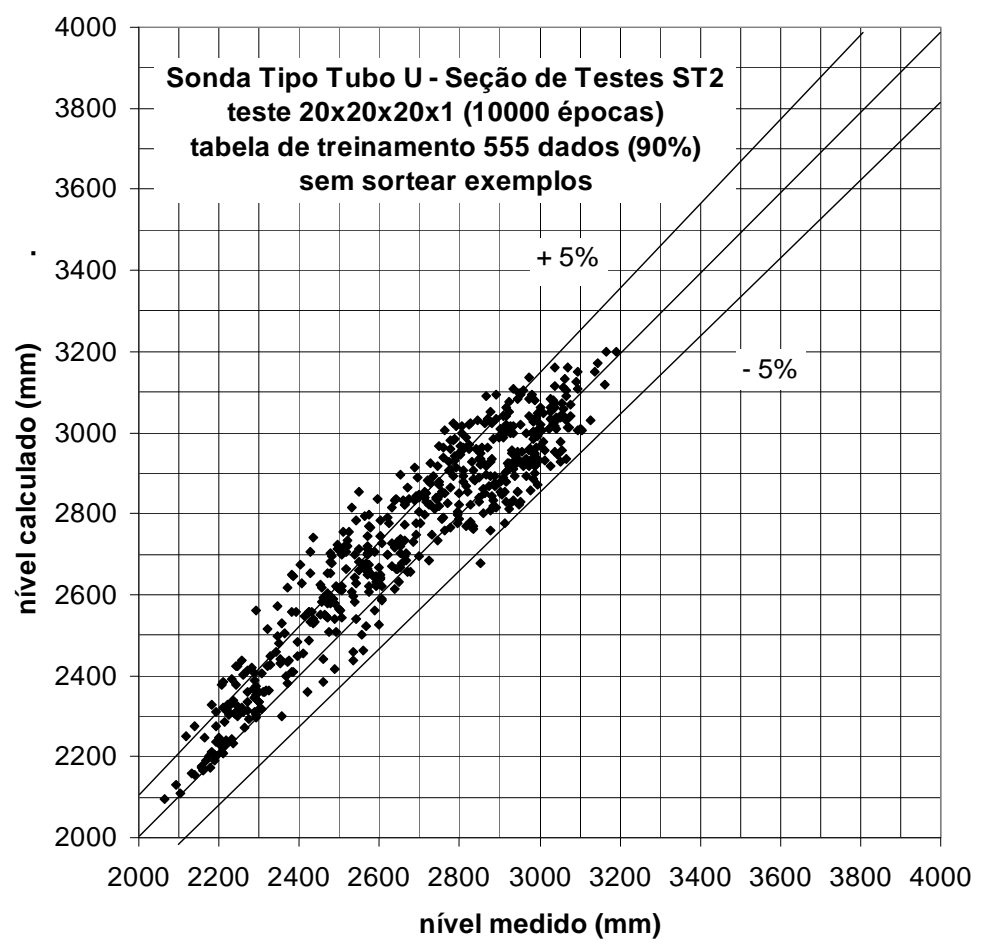

FIGURA 5.90. Análise com RNA 4 camadas (20×20×20×1) e 10000 épocas - tabela de treinamento.

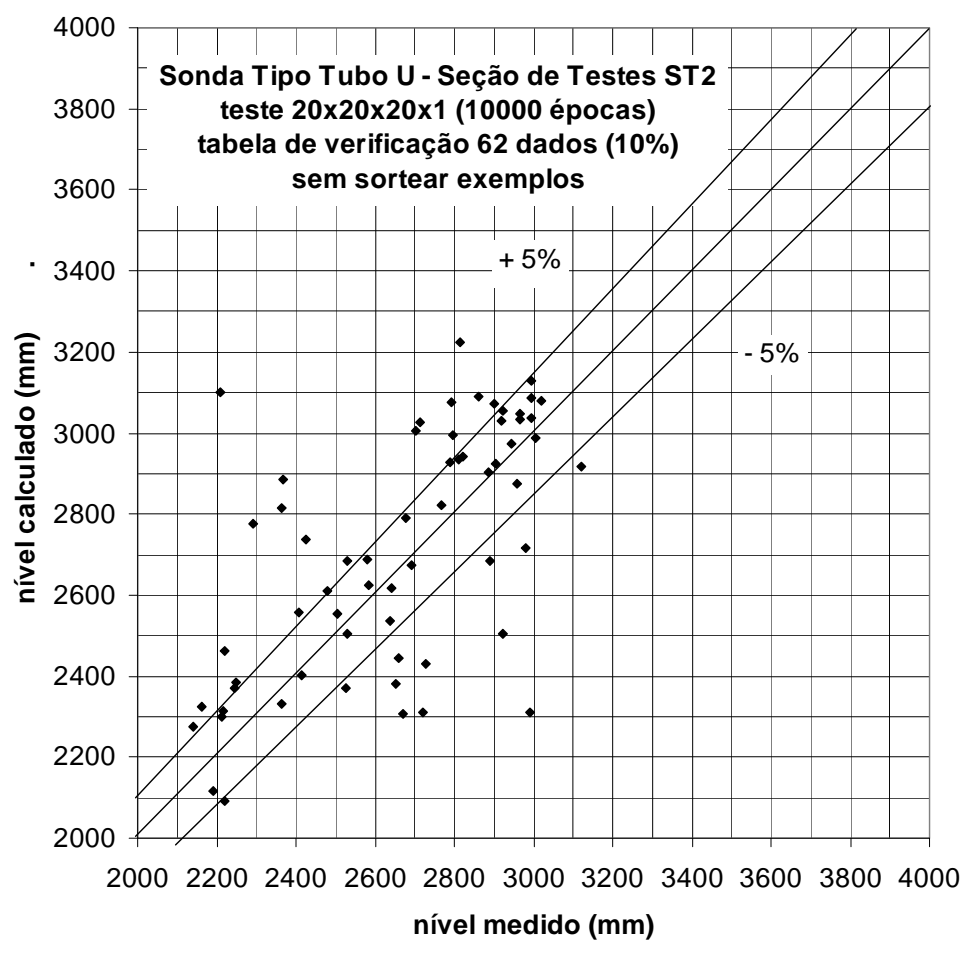

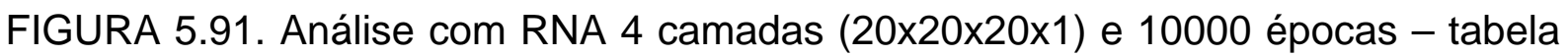
de verificação. 


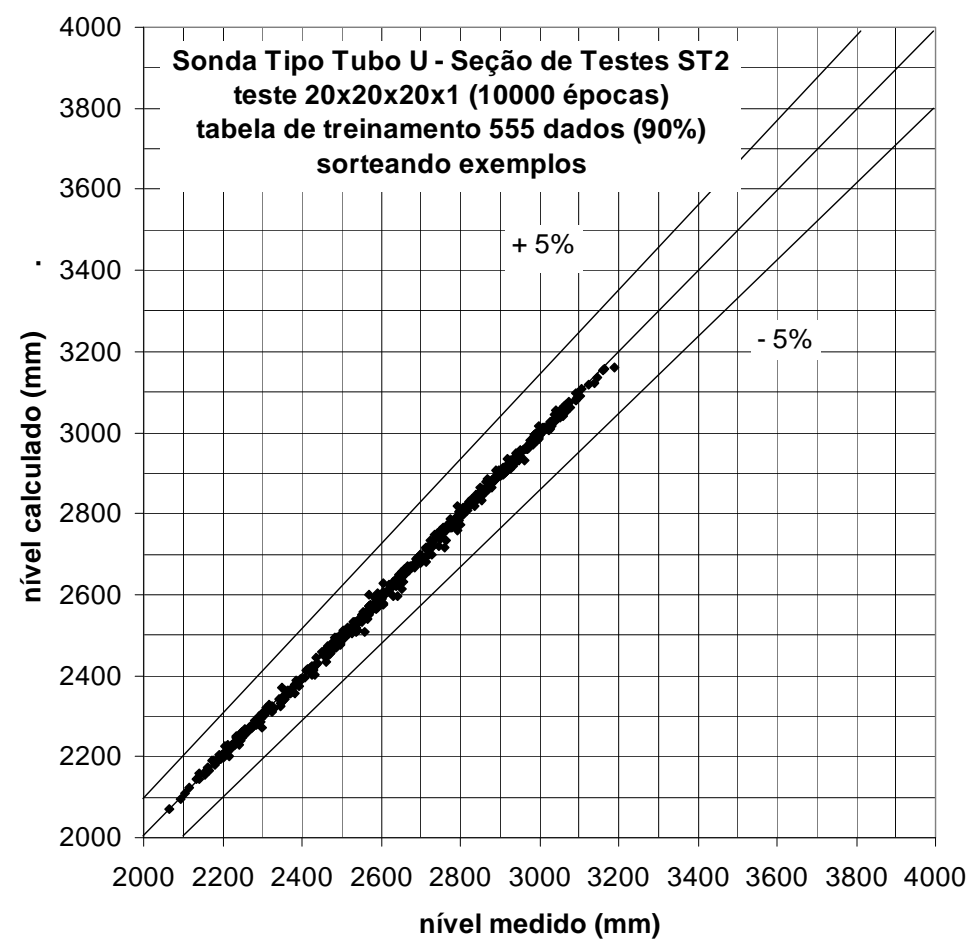

FIGURA 5.92. Análise com RNA 4 camadas $(20 \times 20 \times 20 \times 1), 10000$ épocas e sorteando exemplos - tabela de treinamento ( $90 \%$ dados).

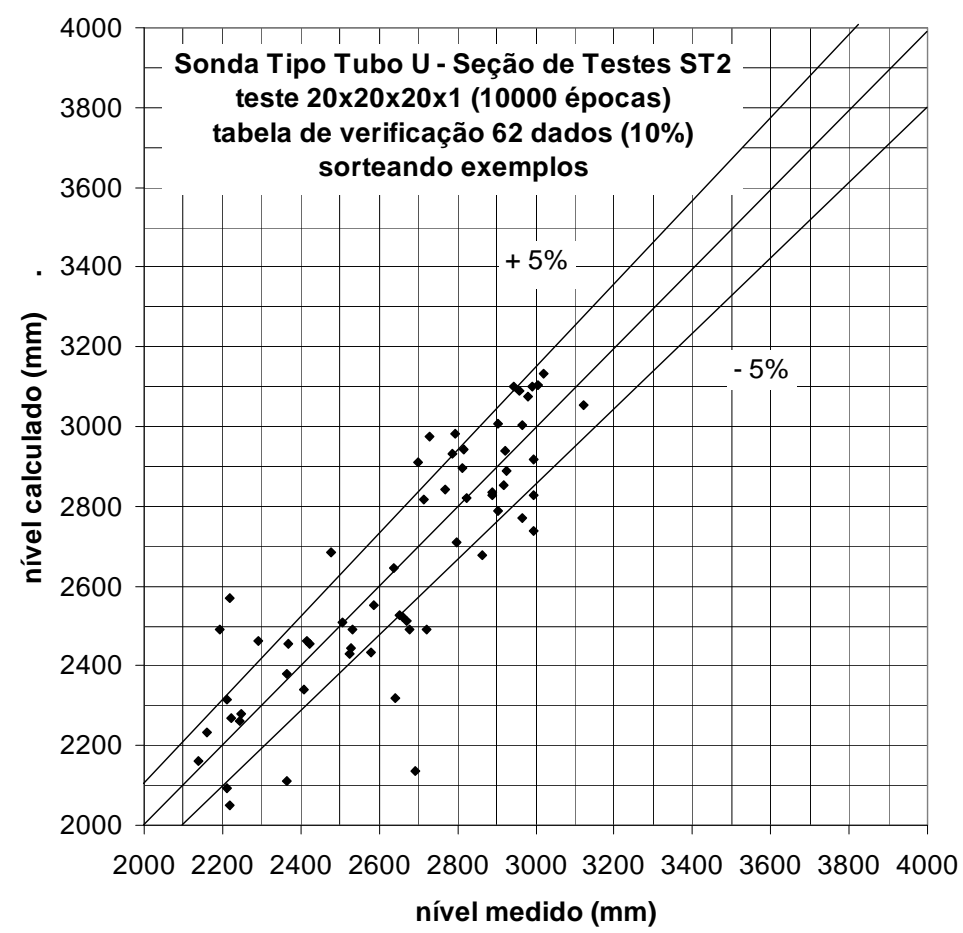

FIGURA 5.93. Análise com RNA 4 camadas $(20 \times 20 \times 20 \times 1)$, 10000 épocas e sorteando exemplos - tabela de verificação (10\% dados). 


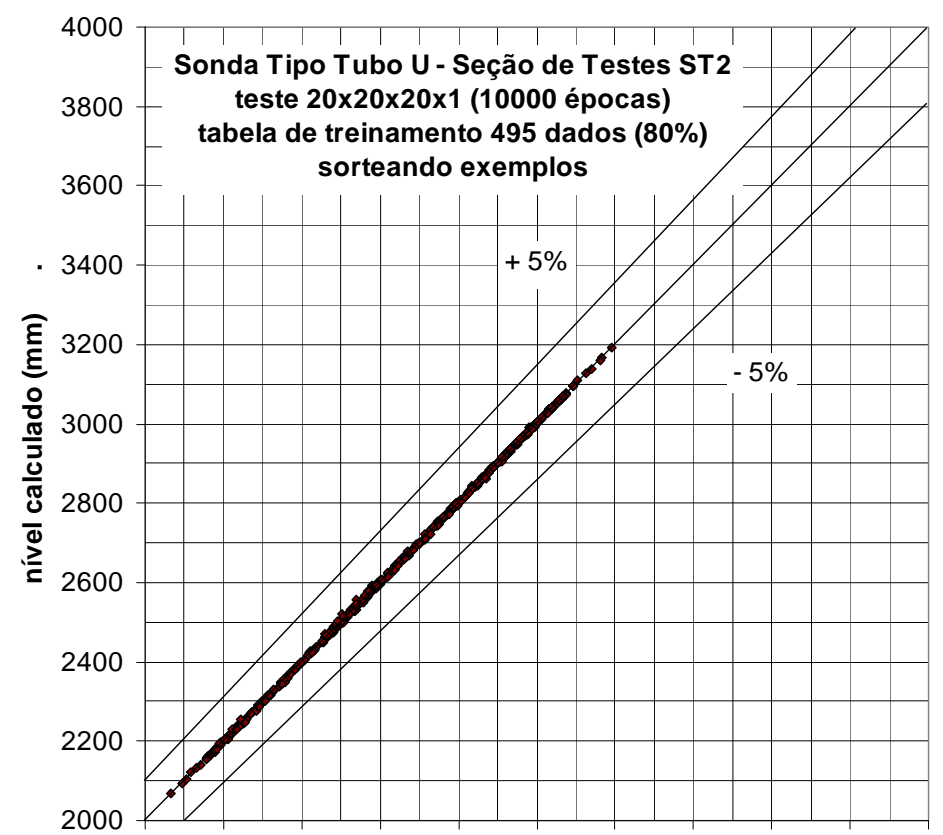

20002200240026002800300032003400360038004000 nível medido $(\mathrm{mm})$

FIGURA 5.94. Análise com RNA 4 camadas $(20 \times 20 \times 20 \times 1), 10000$ épocas e sorteando exemplos - tabela de treinamento ( $80 \%$ dados).

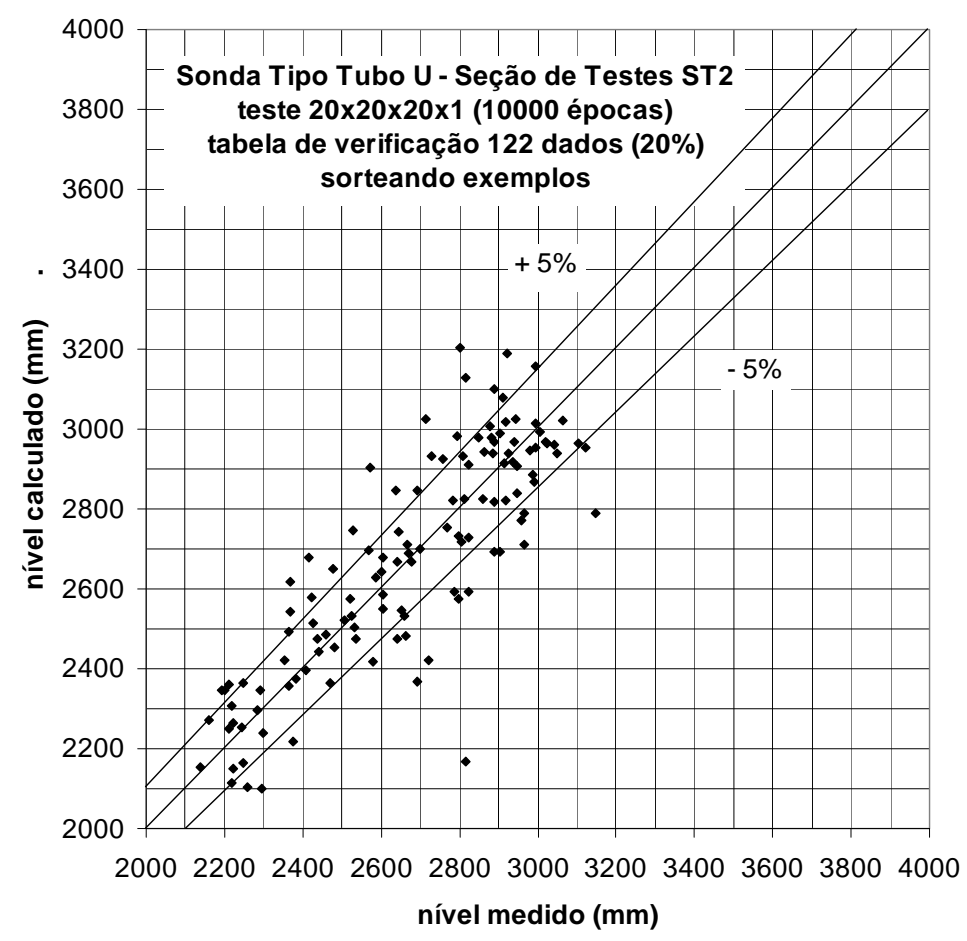

FIGURA 5.95. Análise com RNA 4 camadas $(20 \times 20 \times 20 \times 1), 10000$ épocas e sorteando exemplos - tabela de verificação ( $20 \%$ dados). 


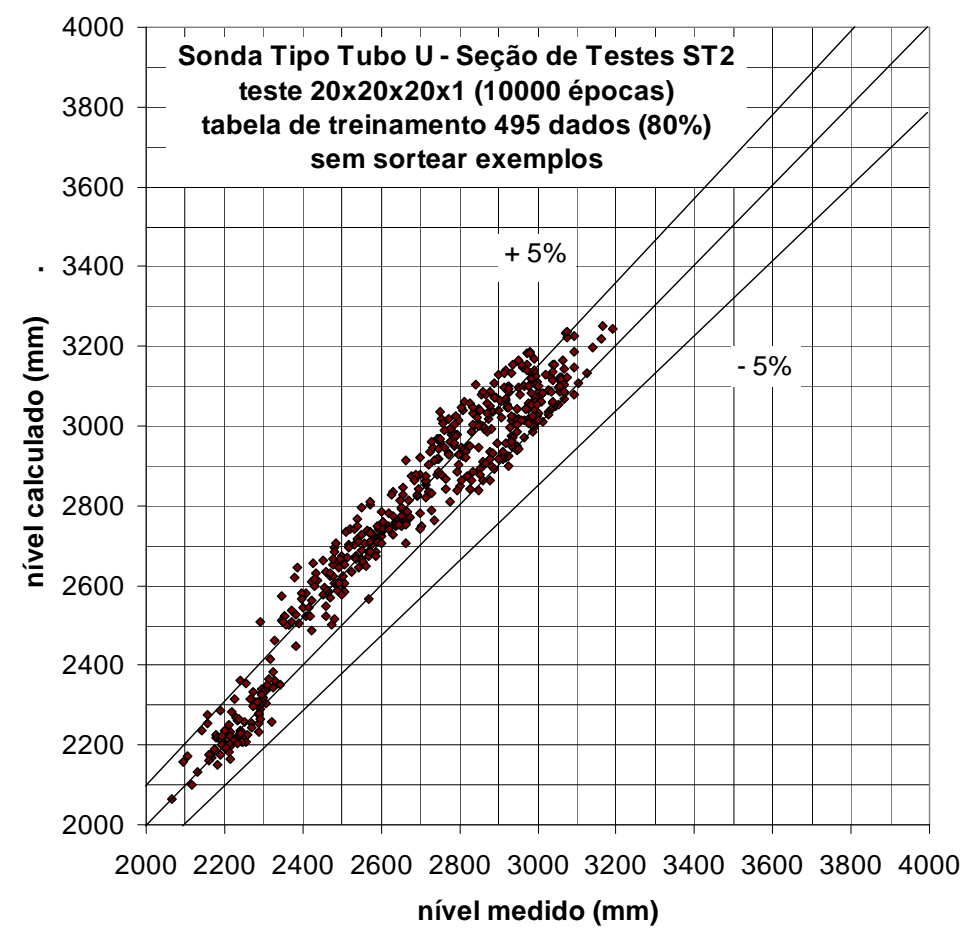

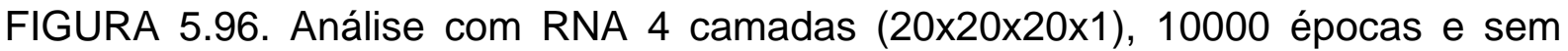
sortear exemplos - tabela de treinamento ( $80 \%$ dados).

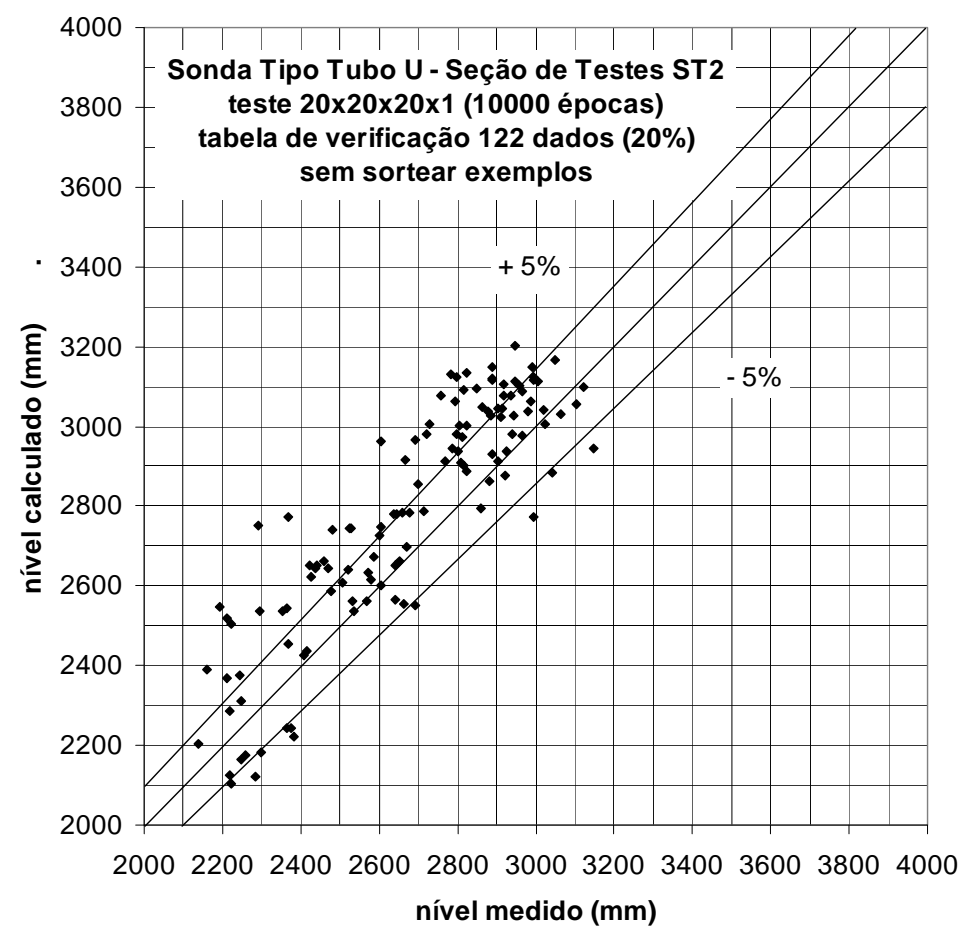

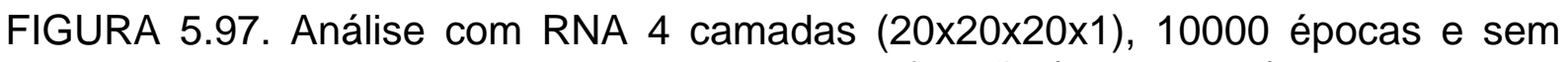
sortear exemplos - tabela de verificação ( $20 \%$ dados). 


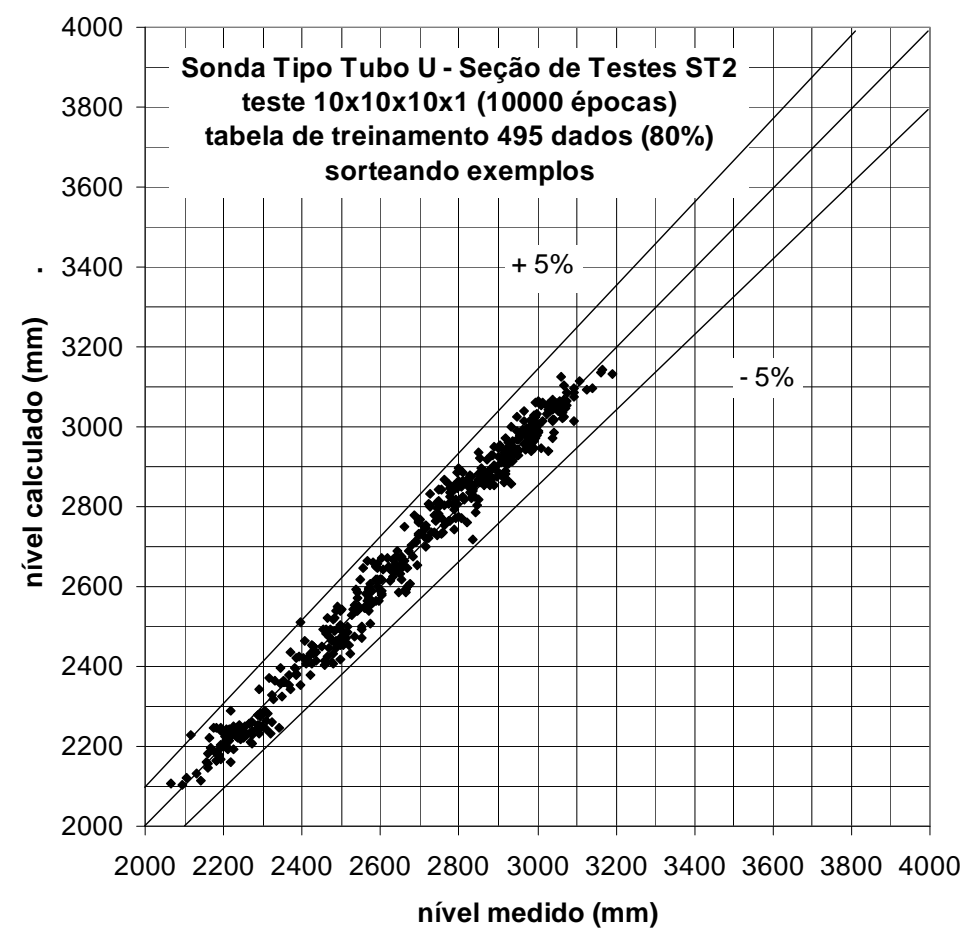

FIGURA 5.98. Análise com RNA 4 camadas $(10 \times 10 \times 10 \times 1), 10000$ épocas e sorteando exemplos - tabela de treinamento ( $80 \%$ dados).

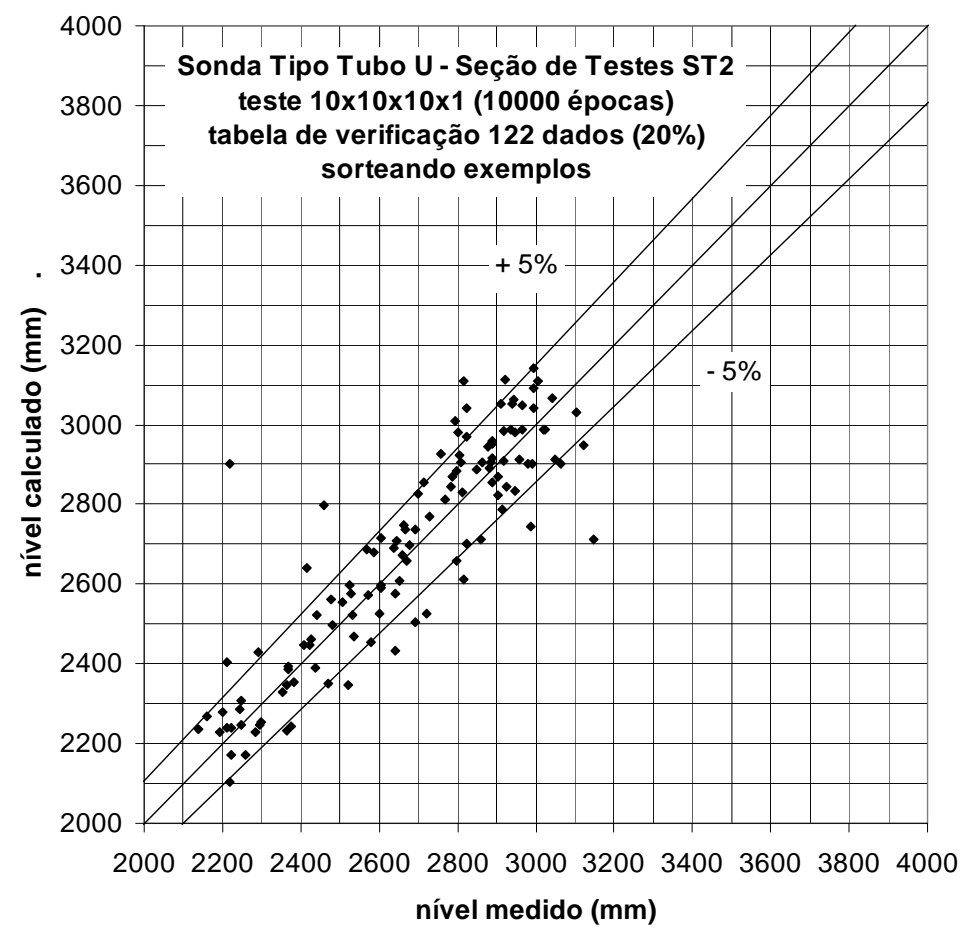

FIGURA 5.99. Análise com RNA 4 camadas $(10 \times 10 \times 10 \times 1)$, 10000 épocas e sorteando exemplos - tabela de verificação (20\% dados). 


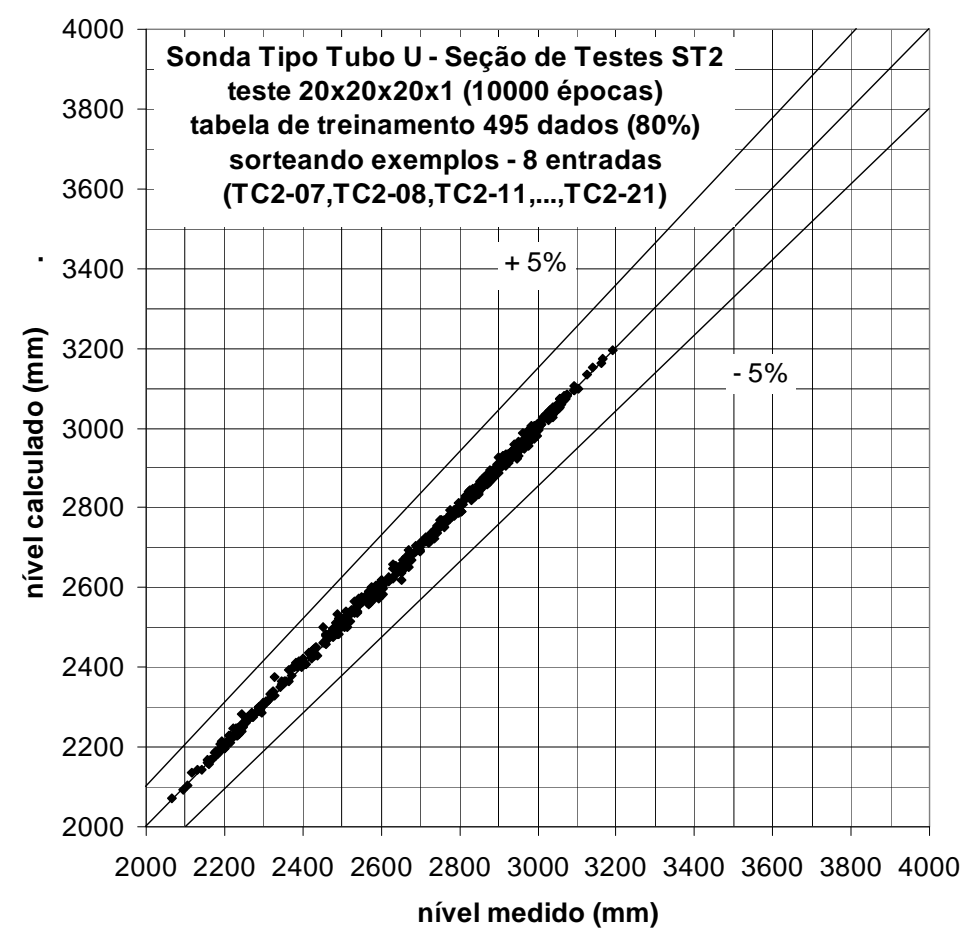

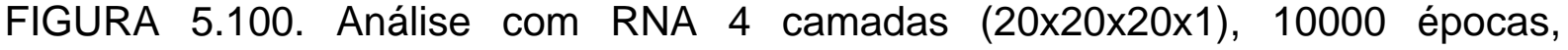
sorteando exemplos e 8 entradas impares - tabela de treinamento (80\% dados).

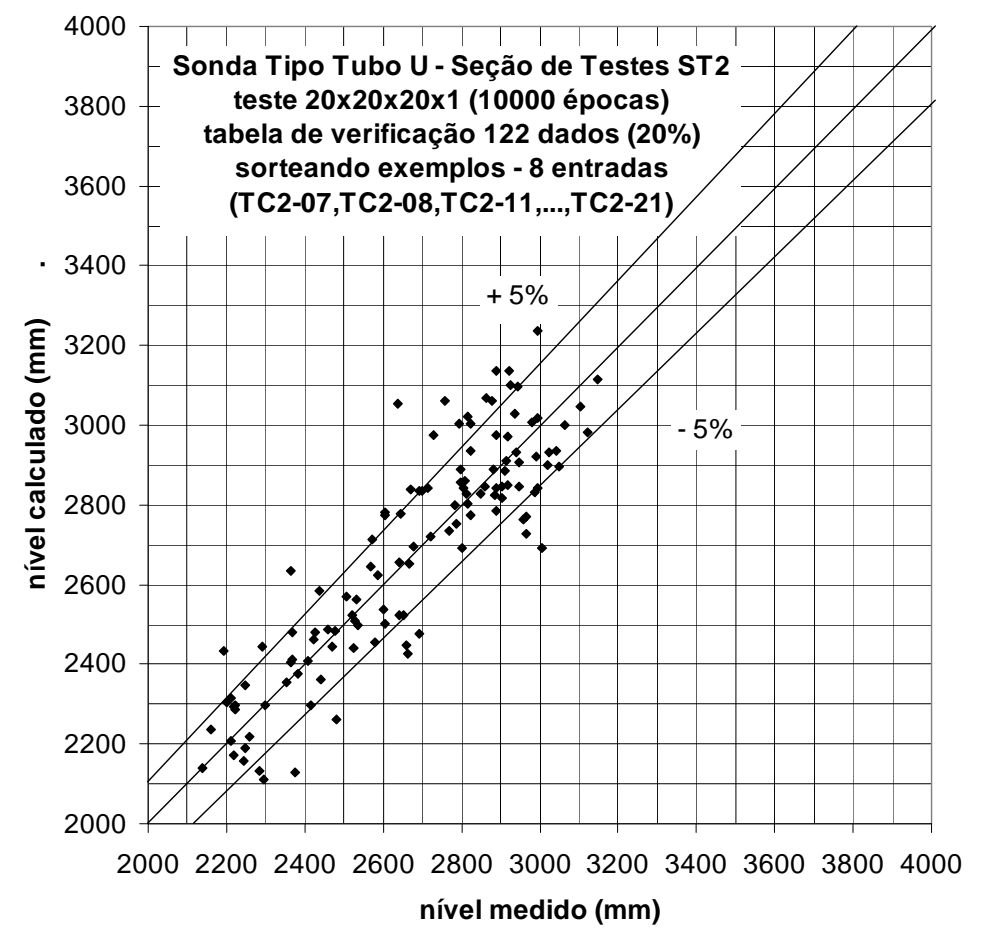

FIGURA 5.101. Análise com RNA 4 camadas $(20 \times 20 \times 20 \times 1), 10000$ épocas, sorteando exemplos e 8 entradas ímpares- tabela de verificação (20\% dados). 


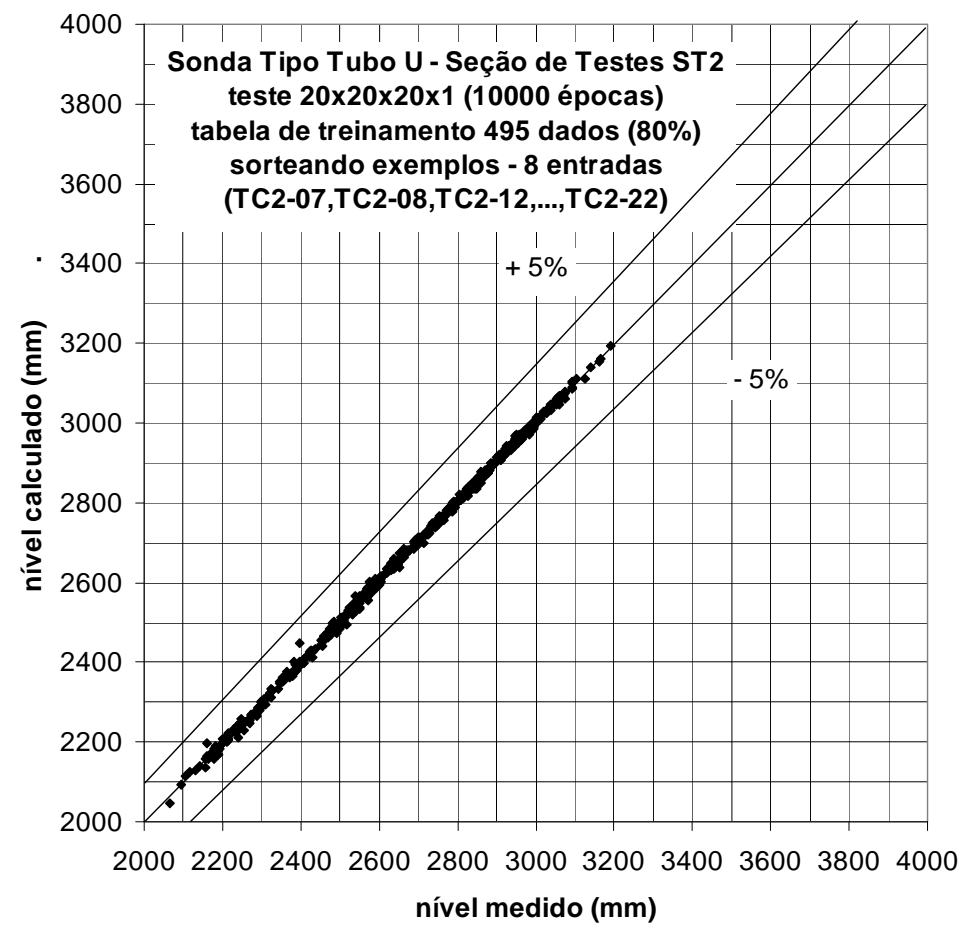

FIGURA 5.102. Análise com RNA 4 camadas (20×20×20x1), 10000 épocas, sorteando exemplos e 8 entradas pares - tabela de treinamento ( $80 \%$ dados).

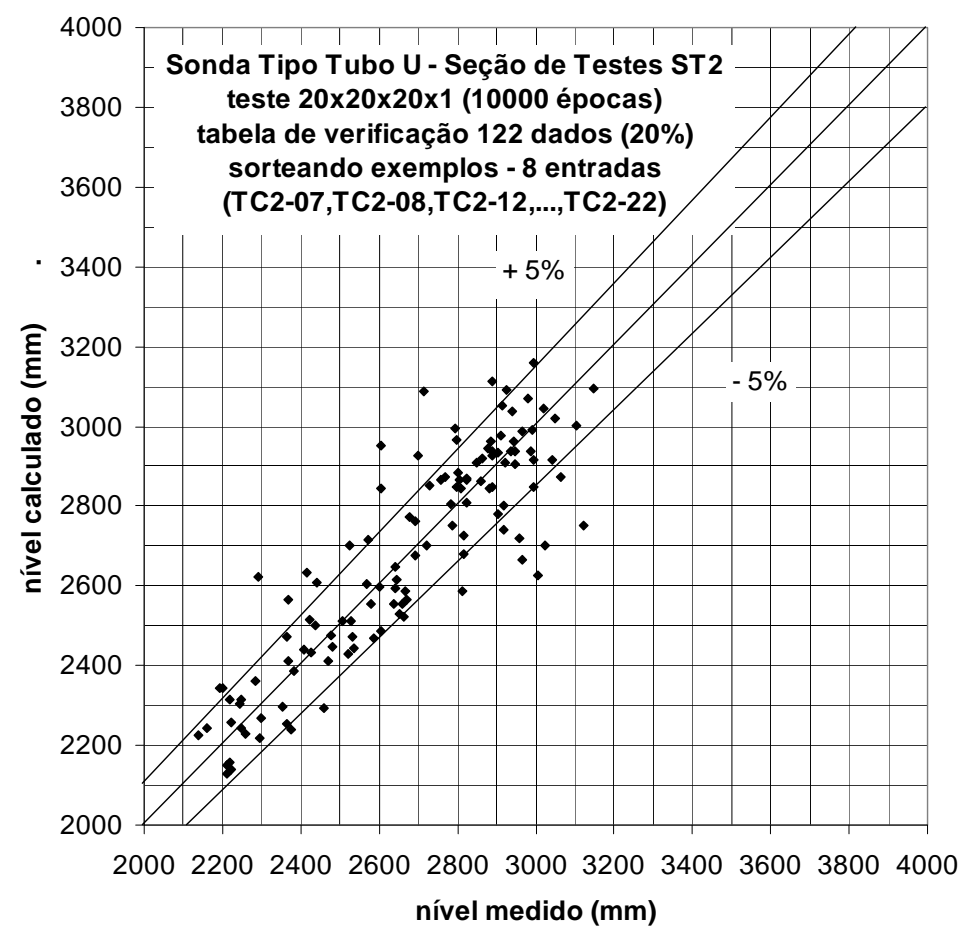

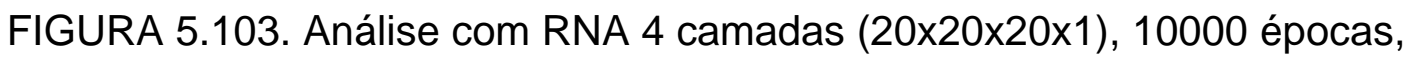
sorteando exemplos e 8 entradas pares - tabela de verificação ( $80 \%$ dados). 


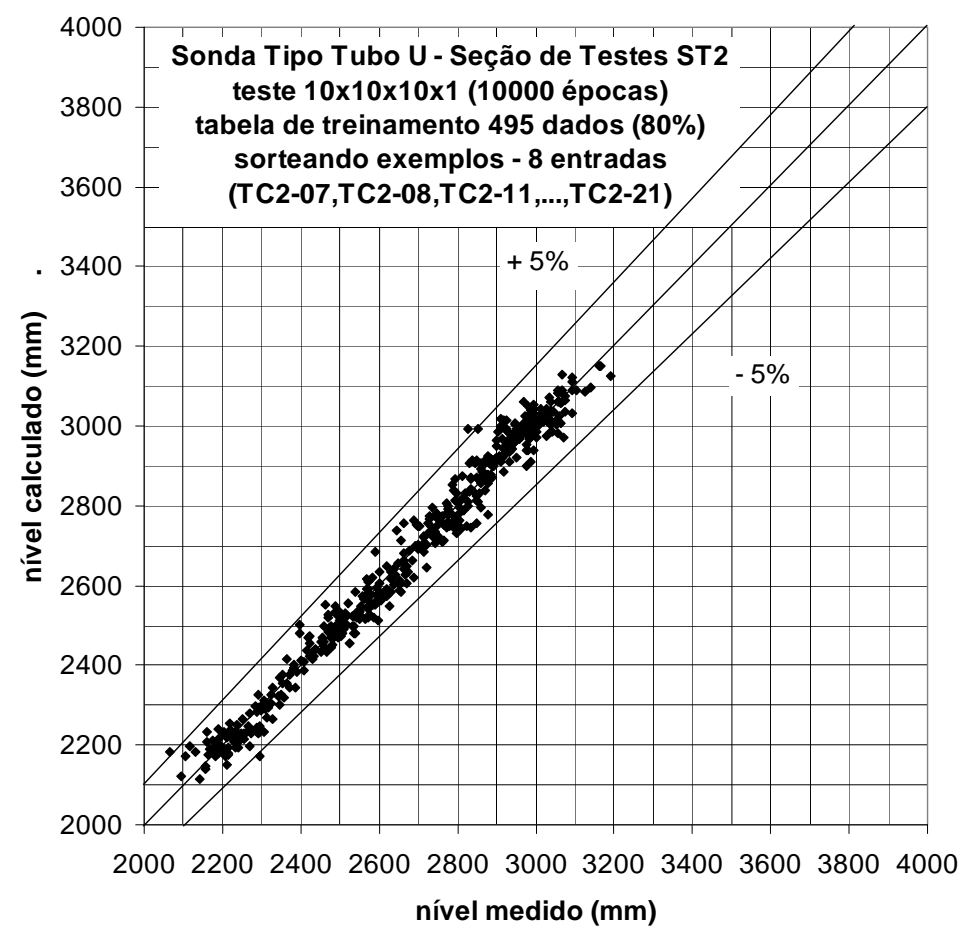

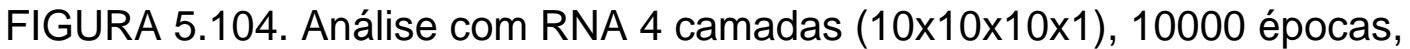
sorteando exemplos e 8 entradas impares - tabela de treinamento ( $80 \%$ dados).

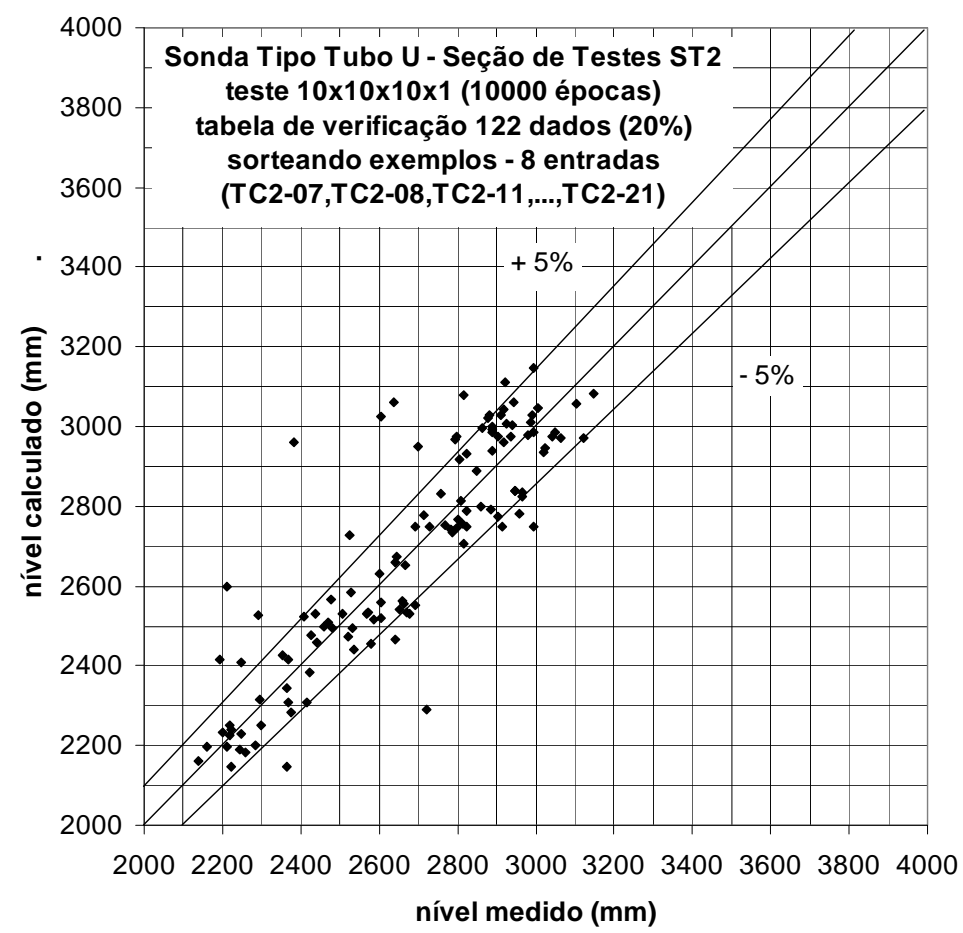

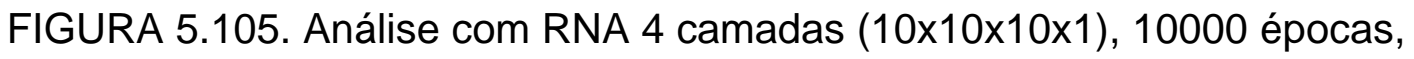
sorteando exemplos e 8 entradas impares - tabela de verificação ( $20 \%$ dados). 
Os resultados das análises apresentados até aqui se referem às condições de funcionamento da sonda tipo tubo $U$ operando em estado estacionário para diferentes níveis na ST2. Entretanto, o que se deseja para um medidor de nível é que o instrumento responda também em condições de transiente, principalmente no caso de vasos de reatores nucleares, para o caso onde ocorre queda de nível e que pode afetar o resfriamento dos elementos combustíveis.

As análises em estado estacionário serviram para o estudo das características das RNA's, tais como o número de camadas, o número de neurônios, a quantidade de épocas de treinamento necessárias, e também verificar que os treinamentos realizados com a opção sorteando exemplos apresentaram os melhores resultados.

Conforme relatado no item 5.1.3, foram realizados testes com a sonda tipo tubo $U$ em condições de transiente variando-se a abertura da válvula da entrada da seção de testes ST2. Foram testadas as aberturas de válvula correspondentes a 0,5 , 1,0 e 2,0 voltas. Os resultados das análises com RNA's são apresentados a seguir.

Nas primeiras análises que foram realizadas com RNA's para as condições de transiente utilizou-se os dados referentes às condições de estado estacionário para a tabela de treinamento da rede, mostradas nas FIG. 5.38 e 5.39 para os vários níveis na seção de testes ST2. Os dados dos testes em transiente foram usado para tabela de verificação.

Uma RNA com 4 camadas $(2 \times 20 \times 20 \times 1)$ foi treinada por 10000 épocas com os dados de estado estacionário e o conjunto com os dados referentes ao transiente de abertura de 0,5 volta na válvula foi usado como conjunto de dados de verificação. A abertura de 0,5 volta que corresponde a uma taxa inicial de diminuição de nível da ordem de $0,27 \mathrm{~mm} / \mathrm{s}(972 \mathrm{~mm} / \mathrm{h})$ como mostrado na FIG. 5.45. Os resultados obtidos com essa análise são apresentados nas FIG. 5.106, 5.107, 5.108 
e 5.109. Observa-se que a rede apresentou bons resultados para os dados da tabela de treinamento, mostrados na FIG. 5.106, contudo os resultados relativos à tabela de verificação, mostrados na FIG. 5.107, não foram considerados bons, fato que pode ser confirmado observando a FIG. 5.108 onde são mostrados os valores de nível calculado pela RNA e o nível medido em função do tempo. As energias dos conjuntos de dados de treinamento e de verificação são apresentadas na FIG. 109, onde é possível verificar a grande diferença entre esses valores ao final do treinamento.

Comparando os dados de temperatura e nível das FIG. 5.38 e 5.39 usados para o treinamento com os dados de temperatura e nível das FIG. 5.47 e 5.48 usados para a verificação, verifica-se que as temperaturas na sonda observadas durante o transiente são muito diferentes daquelas observadas para as condições de estado estacionário para os vários níveis, razão pela qual os resultados calculados para a tabela de verificação foram tão discrepantes. A RNA foi treinada com valores de temperatura muito diferentes daqueles usados na verificação. O contrário também foi verificado, ou seja, o treinamento com dados de transiente e a verificação com dados de estado estacionário. Os resultados também foram insatisfatórios. Em decorrência desses resultados, não foi dada seqüência às análises com esses conjuntos de dados de treinamento e verificação.

O conjunto de dados referentes à condição de transiente com 0,5 volta de abertura da válvula, que corresponde a uma taxa inicial de diminuição de nível da ordem de $0,27 \mathrm{~mm} / \mathrm{s}(972 \mathrm{~mm} / \mathrm{h})$ é mostrado na FIG. 5.45. O conjunto geral com esses dados, composto por 198 valores, foi separado em dois conjuntos para a formação de uma tabela de treinamento, com 80\% (159 dados), e uma tabela de verificação com 20\% (39 dados), como mostrado nas FIG. 5.47, 5.48, 5.49 e 5.50.

Com essas tabelas, foi treinada uma RNA com 4 camadas $(20 \times 20 \times 20 \times 1)$ por 10000 épocas e sorteando os dados. Os resultados referentes às tabelas de treinamento e verificação podem ser vistos nas FIG. 5.110, 5.111, 5.112 e 5.113. 
Neste caso, observa-se uma boa concordância, tanto para os valores calculados para a tabela de treinamento quanto para a tabela de verificação.

Uma análise semelhante foi realizada para uma RNA com 4 camadas $(10 \times 10 \times 10 \times 1)$ e mesmos conjuntos de treinamento e verificação. Os resultados, também considerados bons, são apresentados nas FIG. 5.114, 5.115, 5.116 e 5.117.

O objetivo da redução no número de neurônios nas camadas foi mostrar que quando a RNA é treinada e verificada com dados de um conjunto de dados com "características próximas", é possível usar RNA's menores sem alterar significativamente dos resultados.

A mesma RNA de 4 camadas $(10 \times 10 \times 10 \times 1)$ foi treinada com 10000 épocas e com as tabelas de treinamento (159 dados) e de verificação (39 dados) modificadas para fornecer apenas 8 entradas de temperatura (entradas ímpares), ou seja, TC2-07, TC2-08, TC2-11, TC2-13, TC2-15, TC2-17, TC2-19 e TC2-21. Os resultados, considerados bons, são apresentados nas FIG. 5.118, 5.119, 5.120 e 5.121.

Da mesma forma, essa mesma RNA de 4 camadas $(10 \times 10 \times 10 \times 1)$ foi treinada com as tabelas de treinamento (159 dados) e de verificação (39 dados) modificadas para fornecer apenas 8 entradas de temperatura (entradas pares): TC207, TC2-08, TC2-12, TC2-14, TC2-16, TC2-18, TC2-20 e TC2-22, e os resultados, também considerados bons, podem ser vistos nas FIG. 5.122, 5.123, 5.124 e 5.125.

Nas quatro últimas análises apresentadas utilizou-se um conjunto de dados referentes a um teste em condições de transiente. Esse conjunto foi dividido em dois subconjuntos para formar as tabelas de treinamento e de verificação nas RNA's. Devido ao fato das tabelas de treinamento e de verificação terem origem em 
um mesmo conjunto, é esperado que os resultados sejam bons em decorrência das características semelhantes entre os conjuntos.

Para verificar a capacidade de aprendizado e generalização das RNA's montou-se uma tabela de treinamento (tabela de treinamento - 159 dados) com os dados referentes à condição de transiente de 0,5 volta de abertura de válvula, cuja taxa de diminuição inicial é de aproximadamente $0,27 \mathrm{~mm} / \mathrm{s}(972 \mathrm{~mm} / \mathrm{h})$, e duas tabelas de verificação, uma com dados referentes à condição de transiente e 1,0 volta de abertura da válvula, com uma taxa de diminuição inicial da ordem de 0,40 $\mathrm{mm} / \mathrm{s}(1440 \mathrm{~mm} / \mathrm{h})$ (tabela de verificação - 335 dados) e outra com os dados referentes à condição de transiente e 2,0 volta de abertura da válvula, com uma taxa de diminuição inicial da ordem de 1,46 mm/s $(5256 \mathrm{~mm} / \mathrm{h})$ (tabela de verificação 250 dados). Os dados com as tabelas de treinamento e verificação são apresentados nas FIG. 5.47, 5.48, 5.55, 5.56, 5.61 e 5.62 .

Uma RNA de 4 camadas $(10 \times 10 \times 10 \times 1)$ foi treinada por 10000 e 50000 épocas usando a tabela de treinamento acima. A verificação foi feita usando o conjunto formado pelos dados referentes à condição de transiente e 1,0 volta. Os resultados para o treinamento por 10000 épocas são apresentados nas FIG. 5.126, 5.127, 5.128 e 5.129 e para 50000 épocas, nas FIG. 5.130, 5.131, 5.132 e 5.133 . Observa-se que essa RNA com treinamento por 10000 épocas conseguiu realizar as interpolações com os dados da tabela de treinamento, porém não adquiriu a capacidade de generalização, como mostrado nas FIG. 5.127 e 5.129. Com o aumento do número de épocas de treinamento para 50000 observou-se uma melhora nos resultados, como mostrado nas FIG. 5.131 e 5.133. Neste caso, a RNA treinada já conseguiu generalizar e reproduzir o comportamento da curva de diminuição de nível para o transiente de 1,0 volta de abertura de válvula. Essa análise mostrou que quando os conjuntos de dados de treinamento e verificação possuem características distintas, porém apresentam comportamento semelhante, então se torna necessário treinar a RNA por um número maior de épocas. Diferente da análise anteriormente apresentada quando o treinamento foi feito com dados 
referentes às condições de estado estacionário e a verificação feita com dados do transiente.

Para verificar o efeito do tamanho da rede nos resultados, treinou-se a RNA de 4 camadas $(20 \times 20 \times 20 \times 1)$ por 50000 épocas com os mesmos conjuntos de treinamento e verificação. Os resultados são apresentados nas FIG. 5.134 e 5.135. Comparando esses resultados com os obtidos na análise anterior para RNA $(10 \times 10 \times 10 \times 1)$ para as mesmas 50000 épocas de treinamento, pode-se concluir que a RNA com um número maior de neurônios conseguiu reproduzir melhor a tabela de verificação.

Duas outras análises foram realizadas com a RNA de 4 camadas

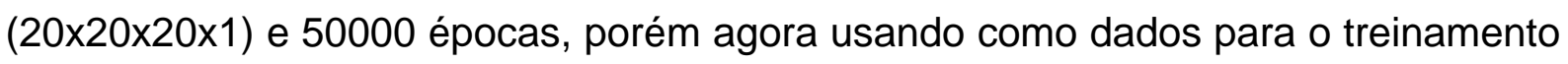
as condições de transiente de 0,5 volta $(0,27 \mathrm{~mm} / \mathrm{s})$ com apenas 8 temperaturas como dados de entrada e para verificação as 8 temperaturas correspondentes e referentes ao transiente de 1,0 volta $(0,40 \mathrm{~mm} / \mathrm{s})$ de abertura de válvula.

$\mathrm{Na}$ primeira análise as temperaturas usadas foram referentes aos 6 termopares de parede localizados da porção inferior da sonda, além das temperaturas de entrada e saída do fluido de resfriamento, ou seja, TC2-07, TC2-08, TC2-11, TC2-12, TC2-13, TC2-14, TC2-15 e TC2-16.

$\mathrm{Na}$ segunda análise as temperaturas usadas foram referentes aos 6 termopares localizados da porção superior da sonda, além das temperaturas de entrada e saída do fluido de resfriamento, ou seja, TC2-07, TC2-08, TC2-17, TC218, TC2-19, TC2-20, TC2-21 e TC2-22.

Os resultados produzidos por essas análises podem ser vistos nas FIG. 5.136 e 5.137, onde se observa que os melhores resultados são obtidos quando são utilizadas as informações contidas nas temperaturas da porção superior da sonda, onde ocorrem as maiores variações de temperatura, as quais são importantes e 
fundamentais para as análises com as RNA's. Aqui, mais uma vez, conclui-se que é possível conseguir bons resultados com um número menor de termopares na sonda e conclui-se ainda que estes termopares podem ser posicionados preferencialmente na porção superior da sonda, possibilitando com isso uma redução no comprimento da sonda.

Em outra análise, a RNA de 4 camadas $(20 \times 20 \times 20 \times 1)$ foi treinada por 20000 épocas com os dados de transiente de 0,5 volta e a tabela de verificação referentes à condição de transiente de 1,0 volta, porém simulando a perda de informação de um termopar na tabela de verificação, ou seja, TC2-18 $=0^{\circ} \mathrm{C}$ (escolhida aleatoriamente). Os resultados obtidos são mostrados na FIG. 5.138, que comparados com aqueles mostrados na FIG. 5.135, apresentam uma diferença principalmente no início do transiente. Essa análise ainda mostra que mesmo com a perda de informação de um termopar, a técnica que utiliza RNA's funciona e é robusta.

Os resultados da análise com a RNA de 4 camadas $(20 \times 20 \times 20 \times 1)$ e 50000 épocas com a tabela de treinamento do transiente de 0,5 volta e a tabela de verificação do transiente de 2,0 volta $(1,46 \mathrm{~mm} / \mathrm{s})$ são apresentados na FIG. 5.139 . Observa-se que a RNA treinada conseguiu generalizar e reproduzir o comportamento da curva de diminuição de nível também para esse transiente. A FIG. 5.140 mostra os resultados para os transientes de 1,0 e 2,0 voltas.

Convém ressaltar que método de retropropagação utilizado não é apropriado para análises em transientes, porém mesmo assim mostrou boa capacidade de aprendizado e de reprodução das tabelas de verificação.

Até este ponto foram utilizados os dados de transiente de 0,5 volta como tabela de treinamento e os dados de transiente referentes a 1,0 e 2,0 voltas como tabela de comparação. Neste caso, o treinamento da RNA foi realizado com um conjunto de dados e a comparação está sendo feita com conjuntos de dados 
relativamente diferentes. Mesmo assim, as análises mostraram que as RNA's treinadas foram capazes de reconhecer relativamente bem as tabelas de verificação. Essa diferença entre as tabelas de treinamento e verificação é um dos motivos que provocaram as diferenças nos resultados.

Para verificar o efeito da tabela de treinamento nos resultados, agrupouse os dados referentes aos transientes de 0,5 , 1,0 e 2,0 voltas em um conjunto geral de dados (783 dados), que foi subdividido em dois conjuntos para representar as tabelas de treinamento (80\%; 627dados) e de verificação (20\%; 156 dados). Os dados do conjunto geral foram separados alternadamente tomando-se 4 dados para o treinamento e 1 dado para a verificação.

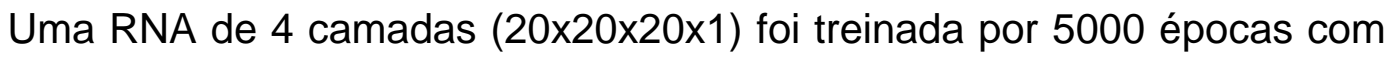
estes conjuntos de dados e os resultados podem ser vistos nas FIG. 5.141. 5.142, 5.143 e 5.144. Neste caso, a RNA foi treinada com um conjunto de dados semelhantes aos dados de verificação e a concordância entre os resultados pode ser considerada muito boa. Por haver essa maior semelhança entre os conjuntos de dados de treinamento e verificação, um treinamento por apenas 5000 épocas foi suficiente para o aprendizado da rede e os resultados foram muito melhores.

Nas FIG. 5.143 e 5.144, os transientes foram propositalmente colocados em seqüência para possibilitar a apresentação numa única figura, tanto para a tabela de treinamento quanto para a tabela de verificação. Essa análise mostrou que para a obtenção de bons resultados em transientes com esse programa de retropropagação é necessário treinar a RNA com dados experimentais representativos para alguns transientes. Quanto mais representativos forem os dados da tabela de treinamento, melhores serão os resultados. 


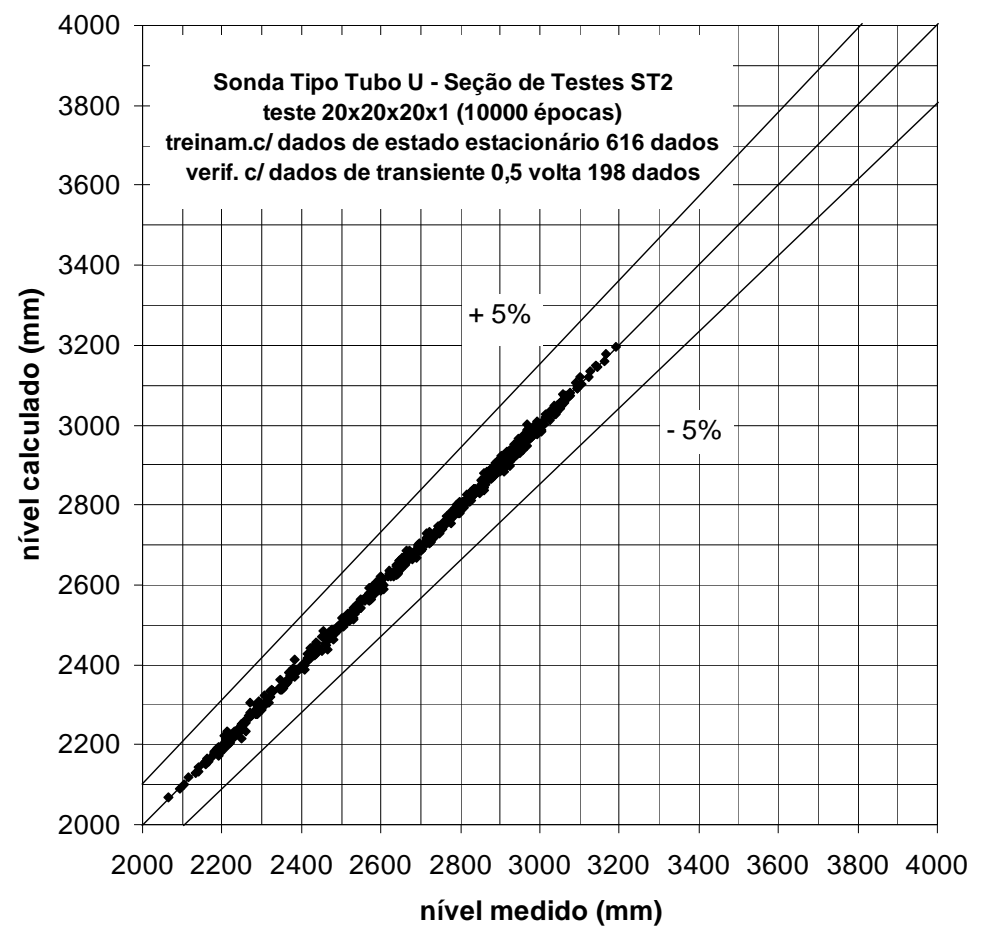

FIGURA 5.106. Análise com RNA 4 camadas (20×20×20×1), 10000 épocas, sorteando exemplos - tabela de treinamento $100 \%$ dados estado estacionário.

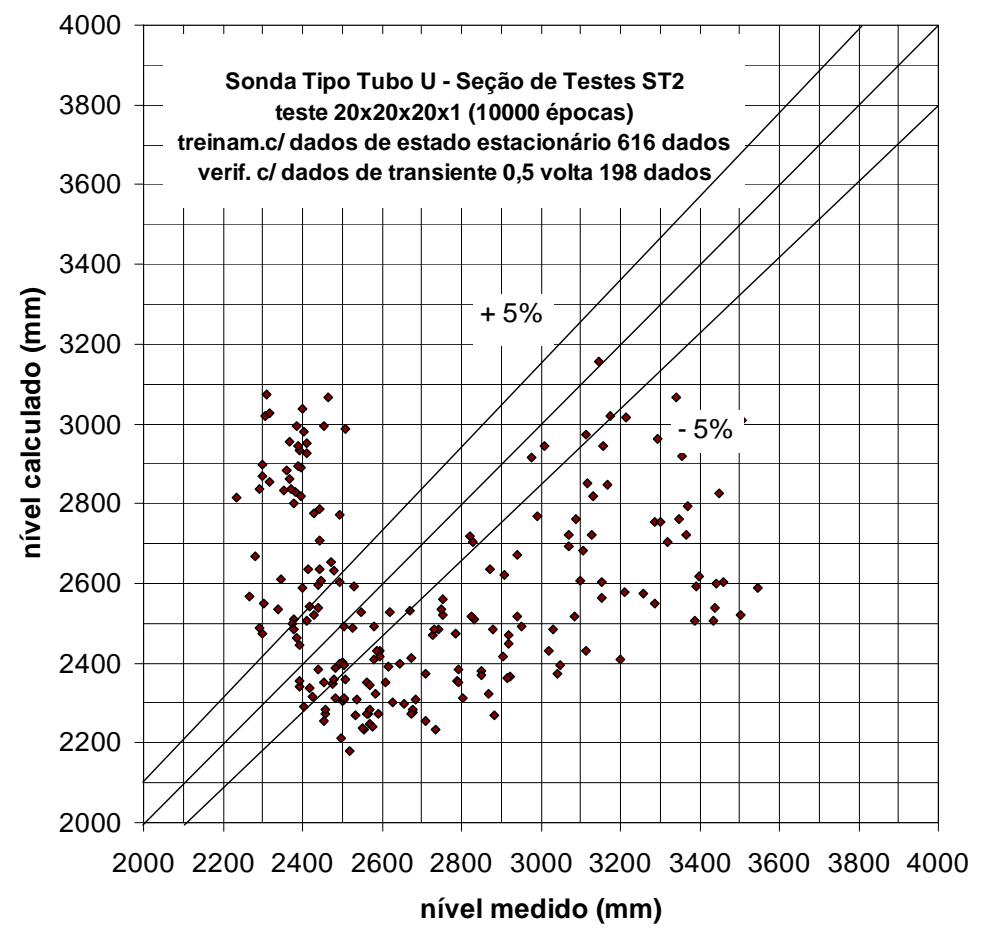

FIGURA 5.107. Análise com RNA 4 camadas (20x20×20x1), 10000 épocas, sorteando exemplos - tabela de verificação com dados transiente 0,5 volta. 


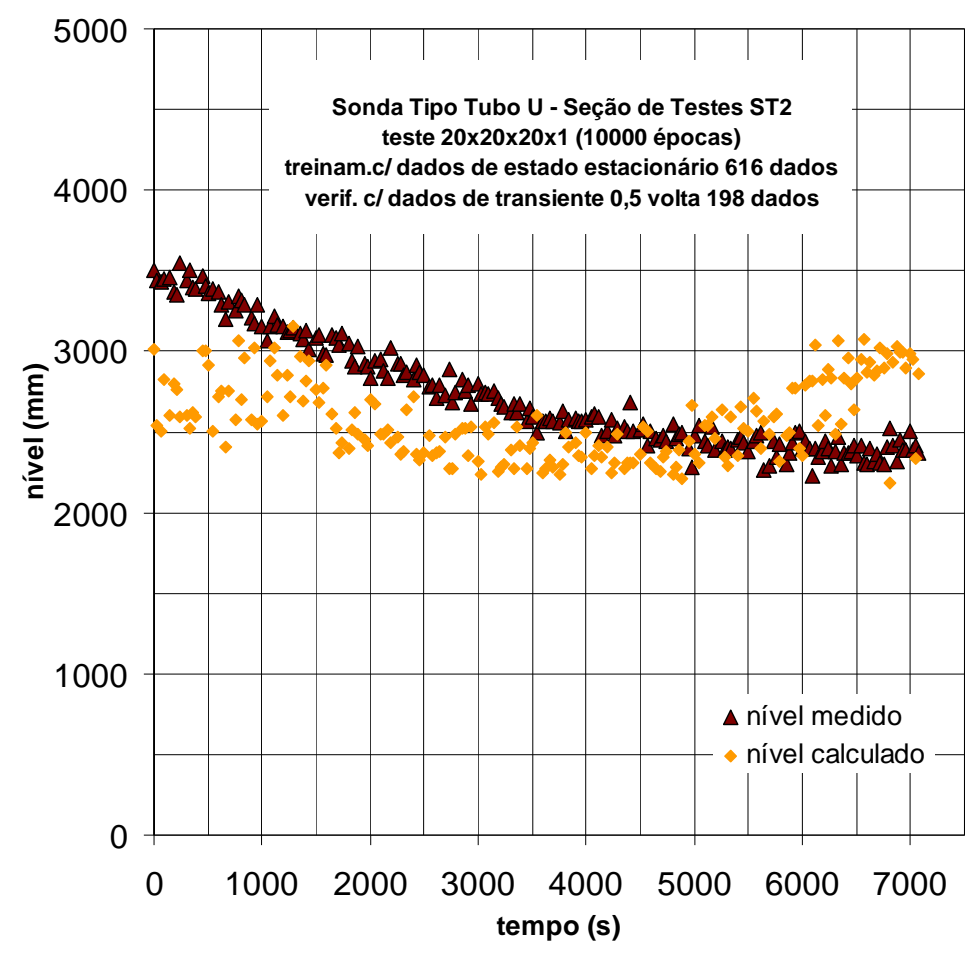

FIGURA 5.108. Nível x tempo para a análise com RNA 4 camadas (20×20×20×1), 10000 épocas, sorteando exemplos.

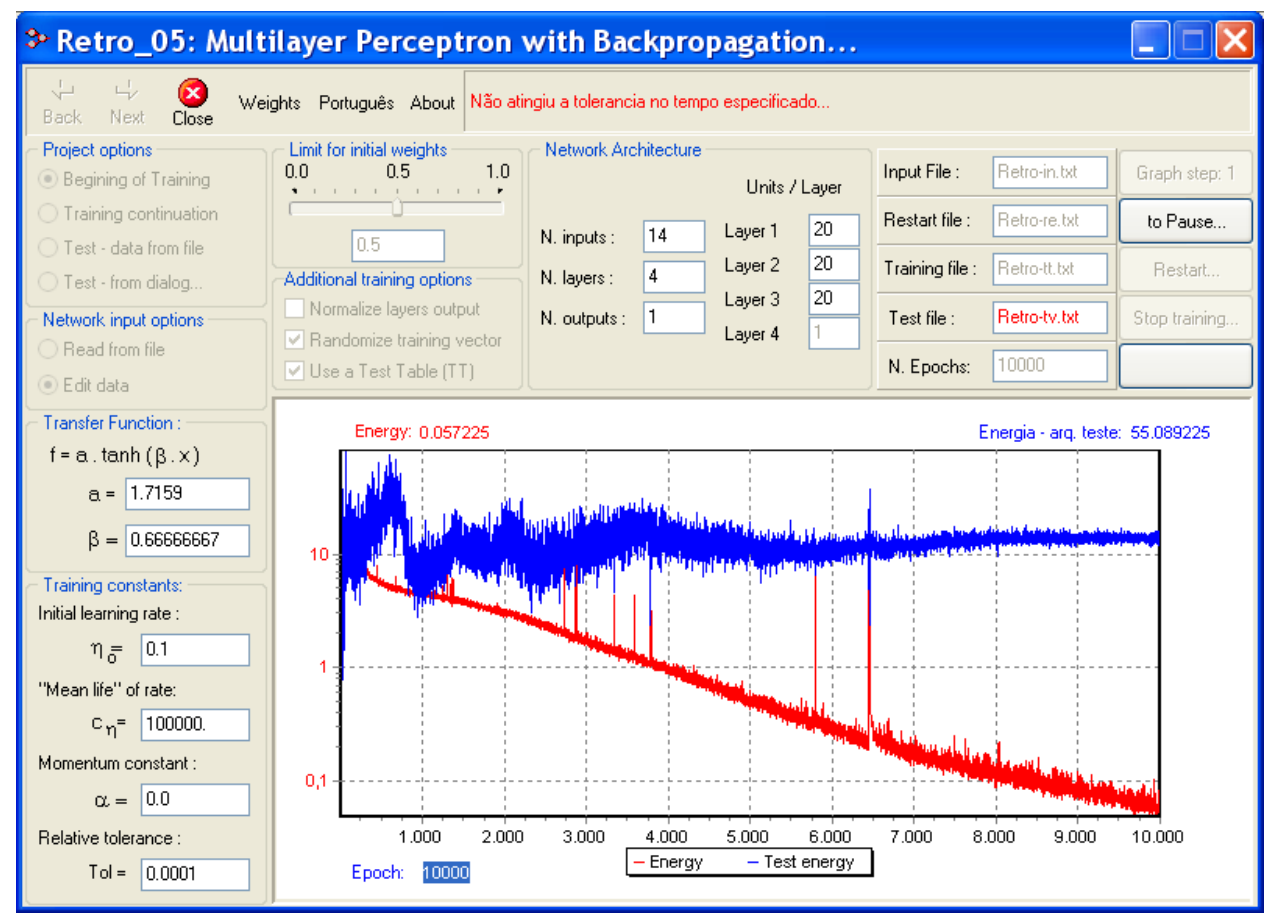

FIGURA 5.109. Energias $x$ épocas para a análise com RNA 4 camadas (20x20x20x1), 10000 épocas, sorteando exemplos. 


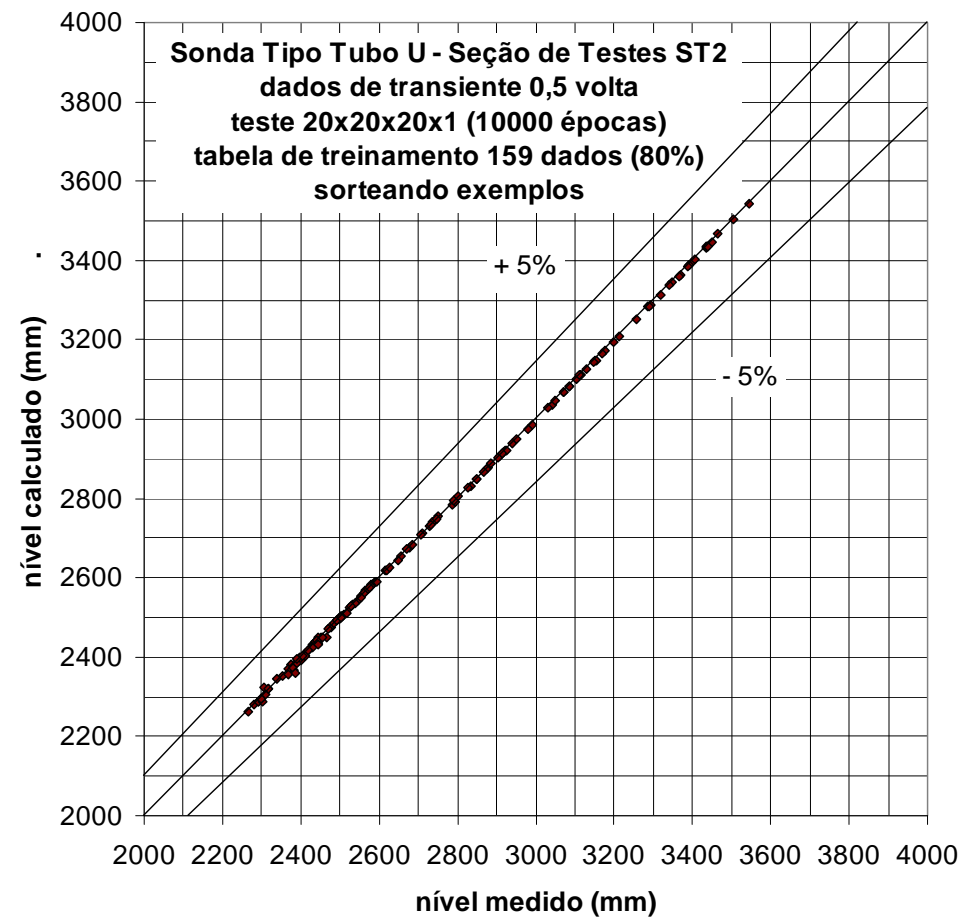

FIGURA 5.110. Análise com RNA 4 camadas (20×20×20×1), 10000 épocas, sorteando exemplos - tabela de treinamento $80 \%$ dados de transiente 0,5 volta.

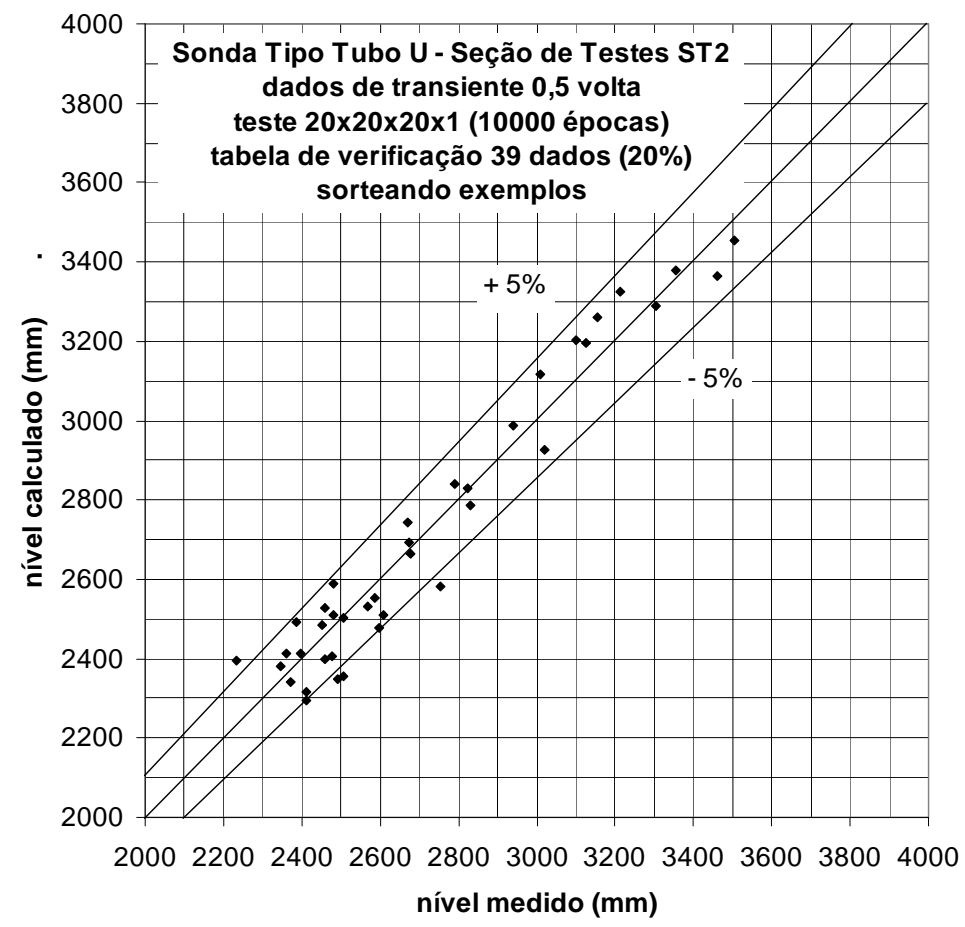

FIGURA 5.111. Análise com RNA 4 camadas (20×20×20×1), 10000 épocas, sorteando exemplos - tabela de verificação $20 \%$ dados de transiente 0,5 volta. 


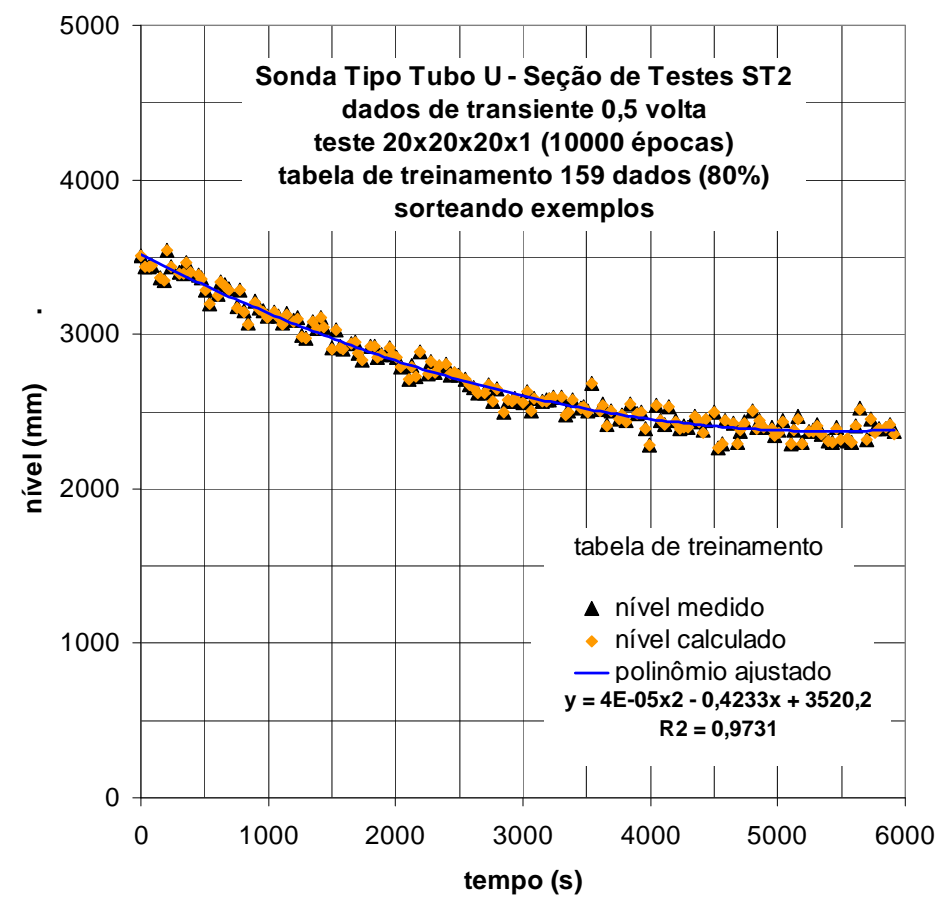

FIGURA 5.112. Nível x tempo para a análise com RNA 4 camadas (20×20×20×1), 10000 épocas, sorteando exemplos e transiente 0,5 volta - tab. treinamento.

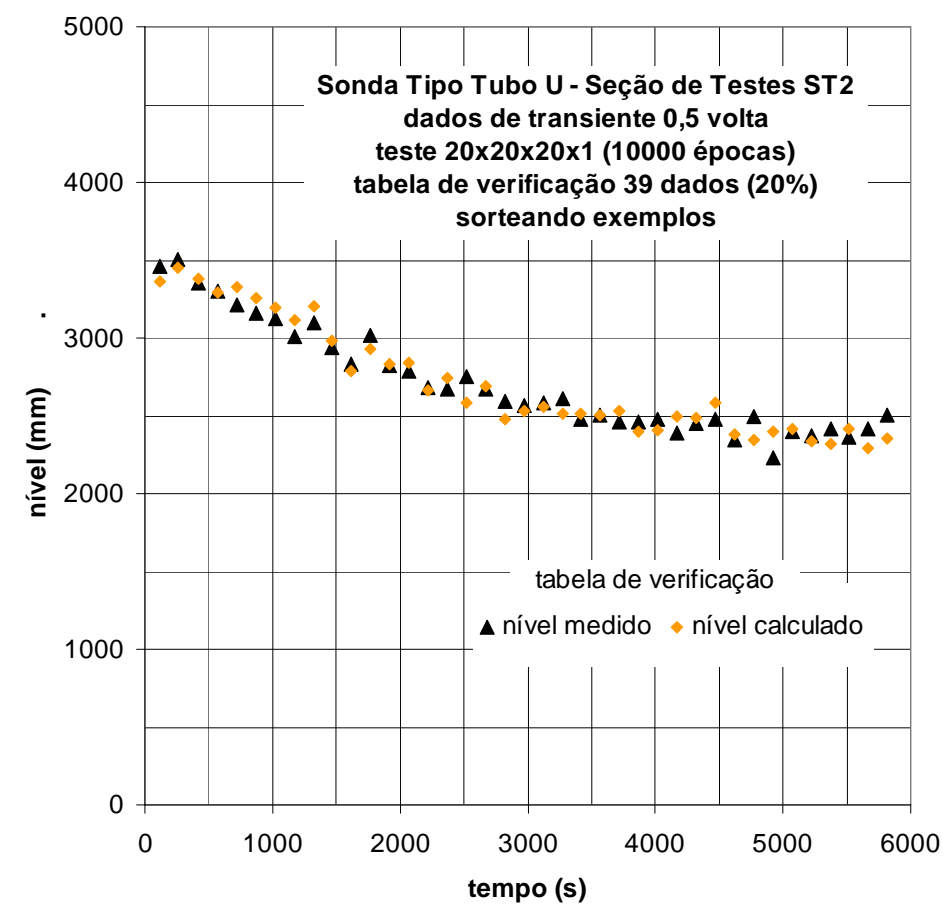

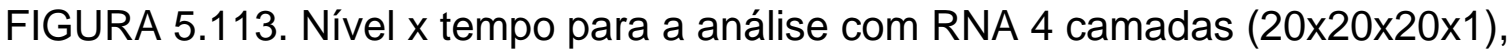
10000 épocas, sorteando exemplos e transiente 0,5 volta - tab. verificação. 


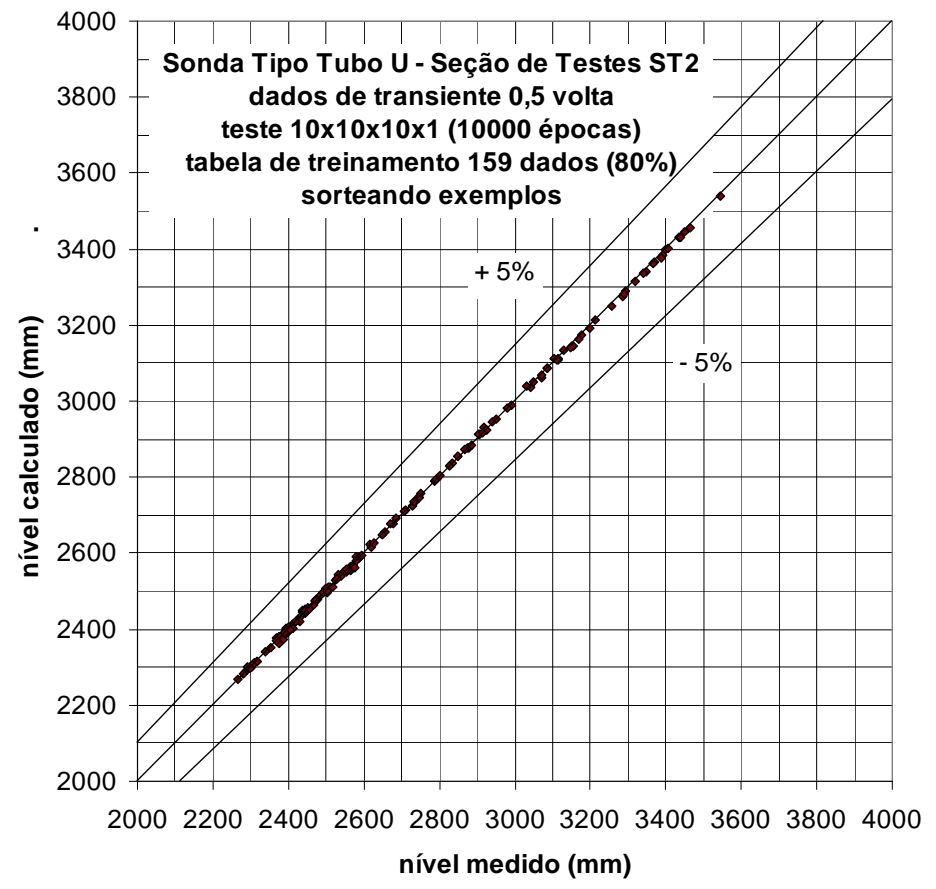

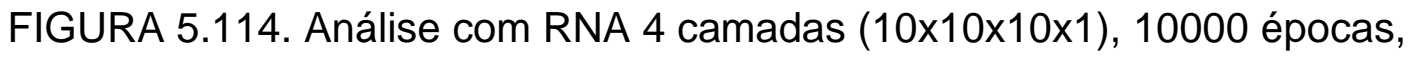
sorteando exemplos - tabela de treinamento $80 \%$ dados de transiente 0,5 volta.

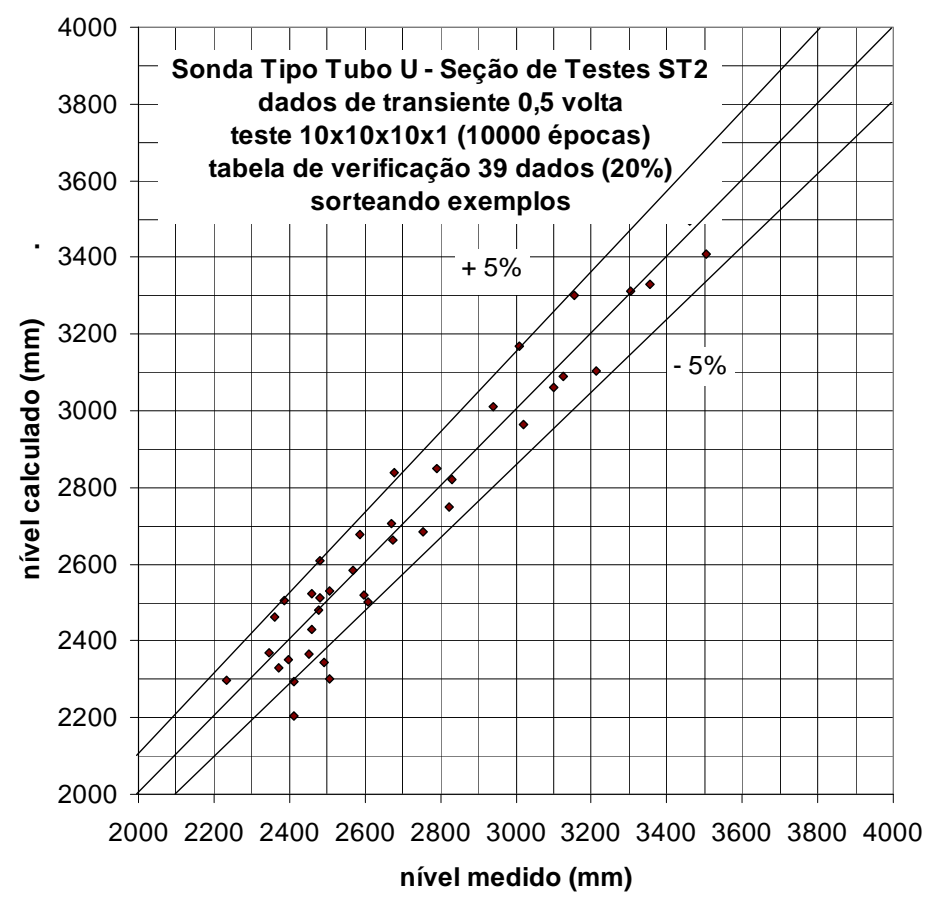

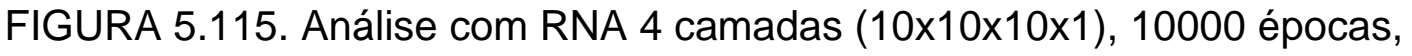
sorteando exemplos - tabela de verificação $20 \%$ dados de transiente 0,5 volta. 


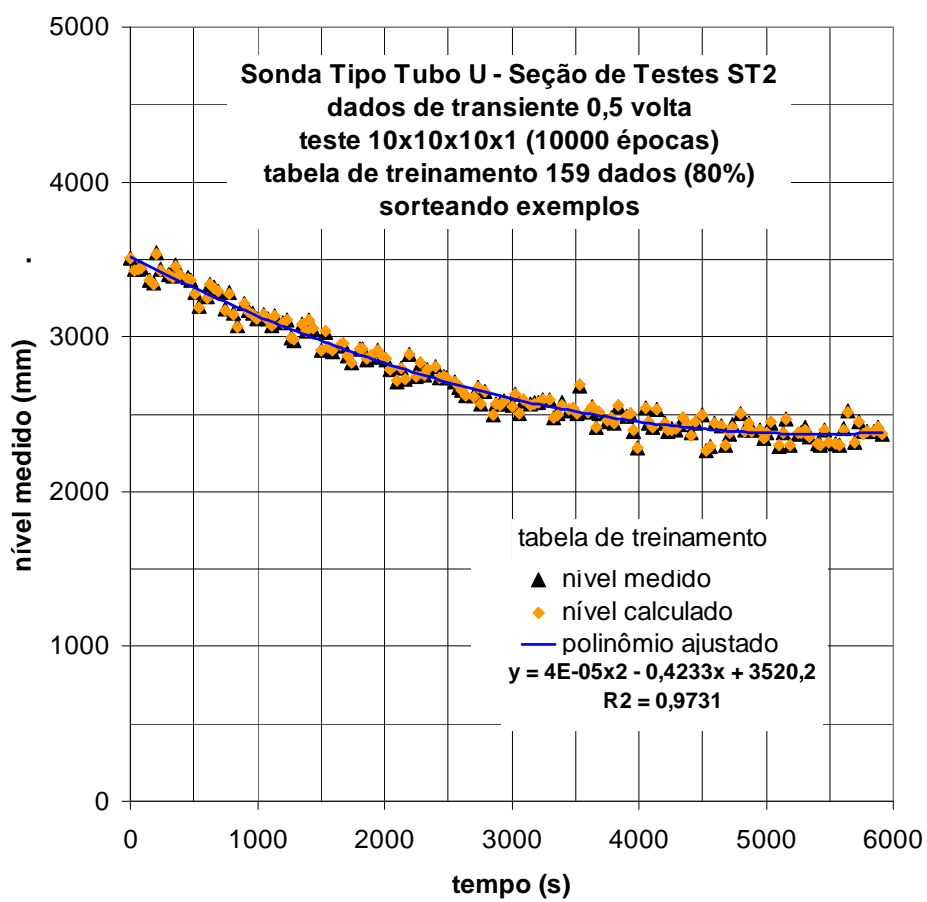

FIGURA 5.116. Nível x tempo para a análise com RNA 4 camadas (10×10×10x1), 10000 épocas, sorteando exemplos e transiente 0,5 volta - tab. treinamento.

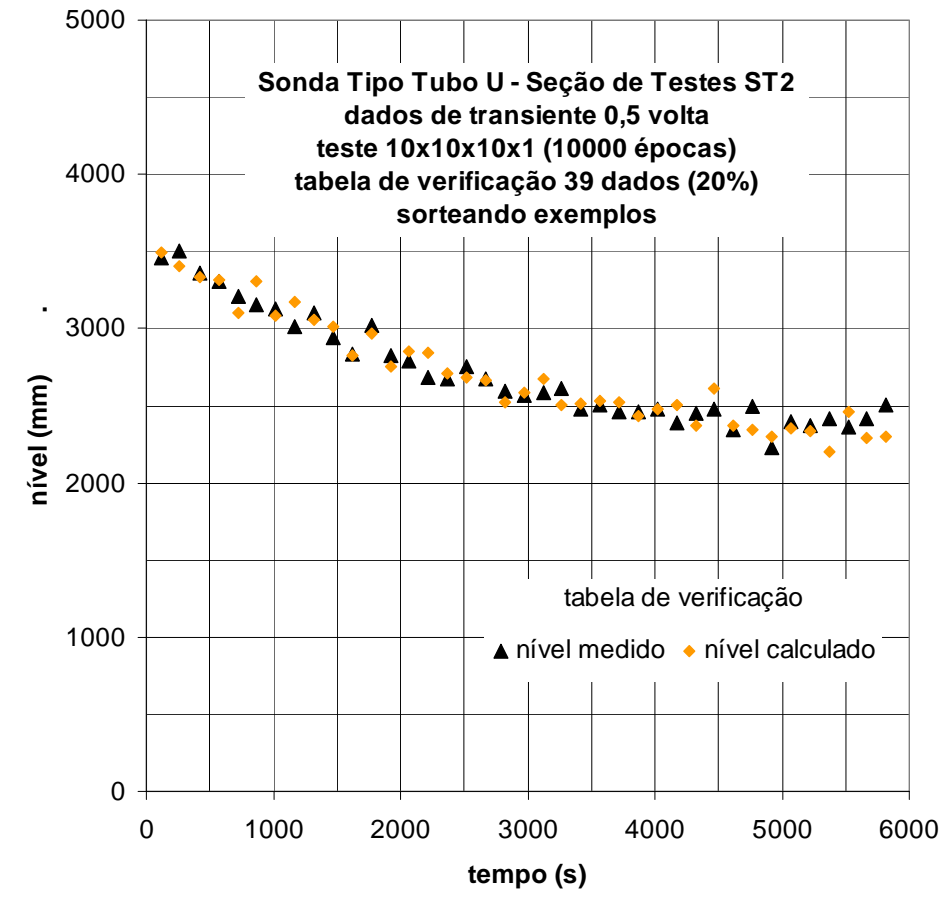

FIGURA 5.117. Nível x tempo para a análise com RNA 4 camadas (10×10×10x1), 10000 épocas, sorteando exemplos e transiente 0,5 volta - tab. verificação. 


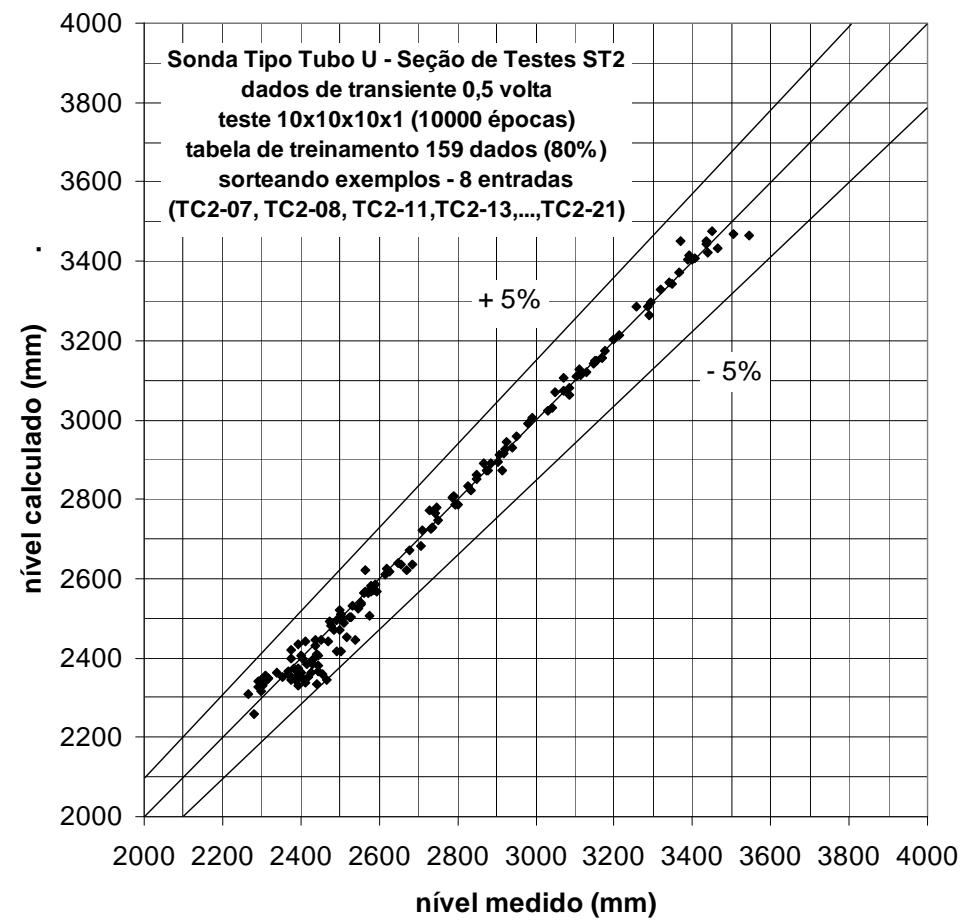

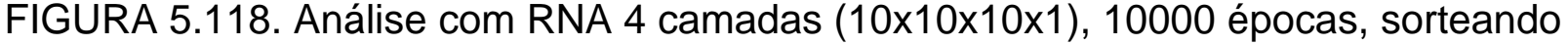
exemplos - tab. de treinamento $80 \%$ dados de transiente 0,5 volta e 8 entradas ímpares.

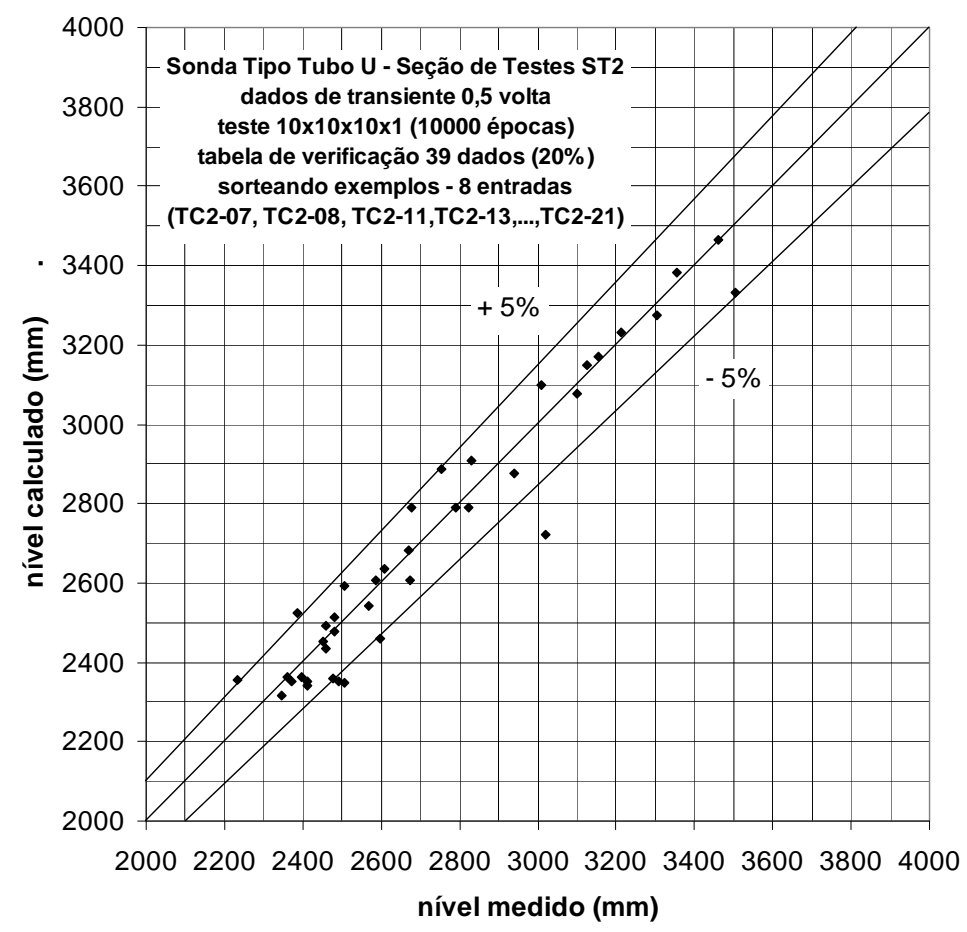

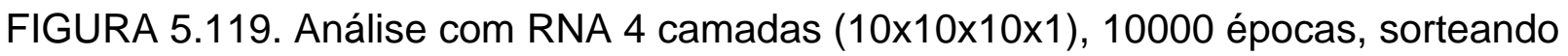
exemplos - tab. de verificação $20 \%$ dados de transiente 0,5 volta e 8 entr. ímpares. 


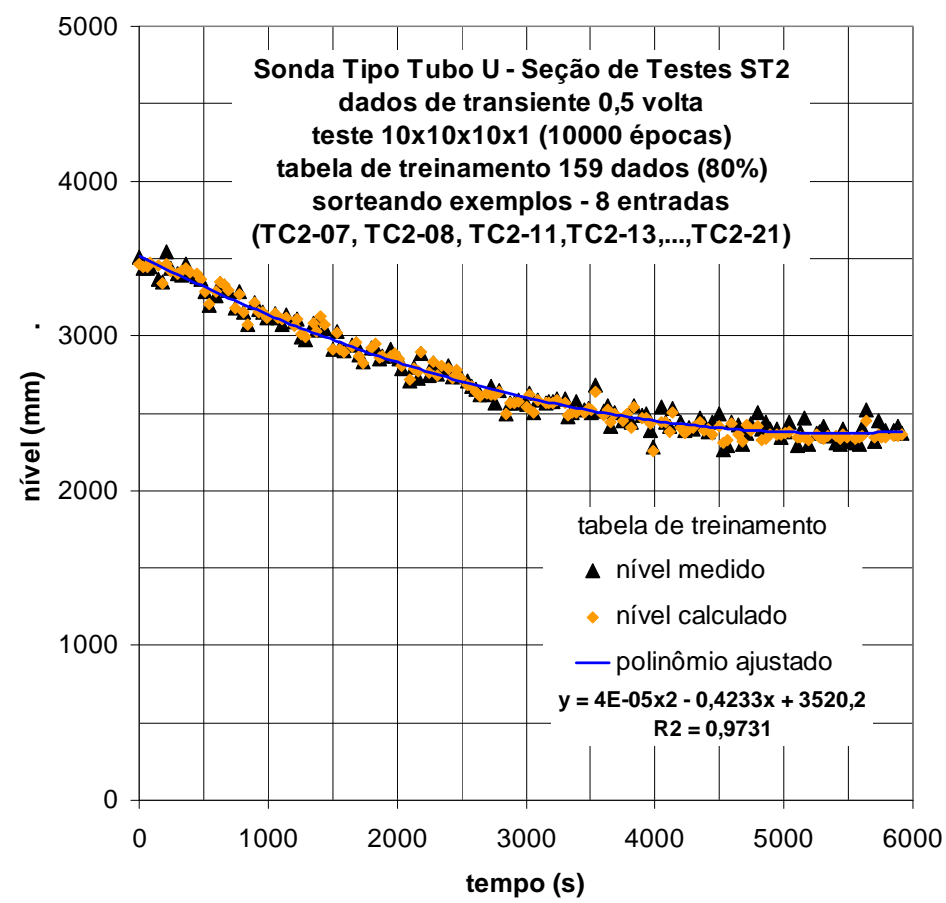

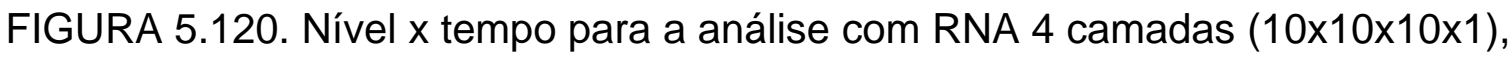
10000 épocas, sorteando exemplos e transiente 0,5 volta e 8 entradas ímpares - tabela de treinamento.

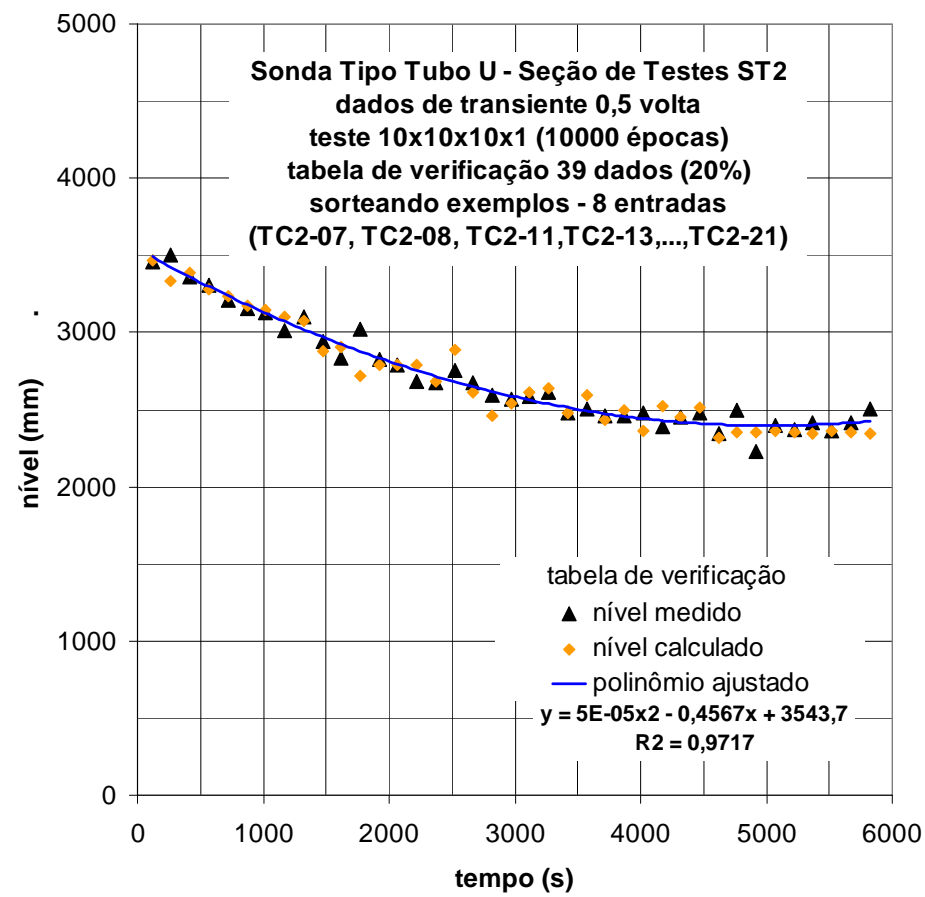

FIGURA 5.121. Nível x tempo para a análise com RNA 4 camadas (10×10×10x1), 10000 épocas, sorteando exemplos e transiente 0,5 volta e 8 entradas ímpares - tabela de verificação. 


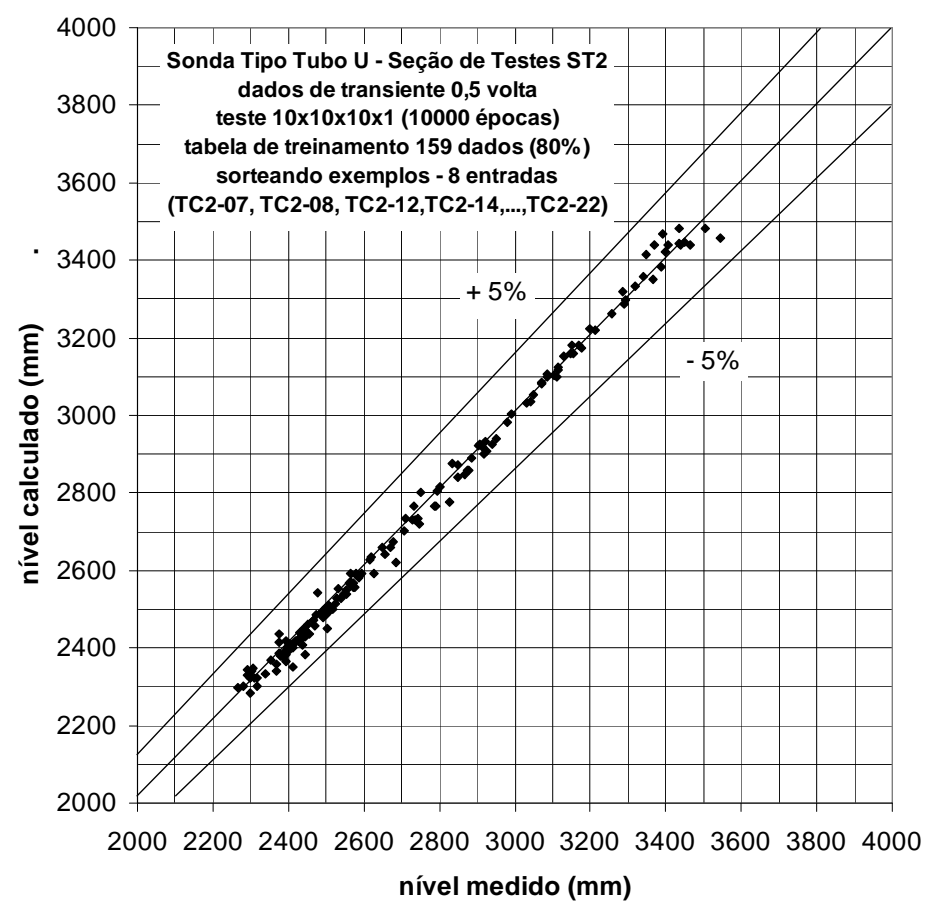

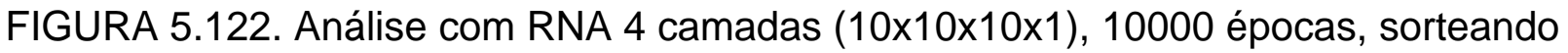
exemplos - tabela de treinamento $80 \%$ dados de transiente 0,5 volta e 8 entradas pares.

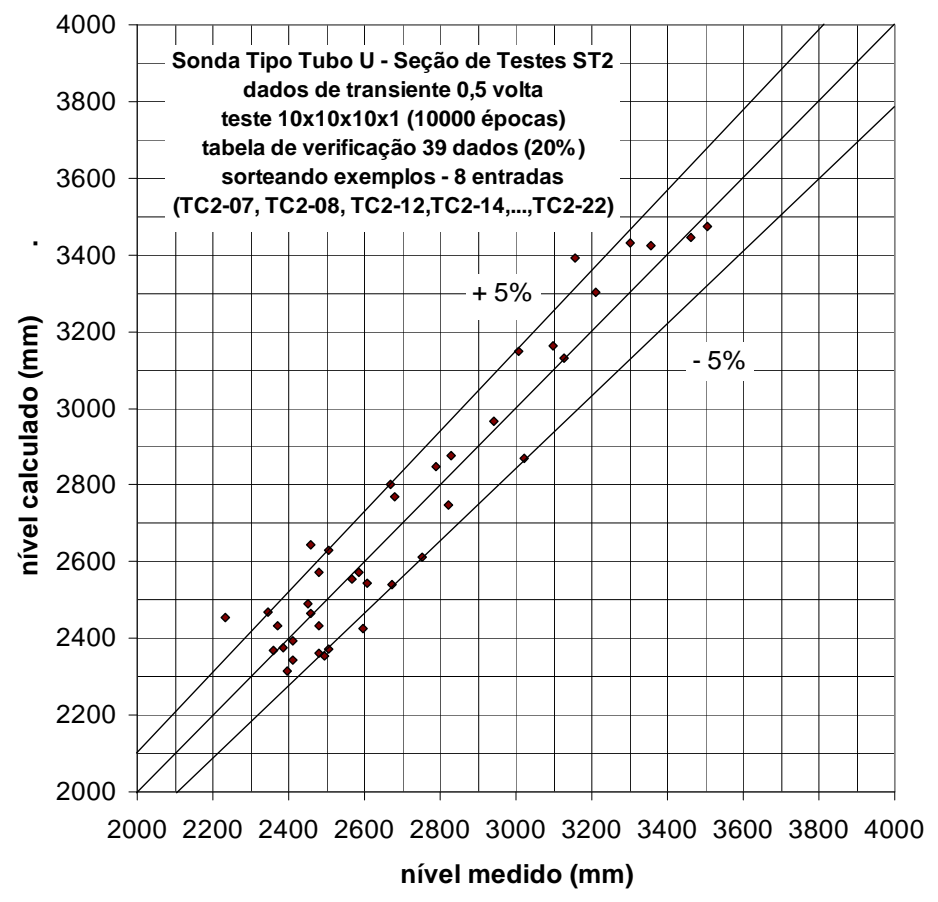

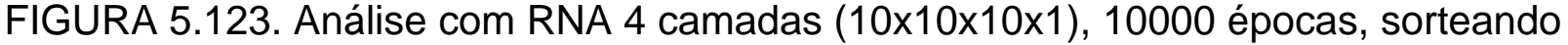
exemplos - tabela de verificação $20 \%$ dados de transiente 0,5 volta e 8 entradas pares. 


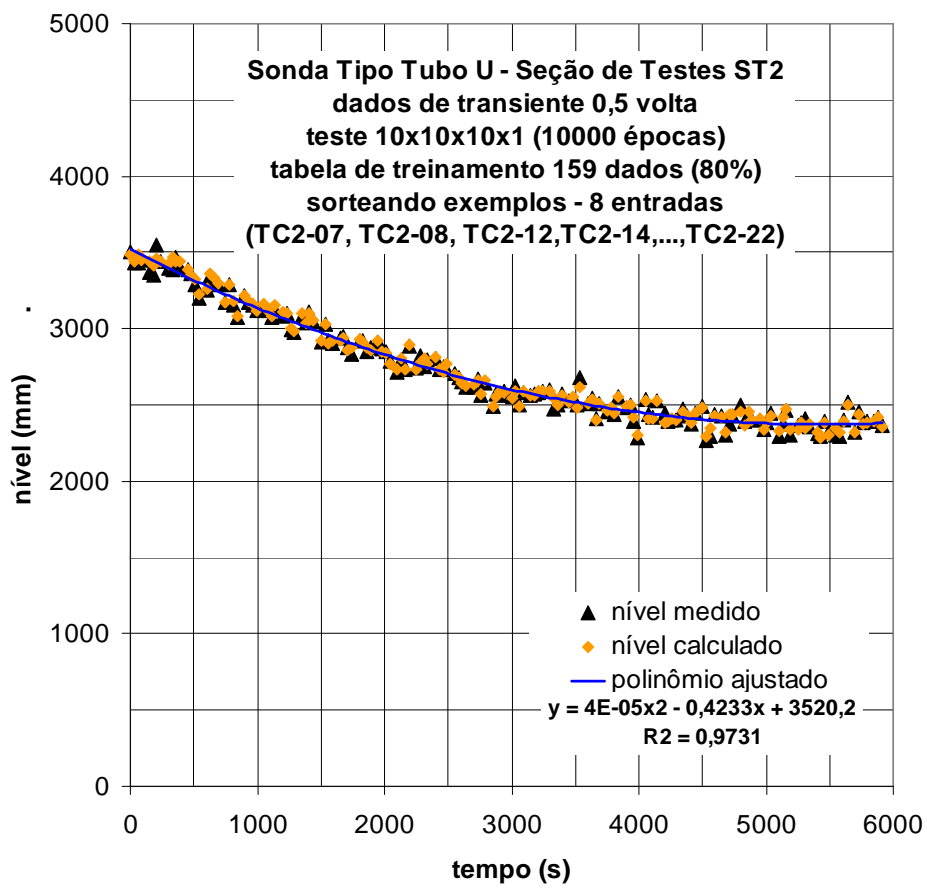

FIGURA 5.124. Nível x tempo para a análise com RNA 4 camadas (10×10×10×1), 10000 épocas, sorteando exemplos e transiente 0,5 volta e 8 entradas pares tabela de treinamento.

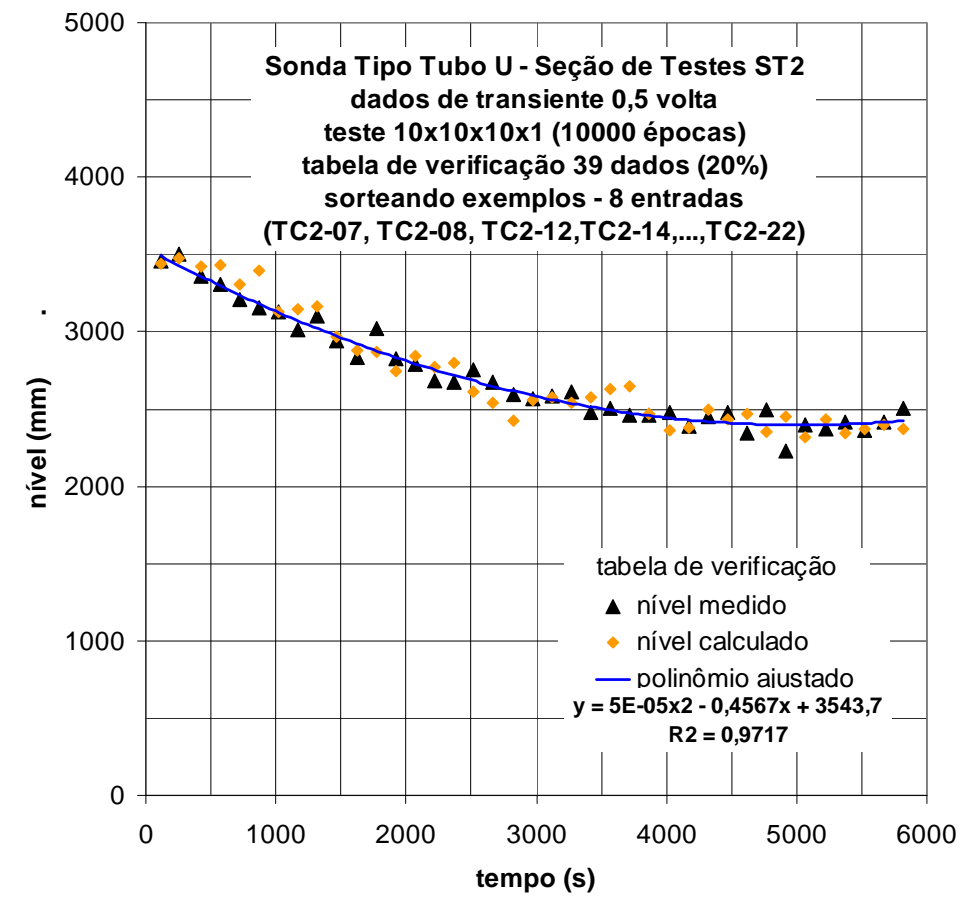

FIGURA 5.125. Nível x tempo para a análise com RNA 4 camadas (10×10×10×1), 10000 épocas, sorteando exemplos e transiente 0,5 volta e 8 entradas pares tabela de. verificação. 


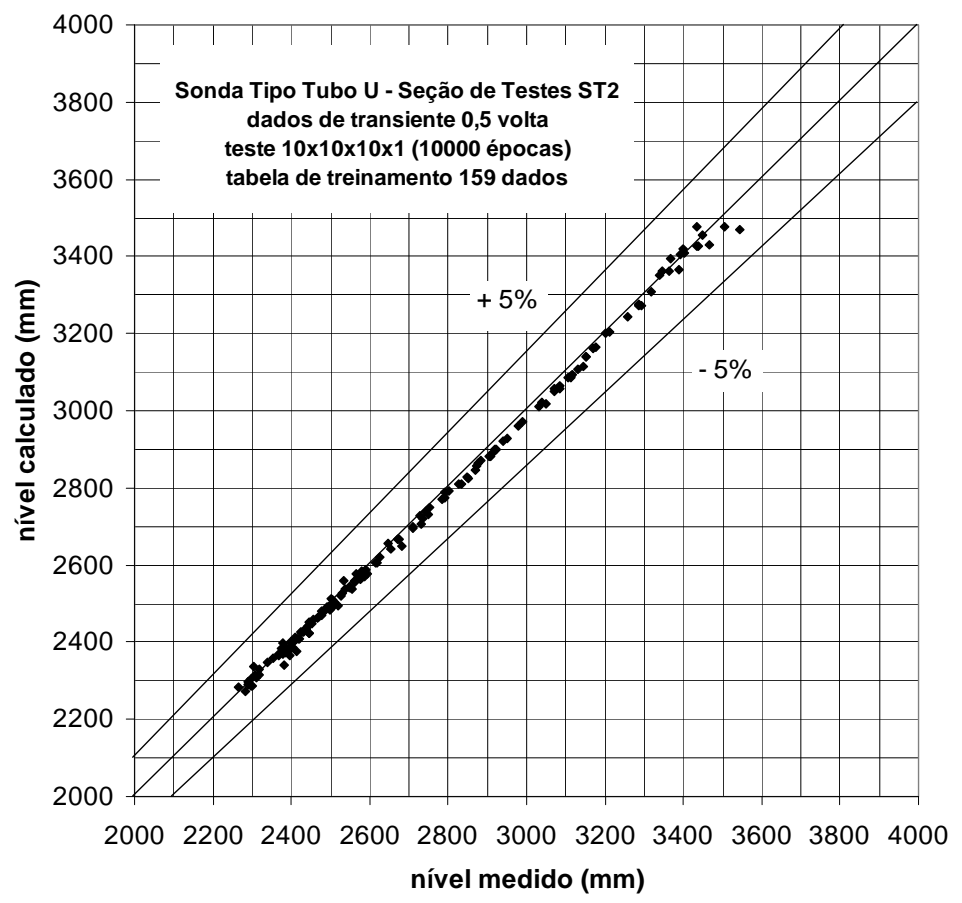

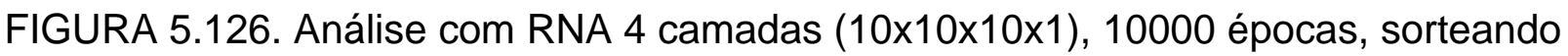
exemplos - tabela de treinamento $80 \%$ dados de transiente 0,5 volta.

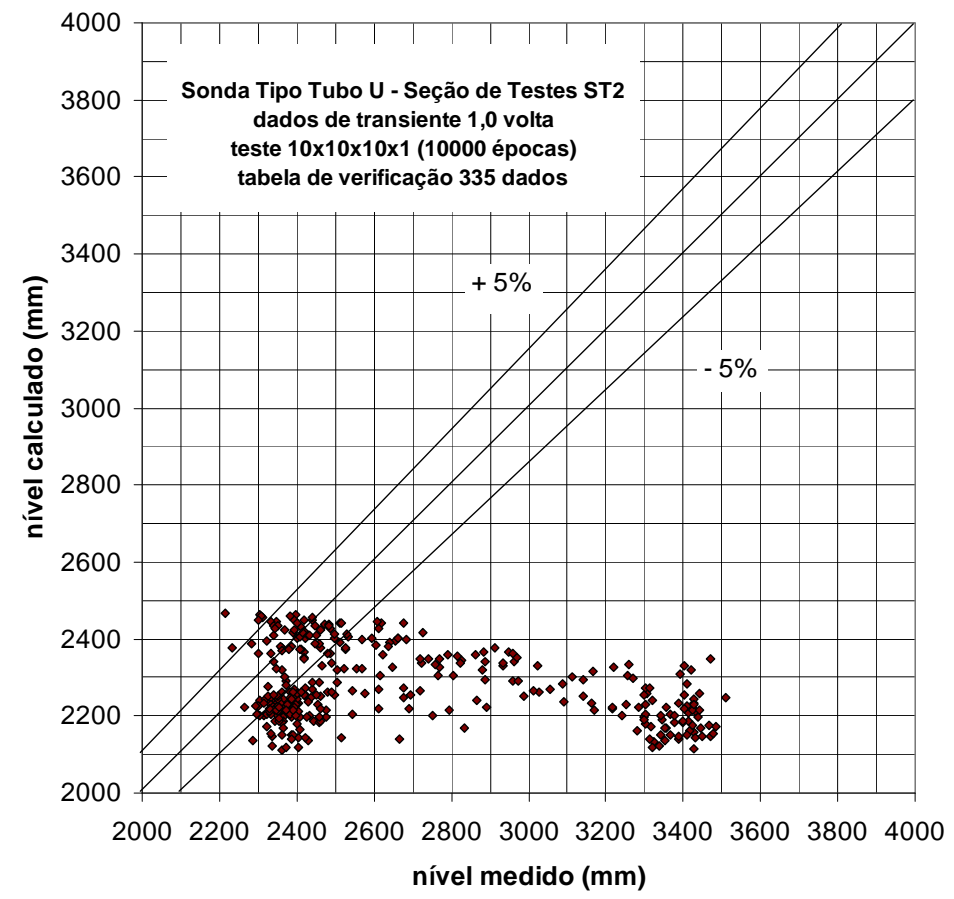

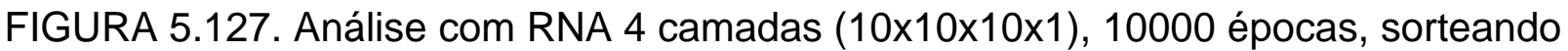
exemplos - tabela de verificação $100 \%$ dados de transiente 1,0 volta. 


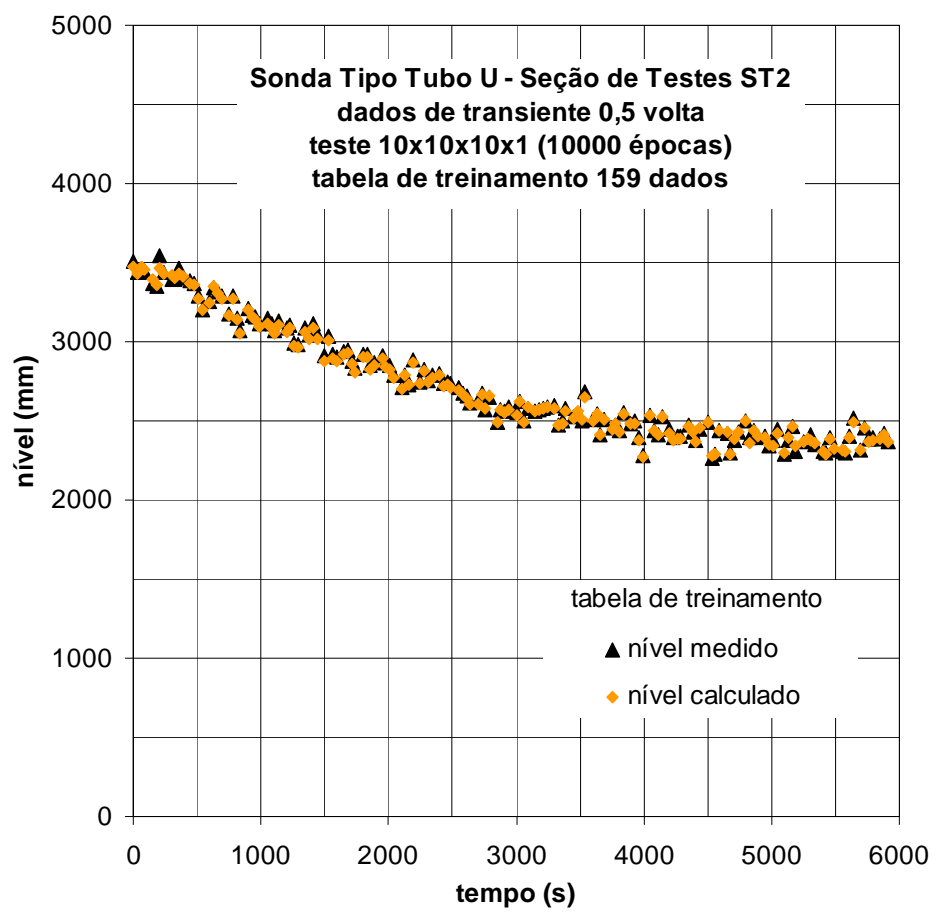

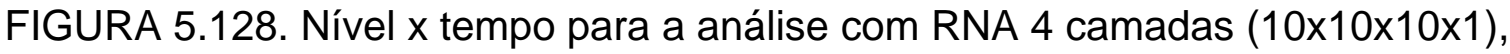
10000 épocas, sorteando exemplos e transiente 0,5 volta - tabela de treinamento.

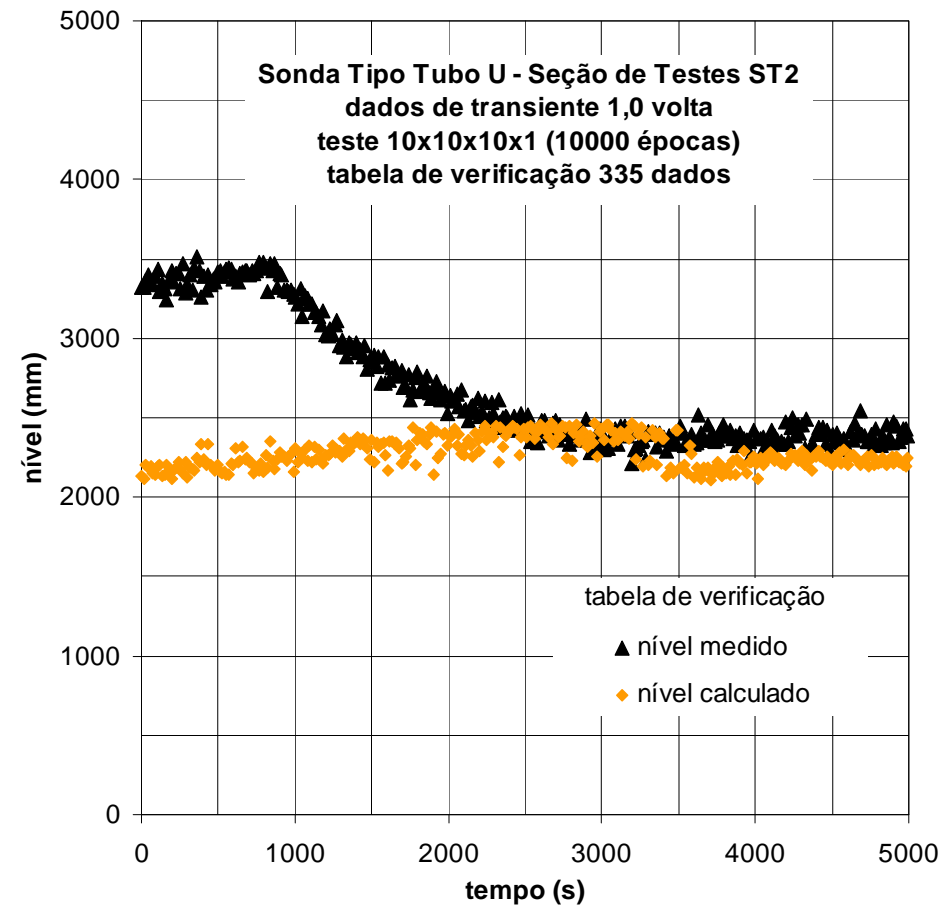

FIGURA 5.129. Nível x tempo para a análise com RNA 4 camadas (10×10×10x1), 10000 épocas, sorteando exemplos e transiente 1,0 volta - tabela de verificação. 


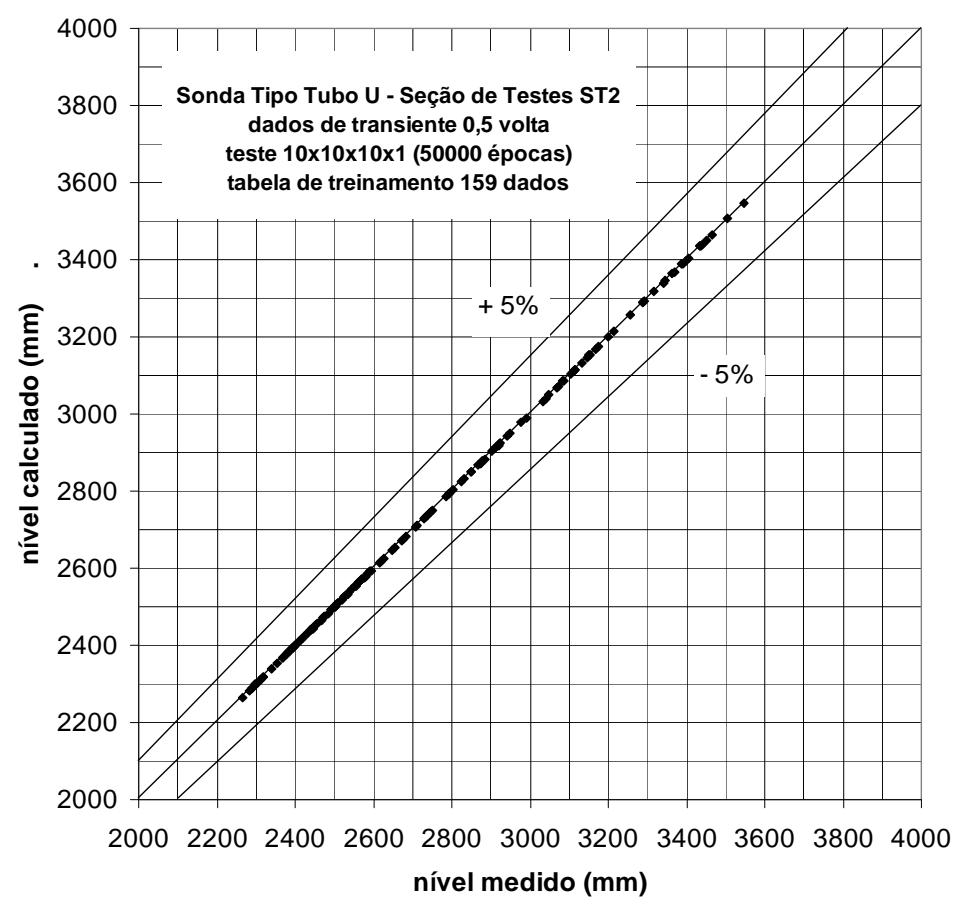

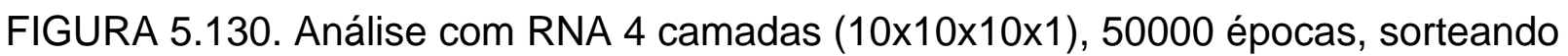
exemplos - tabela de treinamento $80 \%$ dados de transiente 0,5 volta.

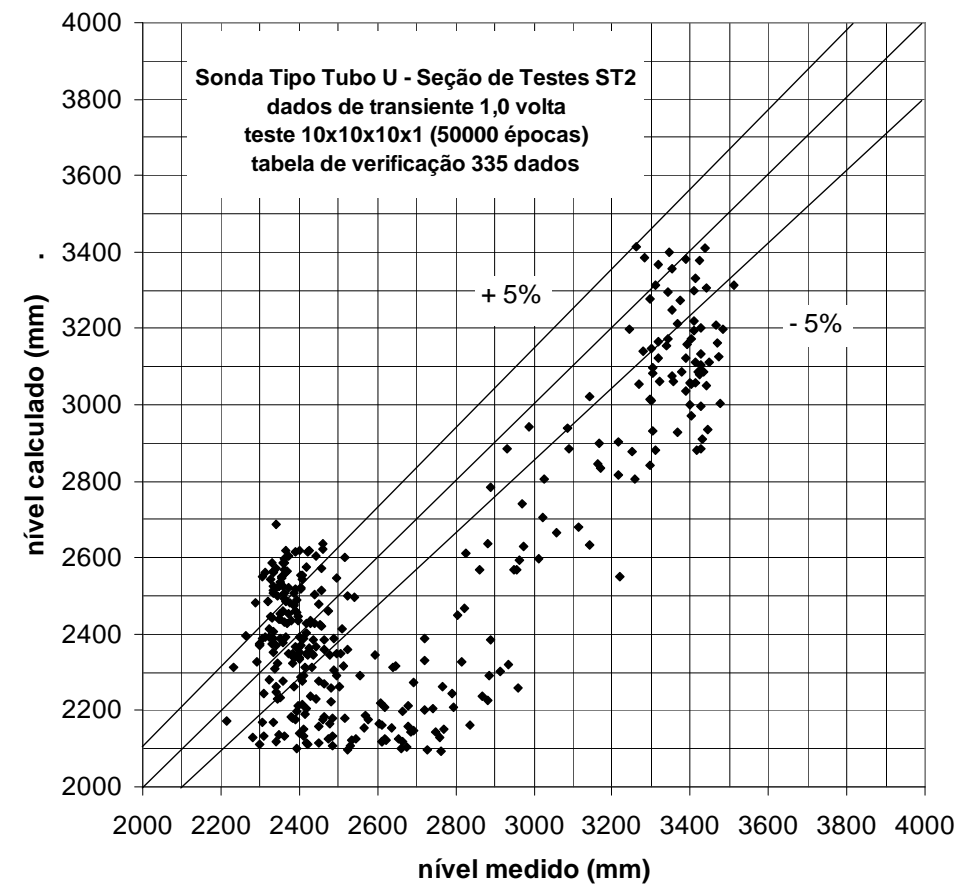

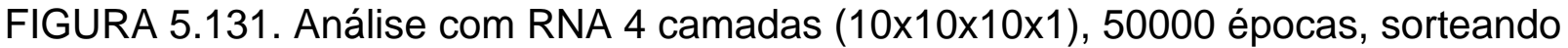
exemplos - tabela de verificação $100 \%$ dados de transiente 1,0 volta. 


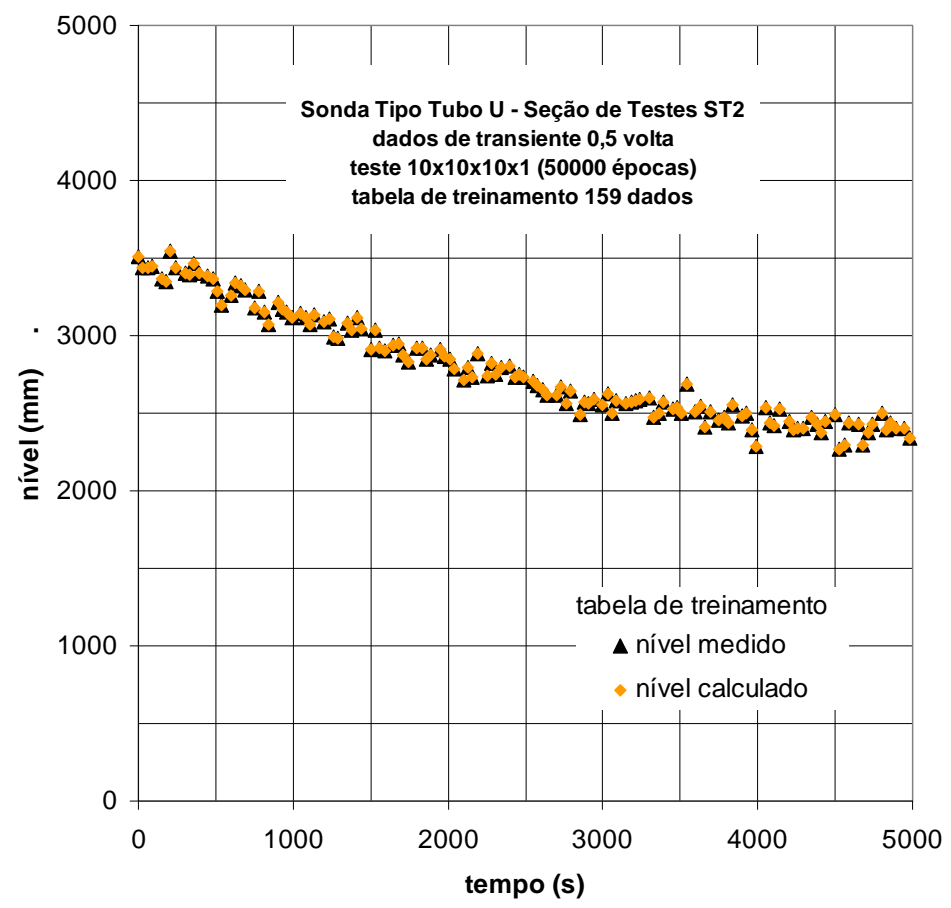

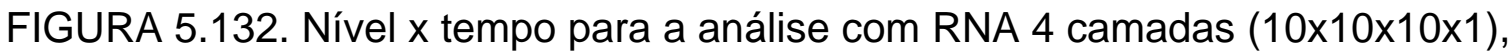
50000 épocas, sorteando exemplos e transiente 0,5 volta - tab. treinamento.

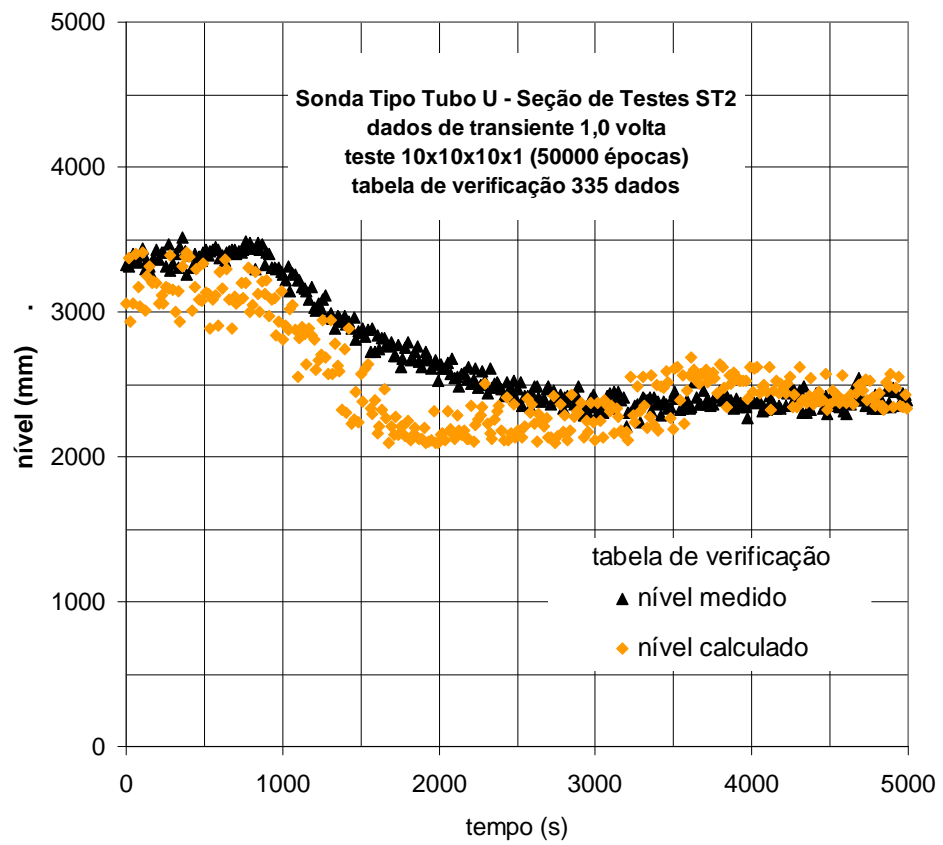

FIGURA 5.133. Nível x tempo para a análise RNA 4 camadas (10x10×10x1), 50000 épocas, sorteando exemplos e transiente 1,0 volta - tabela de verificação. 


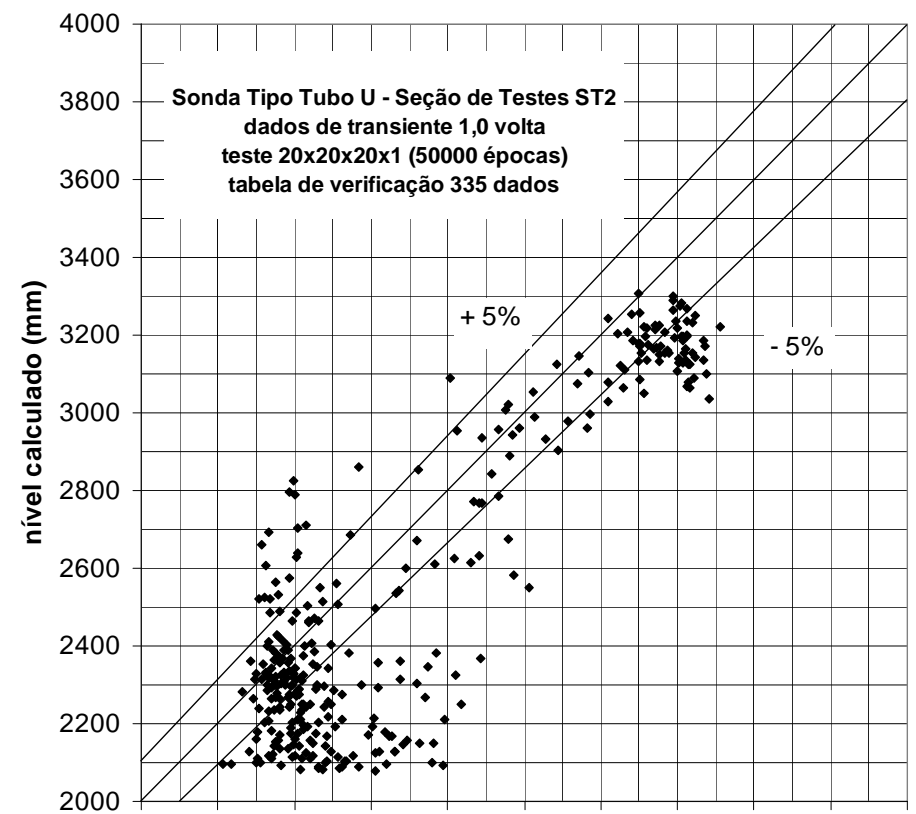

20002200240026002800300032003400360038004000 nível medido $(\mathrm{mm})$

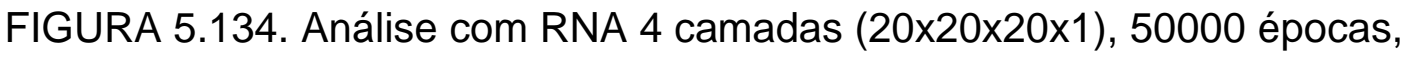
sorteando exemplos - tabela de verificação $100 \%$ dados de transiente 1,0 volta.

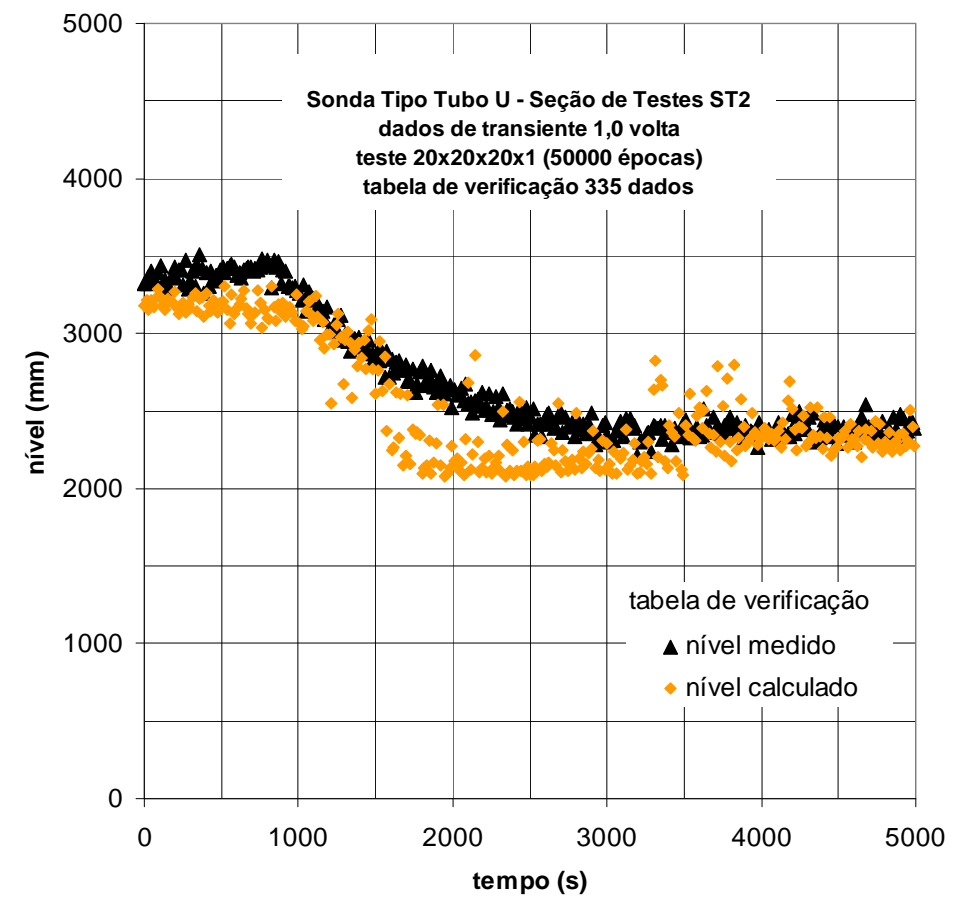

FIGURA 5.135. Nível x tempo para a análise com RNA 4 camadas (20×20×20×1), 50000 épocas, sorteando exemplos e transiente 1,0 volta - tabela de verificação. 


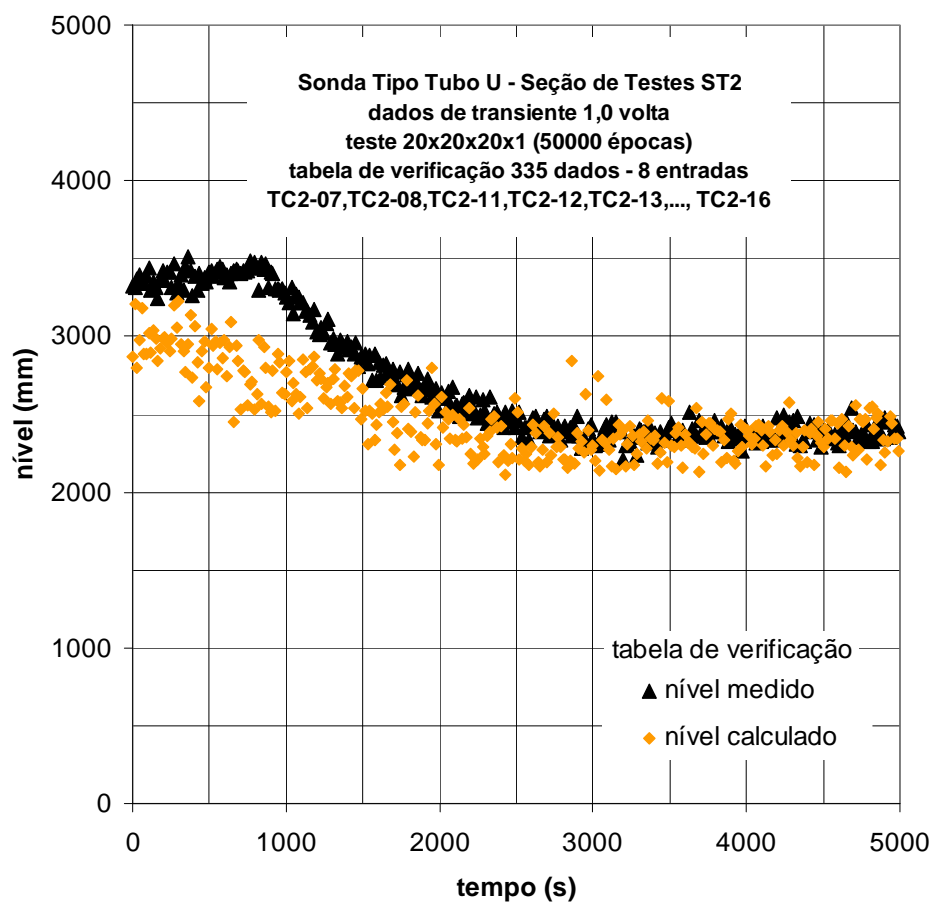

FIGURA 5.136. Nível x tempo para a análise com RNA 4 camadas $(20 \times 20 \times 20 \times 1)$, 50000 épocas, sorteando exemplos, transiente 1,0 volta e 8 entradas superiores.

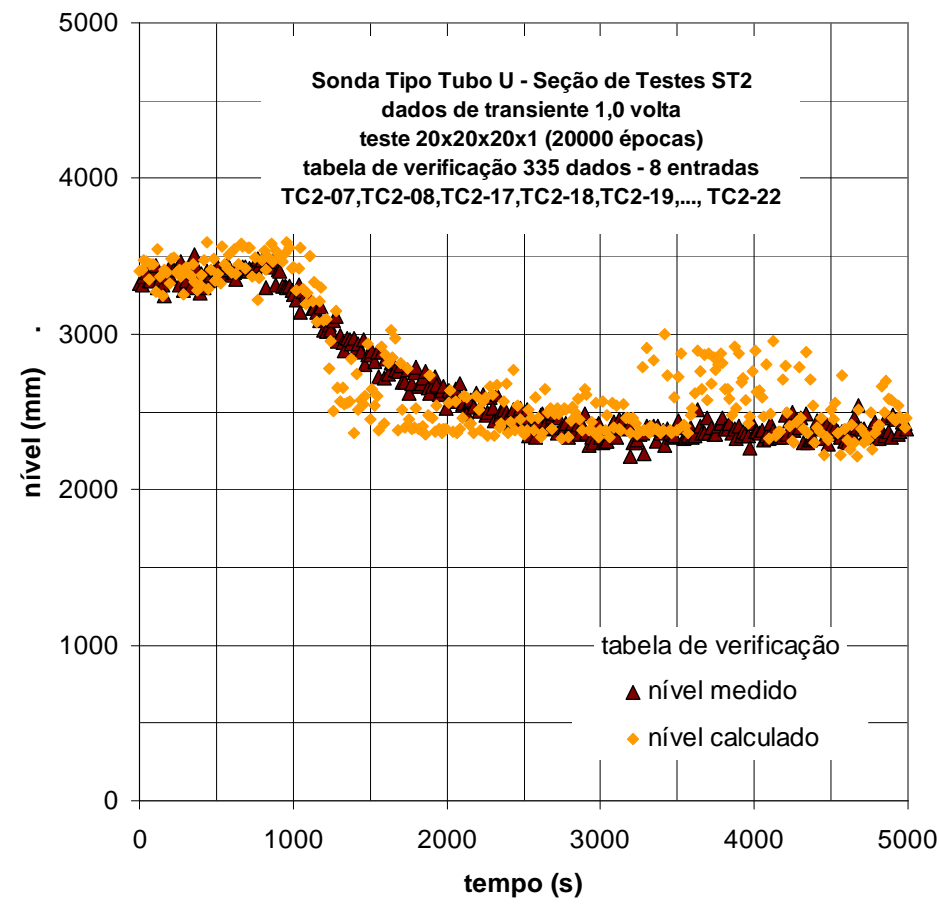

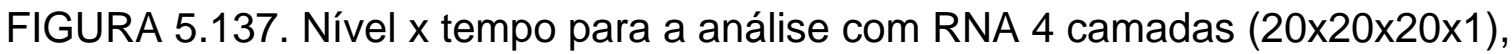
50000 épocas, sorteando exemplos, transiente 1,0 volta e 8 entradas inferiores. 


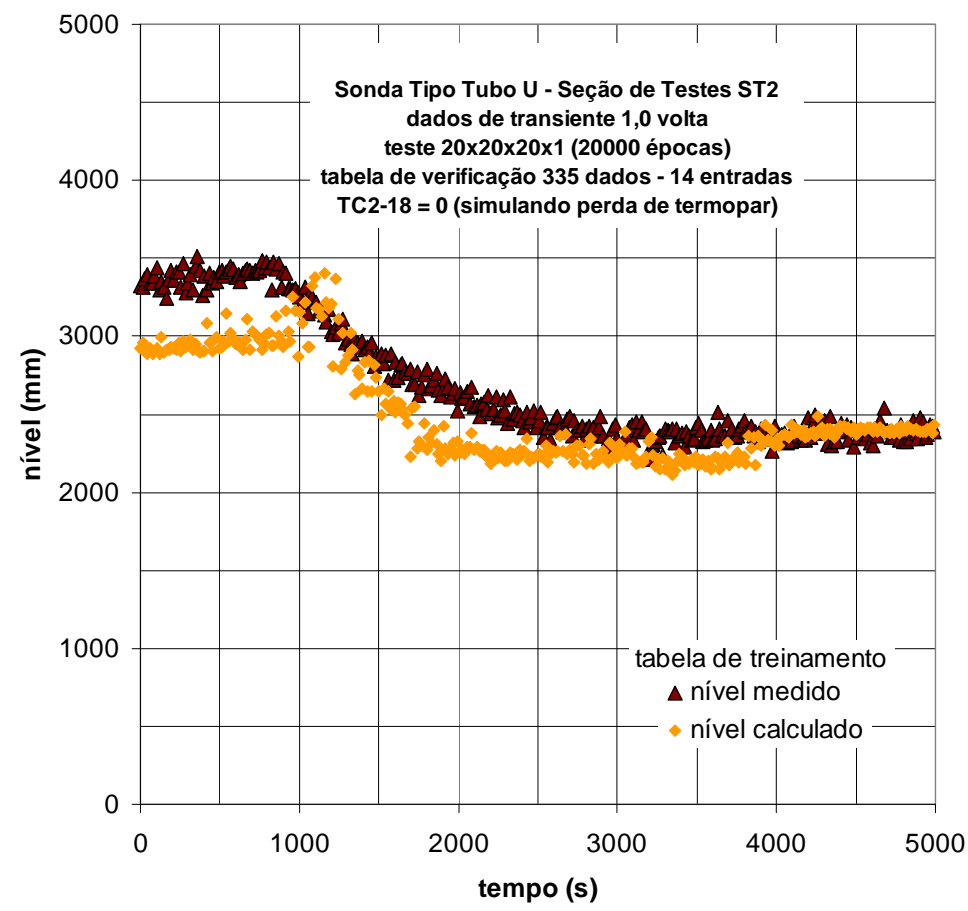

FIGURA 5.138. Nível x tempo para a análise com RNA 4 camadas $(20 \times 20 \times 20 \times 1)$, 20000 épocas, sorteando exemplos, transiente 1,0 volta e TC2-18 $=0-$ tabela de verificação.

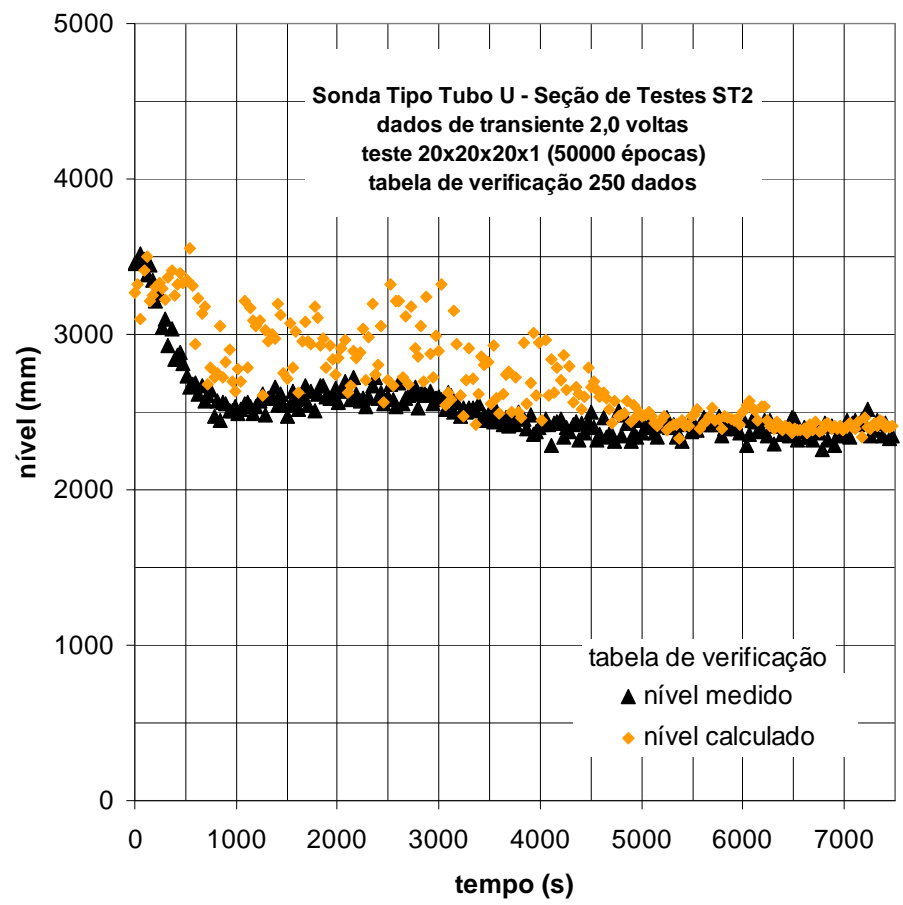

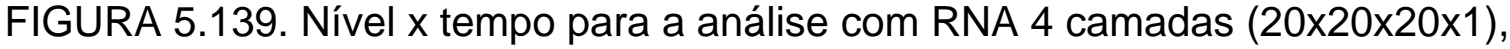
50000 épocas, sorteando exemplos, transiente 2,0 voltas - tabela de verificação. 


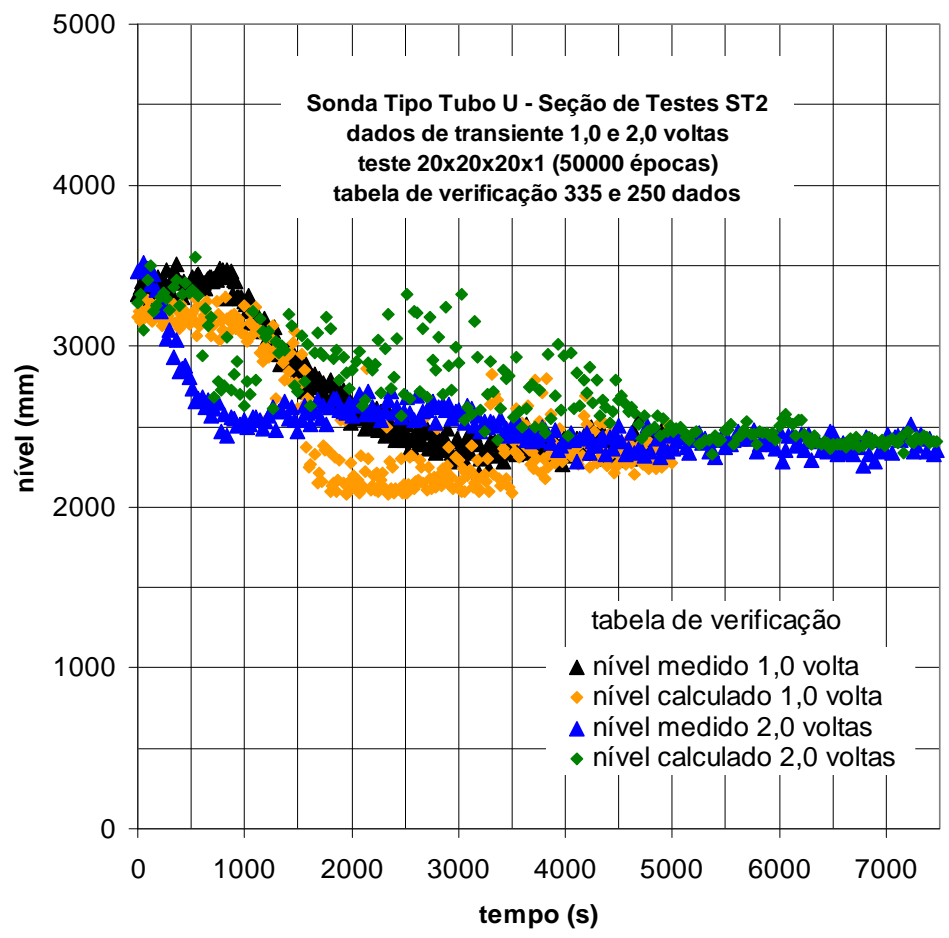

FIGURA 5.140. Nível x tempo para a análise com RNA 4 camadas (20×20×20×1), 50000 épocas, sorteando exemplos, transientes 1,0 e 2,0 voltas tabela de verificação. 


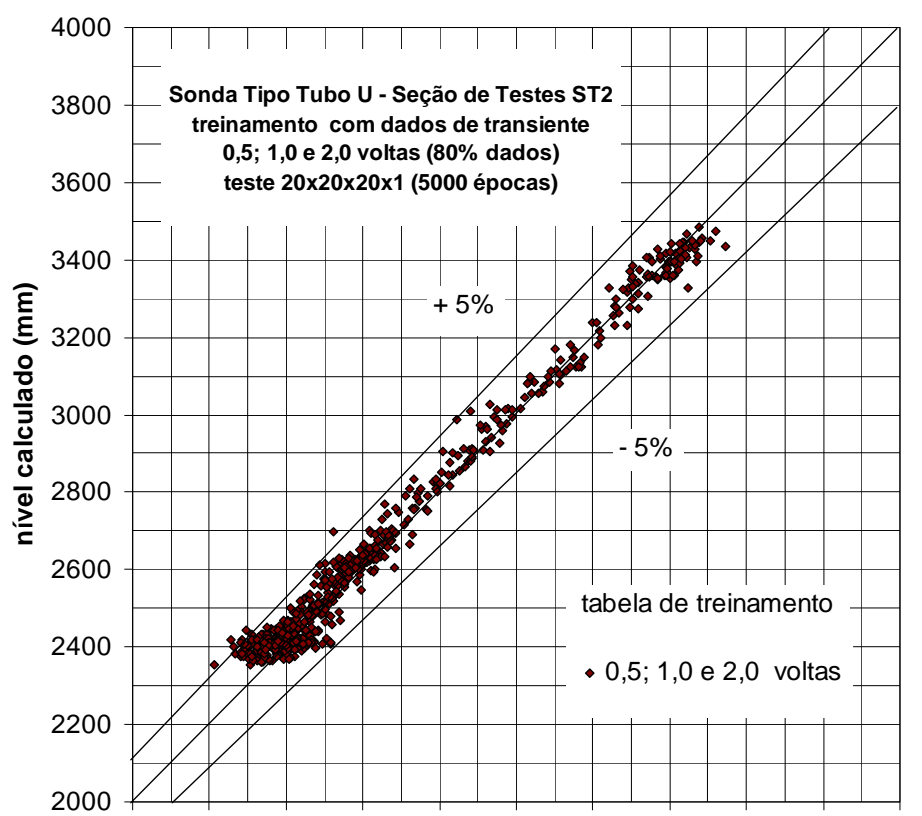

20002200240026002800300032003400360038004000 nível medido (mm)

FIGURA 5.141. Análise com RNA 4 camadas (20×20×20×1), 5000 épocas, sorteando exemplos - tabela de treinamento $80 \%$ dados de transiente 0,$5 ; 1,0$ e 2,0 voltas.

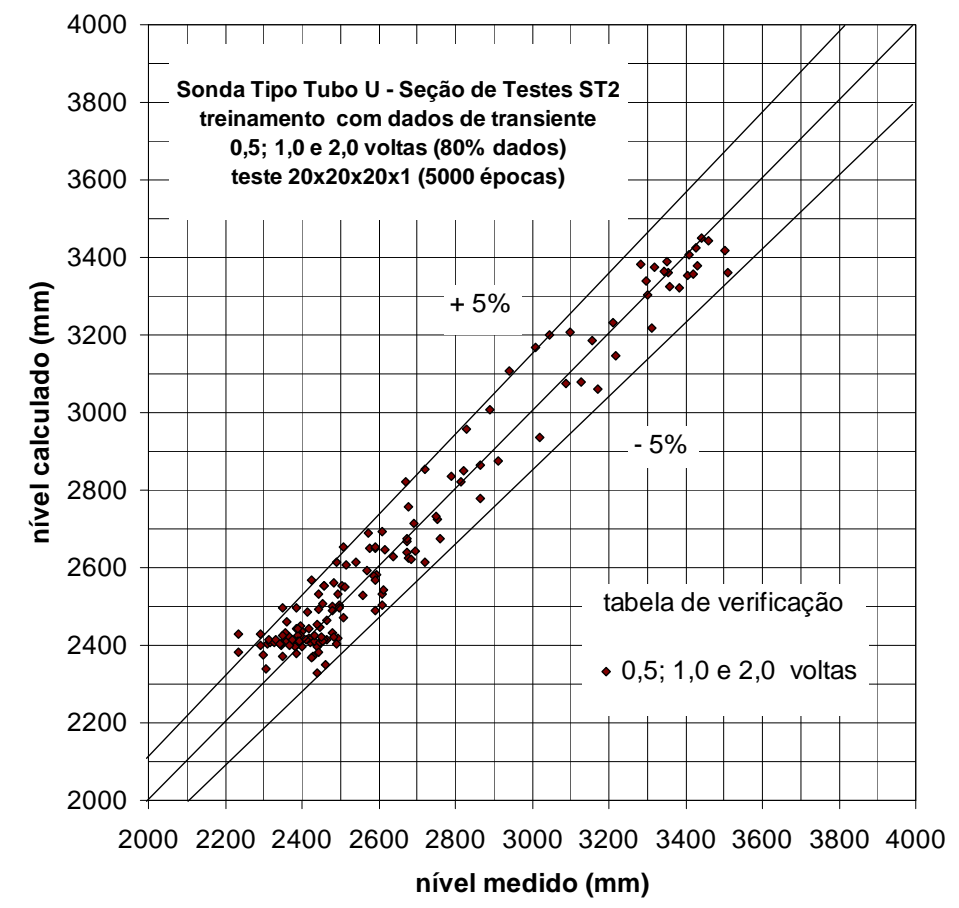

FIGURA 5.142. Análise com RNA 4 camadas (20x20×20x1), 5000 épocas, sorteando exemplos - tabela de verificação $20 \%$ dados de transiente 0,$5 ; 1,0$ e 2,0 voltas. 


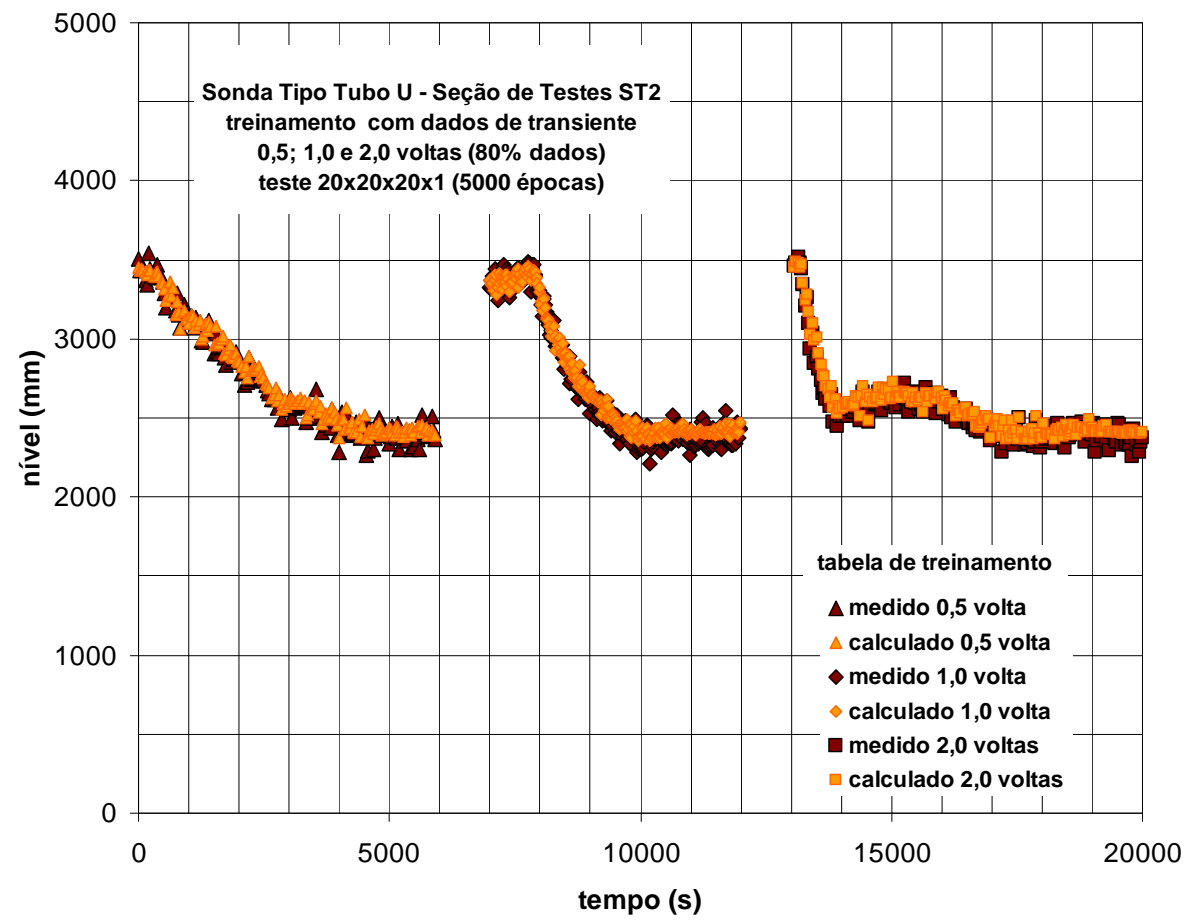

FIGURA 5.143. Nível x tempo para a análise com RNA 4 camadas (20x20×20×1), 5000 épocas, sorteando exemplos, transientes 0,$5 ; 1,0$ e 2,0 voltas tabela de treinamento.

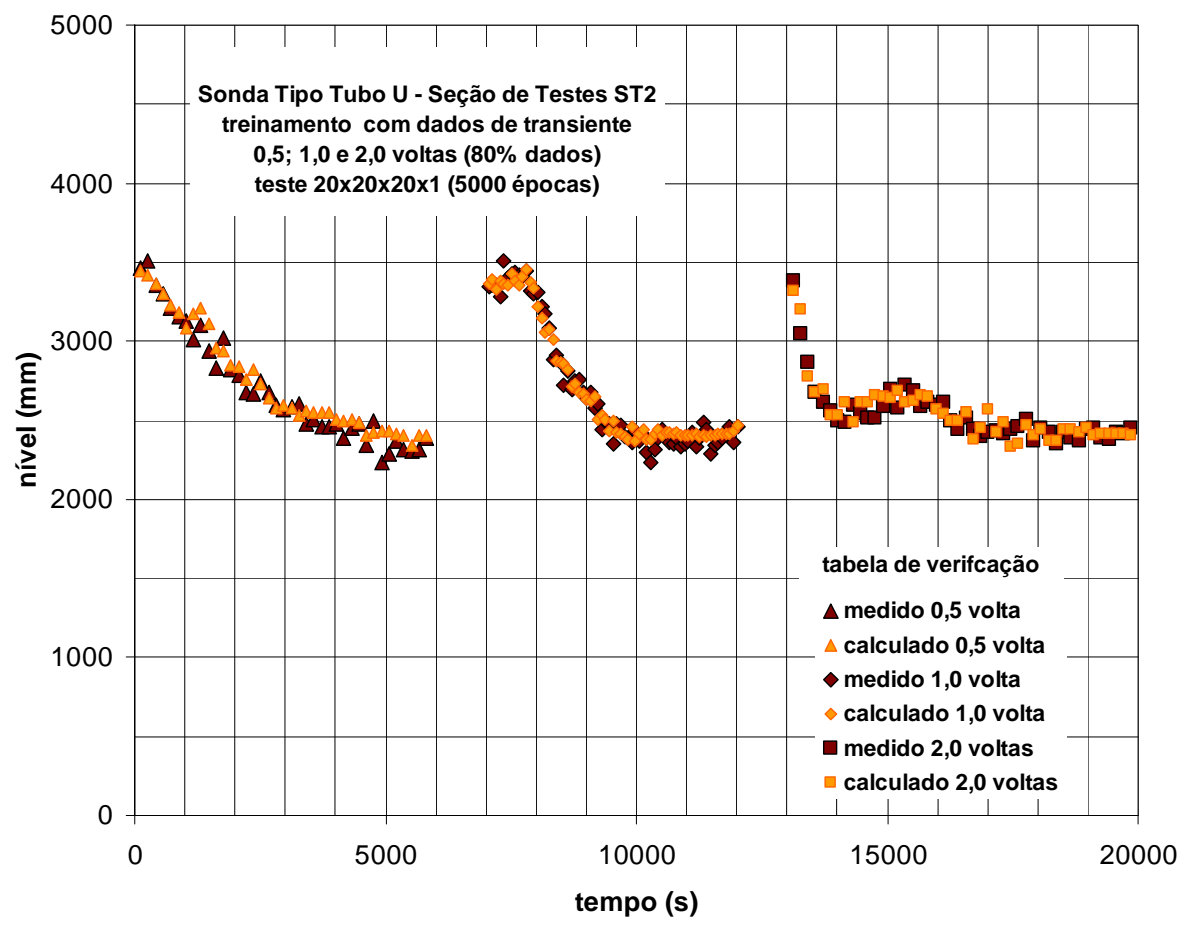

FIGURA 5.144. Nível x tempo para a análise com RNA 4 camadas (20×20×20×1), 5000 épocas, sorteando exemplos, transientes 0,5; 1,0 e 2,0 voltas tabela de verificação. 


\subsubsection{Cálculo da Incerteza na medida de nível para a Sonda de Tubo U}

Durante os testes, o nível colapsado nas seções de testes ST1 e ST2 foi medido por transmissores de pressão diferencial calibrados na faixa de 0 - $5000 \mathrm{mmH} 2 \mathrm{O}(0$ - $48980 \mathrm{~Pa})$. Na calibração destes instrumentos foram usados: um timoneiro, um calibrador microprocessado Cappo 10 da Ecil e um multímetro HP 34410 A para medir o sinal de saída de 4-20 mA. O calibrador Cappo10 é utilizado para calibrar instrumentos de pressão e é aferido regularmente em laboratórios credenciados pela Rede Brasileira de Calibração. Assim sendo é considerado um padrão primário de medida de pressão. O multímetro HP 34410 A, conforme catálogo do fabricante tem capacidade para medir correntes contínuas com uma precisão dada por:

$\Delta \mathrm{I}= \pm(0,06 \%$ do valor medido $+0,03 \%$ da faixa de medida $)$

5.1

Aplicando-se a EQ. 5.1 aos dados de calibração apresentados no APÊNDICE B obtém-se um valor máximo para $\Delta \mathrm{I}=0,2 \%$ nas medidas do sinal de corrente produzido pelos transmissores de pressão diferencial. Considerando essa incerteza de 0,2\% na corrente, nas equações de calibração dos transmissores de pressão diferencial obtém-se uma incerteza máxima nas medidas de pressão de $\pm 5,5 \mathrm{mmH} 2 \mathrm{O}$, considerada desprezível quando comparada com a faixa de calibração de $5000 \mathrm{mmH} 2 \mathrm{O}$. Os transmissores de pressão diferencial foram calibrados de forma a fornecer diretamente o nível colapsado nas seções de testes ST1 e ST2. Portanto, considerou-se que os valores de nível colapsado medidos pelos transmissores de pressão diferencial como sendo os "valores mais prováveis" deste parâmetro. Os valores de nível colapsado calculados pela RNA a partir dos dados de temperatura da sonda de tubo $U$ serão comparados com os valores medidos pelo transmissor de pressão diferencial para estimar a incerteza na medida de nível utilizando a sonda. Outro ponto a se destacar é que a calibração é realizada em laboratório e em condições de pressão constante, portanto as flutuações na 
pressão inexistem ou são desprezíveis, fato que não ocorre durante os testes. Neste caso utilizaremos uma ou mais curvas ajustadas aos valores medidos pelo transmissor de pressão diferencial e que representará os "valores mais prováveis" da medida. Em decorrência dessas flutuações, essas curvas ajustadas apresentam uma incerteza que será estimada.

Considere $\mathrm{n}$ medidas experimentais $\mathrm{y}_{\mathrm{i}}$ fornecidas pelo transmissor de pressão diferencial durante um transiente de queda de nível genérico, como mostrado na FIG. 5.145. As medidas experimentais fornecidas pelo transmissor apresentam valores em torno de um valor médio representado pela curva ajustada. A diferença entre o valor da curva ajustada ( $y_{\text {médio }}$ ) e a medida experimental $y_{i}$ fornece o desvio daquela medida, conforme EQ. 5.2.

$$
d_{i}=y_{\text {médio }}-y_{i}
$$

O desvio padrão em torno do valor médio é dado pela raiz quadrada da soma dos quadrados dos desvios, dividido pelo número de medidas menos um, conforme EQ. 5.3

$$
\sigma=\left(\sum d_{i}^{2} /(n-1)\right)^{0,5}
$$

Considerando um fator de abrangência de $2 \sigma$ (95\%), os valores medidos pelo transmissor de pressão estarão dentro da faixa conforme EQ. 5.4.

$$
y_{i}=y_{\text {médio }}+/-2 \sigma
$$

O parâmetro $2 \sigma$ fornece uma medida da incerteza da medida de nível realizada pelo transmissor de pressão diferencial. Uma vez obtidas as curvas da 
FIG. 5.145, colocaremos na mesma figura os valores de nível calculados pela RNA tanto para a tabela de treinamento quanto para a tabela de verificação.

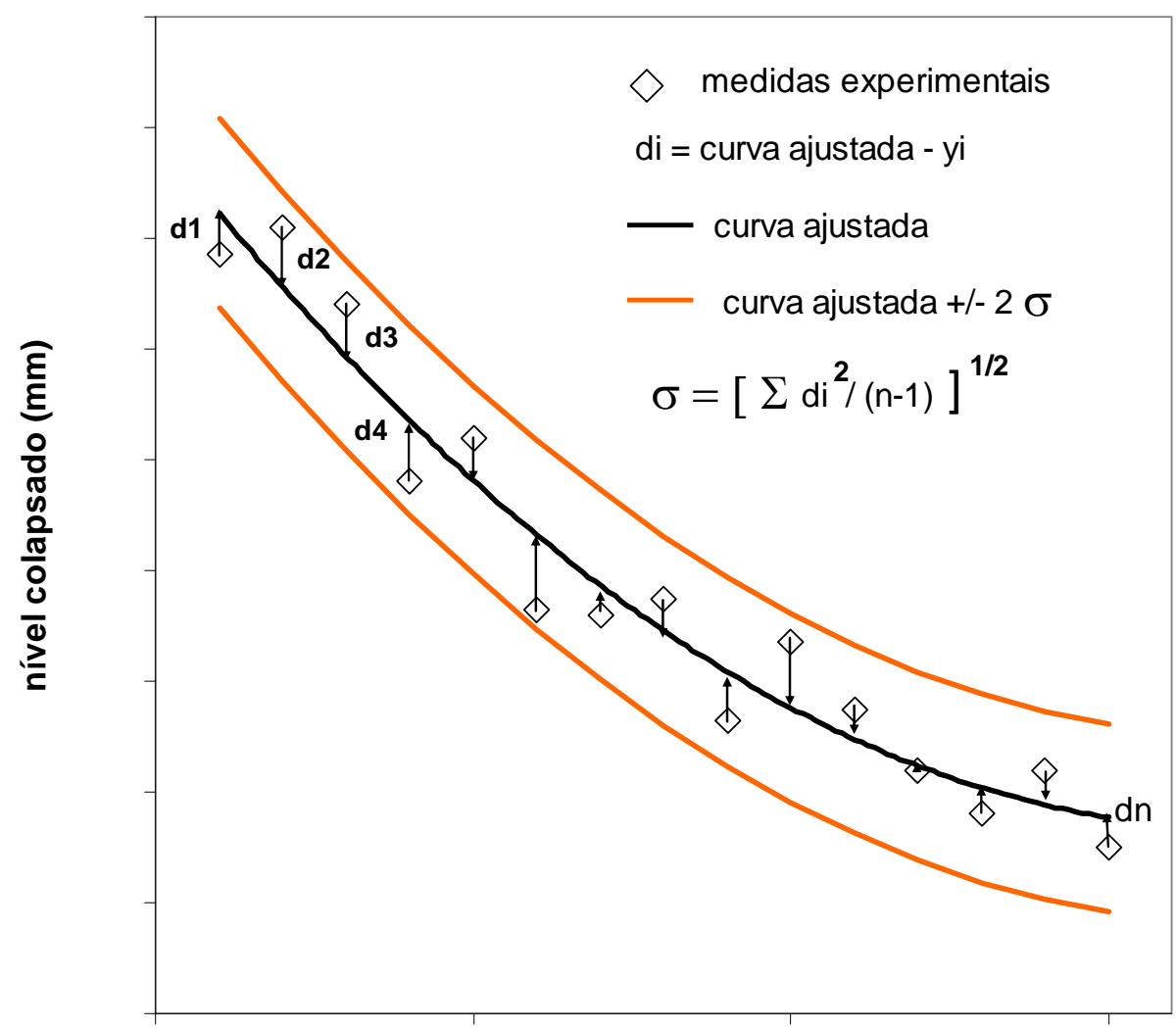

tempo (s)

FIGURA 5.145 - Exemplo ilustrativo de estimativa da Incerteza $(2 \sigma)$ na medida do nível pelo transmissor de pressão diferencial.

Para estimar a incerteza na medida de nível pela sonda de tubo $U$ consideraremos as condições de transiente apresentadas nas FIG. 5.143 e 5.144 referentes a 0,5 , 1,0 e 2,0 de abertura na válvula V1. Como mencionado anteriormente, os dados de temperatura medidos pela sonda de tubo $U$ nestas três condições de transiente foram agrupados e posteriormente separados na proporção de $80 \%$ para a tabela de treinamento e $20 \%$ para a tabela de verificação. 
O procedimento acima descrito foi aplicado às três condições de transiente, calculando-se as curvas ajustadas e os respectivos desvios padrão. Os resultados são apresentados nas FIG. 5.146, 5.147 e 5.148. As medidas fornecidas pelo transmissor de pressão diferencial foram ajustadas por polinômios, cujas equações também são mostradas. Pode-se observar que os valores de nível calculados pela RNA, tanto para a tabela de treinamento quanto para a tabela de verificação ficaram dentro da faixa de incerteza de $+/-2 \sigma$ calculada para 0 transmissor de pressão diferencial. O maior desvio padrão calculado foi de $\sigma=60 \mathrm{~mm}$, referente ao transiente de 0,5 volta em V1. Este valor máximo foi considerado para calcular a incerteza da medida de nível pela sonda de tubo $U$, ou seja, uma incerteza de $+/-120 \mathrm{~mm}$, representando um mínimo de 3,3\% para o nível de $3600 \mathrm{~mm}$ e um máximo de 5\% para o nível de $2400 \mathrm{~mm}$.

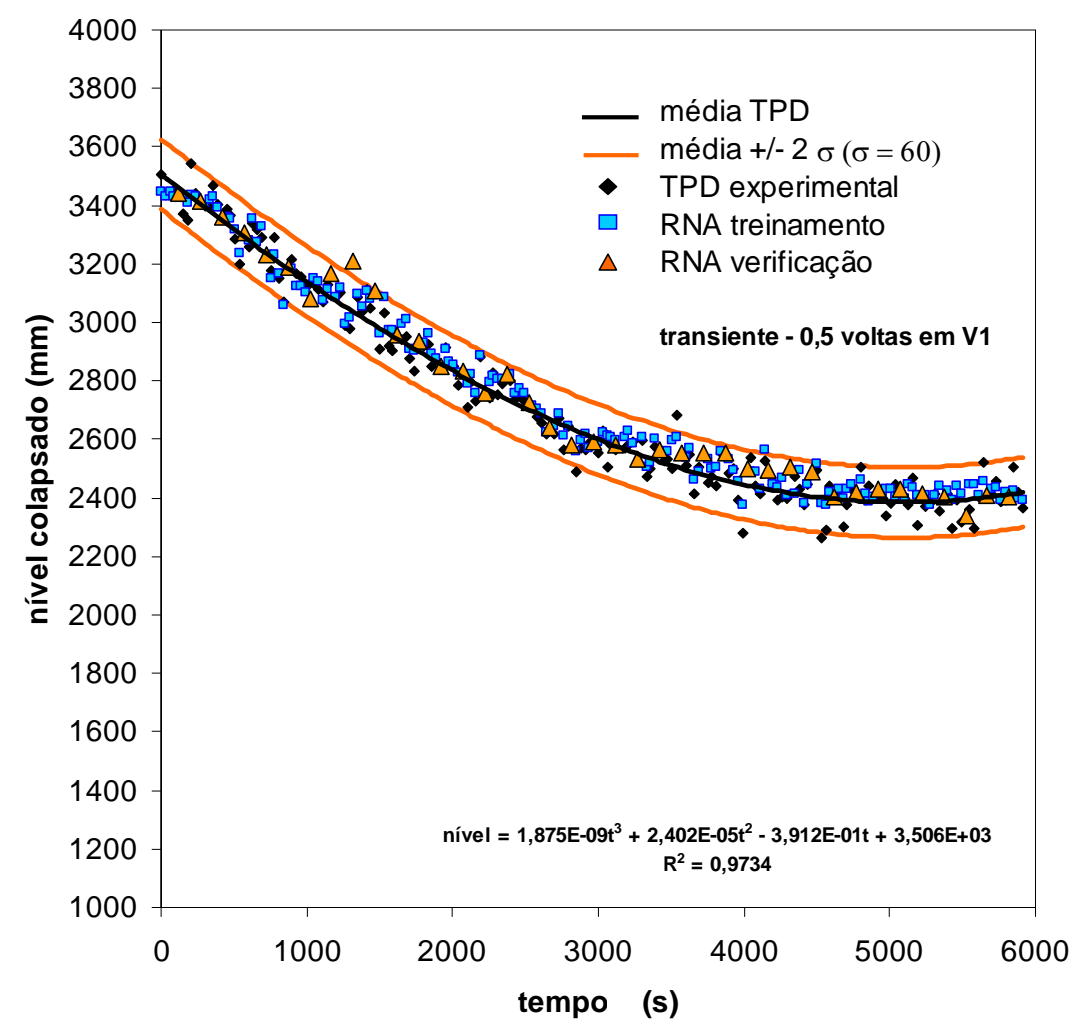

FIGURA 5.146. Incerteza nas medidas de nível para o transiente de 0,5 voltas em V1. 


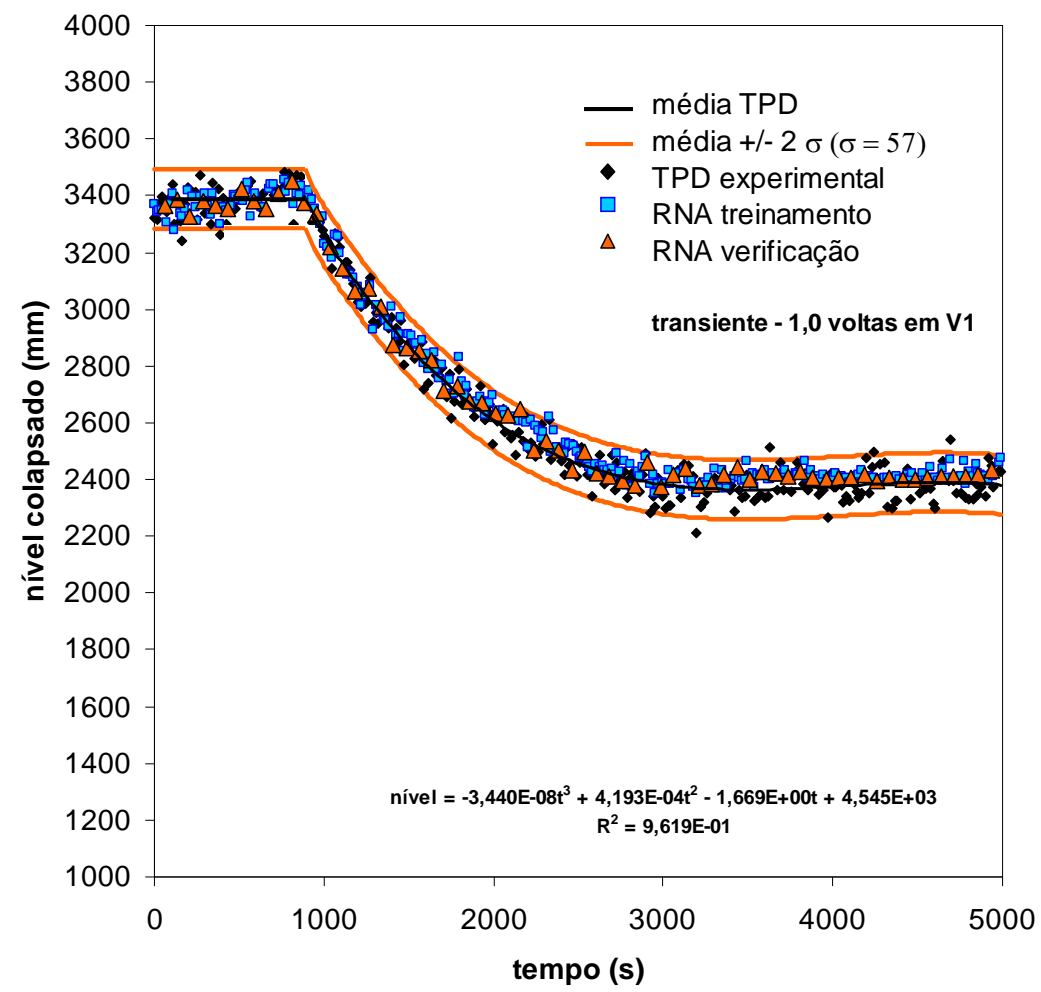

FIGURA 5.147. Incerteza nas medidas de nível para o transiente de 1,0 voltas em V1.

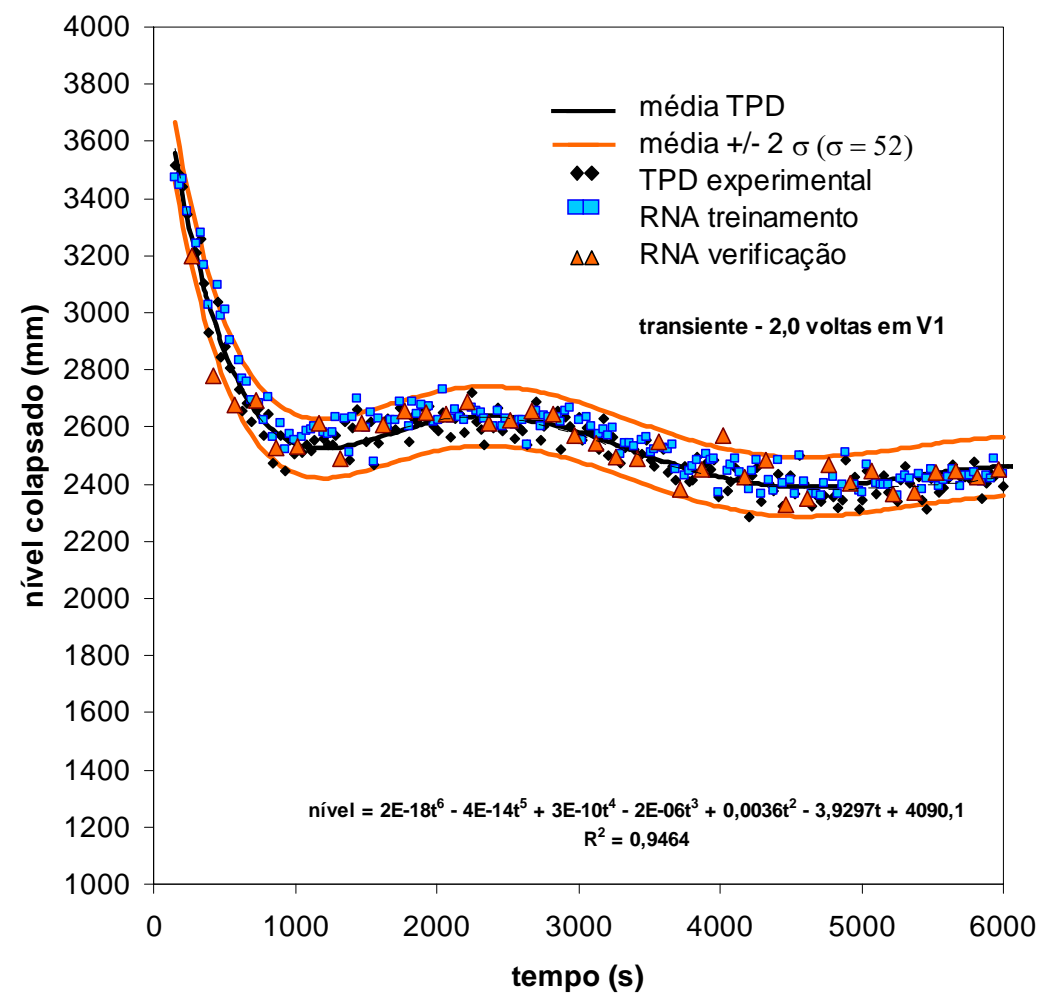

FIGURA 5.148. Incerteza nas medidas de nível para o transiente de 2,0 voltas em V1. 


\subsubsection{Análise dos dados para a Sonda de Tubos Concêntricos na ST1}

As análises com a sonda de tubos concêntricos foram realizadas apenas com os dados dos testes em transientes com 0,5 e 1,0 volta de abertura de válvula apresentados no item 5.2.1. Para a abertura de 0,5 volta mediu-se uma taxa inicial de diminuição de nível de $0,40 \mathrm{~mm} / \mathrm{s}(1440 \mathrm{~mm} / \mathrm{h})$, enquanto que para uma abertura de válvula de 1,0 volta a taxa inicial de diminuição foi de 1,88 mm/s $(6768 \mathrm{~mm} / \mathrm{h})$.

Foram realizados dois testes para o transiente de 0,5 volta em dias distintos. Os dados referentes a um dos testes com 0,5 volta foi usado para compor uma tabela de treinamento com 205 dados e os dados do outro teste foram usados como tabela de verificação com 216 dados. Os dados referentes ao teste de 1,0 volta compuseram outra tabela de verificação com 190 dados.

As análises prévias com RNA's realizadas com os dados dos testes da sonda de tubo $U$ mostraram que os melhores resultados foram obtidos quando se utilizou RNA's com 4 camadas e com um número relativamente elevado de

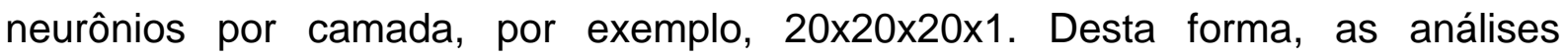
realizadas com os dados experimentais da sonda de tubos concêntricos seguiram nesta mesma linha.

Numa primeira análise utilizaram-se as tabelas de treinamento (205 dados) e verificação (216 dados) referentes ao transiente de 0,5 volta de abertura de válvula, mencionadas anteriormente. Uma RNA de 4 camadas de

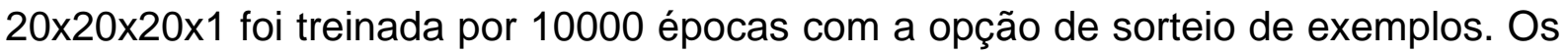
resultados podem ser vistos nas FIG. 5.149 a 5.152. Observa-se que a RNA foi capaz de efetuar as interpolações com os dados de treinamento, produzindo bons resultados, como mostrado nas FIG. 5.149 e 5.150. Contudo, quando esse treinamento é aplicado à tabela de verificação, observa-se que a RNA foi incapaz de generalizar e reproduzir esses dados, mesmo tendo em vista tratar-se de dois transientes semelhantes com mesma abertura de válvula. 
$\mathrm{Na}$ tentativa de melhorar os resultados, uma nova análise foi realizada também com uma RNA de 4 camadas $(20 \times 20 \times 20 \times 1)$ aumentando-se o número de épocas de treinamento para 20000 épocas. Os resultados dessa análise referentes ao aprendizado da tabela de treinamento foram semelhantes àqueles apresentados para 10000 épocas na FIG. 5.149. Quanto à comparação com a tabela de verificação é possível verificar que mesmo com o aumento do número de épocas de treinamento a RNA foi incapaz de generalizar e reproduzir esses dados, como mostra os resultados das FIG. 5.153 e 5.154 .

Em outra análise, aumentou-se em 20000 o número de épocas da análise anterior, usando o recurso proporcionado pelo programa RETRO-05 de reinício de treinamento, portanto a RNA foi treinada por 40000 épocas. Os resultados podem ser vistos nas FIG. 5.155 e 5.156, e são semelhantes aos apresentados na análise anterior.

Duas análises foram realizadas usando a tabela de treinamento anterior e como tabela de verificação os dados referentes ao transiente de 1,0 volta. Uma RNA de 4 camadas $(20 \times 20 \times 20 \times 1)$ foi treinada por 10000 e 20000 épocas com a opção de sorteio de exemplos. Como nas análises anteriores, a RNA efetuou as interpolações com os dados de treinamento, produzindo bons resultados, porém foi incapaz de generalizar e reproduzir os dados da tabela de verificação, conforme mostrado nas FIG. 5.157 a 5.160.

O motivo pelo qual os resultados das análises com RNA's para a sonda de tubos concêntricos produziram resultados insatisfatórios reside nos conjuntos de dados de temperatura obtidos experimentalmente e que apresentaram pouca diferença entre os transientes testados para diferentes números de voltas de abertura de válvula e mesmo para transientes semelhantes, diferentemente do comportamento observado nos resultados experimentais relativos à sonda de tubo U. A RNA consegue interpolar com o conjunto de dados de treinamento, porém não consegue generalizar para outros conjuntos de dados. 


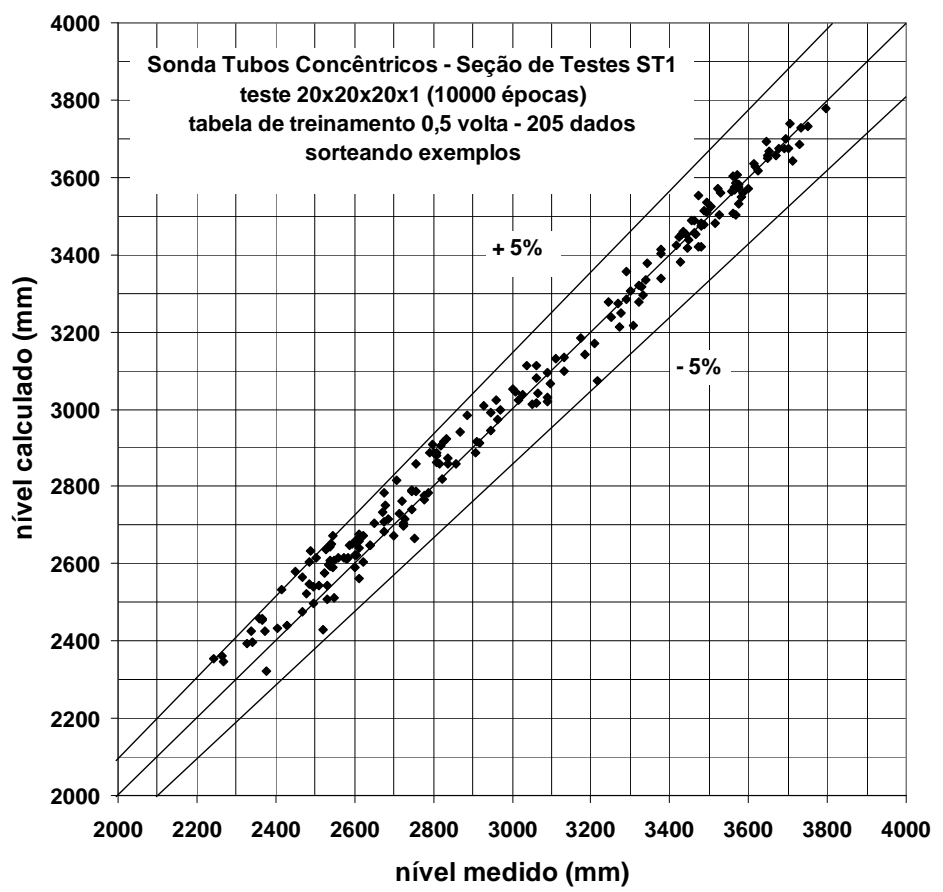

FIGURA 5.149. Análise com RNA 4 camadas (20x20x20x1), 10000 épocas, sorteando exemplos - tabela de treinamento 0,5 volta 205 dados.

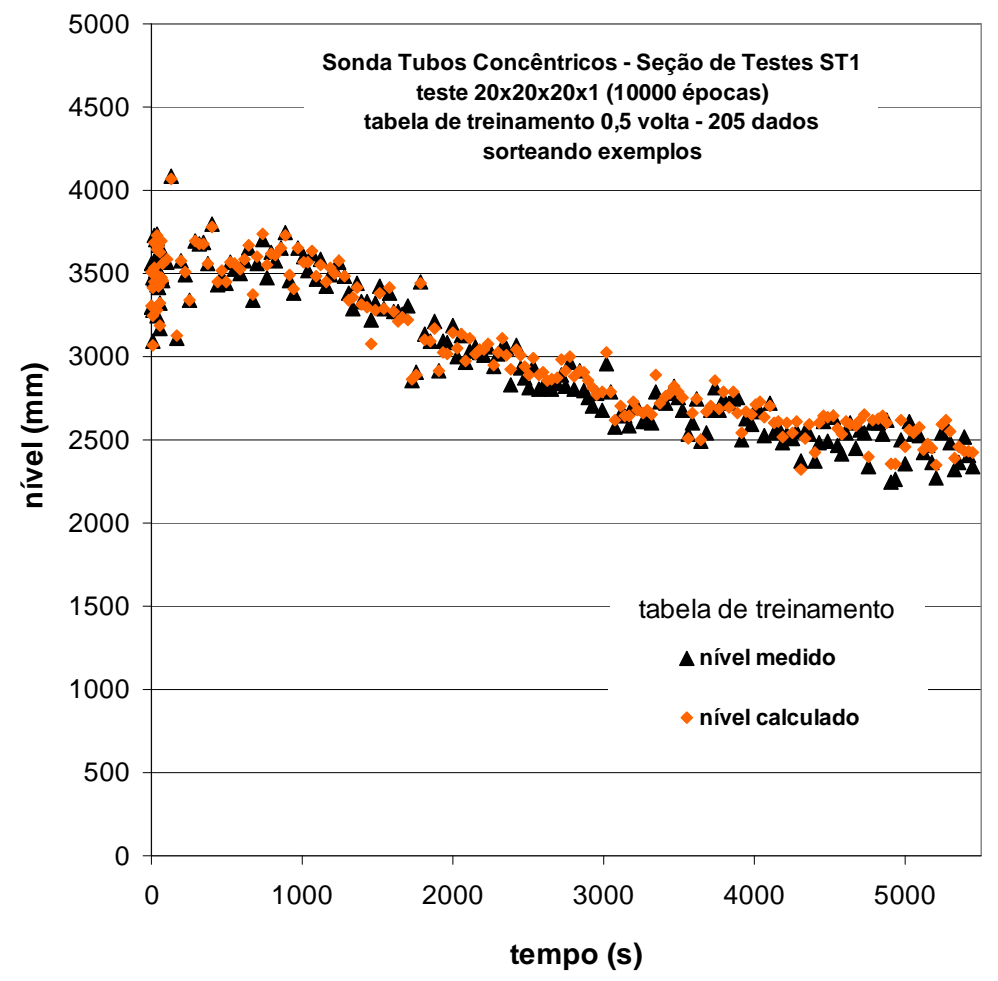

FIGURA 5.150. Nível x tempo para a análise com RNA 4 camadas (20×20×20×1), 10000 épocas, sorteando exemplos e transiente 0,5 volta - tab. treinamento 205 dados. 


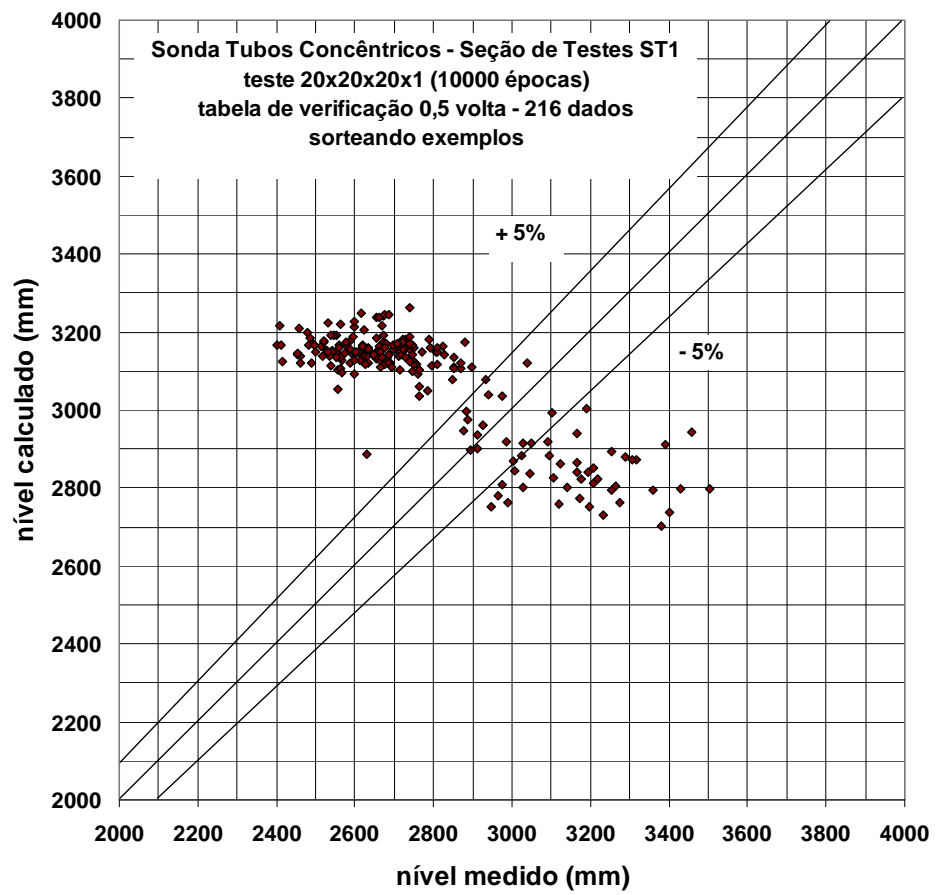

FIGURA 5.151. Análise com RNA 4 camadas (20×20×20×1), 10000 épocas, sorteando exemplos - tabela de verificação 0,5 volta 216 dados.

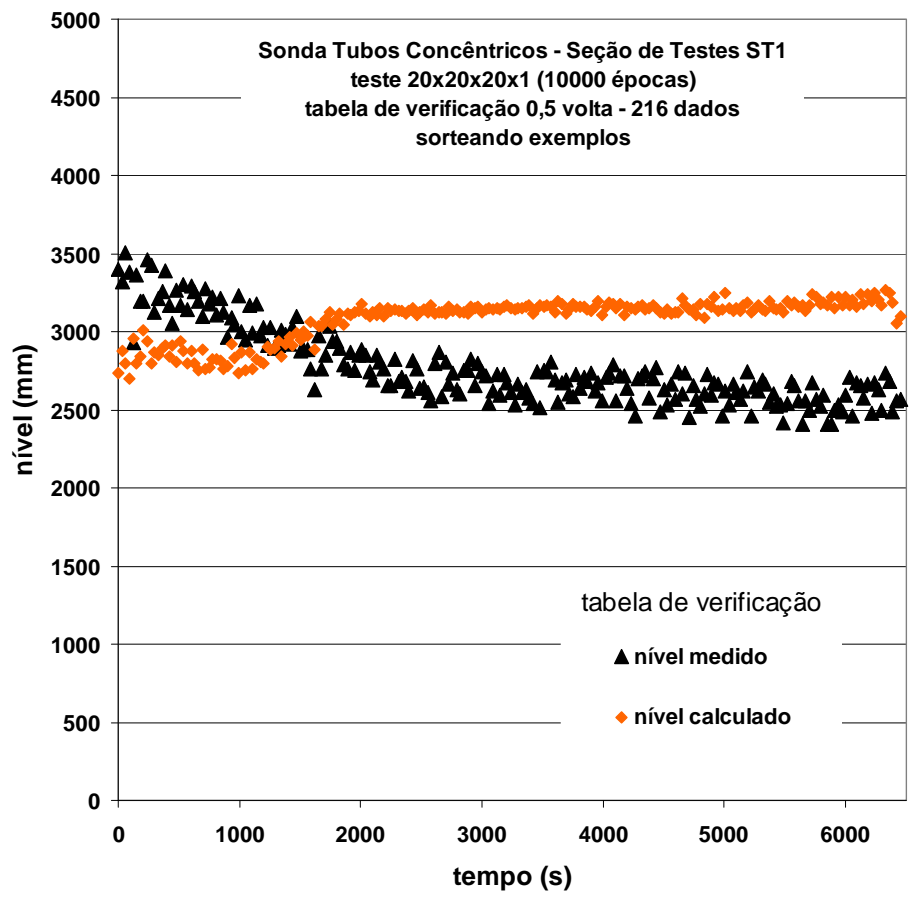

FIGURA 5.152. Nível x tempo para a análise com RNA 4 camadas (20×20×20×1), 10000 épocas, sorteando exemplos e transiente 0,5 volta - tabela de verificação -216 dados. 


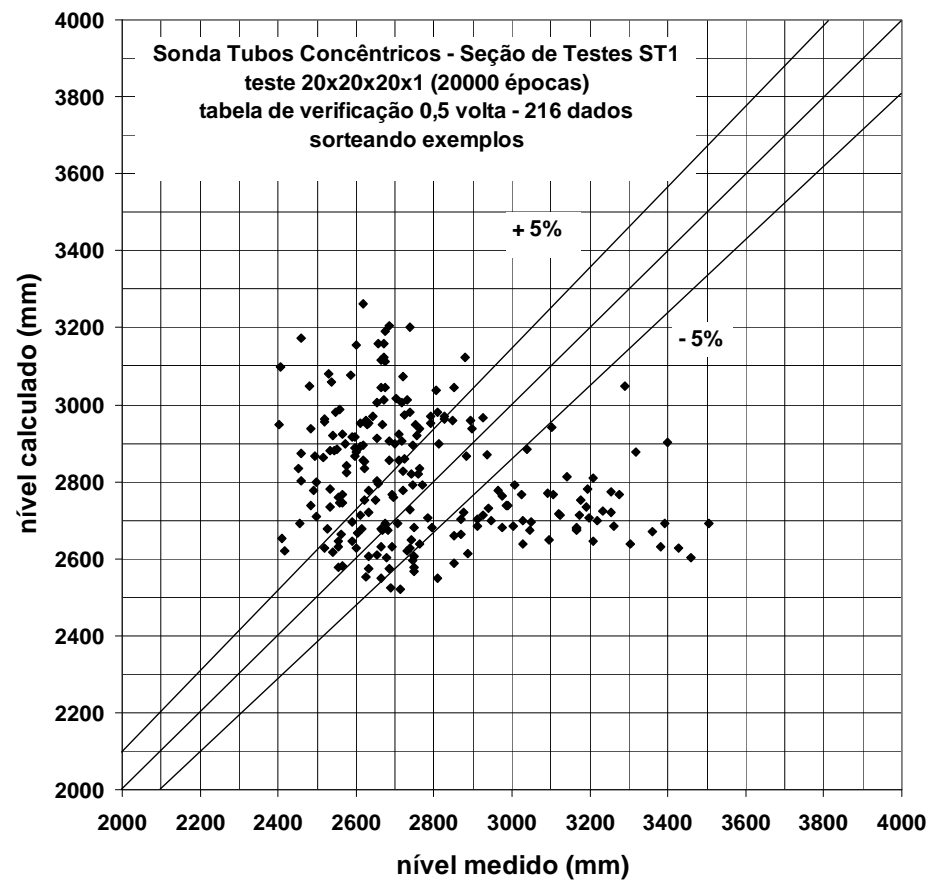

FIGURA 5.153. Análise com RNA 4 camadas (20x20×20x1), 20000 épocas, sorteando exemplos - tabela de verificação 0,5 volta 216 dados.

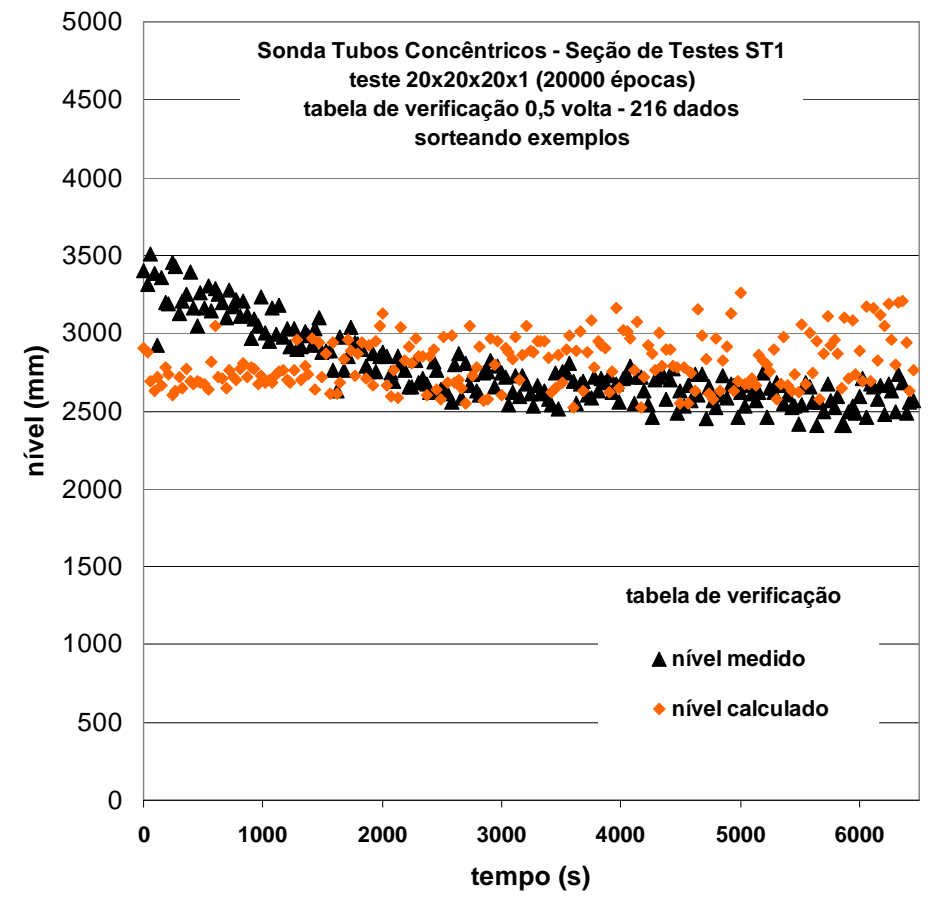

FIGURA 5.154. Nível x tempo para a análise com RNA 4 camadas (20×20×20×1), 20000 épocas, sorteando exemplos e transiente 0,5 volta - tab. verificação 216 dados. 


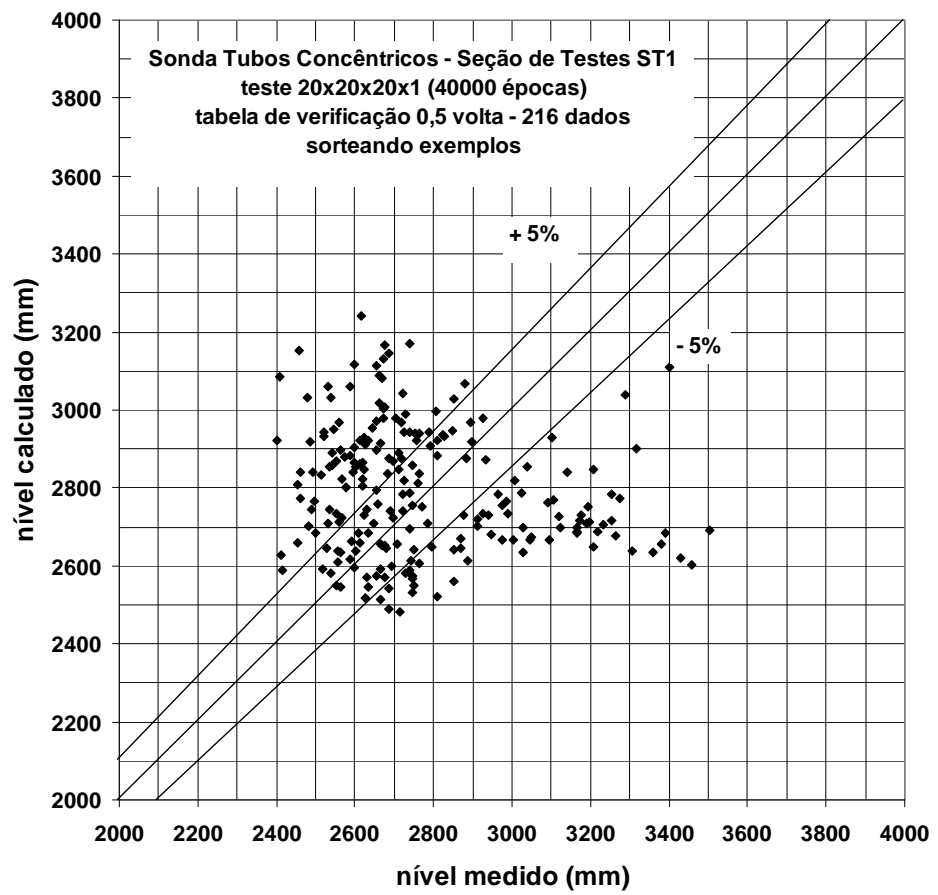

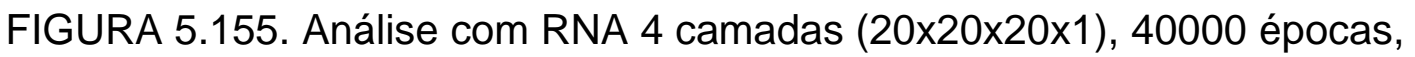
sorteando exemplos - tabela de verificação 0,5 volta 216 dados.

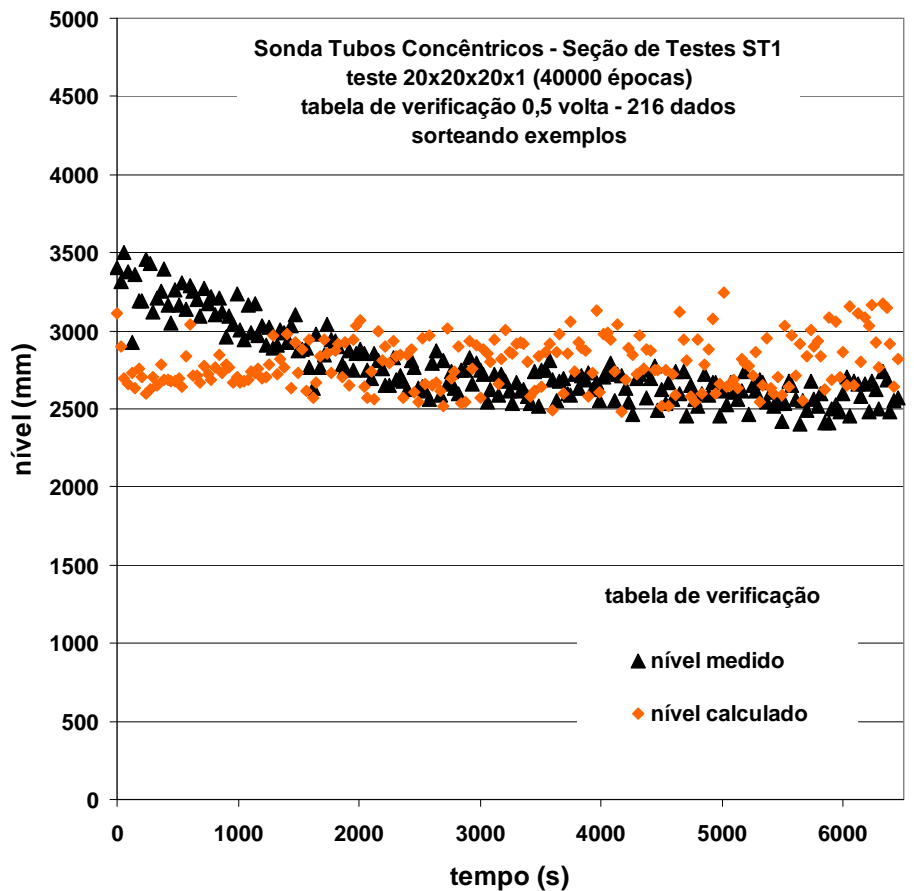

FIGURA 5.156. Nível x tempo para a análise com RNA 4 camadas (20×20×20×1), 40000 épocas, sorteando exemplos e transiente 0,5 volta - tabela de verificação 216 dados. 


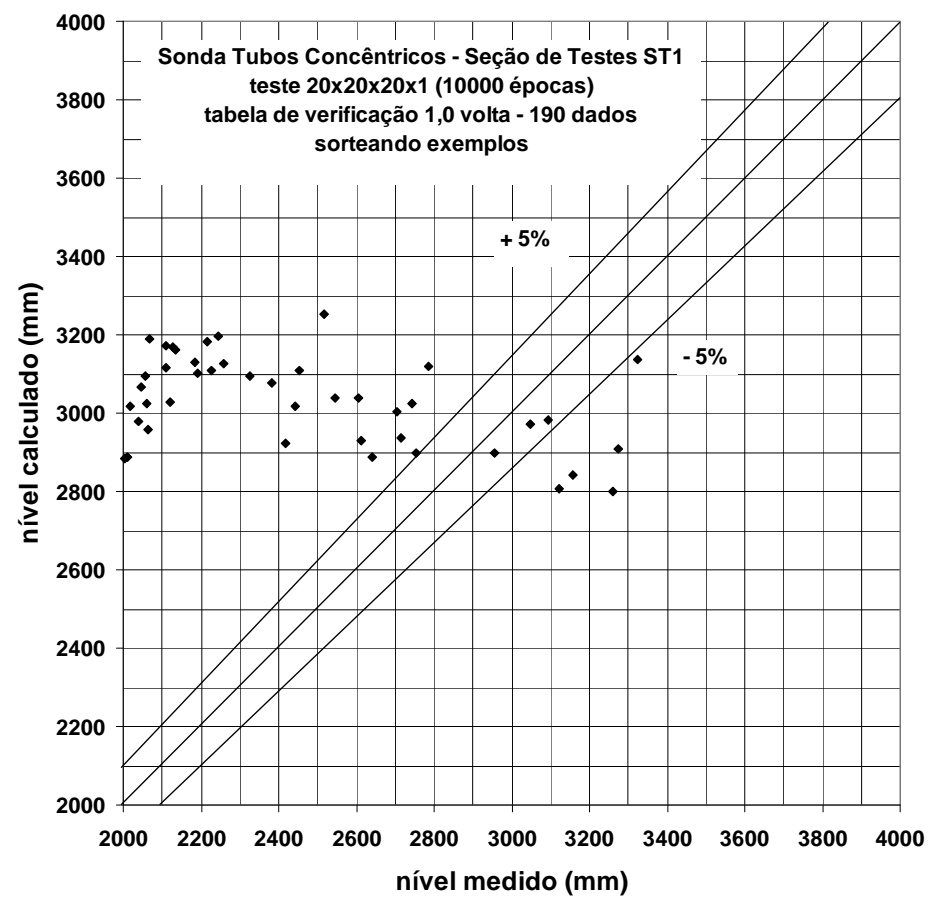

FIGURA 5.157. Análise com RNA 4 camadas (20×20×20x1), 10000 épocas, sorteando exemplos - tabela de verificação 1,0 volta 190 dados.

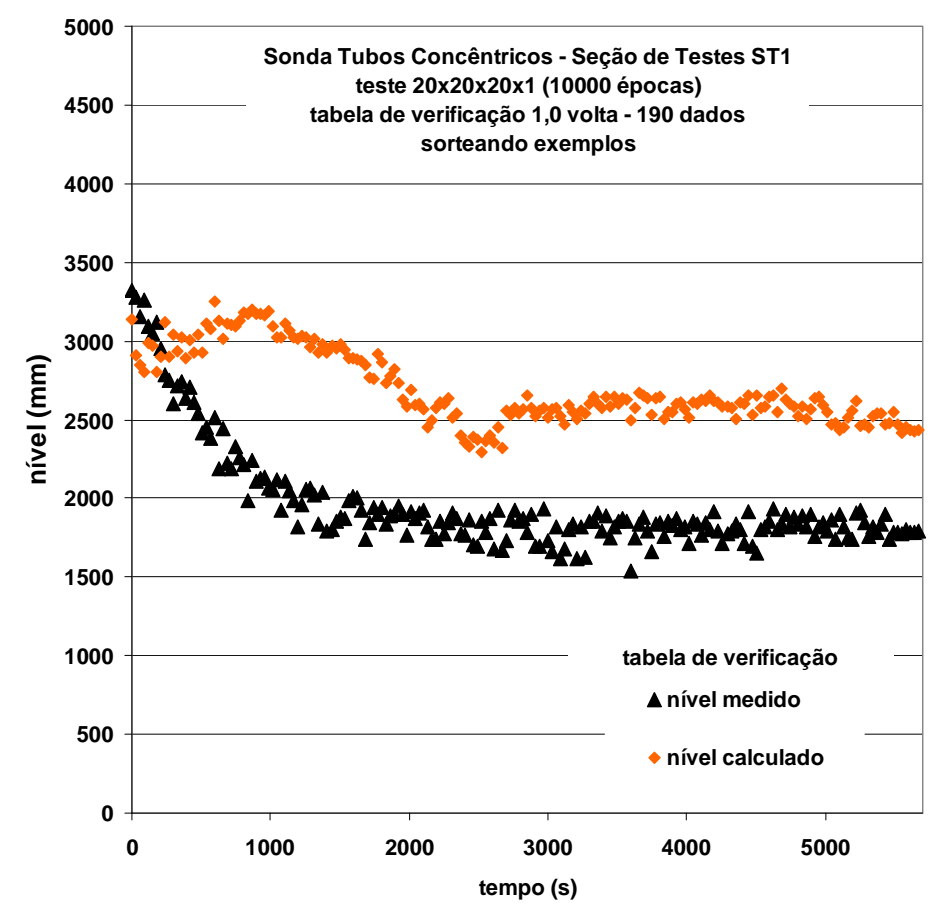

FIGURA 5.158. Nível x tempo para a análise com RNA 4 camadas (20×20×20x1), 10000 épocas, sorteando exemplos e transiente 0,5 volta - tabela de verificação 216 dados. 


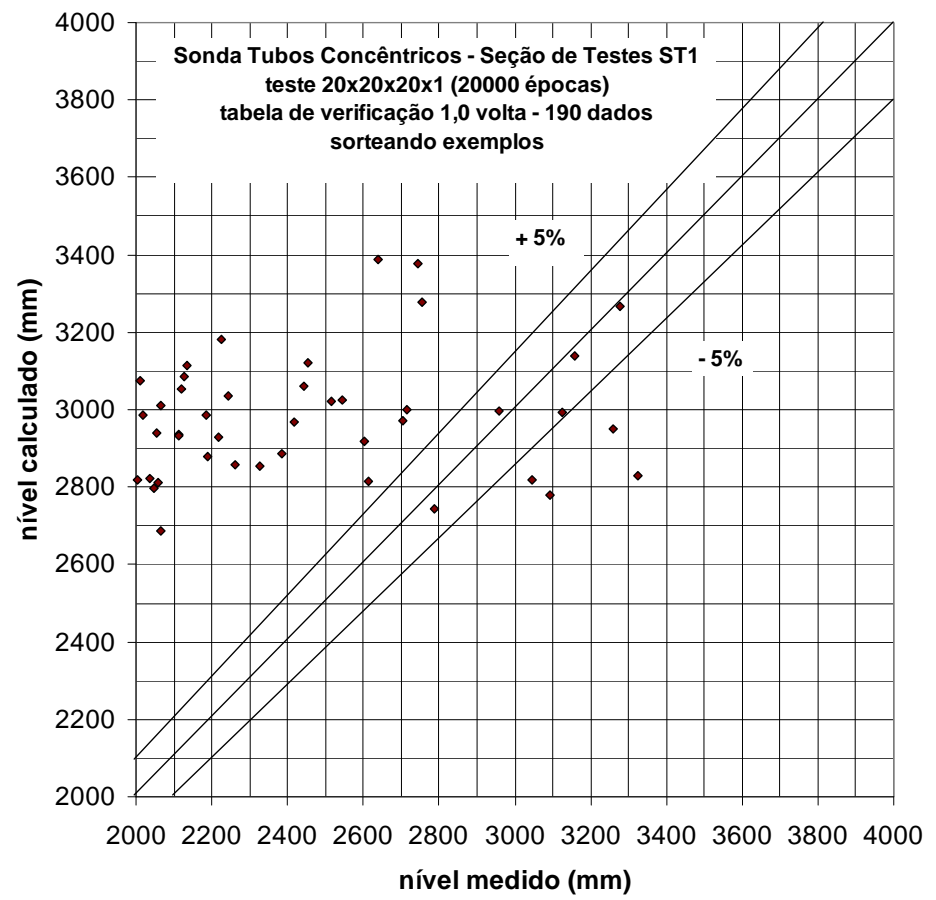

FIGURA 5.159 Análise com RNA 4 camadas (20×20×20×1), 20000 épocas, sorteando exemplos - tabela de verificação 1,0 volta 190 dados.

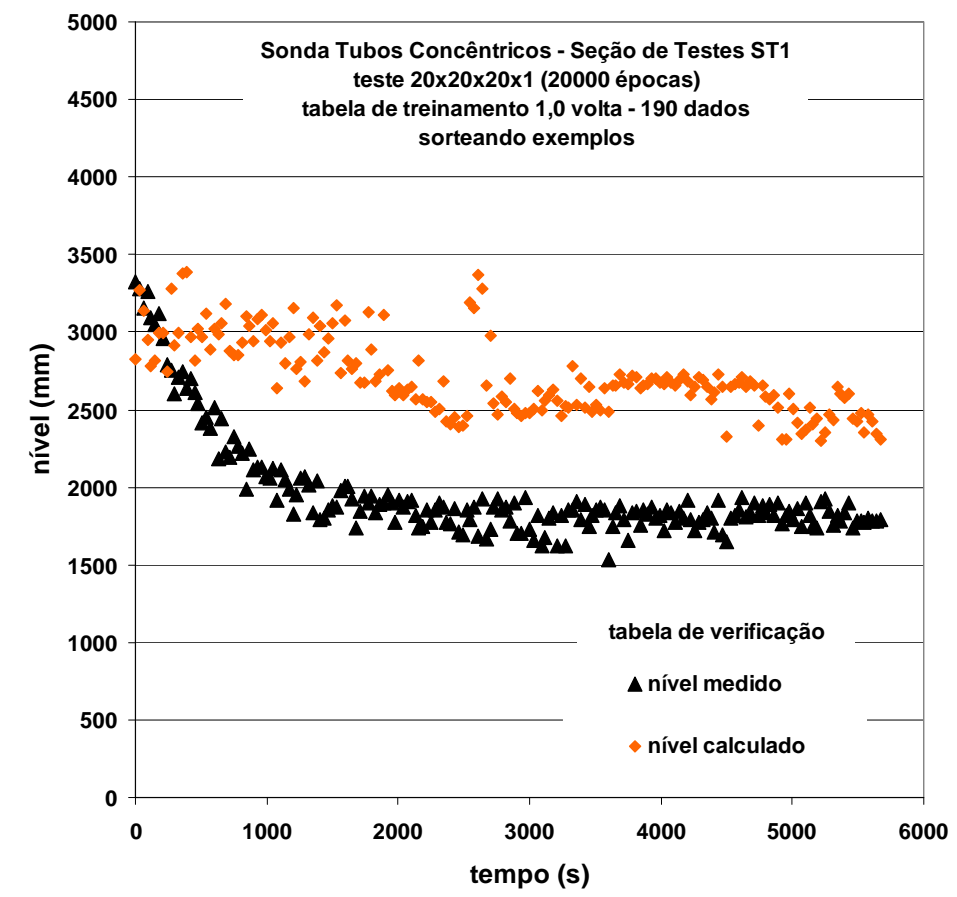

FIGURA 5.160. Nível x tempo para a análise com RNA 4 camadas (20×20×20×1), 20000 épocas, sorteando exemplos e transiente 0,5 volta - tabela de verificação 190 dados. 
Um resumo das análises com RNA's realizadas com os dados de Estado Estacionário de nível na seção de testes ST2 e usando a Sonda de Tubo U é apresentado nas TAB. 5.2, 5.3, 5.4 e 5.5. Nestas TABELAS são apresentados: o número de camadas da rede, o número de elementos por camada, o número de épocas de treinamento, treinamento com e sem sorteio de amostras, número de dados da tabela de treinamento, número de dados da tabela de verificação, as porcentagens dos valores de nível calculados dentro da faixa de $+/-5 \%$ e o valor da energia após o treinamento para as tabelas de treinamento e verificação, e o número da FIGURA correspondente ao caso analisado. De um modo geral é desejado para os resultados é uma elevada porcentagem de valores calculados e um baixo valor da energia após o treinamento. Observou-se que o aumento do número de camadas da rede melhora os resultados, assim como o aumento do número de elementos por camada e do número de épocas de treinamento. Significativa melhora nos resultados foi observada quando os treinamentos das RNA's foram realizados com a opção de sorteio de exemplos. As porcentagens e os valores de energia referentes aos dados de Estado Estacionário podem ser vistos na FIG. 5.161.

Um resumo das análises com RNA's realizadas com os dados de Transientes de nível nas seções de testes ST2 e ST1, usando a Sonda de Tubo U e a Sonda de Tubos Concêntricos é apresentado nas TAB. 5.6, 5.7, 5.8, 5.9, 5.10 e 5.11. Os mesmos parâmetros anteriormente mencionados também compõem essas TABELAS. Neste caso observou-se que o treinamento com dados de Estado Estacionário e a verificação com dados de transiente (caso 1) não produziu bons resultados. Isso ocorreu devido à grande diferença entre os conjuntos de dados de treinamento e verificação. O contrário, ou seja, o treinamento com dados de transiente e a verificação com dados de estado estacionário também não produziu bons resultados pelo mesmo motivo. Os melhores resultados foram obtidos com RNA's com 4 camadas, com elevado número de elementos por camada e com dados representativos dos transientes. As porcentagens e os valores de energia referentes aos dados de Estado Estacionário podem ser vistos na FIG. 5.162. 
TABELA 5.2. Resumo dos Resultados das Análises dos Dados de Estado Estacionário de Nível de 2200 a 3200 mm.

\begin{tabular}{|c|c|c|c|c|c|c|c|c|c|c|}
\hline caso & sonda & $\begin{array}{c}\text { No. } \\
\text { camadas e } \\
\text { Elementos } \\
\text { por camada }\end{array}$ & $\begin{array}{c}\text { No. } \\
\text { entradas }\end{array}$ & $\begin{array}{c}\text { No. } \\
\text { Épocas }\end{array}$ & sorteio & $\begin{array}{l}\text { Tab. } \\
\text { Treinamento } \\
\text { No. dados e } \\
(\%)\end{array}$ & $\begin{array}{l}\text { Tab. } \\
\text { Verificação } \\
\text { No. dados e } \\
(\%)\end{array}$ & $\begin{array}{c}\text { Tab. } \\
\text { Treinamento } \\
\text { dados }+/-5 \% \\
\text { e (energia) }\end{array}$ & $\begin{array}{c}\text { Tab. } \\
\text { Verificação } \\
\text { dados }+/-5 \% \\
\text { e (energia) }\end{array}$ & Figura \\
\hline 1 & $U$ & $\begin{array}{c}2 \\
14 \times 1\end{array}$ & 14 & 5.000 & não & $\begin{array}{c}616 \\
(100 \%)\end{array}$ & $\begin{array}{c}0 \\
(0 \%)\end{array}$ & $\begin{array}{c}55 \% \\
(5,956)\end{array}$ & - & $\begin{array}{l}5.77 \\
5.78\end{array}$ \\
\hline 2 & $U$ & $\begin{array}{c}3 \\
14 \times 14 \times 1\end{array}$ & 14 & 5.000 & não & $\begin{array}{c}616 \\
(100 \%)\end{array}$ & $\begin{array}{c}0 \\
(0 \%)\end{array}$ & $\begin{array}{l}59,4 \% \\
(4,280)\end{array}$ & - & $\begin{array}{l}5.79 \\
5.80\end{array}$ \\
\hline 4 & $U$ & $\begin{array}{c}4 \\
14 \times 14 \times 14 \times 1\end{array}$ & 14 & 10.000 & não & $\begin{array}{c}616 \\
(100 \%)\end{array}$ & $\begin{array}{c}0 \\
(0 \%)\end{array}$ & $\begin{array}{l}79,5 \% \\
(0,814)\end{array}$ & - & $\begin{array}{l}5.83 \\
5.84\end{array}$ \\
\hline
\end{tabular}


TABELA 5.3. Resumo dos Resultados das Análises dos Dados de Estado Estacionário de Nível de 2200 a 3200 mm.

\begin{tabular}{|c|c|c|c|c|c|c|c|c|c|c|}
\hline caso & sonda & $\begin{array}{c}\text { No. } \\
\text { camadas e } \\
\text { Elementos } \\
\text { por camada }\end{array}$ & $\begin{array}{c}\text { No. } \\
\text { entradas }\end{array}$ & $\begin{array}{c}\text { No. } \\
\text { Épocas }\end{array}$ & sorteio & $\begin{array}{c}\text { Tab. } \\
\text { Treinament } \\
0 \\
\text { No. dados e } \\
(\%)\end{array}$ & $\begin{array}{c}\text { Tab. } \\
\text { Verificação } \\
\text { No. dados e } \\
(\%)\end{array}$ & $\begin{array}{c}\text { Tab. } \\
\text { Treinamento } \\
\text { dados }+/-5 \% \\
\text { e (energia) }\end{array}$ & $\begin{array}{c}\text { Tab. } \\
\text { Verificação } \\
\text { dados +/- 5\% } \\
\text { e (energia) }\end{array}$ & Figura \\
\hline 5 & $U$ & $\begin{array}{c}4 \\
7 \times 7 \times 7 \times 1\end{array}$ & 14 & 10.000 & não & $\begin{array}{c}616 \\
(100 \%)\end{array}$ & $\begin{array}{c}0 \\
(0 \%)\end{array}$ & $\begin{array}{l}42,4 \% \\
(3,836)\end{array}$ & - & 5.85 \\
\hline 6 & $U$ & $\begin{array}{c}4 \\
20 \times 20 \times 20 \times 1\end{array}$ & 14 & 10.000 & não & $\begin{array}{c}616 \\
(100 \%)\end{array}$ & $\begin{array}{c}0 \\
(0 \%)\end{array}$ & $\begin{array}{l}81,7 \% \\
(0,754)\end{array}$ & - & 5.86 \\
\hline 8 & $U$ & $\begin{array}{c}4 \\
20 \times 20 \times 20 \times 1\end{array}$ & $\begin{array}{c}8 \\
\text { TP } \\
\text { Ímpares }\end{array}$ & 10.000 & não & $\begin{array}{c}616 \\
(100 \%)\end{array}$ & $\begin{array}{c}0 \\
(0 \%)\end{array}$ & $\begin{array}{c}80 \% \\
(0,810)\end{array}$ & - & 5.88 \\
\hline
\end{tabular}


TABELA 5.4. REsumo dos Resultados das Análises dos Dados de Estado Estacionário de Nível de 2200 a 3200 mm.

\begin{tabular}{|c|c|c|c|c|c|c|c|c|c|c|}
\hline caso & sonda & $\begin{array}{c}\text { No. } \\
\text { camadas e } \\
\text { Elementos } \\
\text { por camada }\end{array}$ & $\begin{array}{c}\text { No. } \\
\text { entradas }\end{array}$ & $\begin{array}{l}\text { No. } \\
\text { Épocas }\end{array}$ & sorteio & $\begin{array}{l}\text { Tab. } \\
\text { Treinamento } \\
\text { No. dados e } \\
(\%)\end{array}$ & $\begin{array}{l}\text { Tab. } \\
\text { Verificação } \\
\text { No. dados e } \\
\quad(\%)\end{array}$ & $\begin{array}{c}\text { Tab. } \\
\text { Treinamento } \\
\text { dados }+/-5 \% \\
\text { e (energia) }\end{array}$ & $\begin{array}{c}\text { Tab. } \\
\text { Verificação } \\
\text { dados }+/-5 \% \\
\text { e (energia) }\end{array}$ & Figura \\
\hline 9 & $U$ & $\begin{array}{c}4 \\
14 \times 14 \times 14 \times 1\end{array}$ & $\begin{array}{c}2 \\
\text { Tentrada } \\
\text { Tsaída } \\
\end{array}$ & 10.000 & não & $\begin{array}{c}616 \\
(100 \%)\end{array}$ & $\begin{array}{c}0 \\
(0 \%)\end{array}$ & $\begin{array}{l}39,1 \% \\
(7,479)\end{array}$ & - & 5.89 \\
\hline 10 & $U$ & $\begin{array}{c}4 \\
20 \times 20 \times 20 \times 1\end{array}$ & 14 & 10.000 & não & $\begin{array}{c}555 \\
(90 \%)\end{array}$ & $\begin{array}{c}62 \\
(10 \%)\end{array}$ & $\begin{array}{l}74,4 \% \\
(0,728)\end{array}$ & $\begin{array}{c}50 \% \\
(6,159)\end{array}$ & $\begin{array}{l}5.90 \\
5.91\end{array}$ \\
\hline 12 & $U$ & $\begin{array}{c}4 \\
20 \times 20 \times 20 \times 1\end{array}$ & 14 & 10.000 & sim & $\begin{array}{c}495 \\
(80 \%)\end{array}$ & $\begin{array}{c}122 \\
(20 \%)\end{array}$ & $\begin{array}{l}100 \% \\
(0,011)\end{array}$ & $\begin{array}{l}65,6 \% \\
(4,526)\end{array}$ & $\begin{array}{l}5.94 \\
5.95\end{array}$ \\
\hline
\end{tabular}


TABELA 5.5. Resumo dos Resultados das Análises dos Dados de Estado Estacionário de Nível de 2200 a 3200 mm.

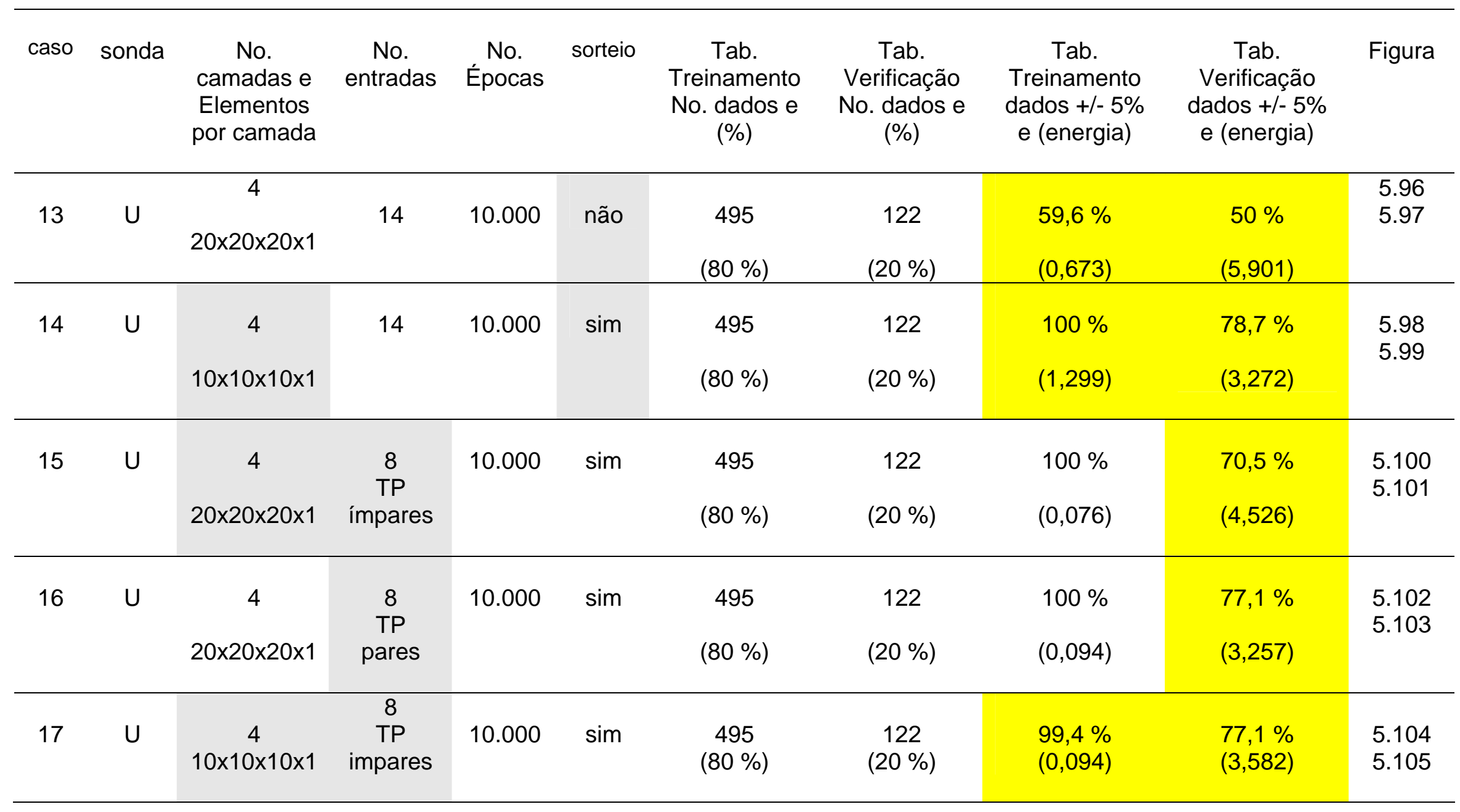


TABELA 5.6. Resumo dos Resultados das Análises dos Dados de Transientes

\begin{tabular}{|c|c|c|c|c|c|c|c|c|c|c|}
\hline caso & sonda & $\begin{array}{c}\text { No. } \\
\text { camadas e } \\
\text { Elementos } \\
\text { por camada }\end{array}$ & $\begin{array}{c}\text { No. } \\
\text { entradas }\end{array}$ & $\begin{array}{c}\text { No. } \\
\text { Épocas }\end{array}$ & sorteio & $\begin{array}{c}\text { Tab. } \\
\text { Treinamento } \\
\text { No. dados e } \\
(\%)\end{array}$ & $\begin{array}{l}\text { Tab. } \\
\text { Verificação } \\
\text { No. dados e } \\
(\%)\end{array}$ & $\begin{array}{c}\text { Tab. } \\
\text { Treinamento } \\
\text { dados }+/-5 \% \\
\text { e (energia) }\end{array}$ & $\begin{array}{c}\text { Tab. } \\
\text { Verificação } \\
\text { dados +/-5\% } \\
\text { e (energia) }\end{array}$ & Figura \\
\hline 1 & $U$ & $\begin{array}{c}4 \\
20 \times 20 \times 20 \times 1\end{array}$ & 14 & 10.000 & $\operatorname{sim}$ & $\begin{array}{c}616 \\
(100 \%) \\
\text { Estado. } \\
\text { Estacionário } \\
\end{array}$ & $\begin{array}{c}198 \\
(100 \%) \\
\text { Transiente } \\
0,5 \text { volta }\end{array}$ & $\begin{array}{l}100 \% \\
(0,057)\end{array}$ & $\begin{array}{l}16,7 \% \\
(55,08)\end{array}$ & $\begin{array}{l}5.106 \\
5.107 \\
\\
5.108 \\
5.109 \\
\end{array}$ \\
\hline 2 & $U$ & $\begin{array}{c}4 \\
20 \times 20 \times 20 \times 1\end{array}$ & 14 & 10.000 & $\operatorname{sim}$ & $\begin{array}{c}159 \\
\text { (80\%) } \\
\text { Transiente } \\
\text { 0,5 volta }\end{array}$ & $\begin{array}{c}39 \\
(20 \%) \\
\text { Transiente } \\
0,5 \text { volta }\end{array}$ & $\begin{array}{l}100 \% \\
(0,006)\end{array}$ & $\begin{array}{l}89,7 \% \\
(0,341)\end{array}$ & $\begin{array}{l}5.110 \\
5.111 \\
5.112 \\
5.113\end{array}$ \\
\hline 3 & $U$ & $\begin{array}{c}4 \\
10 \times 10 \times 10 \times 1\end{array}$ & 14 & 10.000 & $\operatorname{sim}$ & $\begin{array}{c}159 \\
(80 \%) \\
\text { Transiente } \\
\text { 0,5 volta }\end{array}$ & $\begin{array}{c}39 \\
\text { (20\%) } \\
\text { Transiente } \\
\text { 0,5 volta }\end{array}$ & $\begin{array}{l}100 \% \\
(0,007)\end{array}$ & $\begin{array}{l}84,6 \% \\
(0,407)\end{array}$ & $\begin{array}{l}5.114 \\
5.115 \\
\\
5.116 \\
5.117\end{array}$ \\
\hline
\end{tabular}


TABELA 5.7. Resumo dos Resultados das Análises dos Dados de Transientes.

\begin{tabular}{|c|c|c|c|c|c|c|c|c|c|c|}
\hline caso & sonda & $\begin{array}{c}\text { No. } \\
\text { camadas e } \\
\text { Elementos } \\
\text { por camada }\end{array}$ & $\begin{array}{c}\text { No. } \\
\text { entradas }\end{array}$ & $\begin{array}{c}\text { No. } \\
\text { Épocas }\end{array}$ & sorteio & $\begin{array}{l}\text { Tab. } \\
\text { Treinamento } \\
\text { No. dados e } \\
\text { (\%) }\end{array}$ & $\begin{array}{l}\text { Tab. } \\
\text { Verificação } \\
\text { No. dados e } \\
(\%)\end{array}$ & $\begin{array}{c}\text { Tab. } \\
\text { Treinamento } \\
\text { dados }+/-5 \% \\
\text { e (energia) }\end{array}$ & $\begin{array}{c}\text { Tab. } \\
\text { Verificação } \\
\text { dados +/-5\% } \\
\text { e (energia) }\end{array}$ & Figura \\
\hline 4 & $U$ & $\begin{array}{c}4 \\
10 \times 10 \times 10 \times 1\end{array}$ & $\begin{array}{c}8 \\
\text { TP } \\
\text { ímpares }\end{array}$ & 10.000 & $\operatorname{sim}$ & $\begin{array}{c}159 \\
\text { (80\%) } \\
\text { Transiente } \\
\text { 0,5 volta }\end{array}$ & $\begin{array}{c}39 \\
\text { (20\%) } \\
\text { Transiente } \\
0,5 \text { volta }\end{array}$ & $\begin{array}{l}100 \% \\
(0,254)\end{array}$ & $\begin{array}{l}84,6 \% \\
(0,379)\end{array}$ & $\begin{array}{l}5.118 \\
5.119 \\
5.120 \\
5.121\end{array}$ \\
\hline 5 & $U$ & $\begin{array}{c}4 \\
10 \times 10 \times 10 \times 1\end{array}$ & $\begin{array}{c}8 \\
\text { TP } \\
\text { pares }\end{array}$ & 10.000 & $\operatorname{sim}$ & $\begin{array}{c}159 \\
\text { (80\%) } \\
\text { Transiente } \\
\text { 0,5 volta }\end{array}$ & $\begin{array}{c}39 \\
\text { (20\%) } \\
\text { Transiente } \\
0,5 \text { volta }\end{array}$ & $\begin{array}{l}100 \% \\
(0,203)\end{array}$ & $\begin{array}{l}84,6 \% \\
(0,532)\end{array}$ & $\begin{array}{l}5.122 \\
5.123 \\
\\
5.124 \\
5.125\end{array}$ \\
\hline 6 & $U$ & $\begin{array}{c}4 \\
10 \times 10 \times 10 \times 1\end{array}$ & 14 & 10.000 & $\operatorname{sim}$ & $\begin{array}{c}159 \\
\text { (80\%) } \\
\text { Transiente } \\
\text { 0,5 volta }\end{array}$ & $\begin{array}{c}335 \\
(100 \%) \\
\text { Transiente } \\
\text { 1,0 volta }\end{array}$ & $\begin{array}{l}100 \% \\
(0,058)\end{array}$ & $\begin{array}{c}25,4 \% \\
(153,21)\end{array}$ & $\begin{array}{l}5.126 \\
5.127 \\
\\
5.128 \\
5.129\end{array}$ \\
\hline
\end{tabular}


TABELA 5.8. Resumo dos Resultados das Análises dos Dados de Transientes.

\begin{tabular}{|c|c|c|c|c|c|c|c|c|c|c|}
\hline caso & sonda & $\begin{array}{c}\text { No. } \\
\text { camadas e } \\
\text { Elementos } \\
\text { por camada }\end{array}$ & $\begin{array}{c}\text { No. } \\
\text { entradas }\end{array}$ & $\begin{array}{c}\text { No. } \\
\text { Épocas }\end{array}$ & sorteio & $\begin{array}{l}\text { Tab. } \\
\text { Treinamento } \\
\text { No. dados e } \\
(\%)\end{array}$ & $\begin{array}{l}\text { Tab. } \\
\text { Verificação } \\
\text { No. dados e } \\
(\%)\end{array}$ & $\begin{array}{c}\text { Tab. } \\
\text { Treinamento } \\
\text { dados }+/-5 \% \\
\text { e (energia) }\end{array}$ & $\begin{array}{c}\text { Tab. } \\
\text { Verificação } \\
\text { dados +/-5\% } \\
\text { e (energia) }\end{array}$ & Figura \\
\hline 7 & $U$ & $\begin{array}{c}4 \\
10 \times 10 \times 10 \times 1\end{array}$ & 14 & 50.000 & sim & $\begin{array}{c}159 \\
\text { (80 \%) } \\
\text { Transiente } \\
0,5 \text { volta }\end{array}$ & $\begin{array}{c}335 \\
(100 \%) \\
\text { Transiente } \\
\text { 1,0 volta }\end{array}$ & $\begin{array}{c}100 \% \\
(0,000001)\end{array}$ & $\begin{array}{l}34,3 \% \\
(33,306)\end{array}$ & $\begin{array}{l}5.130 \\
5.131 \\
5.132 \\
5.133\end{array}$ \\
\hline 8 & $U$ & $\begin{array}{c}4 \\
20 \times 20 \times 20 \times 1\end{array}$ & 14 & 50.000 & sim & $\begin{array}{c}159 \\
\text { (80\%) } \\
\text { Transiente } \\
\text { 0,5 volta }\end{array}$ & $\begin{array}{c}335 \\
(100 \%) \\
\text { Transiente } \\
\text { 1,0 volta }\end{array}$ & $\begin{array}{c}100 \% \\
(0,0000001)\end{array}$ & $\begin{array}{l}40,3 \% \\
(23,93)\end{array}$ & $\begin{array}{l}5.134 \\
5.135\end{array}$ \\
\hline 9 & $U$ & $\begin{array}{c}4 \\
20 \times 20 \times 20 \times 1\end{array}$ & $\begin{array}{c}8 \\
\text { TP } \\
\text { inferiores }\end{array}$ & 50.000 & $\operatorname{sim}$ & $\begin{array}{c}198 \\
(100 \%) \\
\text { Transiente } \\
0,5 \text { volta }\end{array}$ & $\begin{array}{c}335 \\
(100 \%) \\
\text { Transiente } \\
\text { 1,0 volta }\end{array}$ & $\begin{array}{c}100 \% \\
(0,000075)\end{array}$ & $\begin{array}{l}35,2 \% \\
(40,40)\end{array}$ & 5.136 \\
\hline
\end{tabular}


TABELA 5.9. Resumo dos Resultados das Análises dos Dados de Transientes.

\begin{tabular}{|c|c|c|c|c|c|c|c|c|c|c|}
\hline caso & sonda & $\begin{array}{c}\text { No. } \\
\text { camadas e } \\
\text { Elementos } \\
\text { por camada }\end{array}$ & $\begin{array}{c}\text { No. } \\
\text { entradas }\end{array}$ & $\begin{array}{c}\text { No. } \\
\text { Épocas }\end{array}$ & sorteio & $\begin{array}{l}\text { Tab. } \\
\text { Treinamento } \\
\text { No. dados e } \\
(\%)\end{array}$ & $\begin{array}{l}\text { Tab. } \\
\text { Verificação } \\
\text { No. dados e } \\
(\%)\end{array}$ & $\begin{array}{c}\text { Tab. } \\
\text { Treinamento } \\
\text { dados }+/-5 \% \\
\text { e (energia) }\end{array}$ & $\begin{array}{c}\text { Tab. } \\
\text { Verificação } \\
\text { dados +/-5\% } \\
\text { e (energia) }\end{array}$ & Figura \\
\hline 10 & $U$ & $\begin{array}{c}4 \\
20 \times 20 \times 20 \times 1\end{array}$ & $\begin{array}{c}8 \\
\text { TP } \\
\text { superiores }\end{array}$ & 20.000 & $\operatorname{sim}$ & $\begin{array}{c}198 \\
(100 \%) \\
\text { Transiente } \\
0,5 \text { volta }\end{array}$ & $\begin{array}{c}335 \\
(100 \%) \\
\text { Transiente } \\
\text { 1,0 volta }\end{array}$ & $\begin{array}{l}100 \% \\
(0,017)\end{array}$ & $\begin{array}{l}56,7 \% \\
(16,426)\end{array}$ & 5.137 \\
\hline 11 & $U$ & $\begin{array}{c}4 \\
20 \times 20 \times 20 \times 1\end{array}$ & $\begin{array}{c}14 \\
\mathrm{~T} 18=0\end{array}$ & 20.000 & $\operatorname{sim}$ & $\begin{array}{c}159 \\
(80 \%) \\
\text { Transiente } \\
0,5 \text { volta } \\
\end{array}$ & $\begin{array}{c}335 \\
(100 \%) \\
\text { Transiente } \\
\text { 1,0 volta } \\
\end{array}$ & $\begin{array}{c}100 \% \\
(0,000028)\end{array}$ & $\begin{array}{l}37,6 \% \\
(27,98)\end{array}$ & 5.138 \\
\hline 12 & $U$ & $\begin{array}{c}4 \\
20 \times 20 \times 20 \times 1\end{array}$ & 14 & 50.000 & $\operatorname{sim}$ & $\begin{array}{c}159 \\
(80 \%) \\
\text { Transiente } \\
0,5 \text { volta }\end{array}$ & $\begin{array}{c}250 \\
(100 \%) \\
\text { Transiente } \\
\text { 2,0 voltas }\end{array}$ & $\begin{array}{c}100 \% \\
(0,0000001)\end{array}$ & $\begin{array}{l}46,0 \% \\
(25,50)\end{array}$ & 5.139 \\
\hline
\end{tabular}


TABELA 5.10. REsumo dos Resultados das Análises dos Dados de Transientes.

\begin{tabular}{|c|c|c|c|c|c|c|c|c|c|c|}
\hline caso & sonda & $\begin{array}{c}\text { No. } \\
\text { camadas e } \\
\text { Elementos } \\
\text { por camada }\end{array}$ & $\begin{array}{c}\text { No. } \\
\text { entradas }\end{array}$ & $\begin{array}{c}\text { No. } \\
\text { Épocas }\end{array}$ & sorteio & $\begin{array}{l}\text { Tab. } \\
\text { Treinamento } \\
\text { No. dados e } \\
(\%)\end{array}$ & $\begin{array}{l}\text { Tab. } \\
\text { Verificação } \\
\text { No. dados e } \\
(\%)\end{array}$ & $\begin{array}{c}\text { Tab. } \\
\text { Treinamento } \\
\text { dados }+/-5 \% \\
\text { e (energia) }\end{array}$ & $\begin{array}{c}\text { Tab. } \\
\text { Verificação } \\
\text { dados +/-5\% } \\
\text { e (energia) }\end{array}$ & Figura \\
\hline 13 & $U$ & $\begin{array}{c}4 \\
20 \times 20 \times 20 \times 1\end{array}$ & 14 & 5.000 & $\operatorname{sim}$ & $\begin{array}{c}627 \\
(80 \%) \\
\text { Transientes } \\
0,5,1,0 \text { e } 2,0 \\
\text { voltas }\end{array}$ & $\begin{array}{c}155 \\
(20 \%) \\
\text { Transientes } \\
0,5,1,0 \text { e } 2,0 \\
\text { voltas }\end{array}$ & $\begin{array}{l}97,6 \% \\
(1,572)\end{array}$ & $\begin{array}{l}93,5 \% \\
(9,631)\end{array}$ & $\begin{array}{l}5.141 \\
5.142\end{array}$ \\
\hline 14 & $\mathrm{TC}$ & $\begin{array}{c}4 \\
20 \times 20 \times 20 \times 1\end{array}$ & 14 & 10.000 & $\operatorname{sim}$ & $\begin{array}{c}205 \\
(100 \%) \\
\\
\text { Transiente } \\
0,5 \text { volta } \\
21 / 05 / 08\end{array}$ & $\begin{array}{c}216 \\
(100 \%) \\
\text { Transiente } \\
0,5 \text { volta } \\
23 / 05 / 08\end{array}$ & $\begin{array}{l}99,5 \% \\
(0,2211)\end{array}$ & $\begin{array}{l}8,33 \% \\
(28,73)\end{array}$ & $\begin{array}{l}5.149 \\
5.150 \\
\\
5.151 \\
5.152\end{array}$ \\
\hline 15 & $\mathrm{TC}$ & $\begin{array}{c}4 \\
20 \times 20 \times 20 \times 1\end{array}$ & 14 & 20.000 & sim & $\begin{array}{c}205 \\
(100 \%) \\
\text { Transiente } \\
0,5 \text { volta } \\
21 / 05 / 08\end{array}$ & $\begin{array}{c}216 \\
(100 \%) \\
\text { Transiente } \\
0,5 \text { volta } \\
23 / 05 / 08\end{array}$ & $\begin{array}{c}100 \% \\
(0,0101)\end{array}$ & $\begin{array}{l}26,4 \% \\
(13,39)\end{array}$ & $\begin{array}{l}5.153 \\
5.154\end{array}$ \\
\hline
\end{tabular}


TABELA 5.11. Resumo dos Resultados das Análises dos Dados de Transientes.

\begin{tabular}{|c|c|c|c|c|c|c|c|c|c|c|}
\hline caso & sonda & $\begin{array}{c}\text { No. } \\
\text { camadas e } \\
\text { Elementos } \\
\text { por camada }\end{array}$ & $\begin{array}{c}\text { No. } \\
\text { entradas }\end{array}$ & $\begin{array}{c}\text { No. } \\
\text { Épocas }\end{array}$ & sorteio & $\begin{array}{l}\text { Tab. } \\
\text { Treinamento } \\
\text { No. dados e } \\
(\%)\end{array}$ & $\begin{array}{l}\text { Tab. } \\
\text { Verificação } \\
\text { No. dados e } \\
(\%)\end{array}$ & $\begin{array}{c}\text { Tab. } \\
\text { Treinamento } \\
\text { dados }+/-5 \% \\
\text { e (energia) }\end{array}$ & $\begin{array}{c}\text { Tab. } \\
\text { Verificação } \\
\text { dados }+/-5 \% \\
\text { e (energia) }\end{array}$ & Figura \\
\hline 16 & $\mathrm{TC}$ & $\begin{array}{c}4 \\
20 \times 20 \times 20 \times 1\end{array}$ & 14 & 40.000 & sim & $\begin{array}{c}205 \\
(100 \%) \\
\\
\text { Transiente } \\
0,5 \text { volta } \\
21 / 05 / 08\end{array}$ & $\begin{array}{c}216 \\
(100 \%) \\
\text { Transiente } \\
0,5 \text { volta } \\
23 / 05 / 08\end{array}$ & $\begin{array}{c}100 \% \\
(0,000011)\end{array}$ & $\begin{array}{l}25,9 \% \\
(12,43)\end{array}$ & $\begin{array}{l}5.155 \\
5.156\end{array}$ \\
\hline 17 & $\mathrm{TC}$ & $\begin{array}{c}4 \\
20 \times 20 \times 20 \times 1\end{array}$ & 14 & 10.000 & sim & $\begin{array}{c}205 \\
(100 \%) \\
\text { Transiente } \\
0,5 \text { volta } \\
21 / 05 / 08\end{array}$ & $\begin{array}{c}190 \\
(100 \%) \\
\text { Transiente } \\
1,0 \text { volta } \\
23 / 05 / 08 \\
\end{array}$ & $\begin{array}{l}94,6 \% \\
(0,314)\end{array}$ & $\begin{array}{l}1,58 \% \\
(68,11)\end{array}$ & $\begin{array}{l}5.157 \\
5.158\end{array}$ \\
\hline 18 & $\mathrm{TC}$ & $\begin{array}{c}4 \\
20 \times 20 \times 20 \times 1\end{array}$ & 14 & 20.000 & sim & $\begin{array}{c}205 \\
(100 \%) \\
\text { Transiente } \\
0,5 \text { volta } \\
21 / 05 / 08\end{array}$ & $\begin{array}{c}190 \\
(100 \%) \\
\text { Transiente } \\
\text { 1,0 volta } \\
23 / 05 / 08\end{array}$ & $\begin{array}{l}100 \% \\
(0,033)\end{array}$ & $\begin{array}{l}2,63 \% \\
(71,67)\end{array}$ & $\begin{array}{l}5.159 \\
5.160\end{array}$ \\
\hline
\end{tabular}




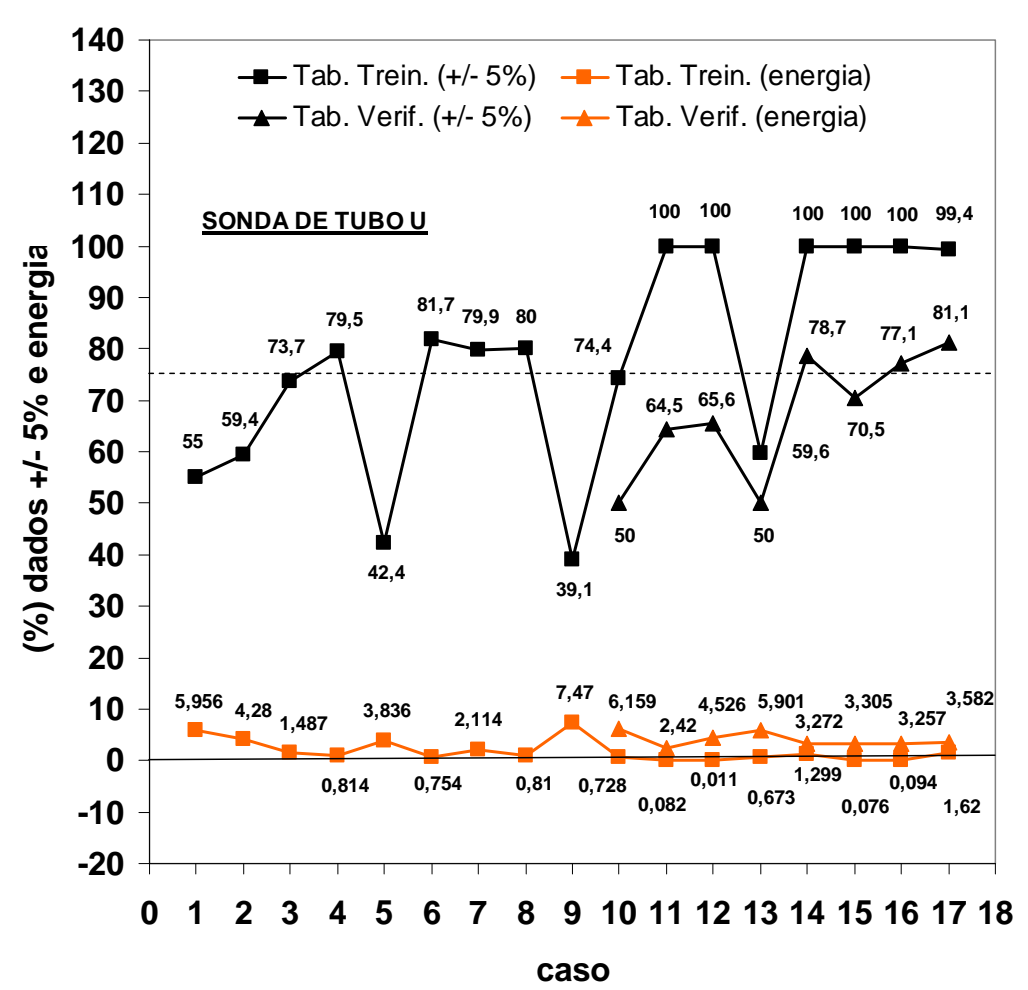

FIGURA 5.161. Resultados das análises com dados de Estado Estacionário.

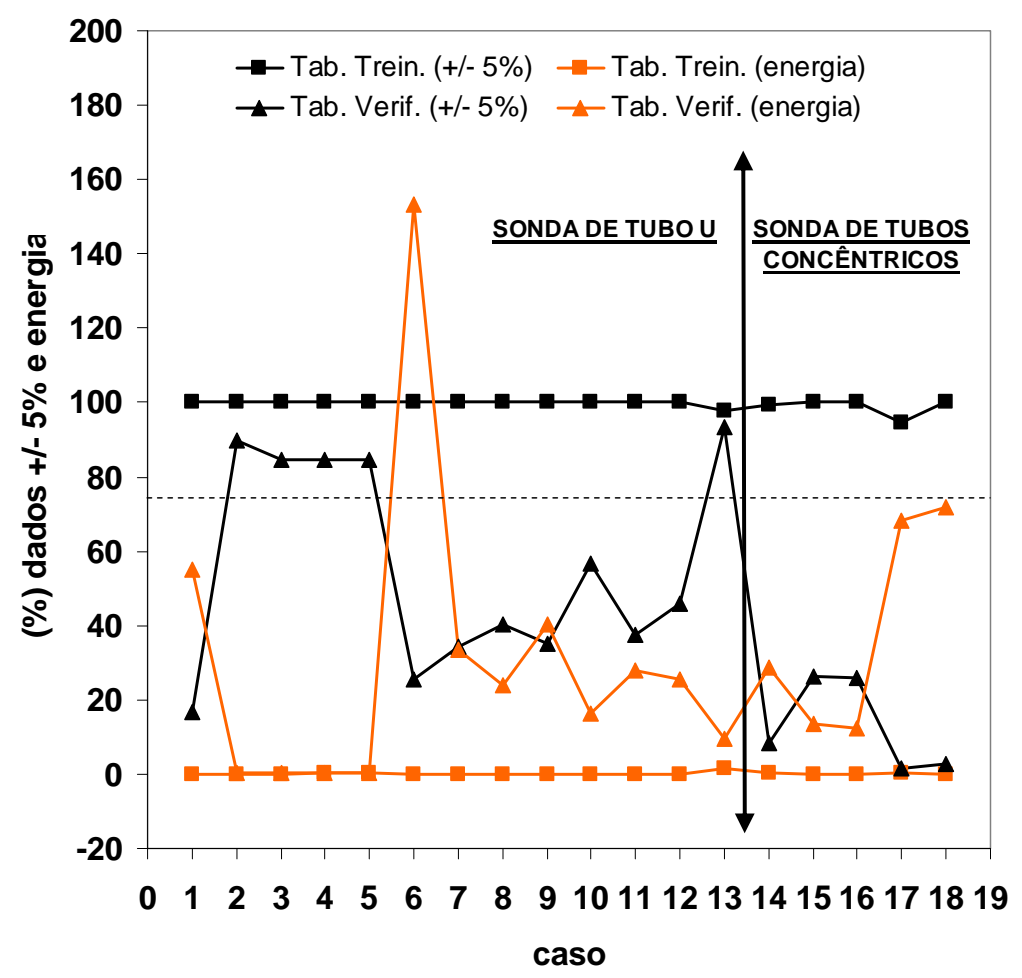

FIGURA 5.162. Resultados das análises com dados de Transiente. 


\subsubsection{Análise dos dados com RNA para a Sonda TRICOTH}

A técnica de uso de RNA's e sondas térmicas para a determinação de nível foi aplicada aos dados experimentais, de literatura, obtidos com um protótipo da sonda TRICOTH (TRinary COding THermocouples) desenvolvida por Termaat et al. (1990). A sonda tem um diâmetro externo de $3,2 \mathrm{~mm}$ e possui um aquecedor elétrico interno de $\mathrm{Ni}-\mathrm{Cr}$ de $18 \mathrm{~W}$ e dois termopares de multi-junções do tipo cromelalumel-constantan, ligados diferencialmente para fornecer as diferenças de F.E.M. (Força Eletro Motriz) produzida pelas diferenças de temperaturas decorrentes dos diferentes coeficientes de transferência de calor que ocorrem dependendo do meio circundante. A tecnologia de fabricação de termopares encamisados foi utilizada na fabricação da sonda. Os testes experimentais foram realizados com água em temperatura ambiente em uma seção de testes formada por um tubo de acrílico vertical de 160 mm de diâmetro e que possui um conjunto de válvulas que permitem aumentar ou diminuir o nível a uma velocidade constante.

Os dados para a formação da tabela de treinamento se referem a um transiente lento de aumento de nível a uma taxa constante de 0,35 mm/s. O tempo total do transiente foi de $3000 \mathrm{~s}$ (50 minutos) para um aumento de nível de 1050 mm. Os sinais E1 e E2, em mV, produzidos pelos termopares são mostrados nas FIG. 5.163 e 5.164, em função do tempo e em função do nível na seção de testes, respectivamente. Os sinais E1 e E2 foram usados como entradas conhecidas, enquanto que o nível foi usado como saída desejada. Os valores de E1, E2 e nível foram retirados dos gráficos disponíveis no artigo de Termaat et al. (1990) a cada 30s, perfazendo um total de 101 dados para a tabela de treinamento.

Para a constituição das tabelas de verificação tv1 e tv2 foram usados os valores de E1, E2 e nível correspondentes a dois transientes. O primeiro refere-se a um transiente de aumento de nível de 0 a $1200 \mathrm{~mm}$ a uma taxa constante de $4,0 \mathrm{~mm} / \mathrm{s}$, enquanto que o segundo refere-se a um transiente de diminuição de nível 
de 1200 a $0 \mathrm{~mm}$ a uma taxa de constante de $0,79 \mathrm{~mm} / \mathrm{s}$. Os dados referentes a esses transientes podem ser vistos nas FIG. 5.165 - 5.168.

A tabela de verificação tv1 (aumento de nível) é formada pelos dados experimentais retirados dos gráficos a cada intervalo de $3 \mathrm{~s}$, perfazendo um total de 91 dados, enquanto que na tabela de verificação tv2 (diminuição de nível), os dados foram retirados a cada intervalo de 15s, perfazendo um total de 101 dados.

Uma RNA de 4 camadas $(20 \times 20 \times 20 \times 1)$ foi treinada com os dados da tabela de treinamento por 10000 épocas com a opção de sorteio dos exemplos, e a rede treinada foi usada para avaliar os dados das duas tabelas de verificação tv1 e tv2. Os resultados são apresentados nas FIG. 5.169 até 5.175. 


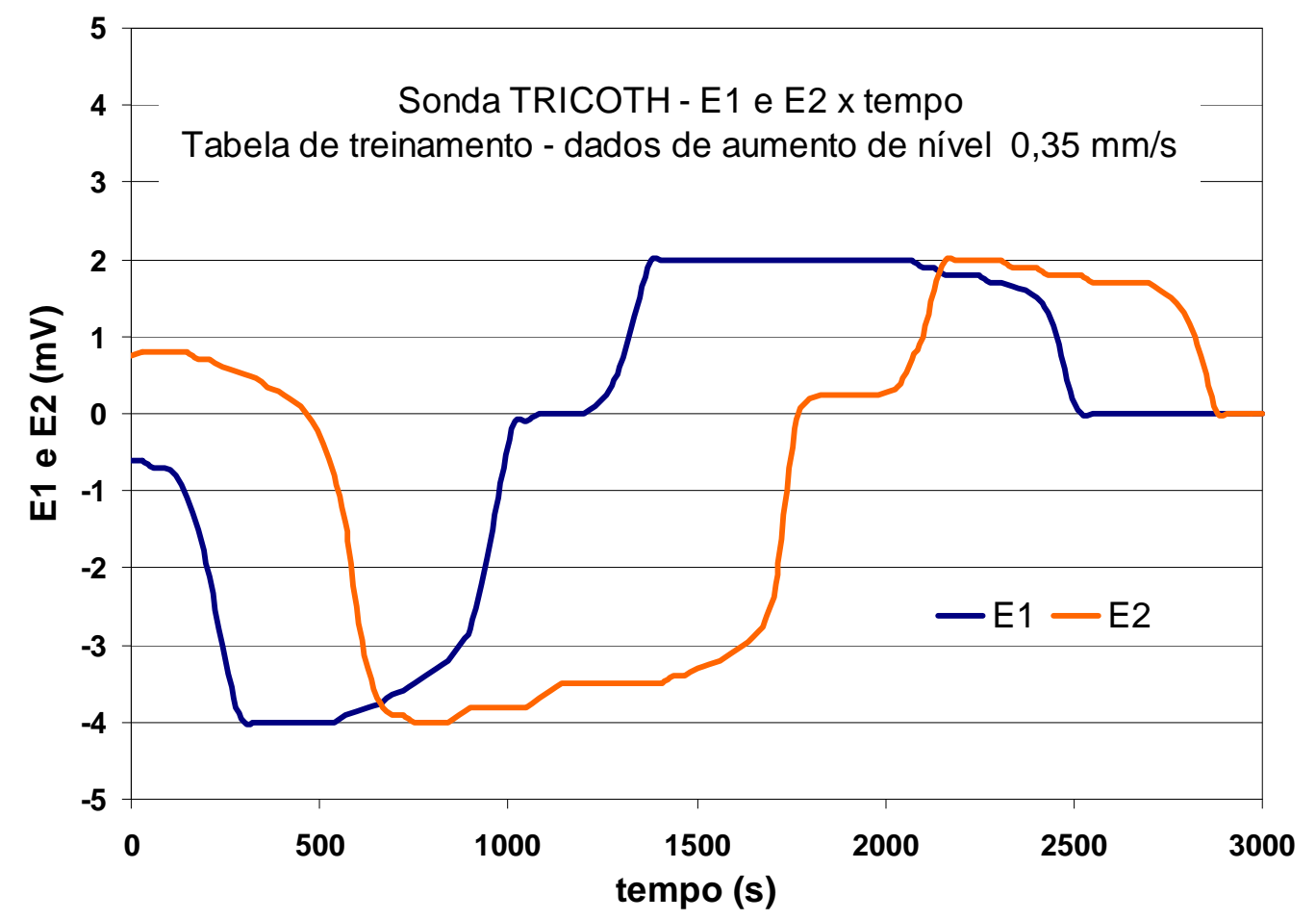

FIGURA 5.163. Sinais E1 e E2 versus tempo - tabela de treinamento tt.

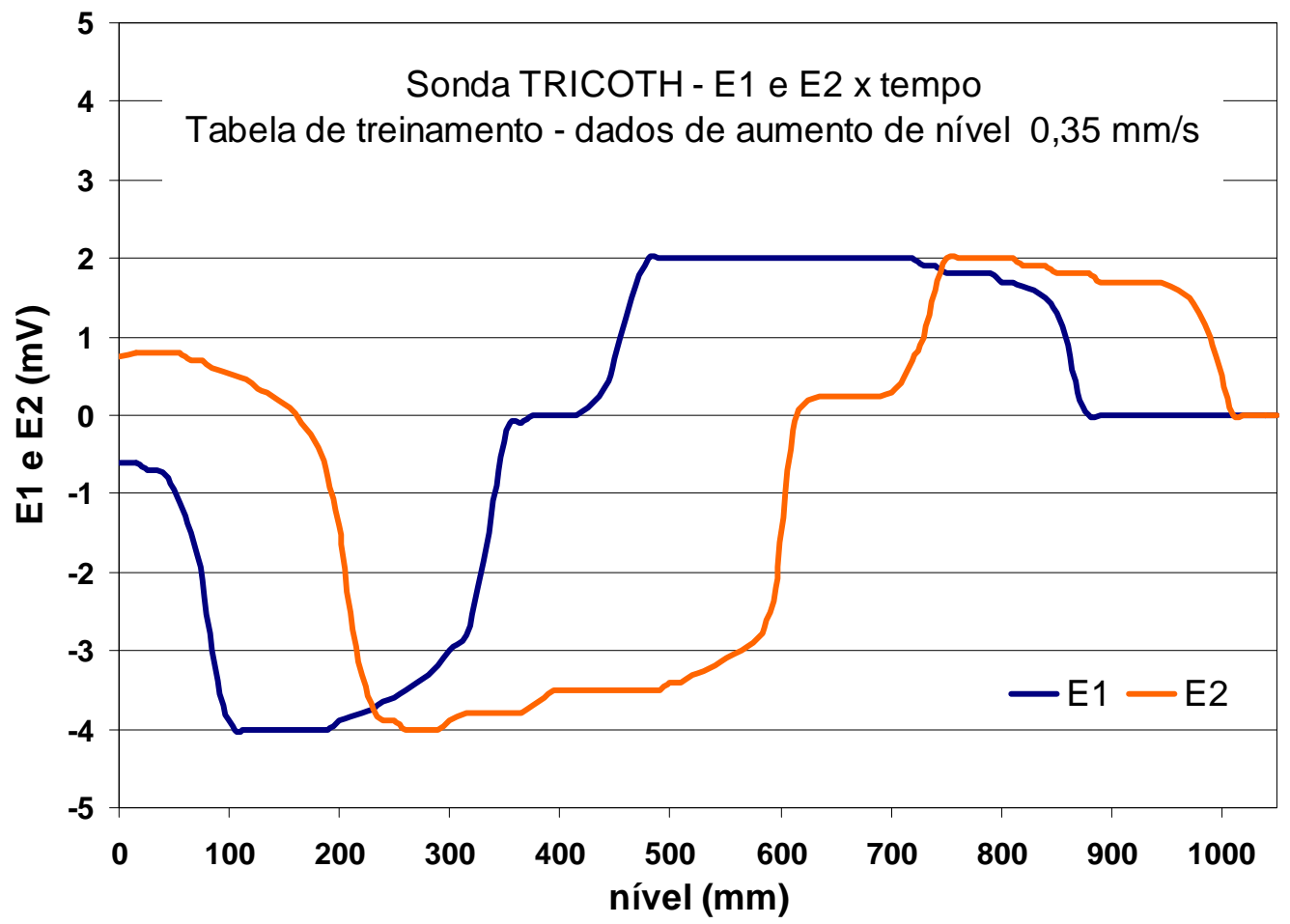

FIGURA 5.164. Sinais E1 e E2 versus nível - tabela de treinamento tt. 


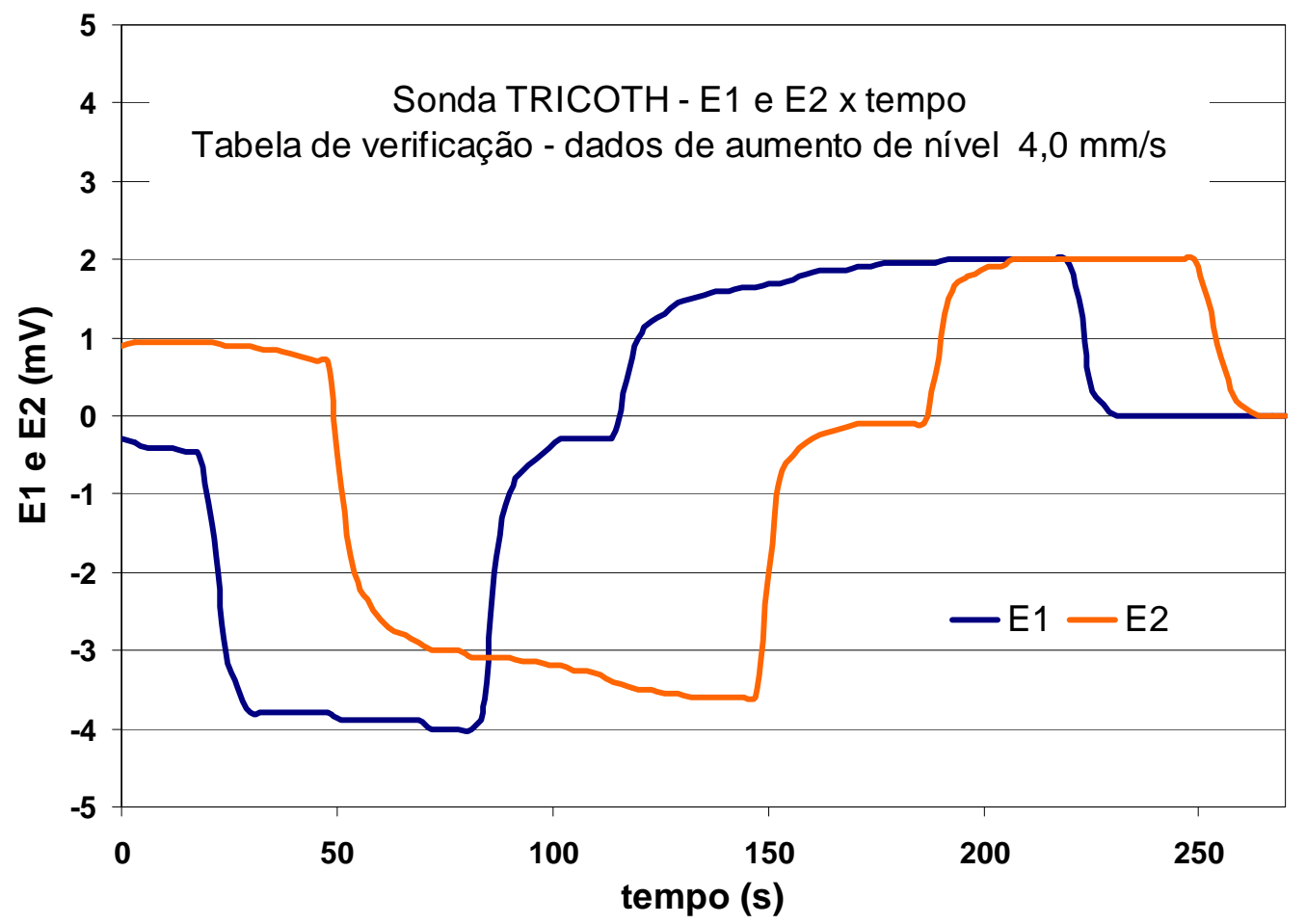

FIGURA 5.165. Sinais E1 e E2 versus tempo - tabela de verificação tv1.

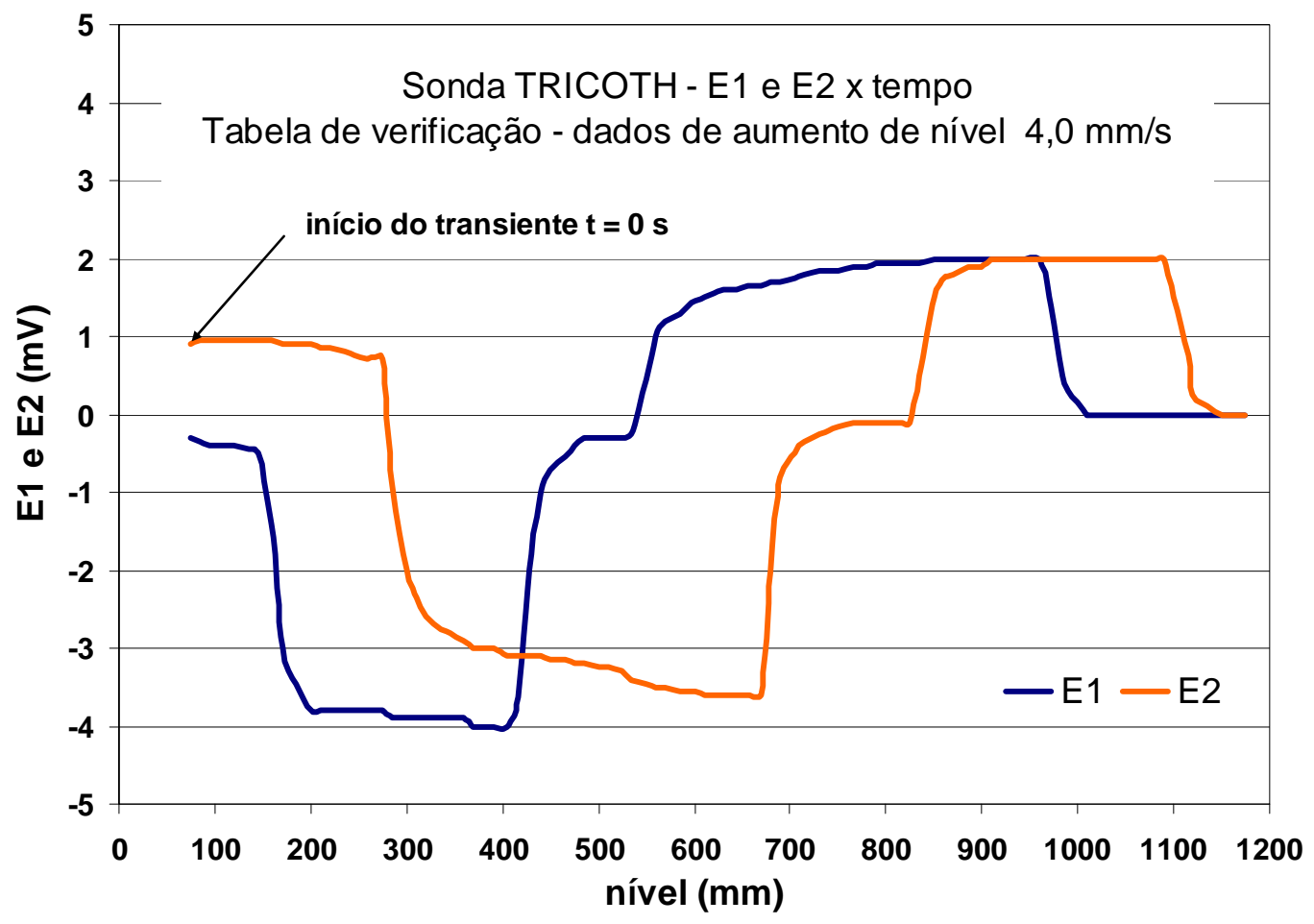

FIGURA 5.166. Sinais E1 e E2 versus nível - tabela de verificação tv1. 


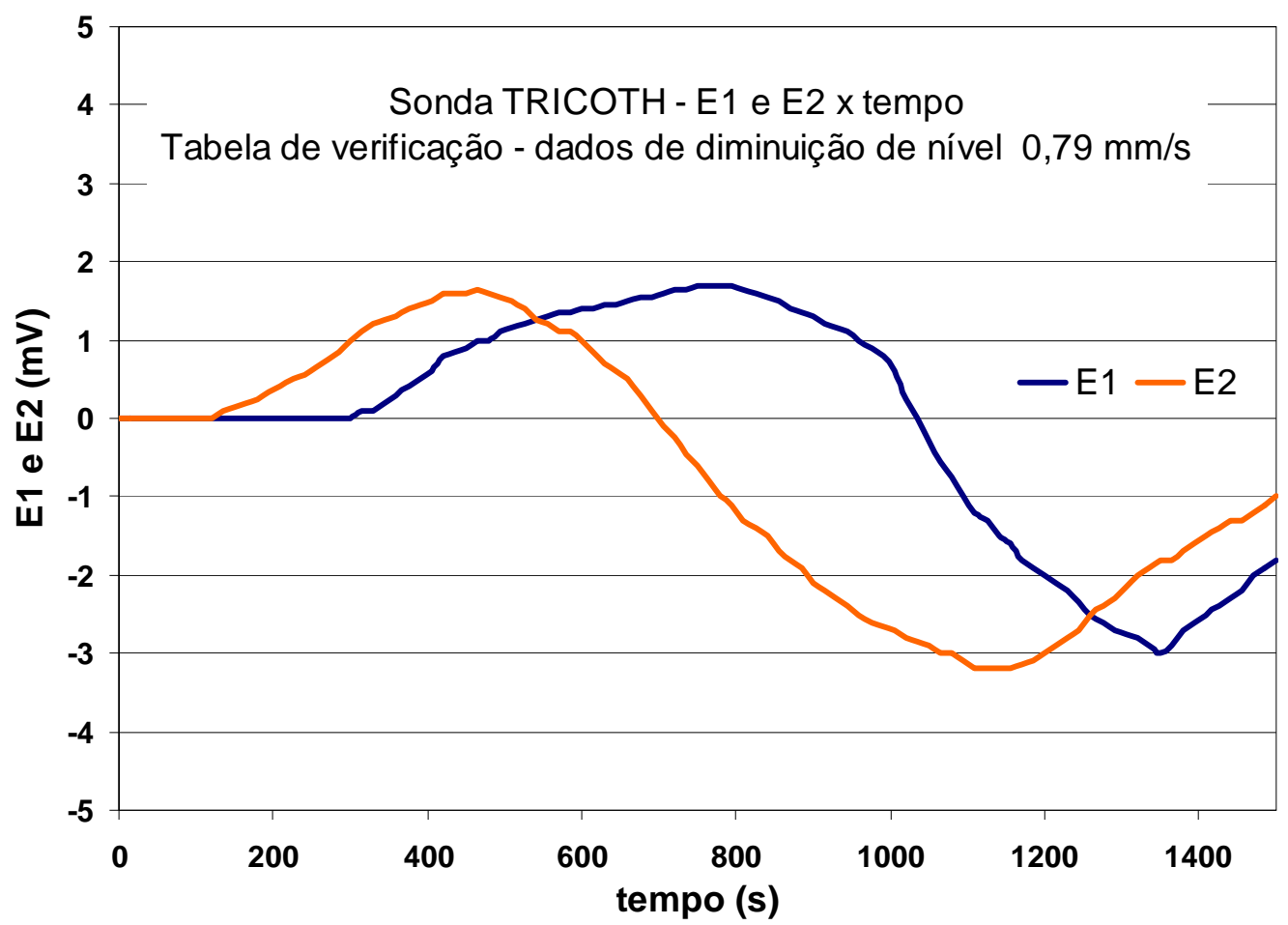

FIGURA 5.167. Sinais E1 e E2 versus tempo - tabela de verificação tv2.

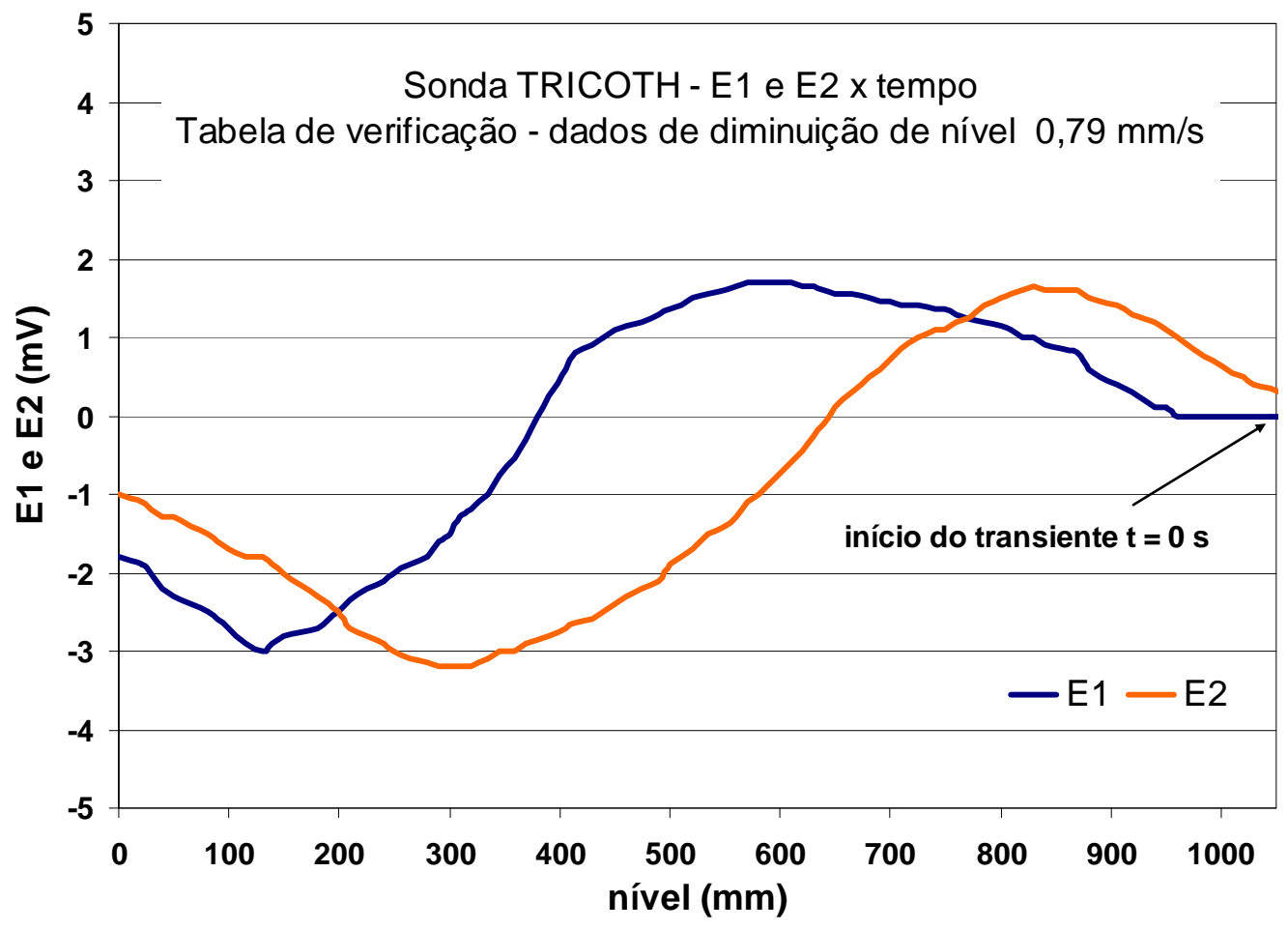

FIGURA 5.168. Sinais E1 e E2 versus nível - tabela de verificação tv2. 


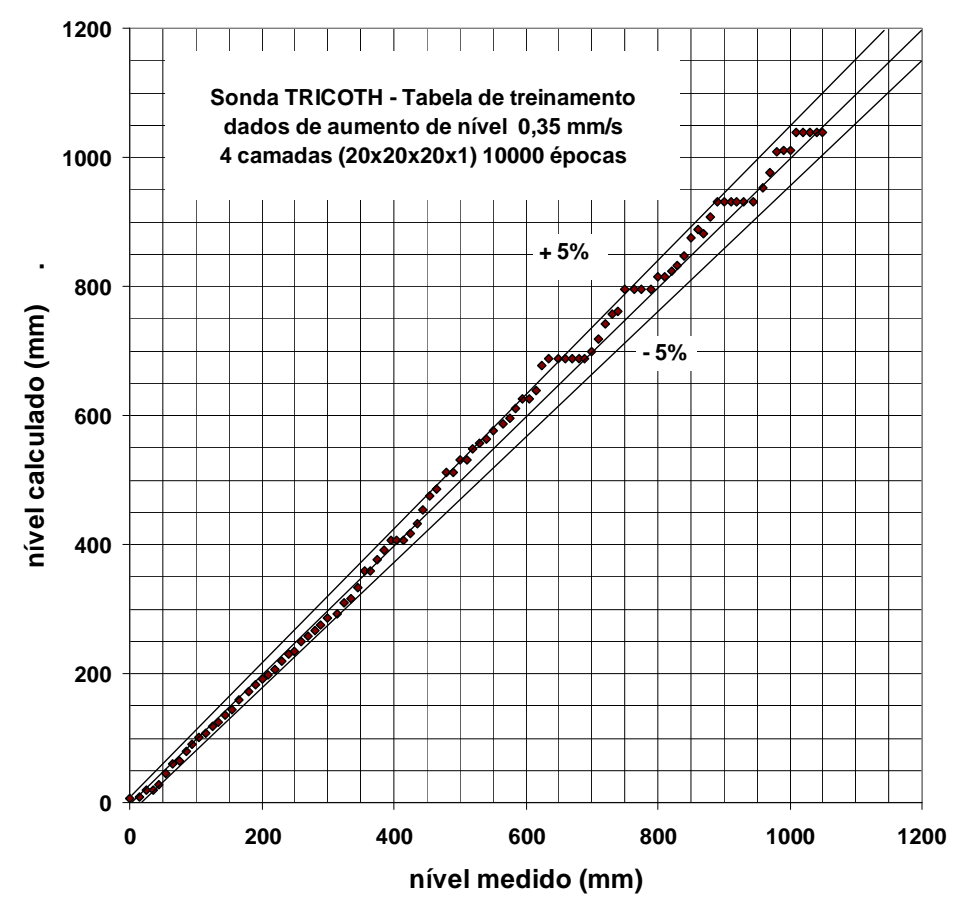

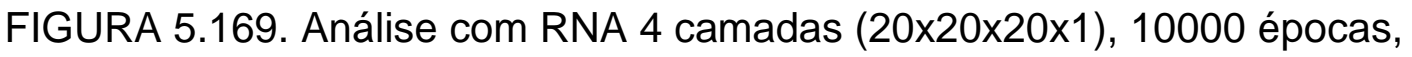
sorteando exemplos - tabela de treinamento $\mathrm{tt}$ - aumento de nível $0,35 \mathrm{~mm} / \mathrm{s}$.

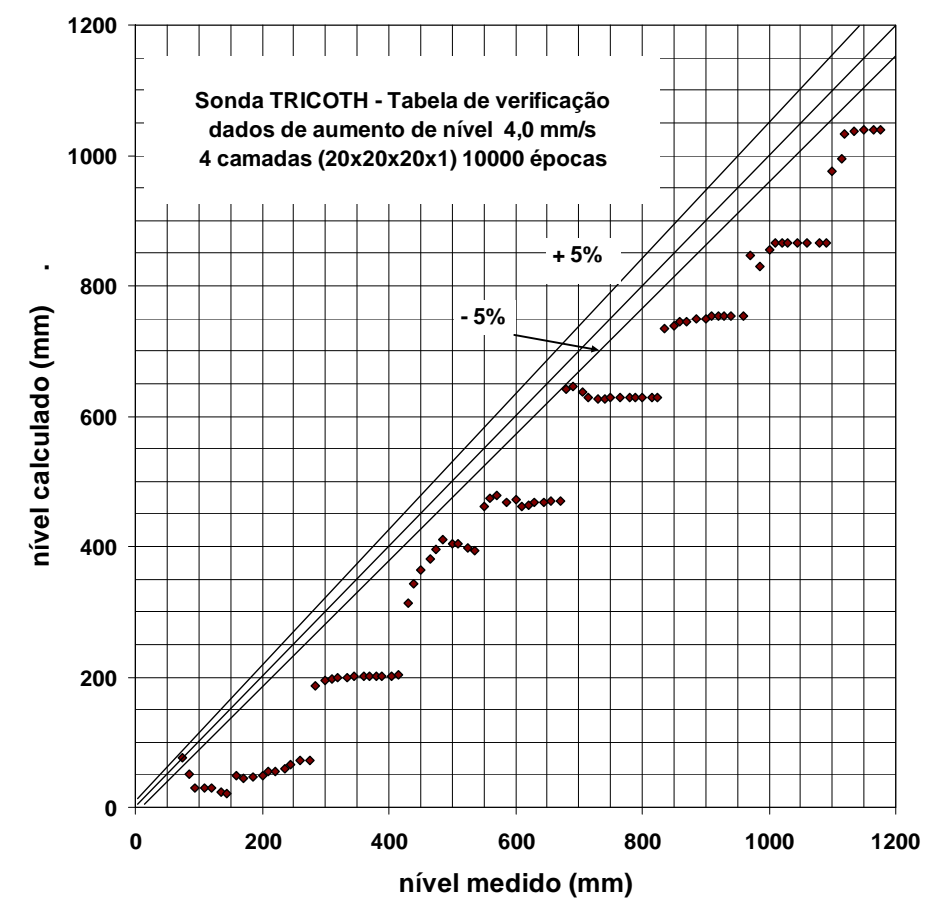

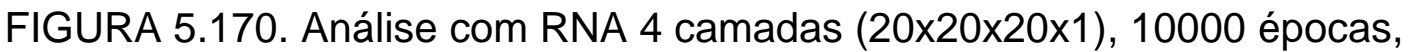
sorteando exemplos - tabela de verificação tv1 - aumento de nível $4,0 \mathrm{~mm} / \mathrm{s}$. 


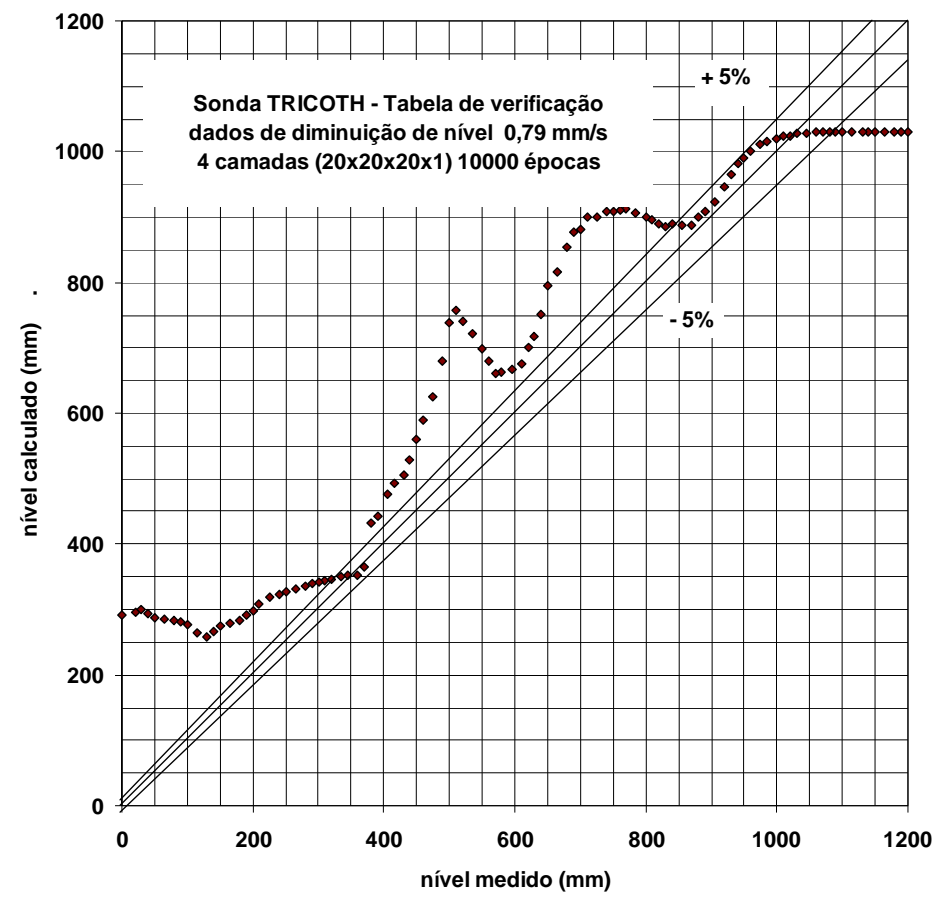

FIGURA 5.171. Análise com RNA 4 camadas (20x20×20x1), 10000 épocas, sorteando exemplos - tabela de verificação tv2 - diminuição de nível $0,79 \mathrm{~mm} / \mathrm{s}$.

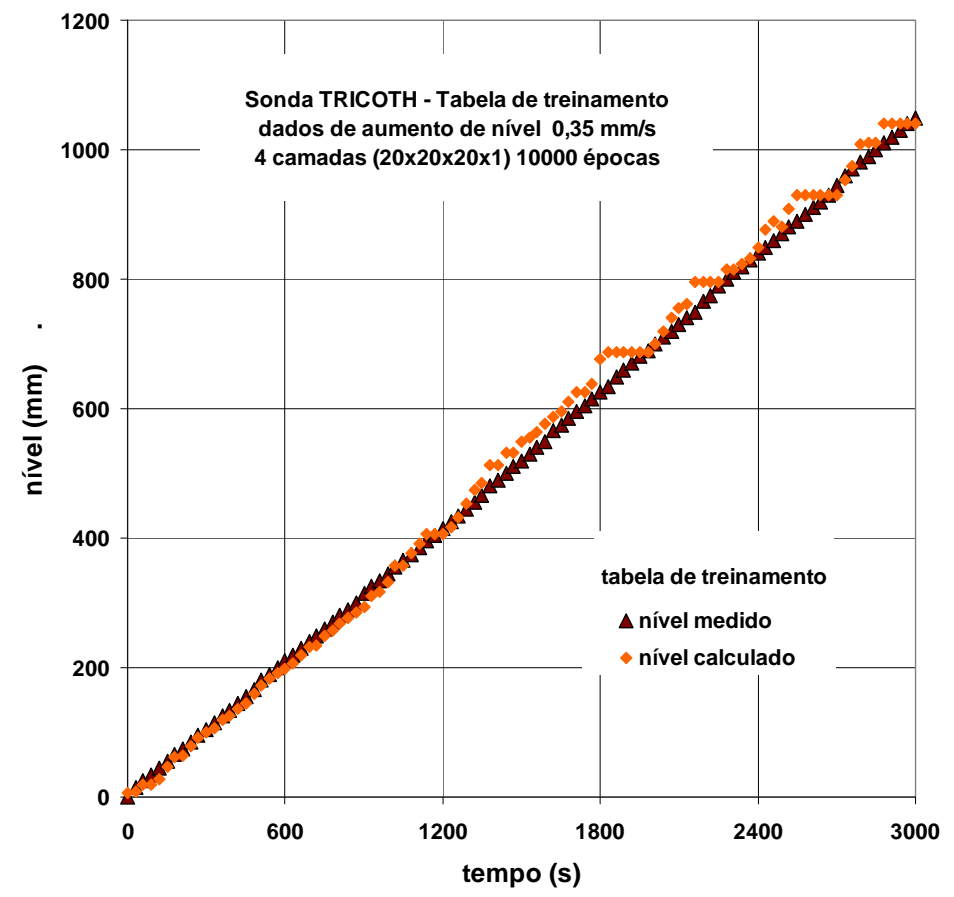

FIGURA 5.172. Nível x tempo para a análise com RNA 4 camadas (20×20×20x1), 10000 épocas, sorteando exemplos - tabela de treinamento tt - aumento de nível $0,35 \mathrm{~mm} / \mathrm{s}$. 


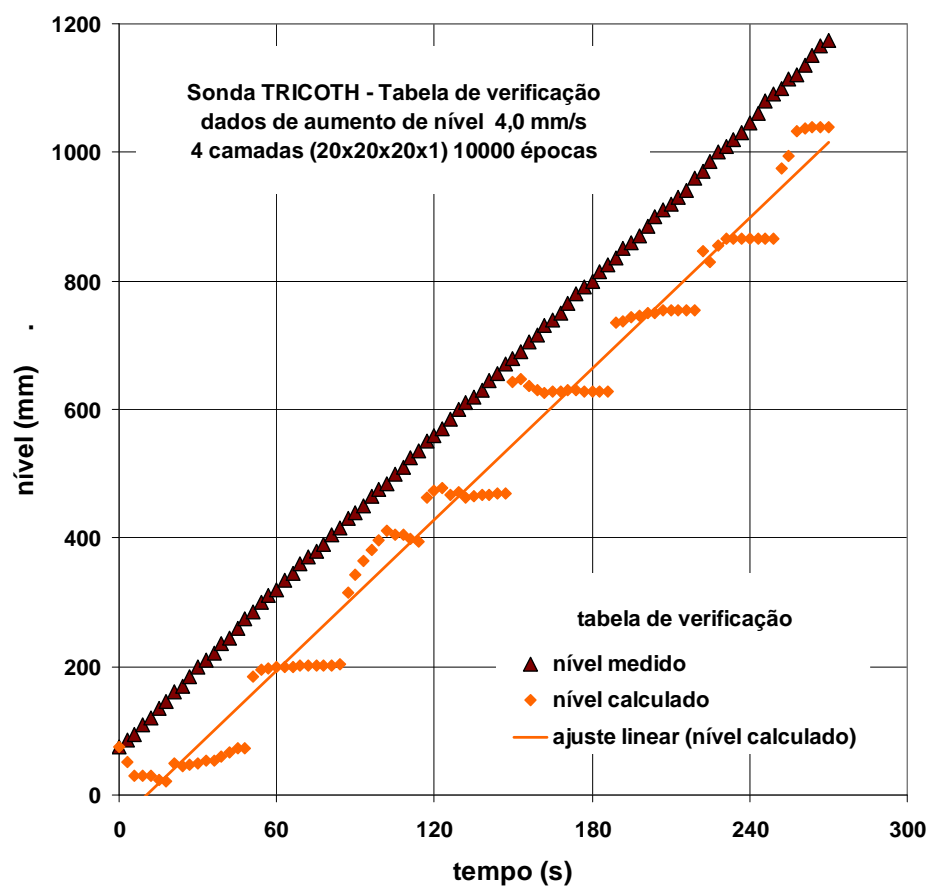

FIGURA 5.173. Nível x tempo para a análise com RNA 4 camadas (20×20×20x1), 10000 épocas, sorteando exemplos - tabela de verificação tv1 - aumento de nível $4,0 \mathrm{~mm} / \mathrm{s}$.

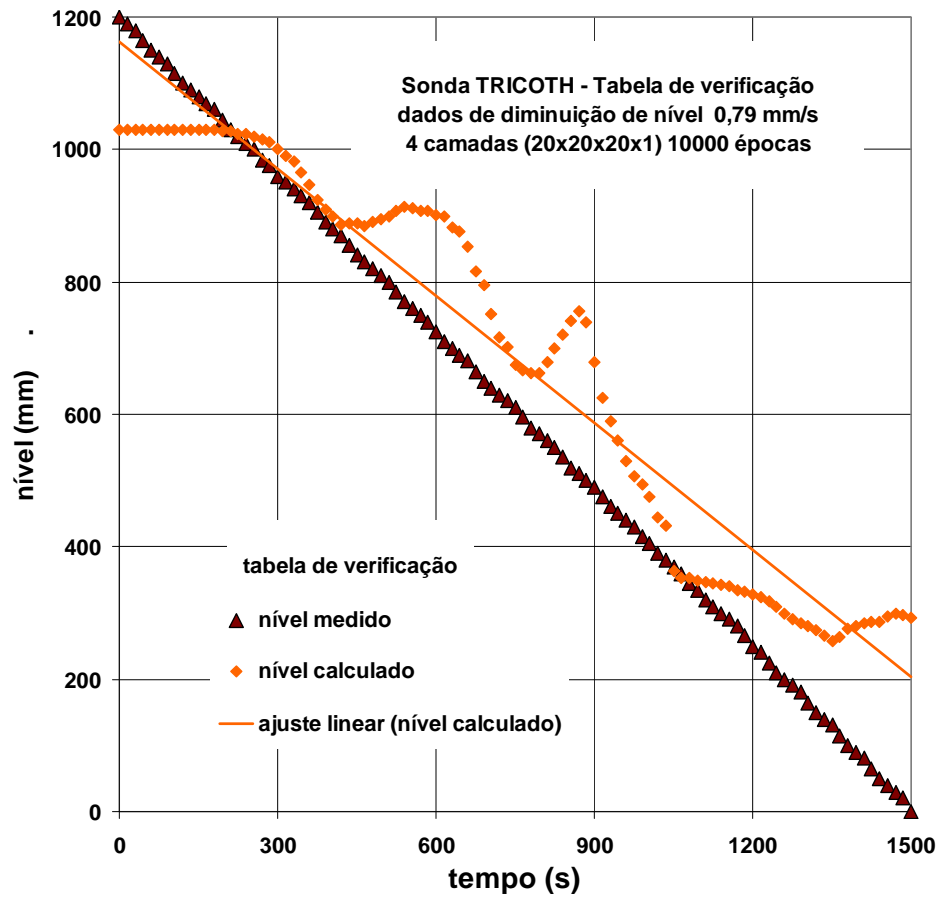

FIGURA 5.174. Nível x tempo para a análise com RNA 4 camadas (20×20×20×1), 10000 épocas, sorteando exemplos - tabela de verificação tv2 - diminuição de nível $4,0 \mathrm{~mm} / \mathrm{s}$. 


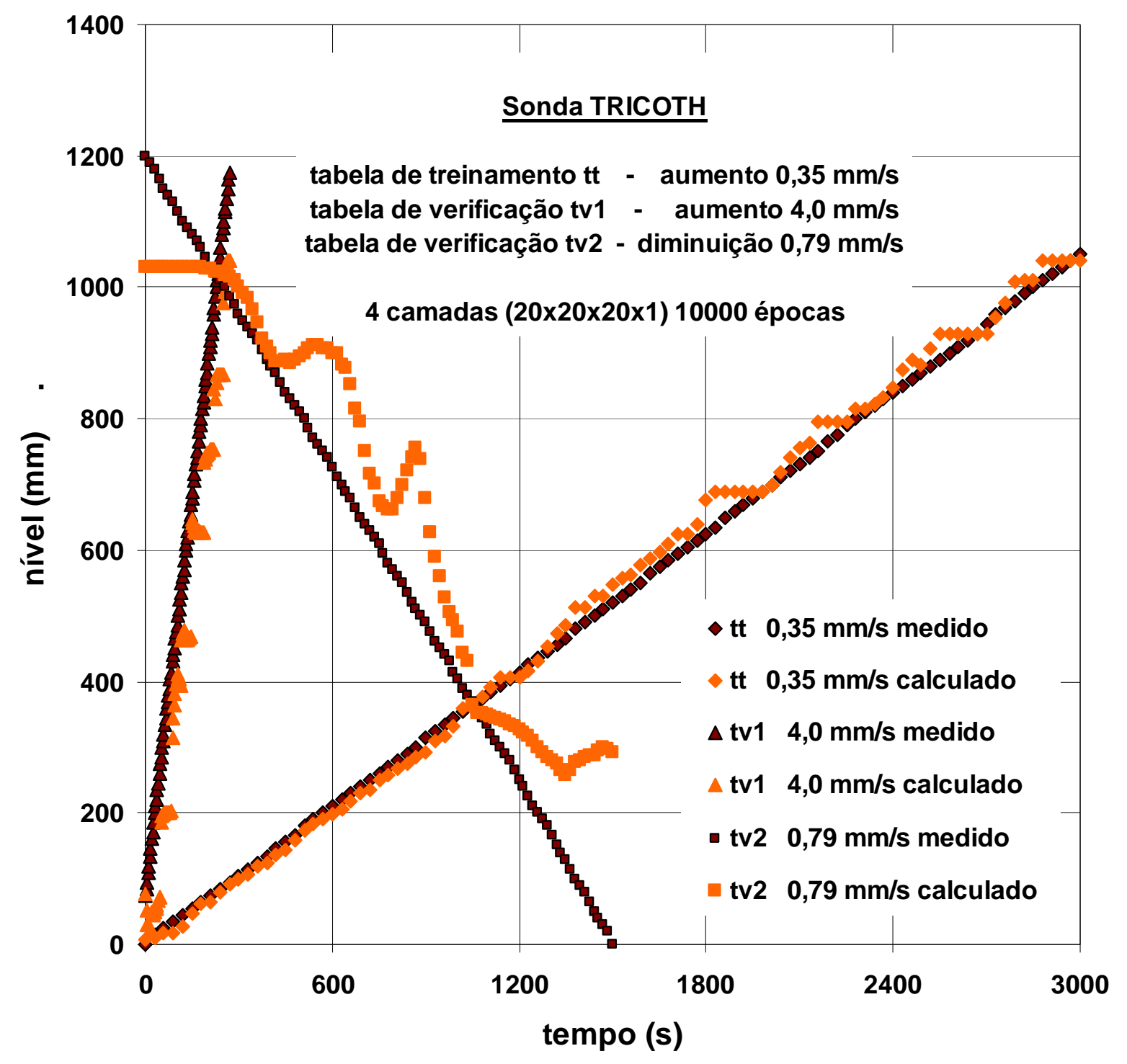

FIGURA 5.175. Nível $x$ tempo para a análise com RNA 4 camadas (20×20×20x1), 10000 épocas, sorteando exemplos - tabela de treinamento tt $\mathrm{e}$ tabelas de verificação tv1 e tv2. 
Neste trabalho foi abordado um novo conceito de sonda térmica, com resfriamento interno por água, para medida de nível em vasos de pressão que operam com uma mistura estratificada de água e vapor saturado. Neste tipo de sonda, os maiores coeficientes de transferência de calor ocorrem na região da sonda em contato com o vapor, onde ocorre preferencialmente o processo de condensação do vapor. $\mathrm{Na}$ região inferior da sonda em contato com a mistura líquido e vapor produzida pelo aquecedor elétrico ocorre um processo complexo de transferência de calor que envolve condução e convecção monofásica e bifásica. Os processos de transferência de calor citados acima produzem diferenças nas temperaturas de parede e de entrada e saída do fluido de resfriamento que estão relacionadas com o nível no vaso. Essas diferenças de temperatura foram tratadas usando Redes Neurais Artificiais para a determinação do nível a partir de dados genéricos de temperatura da sonda.

Os testes com a Sonda de tubo $\mathbf{U}$ foram realizados na seção de testes ST2 para valores constantes (estado estacionário) nível colapsado: 2000, 2200, 2400, 2600, 2800, 3000 e 3200 mm, abrangendo uma faixa de nível igual a $1200 \mathrm{~mm}$.

Os testes de transientes de diminuição de nível para a Sonda de tubo $\mathbf{U}$ foram realizados entre 3600 e $2400 \mathrm{~mm}$ para diferentes taxas de diminuição de nível que é função da abertura da válvula V1 entre as seções de testes ST1 e ST2. Neste caso, os testes também abrangeram uma faixa de nível igual a $1200 \mathrm{~mm}$.

Os testes com a Sonda de Tubos Concêntricos foram realizados na seção de testes ST1. Apenas os testes de transientes de diminuição de nível foram realizados para essa sonda na faixa entre 3600 e 2400 mm, para diferentes taxas de diminuição de nível que é função da abertura da válvula V1 entre as seções de testes ST1 e ST2. Também neste caso os testes abrangeram uma faixa de nível igual a $1200 \mathrm{~mm}$. 
Os dados experimentais de temperatura das sondas não foram submetidos a qualquer processo de suavização para eliminação de oscilações. Foi considerado apenas o valor médio calculado pelo Sistema de Aquisição de Dados de acordo com o tempo solicitado no programa de aquisição dos dados, no caso, a cada 30s. As oscilações observadas nas temperaturas de parede da sonda são decorrentes das condições internas de transferência de calor nas seções de testes. Esse tipo de oscilação não é observado pelos termopares que medem a as temperaturas de entrada e saída do fluido de resfriamento da sonda.

Os dados experimentais dos testes com as sondas em regime de nível em estado estacionário e em transientes foram analisados com as RNA's no programa RETRO-05, onde foi verificado o efeito do número de camadas das RNA`s, da quantidade de "neurônios" por camada, do número de épocas de treinamento e da escolha da opção de sorteio de exemplos durante o treinamento.

As análises realizadas com os dados referentes à Sonda de Tubo $\mathbf{U}$ em condições de nível em estado estacionário serviram para orientar na escolha da configuração adequada para as RNA's a serem usadas para as análises em condições de transientes. Observou-se que os melhores resultados no treinamento das RNA's foram obtidos com RNA's com 3 ou 4 camadas, preferencialmente com 4 camadas, e um número relativamente elevado de "neurônios" por camada, por exemplo, RNA's de 4 camadas com $20 \times 20 \times 20 \times 1$. Treinamentos da rede por 10000 épocas foram suficientes para o treinamento dessas RNA's em estado estacionário, e os treinamentos usando a opção de sorteio de exemplos produziram os melhores resultados.

Nas análises, tanto em regime de estado estacionário quanto em transiente, foram fornecidos como dados de entradas conhecidas 14 valores de temperatura, sendo 12 temperaturas de parede e as temperaturas de entrada e saída do fluido de resfriamento e um valor de nível correspondente como saída desejada. 
Também foram realizadas análises onde foi reduzido o número de temperaturas conhecidas fornecidas ao programa. Treinamentos de RNA's com a informação de temperatura de apenas 6 termopares instalados na parede, escolhidos alternadamente entre os termopares instalados na sonda, (TC2-11, TC2-13, TC2-15, TC2-17, TC2-19 e TC2-21) ou (TC2-12, TC2-14, TC2-16, TC2-18, TC2-20 e TC2-22), além dos dois termopares que medem as temperaturas de entrada (TC2-07) e saída (TC2-08) da água de resfriamento. Os resultados obtidos com essas análises para a sonda tipo tubo $U$ foram considerados bons e mostram que é possível obter bons resultados com um número menor de termopares e que conseqüentemente eles podem estar mais espaçados ao longo do comprimento da sonda.

Outras análises foram realizadas usando como entradas conhecidas apenas as temperaturas de entrada (TC2-07) e saída (TC2-08) da água de resfriamento da sonda tipo tubo U. As RNA's treinadas não foram capazes de aprender com os padrões fornecidos, indicando a necessidade das informações contidas nas demais temperaturas de parede da sonda. Facilitaria muito na construção das sondas e do sistema de medida como um todo, caso fosse possível obter bons resultados tendo como entradas conhecidas apenas as temperaturas de entrada e saída da água de resfriamento.

As análises dos dados em condições de transiente para a Sonda de Tubo U foram realizadas de três modos, ou seja:

No primeiro modo utilizaram-se as condições de estado estacionário para os vários níveis para construir uma tabela de treinamento e os dados experimentais dos testes em transiente de diminuição de nível referentes a 0,5 $(0,27 \mathrm{~mm} / \mathrm{s}), 1,0(0,4 \mathrm{~mm} / \mathrm{s})$ e 2,0 voltas $(1,46 \mathrm{~mm} / \mathrm{s})$ de abertura da válvula para construir as tabelas de verificação. As RNA's foram capazes de realizar as interpolações com os valores da tabela de treinamento, porém não foram capazes de generalizar para os dados das tabelas de verificação apresentadas à rede. O motivo de tal comportamento se deve ao fato das RNA's terem sido treinadas com os dados da tabela de treinamento para as condições 
de estado estacionário, que são muito diferentes daqueles dados das tabelas de verificação para as condições de transiente.

No segundo modo utilizaram-se os dados experimentais do teste referente a 0,5 volta $(0,27 \mathrm{~mm} / \mathrm{s})$ de abertura da válvula como tabela de treinamento e os dados experimentais dos testes referentes a $1,0(0,4 \mathrm{~mm} / \mathrm{s})$ e 2,0 voltas $(1,46 \mathrm{~mm} / \mathrm{s})$ como tabelas de verificação. Os resultados melhoraram muito em comparação aos do primeiro, porém requerendo um treinamento da rede por um número maior de épocas, por exemplo, 50000 épocas. Neste caso, os dados de treinamento e de verificação apresentam comportamentos semelhantes.

No terceiro modo tomou-se a totalidade dos dados referentes aos transientes de 0,5 $(0,27 \mathrm{~mm} / \mathrm{s}), 1,0(0,4 \mathrm{~mm} / \mathrm{s})$ e 2,0 voltas $(1,46 \mathrm{~mm} / \mathrm{s})$ de abertura da válvula e separou-se $80 \%$ dos valores para construir a tabela de treinamento e $20 \%$ para construir a tabela de verificação. Devido ao fato dos conjuntos de treinamento e de verificação apresentarem semelhanças entre si, pois têm origem de um conjunto comum, a rede não encontrou dificuldades para efetuar as interpolações com os dados de treinamento e posterior generalização para os dados de verificação, exigindo um menor número de épocas de treinamento e bons resultados.

As análises mostraram ainda que os termopares posicionados na região superior da sonda tipo tubo $U$, local predominantemente ocupado pela fase de vapor e onde ocorre preferencialmente o processo de condensação, carregam as informações mais importantes para o treinamento das RNA's e para a posterior determinação do nível, do que aqueles posicionados na região inferior da sonda e que estão mergulhados na fase líquida. Neste caso, foram realizados treinamentos de RNA's com a informação de temperatura dos 6 termopares instalados na parede nas regiões superior (TC2-17, TC2-18, TC2-19, TC2-20, TC2-21 e TC2-22) e inferior (TC2-11, TC2-12, TC2-13, TC214, TC2-15 e TC2-16) da sonda e os dois termopares que medem as temperaturas de entrada (TC2-07) e saída (TC2-08) do fluido de resfriamento. Os melhores resultados foram obtidos com os termopares da região superior, indicando que além de ser possível 
operar com uma sonda com um número menor de termopares, é possível construir uma sonda com menor comprimento para uma mesma faixa de medida de nível.

Foi ainda realizada uma análise usando os 14 valores de temperatura para cada ponto experimental na tabela de treinamento, porém na tabela de verificação simulou-se a perda de informação de um termopar da sonda, mais especificamente TC2-18 escolhido aleatoriamente, que na tabela de verificação assumiu o valor TC2-18 $=0^{\circ} \mathrm{C}$. Essa análise teve objetivo de mostrar a robustez da rede na generalização do aprendizado quando ocorre perda de informação. Os resultados foram considerados bons, indicando que a técnica funciona mesmo com a perda de alguma informação.

Os testes com a Sonda de Tubos Concêntricos na seção de testes ST1 foram realizados apenas para as condições de transiente de diminuição de nível referentes a 0,5 (0,4 mm/s) e 1,0 (1,875 mm) voltas de abertura de válvula. As taxas iniciais de diminuição de nível medidas para a sonda de tubos concêntricos foram maiores do que aquelas medidas para a sonda de tubo $U$ para uma mesma abertura de válvula. Essa diferença é decorrente dos diferentes graus de pressão sub-atmosférica obtidos nas ST's durante os testes com as duas sondas. Os dados de temperatura obtidos para diferentes condições de transiente foram muito semelhantes. Testes adicionais podem ser realizados em trabalhos futuros visando aumentar a diferença nas temperaturas para diferentes transientes.

As análises realizadas com os dados experimentais da Sonda de Tubos Concêntricos produziram resultados não satisfatórios. Devido à semelhança nos dados experimentais, a RNA realizou as interpolações com o conjunto de treinamento, contudo não adquiriu a capacidade de reconhecimento de outros padrões devido a essa semelhança. Das análises com a sonda de tubos concêntricos conclui-se que para obtenção de bons resultados com a técnica é necessário que as "assinaturas" das temperaturas apresentem diferenças maiores para diferentes transientes. 
A técnica de medida também foi aplicada aos dados experimentais, disponíveis na literatura, para um protótipo da sonda TRICOTH (Termaat et al., 1990) e os resultados podem ser considerados bons. Diferentemente das sondas desenvolvidas para a realização deste trabalho e que operam com resfriamento por um fluido, a sonda térmica TRICOTH é aquecida eletricamente e possui termopares ligados diferencialmente, que produzem dois sinais de força-eletromotriz E1 e E2, e que são usados para a determinação do nível. Bons resultados foram obtidos, tanto para transientes de aumento de nível quanto para diminuição de nível. Essa sonda possui um número reduzido de fios e cabos, porém, caso ocorra a perda de função de qualquer das junções dos termopares diferenciais, um dos dois sinais E1 ou E2 se perde, incapacitando a operação da sonda.

Os resultados das análises mostraram que a técnica que utiliza as informações de temperatura das sondas térmicas para treinar as RNA's, que posteriormente são usadas para medir o nível a partir de informações genéricas de temperatura da sonda pode ser aplicada com essa finalidade, podendo ser aperfeiçoada e posteriormente usada para o desenvolvimento de um sistema para medida de nível em vasos de pressão que operam com mistura estratificada de água e vapor.

Como desvantagens, a técnica apresenta a necessidade de realização de testes em condições de transiente para a obtenção de dados representativos para o treinamento da rede e o elevado número de termopares necessários, requerendo uma quantidade elevada de cabos de transmissão e a disponibilização de um número elevado de canais no sistema de aquisição de dados. Porém, como vantagem, a técnica de medida de nível provou que pode funcionar mesmo quando ocorrer a perda de função de algum dos termopares instalados na parede da sonda.

As Sondas de Tubos Concêntricos e de Tubo $U$ foram testadas com apenas uma configuração de instalação de termopares na parede. Estudos futuros poderão ser realizados com o objetivo de melhorá-las, alterando-se a disposição e a quantidade de termopares. 
Os testes com as Sondas de Tubos Concêntricos e de Tubo $U$ foram realizados em condições de baixa pressão e na correspondente temperatura de saturação. É também necessária a realização de testes em alta pressão e temperatura para verificar o comportamento dessas sondas nessas condições.

A utilização de tubos em torno das sondas (tubos de acalmação) para diminuir as oscilações que ocorrem nas seções de testes devido à movimentação da mistura bifásica deve melhorar os resultados das medidas de temperatura.

O programa RETRO-05 (Perceptron de Múltiplas Camadas com Retropropagação) não é apropriado para tratar dados que variam com o tempo. Mesmo assim apresentou boa capacidade de aprendizado e de generalização. Redes neurais recorrentes são mais adequadas para esses casos com variação temporal, conforme Tsoukalas e Uhrig (1997), Braga et al. (2000) e Kovács (1996) e podem ser estudadas e aplicadas em trabalhos futuros.

O acoplamento do SAD com o programa de análises com RNA's deve ser desenvolvido para automatizar a técnica para fornecer diretamente o valor do nível à medida que as informações de temperatura são recebidas.

A aplicação deste tipo de sonda resfriada por água para a medida de nível em vasos de reatores nucleares irá requerer outras considerações. Em um circuito primário de um reator PWR convencional, onde se encontra o vaso do reator, existem condições de alta pressão da ordem de $15 \mathrm{MPa}$ (150 bar) e também de temperatura da ordem de $290^{\circ} \mathrm{C}$. Para evitar a formação de vapor no interior da sonda, o sistema de fornecimento de água de resfriamento da sonda deverá também ser pressurizado. A própria água do circuito primário poderia ser usada para o resfriamento da sonda, retirando-a de um ponto de alta pressão e devolvendo-a em um ponto de baixa pressão do próprio circuito. Análises de acidentes devem ser realizadas para verificar o efeito da introdução destas linhas adicionais no potencial de risco de acidentes da planta. 


\section{APÊNDICE A. Calibrações dos Termopares da Bancada Experimental e das Sondas}

O APÊNDICE A apresenta os resultados das calibrações dos termopares utilizados na bancada experimental e nas sondas de tubos concêntricos e de tubo U.

Os termopares TC1-01, TC1-02, TC1-03, TC1-04, TC1-05, TC1-06 são do tipo K com camisa de $12 \mathrm{~mm}$ de diâmetro externo, e foram usados na seção de testes ST1 como termopares de processo. Os termopares TC1-07 e TC1-08 também são do tipo $\mathrm{K}$ com camisa de $12 \mathrm{~mm}$ de diâmetro externo, e foram usados para medir a temperatura de entrada e saída da água de resfriamento respectivamente, na sonda de tubos concêntricos instalada na seção de testes ST1. Estes termopares foram calibrados, usando o forno de calibração Isocal Vênus 2125B da Isothec, com banho térmico com água, e temperaturas na faixa de 35 a $93^{\circ} \mathrm{C}$.

Os termopares TC1-11, TC1-12, TC1-13, TC1-14, TC1-15, TC1-16, TC1-17, TC1-18, TC1-19, TC1-20, TC1-21, TC1-22 são do tipo $\mathrm{K}$ com camisa de $1 \mathrm{~mm}$ de diâmetro e foram usados para medir a temperatura da parede da sonda de tubos concêntricos. Estes termopares foram calibrados, usando o forno de calibração JÚPITER 650B da Isothec, com bloco térmico metálico, e temperaturas na faixa de $35 \mathrm{a}$ $150{ }^{\circ} \mathrm{C}$.

Os termopares TC2-01, TC2-02, TC2-03, TC2-04, TC2-05, TC2-06 são do tipo $\mathrm{K}$ com camisa de $12 \mathrm{~mm}$ de diâmetro externo, e foram usados na seção de testes ST2 como termopares de processo. Os termopares TC2-07 e TC2-08 também são do tipo $\mathrm{K}$ com camisa de $12 \mathrm{~mm}$ de diâmetro externo, e foram usados para medir a temperatura de entrada e saída da água de resfriamento respectivamente, na sonda de tubo $U$ instalada na seção de testes ST2. Estes termopares foram calibrados, usando o forno de calibração Isocal Vênus 2125B da Isothec, com banho térmico com água, e temperaturas na faixa de 35 a $93{ }^{\circ} \mathrm{C}$. 
Os termopares TC2-11, TC2-12, TC2-13, TC2-14, TC2-15, TC2-16, TC2-17, TC2-18, TC2-19, TC2-20, TC2-21, TC2-22 são do tipo K com camisa de $1 \mathrm{~mm}$ de diâmetro e foram usados para medir a temperatura da parede da sonda de tubo U. Estes termopares foram calibrados, usando o forno de calibração JÚPITER 650B da Isothec, com bloco térmico metálico, e temperaturas na faixa de 35 a $150{ }^{\circ} \mathrm{C}$.

Um termômetro de resistência do tipo RTD (Resistance Temperature Detector) PT-100 calibrado foi utilizado como padrão primário no processo de calibração. A calibração do RTD, realizada na faixa de -30 a $300{ }^{\circ} \mathrm{C}$, foi feita pelo Laboratório de Metrologia da empresa CONTEMP, que é associado à Rede Brasileira de Calibração. A curva de calibração de temperatura versus resistência elétrica deste instrumento é apresentada na FIG. A1, que também contém os pontos de calibração.

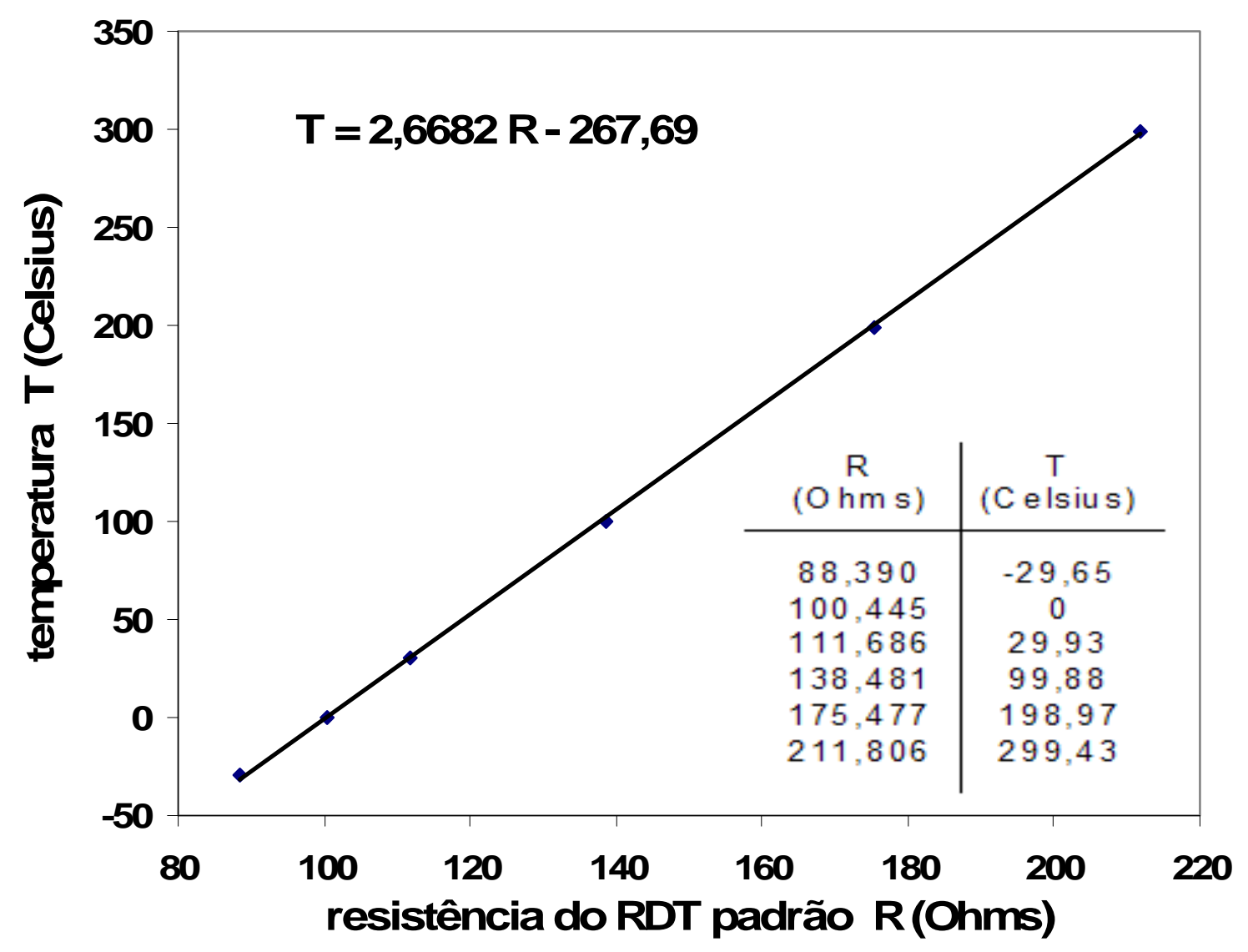

FIGURA A1. Curva de calibração do RTD tipo PT-100 usado na calibração dos termopares do experimento. 
TABELA A1. Dados de calibração do termopar TC1-01.

\begin{tabular}{cccc|cccc}
\hline $\begin{array}{c}\text { PT-001 } \\
\left({ }^{\circ} \mathrm{C}\right)\end{array}$ & $\begin{array}{c}\text { TC1-01 } \\
\left({ }^{\circ} \mathrm{C}\right)\end{array}$ & $\begin{array}{c}\text { TC1-01 } \\
\text { corrigida } \\
\left({ }^{\circ} \mathrm{C}\right)\end{array}$ & $\begin{array}{c}\text { diferença } \\
\text { percentual } \\
(\%)\end{array}$ & $\begin{array}{c}\text { PT-001 } \\
\left({ }^{\circ} \mathrm{C}\right)\end{array}$ & $\begin{array}{c}\text { TC1-01 } \\
\left({ }^{\circ} \mathrm{C}\right)\end{array}$ & $\begin{array}{c}\text { TC1-01 } \\
\text { corrigida } \\
\left({ }^{\circ} \mathrm{C}\right)\end{array}$ & $\begin{array}{c}\text { diferença } \\
\text { percentual } \\
(\%)\end{array}$ \\
\hline 34,76 & 34,00 & 34,80 & $-0,13$ & 75,03 & 73,20 & 74,91 & 0,16 \\
34,73 & 34,00 & 34,80 & $-0,21$ & 74,97 & 73,20 & 74,91 & 0,09 \\
34,81 & 34,00 & 34,80 & 0,02 & 74,95 & 73,20 & 74,91 & 0,05 \\
34,84 & 34,00 & 34,80 & 0,10 & 75,05 & 73,20 & 74,91 & 0,19 \\
34,86 & 34,00 & 34,80 & 0,17 & 75,03 & 73,20 & 74,91 & 0,16 \\
49,93 & 48,60 & 49,96 & $-0,06$ & 85,04 & 83,20 & 84,96 & 0,09 \\
49,95 & 48,60 & 49,96 & $-0,01$ & 85,01 & 83,20 & 84,96 & 0,06 \\
49,95 & 48,60 & 49,96 & $-0,01$ & 84,98 & 83,20 & 84,96 & 0,03 \\
49,93 & 48,60 & 49,96 & $-0,06$ & 84,98 & 83,20 & 84,96 & 0,03 \\
49,93 & 48,60 & 49,96 & $-0,06$ & 84,96 & 83,20 & 84,96 & 0,00 \\
65,07 & 63,40 & 65,03 & 0,07 & 92,86 & 90,90 & 92,70 & 0,17 \\
65,07 & 63,40 & 65,03 & 0,07 & 92,86 & 90,90 & 92,70 & 0,17 \\
65,07 & 63,40 & 65,03 & 0,07 & 92,89 & 90,90 & 92,70 & 0,20 \\
65,02 & 63,40 & 65,03 & $-0,01$ & 92,86 & 90,90 & 92,70 & 0,17 \\
65,02 & 63,40 & 65,03 & $-0,01$ & 92,89 & 90,90 & 92,70 & 0,20 \\
\hline
\end{tabular}

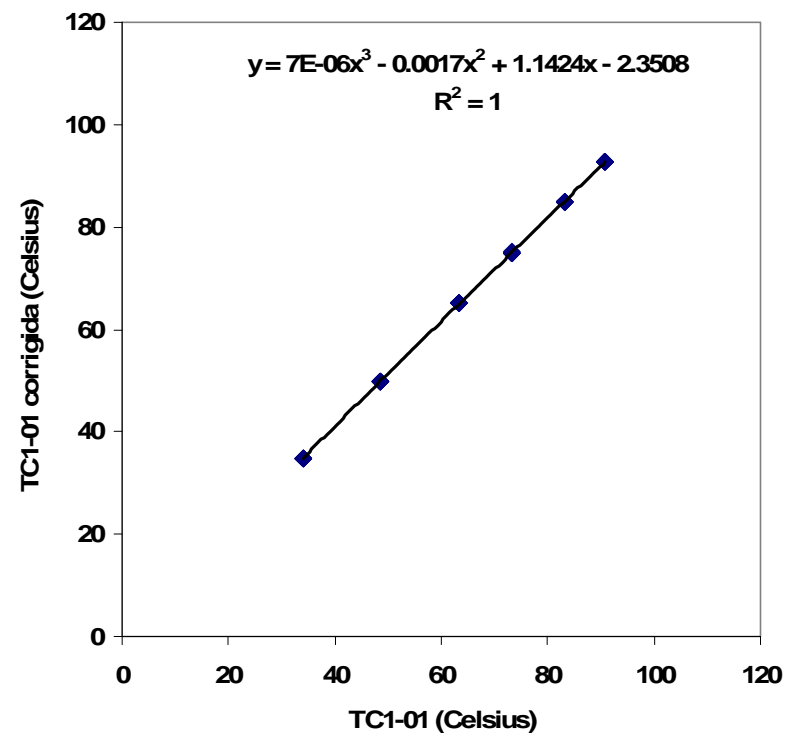

$\mathrm{A} 2 \mathrm{a}$

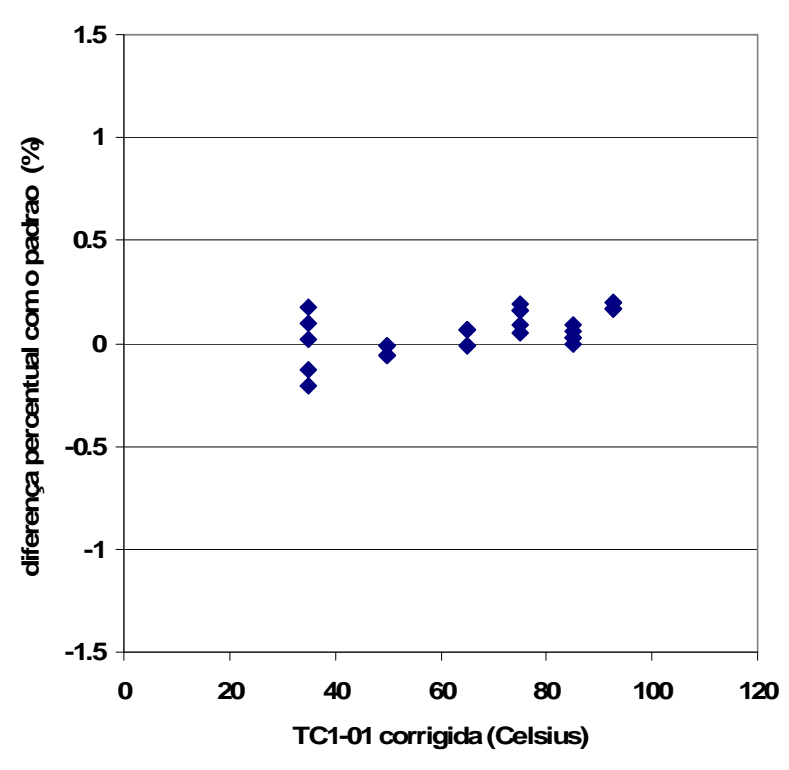

$\mathrm{A} 2 \mathrm{~b}$

FIGURA A2. Curva de calibração TC1-01(A2a) e diferença percentual com o padrão (A2b). 
TABELA A2. Dados de calibração do termopar TC1-02.

\begin{tabular}{cccc|cccc}
\hline $\begin{array}{c}\text { PT-001 } \\
\left({ }^{\circ} \mathrm{C}\right)\end{array}$ & $\begin{array}{c}\text { TC1-02 } \\
\left({ }^{\circ} \mathrm{C}\right)\end{array}$ & $\begin{array}{c}\text { TC1-02 } \\
\text { corrigida } \\
\left({ }^{\circ} \mathrm{C}\right)\end{array}$ & $\begin{array}{c}\text { diferença } \\
\text { percentual } \\
(\%)\end{array}$ & $\begin{array}{c}\text { PT-001 } \\
\left({ }^{\circ} \mathrm{C}\right)\end{array}$ & $\begin{array}{c}\text { TC1-02 } \\
\left({ }^{\circ} \mathrm{C}\right)\end{array}$ & $\begin{array}{c}\text { TC1-02 } \\
\text { corrigida } \\
\left({ }^{\circ} \mathrm{C}\right)\end{array}$ & $\begin{array}{c}\text { diferença } \\
\text { percentual } \\
(\%)\end{array}$ \\
\hline & & & & & & & \\
35,02 & 34,10 & 35,08 & $-0,18$ & 74,92 & 73,20 & 75,17 & $-0,33$ \\
34,99 & 34,10 & 35,08 & $-0,25$ & 74,95 & 73,20 & 75,17 & $-0,29$ \\
34,99 & 34,10 & 35,08 & $-0,25$ & 74,95 & 73,30 & 75,27 & $-0,43$ \\
34,99 & 34,00 & 34,98 & 0,04 & 74,92 & 73,20 & 75,17 & $-0,33$ \\
34,97 & 34,00 & 34,98 & $-0,04$ & 74,95 & 73,30 & 75,27 & $-0,43$ \\
50,22 & 49,00 & 50,32 & $-0,19$ & 84,77 & 82,80 & 84,99 & $-0,25$ \\
50,22 & 49,00 & 50,32 & $-0,19$ & 84,77 & 82,90 & 85,09 & $-0,37$ \\
50,22 & 49,00 & 50,32 & $-0,19$ & 84,80 & 82,90 & 85,09 & $-0,34$ \\
50,19 & 49,00 & 50,32 & $-0,24$ & 84,80 & 82,90 & 85,09 & $-0,34$ \\
50,19 & 49,00 & 50,32 & $-0,24$ & 84,80 & 82,90 & 85,09 & $-0,34$ \\
65,05 & 63,50 & 65,21 & $-0,25$ & 92,86 & 90,90 & 93,22 & $-0,39$ \\
65,05 & 63,50 & 65,21 & $-0,25$ & 92,86 & 90,90 & 93,22 & $-0,39$ \\
65,02 & 63,50 & 65,21 & $-0,29$ & 92,84 & 90,90 & 93,22 & $-0,42$ \\
65,02 & 63,50 & 65,21 & $-0,29$ & 92,84 & 90,90 & 93,22 & $-0,42$ \\
65,05 & 63,40 & 65,11 & $-0,09$ & 92,81 & 90,90 & 93,22 & $-0,44$ \\
\hline
\end{tabular}

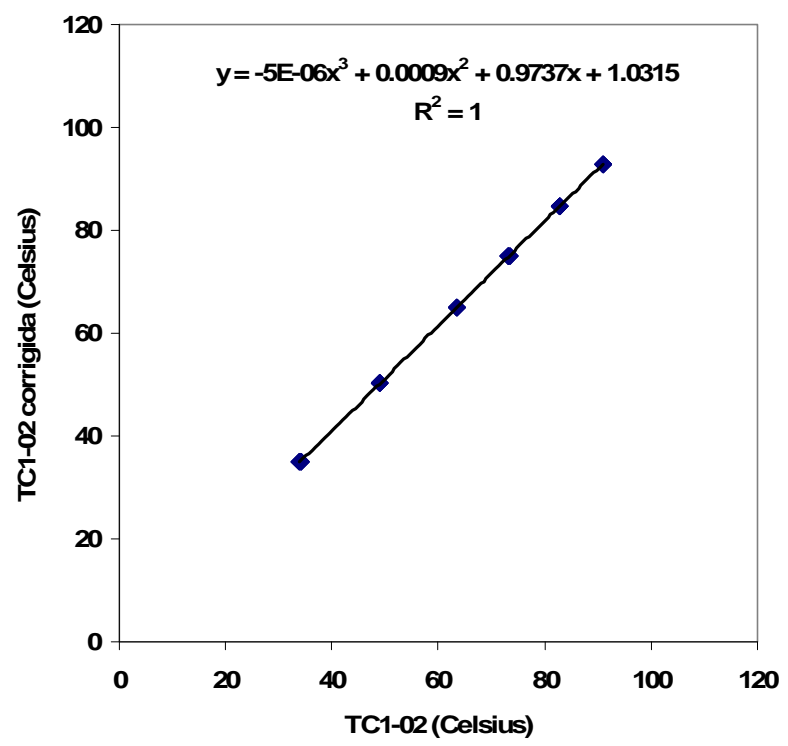

$\mathrm{A} 3 \mathrm{a}$

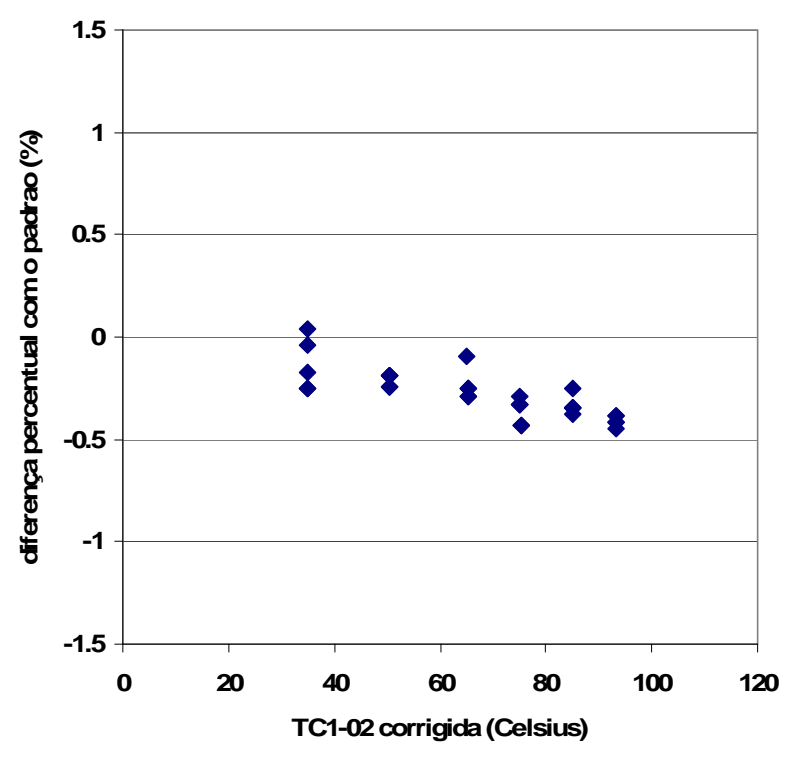

$\mathrm{A} 3 \mathrm{~b}$

FIGURA A3. Curva de calibração TC1-02 (A3a) e diferença percentual com o padrão(A3b). 
TABELA A3. Dados de calibração do termopar TC1-03.

\begin{tabular}{cccc|cccc}
\hline $\begin{array}{c}\text { PT-001 } \\
\left({ }^{\circ} \mathrm{C}\right)\end{array}$ & $\begin{array}{c}\text { TC1-03 } \\
\left({ }^{\circ} \mathrm{C}\right)\end{array}$ & $\begin{array}{c}\text { TC1-03 } \\
\text { corrigida } \\
\left({ }^{\circ} \mathrm{C}\right)\end{array}$ & $\begin{array}{c}\text { diferença } \\
\text { percentual } \\
(\%)\end{array}$ & $\begin{array}{c}\text { PT-001 } \\
\left({ }^{\circ} \mathrm{C}\right)\end{array}$ & $\begin{array}{c}\text { TC1-03 } \\
\left({ }^{\circ} \mathrm{C}\right)\end{array}$ & $\begin{array}{c}\text { TC1-03 } \\
\text { corrigida } \\
\left({ }^{\circ} \mathrm{C}\right)\end{array}$ & $\begin{array}{c}\text { diferença } \\
\text { percentual } \\
(\%)\end{array}$ \\
\hline & & & & & & & \\
34,70 & 33,80 & 34,66 & 0,12 & 75,77 & 73,90 & 75,69 & 0,11 \\
34,70 & 33,80 & 34,66 & 0,12 & 75,77 & 73,90 & 75,69 & 0,11 \\
34,70 & 33,90 & 34,76 & $-0,17$ & 75,77 & 73,90 & 75,69 & 0,11 \\
34,70 & 33,80 & 34,66 & 0,12 & 75,77 & 73,90 & 75,69 & 0,11 \\
34,70 & 33,80 & 34,66 & 0,12 & 75,77 & 73,90 & 75,69 & 0,11 \\
50,35 & 49,10 & 50,31 & 0,08 & 85,12 & 83,20 & 85,10 & 0,02 \\
50,35 & 49,10 & 50,31 & 0,08 & 85,12 & 83,20 & 85,10 & 0,02 \\
50,35 & 49,10 & 50,31 & 0,08 & 85,12 & 83,20 & 85,10 & 0,02 \\
50,35 & 49,10 & 50,31 & 0,08 & 85,09 & 83,20 & 85,10 & $-0,01$ \\
50,35 & 49,10 & 50,31 & 0,08 & 85,12 & 83,30 & 85,20 & $-0,09$ \\
65,61 & 64,00 & 65,59 & 0,02 & 92,97 & 91,10 & 93,00 & $-0,03$ \\
65,63 & 64,10 & 65,69 & $-0,09$ & 92,97 & 91,10 & 93,00 & $-0,03$ \\
65,63 & 64,00 & 65,59 & 0,06 & 93,00 & 91,00 & 92,90 & 0,10 \\
65,63 & 64,00 & 65,59 & 0,06 & 92,97 & 91,00 & 92,90 & 0,07 \\
65,63 & 64,00 & 65,59 & 0,06 & 93,05 & 91,10 & 93,00 & 0,05 \\
\hline
\end{tabular}

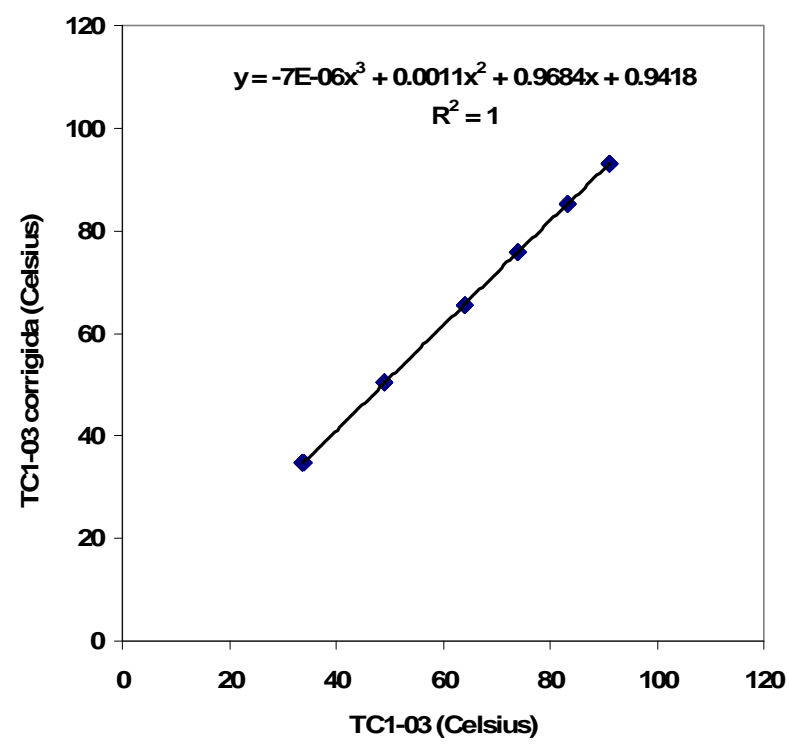

$\mathrm{A} 4 \mathrm{a}$

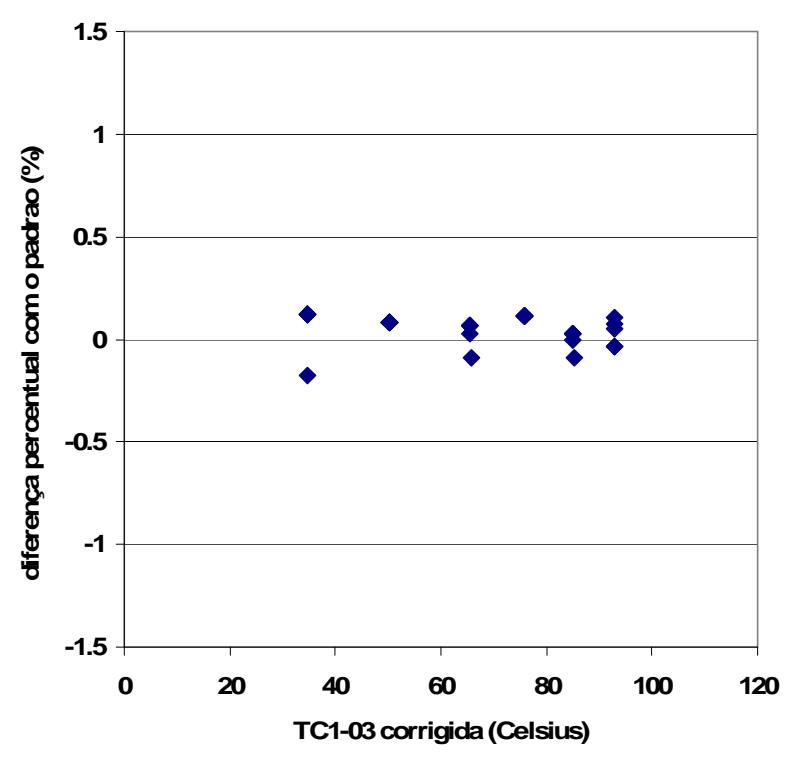

$A 4 b$

FIGURA A4. Curva de calibração TC1-03 (A4a) e diferença percentual com o padrão (A4b). 
TABELA A4 . Dados de calibração do termopar TC1-04.

\begin{tabular}{cccc|cccc}
\hline $\begin{array}{c}\text { PT-001 } \\
\left({ }^{\circ} \mathrm{C}\right)\end{array}$ & $\begin{array}{c}\text { TC1-04 } \\
\left({ }^{\circ} \mathrm{C}\right)\end{array}$ & $\begin{array}{c}\text { TC1-04 } \\
\text { corrigida } \\
\left({ }^{\circ} \mathrm{C}\right)\end{array}$ & $\begin{array}{c}\text { diferença } \\
\text { percentual } \\
(\%)\end{array}$ & $\begin{array}{c}\text { PT-001 } \\
\left({ }^{\circ} \mathrm{C}\right)\end{array}$ & $\begin{array}{c}\text { TC1-04 } \\
\left({ }^{\circ} \mathrm{C}\right)\end{array}$ & $\begin{array}{c}\text { TC1-04 } \\
\text { corrigida } \\
\left({ }^{\circ} \mathrm{C}\right)\end{array}$ & $\begin{array}{c}\text { diferença } \\
\text { percentual } \\
(\%)\end{array}$ \\
\hline & & & & & & & \\
34,68 & 33,80 & 34,81 & $-0,39$ & 75,21 & 73,50 & 75,50 & $-0,37$ \\
34,68 & 33,80 & 34,81 & $-0,39$ & 75,24 & 73,50 & 75,50 & $-0,34$ \\
34,70 & 33,90 & 34,92 & $-0,62$ & 75,24 & 73,50 & 75,50 & $-0,34$ \\
34,70 & 33,90 & 34,92 & $-0,62$ & 75,24 & 73,50 & 75,50 & $-0,34$ \\
34,70 & 33,90 & 34,92 & $-0,62$ & 75,24 & 73,50 & 75,50 & $-0,34$ \\
49,98 & 48,60 & 50,20 & $-0,44$ & 85,14 & 83,40 & 85,50 & $-0,42$ \\
49,98 & 48,60 & 50,20 & $-0,44$ & 85,12 & 83,30 & 85,40 & $-0,33$ \\
49,98 & 48,60 & 50,20 & $-0,44$ & 85,12 & 83,30 & 85,40 & $-0,33$ \\
49,98 & 48,60 & 50,20 & $-0,44$ & 85,14 & 83,30 & 85,40 & $-0,30$ \\
49,98 & 48,60 & 50,20 & $-0,44$ & 85,14 & 83,40 & 85,50 & $-0,42$ \\
65,10 & 63,40 & 65,28 & $-0,28$ & 93,05 & 91,20 & 93,42 & $-0,40$ \\
65,13 & 63,40 & 65,28 & $-0,24$ & 93,05 & 91,20 & 93,42 & $-0,40$ \\
65,13 & 63,40 & 65,28 & $-0,24$ & 93,08 & 91,20 & 93,42 & $-0,37$ \\
65,07 & 63,40 & 65,28 & $-0,32$ & 93,10 & 91,10 & 93,31 & $-0,23$ \\
65,10 & 63,40 & 65,28 & $-0,28$ & 93,08 & 91,20 & 93,42 & $-0,37$ \\
& & & & & & \\
\hline
\end{tabular}

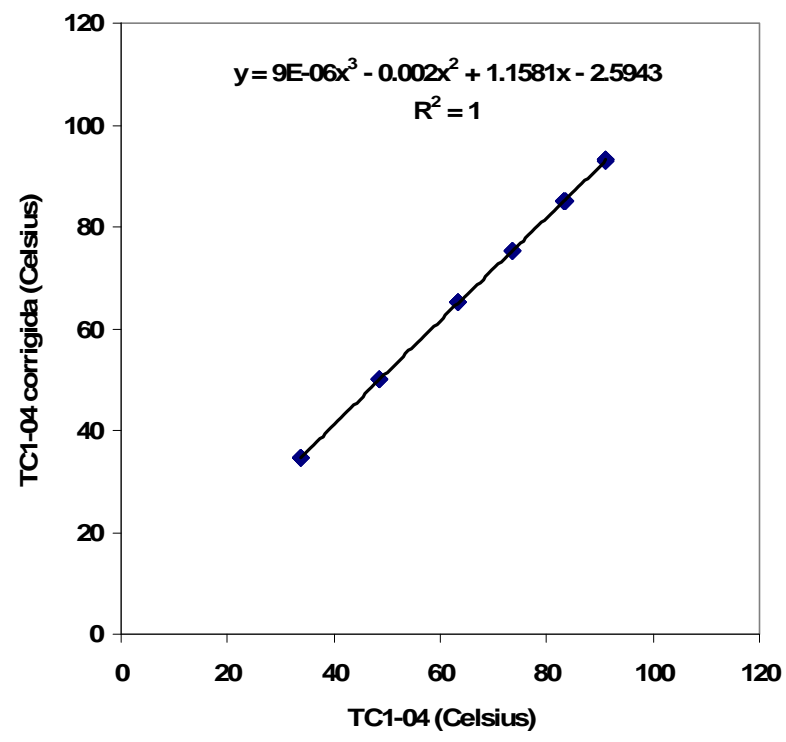

$\mathrm{A} 5 \mathrm{a}$

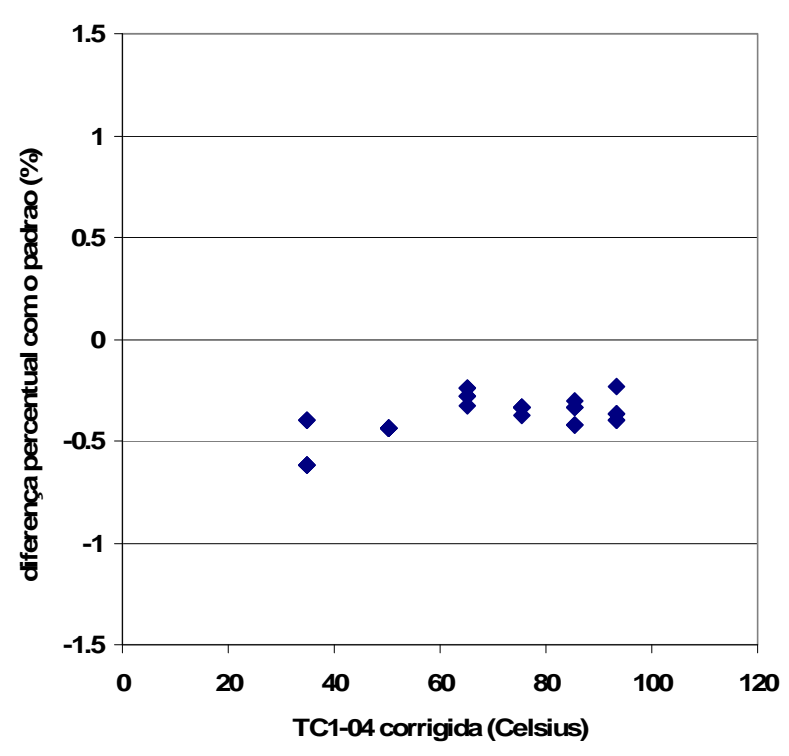

$\mathrm{A} 5 \mathrm{~b}$

FIGURA A5. Curva de calibração TC1-04 (A5a) e diferença percentual com o padrão(A5b). 
TABELA A5. Dados de calibração do termopar TC1-05.

\begin{tabular}{cccc|cccc}
\hline $\begin{array}{c}\text { PT-001 } \\
\left({ }^{\circ} \mathrm{C}\right)\end{array}$ & $\begin{array}{c}\text { TC1-05 } \\
\left({ }^{\circ} \mathrm{C}\right)\end{array}$ & $\begin{array}{c}\text { TC1-05 } \\
\text { corrigida } \\
\left({ }^{\circ} \mathrm{C}\right)\end{array}$ & $\begin{array}{c}\text { diferença } \\
\text { percentual } \\
(\%)\end{array}$ & $\begin{array}{c}\text { PT-001 } \\
\left({ }^{\circ} \mathrm{C}\right)\end{array}$ & $\begin{array}{c}\text { TC1-05 } \\
\left({ }^{\circ} \mathrm{C}\right)\end{array}$ & $\begin{array}{c}\text { TC1-05 } \\
\text { corrigida } \\
\left({ }^{\circ} \mathrm{C}\right)\end{array}$ & $\begin{array}{c}\text { diferença } \\
\text { percentual } \\
(\%)\end{array}$ \\
\hline & & & & & & & \\
34,91 & 34,00 & 34,97 & $-0,15$ & 75,13 & 73,40 & 75,31 & $-0,23$ \\
34,91 & 33,90 & 34,87 & 0,14 & 75,11 & 73,40 & 75,31 & $-0,27$ \\
34,91 & 33,90 & 34,87 & 0,14 & 75,11 & 73,40 & 75,31 & $-0,27$ \\
34,89 & 34,00 & 34,97 & $-0,23$ & 75,13 & 73,40 & 75,31 & $-0,23$ \\
34,89 & 34,00 & 34,97 & $-0,23$ & 75,13 & 73,40 & 75,31 & $-0,23$ \\
49,93 & 48,70 & 50,00 & $-0,14$ & 85,22 & 83,30 & 85,38 & $-0,18$ \\
49,95 & 48,80 & 50,10 & $-0,29$ & 85,22 & 83,40 & 85,48 & $-0,30$ \\
49,95 & 48,80 & 50,10 & $-0,29$ & 85,25 & 83,40 & 85,48 & $-0,27$ \\
49,98 & 48,80 & 50,10 & $-0,24$ & 85,22 & 83,40 & 85,48 & $-0,30$ \\
50,01 & 48,80 & 50,10 & $-0,18$ & 85,25 & 83,40 & 85,48 & $-0,27$ \\
65,26 & 63,60 & 65,28 & $-0,04$ & 93,10 & 91,20 & 93,34 & $-0,26$ \\
65,23 & 63,60 & 65,28 & $-0,08$ & 93,10 & 91,20 & 93,34 & $-0,26$ \\
65,23 & 63,60 & 65,28 & $-0,08$ & 93,13 & 91,20 & 93,34 & $-0,23$ \\
65,23 & 63,60 & 65,28 & $-0,08$ & 93,16 & 91,20 & 93,34 & $-0,20$ \\
65,26 & 63,60 & 65,28 & $-0,04$ & 93,13 & 91,20 & 93,34 & $-0,23$ \\
& & & & & & \\
\hline
\end{tabular}

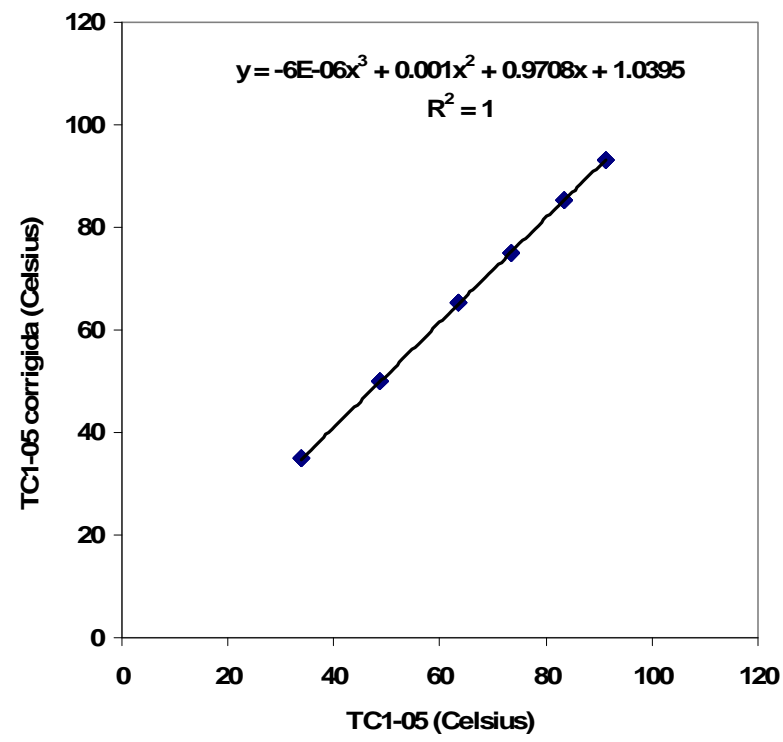

$\mathrm{A} 6 \mathrm{a}$

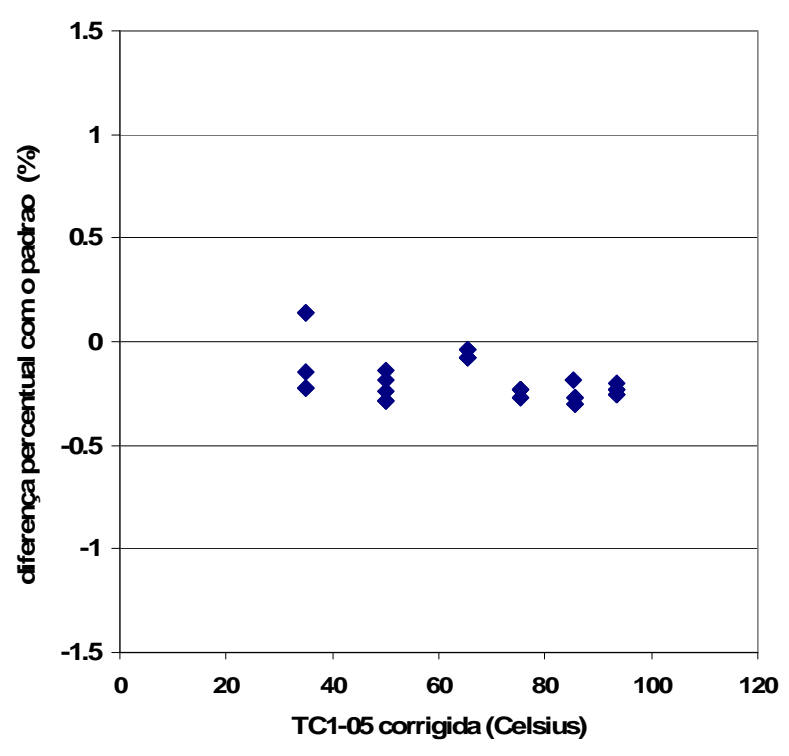

$A 6 b$

FIGURA A6. Curva de calibração TC1-05.(A6a) e diferença percentual com o padrão(A6b). 
TABELA A6. Dados de calibração do termopar TC1-06.

\begin{tabular}{cccc|cccc}
\hline $\begin{array}{c}\text { PT-001 } \\
\left({ }^{\circ} \mathrm{C}\right)\end{array}$ & $\begin{array}{c}\text { TC1-06 } \\
\left({ }^{\circ} \mathrm{C}\right)\end{array}$ & $\begin{array}{c}\text { TC1-06 } \\
\text { corrigida } \\
\left({ }^{\circ} \mathrm{C}\right)\end{array}$ & $\begin{array}{c}\text { diferença } \\
\text { percentual } \\
(\%)\end{array}$ & $\begin{array}{c}\text { PT-001 } \\
\left({ }^{\circ} \mathrm{C}\right)\end{array}$ & $\begin{array}{c}\text { TC1-06 } \\
\left({ }^{\circ} \mathrm{C}\right)\end{array}$ & $\begin{array}{c}\text { TC1-06 } \\
\text { corrigida } \\
\left({ }^{\circ} \mathrm{C}\right)\end{array}$ & $\begin{array}{c}\text { diferença } \\
\text { percentual } \\
(\%)\end{array}$ \\
\hline & & & & & & & \\
34,57 & 33,70 & 34,57 & 0,01 & 75,03 & 73,40 & 75,27 & $-0,32$ \\
34,57 & 33,70 & 34,57 & 0,01 & 75,08 & 73,40 & 75,27 & $-0,25$ \\
34,54 & 33,70 & 34,57 & $-0,07$ & 75,11 & 73,40 & 75,27 & $-0,21$ \\
34,54 & 33,70 & 34,57 & $-0,07$ & 75,13 & 73,40 & 75,27 & $-0,18$ \\
34,54 & 33,70 & 34,57 & $-0,07$ & 75,11 & 73,40 & 75,27 & $-0,21$ \\
49,55 & 48,30 & 49,72 & $-0,33$ & 85,04 & 83,40 & 85,43 & $-0,46$ \\
49,53 & 48,20 & 49,62 & $-0,18$ & 85,06 & 83,40 & 85,43 & $-0,43$ \\
49,53 & 48,20 & 49,62 & $-0,18$ & 85,09 & 83,40 & 85,43 & $-0,40$ \\
49,55 & 48,30 & 49,72 & $-0,33$ & 85,12 & 83,40 & 85,43 & $-0,36$ \\
49,55 & 48,20 & 49,62 & $-0,12$ & 85,12 & 83,40 & 85,43 & $-0,36$ \\
64,57 & 62,90 & 64,62 & $-0,07$ & 94,17 & 92,20 & 94,42 & $-0,27$ \\
64,59 & 62,90 & 64,62 & $-0,03$ & 94,25 & 92,30 & 94,53 & $-0,30$ \\
64,54 & 62,90 & 64,62 & $-0,12$ & 94,19 & 92,30 & 94,53 & $-0,35$ \\
64,46 & 62,90 & 64,62 & $-0,24$ & 94,01 & 92,20 & 94,42 & $-0,44$ \\
64,51 & 62,90 & 64,62 & $-0,16$ & 93,85 & 92,00 & 94,22 & $-0,39$ \\
& & & & & & \\
\hline
\end{tabular}

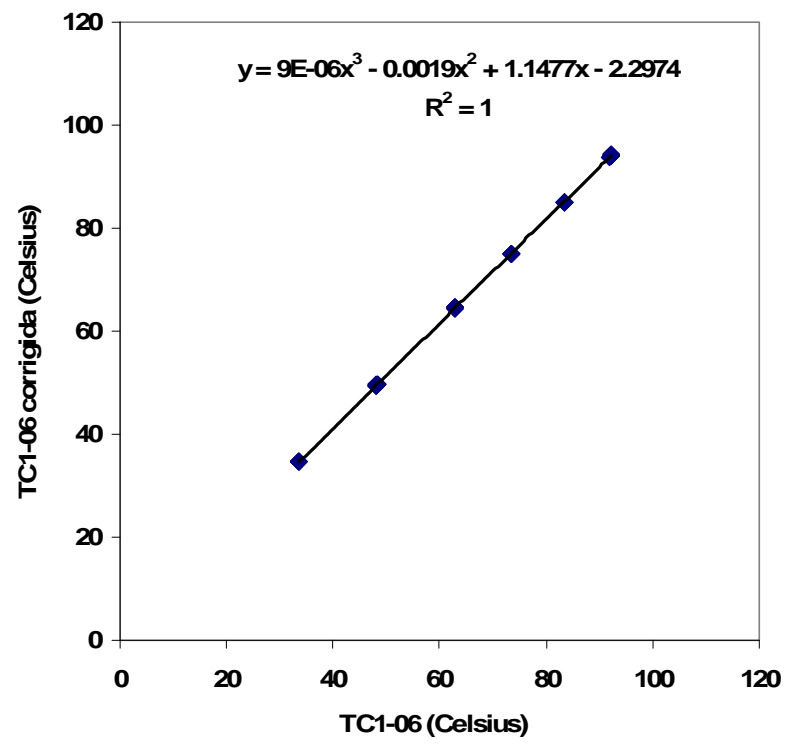

A7a

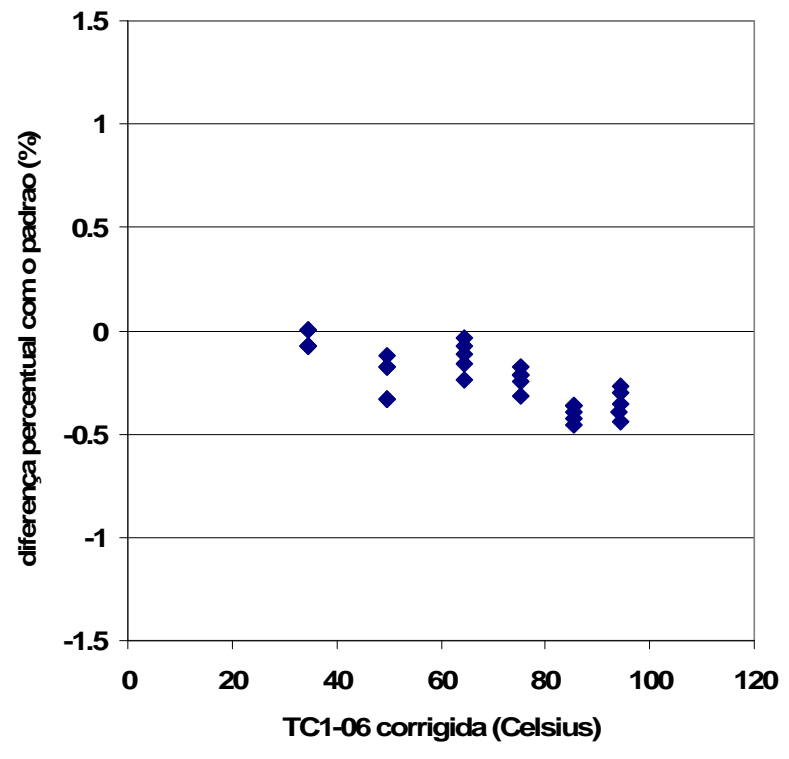

A7b.

FIGURA A7. Curva de calibração TC1-06 (A7a) e diferença percentual com o padrão (A7b) 
TABELA A7. Dados de calibração do termopar TC1-07.

\begin{tabular}{cccc|cccc}
\hline $\begin{array}{c}\text { PT-001 } \\
\left({ }^{\circ} \mathrm{C}\right)\end{array}$ & $\begin{array}{c}\text { TC1-07 } \\
\left({ }^{\circ} \mathrm{C}\right)\end{array}$ & $\begin{array}{c}\text { TC1-07 } \\
\text { corrigida } \\
\left({ }^{\circ} \mathrm{C}\right)\end{array}$ & $\begin{array}{c}\text { diferença } \\
\text { percentual } \\
(\%)\end{array}$ & $\begin{array}{c}\text { PT-001 } \\
\left({ }^{\circ} \mathrm{C}\right)\end{array}$ & $\begin{array}{c}\text { TC1-07 } \\
\left({ }^{\circ} \mathrm{C}\right)\end{array}$ & $\begin{array}{c}\text { TC1-07 } \\
\text { corrigida } \\
\left({ }^{\circ} \mathrm{C}\right)\end{array}$ & $\begin{array}{c}\text { diferença } \\
\text { percentual } \\
(\%)\end{array}$ \\
\hline & & & & & & & \\
34,52 & 33,80 & 34,46 & 0,15 & 74,79 & 73,40 & 74,54 & 0,34 \\
34,52 & 33,80 & 34,46 & 0,15 & 74,82 & 73,40 & 74,54 & 0,37 \\
34,52 & 33,80 & 34,46 & 0,15 & 74,82 & 73,40 & 74,54 & 0,37 \\
34,52 & 33,80 & 34,46 & 0,15 & 74,84 & 73,40 & 74,54 & 0,41 \\
34,52 & 33,80 & 34,46 & 0,15 & 74,84 & 73,40 & 74,54 & 0,41 \\
49,74 & 48,70 & 49,63 & 0,23 & 84,74 & 83,10 & 84,29 & 0,54 \\
49,74 & 48,70 & 49,63 & 0,23 & 84,74 & 83,10 & 84,29 & 0,54 \\
49,74 & 48,70 & 49,63 & 0,23 & 84,74 & 83,10 & 84,29 & 0,54 \\
49,74 & 48,70 & 49,63 & 0,23 & 84,72 & 83,10 & 84,29 & 0,51 \\
49,74 & 48,70 & 49,63 & 0,23 & 84,69 & 83,10 & 84,29 & 0,47 \\
64,81 & 63,50 & 64,57 & 0,36 & 92,57 & 90,80 & 92,04 & 0,57 \\
64,81 & 63,50 & 64,57 & 0,36 & 92,57 & 90,80 & 92,04 & 0,57 \\
64,81 & 63,50 & 64,57 & 0,36 & 92,54 & 90,80 & 92,04 & 0,55 \\
64,81 & 63,50 & 64,57 & 0,36 & 92,54 & 90,80 & 92,04 & 0,55 \\
64,81 & 63,50 & 64,57 & 0,36 & 92,54 & 90,80 & 92,04 & 0,55 \\
\hline
\end{tabular}

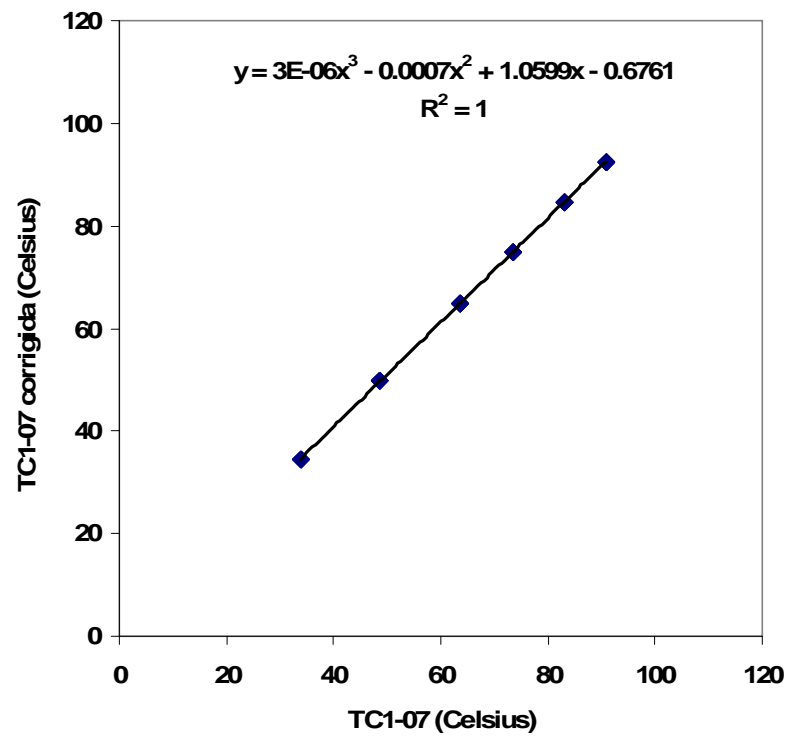

A8a

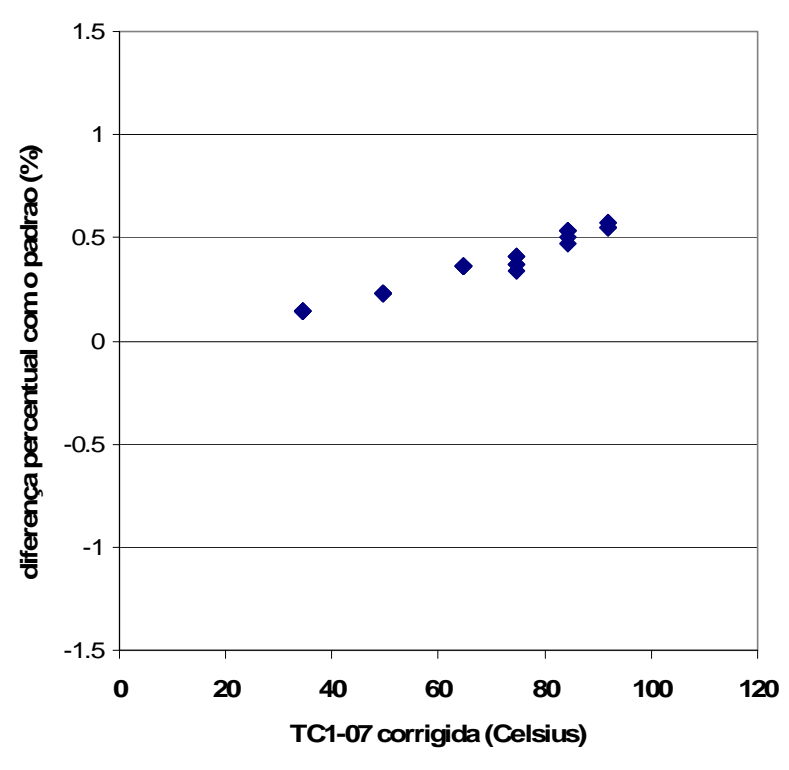

$\mathrm{A} 8 \mathrm{~b}$

FIGURA A8. Curva de calibração TC1-07 (A8a) e diferença percentual com o padrão (A8b). 
TABELA A8. Dados de calibração do termopar TC1-08.

\begin{tabular}{cccc|cccc}
\hline $\begin{array}{c}\text { PT-001 } \\
\left({ }^{\circ} \mathrm{C}\right)\end{array}$ & $\begin{array}{c}\text { TC1-08 } \\
\left({ }^{\circ} \mathrm{C}\right)\end{array}$ & $\begin{array}{c}\text { TC1-08 } \\
\text { corrigida } \\
\left({ }^{\circ} \mathrm{C}\right)\end{array}$ & $\begin{array}{c}\text { diferença } \\
\text { percentual } \\
(\%)\end{array}$ & $\begin{array}{c}\text { PT-001 } \\
\left({ }^{\circ} \mathrm{C}\right)\end{array}$ & $\begin{array}{c}\text { TC1-08 } \\
\left({ }^{\circ} \mathrm{C}\right)\end{array}$ & $\begin{array}{c}\text { TC1-08 } \\
\text { corrigida } \\
\left({ }^{\circ} \mathrm{C}\right)\end{array}$ & $\begin{array}{c}\text { diferença } \\
\text { percentual } \\
(\%)\end{array}$ \\
\hline & & & & & & & \\
34,62 & 33,90 & 34,62 & 0,00 & 74,92 & 73,10 & 74,95 & $-0,03$ \\
34,62 & 33,90 & 34,62 & 0,00 & 74,92 & 73,10 & 74,95 & $-0,03$ \\
34,62 & 33,90 & 34,62 & 0,00 & 74,92 & 73,10 & 74,95 & $-0,03$ \\
34,62 & 33,90 & 34,62 & 0,00 & 74,92 & 73,10 & 74,95 & $-0,03$ \\
34,62 & 33,90 & 34,62 & 0,00 & 74,90 & 73,10 & 74,95 & $-0,07$ \\
49,82 & 48,60 & 49,84 & $-0,05$ & 84,85 & 83,00 & 85,06 & $-0,25$ \\
49,82 & 48,60 & 49,84 & $-0,05$ & 84,85 & 82,90 & 84,96 & $-0,13$ \\
49,82 & 48,60 & 49,84 & $-0,05$ & 84,85 & 82,90 & 84,96 & $-0,13$ \\
49,85 & 48,60 & 49,84 & 0,01 & 84,85 & 82,90 & 84,96 & $-0,13$ \\
49,85 & 48,60 & 49,84 & 0,01 & 84,80 & 82,90 & 84,96 & $-0,19$ \\
64,94 & 63,40 & 65,03 & $-0,14$ & 92,09 & 90,00 & 92,23 & $-0,15$ \\
64,97 & 63,40 & 65,03 & $-0,10$ & 92,09 & 90,00 & 92,23 & $-0,15$ \\
64,99 & 63,40 & 65,03 & $-0,06$ & 92,12 & 90,00 & 92,23 & $-0,12$ \\
64,99 & 63,40 & 65,03 & $-0,06$ & 92,09 & 90,00 & 92,23 & $-0,15$ \\
64,99 & 63,40 & 65,03 & $-0,06$ & 92,09 & 90,00 & 92,23 & $-0,15$ \\
& & & & & & \\
\hline
\end{tabular}

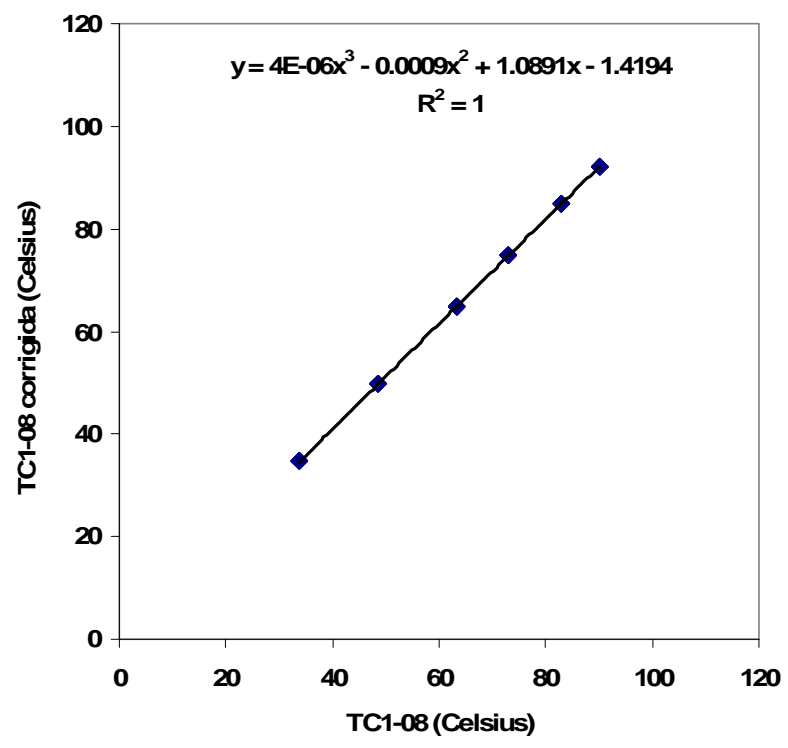

A9a

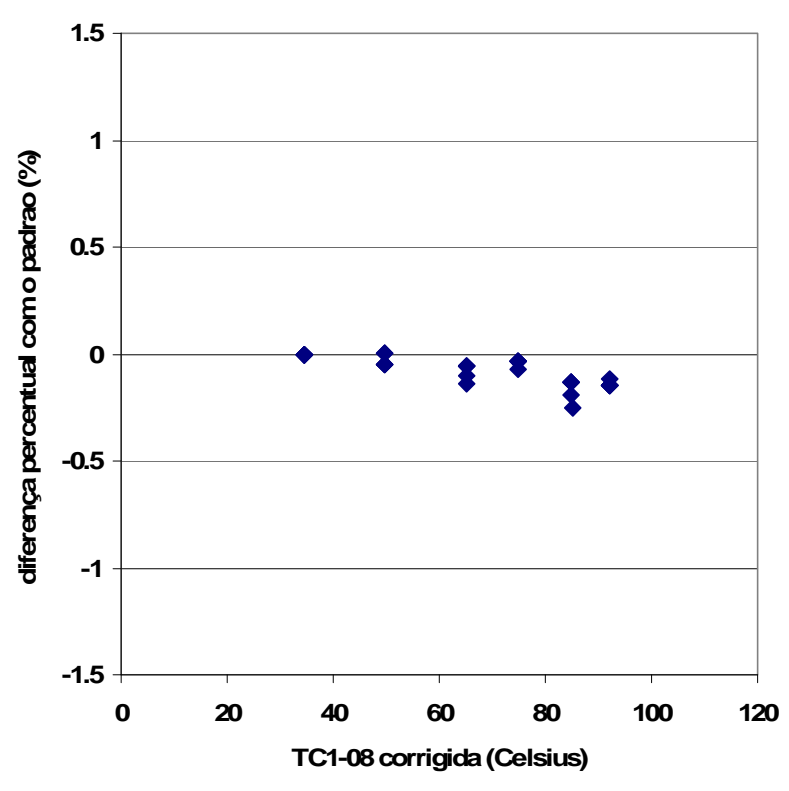

$\mathrm{A} 9 \mathrm{~b}$

FIGURA A9. Curva de calibração TC1-08 (A9a) e diferença percentual com o padrão (A9b). 
TABELA A9. Dados de calibração do termopar TC1-11.

\begin{tabular}{cccc|cccc}
\hline $\begin{array}{c}\text { PT-001 } \\
\left({ }^{\circ} \mathrm{C}\right)\end{array}$ & $\begin{array}{c}\text { TC1-11 } \\
\left({ }^{\circ} \mathrm{C}\right)\end{array}$ & $\begin{array}{c}\text { TC1-11 } \\
\text { corrigida } \\
\left({ }^{\circ} \mathrm{C}\right)\end{array}$ & $\begin{array}{c}\text { diferença } \\
\text { percentua } \\
(\%)\end{array}$ & $\begin{array}{c}\text { PT-001 } \\
\left({ }^{\circ} \mathrm{C}\right)\end{array}$ & $\begin{array}{c}\text { TC1-11 } \\
\left({ }^{\circ} \mathrm{C}\right)\end{array}$ & $\begin{array}{c}\text { TC1-11 } \\
\text { corrigida } \\
\left({ }^{\circ} \mathrm{C}\right)\end{array}$ & $\begin{array}{c}\text { diferença } \\
\text { percentual } \\
(\%)\end{array}$ \\
\hline 36,46 & 35,6 & 36,52 & $-0,16$ & 102,31 & 100,50 & 102,20 & 0,11 \\
36,41 & 35,5 & 36,41 & $-0,02$ & 102,34 & 100,30 & 102,00 & 0,33 \\
36,41 & 35,5 & 36,41 & $-0,02$ & 102,34 & 100,30 & 102,00 & 0,33 \\
36,38 & 35,5 & 36,41 & $-0,09$ & 102,36 & 100,30 & 102,00 & 0,35 \\
36,38 & 35,6 & 36,52 & $-0,38$ & 102,36 & 100,30 & 102,00 & 0,35 \\
51,66 & 49,9 & 51,27 & 0,75 & 127,49 & 125,90 & 127,03 & 0,36 \\
51,66 & 50 & 51,37 & 0,55 & 127,49 & 125,90 & 127,03 & 0,36 \\
51,66 & 50,1 & 51,47 & 0,36 & 127,49 & 125,90 & 127,03 & 0,36 \\
51,66 & 50,1 & 51,47 & 0,36 & 127,49 & 125,90 & 127,03 & 0,36 \\
51,66 & 50,1 & 51,47 & 0,36 & 127,49 & 125,90 & 127,03 & 0,36 \\
77,13 & 75,3 & 77,08 & 0,06 & 152,35 & 151,70 & 151,76 & 0,39 \\
77,13 & 75,4 & 77,18 & $-0,07$ & 152,35 & 151,70 & 151,76 & 0,39 \\
77,13 & 75,5 & 77,28 & $-0,20$ & 152,35 & 151,70 & 151,76 & 0,39 \\
77,13 & 75,3 & 77,08 & 0,06 & 152,38 & 151,70 & 151,76 & 0,40 \\
77,10 & 75,2 & 76,98 & 0,16 & 152,38 & 151,70 & 151,76 & 0,40 \\
\hline
\end{tabular}

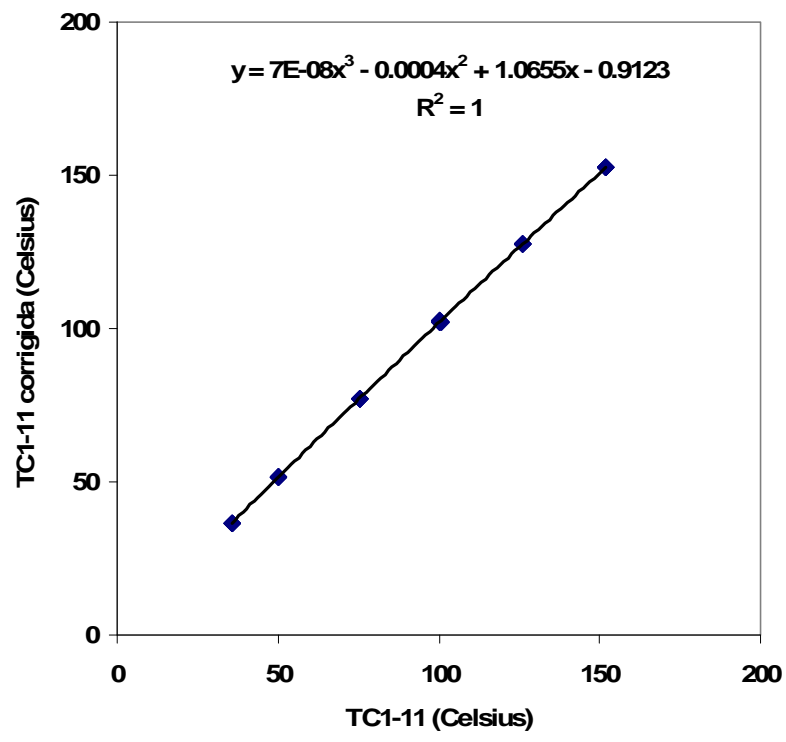

(a)

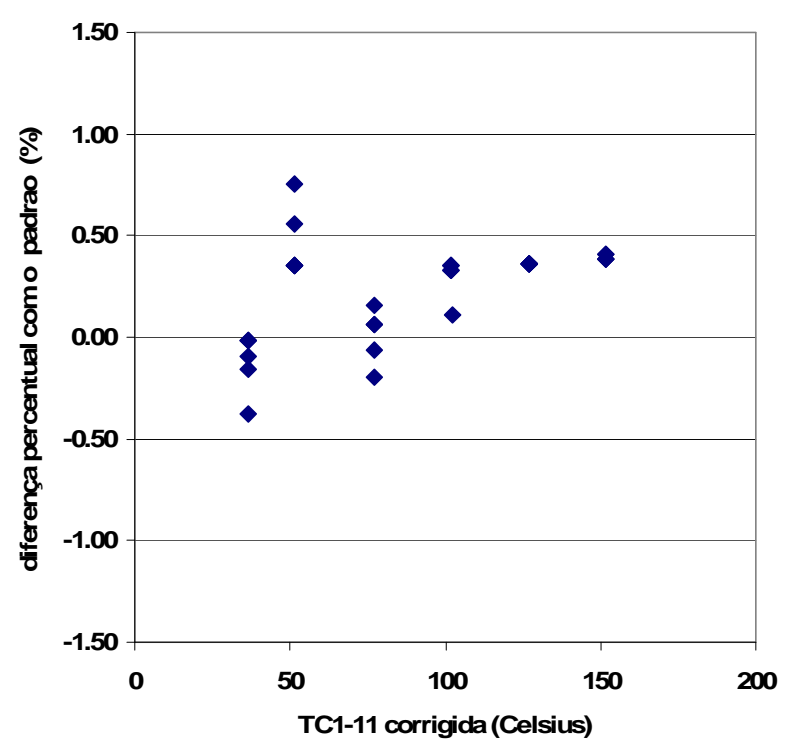

(b)

FIGURA A10. Curva de calibração TC1-11 (A10a) e diferença percentual com o padrão (A10b). 
TABELA A10. Dados de calibração do termopar TC1-12.

\begin{tabular}{cccc|cccc}
\hline $\begin{array}{c}\text { PT-001 } \\
\left({ }^{\circ} \mathrm{C}\right)\end{array}$ & $\begin{array}{c}\text { TC1-12 } \\
\left({ }^{\circ} \mathrm{C}\right)\end{array}$ & $\begin{array}{c}\text { TC1-12 } \\
\text { corrigida } \\
\left({ }^{\circ} \mathrm{C}\right)\end{array}$ & $\begin{array}{c}\text { diferença } \\
\text { percentual } \\
(\%)\end{array}$ & $\begin{array}{c}\text { PT-001 } \\
\left({ }^{\circ} \mathrm{C}\right)\end{array}$ & $\begin{array}{c}\text { TC1-12 } \\
\left({ }^{\circ} \mathrm{C}\right)\end{array}$ & $\begin{array}{c}\text { TC1-12 } \\
\text { corrigida } \\
\left({ }^{\circ} \mathrm{C}\right)\end{array}$ & $\begin{array}{c}\text { diferença } \\
\text { percentual } \\
(\%)\end{array}$ \\
\hline 36,46 & 34,90 & 36,48 & $-0,06$ & 102,36 & 99,80 & 101,97 & 0,39 \\
36,35 & 34,80 & 36,37 & $-0,06$ & 102,39 & 99,80 & 101,97 & 0,42 \\
36,35 & 34,80 & 36,37 & $-0,06$ & 102,39 & 99,80 & 101,97 & 0,42 \\
36,35 & 34,70 & 36,27 & 0,22 & 102,39 & 99,80 & 101,97 & 0,42 \\
36,33 & 34,70 & 36,27 & 0,15 & 102,39 & 99,80 & 101,97 & 0,42 \\
51,66 & 49,50 & 51,56 & 0,19 & 127,49 & 125,70 & 127,12 & 0,29 \\
51,68 & 49,50 & 51,56 & 0,25 & 127,49 & 125,80 & 127,21 & 0,22 \\
51,68 & 49,50 & 51,56 & 0,25 & 127,49 & 125,80 & 127,21 & 0,22 \\
51,68 & 49,50 & 51,56 & 0,25 & 127,49 & 125,70 & 127,12 & 0,29 \\
51,68 & 49,50 & 51,56 & 0,25 & 127,49 & 125,70 & 127,12 & 0,29 \\
77,10 & 74,70 & 77,09 & 0,02 & 152,38 & 151,50 & 151,72 & 0,43 \\
77,10 & 74,70 & 77,09 & 0,02 & 152,38 & 151,50 & 151,72 & 0,43 \\
77,10 & 74,70 & 77,09 & 0,02 & 152,38 & 151,50 & 151,72 & 0,43 \\
77,10 & 74,70 & 77,09 & 0,02 & 152,38 & 151,50 & 151,72 & 0,43 \\
77,10 & 74,70 & 77,09 & 0,02 & 152,38 & 151,50 & 151,72 & 0,43 \\
\hline
\end{tabular}

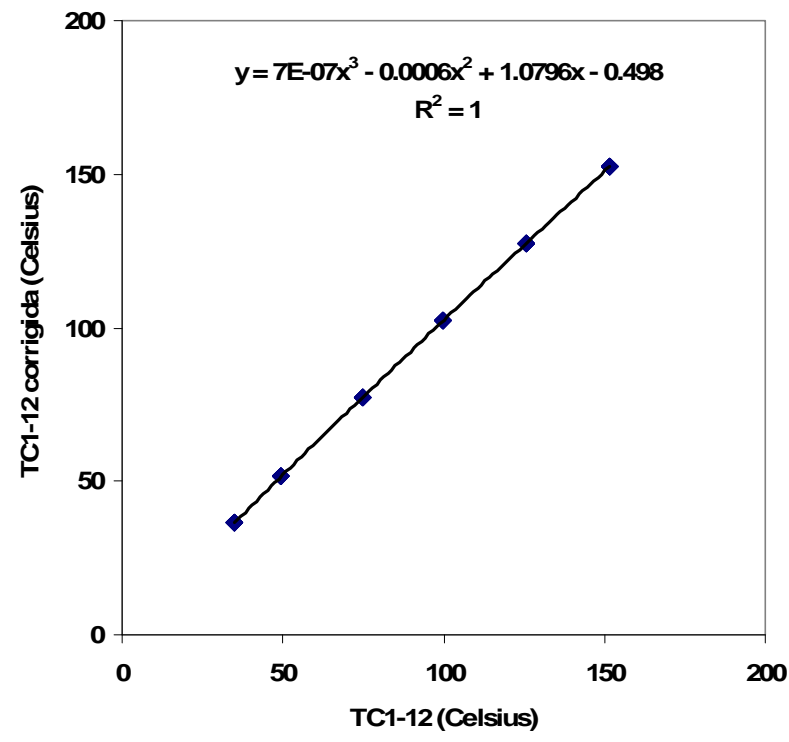

A11a

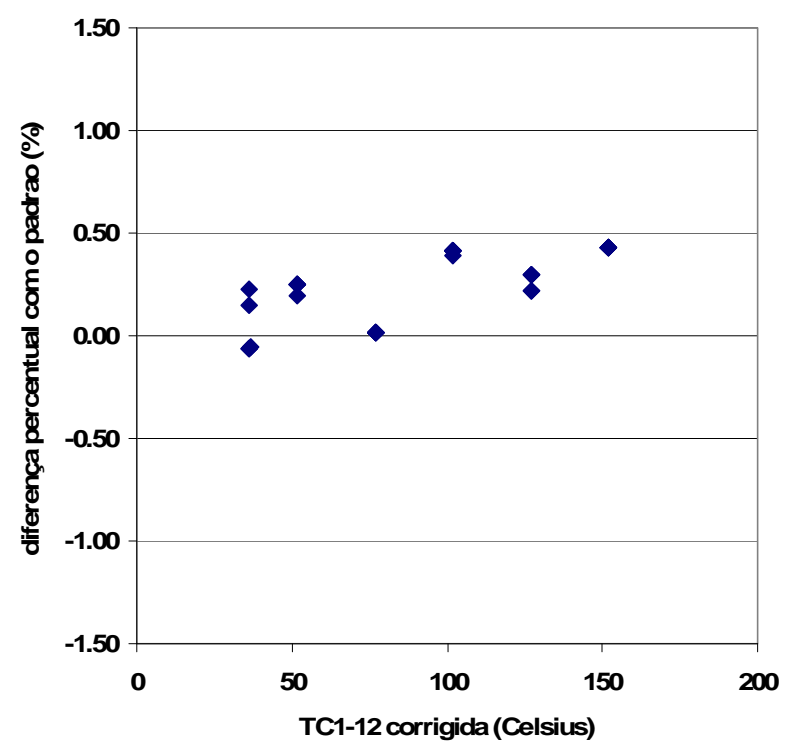

A11b

FIGURA A11. Curva de calibração TC1-12 (A11a) e diferença percentual com o padrão (A11b). 
TABELA A11. Dados de calibração do termopar TC1-13.

\begin{tabular}{cccc|cccc}
\hline $\begin{array}{c}\text { PT-001 } \\
\left({ }^{\circ} \mathrm{C}\right)\end{array}$ & $\begin{array}{c}\text { TC1-13 } \\
\left({ }^{\circ} \mathrm{C}\right)\end{array}$ & $\begin{array}{c}\text { TC1-13 } \\
\text { corrigida } \\
\left({ }^{\circ} \mathrm{C}\right)\end{array}$ & $\begin{array}{c}\text { diferença } \\
\text { percentual } \\
(\%)\end{array}$ & $\begin{array}{c}\text { PT-001 } \\
\left({ }^{\circ} \mathrm{C}\right)\end{array}$ & $\begin{array}{c}\text { TC1-13 } \\
\left({ }^{\circ} \mathrm{C}\right)\end{array}$ & $\begin{array}{c}\text { TC1-13 } \\
\text { corrigida } \\
\left({ }^{\circ} \mathrm{C}\right)\end{array}$ & $\begin{array}{c}\text { diferença } \\
\text { percentual } \\
(\%)\end{array}$ \\
\hline & & & & & & & \\
36,46 & 36,10 & 36,33 & 0,34 & 102,39 & 101,10 & 102,43 & $-0,04$ \\
36,33 & 36,10 & 36,33 & $-0,02$ & 102,39 & 101,20 & 102,53 & $-0,13$ \\
36,33 & 36,20 & 36,44 & $-0,31$ & 102,39 & 101,10 & 102,43 & $-0,04$ \\
36,33 & 36,20 & 36,44 & $-0,31$ & 102,42 & 101,30 & 102,63 & $-0,20$ \\
36,33 & 36,20 & 36,44 & $-0,31$ & 102,42 & 101,40 & 102,73 & $-0,30$ \\
51,71 & 50,90 & 51,61 & 0,19 & 127,49 & 126,70 & 127,73 & $-0,18$ \\
51,71 & 51,00 & 51,72 & $-0,01$ & 127,49 & 126,70 & 127,73 & $-0,18$ \\
51,71 & 51,00 & 51,72 & $-0,01$ & 127,49 & 126,70 & 127,73 & $-0,18$ \\
51,71 & 51,00 & 51,72 & $-0,01$ & 127,49 & 126,70 & 127,73 & $-0,18$ \\
51,71 & 51,00 & 51,72 & $-0,01$ & 127,49 & 126,70 & 127,73 & $-0,18$ \\
77,13 & 76,10 & 77,32 & $-0,24$ & 152,38 & 152,50 & 152,79 & $-0,27$ \\
77,10 & 76,10 & 77,32 & $-0,28$ & 152,38 & 152,50 & 152,79 & $-0,27$ \\
77,13 & 76,00 & 77,22 & $-0,11$ & 152,38 & 152,40 & 152,70 & $-0,21$ \\
77,13 & 76,00 & 77,22 & $-0,11$ & 152,38 & 152,40 & 152,70 & $-0,21$ \\
77,13 & 76,00 & 77,22 & $-0,11$ & 152,38 & 152,40 & 152,70 & $-0,21$ \\
& & 76 & & & & \\
\hline
\end{tabular}

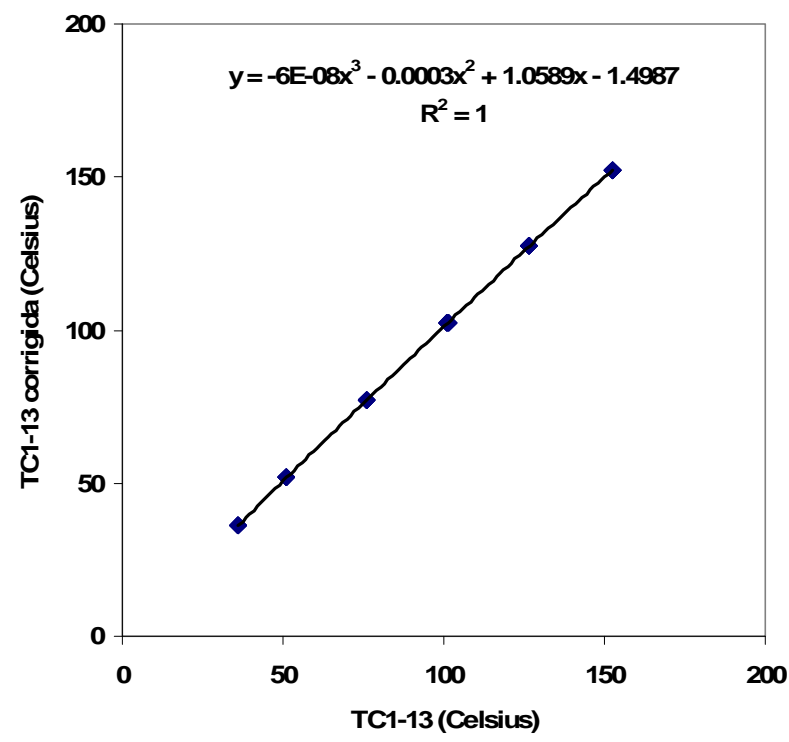

$\mathrm{A} 12 \mathrm{a}$

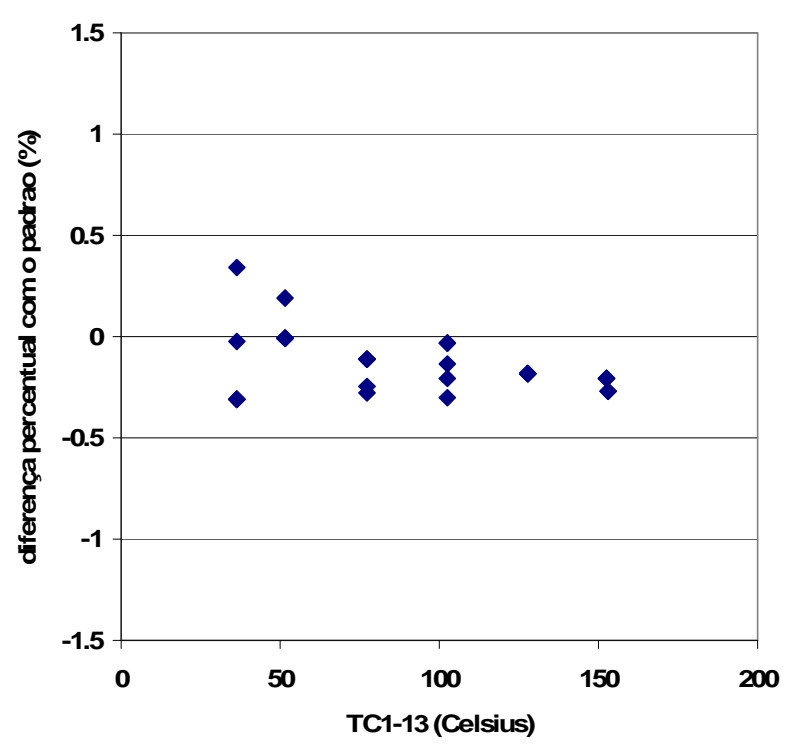

A12b

FIGURA A12. Curva de calibração TC1-13 (A12a) e diferença percentual com o padrão (A12b). 
TABELA A12. Dados de calibração do termopar TC1-14.

\begin{tabular}{cccc|cccc}
\hline $\begin{array}{c}\text { PT-001 } \\
\left({ }^{\circ} \mathrm{C}\right)\end{array}$ & $\begin{array}{c}\text { TC1-14 } \\
\left({ }^{\circ} \mathrm{C}\right)\end{array}$ & $\begin{array}{c}\text { TC1-14 } \\
\text { corrigida } \\
\left({ }^{\circ} \mathrm{C}\right)\end{array}$ & $\begin{array}{c}\text { diferença } \\
\text { percentual } \\
(\%)\end{array}$ & $\begin{array}{c}\text { PT-001 } \\
\left({ }^{\circ} \mathrm{C}\right)\end{array}$ & $\begin{array}{c}\text { TC1-14 } \\
\left({ }^{\circ} \mathrm{C}\right)\end{array}$ & $\begin{array}{c}\text { TC1-14 } \\
\text { corrigida } \\
\left({ }^{\circ} \mathrm{C}\right)\end{array}$ & $\begin{array}{c}\text { diferença } \\
\text { percentual } \\
(\%)\end{array}$ \\
\hline & & & & & & & \\
36,43 & 35,70 & 36,30 & 0,37 & 102,42 & 100,90 & 102,69 & $-0,26$ \\
36,33 & 35,70 & 36,30 & 0,08 & 102,39 & 100,90 & 102,69 & $-0,29$ \\
36,33 & 35,80 & 36,40 & $-0,21$ & 102,39 & 100,90 & 102,69 & $-0,29$ \\
36,33 & 35,80 & 36,40 & $-0,21$ & 102,39 & 100,90 & 102,69 & $-0,29$ \\
36,33 & 35,70 & 36,30 & 0,08 & 102,39 & 100,90 & 102,69 & $-0,29$ \\
51,68 & 50,50 & 51,68 & 0,00 & 127,49 & 126,60 & 128,21 & $-0,57$ \\
51,68 & 50,50 & 51,68 & 0,00 & 127,49 & 126,50 & 128,12 & $-0,49$ \\
51,66 & 50,50 & 51,68 & $-0,05$ & 127,49 & 126,50 & 128,12 & $-0,49$ \\
51,66 & 50,60 & 51,79 & $-0,25$ & 127,49 & 126,40 & 128,02 & $-0,41$ \\
51,68 & 50,50 & 51,68 & 0,00 & 127,49 & 126,40 & 128,02 & $-0,41$ \\
77,13 & 75,50 & 77,20 & $-0,09$ & 152,38 & 152,20 & 153,59 & $-0,79$ \\
77,13 & 75,50 & 77,20 & $-0,09$ & 152,38 & 152,10 & 153,49 & $-0,73$ \\
77,13 & 75,50 & 77,20 & $-0,09$ & 152,38 & 152,10 & 153,49 & $-0,73$ \\
77,13 & 75,50 & 77,20 & $-0,09$ & 152,38 & 152,10 & 153,49 & $-0,73$ \\
77,13 & 75,50 & 77,20 & $-0,09$ & 152,38 & 152,10 & 153,49 & $-0,73$ \\
\hline
\end{tabular}

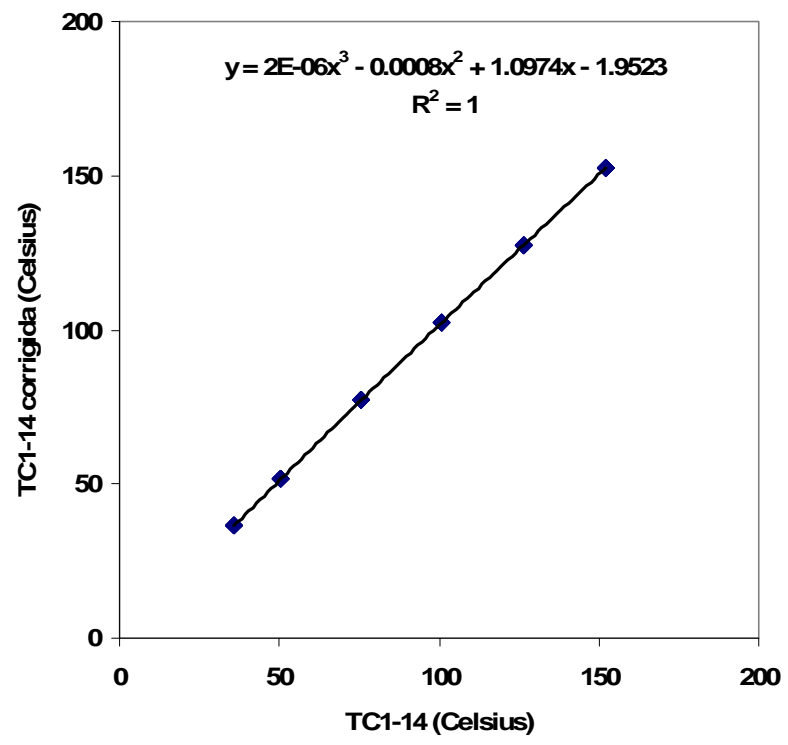

A13a

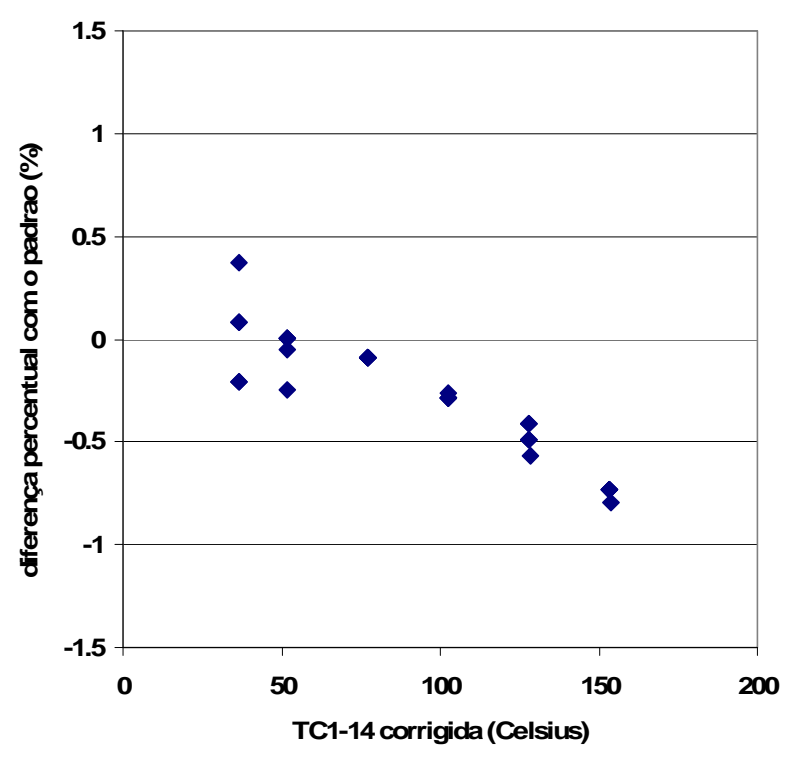

A13b

FIGURA A13. Curva de calibração TC1-14 (A13a) e diferença percentual com o padrão (A13b). 
TABELA A13. Dados de calibração do termopar TC1-15.

\begin{tabular}{cccc|cccc}
\hline $\begin{array}{c}\text { PT-001 } \\
\left({ }^{\circ} \mathrm{C}\right)\end{array}$ & $\begin{array}{c}\text { TC1-15 } \\
\left({ }^{\circ} \mathrm{C}\right)\end{array}$ & $\begin{array}{c}\text { TC1-15 } \\
\text { corrigida } \\
\left({ }^{\circ} \mathrm{C}\right)\end{array}$ & $\begin{array}{c}\text { diferença } \\
\text { percentual } \\
(\%)\end{array}$ & $\begin{array}{c}\text { PT-001 } \\
\left({ }^{\circ} \mathrm{C}\right)\end{array}$ & $\begin{array}{c}\text { TC1-15 } \\
\left({ }^{\circ} \mathrm{C}\right)\end{array}$ & $\begin{array}{c}\text { TC1-15 } \\
\text { corrigida } \\
\left({ }^{\circ} \mathrm{C}\right)\end{array}$ & $\begin{array}{c}\text { diferença } \\
\text { percentual } \\
(\%)\end{array}$ \\
\hline & & & & & & & \\
36,41 & 35,60 & 36,25 & 0,44 & 102,39 & 100,60 & 102,11 & 0,28 \\
36,30 & 35,70 & 36,35 & $-0,14$ & 102,42 & 100,50 & 102,01 & 0,40 \\
36,30 & 35,60 & 36,25 & 0,15 & 102,42 & 100,50 & 102,01 & 0,40 \\
36,30 & 35,60 & 36,25 & 0,15 & 102,42 & 100,50 & 102,01 & 0,40 \\
36,30 & 35,60 & 36,25 & 0,15 & 102,42 & 100,50 & 102,01 & 0,40 \\
51,68 & 50,50 & 51,68 & 0,01 & 127,49 & 126,00 & 126,95 & 0,43 \\
51,68 & 50,40 & 51,58 & 0,21 & 127,49 & 126,00 & 126,95 & 0,43 \\
51,68 & 50,40 & 51,58 & 0,21 & 127,49 & 126,00 & 126,95 & 0,43 \\
51,68 & 50,40 & 51,58 & 0,21 & 127,49 & 126,00 & 126,95 & 0,43 \\
51,68 & 50,40 & 51,58 & 0,21 & 127,47 & 126,00 & 126,95 & 0,41 \\
77,13 & 75,30 & 76,90 & 0,29 & 152,38 & 151,60 & 151,60 & 0,51 \\
77,13 & 75,30 & 76,90 & 0,29 & 152,38 & 151,60 & 151,60 & 0,51 \\
77,13 & 75,30 & 76,90 & 0,29 & 152,38 & 151,60 & 151,60 & 0,51 \\
77,13 & 75,30 & 76,90 & 0,29 & 152,38 & 151,60 & 151,60 & 0,51 \\
77,13 & 75,40 & 77,00 & 0,16 & 152,38 & 151,60 & 151,60 & 0,51 \\
\hline
\end{tabular}

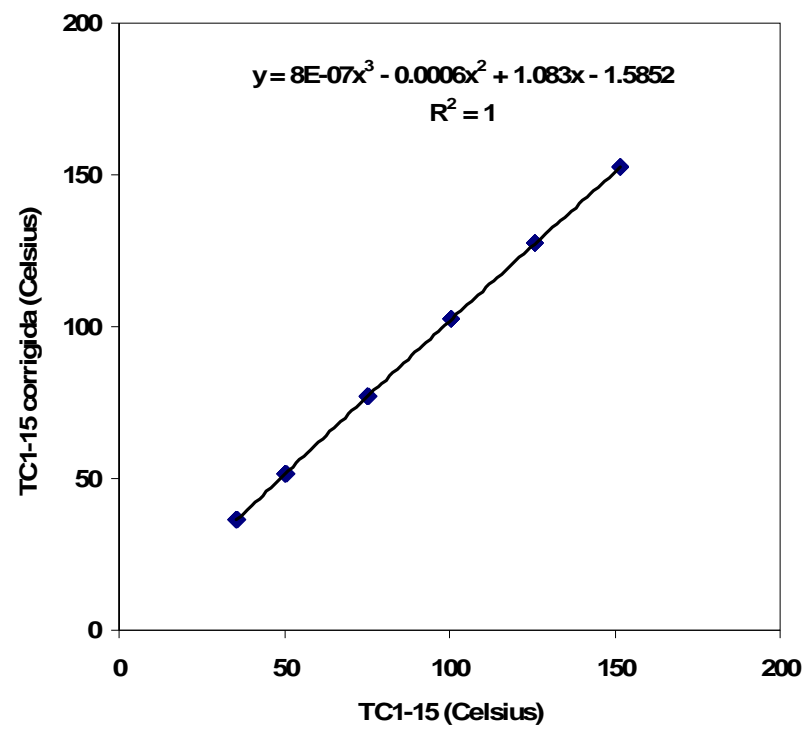

A14a

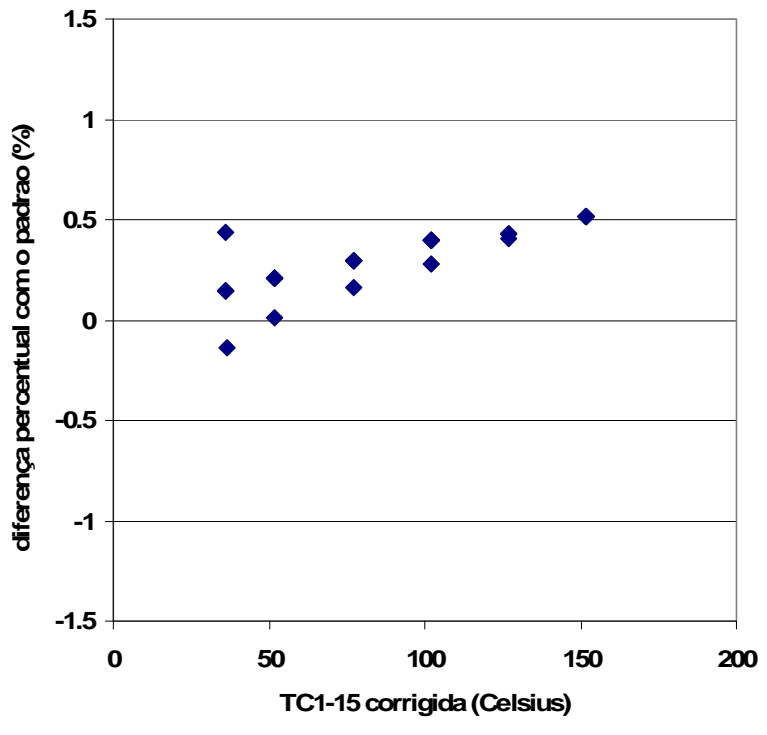

A14b

FIGURA A14. Curva de calibração TC1-15 (A41a) e diferença percentual com o padrão (A14b). 
TABELA A14. Dados de calibração do termopar TC1-16.

\begin{tabular}{cccc|cccc}
\hline $\begin{array}{c}\text { PT-001 } \\
\left({ }^{\circ} \mathrm{C}\right)\end{array}$ & $\begin{array}{c}\text { TC1-16 } \\
\left({ }^{\circ} \mathrm{C}\right)\end{array}$ & $\begin{array}{c}\text { TC1-16 } \\
\text { corrigida } \\
\left({ }^{\circ} \mathrm{C}\right)\end{array}$ & $\begin{array}{c}\text { diferença } \\
\text { percentual } \\
(\%)\end{array}$ & $\begin{array}{c}\text { PT-001 } \\
\left({ }^{\circ} \mathrm{C}\right)\end{array}$ & $\begin{array}{c}\text { TC1-16 } \\
\left({ }^{\circ} \mathrm{C}\right)\end{array}$ & $\begin{array}{c}\text { TC1-16 } \\
\text { corrigida } \\
\left({ }^{\circ} \mathrm{C}\right)\end{array}$ & $\begin{array}{c}\text { diferença } \\
\text { percentual } \\
(\%)\end{array}$ \\
\hline & & & & & & & \\
36,49 & 35,50 & 36,53 & $-0,13$ & 102,21 & 100,30 & 102,19 & 0,01 \\
36,46 & 35,40 & 36,43 & 0,09 & 102,23 & 100,30 & 102,19 & 0,04 \\
36,43 & 35,40 & 36,43 & 0,01 & 102,23 & 100,40 & 102,29 & $-0,06$ \\
36,43 & 35,40 & 36,43 & 0,01 & 102,23 & 100,40 & 102,29 & $-0,06$ \\
36,41 & 35,40 & 36,43 & $-0,06$ & 102,23 & 100,40 & 102,29 & $-0,06$ \\
51,58 & 50,10 & 51,63 & $-0,10$ & 127,28 & 126,20 & 127,64 & $-0,29$ \\
51,58 & 50,10 & 51,63 & $-0,10$ & 127,28 & 126,10 & 127,55 & $-0,21$ \\
51,58 & 50,10 & 51,63 & $-0,10$ & 127,28 & 126,00 & 127,45 & $-0,13$ \\
51,60 & 50,10 & 51,63 & $-0,05$ & 127,28 & 126,00 & 127,45 & $-0,13$ \\
51,60 & 50,10 & 51,63 & $-0,05$ & 127,28 & 126,00 & 127,45 & $-0,13$ \\
77,00 & 75,20 & 77,15 & $-0,19$ & 152,06 & 151,60 & 152,31 & $-0,17$ \\
77,05 & 75,20 & 77,15 & $-0,12$ & 152,09 & 151,60 & 152,31 & $-0,15$ \\
77,05 & 75,20 & 77,15 & $-0,12$ & 152,11 & 151,60 & 152,31 & $-0,13$ \\
77,05 & 75,20 & 77,15 & $-0,12$ & 152,14 & 151,60 & 152,31 & $-0,11$ \\
77,05 & 75,20 & 77,15 & $-0,12$ & 152,14 & 151,60 & 152,31 & $-0,11$ \\
\hline
\end{tabular}

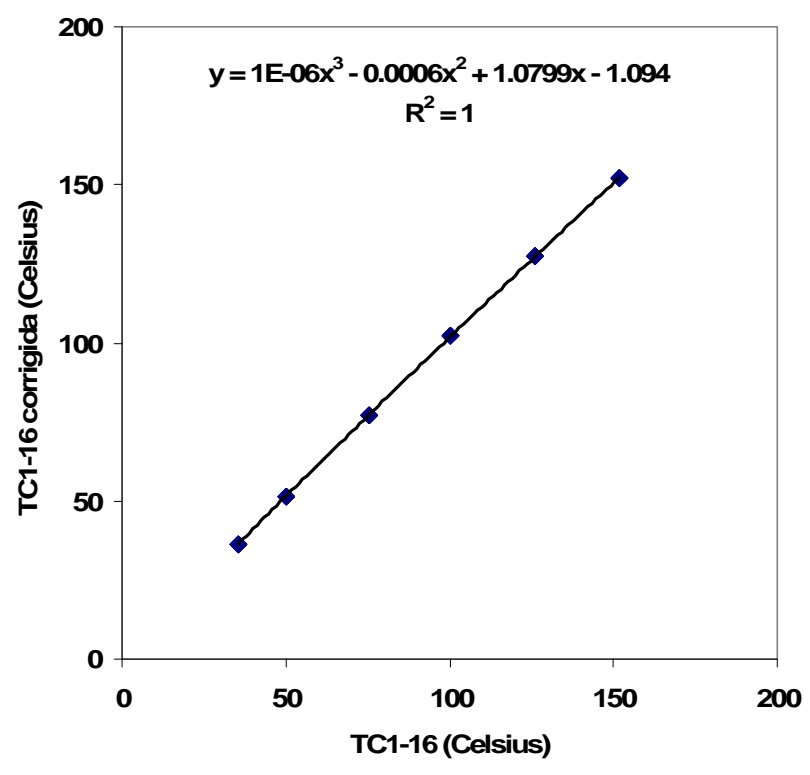

(a)

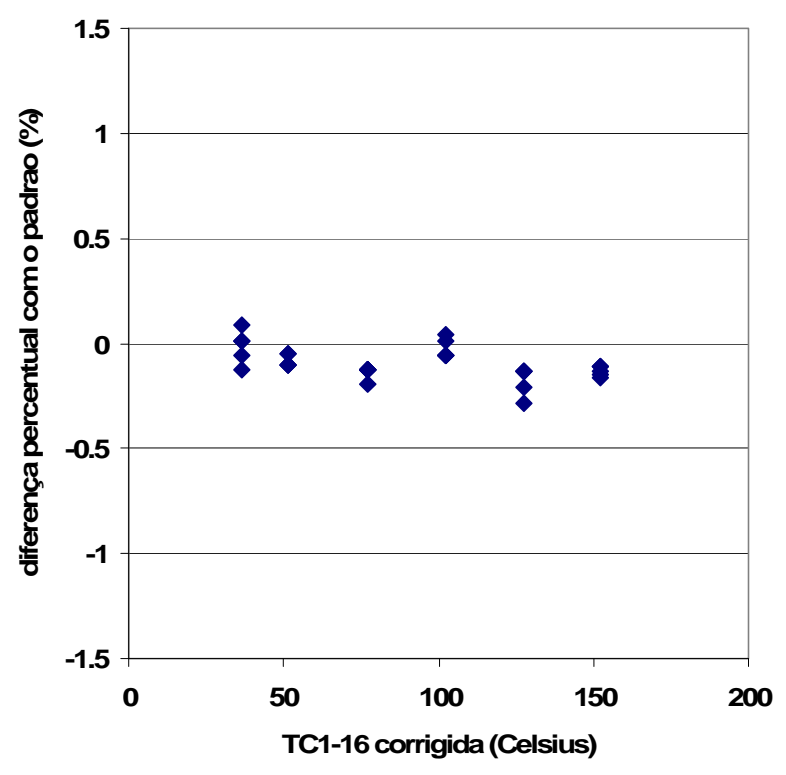

(b)

FIGURA A15. Curva de calibração TC1-16 (A15a) e diferença percentual com o padrão (A15b). 
TABELA A15. Dados de calibração do termopar TC1-17.

\begin{tabular}{cccc|cccc}
\hline $\begin{array}{c}\text { PT-001 } \\
\left({ }^{\circ} \mathrm{C}\right)\end{array}$ & $\begin{array}{c}\text { TC1-17 } \\
\left({ }^{\circ} \mathrm{C}\right)\end{array}$ & $\begin{array}{c}\text { TC1-17 } \\
\text { corrigida } \\
\left({ }^{\circ} \mathrm{C}\right)\end{array}$ & $\begin{array}{c}\text { diferença } \\
\text { percentual } \\
(\%)\end{array}$ & $\begin{array}{c}\text { PT-001 } \\
\left({ }^{\circ} \mathrm{C}\right)\end{array}$ & $\begin{array}{c}\text { TC1-17 } \\
\left({ }^{\circ} \mathrm{C}\right)\end{array}$ & $\begin{array}{c}\text { TC1-17 } \\
\text { corrigida } \\
\left({ }^{\circ} \mathrm{C}\right)\end{array}$ & $\begin{array}{c}\text { diferença } \\
\text { percentual } \\
(\%)\end{array}$ \\
\hline & & & & & & & \\
36,41 & 35,40 & 36,27 & 0,37 & 102,23 & 100,30 & 102,21 & 0,02 \\
36,41 & 35,40 & 36,27 & 0,37 & 102,23 & 100,30 & 102,21 & 0,02 \\
36,38 & 35,60 & 36,48 & $-0,27$ & 102,23 & 100,30 & 102,21 & 0,02 \\
36,38 & 35,60 & 36,48 & $-0,27$ & 102,23 & 100,30 & 102,21 & 0,02 \\
36,38 & 35,60 & 36,48 & $-0,27$ & 102,23 & 100,30 & 102,21 & 0,02 \\
51,60 & 50,20 & 51,61 & $-0,01$ & 127,31 & 126,00 & 127,46 & $-0,12$ \\
51,60 & 50,20 & 51,61 & $-0,01$ & 127,31 & 126,00 & 127,46 & $-0,12$ \\
51,60 & 50,20 & 51,61 & $-0,01$ & 127,31 & 126,00 & 127,46 & $-0,12$ \\
51,60 & 50,20 & 51,61 & $-0,01$ & 127,31 & 126,10 & 127,56 & $-0,20$ \\
51,60 & 50,30 & 51,71 & $-0,21$ & 127,31 & 126,10 & 127,56 & $-0,20$ \\
77,05 & 75,20 & 77,10 & $-0,06$ & 152,14 & 151,60 & 152,20 & $-0,04$ \\
77,05 & 75,20 & 77,10 & $-0,06$ & 152,14 & 151,70 & 152,30 & $-0,10$ \\
77,05 & 75,30 & 77,20 & $-0,19$ & 152,14 & 151,70 & 152,30 & $-0,10$ \\
77,05 & 75,30 & 77,20 & $-0,19$ & 152,17 & 151,70 & 152,30 & $-0,09$ \\
77,05 & 75,30 & 77,20 & $-0,19$ & 152,17 & 151,70 & 152,30 & $-0,09$ \\
\hline
\end{tabular}

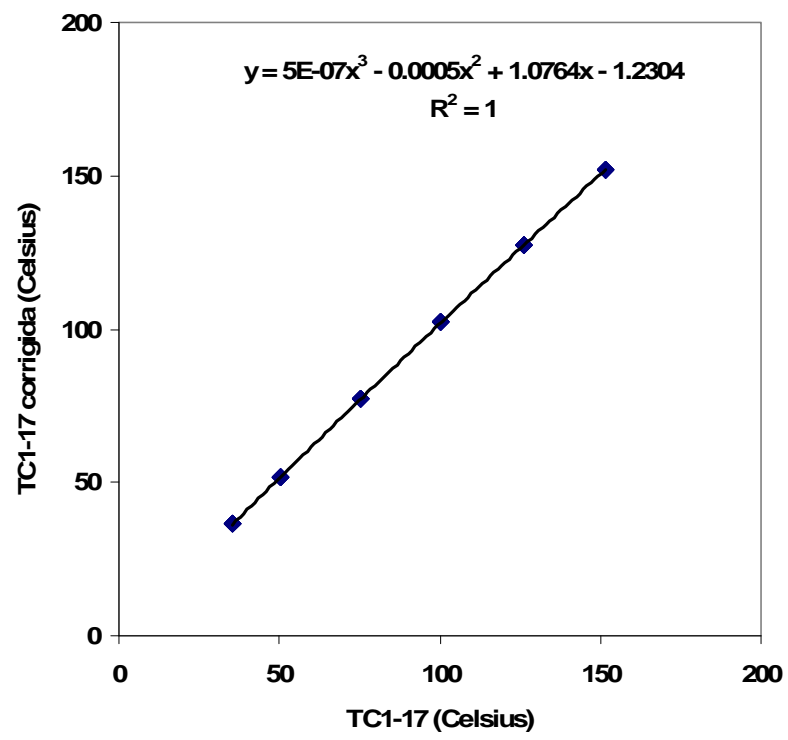

A16a

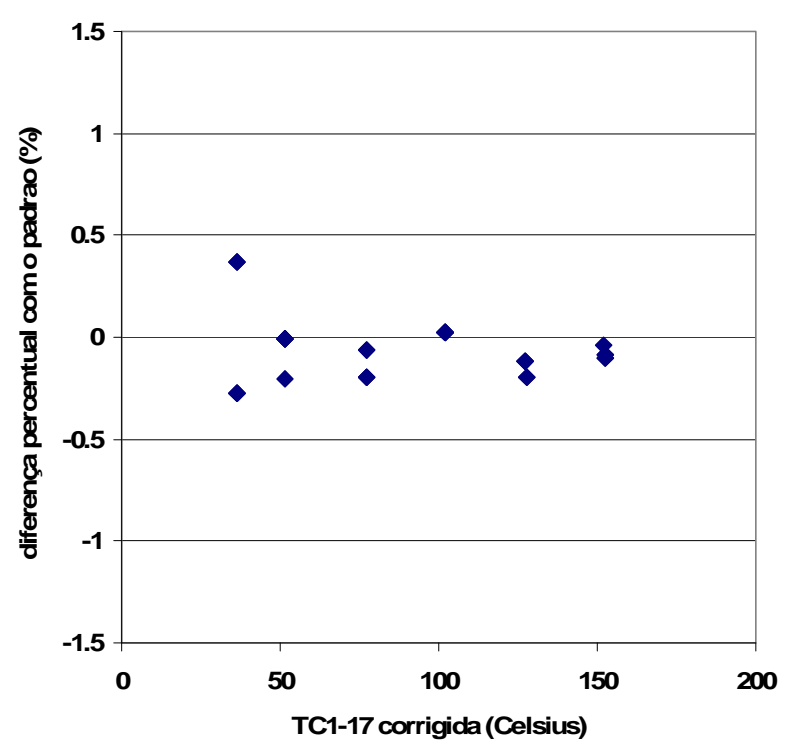

A16b

FIGURA A16. Curva de calibração TC1-17 (A16a) e diferença percentual com o padrão (A16b). 
TABELA A16. Dados de calibração do termopar TC1-18.

\begin{tabular}{cccc|cccc}
\hline $\begin{array}{c}\text { PT-001 } \\
\left({ }^{\circ} \mathrm{C}\right)\end{array}$ & $\begin{array}{c}\text { TC1-18 } \\
\left({ }^{\circ} \mathrm{C}\right)\end{array}$ & $\begin{array}{c}\text { TC1-18 } \\
\text { corrigida } \\
\left({ }^{\circ} \mathrm{C}\right)\end{array}$ & $\begin{array}{c}\text { diferença } \\
\text { percentual } \\
(\%)\end{array}$ & $\begin{array}{c}\text { PT-001 } \\
\left({ }^{\circ} \mathrm{C}\right)\end{array}$ & $\begin{array}{c}\text { TC1-18 } \\
\left({ }^{\circ} \mathrm{C}\right)\end{array}$ & $\begin{array}{c}\text { TC1-18 } \\
\text { corrigida } \\
\left({ }^{\circ} \mathrm{C}\right)\end{array}$ & $\begin{array}{c}\text { diferença } \\
\text { percentual } \\
(\%)\end{array}$ \\
\hline & & & & & & & \\
36,35 & 35,50 & 36,36 & $-0,01$ & 102,23 & 100,30 & 102,27 & $-0,04$ \\
36,35 & 35,50 & 36,36 & $-0,01$ & 102,23 & 100,30 & 102,27 & $-0,04$ \\
36,35 & 35,50 & 36,36 & $-0,01$ & 102,23 & 100,30 & 102,27 & $-0,04$ \\
36,35 & 35,50 & 36,36 & $-0,01$ & 102,23 & 100,30 & 102,27 & $-0,04$ \\
36,33 & 35,40 & 36,25 & 0,20 & 102,23 & 100,30 & 102,27 & $-0,04$ \\
51,60 & 50,30 & 51,67 & $-0,12$ & 127,31 & 126,10 & 127,77 & $-0,36$ \\
51,60 & 50,40 & 51,77 & $-0,32$ & 127,31 & 126,10 & 127,77 & $-0,36$ \\
51,60 & 50,40 & 51,77 & $-0,32$ & 127,31 & 126,00 & 127,67 & $-0,29$ \\
51,60 & 50,30 & 51,67 & $-0,12$ & 127,31 & 126,00 & 127,67 & $-0,29$ \\
51,60 & 50,30 & 51,67 & $-0,12$ & 127,31 & 126,00 & 127,67 & $-0,29$ \\
77,05 & 75,30 & 77,18 & $-0,16$ & 152,17 & 151,60 & 152,59 & $-0,28$ \\
77,05 & 75,40 & 77,28 & $-0,30$ & 152,17 & 151,50 & 152,49 & $-0,21$ \\
77,05 & 75,30 & 77,18 & $-0,16$ & 152,17 & 151,50 & 152,49 & $-0,21$ \\
77,05 & 75,30 & 77,18 & $-0,16$ & 152,17 & 151,50 & 152,49 & $-0,21$ \\
77,05 & 75,30 & 77,18 & $-0,16$ & 152,17 & 151,60 & 152,59 & $-0,28$ \\
\hline
\end{tabular}

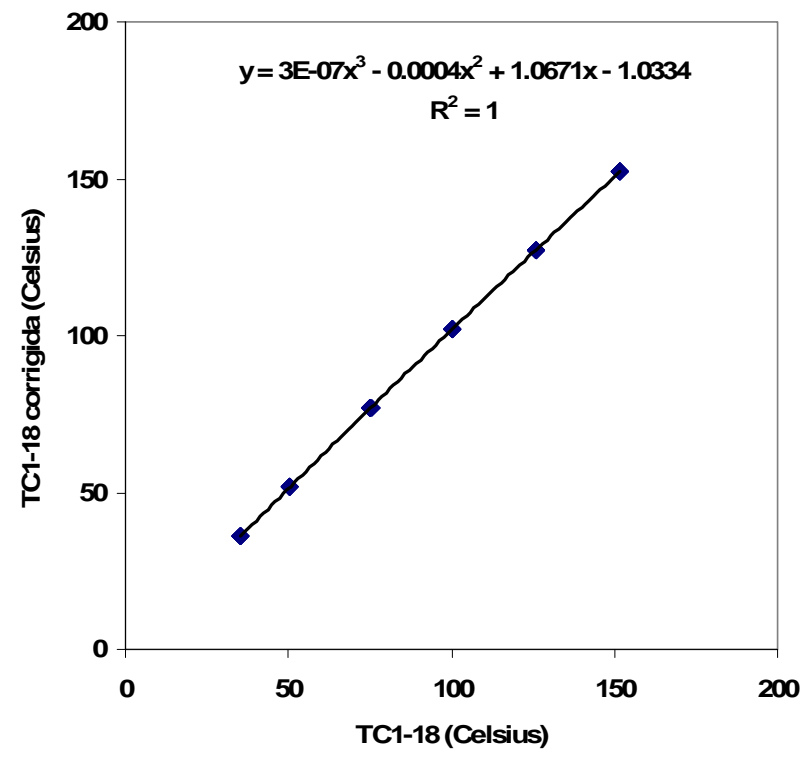

A16a

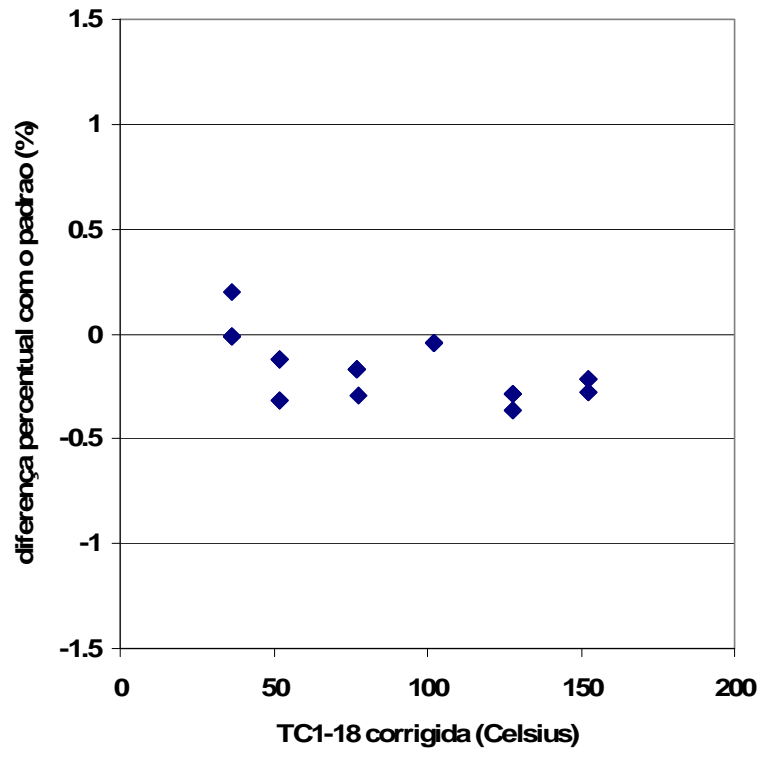

A16b

FIGURA A17. Curva de calibração TC1-18 (A17a) e diferença percentual com o padrão (A17b). 
TABELA A17. Dados de calibração do termopar TC1-19.

\begin{tabular}{cccc|cccc}
\hline $\begin{array}{c}\text { PT-001 } \\
\left({ }^{\circ} \mathrm{C}\right)\end{array}$ & $\begin{array}{c}\text { TC1-19 } \\
\left({ }^{\circ} \mathrm{C}\right)\end{array}$ & $\begin{array}{c}\text { TC1-19 } \\
\text { corrigida } \\
\left({ }^{\circ} \mathrm{C}\right)\end{array}$ & $\begin{array}{c}\text { diferença } \\
\text { percentual } \\
(\%)\end{array}$ & $\begin{array}{c}\text { PT-001 } \\
\left({ }^{\circ} \mathrm{C}\right)\end{array}$ & $\begin{array}{c}\text { TC1-19 } \\
\left({ }^{\circ} \mathrm{C}\right)\end{array}$ & $\begin{array}{c}\text { TC1-19 } \\
\text { corrigida } \\
\left({ }^{\circ} \mathrm{C}\right)\end{array}$ & $\begin{array}{c}\text { diferença } \\
\text { percentual } \\
(\%)\end{array}$ \\
\hline & & & & & & & \\
36,33 & 35,50 & 36,36 & $-0,09$ & 102,23 & 100,40 & 102,27 & $-0,03$ \\
36,33 & 35,50 & 36,36 & $-0,09$ & 102,23 & 100,50 & 102,36 & $-0,13$ \\
36,33 & 35,50 & 36,36 & $-0,09$ & 102,23 & 100,50 & 102,36 & $-0,13$ \\
36,30 & 35,40 & 36,25 & 0,13 & 102,23 & 100,50 & 102,36 & $-0,13$ \\
36,30 & 35,40 & 36,25 & 0,13 & 102,23 & 100,50 & 102,36 & $-0,13$ \\
51,60 & 50,40 & 51,73 & $-0,23$ & 127,31 & 126,10 & 127,61 & $-0,23$ \\
51,63 & 50,30 & 51,62 & 0,02 & 127,31 & 126,00 & 127,51 & $-0,16$ \\
51,63 & 50,30 & 51,62 & 0,02 & 127,31 & 126,00 & 127,51 & $-0,16$ \\
51,63 & 50,40 & 51,73 & $-0,18$ & 127,31 & 126,00 & 127,51 & $-0,16$ \\
51,63 & 50,40 & 51,73 & $-0,18$ & 127,31 & 125,90 & 127,41 & $-0,08$ \\
77,05 & 75,30 & 77,10 & $-0,06$ & 152,17 & 151,70 & 152,40 & $-0,15$ \\
77,05 & 75,30 & 77,10 & $-0,06$ & 152,17 & 151,80 & 152,50 & $-0,22$ \\
77,05 & 75,30 & 77,10 & $-0,06$ & 152,17 & 151,80 & 152,50 & $-0,22$ \\
77,05 & 75,30 & 77,10 & $-0,06$ & 152,17 & 151,70 & 152,40 & $-0,15$ \\
77,05 & 75,30 & 77,10 & $-0,06$ & 152,17 & 151,70 & 152,40 & $-0,15$ \\
& & & & & & & \\
\hline
\end{tabular}

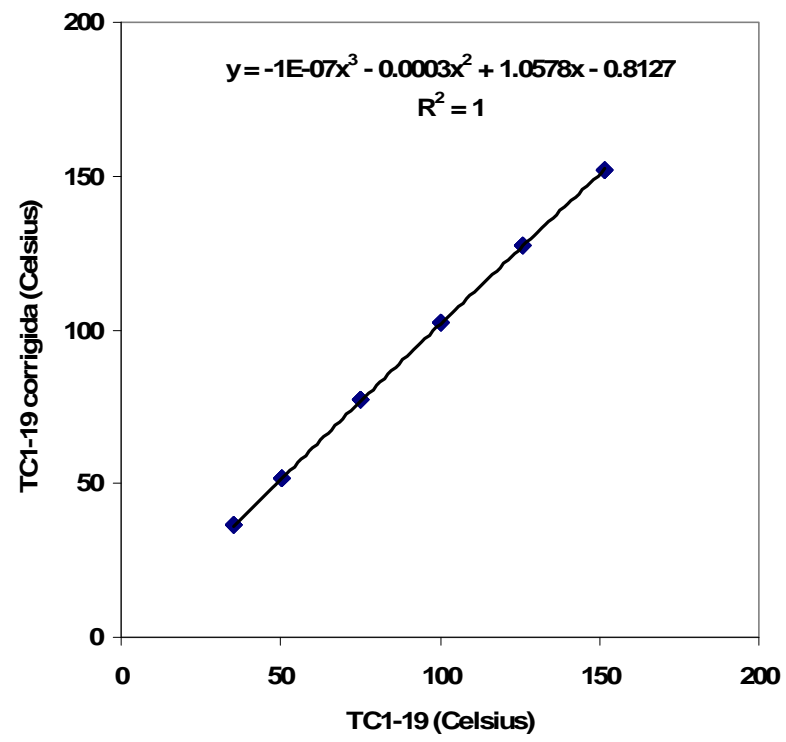

A18a

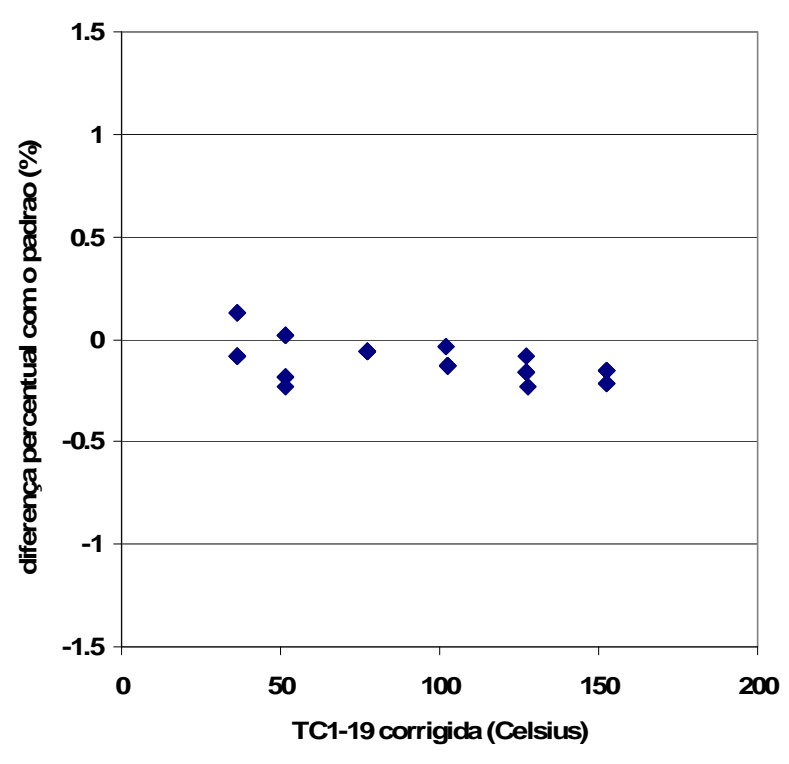

A18b

FIGURA A18.Curva de calibração TC1-19 (A18a) e diferença percentual com o padrão (A18b). 
TABELA A18. Dados de calibração do termopar TC1-20.

\begin{tabular}{cccc|cccc}
\hline $\begin{array}{c}\text { PT-001 } \\
\left({ }^{\circ} \mathrm{C}\right)\end{array}$ & $\begin{array}{c}\text { TC1-20 } \\
\left({ }^{\circ} \mathrm{C}\right)\end{array}$ & $\begin{array}{c}\text { TC1-20 } \\
\text { corrigida } \\
\left({ }^{\circ} \mathrm{C}\right)\end{array}$ & $\begin{array}{c}\text { diferença } \\
\text { percentual } \\
(\%)\end{array}$ & $\begin{array}{c}\text { PT-001 } \\
\left({ }^{\circ} \mathrm{C}\right)\end{array}$ & $\begin{array}{c}\text { TC1-20 } \\
\left({ }^{\circ} \mathrm{C}\right)\end{array}$ & $\begin{array}{c}\text { TC1-20 } \\
\text { corrigida } \\
\left({ }^{\circ} \mathrm{C}\right)\end{array}$ & $\begin{array}{c}\text { diferença } \\
\text { percentual } \\
(\%)\end{array}$ \\
\hline & & & & & & & \\
36,30 & 35,40 & 36,30 & $-0,01$ & 102,23 & 100,20 & 102,44 & $-0,20$ \\
36,30 & 35,40 & 36,30 & $-0,01$ & 102,23 & 100,20 & 102,44 & $-0,20$ \\
36,30 & 35,40 & 36,30 & $-0,01$ & 102,23 & 100,20 & 102,44 & $-0,20$ \\
36,30 & 35,40 & 36,30 & $-0,01$ & 102,23 & 100,20 & 102,44 & $-0,20$ \\
36,30 & 35,50 & 36,41 & $-0,30$ & 102,23 & 100,20 & 102,44 & $-0,20$ \\
51,63 & 50,20 & 51,68 & $-0,10$ & 127,31 & 125,70 & 127,73 & $-0,33$ \\
51,63 & 50,20 & 51,68 & $-0,10$ & 127,31 & 125,70 & 127,73 & $-0,33$ \\
51,63 & 50,20 & 51,68 & $-0,10$ & 127,31 & 125,70 & 127,73 & $-0,33$ \\
51,63 & 50,20 & 51,68 & $-0,10$ & 127,31 & 125,60 & 127,63 & $-0,26$ \\
51,63 & 50,20 & 51,68 & $-0,10$ & 127,31 & 125,60 & 127,63 & $-0,26$ \\
77,05 & 75,10 & 77,17 & $-0,16$ & 152,17 & 151,20 & 152,72 & $-0,36$ \\
77,05 & 75,10 & 77,17 & $-0,16$ & 152,17 & 151,20 & 152,72 & $-0,36$ \\
77,02 & 75,10 & 77,17 & $-0,19$ & 152,17 & 151,20 & 152,72 & $-0,36$ \\
77,02 & 75,10 & 77,17 & $-0,19$ & 152,17 & 151,30 & 152,82 & $-0,43$ \\
77,02 & 75,10 & 77,17 & $-0,19$ & 152,17 & 151,10 & 152,62 & $-0,30$ \\
& & & & & & & \\
\hline
\end{tabular}

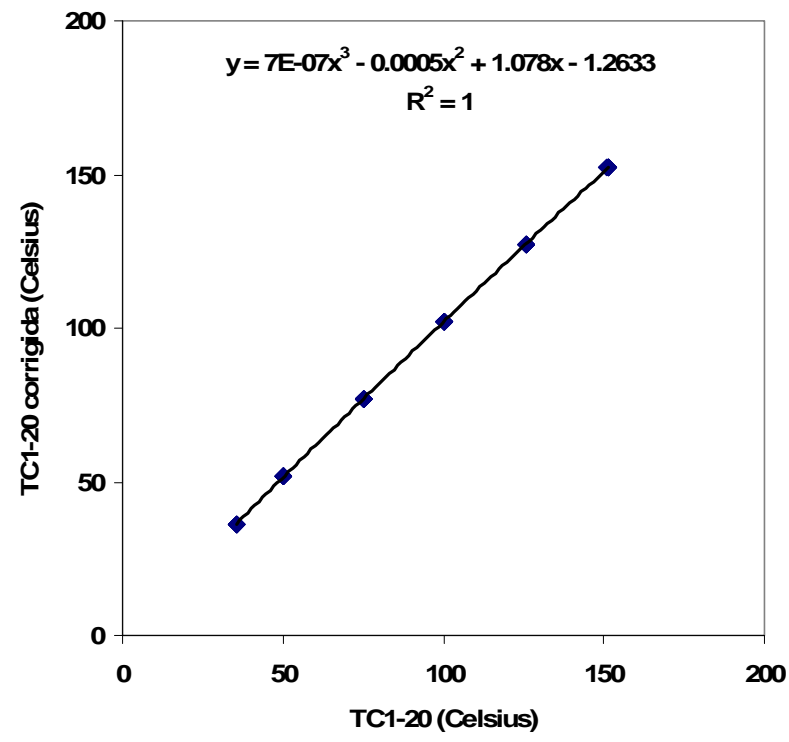

A19a

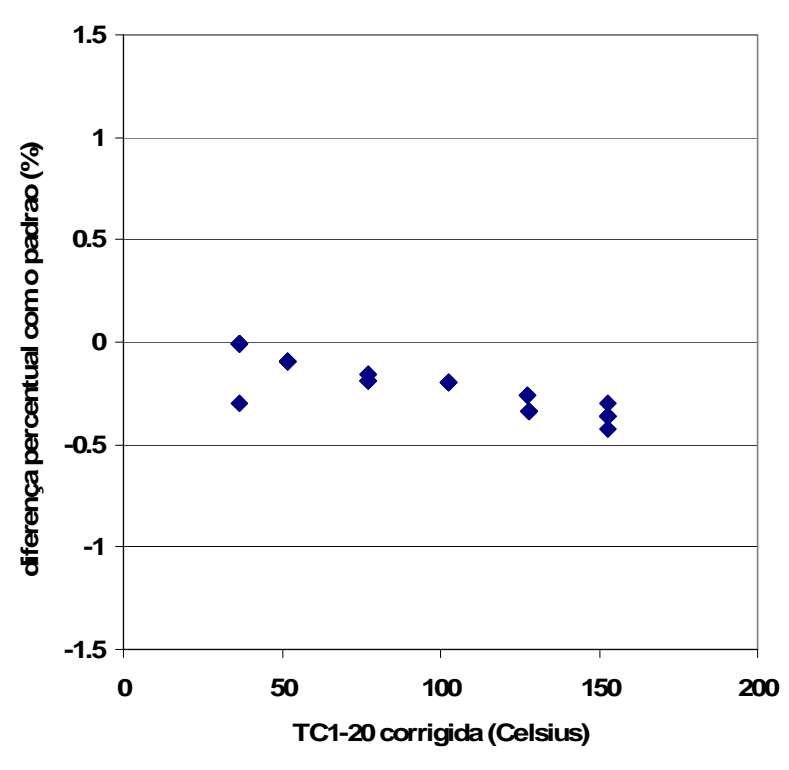

A19b

FIGURA A19. Curva de calibração TC1-20 (A19a) e diferença percentual com o padrão (A19b). 
TABELA A19. Dados de calibração do termopar TC1-21.

\begin{tabular}{cccc|cccc}
\hline $\begin{array}{c}\text { PT-001 } \\
\left({ }^{\circ} \mathrm{C}\right)\end{array}$ & $\begin{array}{c}\text { TC1-21 } \\
\left({ }^{\circ} \mathrm{C}\right)\end{array}$ & $\begin{array}{c}\text { TC1-21 } \\
\text { corrigida } \\
\left({ }^{\circ} \mathrm{C}\right)\end{array}$ & $\begin{array}{c}\text { diferença } \\
\text { percentual } \\
(\%)\end{array}$ & $\begin{array}{c}\text { PT-001 } \\
\left({ }^{\circ} \mathrm{C}\right)\end{array}$ & $\begin{array}{c}\text { TC1-21 } \\
\left({ }^{\circ} \mathrm{C}\right)\end{array}$ & $\begin{array}{c}\text { TC1-21 } \\
\text { corrigida } \\
\left({ }^{\circ} \mathrm{C}\right)\end{array}$ & $\begin{array}{c}\text { diferença } \\
\text { percentual } \\
(\%)\end{array}$ \\
\hline & & & & & & & \\
36,51 & 35,60 & 36,52 & $-0,02$ & 102,29 & 100,40 & 102,28 & 0,01 \\
36,54 & 35,60 & 36,52 & 0,05 & 102,34 & 100,50 & 102,38 & $-0,04$ \\
36,54 & 35,60 & 36,52 & 0,05 & 102,36 & 100,50 & 102,38 & $-0,01$ \\
36,57 & 35,60 & 36,52 & 0,12 & 102,39 & 100,50 & 102,38 & 0,01 \\
36,57 & 35,60 & 36,52 & 0,12 & 102,42 & 100,40 & 102,28 & 0,14 \\
51,23 & 49,90 & 51,29 & $-0,12$ & 127,41 & 126,00 & 127,45 & $-0,03$ \\
51,55 & 50,30 & 51,70 & $-0,30$ & 127,47 & 126,00 & 127,45 & 0,01 \\
51,66 & 50,30 & 51,70 & $-0,09$ & 127,47 & 126,00 & 127,45 & 0,01 \\
51,63 & 50,20 & 51,60 & 0,06 & 127,49 & 126,00 & 127,45 & 0,03 \\
51,63 & 50,30 & 51,70 & $-0,14$ & 127,49 & 126,00 & 127,45 & 0,03 \\
76,63 & 74,80 & 76,66 & $-0,04$ & 152,22 & 151,60 & 152,20 & 0,01 \\
76,73 & 74,80 & 76,66 & 0,10 & 152,27 & 151,60 & 152,20 & 0,05 \\
76,78 & 74,90 & 76,76 & 0,03 & 152,30 & 151,60 & 152,20 & 0,07 \\
76,84 & 74,90 & 76,76 & 0,10 & 152,33 & 151,60 & 152,20 & 0,08 \\
76,89 & 75,00 & 76,86 & 0,04 & 152,35 & 151,60 & 152,20 & 0,10 \\
\hline
\end{tabular}

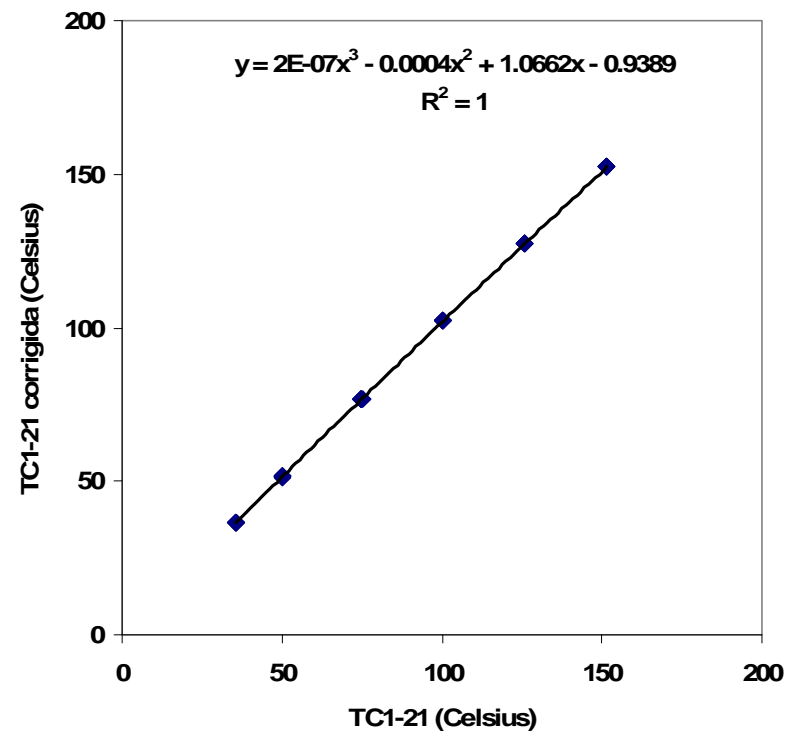

A20a

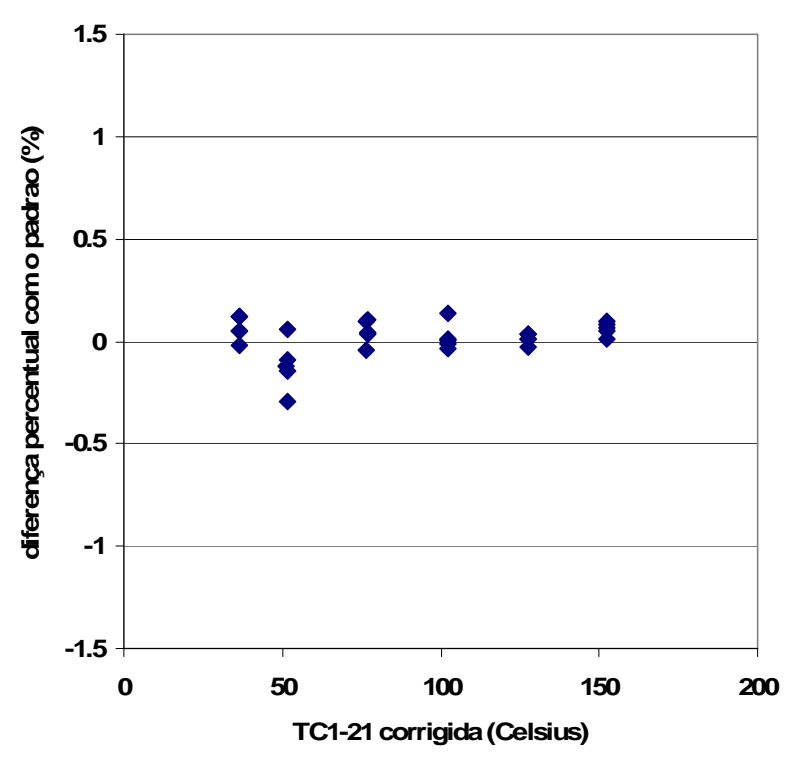

A20b

FIGURA A20. Curva de calibração TC1-21 (A20a) e diferença percentual com o padrão (A20b). 
TABELA A20. Dados de calibração do termopar TC1-22.

\begin{tabular}{cccc|cccc}
\hline $\begin{array}{c}\text { PT- 001 } \\
\left({ }^{\circ} \mathrm{C}\right)\end{array}$ & $\begin{array}{c}\text { TC1-22 } \\
\left({ }^{\circ} \mathrm{C}\right)\end{array}$ & $\begin{array}{c}\text { TC1-22 } \\
\text { corrigida } \\
\left({ }^{\circ} \mathrm{C}\right)\end{array}$ & $\begin{array}{c}\text { diferença } \\
\text { percentual } \\
(\%)\end{array}$ & $\begin{array}{c}\text { PT-001 } \\
\left({ }^{\circ} \mathrm{C}\right)\end{array}$ & $\begin{array}{c}\text { TC1-22 } \\
\left({ }^{\circ} \mathrm{C}\right)\end{array}$ & $\begin{array}{c}\text { TC1-22 } \\
\text { corrigida } \\
\left({ }^{\circ} \mathrm{C}\right)\end{array}$ & $\begin{array}{c}\text { diferença } \\
\text { percentual } \\
(\%)\end{array}$ \\
\hline & & & & & & & \\
36,57 & 35,70 & 36,54 & 0,08 & 102,44 & 100,90 & 102,36 & 0,08 \\
36,57 & 35,70 & 36,54 & 0,08 & 102,44 & 100,80 & 102,26 & 0,18 \\
36,57 & 35,70 & 36,54 & 0,08 & 102,44 & 100,80 & 102,26 & 0,18 \\
36,54 & 35,80 & 36,64 & $-0,28$ & 102,44 & 101,00 & 102,46 & $-0,02$ \\
36,54 & 35,80 & 36,64 & $-0,28$ & 102,44 & 100,90 & 102,36 & 0,08 \\
51,39 & 50,20 & 51,29 & 0,19 & 127,52 & 125,80 & 126,63 & 0,70 \\
51,58 & 50,40 & 51,50 & 0,15 & 127,52 & 125,80 & 126,63 & 0,70 \\
51,66 & 50,40 & 51,50 & 0,31 & 127,52 & 126,00 & 126,82 & 0,55 \\
51,63 & 50,40 & 51,50 & 0,26 & 127,52 & 125,90 & 126,73 & 0,62 \\
51,63 & 50,50 & 51,60 & 0,06 & 127,52 & 125,90 & 126,73 & 0,62 \\
76,92 & 75,20 & 76,65 & 0,34 & 152,38 & 152,20 & 151,36 & 0,67 \\
76,94 & 75,30 & 76,76 & 0,25 & 152,38 & 152,10 & 151,27 & 0,73 \\
76,97 & 75,30 & 76,76 & 0,28 & 152,41 & 152,20 & 151,36 & 0,68 \\
77,00 & 75,30 & 76,76 & 0,31 & 152,41 & 152,20 & 151,36 & 0,68 \\
77,00 & 75,30 & 76,76 & 0,31 & 152,41 & 152,20 & 151,36 & 0,68 \\
\hline
\end{tabular}

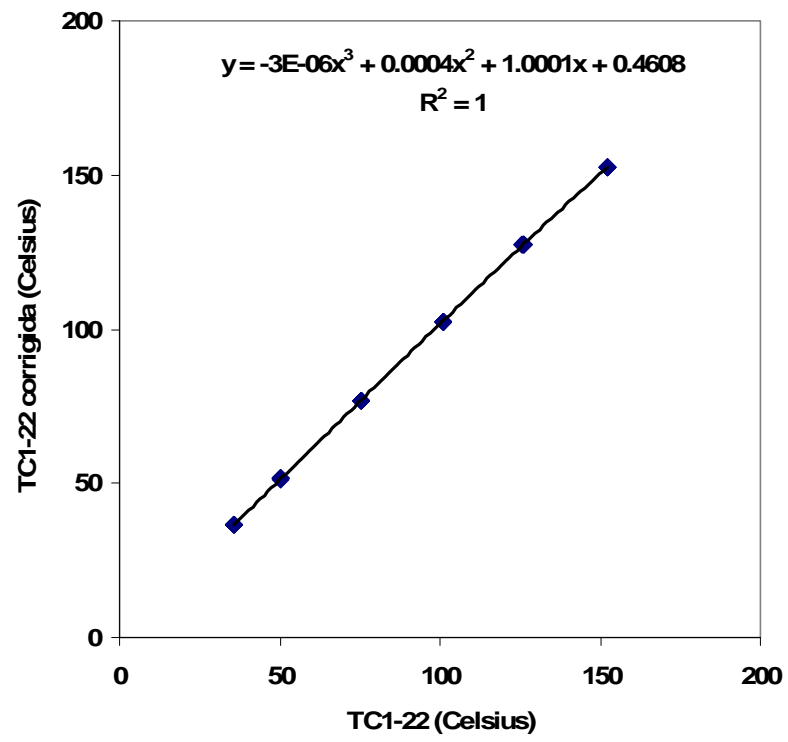

A21a

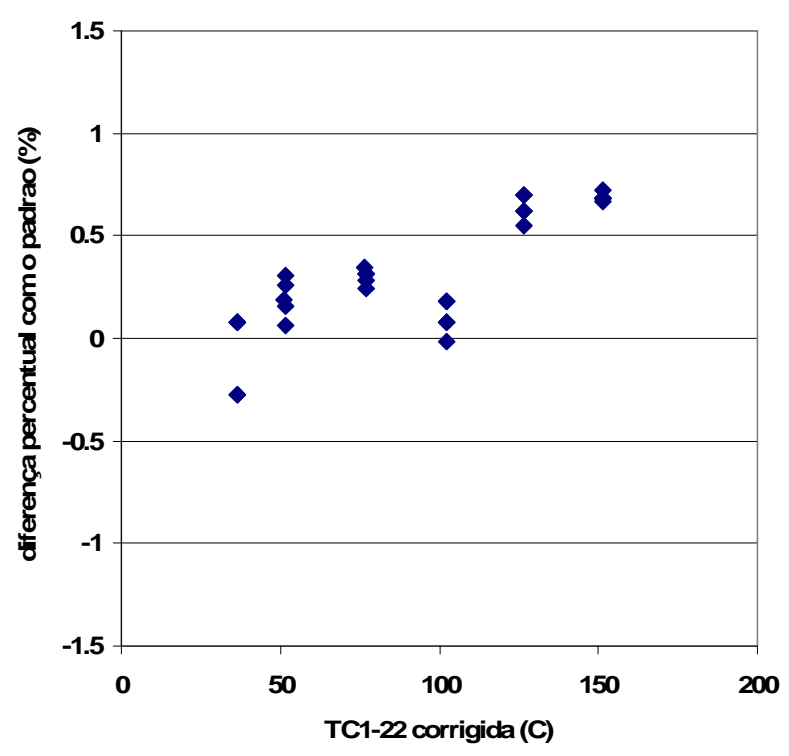

A21b

FIGURA A21. Curva de calibração TC1-22(A21a) e diferença percentual com o padrão (A21b). 
TABELA A21. Dados de calibração do termopar TC2-01.

\begin{tabular}{cccc|cccc}
\hline $\begin{array}{c}\text { PT-001 } \\
\left({ }^{\circ} \mathrm{C}\right)\end{array}$ & $\begin{array}{c}\text { TC2-01 } \\
\left({ }^{\circ} \mathrm{C}\right)\end{array}$ & $\begin{array}{c}\text { TC2-01 } \\
\text { corrigida } \\
\left({ }^{\circ} \mathrm{C}\right)\end{array}$ & $\begin{array}{c}\text { diferença } \\
\text { percentual } \\
(\%)\end{array}$ & $\begin{array}{c}\text { PT-001 } \\
\left({ }^{\circ} \mathrm{C}\right)\end{array}$ & $\begin{array}{c}\text { TC2-01 } \\
\left({ }^{\circ} \mathrm{C}\right)\end{array}$ & $\begin{array}{c}\text { TC2-01 } \\
\text { corrigida } \\
\left({ }^{\circ} \mathrm{C}\right)\end{array}$ & $\begin{array}{c}\text { diferença } \\
\text { percentual } \\
(\%)\end{array}$ \\
\hline & & & & & & & \\
34,89 & 34,00 & 34,83 & 0,16 & 75,51 & 73,80 & 75,61 & $-0,13$ \\
34,89 & 34,00 & 34,83 & 0,16 & 75,51 & 73,80 & 75,61 & $-0,13$ \\
34,89 & 34,10 & 34,94 & $-0,14$ & 75,56 & 73,80 & 75,61 & $-0,06$ \\
34,89 & 34,10 & 34,94 & $-0,14$ & 75,53 & 73,70 & 75,51 & 0,04 \\
34,86 & 34,10 & 34,94 & $-0,22$ & 75,51 & 73,70 & 75,51 & 0,00 \\
50,09 & 48,80 & 50,14 & $-0,10$ & 85,57 & 83,70 & 85,59 & $-0,03$ \\
50,09 & 48,80 & 50,14 & $-0,10$ & 85,60 & 83,70 & 85,59 & 0,00 \\
50,09 & 48,80 & 50,14 & $-0,10$ & 85,60 & 83,70 & 85,59 & 0,00 \\
50,09 & 48,70 & 50,04 & 0,10 & 85,57 & 83,70 & 85,59 & $-0,03$ \\
50,09 & 48,70 & 50,04 & 0,10 & 85,57 & 83,70 & 85,59 & $-0,03$ \\
65,42 & 63,60 & 65,26 & 0,24 & 93,42 & 91,50 & 93,43 & $-0,01$ \\
65,42 & 63,70 & 65,37 & 0,08 & 93,47 & 91,50 & 93,43 & 0,04 \\
65,39 & 63,80 & 65,47 & $-0,12$ & 93,45 & 91,60 & 93,53 & $-0,09$ \\
65,39 & 63,90 & 65,57 & $-0,27$ & 93,45 & 91,60 & 93,53 & $-0,09$ \\
65,37 & 63,80 & 65,47 & $-0,16$ & 93,45 & 91,60 & 93,53 & $-0,09$ \\
\hline
\end{tabular}

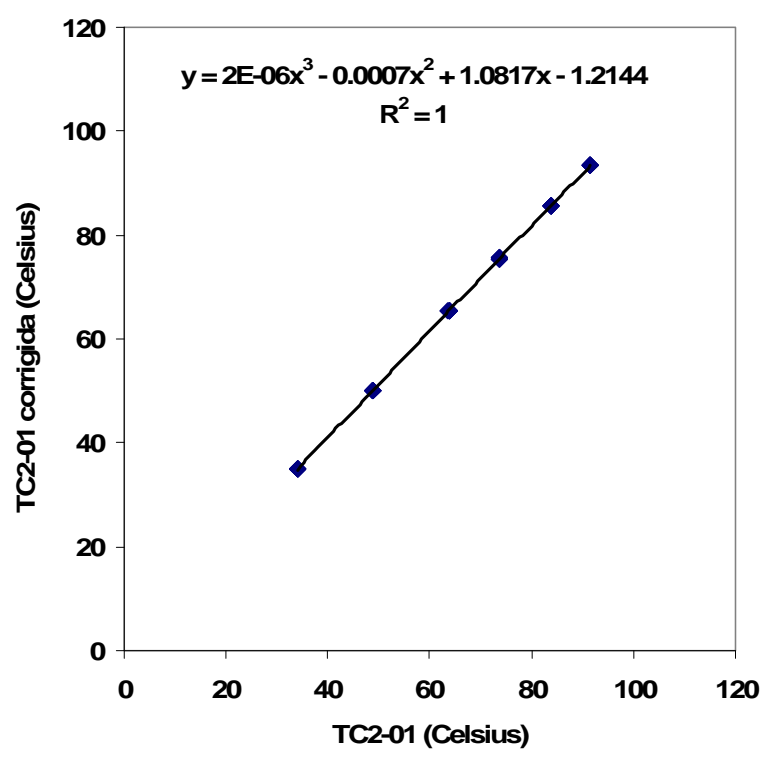

$\mathrm{A} 22 \mathrm{a}$

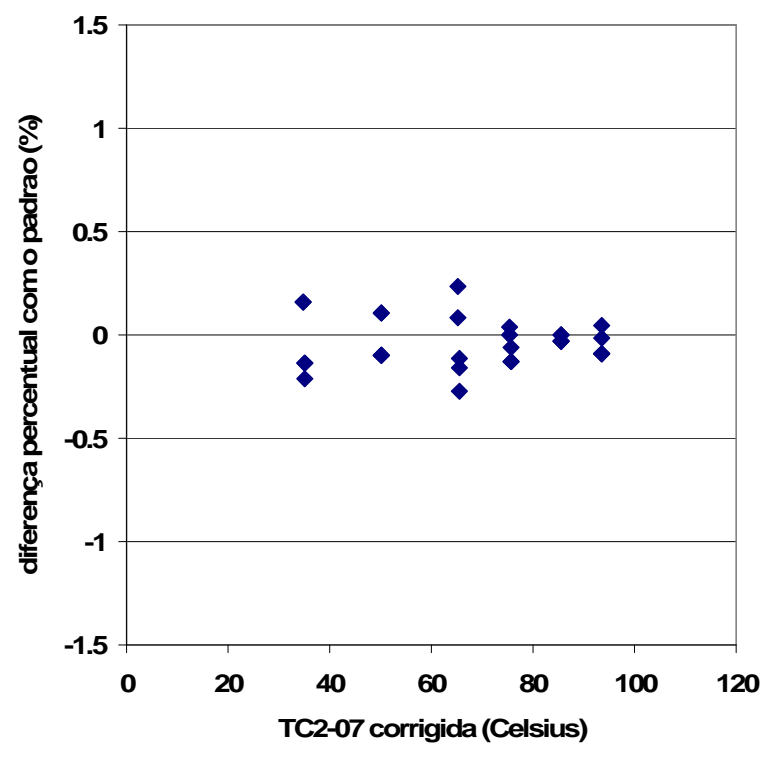

$\mathrm{A} 22 \mathrm{~b}$

FIGURA A22. Curva de calibração TC2-01(A22a) e diferença percentual com o padrão (A22b). 
TABELA A22. Dados de calibração do termopar TC2-02.

\begin{tabular}{cccc|cccc}
\hline $\begin{array}{c}\text { PT-001 } \\
\left({ }^{\circ} \mathrm{C}\right)\end{array}$ & $\begin{array}{c}\text { TC2-02 } \\
\left({ }^{\circ} \mathrm{C}\right)\end{array}$ & $\begin{array}{c}\text { TC2-02 } \\
\text { corrigida } \\
\left({ }^{\circ} \mathrm{C}\right)\end{array}$ & $\begin{array}{c}\text { diferença } \\
\text { percentual } \\
(\%)\end{array}$ & $\begin{array}{c}\text { PT-001 } \\
\left({ }^{\circ} \mathrm{C}\right)\end{array}$ & $\begin{array}{c}\text { TC2-02 } \\
\left({ }^{\circ} \mathrm{C}\right)\end{array}$ & $\begin{array}{c}\text { TC2-02 } \\
\text { corrigida } \\
\left({ }^{\circ} \mathrm{C}\right)\end{array}$ & $\begin{array}{c}\text { diferença } \\
\text { percentual } \\
(\%)\end{array}$ \\
\hline & & & & & & & \\
34,62 & 33,80 & 34,63 & $-0,01$ & 75,35 & 73,70 & 75,51 & $-0,21$ \\
34,60 & 33,80 & 34,63 & $-0,09$ & 75,45 & 73,70 & 75,51 & $-0,07$ \\
34,60 & 33,80 & 34,63 & $-0,09$ & 75,53 & 73,70 & 75,51 & 0,04 \\
34,60 & 33,80 & 34,63 & $-0,09$ & 75,45 & 73,70 & 75,51 & $-0,07$ \\
34,57 & 33,80 & 34,63 & $-0,17$ & 75,37 & 73,70 & 75,51 & $-0,18$ \\
50,09 & 48,70 & 50,16 & $-0,14$ & 85,70 & 83,80 & 85,62 & 0,09 \\
50,11 & 48,60 & 50,05 & 0,12 & 85,68 & 83,80 & 85,62 & 0,06 \\
50,14 & 48,60 & 50,05 & 0,17 & 85,62 & 83,80 & 85,62 & 0,00 \\
50,11 & 48,70 & 50,16 & $-0,08$ & 85,60 & 83,80 & 85,62 & $-0,03$ \\
50,09 & 48,70 & 50,16 & $-0,14$ & 85,57 & 83,80 & 85,62 & $-0,06$ \\
65,55 & 63,90 & 65,64 & $-0,14$ & 93,55 & 91,80 & 93,63 & $-0,08$ \\
65,53 & 63,90 & 65,64 & $-0,18$ & 93,45 & 91,80 & 93,63 & $-0,19$ \\
65,53 & 63,90 & 65,64 & $-0,18$ & 93,55 & 91,80 & 93,63 & $-0,08$ \\
65,61 & 63,90 & 65,64 & $-0,06$ & 93,61 & 91,80 & 93,63 & $-0,02$ \\
65,61 & 63,90 & 65,64 & $-0,06$ & 93,63 & 91,80 & 93,63 & 0,01 \\
\hline
\end{tabular}

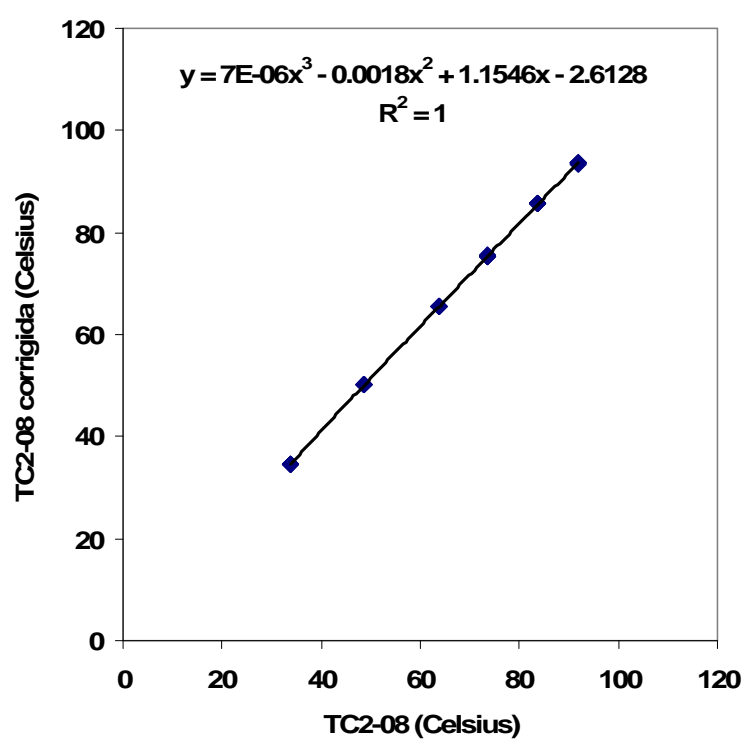

A23a

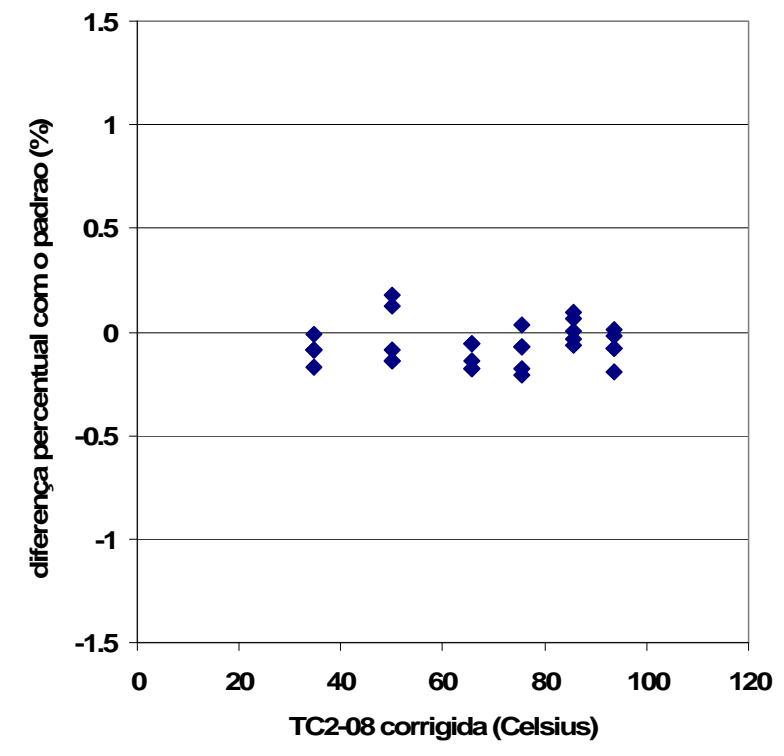

$\mathrm{A} 23 \mathrm{~b}$

FIGURA A23. Curva de calibração TC2-02 (A23a) e diferença percentual com o padrão (A23b). 
TABELA A23. Dados de calibração do termopar TC2-03.

\begin{tabular}{cccc|cccc}
\hline $\begin{array}{c}\text { PT-001 } \\
\left({ }^{\circ} \mathrm{C}\right)\end{array}$ & $\begin{array}{c}\text { TC2-03 } \\
\left({ }^{\circ} \mathrm{C}\right)\end{array}$ & $\begin{array}{c}\text { TC2-03 } \\
\text { corrigida } \\
\left({ }^{\circ} \mathrm{C}\right)\end{array}$ & $\begin{array}{c}\text { diferença } \\
\text { percentual } \\
(\%)\end{array}$ & $\begin{array}{c}\text { PT-001 } \\
\left({ }^{\circ} \mathrm{C}\right)\end{array}$ & $\begin{array}{c}\text { TC2-03 } \\
\left({ }^{\circ} \mathrm{C}\right)\end{array}$ & $\begin{array}{c}\text { TC2-03 } \\
\text { corrigida } \\
\left({ }^{\circ} \mathrm{C}\right)\end{array}$ & $\begin{array}{c}\text { diferença } \\
\text { percentual } \\
(\%)\end{array}$ \\
\hline & & & & & & & \\
34,70 & 34,00 & 34,80 & $-0,27$ & 75,56 & 73,90 & 75,77 & $-0,27$ \\
34,70 & 34,00 & 34,80 & $-0,27$ & 75,56 & 73,90 & 75,77 & $-0,27$ \\
34,70 & 33,90 & 34,69 & 0,03 & 75,56 & 73,90 & 75,77 & $-0,27$ \\
34,70 & 33,90 & 34,69 & 0,03 & 75,61 & 73,90 & 75,77 & $-0,20$ \\
34,70 & 33,90 & 34,69 & 0,03 & 75,56 & 73,90 & 75,77 & $-0,27$ \\
50,17 & 49,00 & 50,32 & $-0,30$ & 86,02 & 84,30 & 86,37 & $-0,41$ \\
50,14 & 48,90 & 50,21 & $-0,14$ & 85,99 & 84,30 & 86,37 & $-0,44$ \\
50,11 & 48,90 & 50,21 & $-0,20$ & 85,97 & 84,30 & 86,37 & $-0,47$ \\
50,11 & 48,90 & 50,21 & $-0,20$ & 85,94 & 84,30 & 86,37 & $-0,50$ \\
50,09 & 48,90 & 50,21 & $-0,25$ & 85,94 & 84,30 & 86,37 & $-0,50$ \\
65,47 & 64,00 & 65,67 & $-0,31$ & 94,19 & 92,30 & 94,55 & $-0,38$ \\
65,50 & 64,00 & 65,67 & $-0,26$ & 94,19 & 92,30 & 94,55 & $-0,38$ \\
65,50 & 64,00 & 65,67 & $-0,26$ & 94,19 & 92,30 & 94,55 & $-0,38$ \\
65,50 & 64,00 & 65,67 & $-0,26$ & 94,17 & 92,30 & 94,55 & $-0,41$ \\
65,50 & 63,90 & 65,57 & $-0,11$ & 94,06 & 92,30 & 94,55 & $-0,53$ \\
& & & & & & \\
\hline
\end{tabular}

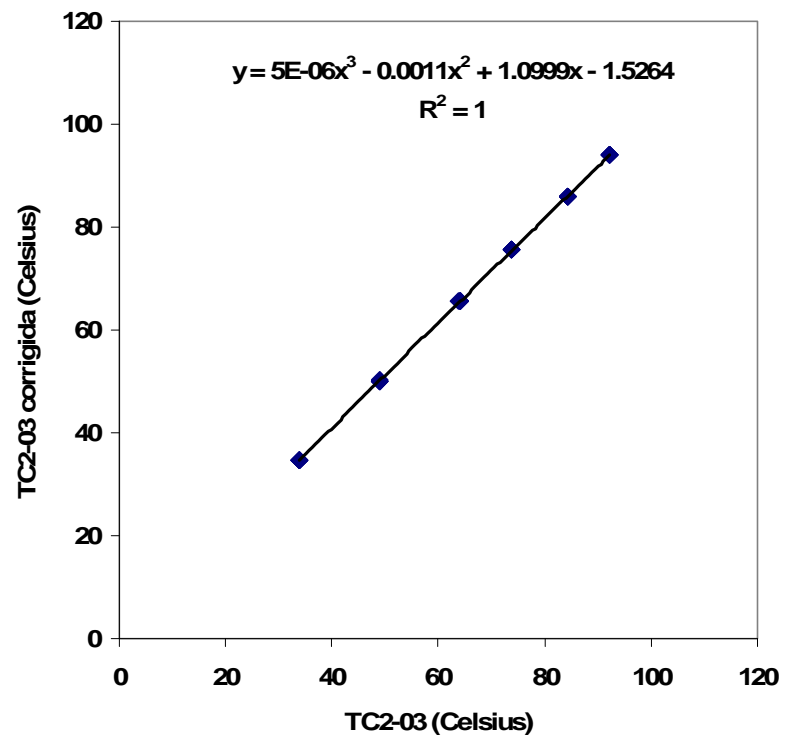

A24a

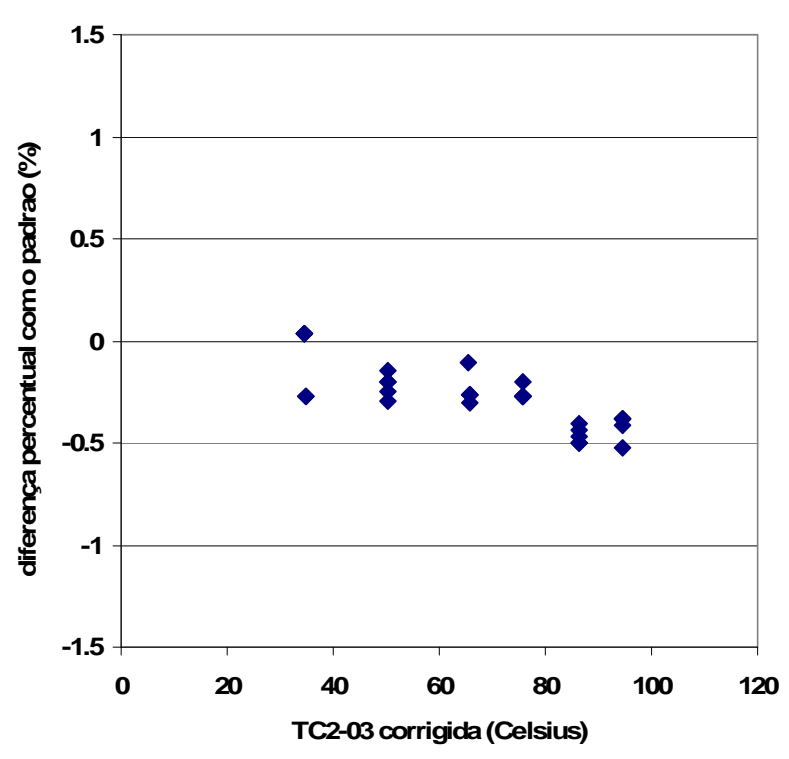

A24b

FIGURA A24. Curva de calibração TC2-03 (A24a) e diferença percentual com o padrão (A24b). 
TABELA A24. Dados de calibração do termopar TC2-04.

\begin{tabular}{cccc|cccc}
\hline $\begin{array}{c}\text { PT-001 } \\
\left({ }^{\circ} \mathrm{C}\right)\end{array}$ & $\begin{array}{c}\text { TC2-04 } \\
\left({ }^{\circ} \mathrm{C}\right)\end{array}$ & $\begin{array}{c}\text { TC2-04 } \\
\text { corrigida } \\
\left({ }^{\circ} \mathrm{C}\right)\end{array}$ & $\begin{array}{c}\text { diferença } \\
\text { percentual } \\
(\%)\end{array}$ & $\begin{array}{c}\text { PT- 001 } \\
\left({ }^{\circ} \mathrm{C}\right)\end{array}$ & $\begin{array}{c}\text { TC2-04 } \\
\left({ }^{\circ} \mathrm{C}\right)\end{array}$ & $\begin{array}{c}\text { TC2-04 } \\
\text { corrigida } \\
\left({ }^{\circ} \mathrm{C}\right)\end{array}$ & $\begin{array}{c}\text { diferença } \\
\text { percentual } \\
(\%)\end{array}$ \\
\hline & & & & & & & \\
35,13 & 34,20 & 35,13 & $-0,02$ & 75,67 & 73,80 & 75,81 & $-0,18$ \\
35,13 & 34,20 & 35,13 & $-0,02$ & 75,69 & 73,90 & 75,91 & $-0,28$ \\
35,10 & 34,20 & 35,13 & $-0,09$ & 75,75 & 73,90 & 75,91 & $-0,21$ \\
35,10 & 34,10 & 35,03 & 0,20 & 75,72 & 73,90 & 75,91 & $-0,25$ \\
35,07 & 34,10 & 35,03 & 0,12 & 75,69 & 73,90 & 75,91 & $-0,28$ \\
50,51 & 49,40 & 50,62 & $-0,22$ & 85,86 & 84,00 & 86,27 & $-0,48$ \\
50,46 & 49,40 & 50,62 & $-0,33$ & 85,86 & 84,00 & 86,27 & $-0,48$ \\
50,43 & 49,40 & 50,62 & $-0,38$ & 85,94 & 84,10 & 86,37 & $-0,50$ \\
50,41 & 49,30 & 50,52 & $-0,23$ & 86,02 & 84,20 & 86,48 & $-0,53$ \\
50,41 & 49,30 & 50,52 & $-0,23$ & 86,07 & 84,20 & 86,48 & $-0,47$ \\
65,90 & 64,30 & 66,00 & $-0,15$ & 93,74 & 91,80 & 94,19 & $-0,48$ \\
65,85 & 64,30 & 66,00 & $-0,23$ & 93,77 & 91,80 & 94,19 & $-0,45$ \\
65,79 & 64,30 & 66,00 & $-0,31$ & 93,79 & 91,80 & 94,19 & $-0,42$ \\
65,79 & 64,20 & 65,89 & $-0,16$ & 93,87 & 91,90 & 94,29 & $-0,45$ \\
65,79 & 64,20 & 65,89 & $-0,16$ & 93,85 & 91,90 & 94,29 & $-0,48$ \\
& & & & & & \\
\hline
\end{tabular}

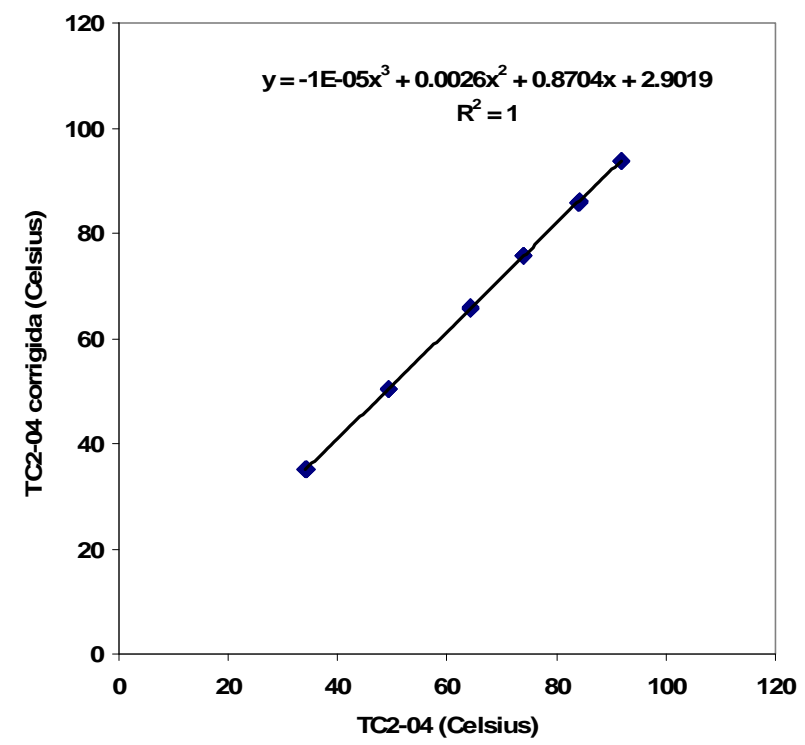

$\mathrm{A} 25 \mathrm{a}$

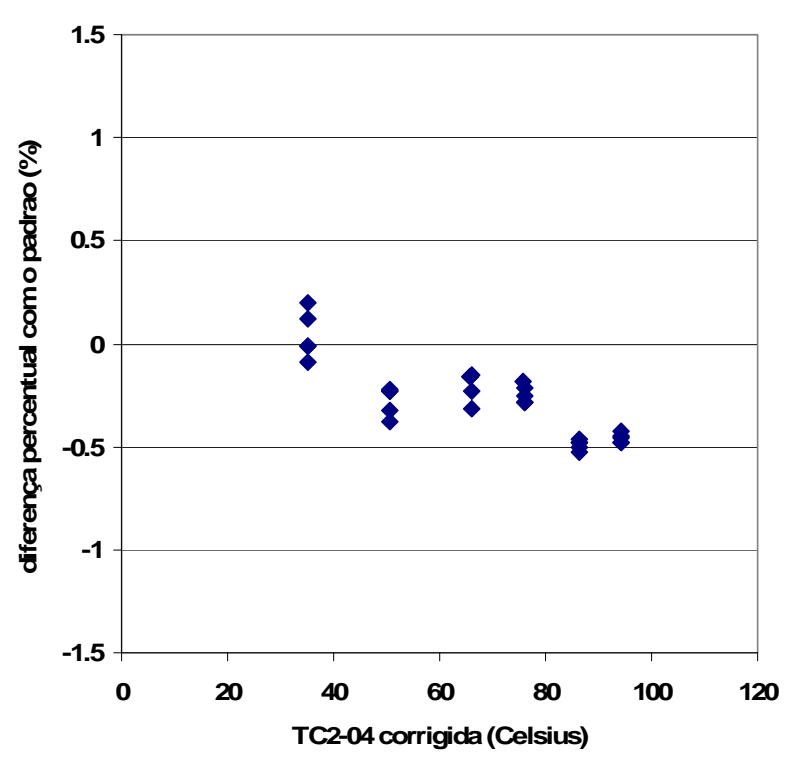

A25b

FIGURA A25. Curva de calibração TC2-04 (A25a) e diferença percentual com o padrão (A25b). 
TABELA A25. Dados de calibração do termopar TC2-05.

\begin{tabular}{cccc|cccc}
\hline $\begin{array}{c}\text { PT-001 } \\
\left({ }^{\circ} \mathrm{C}\right)\end{array}$ & $\begin{array}{c}\text { TC2-05 } \\
\left({ }^{\circ} \mathrm{C}\right)\end{array}$ & $\begin{array}{c}\text { TC2-05 } \\
\text { corrigida } \\
\left({ }^{\circ} \mathrm{C}\right)\end{array}$ & $\begin{array}{c}\text { diferença } \\
\text { percentual } \\
(\%)\end{array}$ & $\begin{array}{c}\text { PT-001 } \\
\left({ }^{\circ} \mathrm{C}\right)\end{array}$ & $\begin{array}{c}\text { TC2-05 } \\
\left({ }^{\circ} \mathrm{C}\right)\end{array}$ & $\begin{array}{c}\text { TC2-05 } \\
\text { corrigida } \\
\left({ }^{\circ} \mathrm{C}\right)\end{array}$ & $\begin{array}{c}\text { diferença } \\
\text { percentual } \\
(\%)\end{array}$ \\
\hline & & & & & & & \\
34,84 & 34,00 & 34,82 & 0,05 & 75,53 & 73,80 & 75,27 & 0,36 \\
34,84 & 34,00 & 34,82 & 0,05 & 75,51 & 73,80 & 75,27 & 0,32 \\
34,84 & 34,00 & 34,82 & 0,05 & 75,51 & 73,80 & 75,27 & 0,32 \\
34,84 & 34,00 & 34,82 & 0,05 & 75,48 & 73,80 & 75,27 & 0,28 \\
34,84 & 34,00 & 34,82 & 0,05 & 75,51 & 73,90 & 75,37 & 0,19 \\
50,11 & 49,00 & 49,97 & 0,28 & 85,68 & 83,90 & 85,47 & 0,24 \\
50,14 & 49,00 & 49,97 & 0,33 & 85,68 & 83,90 & 85,47 & 0,24 \\
50,11 & 49,00 & 49,97 & 0,28 & 85,70 & 83,90 & 85,47 & 0,27 \\
50,09 & 49,00 & 49,97 & 0,22 & 85,70 & 83,90 & 85,47 & 0,27 \\
50,06 & 49,00 & 49,97 & 0,17 & 85,70 & 83,90 & 85,47 & 0,27 \\
65,39 & 64,10 & 65,38 & 0,01 & 93,71 & 91,90 & 93,45 & 0,28 \\
65,39 & 64,10 & 65,38 & 0,01 & 93,63 & 91,90 & 93,45 & 0,19 \\
65,39 & 64,10 & 65,38 & 0,01 & 93,63 & 91,90 & 93,45 & 0,19 \\
65,39 & 64,10 & 65,38 & 0,01 & 93,69 & 91,90 & 93,45 & 0,25 \\
65,39 & 64,10 & 65,38 & 0,01 & 93,74 & 91,90 & 93,45 & 0,31 \\
\hline
\end{tabular}

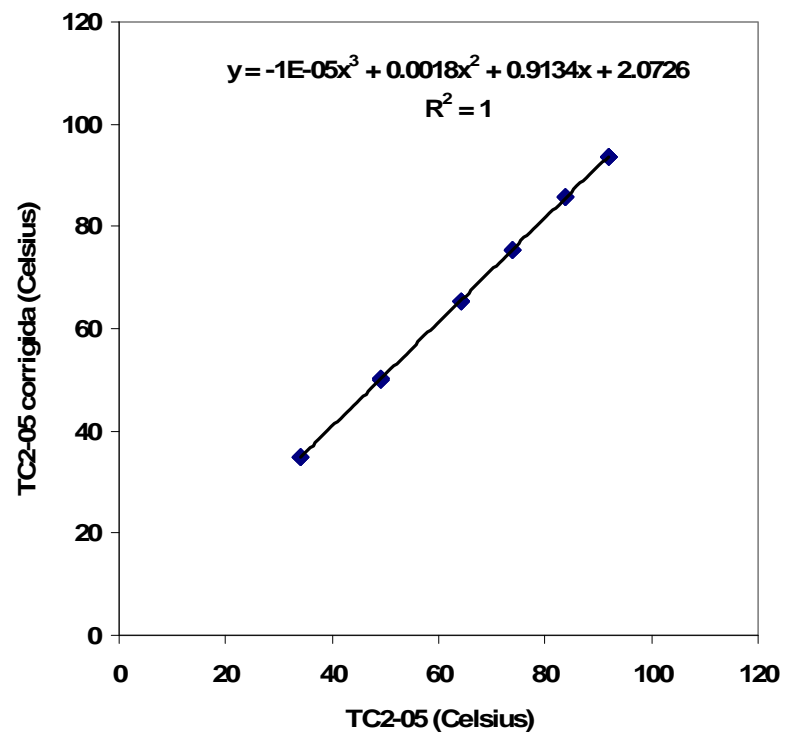

A26a

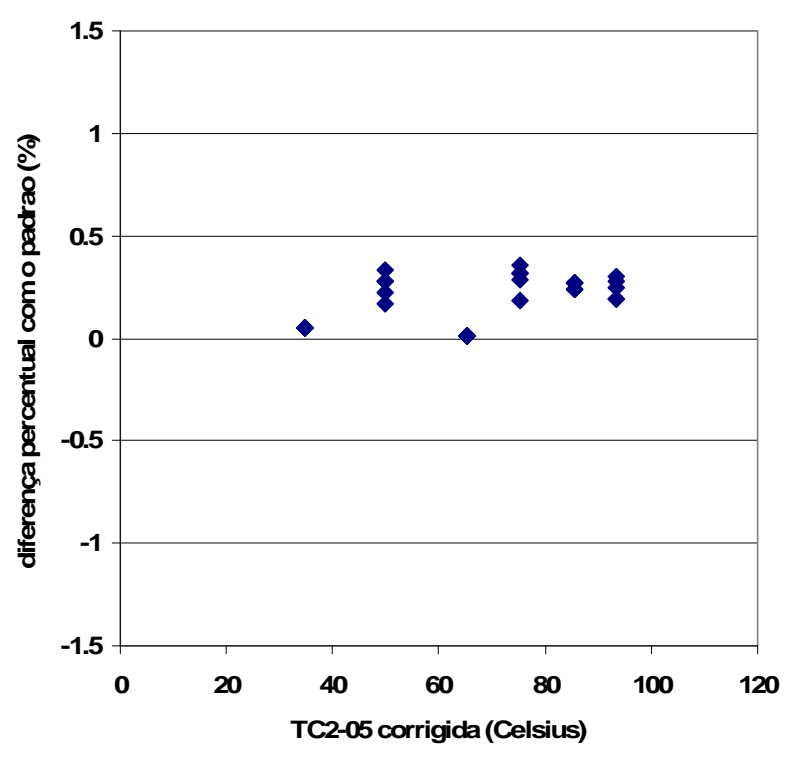

A26b

FIGURA A26. Curva de calibração TC2-05 (A26a) e diferença percentual com o padrão (A26b). 
TABELA A26. Dados de calibração do termopar TC2-06.

\begin{tabular}{cccc|cccc}
\hline $\begin{array}{c}\text { PT-001 } \\
\left({ }^{\circ} \mathrm{C}\right)\end{array}$ & $\begin{array}{c}\text { TC2-06 } \\
\left({ }^{\circ} \mathrm{C}\right)\end{array}$ & $\begin{array}{c}\text { TC2-06 } \\
\text { corrigida } \\
\left({ }^{\circ} \mathrm{C}\right)\end{array}$ & $\begin{array}{c}\text { diferença } \\
\text { percentual } \\
(\%)\end{array}$ & $\begin{array}{c}\text { PT-001 } \\
\left({ }^{\circ} \mathrm{C}\right)\end{array}$ & $\begin{array}{c}\text { TC2-06 } \\
\left({ }^{\circ} \mathrm{C}\right)\end{array}$ & $\begin{array}{c}\text { TC2-06 } \\
\text { corrigida } \\
\left({ }^{\circ} \mathrm{C}\right)\end{array}$ & $\begin{array}{c}\text { diferença } \\
\text { percentual } \\
(\%)\end{array}$ \\
\hline & & & & & & & \\
34,99 & 33,90 & 34,93 & 0,20 & 75,80 & 73,70 & 75,26 & 0,72 \\
34,99 & 33,90 & 34,93 & 0,20 & 75,83 & 73,70 & 75,26 & 0,75 \\
34,99 & 33,90 & 34,93 & 0,20 & 75,80 & 73,70 & 75,26 & 0,72 \\
34,99 & 33,90 & 34,93 & 0,20 & 75,77 & 73,70 & 75,26 & 0,68 \\
34,99 & 33,90 & 34,93 & 0,20 & 75,80 & 73,70 & 75,26 & 0,72 \\
50,46 & 48,90 & 50,21 & 0,49 & 85,94 & 83,90 & 85,36 & 0,67 \\
50,43 & 48,90 & 50,21 & 0,43 & 85,97 & 83,90 & 85,36 & 0,70 \\
50,43 & 48,90 & 50,21 & 0,43 & 85,94 & 83,90 & 85,36 & 0,67 \\
50,41 & 48,90 & 50,21 & 0,38 & 85,97 & 83,90 & 85,36 & 0,70 \\
50,41 & 48,90 & 50,21 & 0,38 & 85,94 & 83,80 & 85,27 & 0,79 \\
65,74 & 64,00 & 65,52 & 0,33 & 94,01 & 91,90 & 93,17 & 0,89 \\
65,74 & 64,00 & 65,52 & 0,33 & 93,98 & 91,90 & 93,17 & 0,86 \\
65,77 & 64,00 & 65,52 & 0,37 & 93,98 & 91,90 & 93,17 & 0,86 \\
65,77 & 64,00 & 65,52 & 0,37 & 93,95 & 91,90 & 93,17 & 0,83 \\
65,74 & 63,90 & 65,42 & 0,48 & 93,93 & 91,90 & 93,17 & 0,80 \\
\hline
\end{tabular}

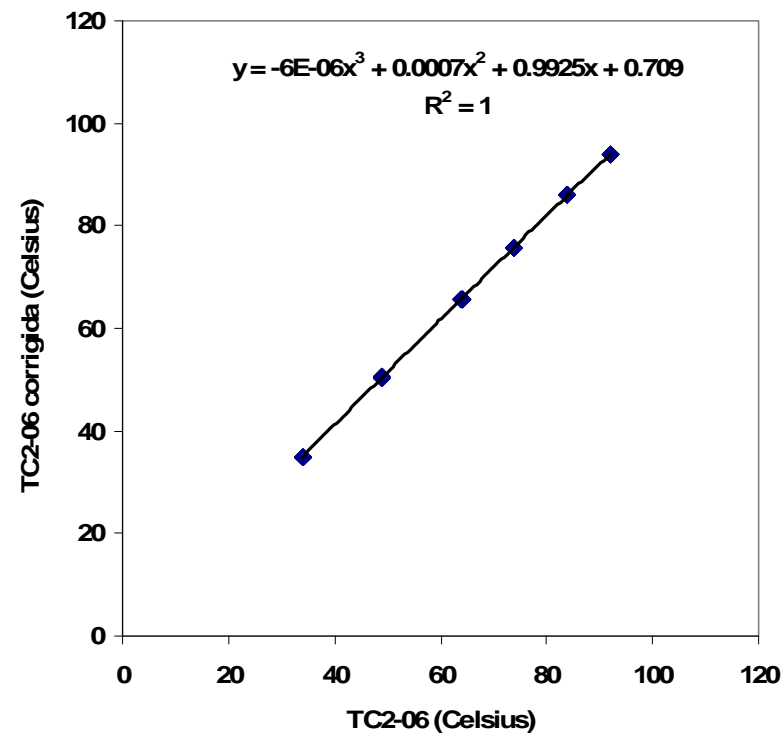

A27a

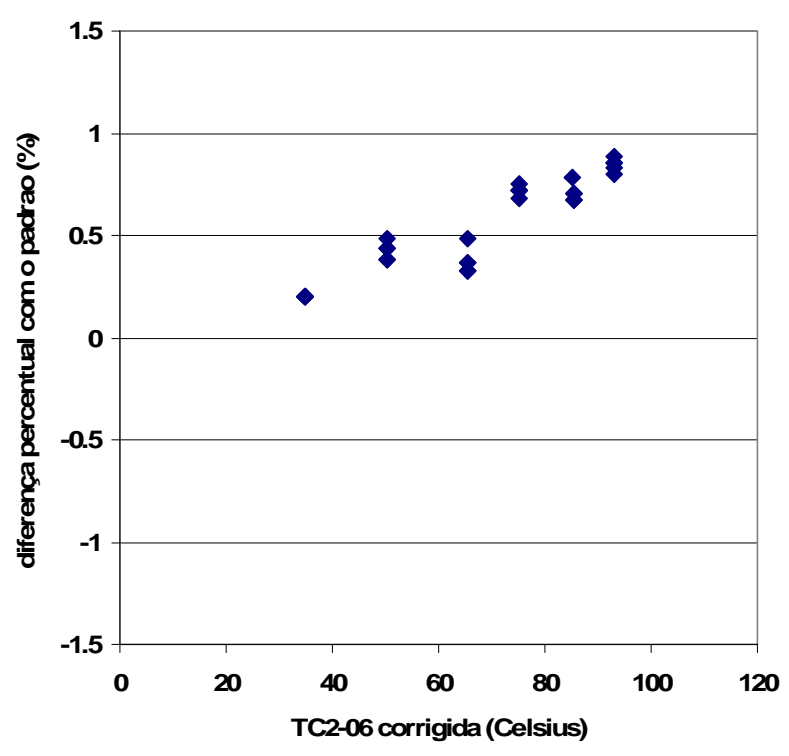

A27b

FIGURA A27. Curva de calibração TC2-06 (A27a) e diferença percentual com o padrão (A27b). 
TABELA A27. Dados de calibração do termopar TC2-07.

\begin{tabular}{cccc|cccc}
\hline $\begin{array}{c}\text { PT-001 } \\
\left({ }^{\circ} \mathrm{C}\right)\end{array}$ & $\begin{array}{c}\text { TC2-07 } \\
\left({ }^{\circ} \mathrm{C}\right)\end{array}$ & $\begin{array}{c}\text { TC2-07 } \\
\text { corrigida } \\
\left({ }^{\circ} \mathrm{C}\right)\end{array}$ & $\begin{array}{c}\text { diferença } \\
\text { percentual } \\
(\%)\end{array}$ & $\begin{array}{c}\text { PT-001 } \\
\left({ }^{\circ} \mathrm{C}\right)\end{array}$ & $\begin{array}{c}\text { TC2-07 } \\
\left({ }^{\circ} \mathrm{C}\right)\end{array}$ & $\begin{array}{c}\text { TC2-07 } \\
\text { corrigida } \\
\left({ }^{\circ} \mathrm{C}\right)\end{array}$ & $\begin{array}{c}\text { diferença } \\
\text { percentual } \\
(\%)\end{array}$ \\
\hline & & & & & & & \\
35,31 & 34,00 & 35,43 & $-0,33$ & 75,35 & 70,00 & 75,66 & $-0,42$ \\
35,29 & 33,90 & 35,31 & $-0,07$ & 75,35 & 70,00 & 75,66 & $-0,42$ \\
35,26 & 33,90 & 35,31 & $-0,14$ & 75,35 & 70,00 & 75,66 & $-0,42$ \\
35,26 & 33,90 & 35,31 & $-0,14$ & 75,35 & 70,00 & 75,66 & $-0,42$ \\
35,23 & 33,80 & 35,19 & 0,12 & 75,32 & 70,00 & 75,66 & $-0,45$ \\
49,95 & 46,70 & 50,16 & $-0,40$ & 85,46 & 79,90 & 85,94 & $-0,56$ \\
49,95 & 46,70 & 50,16 & $-0,40$ & 85,44 & 79,90 & 85,94 & $-0,59$ \\
49,95 & 46,70 & 50,16 & $-0,40$ & 85,41 & 79,90 & 85,94 & $-0,62$ \\
49,95 & 46,70 & 50,16 & $-0,40$ & 85,44 & 79,90 & 85,94 & $-0,59$ \\
49,95 & 46,70 & 50,16 & $-0,40$ & 85,41 & 79,90 & 85,94 & $-0,62$ \\
65,23 & 60,40 & 65,38 & $-0,23$ & 93,31 & 87,70 & 93,81 & $-0,53$ \\
65,26 & 60,40 & 65,38 & $-0,19$ & 93,31 & 87,70 & 93,81 & $-0,53$ \\
65,26 & 60,40 & 65,38 & $-0,19$ & 93,31 & 87,70 & 93,81 & $-0,53$ \\
65,26 & 60,40 & 65,38 & $-0,19$ & 93,31 & 87,70 & 93,81 & $-0,53$ \\
65,26 & 60,40 & 65,38 & $-0,19$ & 93,29 & 87,70 & 93,81 & $-0,56$ \\
\hline
\end{tabular}

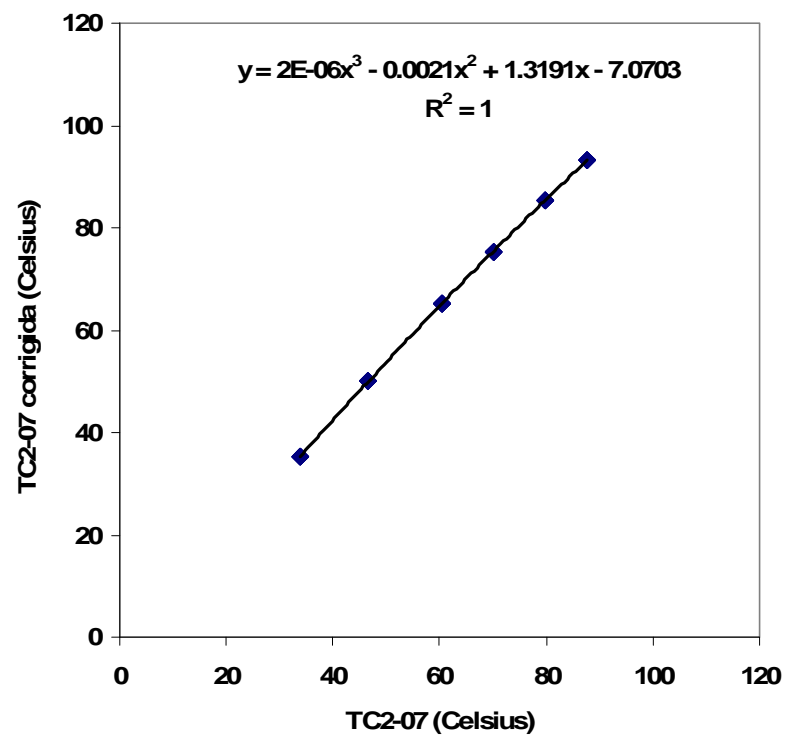

A28a

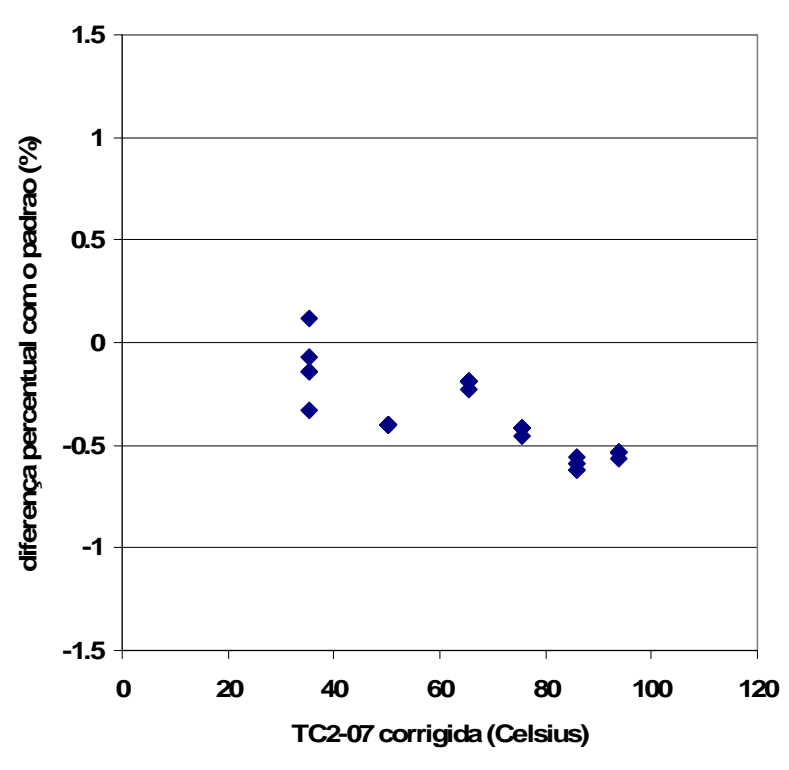

A28b

FIGURA A28. Curva de calibração TC2-07 (A28a) e diferença percentual com o padrão (A28b). 
TABELA A28. Dados de calibração do termopar TC2-08.

\begin{tabular}{cccc|cccc}
\hline $\begin{array}{c}\text { PT-001 } \\
\left({ }^{\circ} \mathrm{C}\right)\end{array}$ & $\begin{array}{c}\text { TC2-08 } \\
\left({ }^{\circ} \mathrm{C}\right)\end{array}$ & $\begin{array}{c}\text { TC2-08 } \\
\text { corrigida } \\
\left({ }^{\circ} \mathrm{C}\right)\end{array}$ & $\begin{array}{c}\text { diferença } \\
\text { percentual } \\
(\%)\end{array}$ & $\begin{array}{c}\text { PT-001 } \\
\left({ }^{\circ} \mathrm{C}\right)\end{array}$ & $\begin{array}{c}\text { TC2-08 } \\
\left({ }^{\circ} \mathrm{C}\right)\end{array}$ & $\begin{array}{c}\text { TC2-08 } \\
\text { corrigida } \\
\left({ }^{\circ} \mathrm{C}\right)\end{array}$ & $\begin{array}{c}\text { diferença } \\
\text { percentual } \\
(\%)\end{array}$ \\
\hline & & & & & & & \\
34,76 & 34,00 & 34,69 & 0,17 & 74,74 & 73,10 & 74,46 & 0,37 \\
34,76 & 34,00 & 34,69 & 0,17 & 74,76 & 73,10 & 74,46 & 0,41 \\
34,76 & 34,00 & 34,69 & 0,17 & 74,76 & 73,10 & 74,46 & 0,41 \\
34,76 & 34,00 & 34,69 & 0,17 & 74,79 & 73,10 & 74,46 & 0,44 \\
34,76 & 34,00 & 34,69 & 0,17 & 74,82 & 73,10 & 74,46 & 0,48 \\
49,82 & 48,70 & 49,72 & 0,20 & 84,69 & 83,00 & 84,39 & 0,36 \\
49,82 & 48,70 & 49,72 & 0,20 & 84,64 & 83,00 & 84,39 & 0,29 \\
49,82 & 48,70 & 49,72 & 0,20 & 84,61 & 83,00 & 84,39 & 0,26 \\
49,82 & 48,70 & 49,72 & 0,20 & 84,66 & 83,00 & 84,39 & 0,32 \\
49,82 & 48,70 & 49,72 & 0,20 & 84,72 & 83,00 & 84,39 & 0,39 \\
64,73 & 63,30 & 64,56 & 0,26 & 92,25 & 90,40 & 91,76 & 0,53 \\
64,75 & 63,30 & 64,56 & 0,30 & 92,25 & 90,40 & 91,76 & 0,53 \\
64,78 & 63,30 & 64,56 & 0,34 & 92,28 & 90,50 & 91,86 & 0,45 \\
64,78 & 63,30 & 64,56 & 0,34 & 92,25 & 90,50 & 91,86 & 0,42 \\
64,73 & 63,30 & 64,56 & 0,26 & 92,25 & 90,50 & 91,86 & 0,42 \\
\hline
\end{tabular}

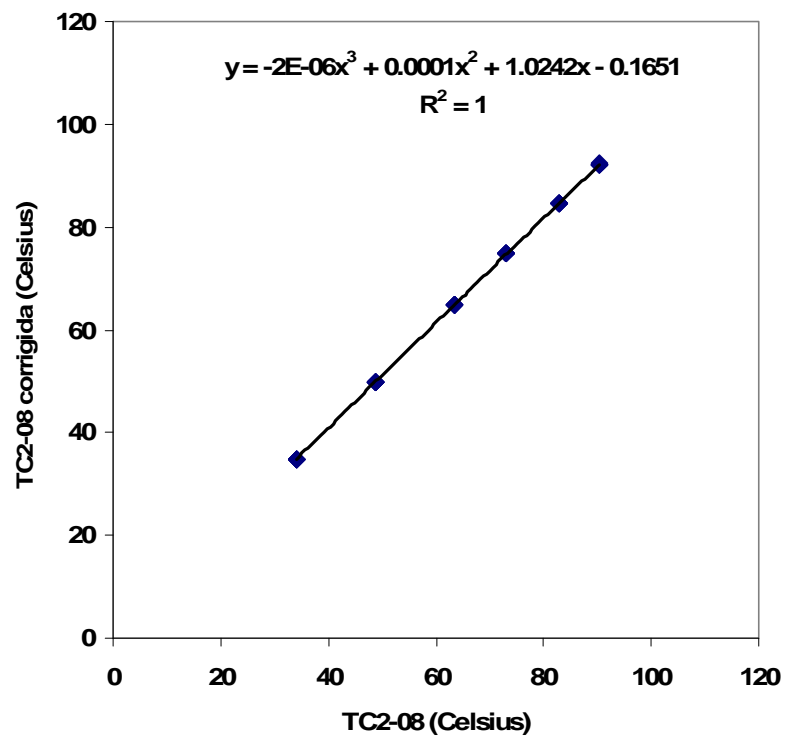

$\mathrm{A} 29 \mathrm{a}$

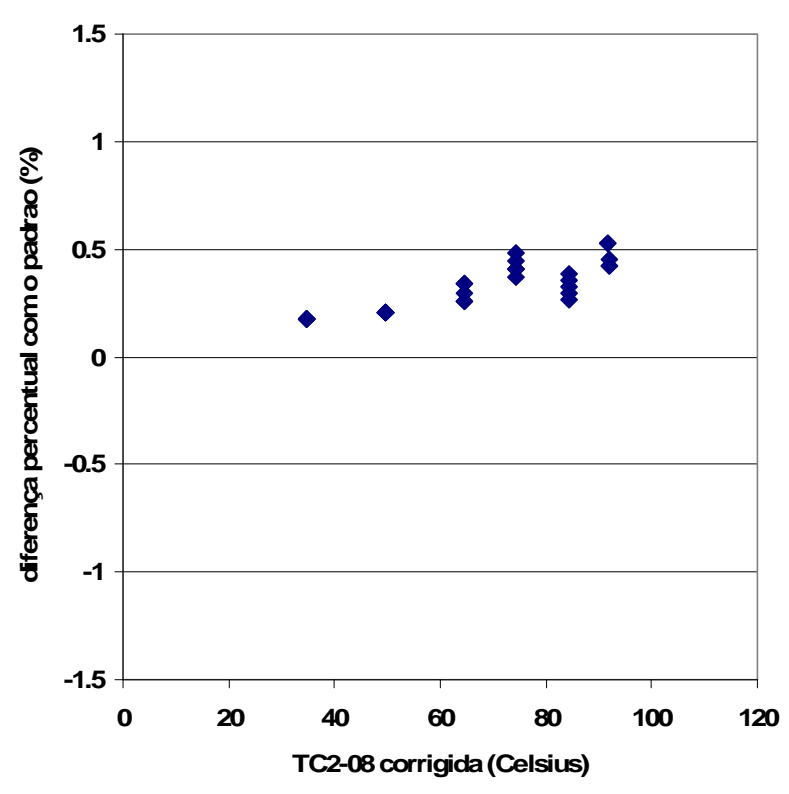

A29b

FIGURA A29. Curva de calibração TC2-08 (A29a) e diferença percentual com o padrão (A29b). 
TABELA A29. Dados de calibração do termopar TC2-11.

\begin{tabular}{cccc|cccc}
\hline $\begin{array}{c}\text { PT-001 } \\
\left({ }^{\circ} \mathrm{C}\right)\end{array}$ & $\begin{array}{c}\text { TC2-11 } \\
\left({ }^{\circ} \mathrm{C}\right)\end{array}$ & $\begin{array}{c}\text { TC2-11 } \\
\text { corrigida } \\
\left({ }^{\circ} \mathrm{C}\right)\end{array}$ & $\begin{array}{c}\text { diferença } \\
\text { percentual } \\
(\%)\end{array}$ & $\begin{array}{c}\text { PT-001 } \\
\left({ }^{\circ} \mathrm{C}\right)\end{array}$ & $\begin{array}{c}\text { TC2-11 } \\
\left({ }^{\circ} \mathrm{C}\right)\end{array}$ & $\begin{array}{c}\text { TC2-11 } \\
\text { corrigida } \\
\left({ }^{\circ} \mathrm{C}\right)\end{array}$ & $\begin{array}{c}\text { diferença } \\
\text { percentual } \\
(\%)\end{array}$ \\
\hline & & & & & & & \\
36,54 & 35,80 & 36,59 & $-0,14$ & 102,44 & 100,50 & 102,26 & 0,18 \\
36,54 & 35,70 & 36,48 & 0,15 & 102,42 & 100,40 & 102,16 & 0,25 \\
36,51 & 35,70 & 36,48 & 0,08 & 102,42 & 100,30 & 102,06 & 0,35 \\
36,51 & 35,70 & 36,48 & 0,08 & 102,42 & 100,40 & 102,16 & 0,25 \\
36,49 & 35,60 & 36,38 & 0,29 & 102,42 & 100,50 & 102,26 & 0,16 \\
51,42 & 50,10 & 51,47 & $-0,11$ & 127,52 & 125,90 & 127,04 & 0,38 \\
51,60 & 50,30 & 51,68 & $-0,15$ & 127,52 & 125,90 & 127,04 & 0,38 \\
51,63 & 50,20 & 51,58 & 0,11 & 127,52 & 125,90 & 127,04 & 0,38 \\
51,63 & 50,20 & 51,58 & 0,11 & 127,52 & 125,80 & 126,94 & 0,45 \\
51,60 & 50,30 & 51,68 & $-0,15$ & 127,52 & 125,80 & 126,94 & 0,45 \\
77,00 & 75,00 & 76,86 & 0,17 & 152,41 & 151,40 & 151,49 & 0,60 \\
77,02 & 75,00 & 76,86 & 0,21 & 152,41 & 151,40 & 151,49 & 0,60 \\
77,02 & 75,00 & 76,86 & 0,21 & 152,41 & 151,40 & 151,49 & 0,60 \\
77,02 & 75,00 & 76,86 & 0,21 & 152,43 & 151,40 & 151,49 & 0,62 \\
77,02 & 75,00 & 76,86 & 0,21 & 152,43 & 151,40 & 151,49 & 0,62 \\
\hline
\end{tabular}

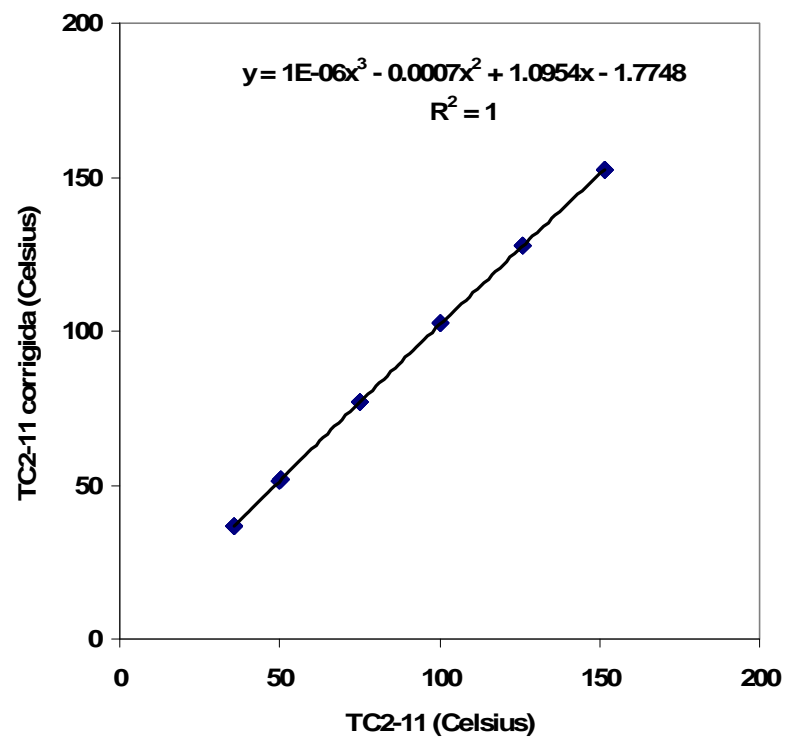

A30a

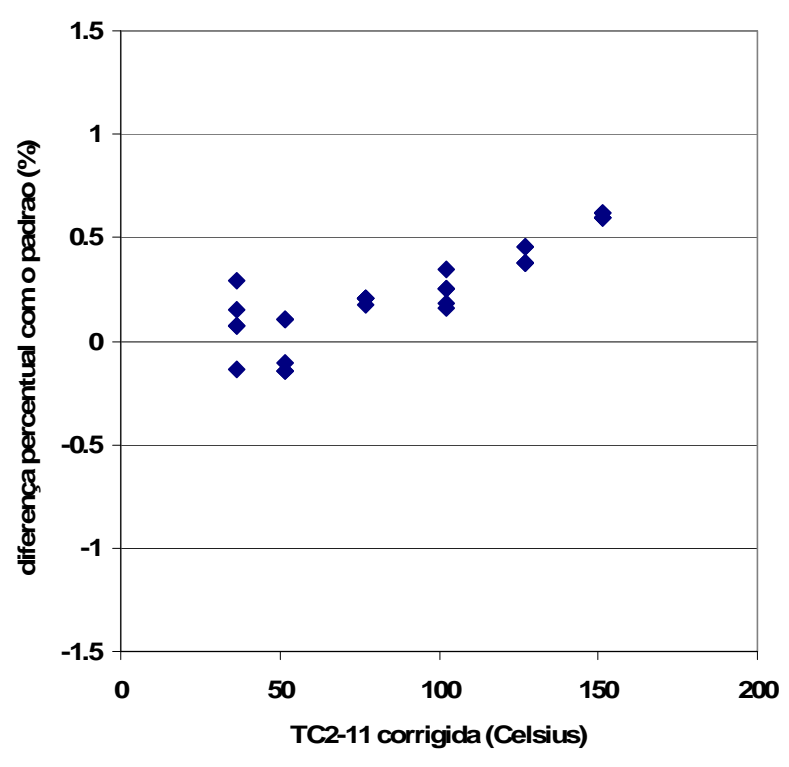

A30b

FIGURA A30. Curva de calibração TC2-11 (A30a) e diferença percentual com o padrão (A30b). 
TABELA A30. Dados de calibração do termopar TC2-12.

\begin{tabular}{cccc|cccc}
\hline $\begin{array}{c}\text { PT-001 } \\
\left({ }^{\circ} \mathrm{C}\right)\end{array}$ & $\begin{array}{c}\text { TC2-12 } \\
\left({ }^{\circ} \mathrm{C}\right)\end{array}$ & $\begin{array}{c}\text { TC2-12 } \\
\text { corrigida } \\
\left({ }^{\circ} \mathrm{C}\right)\end{array}$ & $\begin{array}{c}\text { diferença } \\
\text { percentual } \\
(\%)\end{array}$ & $\begin{array}{c}\text { PT-001 } \\
\left({ }^{\circ} \mathrm{C}\right)\end{array}$ & $\begin{array}{c}\text { TC2-12 } \\
\left({ }^{\circ} \mathrm{C}\right)\end{array}$ & $\begin{array}{c}\text { TC2-12 } \\
\text { corrigida } \\
\left({ }^{\circ} \mathrm{C}\right)\end{array}$ & $\begin{array}{c}\text { diferença } \\
\text { percentual } \\
(\%)\end{array}$ \\
\hline & & & & & & & \\
36,49 & 35,70 & 36,49 & $-0,01$ & 102,42 & 100,70 & 102,63 & $-0,20$ \\
36,46 & 35,60 & 36,38 & 0,20 & 102,39 & 100,70 & 102,63 & $-0,23$ \\
36,46 & 35,70 & 36,49 & $-0,08$ & 102,39 & 100,60 & 102,53 & $-0,13$ \\
36,46 & 35,70 & 36,49 & $-0,08$ & 102,39 & 100,60 & 102,53 & $-0,13$ \\
36,46 & 35,80 & 36,59 & $-0,37$ & 102,39 & 100,80 & 102,73 & $-0,33$ \\
51,47 & 50,30 & 51,62 & $-0,28$ & 127,52 & 126,20 & 127,84 & $-0,25$ \\
51,63 & 50,40 & 51,72 & $-0,17$ & 127,52 & 126,20 & 127,84 & $-0,25$ \\
51,63 & 50,30 & 51,62 & 0,03 & 127,52 & 126,30 & 127,94 & $-0,33$ \\
51,63 & 50,30 & 51,62 & 0,03 & 127,52 & 126,30 & 127,94 & $-0,33$ \\
51,63 & 50,40 & 51,72 & $-0,17$ & 127,52 & 126,30 & 127,94 & $-0,33$ \\
77,02 & 75,20 & 77,04 & $-0,01$ & 152,41 & 151,90 & 152,95 & $-0,36$ \\
77,02 & 75,30 & 77,14 & $-0,14$ & 152,41 & 151,90 & 152,95 & $-0,36$ \\
77,05 & 75,40 & 77,24 & $-0,24$ & 152,43 & 151,90 & 152,95 & $-0,34$ \\
77,05 & 75,40 & 77,24 & $-0,24$ & 152,41 & 151,90 & 152,95 & $-0,36$ \\
77,05 & 75,40 & 77,24 & $-0,24$ & 152,41 & 151,90 & 152,95 & $-0,36$ \\
\hline
\end{tabular}

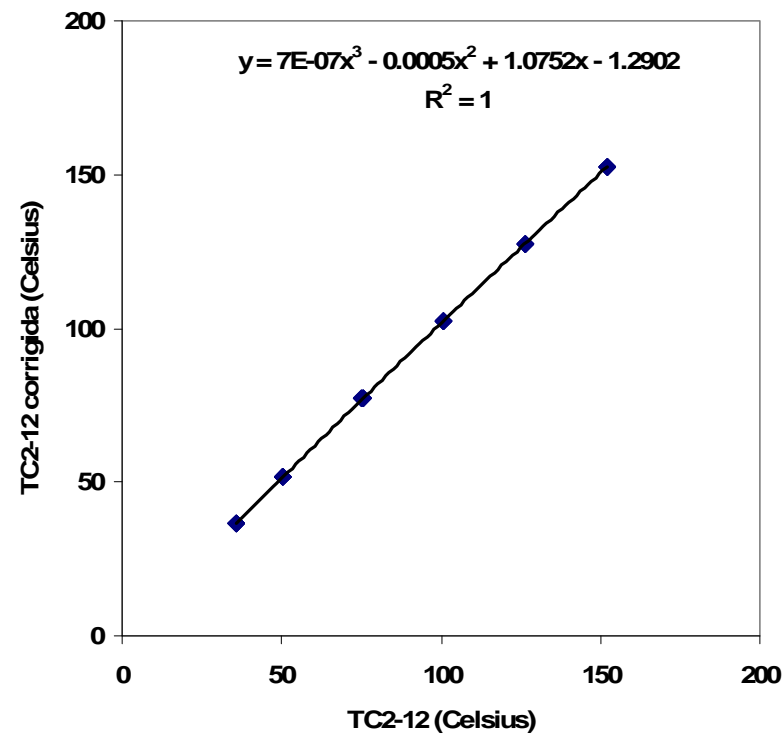

A31a

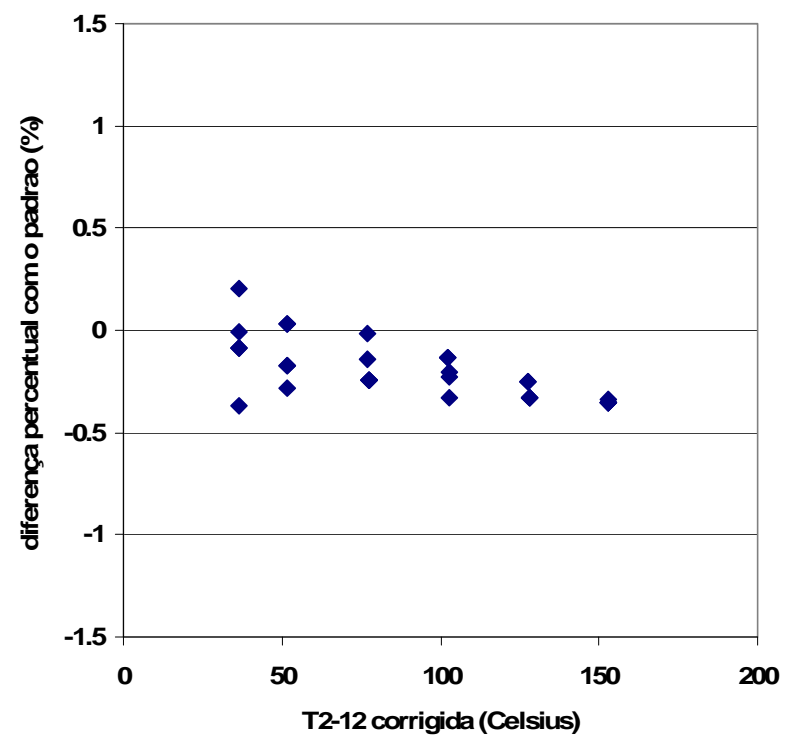

A31b

FIGURA A31. Curva de calibração TC2-12(A31a) e diferença percentual com o padrão (A31b). 
TABELA A31. Dados de calibração do termopar TC2-13.

\begin{tabular}{cccc|cccc}
\hline $\begin{array}{c}\text { PT-001 } \\
\left({ }^{\circ} \mathrm{C}\right)\end{array}$ & $\begin{array}{c}\text { TC2-13 } \\
\left({ }^{\circ} \mathrm{C}\right)\end{array}$ & $\begin{array}{c}\text { TC2-13 } \\
\text { corrigida } \\
\left({ }^{\circ} \mathrm{C}\right)\end{array}$ & $\begin{array}{c}\text { diferença } \\
\text { percentual } \\
(\%)\end{array}$ & $\begin{array}{c}\text { PT-001 } \\
\left({ }^{\circ} \mathrm{C}\right)\end{array}$ & $\begin{array}{c}\text { TC2-13 } \\
\left({ }^{\circ} \mathrm{C}\right)\end{array}$ & $\begin{array}{c}\text { TC2-13 } \\
\text { corrigida } \\
\left({ }^{\circ} \mathrm{C}\right)\end{array}$ & $\begin{array}{c}\text { diferença } \\
\text { percentual } \\
(\%)\end{array}$ \\
\hline & & & & & & & \\
36,46 & 35,80 & 36,54 & $-0,22$ & 102,39 & 100,90 & 102,61 & $-0,22$ \\
36,46 & 35,80 & 36,54 & $-0,22$ & 102,39 & 100,90 & 102,61 & $-0,22$ \\
36,46 & 35,80 & 36,54 & $-0,22$ & 102,39 & 100,80 & 102,51 & $-0,12$ \\
36,46 & 35,70 & 36,43 & 0,07 & 102,39 & 100,80 & 102,51 & $-0,12$ \\
36,46 & 35,70 & 36,43 & 0,07 & 102,39 & 101,00 & 102,71 & $-0,31$ \\
51,52 & 50,40 & 51,66 & $-0,27$ & 127,52 & 126,50 & 127,81 & $-0,23$ \\
51,63 & 50,40 & 51,66 & $-0,06$ & 127,52 & 126,50 & 127,81 & $-0,23$ \\
51,63 & 50,40 & 51,66 & $-0,06$ & 127,52 & 126,50 & 127,81 & $-0,23$ \\
51,63 & 50,40 & 51,66 & $-0,06$ & 127,52 & 126,50 & 127,81 & $-0,23$ \\
51,63 & 50,50 & 51,76 & $-0,26$ & 127,52 & 126,50 & 127,81 & $-0,23$ \\
77,05 & 75,50 & 77,22 & $-0,22$ & 152,43 & 152,10 & 152,72 & $-0,19$ \\
77,08 & 75,50 & 77,22 & $-0,19$ & 152,43 & 152,20 & 152,82 & $-0,25$ \\
77,08 & 75,50 & 77,22 & $-0,19$ & 152,43 & 152,10 & 152,72 & $-0,19$ \\
77,08 & 75,50 & 77,22 & $-0,19$ & 152,41 & 152,10 & 152,72 & $-0,21$ \\
77,08 & 75,50 & 77,22 & $-0,19$ & 152,41 & 152,10 & 152,72 & $-0,21$ \\
\hline
\end{tabular}

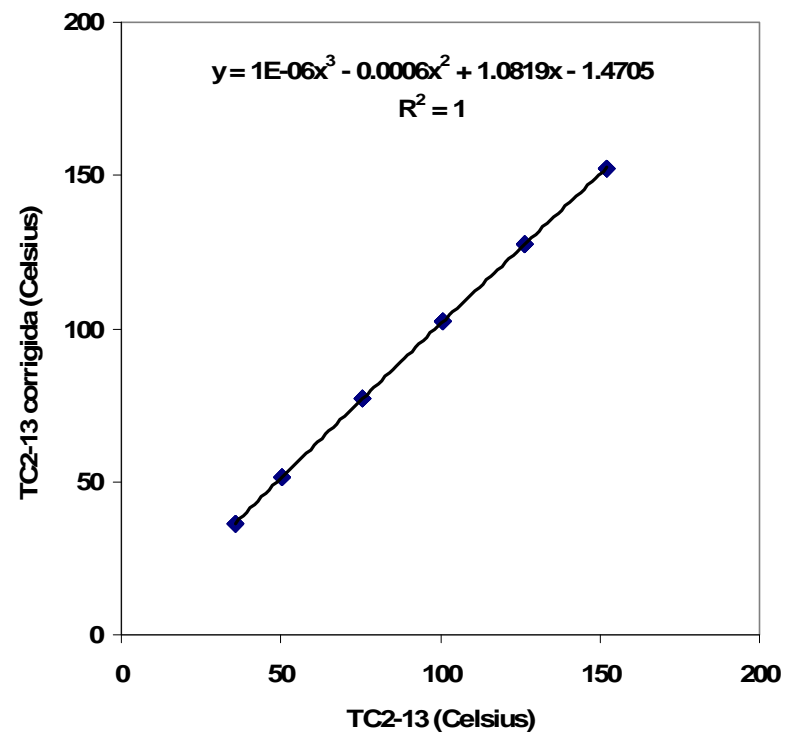

A32a

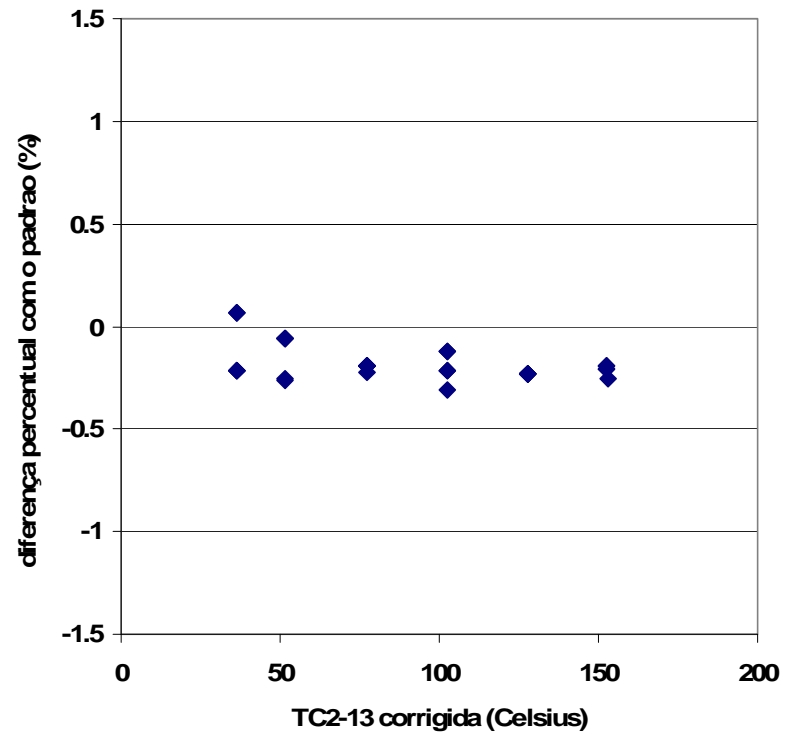

A32b

FIGURA A32. Curva de calibração TC2-13 (A32a) e diferença percentual com o padrão (A32b). 
TABELA A32. Dados de calibração do termopar TC2-14.

\begin{tabular}{cccc|cccc}
\hline $\begin{array}{c}\text { PT-001 } \\
\left({ }^{\circ} \mathrm{C}\right)\end{array}$ & $\begin{array}{c}\text { TC2-14 } \\
\left({ }^{\circ} \mathrm{C}\right)\end{array}$ & $\begin{array}{c}\text { TC2-14 } \\
\text { corrigida } \\
\left({ }^{\circ} \mathrm{C}\right)\end{array}$ & $\begin{array}{c}\text { diferença } \\
\text { percentual } \\
(\%)\end{array}$ & $\begin{array}{c}\text { PT-001 } \\
\left({ }^{\circ} \mathrm{C}\right)\end{array}$ & $\begin{array}{c}\text { TC2-14 } \\
\left({ }^{\circ} \mathrm{C}\right)\end{array}$ & $\begin{array}{c}\text { TC2-14 } \\
\text { corrigida } \\
\left({ }^{\circ} \mathrm{C}\right)\end{array}$ & $\begin{array}{c}\text { diferença } \\
\text { percentual } \\
(\%)\end{array}$ \\
\hline & & & & & & & \\
36,35 & 35,60 & 36,40 & $-0,14$ & 102,26 & 100,40 & 102,59 & $-0,33$ \\
36,38 & 35,60 & 36,40 & $-0,07$ & 102,31 & 100,50 & 102,69 & $-0,37$ \\
36,35 & 35,60 & 36,40 & $-0,14$ & 102,34 & 100,50 & 102,69 & $-0,35$ \\
36,38 & 35,60 & 36,40 & $-0,07$ & 102,36 & 100,60 & 102,79 & $-0,42$ \\
36,35 & 35,60 & 36,40 & $-0,14$ & 102,36 & 100,60 & 102,79 & $-0,42$ \\
51,58 & 50,30 & 51,63 & $-0,11$ & 127,44 & 126,00 & 127,98 & $-0,42$ \\
51,60 & 50,30 & 51,63 & $-0,06$ & 127,44 & 126,00 & 127,98 & $-0,42$ \\
51,60 & 50,30 & 51,63 & $-0,06$ & 127,44 & 126,00 & 127,98 & $-0,42$ \\
51,63 & 50,30 & 51,63 & $-0,01$ & 127,44 & 126,00 & 127,98 & $-0,42$ \\
51,63 & 50,70 & 52,05 & $-0,81$ & 127,44 & 126,00 & 127,98 & $-0,42$ \\
77,29 & 75,50 & 77,46 & $-0,22$ & 152,43 & 152,00 & 153,23 & $-0,52$ \\
77,29 & 75,50 & 77,46 & $-0,22$ & 152,43 & 152,00 & 153,23 & $-0,52$ \\
77,29 & 75,50 & 77,46 & $-0,22$ & 152,43 & 152,00 & 153,23 & $-0,52$ \\
77,29 & 75,50 & 77,46 & $-0,22$ & 152,43 & 152,00 & 153,23 & $-0,52$ \\
77,29 & 75,50 & 77,46 & $-0,22$ & 152,43 & 152,00 & 153,23 & $-0,52$ \\
\hline
\end{tabular}

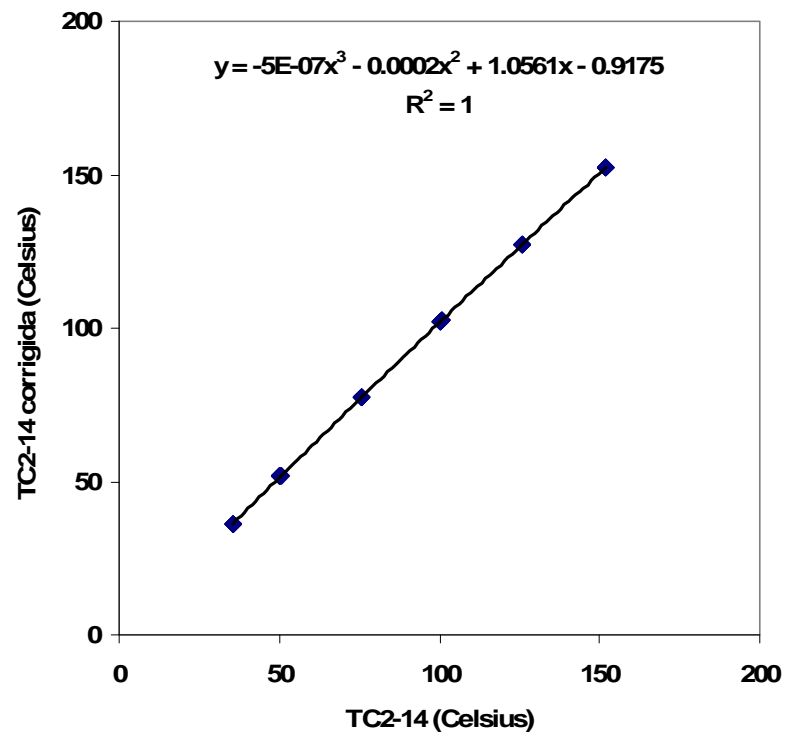

A33a

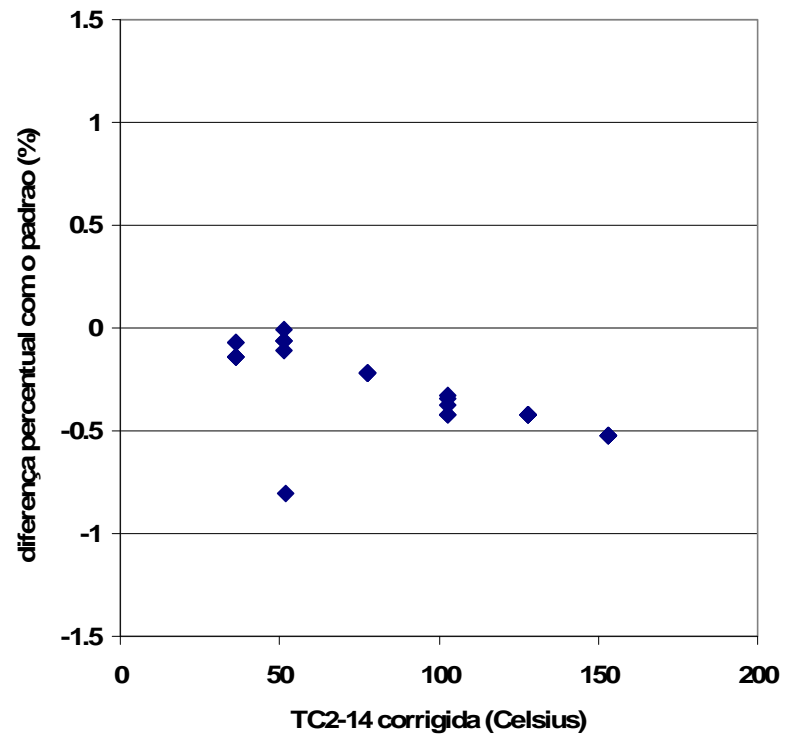

A33b

FIGURA A33. Curva de calibração TC2-14 (A33a) e diferença percentual com o padrão (A33b). 
TABELA A33. Dados de calibração do termopar TC2-15.

\begin{tabular}{cccc|cccc}
\hline $\begin{array}{c}\text { PT-001 } \\
\left({ }^{\circ} \mathrm{C}\right)\end{array}$ & $\begin{array}{c}\text { TC2-15 } \\
\left({ }^{\circ} \mathrm{C}\right)\end{array}$ & $\begin{array}{c}\text { TC2-15 } \\
\text { corrigida } \\
\left({ }^{\circ} \mathrm{C}\right)\end{array}$ & $\begin{array}{c}\text { diferença } \\
\text { percentual } \\
(\%)\end{array}$ & $\begin{array}{c}\text { PT-001 } \\
\left({ }^{\circ} \mathrm{C}\right)\end{array}$ & $\begin{array}{c}\text { TC2-15 } \\
\left({ }^{\circ} \mathrm{C}\right)\end{array}$ & $\begin{array}{c}\text { TC2-15 } \\
\text { corrigida } \\
\left({ }^{\circ} \mathrm{C}\right)\end{array}$ & $\begin{array}{c}\text { diferença } \\
\text { percentual } \\
(\%)\end{array}$ \\
\hline & & & & & & & \\
36,35 & 35,50 & 36,45 & $-0,27$ & 102,36 & 100,70 & 102,97 & $-0,59$ \\
36,38 & 35,50 & 36,45 & $-0,19$ & 102,36 & 100,60 & 102,87 & $-0,49$ \\
36,38 & 35,50 & 36,45 & $-0,19$ & 102,36 & 100,60 & 102,87 & $-0,49$ \\
36,35 & 35,40 & 36,34 & 0,02 & 102,39 & 100,60 & 102,87 & $-0,47$ \\
36,35 & 35,50 & 36,45 & $-0,27$ & 102,36 & 100,60 & 102,87 & $-0,49$ \\
51,63 & 50,30 & 51,75 & $-0,24$ & 127,44 & 126,10 & 128,18 & $-0,58$ \\
51,63 & 50,30 & 51,75 & $-0,24$ & 127,44 & 126,10 & 128,18 & $-0,58$ \\
51,63 & 50,30 & 51,75 & $-0,24$ & 127,47 & 126,10 & 128,18 & $-0,56$ \\
51,63 & 50,30 & 51,75 & $-0,24$ & 127,47 & 126,10 & 128,18 & $-0,56$ \\
51,63 & 50,30 & 51,75 & $-0,24$ & 127,47 & 126,10 & 128,18 & $-0,56$ \\
77,29 & 75,50 & 77,55 & $-0,33$ & 152,43 & 152,10 & 153,52 & $-0,71$ \\
77,29 & 75,50 & 77,55 & $-0,33$ & 152,43 & 152,10 & 153,52 & $-0,71$ \\
77,29 & 75,50 & 77,55 & $-0,33$ & 152,43 & 152,10 & 153,52 & $-0,71$ \\
77,29 & 75,50 & 77,55 & $-0,33$ & 152,43 & 152,10 & 153,52 & $-0,71$ \\
77,29 & 75,50 & 77,55 & $-0,33$ & 152,41 & 152,10 & 153,52 & $-0,73$ \\
\hline
\end{tabular}

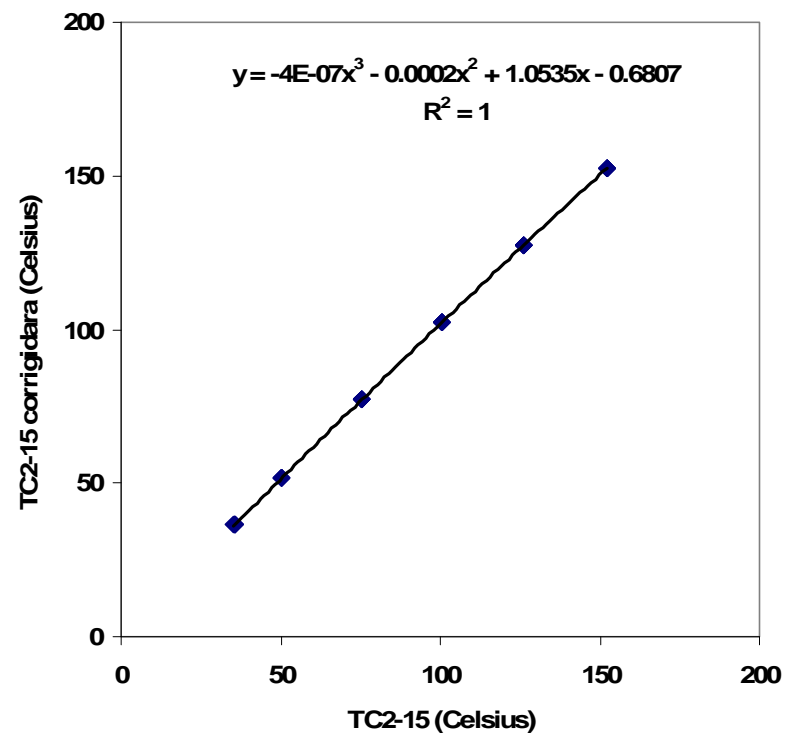

A34a

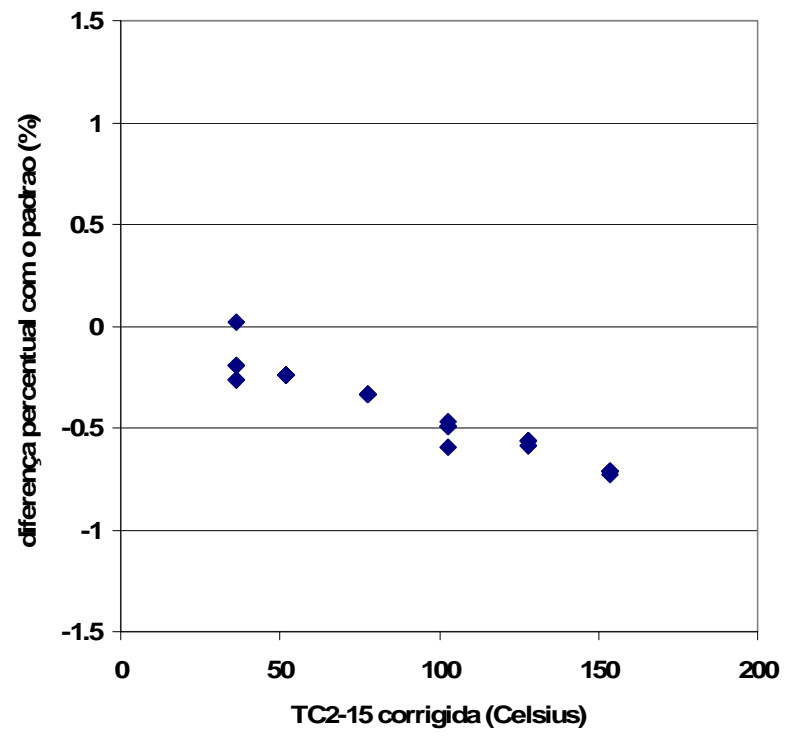

A34b

FIGURA A34. Curva de calibração TC2-15 (A34a) e diferença percentual com o padrão (A34b). 
TABELA A34. Dados de calibração do termopar TC2-16.

\begin{tabular}{cccc|cccc}
\hline $\begin{array}{c}\text { PT-001 } \\
\left({ }^{\circ} \mathrm{C}\right)\end{array}$ & $\begin{array}{c}\text { TC2-16 } \\
\left({ }^{\circ} \mathrm{C}\right)\end{array}$ & $\begin{array}{c}\text { TC2-16 } \\
\text { corrigida } \\
\left({ }^{\circ} \mathrm{C}\right)\end{array}$ & $\begin{array}{c}\text { diferença } \\
\text { percentual } \\
(\%)\end{array}$ & $\begin{array}{c}\text { PT-001 } \\
\left({ }^{\circ} \mathrm{C}\right)\end{array}$ & $\begin{array}{c}\text { TC2-16 } \\
\left({ }^{\circ} \mathrm{C}\right)\end{array}$ & $\begin{array}{c}\text { TC2-16 } \\
\text { corrigida } \\
\left({ }^{\circ} \mathrm{C}\right)\end{array}$ & $\begin{array}{c}\text { diferença } \\
\text { percentual } \\
(\%)\end{array}$ \\
\hline & & & & & & & \\
36,35 & 35,60 & 36,29 & 0,16 & 102,36 & 100,70 & 102,58 & $-0,21$ \\
36,35 & 35,60 & 36,29 & 0,16 & 102,39 & 100,70 & 102,58 & $-0,19$ \\
36,33 & 35,50 & 36,19 & 0,38 & 102,36 & 100,60 & 102,48 & $-0,11$ \\
36,33 & 35,60 & 36,29 & 0,09 & 102,36 & 100,60 & 102,48 & $-0,11$ \\
36,33 & 35,70 & 36,40 & $-0,20$ & 102,36 & 100,60 & 102,48 & $-0,11$ \\
51,63 & 50,40 & 51,68 & $-0,10$ & 127,47 & 126,40 & 128,11 & $-0,50$ \\
51,63 & 50,40 & 51,68 & $-0,10$ & 127,47 & 126,40 & 128,11 & $-0,50$ \\
51,63 & 50,40 & 51,68 & $-0,10$ & 127,47 & 126,40 & 128,11 & $-0,50$ \\
51,63 & 50,40 & 51,68 & $-0,10$ & 127,44 & 126,30 & 128,01 & $-0,45$ \\
51,63 & 50,40 & 51,68 & $-0,10$ & 127,44 & 126,30 & 128,01 & $-0,45$ \\
77,24 & 75,50 & 77,30 & $-0,08$ & 152,41 & 152,00 & 153,48 & $-0,71$ \\
77,24 & 75,50 & 77,30 & $-0,08$ & 152,41 & 152,00 & 153,48 & $-0,71$ \\
77,24 & 75,50 & 77,30 & $-0,08$ & 152,41 & 152,00 & 153,48 & $-0,71$ \\
77,21 & 75,40 & 77,20 & 0,02 & 152,41 & 152,00 & 153,48 & $-0,71$ \\
77,21 & 75,50 & 77,30 & $-0,12$ & 152,41 & 151,90 & 153,38 & $-0,64$ \\
\hline
\end{tabular}

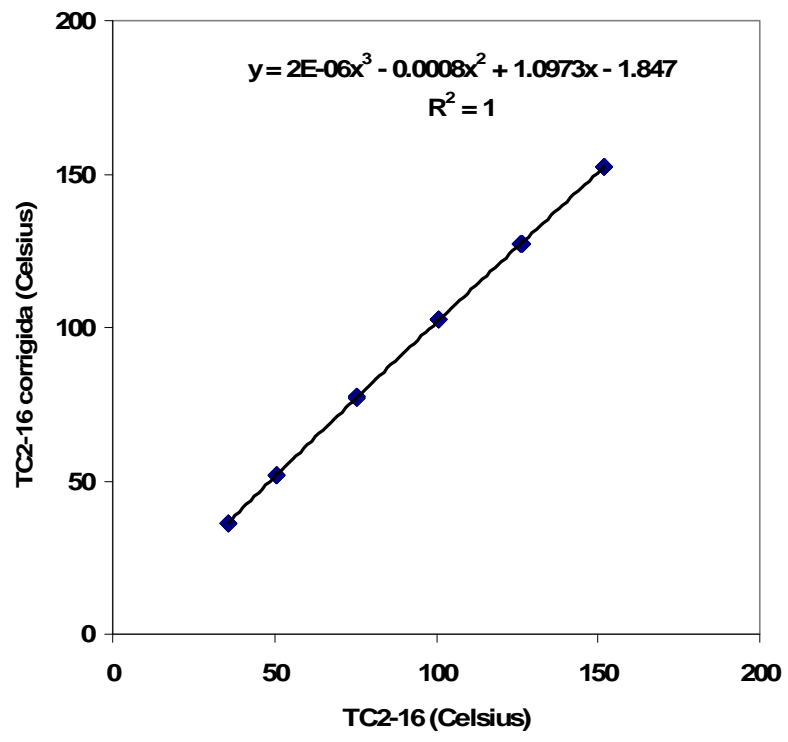

A34a

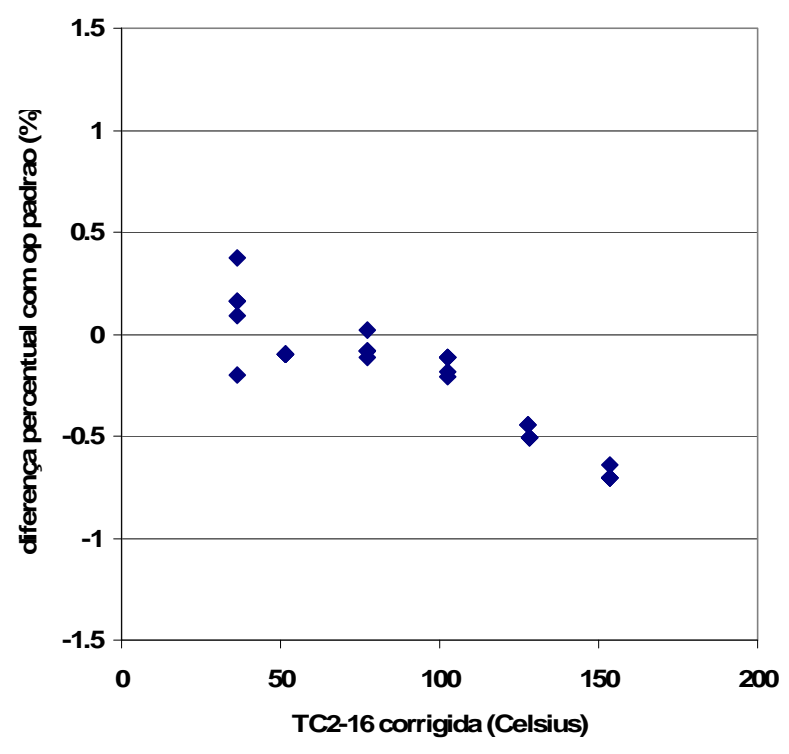

A34b

FIGURA A35. Curva de calibração TC2-16 (A34a) e diferença percentual com o padrão (A34b). 
TABELA A35. Dados de calibração do termopar TC2-17.

\begin{tabular}{cccc|cccc}
\hline $\begin{array}{c}\text { PT-001 } \\
\left({ }^{\circ} \mathrm{C}\right)\end{array}$ & $\begin{array}{c}\text { TC2-17 } \\
\left({ }^{\circ} \mathrm{C}\right)\end{array}$ & $\begin{array}{c}\text { TC2-17 } \\
\text { corrigida } \\
\left({ }^{\circ} \mathrm{C}\right)\end{array}$ & $\begin{array}{c}\text { diferença } \\
\text { percentual } \\
(\%)\end{array}$ & $\begin{array}{c}\text { PT-001 } \\
\left({ }^{\circ} \mathrm{C}\right)\end{array}$ & $\begin{array}{c}\text { TC2-17 } \\
\left({ }^{\circ} \mathrm{C}\right)\end{array}$ & $\begin{array}{c}\text { TC2-17 } \\
\text { corrigida } \\
\left({ }^{\circ} \mathrm{C}\right)\end{array}$ & $\begin{array}{c}\text { diferença } \\
\text { percentual } \\
(\%)\end{array}$ \\
\hline & & & & & & & \\
36,30 & 35,60 & 36,37 & $-0,19$ & 102,36 & 100,70 & 102,65 & $-0,28$ \\
36,30 & 35,60 & 36,37 & $-0,19$ & 102,36 & 100,70 & 102,65 & $-0,28$ \\
36,30 & 35,60 & 36,37 & $-0,19$ & 102,36 & 100,70 & 102,65 & $-0,28$ \\
36,30 & 35,60 & 36,37 & $-0,19$ & 102,36 & 100,80 & 102,75 & $-0,38$ \\
36,30 & 35,60 & 36,37 & $-0,19$ & 102,36 & 100,80 & 102,75 & $-0,38$ \\
51,63 & 50,40 & 51,71 & $-0,16$ & 127,44 & 126,40 & 128,08 & $-0,50$ \\
51,63 & 50,30 & 51,61 & 0,04 & 127,44 & 126,30 & 127,98 & $-0,43$ \\
51,63 & 50,30 & 51,61 & 0,04 & 127,44 & 126,30 & 127,98 & $-0,43$ \\
51,63 & 50,40 & 51,71 & $-0,16$ & 127,44 & 126,30 & 127,98 & $-0,43$ \\
51,63 & 50,40 & 51,71 & $-0,16$ & 127,44 & 126,20 & 127,88 & $-0,35$ \\
77,18 & 75,70 & 77,55 & $-0,47$ & 152,41 & 151,80 & 152,91 & $-0,33$ \\
77,18 & 75,60 & 77,45 & $-0,34$ & 152,38 & 152,10 & 153,20 & $-0,54$ \\
77,16 & 75,60 & 77,45 & $-0,38$ & 152,38 & 152,10 & 153,20 & $-0,54$ \\
77,16 & 75,50 & 77,35 & $-0,25$ & 152,38 & 152,10 & 153,20 & $-0,54$ \\
77,16 & 75,50 & 77,35 & $-0,25$ & 152,38 & 152,10 & 153,20 & $-0,54$ \\
\hline
\end{tabular}

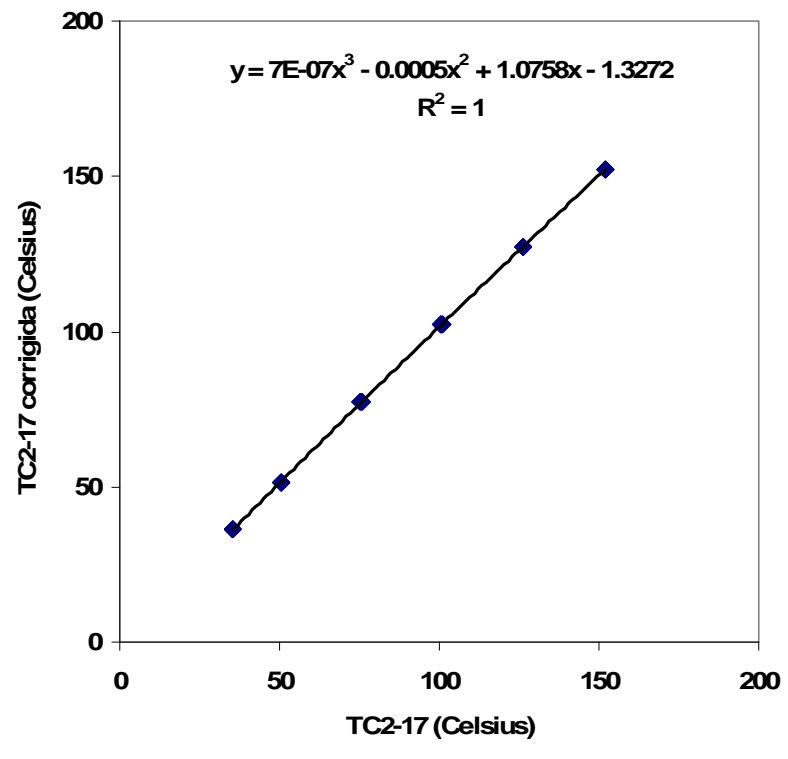

A36a

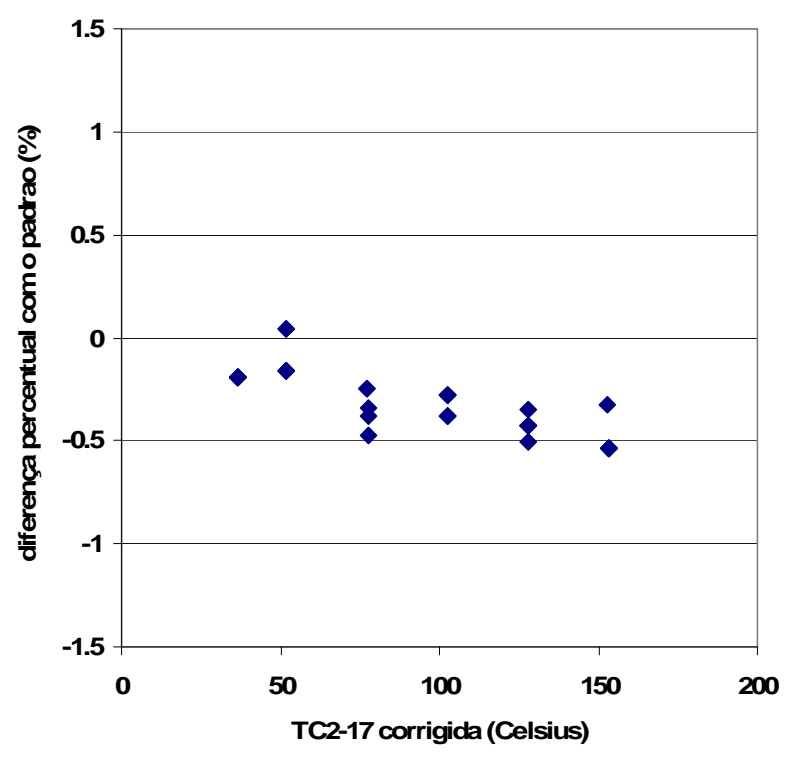

A36b

FIGURA A36.Curva de calibração TC2-17 (A36a) e diferença percentual com o padrão (A36b). 
TABELA A36. Dados de calibração do termopar TC2-18.

\begin{tabular}{cccc|cccc}
\hline $\begin{array}{c}\text { PT-001 } \\
\left({ }^{\circ} \mathrm{C}\right)\end{array}$ & $\begin{array}{c}\text { TC2-18 } \\
\left({ }^{\circ} \mathrm{C}\right)\end{array}$ & $\begin{array}{c}\text { TC2-18 } \\
\text { corrigida } \\
\left({ }^{\circ} \mathrm{C}\right)\end{array}$ & $\begin{array}{c}\text { diferença } \\
\text { percentual } \\
(\%)\end{array}$ & $\begin{array}{c}\text { PT-001 } \\
\left({ }^{\circ} \mathrm{C}\right)\end{array}$ & $\begin{array}{c}\text { TC2-18 } \\
\left({ }^{\circ} \mathrm{C}\right)\end{array}$ & $\begin{array}{c}\text { TC2-18 } \\
\text { corrigida } \\
\left({ }^{\circ} \mathrm{C}\right)\end{array}$ & $\begin{array}{c}\text { diferença } \\
\text { percentual } \\
(\%)\end{array}$ \\
\hline & & & & & & & \\
36,30 & 35,60 & 36,32 & $-0,06$ & 102,36 & 100,70 & 102,46 & $-0,10$ \\
36,30 & 35,60 & 36,32 & $-0,06$ & 102,36 & 100,70 & 102,46 & $-0,10$ \\
36,30 & 35,60 & 36,32 & $-0,06$ & 102,36 & 100,70 & 102,46 & $-0,10$ \\
36,30 & 35,60 & 36,32 & $-0,06$ & 102,36 & 100,60 & 102,36 & 0,00 \\
36,30 & 35,60 & 36,32 & $-0,06$ & 102,36 & 100,60 & 102,36 & 0,00 \\
51,63 & 50,40 & 51,68 & $-0,09$ & 127,44 & 126,20 & 127,53 & $-0,07$ \\
51,63 & 50,40 & 51,68 & $-0,09$ & 127,44 & 126,10 & 127,43 & 0,00 \\
51,63 & 50,30 & 51,58 & 0,11 & 127,44 & 126,10 & 127,43 & 0,00 \\
51,63 & 50,30 & 51,58 & 0,11 & 127,44 & 126,10 & 127,43 & 0,00 \\
51,63 & 50,30 & 51,58 & 0,11 & 127,44 & 126,10 & 127,43 & 0,00 \\
77,16 & 75,50 & 77,27 & $-0,15$ & 152,38 & 151,90 & 152,46 & $-0,05$ \\
77,13 & 75,40 & 77,17 & $-0,05$ & 152,38 & 151,90 & 152,46 & $-0,05$ \\
77,13 & 75,40 & 77,17 & $-0,05$ & 152,38 & 151,90 & 152,46 & $-0,05$ \\
77,13 & 75,40 & 77,17 & $-0,05$ & 152,38 & 151,80 & 152,36 & 0,01 \\
77,13 & 75,30 & 77,07 & 0,08 & 152,38 & 151,80 & 152,36 & 0,01 \\
\hline
\end{tabular}

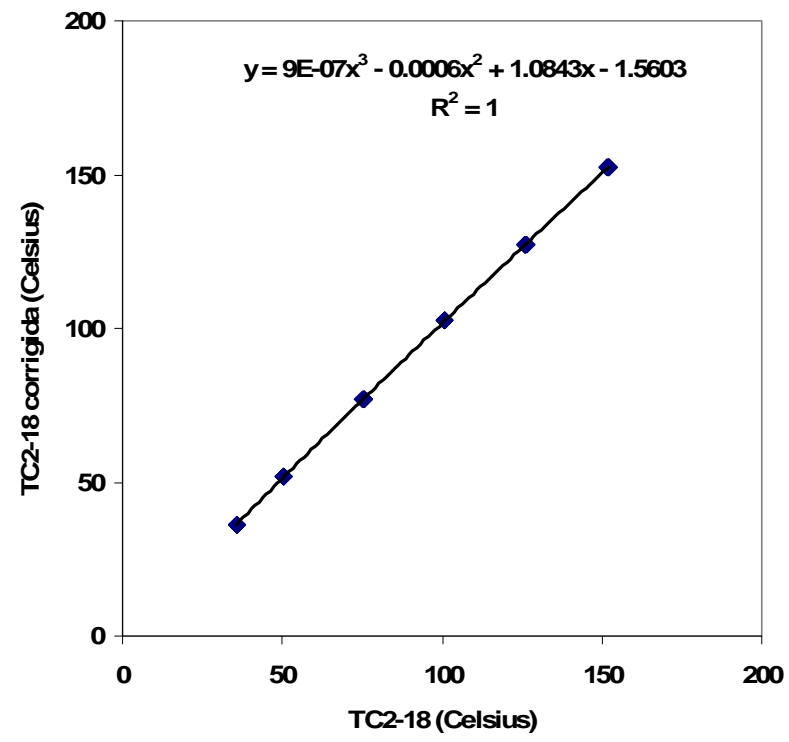

A37a

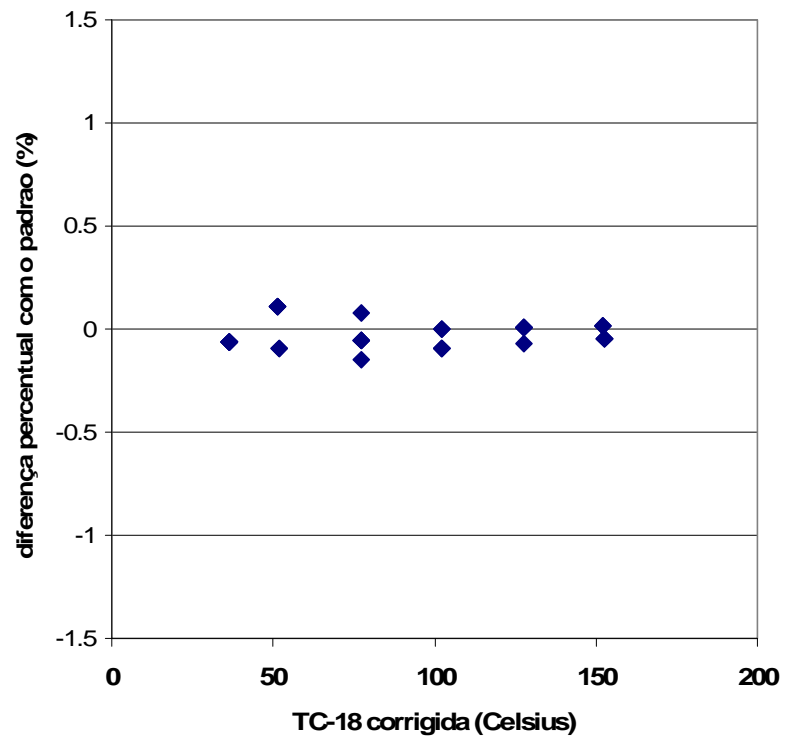

A37b

FIGURA A37. Curva de calibração TC2-18 (A37a) e diferença percentual com o padrão (A37b). 
TABELA A37. Dados de calibração do termopar TC2-19.

\begin{tabular}{cccc|cccc}
\hline $\begin{array}{c}\text { PT-001 } \\
\left({ }^{\circ} \mathrm{C}\right)\end{array}$ & $\begin{array}{c}\text { TC2-19 } \\
\left({ }^{\circ} \mathrm{C}\right)\end{array}$ & $\begin{array}{c}\text { TC2-19 } \\
\text { corrigida } \\
\left({ }^{\circ} \mathrm{C}\right)\end{array}$ & $\begin{array}{c}\text { diferença } \\
\text { percentual } \\
(\%)\end{array}$ & $\begin{array}{c}\text { PT-001 } \\
\left({ }^{\circ} \mathrm{C}\right)\end{array}$ & $\begin{array}{c}\text { TC2-19 } \\
\left({ }^{\circ} \mathrm{C}\right)\end{array}$ & $\begin{array}{c}\text { TC2-19 } \\
\text { corrigida } \\
\left({ }^{\circ} \mathrm{C}\right)\end{array}$ & $\begin{array}{c}\text { diferença } \\
\text { percentual } \\
(\%)\end{array}$ \\
\hline & & & & & & & \\
36,43 & 35,40 & 36,44 & $-0,01$ & 102,29 & 100,20 & 102,81 & $-0,51$ \\
36,43 & 35,40 & 36,44 & $-0,01$ & 102,29 & 100,20 & 102,81 & $-0,51$ \\
36,43 & 35,50 & 36,54 & $-0,30$ & 102,31 & 100,20 & 102,81 & $-0,49$ \\
36,43 & 35,50 & 36,54 & $-0,30$ & 102,31 & 100,20 & 102,81 & $-0,49$ \\
36,41 & 35,50 & 36,54 & $-0,37$ & 102,31 & 100,20 & 102,81 & $-0,49$ \\
51,79 & 50,20 & 51,86 & $-0,13$ & 127,44 & 125,50 & 128,06 & $-0,49$ \\
51,79 & 50,20 & 51,86 & $-0,13$ & 127,44 & 125,50 & 128,06 & $-0,49$ \\
51,79 & 50,20 & 51,86 & $-0,13$ & 127,44 & 125,50 & 128,06 & $-0,49$ \\
51,76 & 50,20 & 51,86 & $-0,18$ & 127,41 & 125,50 & 128,06 & $-0,51$ \\
51,76 & 50,20 & 51,86 & $-0,18$ & 127,41 & 125,50 & 128,06 & $-0,51$ \\
77,10 & 75,00 & 77,33 & $-0,29$ & 152,22 & 151,00 & 153,25 & $-0,68$ \\
77,10 & 75,00 & 77,33 & $-0,29$ & 152,22 & 151,00 & 153,25 & $-0,68$ \\
77,10 & 75,00 & 77,33 & $-0,29$ & 152,22 & 151,00 & 153,25 & $-0,68$ \\
77,10 & 75,00 & 77,33 & $-0,29$ & 152,22 & 151,00 & 153,25 & $-0,68$ \\
77,10 & 75,00 & 77,33 & $-0,29$ & 152,22 & 151,00 & 153,25 & $-0,68$ \\
\hline
\end{tabular}

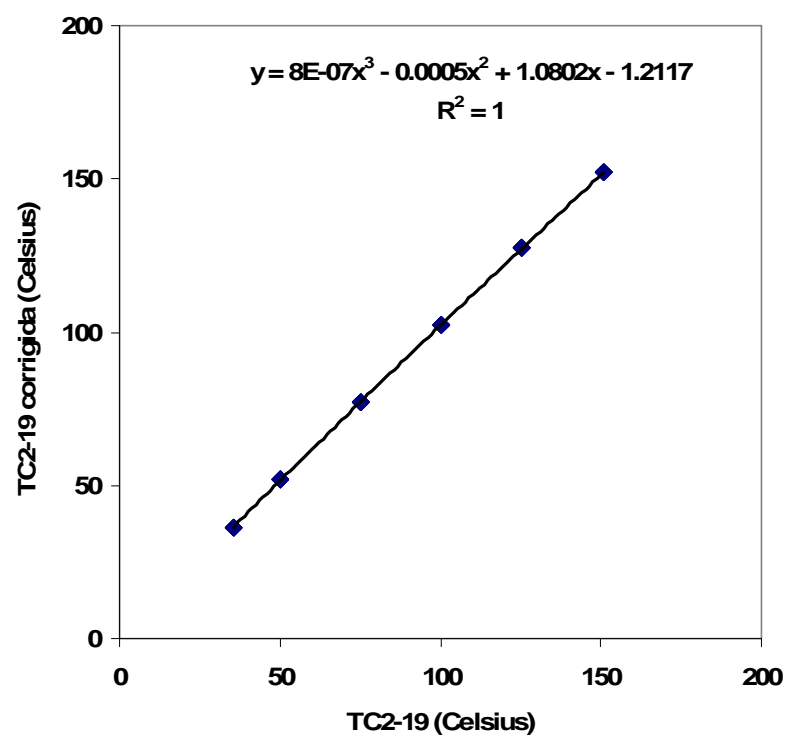

A38a

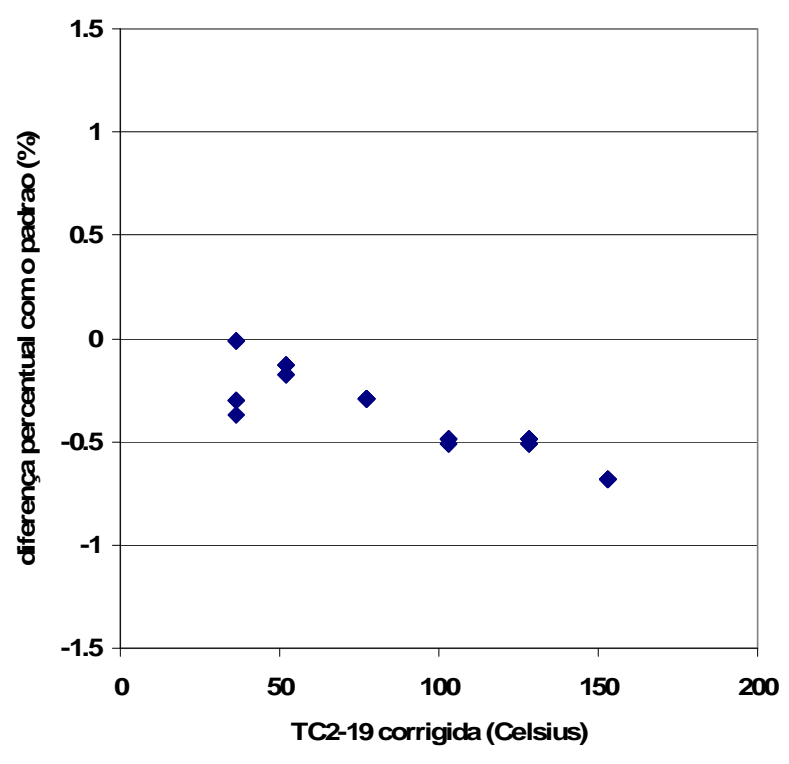

A38b

FIGURA A38. Curva de calibração TC2-19 (A38a) e diferença percentual com o padrão (A38b). 
TABELA A38. Dados de calibração do termopar TC2-20.

\begin{tabular}{cccc|cccc}
\hline $\begin{array}{c}\text { PT-001 } \\
\left({ }^{\circ} \mathrm{C}\right)\end{array}$ & $\begin{array}{c}\text { TC2-20 } \\
\left({ }^{\circ} \mathrm{C}\right)\end{array}$ & $\begin{array}{c}\text { TC2-20 } \\
\text { corrigida } \\
\left({ }^{\circ} \mathrm{C}\right)\end{array}$ & $\begin{array}{c}\text { diferença } \\
\text { percentual } \\
(\%)\end{array}$ & $\begin{array}{c}\text { PT-001 } \\
\left({ }^{\circ} \mathrm{C}\right)\end{array}$ & $\begin{array}{c}\text { TC2-20 } \\
\left({ }^{\circ} \mathrm{C}\right)\end{array}$ & $\begin{array}{c}\text { TC2-20 } \\
\text { corrigida } \\
\left({ }^{\circ} \mathrm{C}\right)\end{array}$ & $\begin{array}{c}\text { diferença } \\
\text { percentual } \\
(\%)\end{array}$ \\
\hline & & & & & & & \\
36,41 & 35,60 & 36,41 & 0,00 & 102,31 & 100,70 & 101,83 & 0,47 \\
36,41 & 35,60 & 36,41 & 0,00 & 102,31 & 100,60 & 101,73 & 0,56 \\
36,38 & 35,50 & 36,30 & 0,21 & 102,31 & 100,60 & 101,73 & 0,56 \\
36,38 & 35,50 & 36,30 & 0,21 & 102,31 & 100,60 & 101,73 & 0,56 \\
36,38 & 35,50 & 36,30 & 0,21 & 102,31 & 100,60 & 101,73 & 0,56 \\
51,74 & 50,30 & 51,56 & 0,34 & 127,41 & 126,00 & 126,26 & 0,91 \\
51,74 & 50,30 & 51,56 & 0,34 & 127,41 & 126,00 & 126,26 & 0,91 \\
51,74 & 50,30 & 51,56 & 0,34 & 127,41 & 126,00 & 126,26 & 0,91 \\
51,74 & 50,30 & 51,56 & 0,34 & 127,41 & 126,00 & 126,26 & 0,91 \\
51,71 & 50,30 & 51,56 & 0,29 & 127,41 & 126,00 & 126,26 & 0,91 \\
77,10 & 75,30 & 76,80 & 0,40 & 152,22 & 151,60 & 150,55 & 1,10 \\
77,10 & 75,30 & 76,80 & 0,40 & 152,22 & 151,60 & 150,55 & 1,10 \\
77,10 & 75,20 & 76,70 & 0,53 & 152,22 & 151,60 & 150,55 & 1,10 \\
77,10 & 75,20 & 76,70 & 0,53 & 152,22 & 151,60 & 150,55 & 1,10 \\
77,08 & 75,20 & 76,70 & 0,49 & 152,22 & 151,70 & 150,65 & 1,03 \\
\hline
\end{tabular}

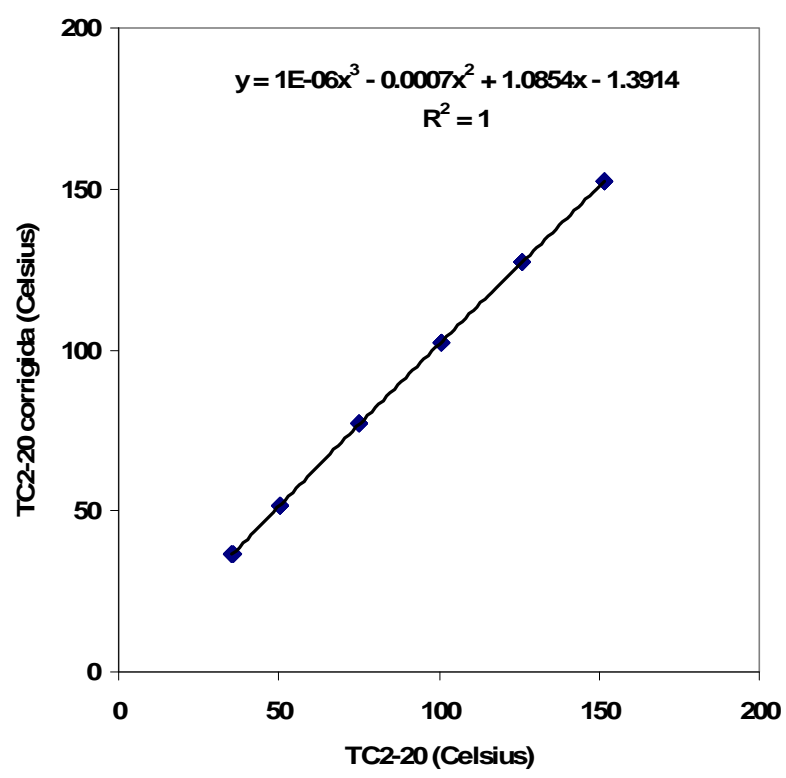

A39a

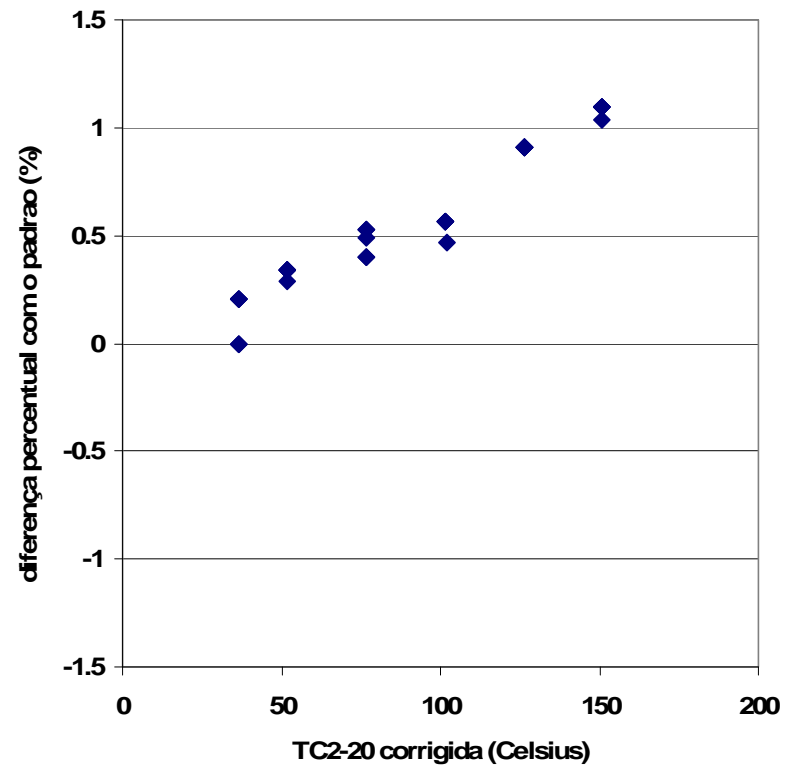

A39b

FIGURA A39. Curva de calibração TC2-20 (A39a) e diferença percentual com o padrão (A39b). 
TABELA A39. Dados de calibração do termopar TC2-21.

\begin{tabular}{cccc|cccc}
\hline $\begin{array}{c}\text { PT-001 } \\
\left({ }^{\circ} \mathrm{C}\right)\end{array}$ & $\begin{array}{c}\text { TC2-21 } \\
\left({ }^{\circ} \mathrm{C}\right)\end{array}$ & $\begin{array}{c}\text { TC2-21 } \\
\text { corrigida } \\
\left({ }^{\circ} \mathrm{C}\right)\end{array}$ & $\begin{array}{c}\text { diferença } \\
\text { percentual } \\
(\%)\end{array}$ & $\begin{array}{c}\text { PT-001 } \\
\left({ }^{\circ} \mathrm{C}\right)\end{array}$ & $\begin{array}{c}\text { TC2-21 } \\
\left({ }^{\circ} \mathrm{C}\right)\end{array}$ & $\begin{array}{c}\text { TC2-21 } \\
\text { corrigida } \\
\left({ }^{\circ} \mathrm{C}\right)\end{array}$ & $\begin{array}{c}\text { diferença } \\
\text { percentual } \\
(\%)\end{array}$ \\
\hline & & & & & & & \\
36,38 & 35,60 & 36,37 & 0,01 & 102,31 & 100,80 & 102,16 & 0,15 \\
36,35 & 35,60 & 36,37 & $-0,06$ & 102,31 & 100,80 & 102,16 & 0,15 \\
36,35 & 35,60 & 36,37 & $-0,06$ & 102,31 & 100,80 & 102,16 & 0,15 \\
36,35 & 35,60 & 36,37 & $-0,06$ & 102,31 & 100,80 & 102,16 & 0,15 \\
36,35 & 35,60 & 36,37 & $-0,06$ & 102,31 & 100,80 & 102,16 & 0,15 \\
51,71 & 50,40 & 51,60 & 0,22 & 127,39 & 126,30 & 127,10 & 0,23 \\
51,71 & 50,40 & 51,60 & 0,22 & 127,39 & 126,40 & 127,20 & 0,15 \\
51,71 & 50,40 & 51,60 & 0,22 & 127,39 & 126,40 & 127,20 & 0,15 \\
51,71 & 50,40 & 51,60 & 0,22 & 127,39 & 126,40 & 127,20 & 0,15 \\
51,71 & 50,40 & 51,60 & 0,22 & 127,39 & 126,40 & 127,20 & 0,15 \\
77,08 & 75,50 & 77,01 & 0,09 & 152,22 & 152,00 & 151,87 & 0,23 \\
77,08 & 75,50 & 77,01 & 0,09 & 152,22 & 152,10 & 151,97 & 0,16 \\
77,08 & 75,60 & 77,11 & $-0,04$ & 152,22 & 152,10 & 151,97 & 0,16 \\
77,08 & 75,60 & 77,11 & $-0,04$ & 152,22 & 152,10 & 151,97 & 0,16 \\
77,08 & 75,60 & 77,11 & $-0,04$ & 152,22 & 152,10 & 151,97 & 0,16 \\
\hline
\end{tabular}

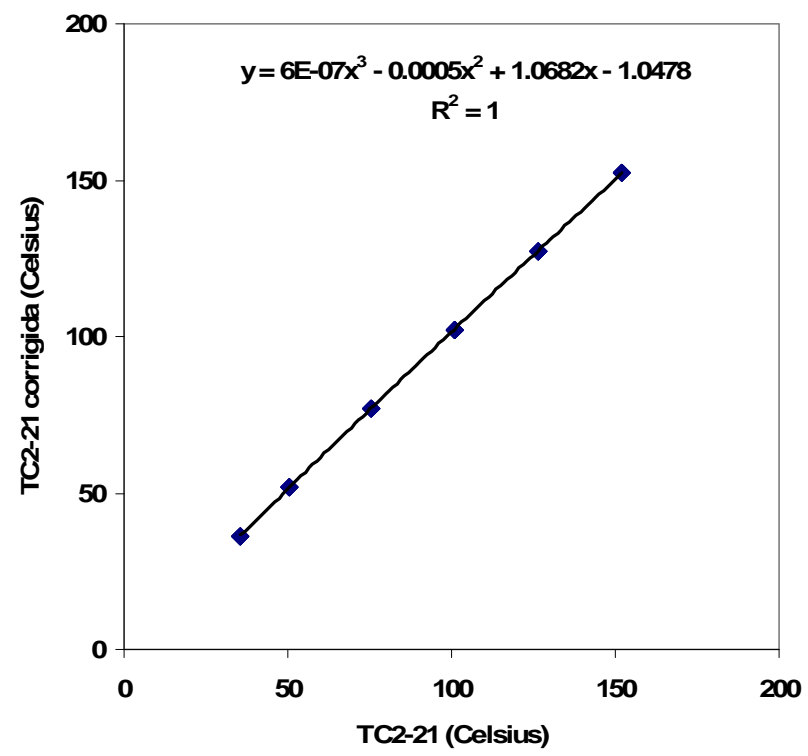

A40a

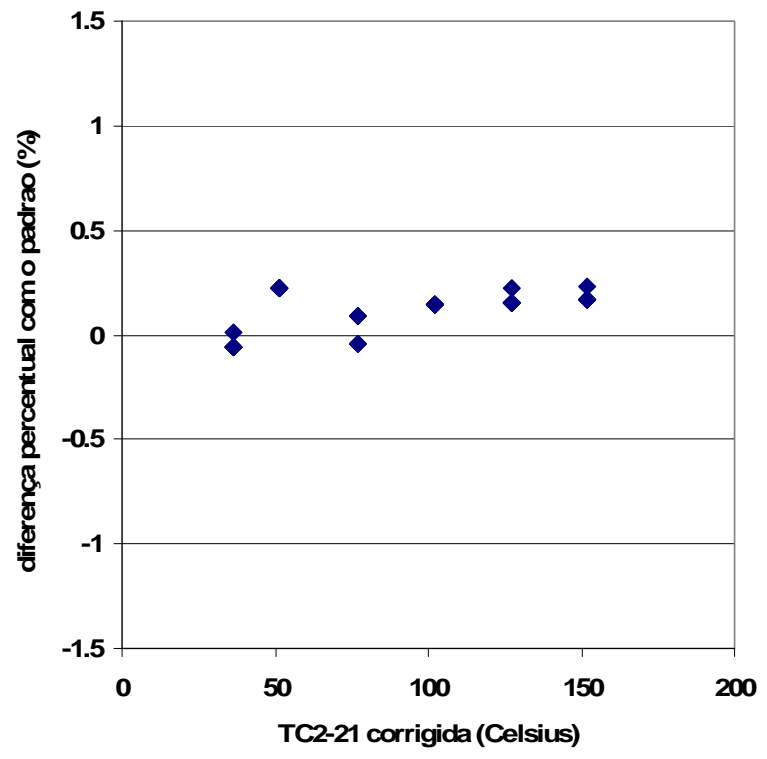

A40b

FIGURA A40. Curva de calibração TC2-21 (A40a) e diferença percentual com o padrão (A40b). 
TABELA A40. Dados de calibração do termopar TC2-22.

\begin{tabular}{cccc|cccc}
\hline $\begin{array}{c}\text { PT- 001 } \\
\left({ }^{\circ} \mathrm{C}\right)\end{array}$ & $\begin{array}{c}\text { TC2-22 } \\
\left({ }^{\circ} \mathrm{C}\right)\end{array}$ & $\begin{array}{c}\text { TC2-22 } \\
\text { corrigida } \\
\left({ }^{\circ} \mathrm{C}\right)\end{array}$ & $\begin{array}{c}\text { diferença } \\
\text { percentual } \\
(\%)\end{array}$ & $\begin{array}{c}\text { PT-001 } \\
\left({ }^{\circ} \mathrm{C}\right)\end{array}$ & $\begin{array}{c}\text { TC2-22 } \\
\left({ }^{\circ} \mathrm{C}\right)\end{array}$ & $\begin{array}{c}\text { TC2-22 } \\
\text { corrigida } \\
\left({ }^{\circ} \mathrm{C}\right)\end{array}$ & $\begin{array}{c}\text { diferença } \\
\text { percentual } \\
(\%)\end{array}$ \\
\hline & & & & & & & \\
36,35 & 35,60 & 36,30 & 0,14 & 102,31 & 100,70 & 101,97 & 0,33 \\
36,33 & 35,60 & 36,30 & 0,07 & 102,31 & 100,70 & 101,97 & 0,33 \\
36,35 & 35,60 & 36,30 & 0,14 & 102,31 & 100,70 & 101,97 & 0,33 \\
36,33 & 35,60 & 36,30 & 0,07 & 102,31 & 100,70 & 101,97 & 0,33 \\
36,33 & 35,60 & 36,30 & 0,07 & 102,31 & 100,80 & 102,07 & 0,24 \\
51,68 & 50,50 & 51,62 & 0,13 & 127,39 & 126,30 & 126,93 & 0,36 \\
51,68 & 50,50 & 51,62 & 0,13 & 127,39 & 126,30 & 126,93 & 0,36 \\
51,68 & 50,50 & 51,62 & 0,13 & 127,39 & 126,30 & 126,93 & 0,36 \\
51,68 & 50,50 & 51,62 & 0,13 & 127,39 & 126,30 & 126,93 & 0,36 \\
51,68 & 50,50 & 51,62 & 0,13 & 127,39 & 126,30 & 126,93 & 0,36 \\
77,08 & 75,50 & 76,93 & 0,19 & 152,22 & 152,00 & 151,51 & 0,47 \\
77,08 & 75,50 & 76,93 & 0,19 & 152,22 & 152,00 & 151,51 & 0,47 \\
77,08 & 75,50 & 76,93 & 0,19 & 152,22 & 152,00 & 151,51 & 0,47 \\
77,08 & 75,50 & 76,93 & 0,19 & 152,22 & 152,00 & 151,51 & 0,47 \\
77,08 & 75,50 & 76,93 & 0,19 & 152,22 & 152,00 & 151,51 & 0,47 \\
\hline
\end{tabular}

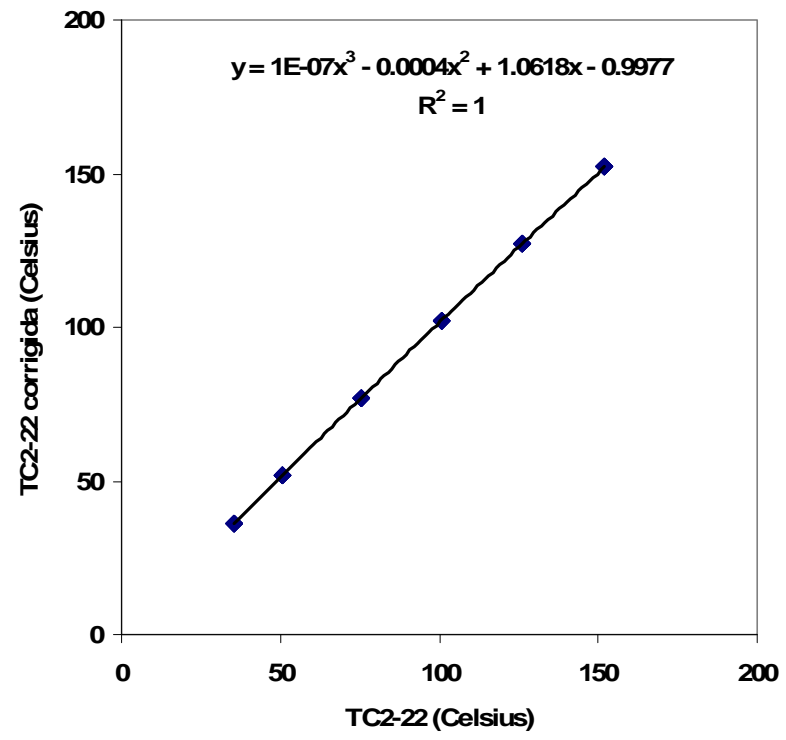

A41a

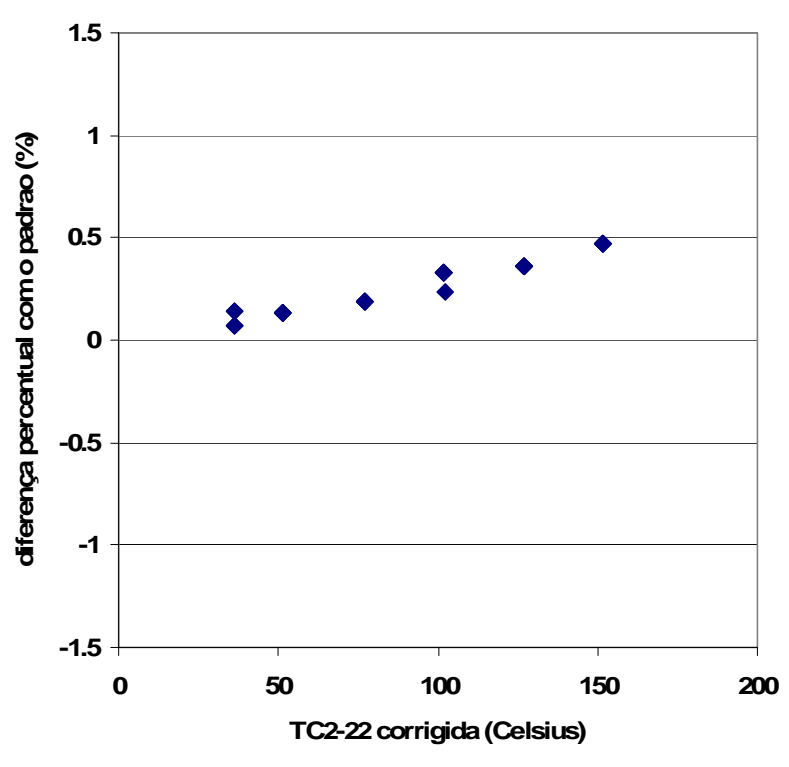

A41b

FIGURA A41. Curva de calibração TC2-22 (A41a) e diferença percentual com o padrão (A41b). 


\section{APÊNDICE B. Calibração dos Transmissores de Pressão Diferencial TPD1 e TPD2}

Os transmissores de pressão diferencial TPD1(marca Fisher modelo 1151 DP) instalado na seção de testes ST1 e TPD2 (marca SMAR modelo LD-301) instalado na seção de testes ST2 foram calibrados para fornecer diretamente a informação de nível colapsado nas respectivas seções de testes. Na calibração, a pressão foi aplicada à câmara de baixa pressão (BP), usando um timoneiro, ficando a câmara de alta pressão (AP) aberta para a atmosfera $\left(\mathrm{P}_{\mathrm{atm}}\right)$. Para uma pressão de $5000 \mathrm{mmH}_{2} \mathrm{O}$ aplicada na câmara de baixa pressão, o sinal de saída em corrente dos TDP's foi ajustado para fornecer $4 \mathrm{~mA}$, correspondente a um nível zero nas seções de testes. Quando existir uma pressão aplicada por uma coluna de água $\mathrm{H}_{2}$ na câmara de alta pressão, o sinal de saída dos TPD's estará relacionado unicamente com $\mathrm{H}_{2}$, o nível nas seções de testes, como mostrado nas FIG. B1 e B2. A faixa de calibração foi de $0-5000$ mmH2O $(0-48980$ $\mathrm{Pa}$ ). Nas calibrações destes instrumentos foram usados: um timoneiro, um calibrador microprocessado Cappo 10 da Ecil e um multímetro HP 34401A para medir o sinal de saída de 4-20 mA produzido pelos transmissores, como mostrado anteriormente na FIG. 3.13.

As curvas de calibração, pressão aplicada em BP versus sinal de saída em corrente dos transmissores TPD1 e TPD2, são mostradas nas FIG. B3 e B4, onde também são apresentados os dados de calibração e as equações obtidas após ajuste linear desses dados de calibração, tanto para unidade de pressão em $\mathrm{mmH}_{2} \mathrm{O}$, quanto para unidade de pressão em $\mathrm{Pa}$ (Pascal).

Os transmissores de pressão diferencial, da forma como estão instalados nas seções de testes ST1 e ST2 são capazes de medir somente o nível colapsado de água nas seções de testes. Eles são incapazes de medir a variação de nível por expansão térmica do fluido e ou também pela presença de vazios na mistura, como mostrado nas FIG. B5. 


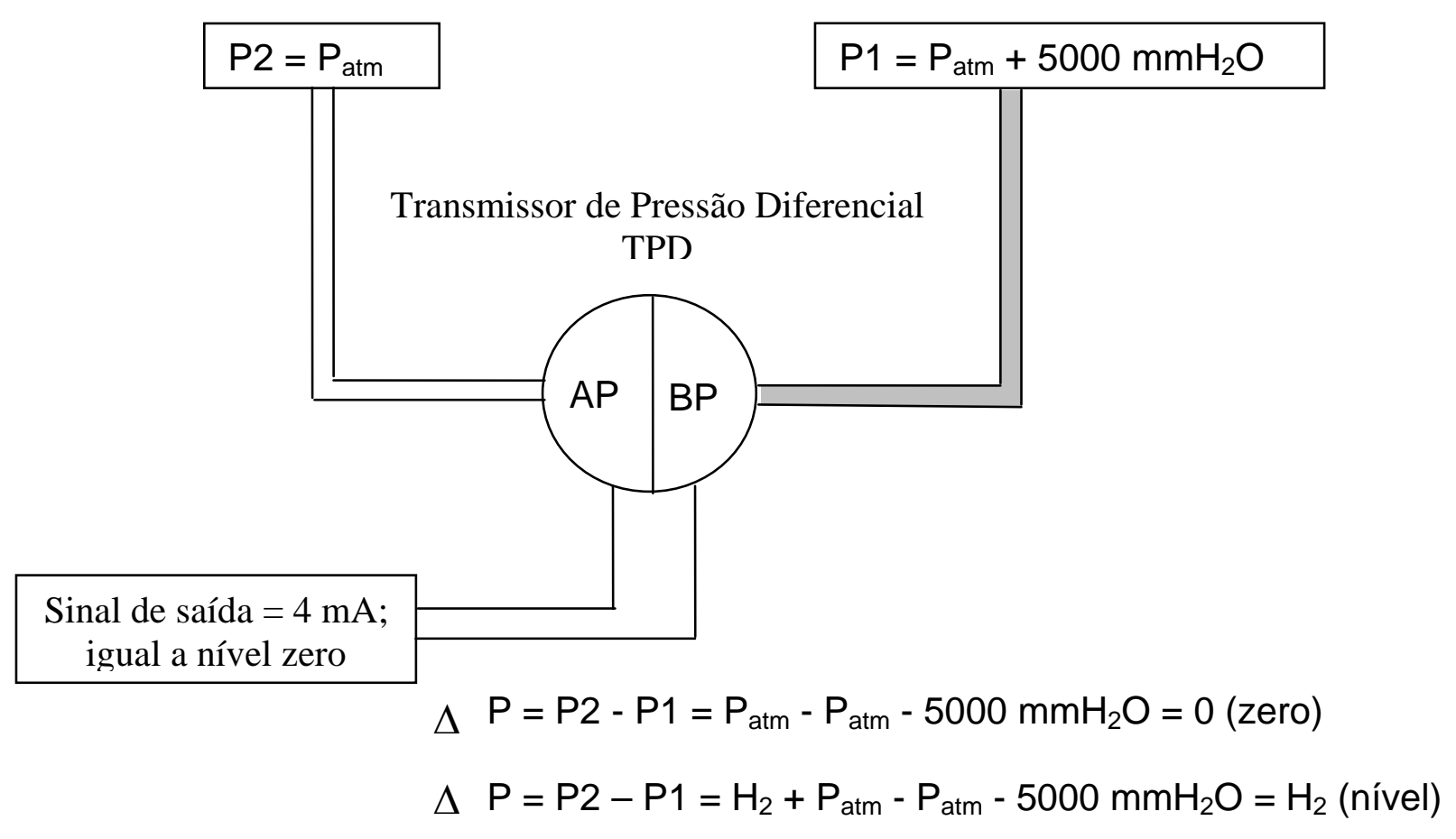

FIGURA B1. Desenho esquemático da calibração dos TPD’s.

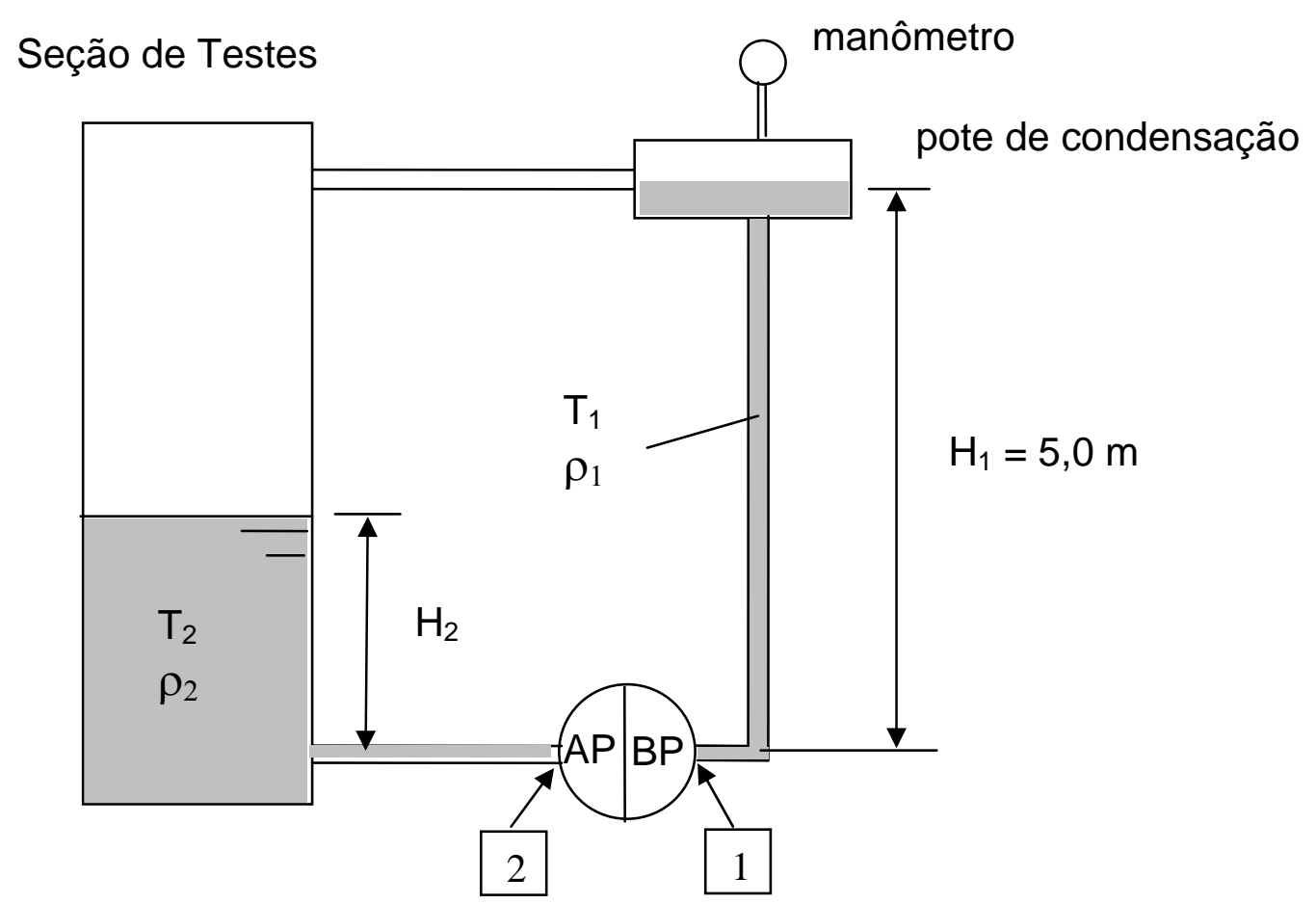

FIGURA B2. Desenho esquemático do TPD instalado na seção de testes. 


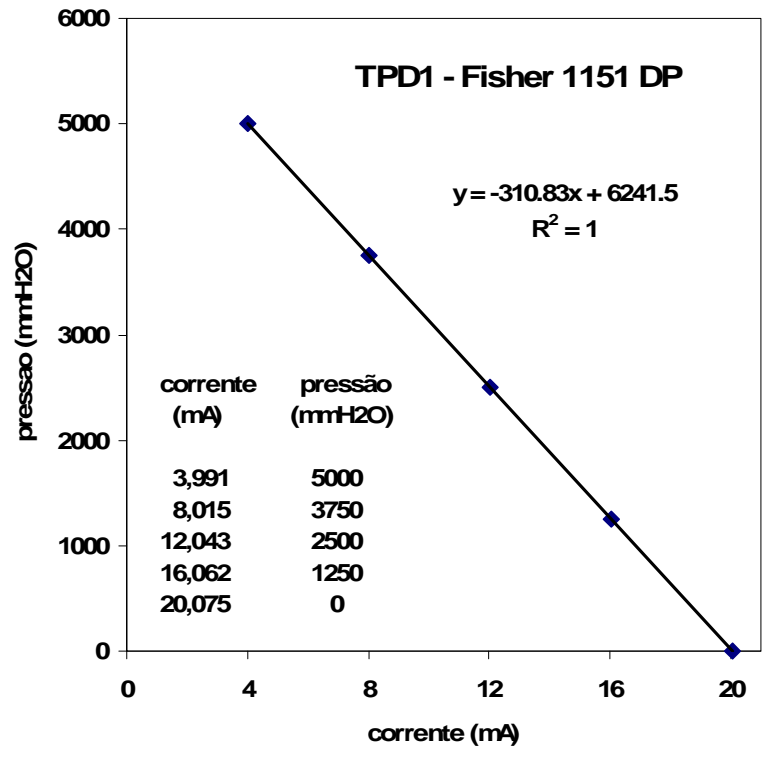

B2a

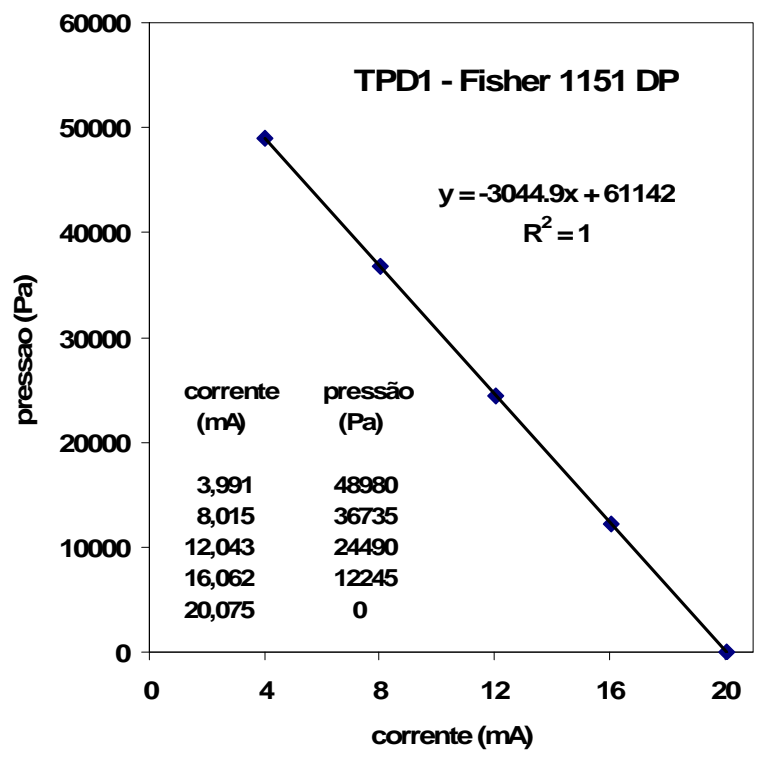

$\mathrm{B} 2 \mathrm{~b}$

FIGURA B3. Curva e dados de calibração do transmissor de pressão diferencial TPD-1 -

Fisher 1151 DP - (a) pressão (mmH2O); (b) pressão (Pa).

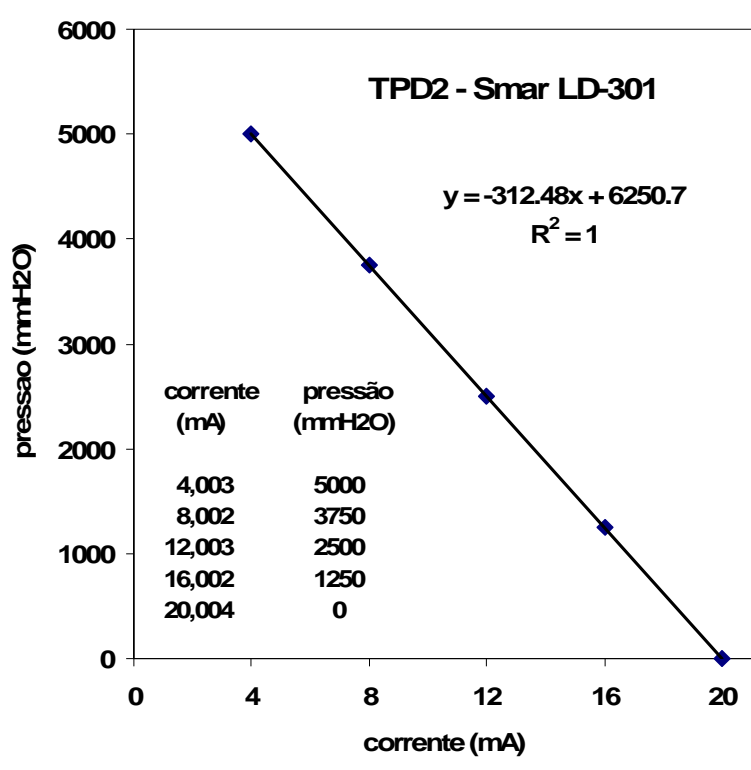

B3a

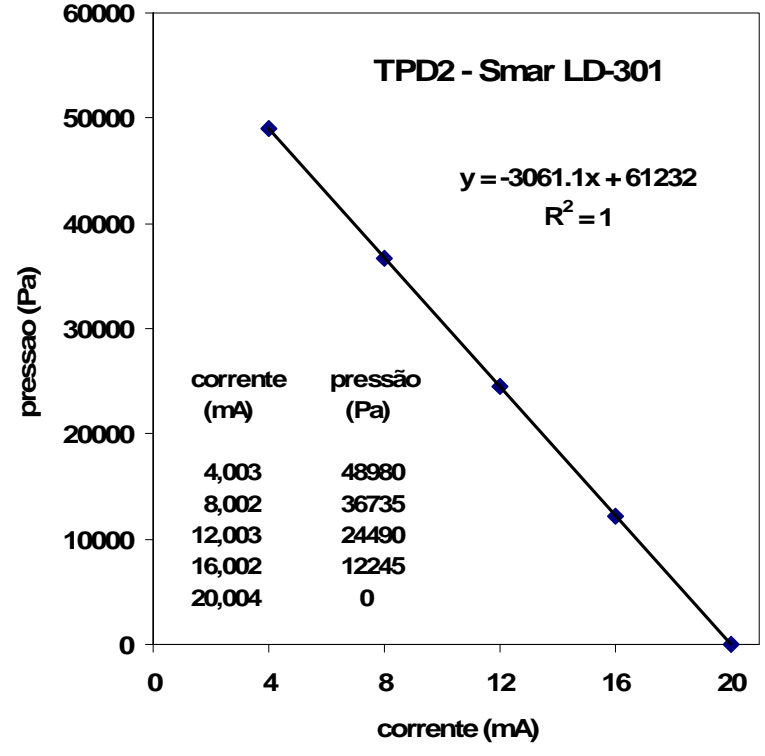

B3b

FIGURA B4. Curva e dados de calibração do transmissor de pressão diferencial TPD-2 Smar LD-301 - (a) pressão (mmH2O); (b) pressão (Pa). 
Considere, para fins de exemplificação, as condições no início do processo de aquecimento do fluido na seção de testes como: pressão atmosférica na região acima do fluido, temperatura inicial do fluido de $25^{\circ} \mathrm{C}$ e temperatura final do fluido de $80^{\circ} \mathrm{C}$. A pressão atmosférica medida no local dos experimentos é igual a 91,2 kPa (0,912 bar). Nessas condições, a densidade inicial do fluido é $\rho_{1 i}=\rho_{2 i}=997,01 \mathrm{~kg} / \mathrm{m}^{3}$. Considere também que o nível inicial na seção de teste é $\mathrm{H}_{2 i}=3,0 \mathrm{~m}$. A pressão na câmara de baixa pressão BP e na câmara de alta pressão AP podem ser calculadas pela EQ. B1 e B2.

$$
\begin{aligned}
& P_{1 i}=P_{a t m}+\rho_{1 i} \cdot g \cdot H_{1 i}=P_{a t m}+997,01 \cdot 9,81 \cdot 5=P_{a t m}+48903[P a] \\
& P_{2 i}=P_{a t m}+\rho_{2 i} \cdot g \cdot H_{2 i}=P_{a t m}+997,01 \cdot 9,81 \cdot 3=P_{a t m}+29342[P a]
\end{aligned}
$$

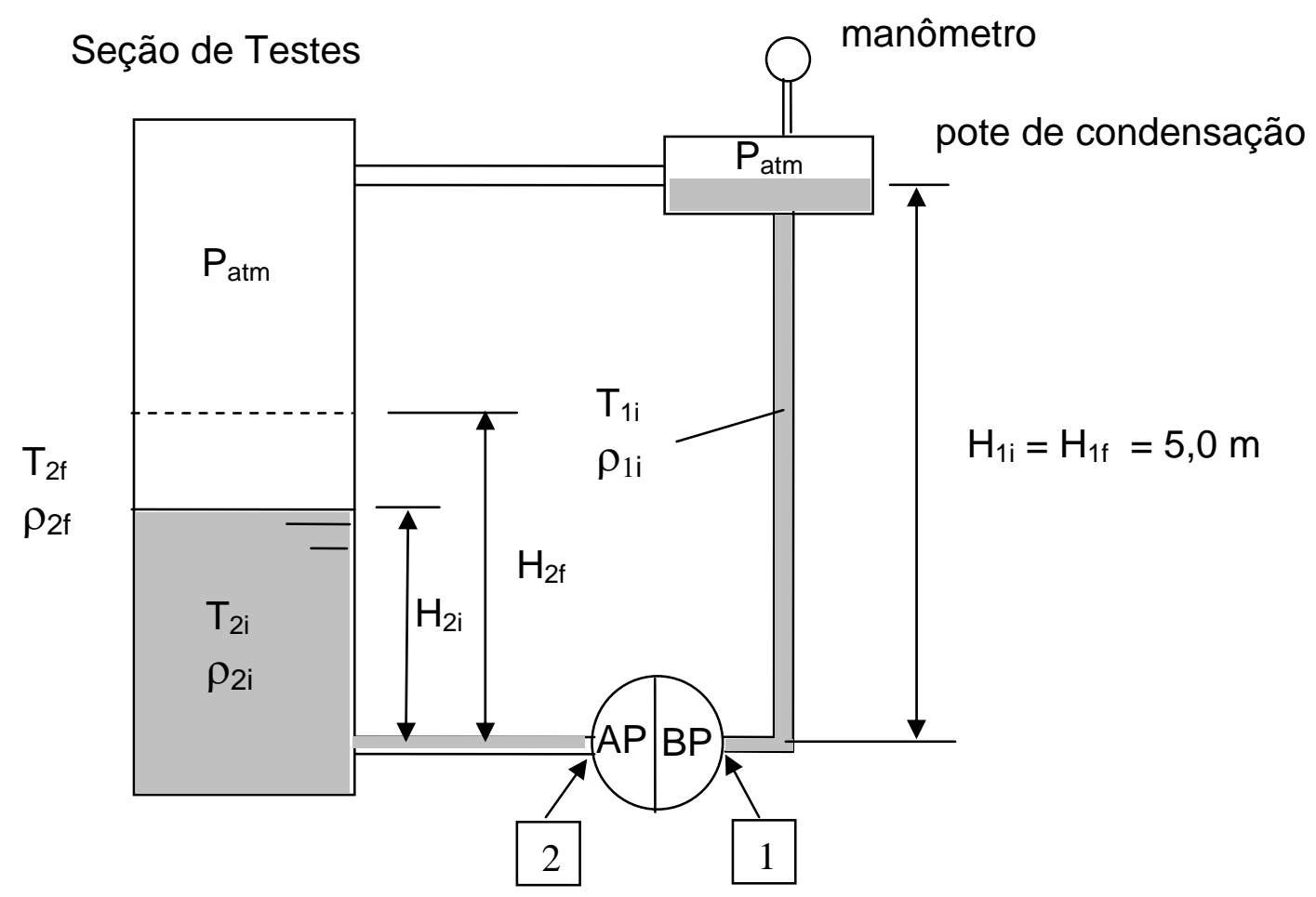

FIGURA B5. Desenho esquemático ilustrando a medida pelo TPD quando ocorre expansão térmica do fluido. 
A diferença de pressão estática $\Delta \mathrm{P}_{21 i}$ medida pelo TPD para essas condições iniciais pode ser calculada pela EQ. B3, considerando a condição especial de calibração mostrada na FIG. B1.

$$
\Delta P_{21 i}=P_{2 i}-P_{1 i}=P_{a t m}+29342-P_{a t m}-48903=29342[\mathrm{~Pa}]
$$

$\mathrm{Na}$ condição final considerada, ou seja, fluido na seção de testes a $80^{\circ} \mathrm{C}$, e ainda desprezando-se a expansão térmica do vaso da seção de testes e o aquecimento do fluido contido na linha de baixa pressão, temos $\rho_{1 \mathrm{f}}=997,01 \mathrm{~kg} / \mathrm{m}^{3}$ e $\rho_{2 \mathrm{f}}=977,71 \mathrm{~kg} / \mathrm{m}^{3}$. Os volumes, inicial $V_{2 i}$ e final $V_{2 f}$, ocupado pelo fluido na seção de testes podem ser calculados pelas EQ. B4 e B5, onde A é a seção reta do tubo da seção de testes. A variação de volume $\Delta \mathrm{V}_{2 \mathrm{f}}$ pode ser calculada por EQ. B6.

$$
\begin{aligned}
& V_{2 i}=A \cdot H_{2 i} \\
& V_{2 f}=A \cdot H_{2 f} \\
& \Delta V_{2 f i}=V_{2 f}-V_{2 i}=A \cdot H_{2 f}-A \cdot H_{2 i}=A \cdot\left(H_{2 f}-H_{2 i}\right)=A \cdot \Delta H_{2 f i}
\end{aligned}
$$

Considerando que a massa de fluido na seção de testes se mantém no processo de aquecimento, ou seja,

$$
\begin{aligned}
& m_{2}=m_{2 i}=m_{2 f} \\
& m_{2 i}=\rho_{2 i} \cdot v_{2 i}=A \cdot H_{2 i} \cdot \rho_{2 i} \\
& m_{2 f}=\rho_{2 f} \cdot v_{2 f}=A \cdot H_{2 f} \cdot \rho_{2 f}
\end{aligned}
$$

Rearranjando as EQ. B4 a B9, obtém-se a relação entre o nível final $\mathrm{H}_{2 f}$ e o nível inicial $\mathrm{H}_{2 i}$ na seção de testes, dada pela EQ. B10. 


$$
H_{2 f}=H_{2 i}+H_{2 i}\left(\left(\rho_{2 i} / \rho_{2 f}\right)-1\right)
$$

Substituindo os valores de $\mathrm{H}_{2 \mathrm{i}}, \rho_{2 \mathrm{i}}$ e $\rho_{2 \mathrm{f}}$ na EQ. B10, obtém-se

$$
H_{2 f}=3,0+3,0((997,01 / 977,71)-1)=3,0592 m
$$

A diferença de pressão estática $\Delta \mathrm{P}_{\mathrm{f} 21}$ medida pelo TPD na condição aquecida $\left(80^{\circ} \mathrm{C}\right)$ é dada pela $E Q . B 12$

$$
\Delta P_{f 21}=P_{2 f}-P_{1 f}=P_{a t m}+\rho_{2 f} \cdot g \cdot H_{2 f}-P_{a t m}-\rho_{1 f} \cdot g \cdot H_{1 f}
$$

Considerando que as condições de pressão impostas à câmara de baixa pressão BP não se alteraram e também as condições especiais de calibração do TPD, e substituindo os valores de $\rho_{2 f}$ e $H_{2 f}$ na EQ. B12, temos

$$
\begin{aligned}
& \Delta \mathrm{P}_{\mathrm{f} 21}=\mathrm{P}_{\mathrm{atm}}+977,71.9,81.3,0592-\mathrm{P}_{\mathrm{atm}}-997,01 \cdot 9,81.5,0 \\
& \Delta \mathrm{P}_{\mathrm{f} 21}=\mathrm{P}_{\mathrm{atm}}+29341,8-\mathrm{P}_{\mathrm{atm}}-48903=29341,8[\mathrm{~Pa}]
\end{aligned}
$$

Comparando-se o resultado apresentado na EQ. B3 com o resultado da EQ. B14, conclui-se que, a variação de nível decorrente do aumento da temperatura do fluido $\Delta \mathrm{H}_{2 f i}$ não é percebida pelo TPD, fato observado experimentalmente. A variação do volume, e portanto, do nível na seção de testes é compensada pela diminuição na densidade do fluido, de forma que o balanço de pressões no TPD resultam num mesmo valor, quer o fluido na seção de testes esteja na temperatura ambiente ou aquecido. Cálculos semelhantes, porém um pouco mais elaborados, podem ser realizados considerando a condição de saturação na seção de testes (liquido - vapor) e a conclusão será a mesma. 


\section{APÊNDICE C. Calibração dos rotâmetros R1 e R2}

Para medir a vazão de resfriamento das sondas de tubos concêntricos e de tubo $U$, foram instalados dois rotâmetros da marca KHRONE, um em cada sonda, com capacidade de medida de vazão na faixa de $0-250 \mathrm{l} / \mathrm{h}\left(0-0,25 \mathrm{~m}^{3} / \mathrm{h}\right)$. O rotâmetro $\mathrm{R} 1$ foi usado para medir a vazão de resfriamento na sonda de tubos concêntricos, instalada na seção de testes ST1, enquanto que o rotâmetro R2 foi usado para medir a vazão de resfriamento na sonda de tubo $U$, instalado na seção de testes ST2.

Esses rotâmetros foram calibrados pela técnica de calibração que usa cronômetro e volume conhecido. Foram usados: um balão de vidro graduado com capacidade de 2 litros e um cronômetro digital. As medidas para calibração foram realizadas a uma temperatura ambiente média de $23^{\circ} \mathrm{C}$, e os resultados são apresentados nas TAB. C1 e C2. Os gráficos construídos a partir destes resultados são apresentados nas FIG. C1 e C1, tanto para medidas em I/h quanto para medidas em $\mathrm{kg} / \mathrm{s}$. Observa-se que os rotâmetros apresentam bons resultados, com diferenças percentuais entre valores lidos e valores medidos, da ordem de $4 \%$. 
TABELA C1. Dados de calibração do rotâmetro 1 - R1.

\begin{tabular}{cccccc}
\hline $\begin{array}{c}\text { vazão lida } \\
(/ / \text { hora })\end{array}$ & $\begin{array}{c}\text { tempo por } 2 \\
\text { litros } \\
(\mathrm{s})\end{array}$ & $\begin{array}{c}\text { vazão medida } \\
(\mathrm{l} / \mathrm{hora})\end{array}$ & $\begin{array}{c}\text { Diferença } \\
(\%)\end{array}$ & $\begin{array}{c}\text { vazão medida } \\
(\mathrm{m} 3 / \mathrm{s})\end{array}$ & $\begin{array}{c}\text { vazão medida } \\
(\mathrm{kg} / \mathrm{s})\end{array}$ \\
\hline 50 & 141 & 51,06 & $+2,12$ & $1,42 \mathrm{E}-05$ & 0,0141 \\
50 & 148 & 48,65 & $-2,70$ & $1,35 \mathrm{E}-05$ & 0,0134 \\
60 & 124 & 58,06 & $-3,23$ & $1,61 \mathrm{E}-05$ & 0,0160 \\
60 & 125 & 57,60 & $-4,00$ & $1,61 \mathrm{E}-05$ & 0,0159 \\
120 & 62 & 116,13 & $-3,23$ & $3,23 \mathrm{E}-05$ & 0,0321 \\
120 & 63 & 114,29 & $-4,76$ & $3,17 \mathrm{E}-05$ & 0,0316 \\
180 & 41 & 175,61 & $-2,44$ & $4,88 \mathrm{E}-05$ & 0,0485 \\
180 & 41 & 175,61 & $-2,44$ & $4,88 \mathrm{E}-05$ & 0,0485 \\
250 & 30 & 240,00 & $-4,00$ & $6,67 \mathrm{E}-05$ & 0,0663 \\
\hline
\end{tabular}

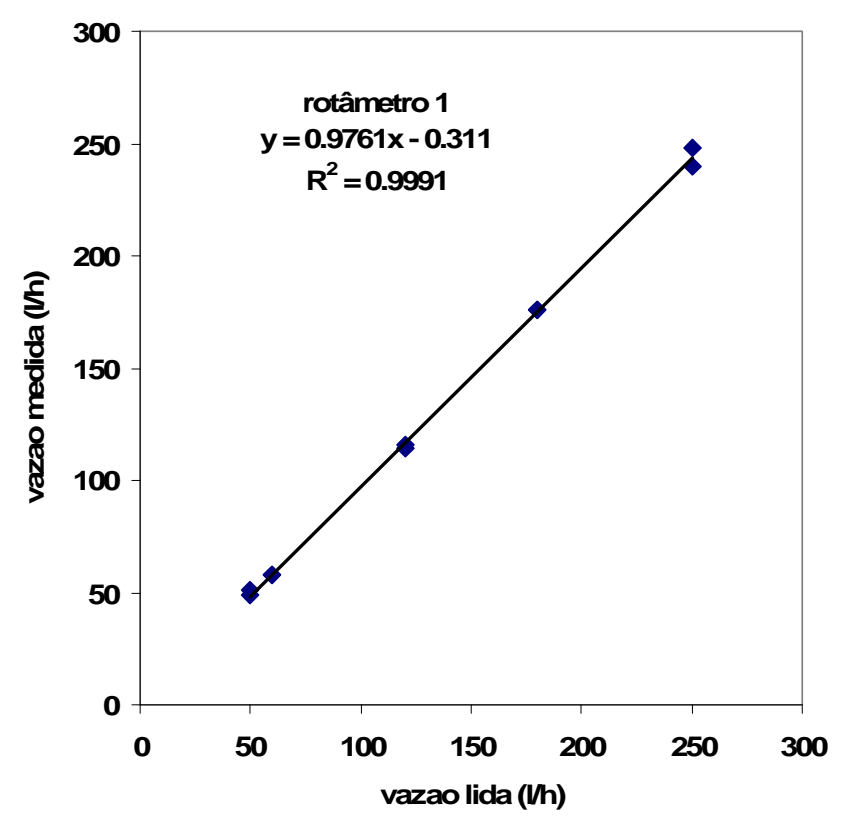

C1a

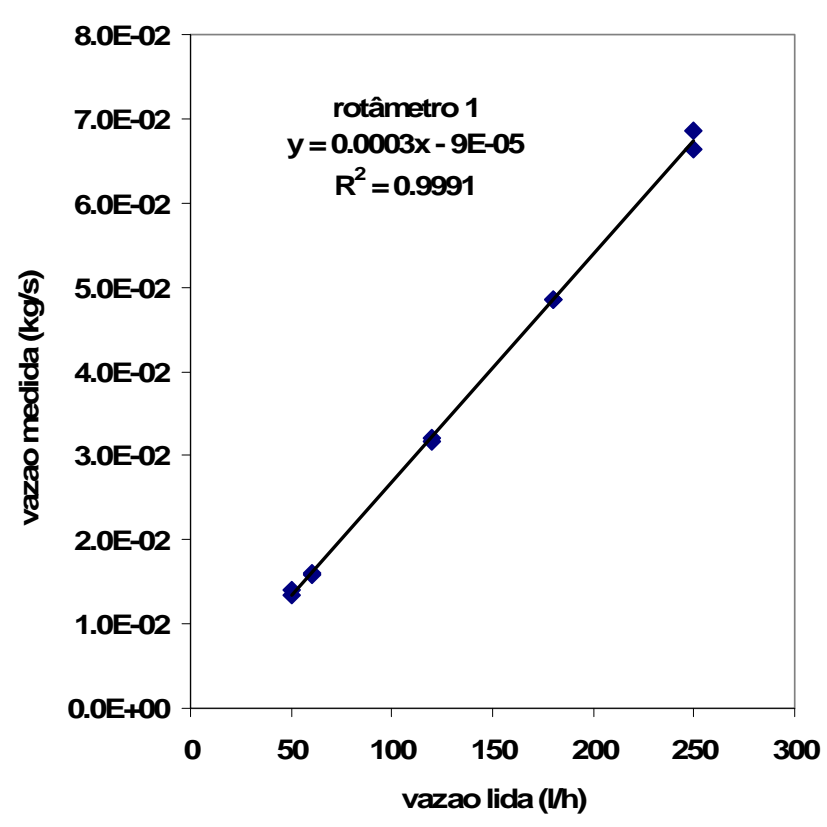

$\mathrm{C} 1 \mathrm{~b}$

FIGURA C1. Curvas de calibração do rotâmetro 1 - R1, C1a vazão em (I/h); e C1b vazão em (kg/s). 
TABELA C2. Dados de calibração do rotâmetro 2 - R2.

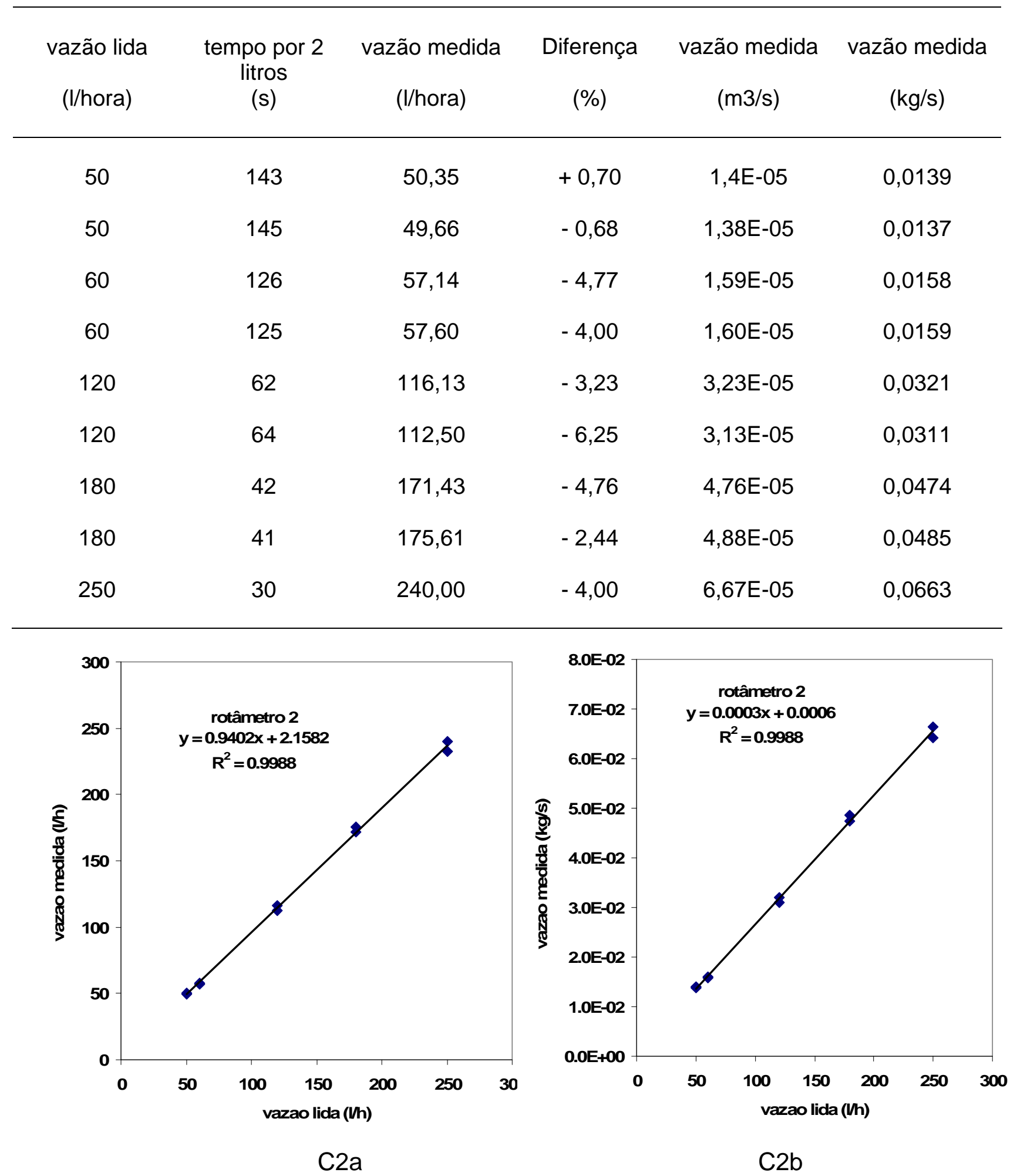

FIGURA C2. Curva de calibração do rotâmetro 2 - R2. C2a vazão em (l/h); e C2b vazão em (kg/s). 


\section{APÊNDICE D. Procedimento experimental para ligar o SAD e computador PC}

O APÊNDICE D apresenta o procedimento experimental a ser seguido para ligar o Sistema de Aquisição de Dados (SAD) e o computador (PC). Os passos abaixo enumerados devem ser realizados.

1. Ligar estabilizador de tensão que alimenta o SAD e o PC;

2. Ligar a fonte de tensão que alimenta os transmissores de pressão diferencial (TPD's) e ligar o Chassi do SAD;

3. Ligar o PC;

4. Acessar o programa de aquisição de dados BETSNI prog.vi, em LabVieW, através do ícone da National Instruments, na tela principal do PC;

5. Após aberto o programa BETSNI prog.vi, selecionar no diagrama frontal deste, as variáveis de temperatura que serão lidas e registradas, ou seja : TC1-01, TC1-02; TC1-03, TC1-04, TC1-05, TC1-06, TC1-07, TC1-08, TC1-11, TC1-12, TC1-13, TC1-14, TC1-15, TC1-16, TC1-17, TC1-18, TC119, TC1-20, TC1-21 e TC1-22; e TC2-01, TC2-02; TC2-03, TC2-04, TC2-05, TC2-06, TC2-07, TC2-08, TC2-11, TC2-12, TC2-13, TC2-14, TC215, TC2-16, TC2-17, TC2-18, TC2-19, TC2-20, TC2-21, TC2-22; TC2-23, TC2-24, TC2-25 e TC2-26;

6. Selecionar com o "browser" também as variáveis de pressão referentes aos transmissores de pressão diferencial TPD1 e TPD2;

7. Ajustar o tempo de atualização de gravação dos dados, exemplo 5, 10, 15 e 30s;

8. Escolher um nome para o arquivo de gravação dos dados e selecionar as opções SIM para "adicionar ao arquivo" e SIM para "gravar dados". Sugere-se que seja um nome relacionado com a data de realização do teste;

9. Rodar o programa, alimentando-o com as variáveis medidas externamente, tais como: tensão de alimentação das resistências, valores das resistências e vazão de água de resfriamento no secundário da sonda;

10. Após terminado o teste, parar o programa BETSNI prog.vi, desligar a fonte de alimentação dos TPD's, desligar o chassi do SAD e o PC. 


\section{APÊNDICE E. Procedimento Experimental para testes em estado estacionário com nível constante e com variação da vazão de água de resfriamento das sondas.}

O APÊNDICE E apresenta o procedimento experimental a ser seguido para realização de testes com nível constante na seção de testes, variando-se a vazão de resfriamento da sonda. Este procedimento é válido tanto para a seção de testes ST1 com a sonda de tubos concêntricos quanto para ST2 com a sonda de tubo $U$. No caso deste procedimento, utiliza-se apenas uma seção de testes isoladamente, ST1 ou ST2. Os passos abaixo enumerados devem ser realizados.

1. Executar o procedimento para ligar o SAD e o PC apresentado no APÊNDICE D. No programa BETSNI prog.vi ajustar para gravar os dados desde o início do experimento;

2. Remover o manômetro instalado no pote de condensação da seção de testes a ser testada. Colocar água no pote de condensação até o seu transbordamento, através da conexão onde é instalado o manômetro. Após esta operação, reinstalar o manômetro. Esta operação tem o objetivo de assegurar que a linha de baixa pressão do TPD esteja sempre cheia com água. $\mathrm{O}$ excedente de água colocado no pote de condensação irá escoar para o vaso da seção de testes, ficando o nível de água no pote na linha inferior do tubo que liga o pote de condensação ao vaso da seção de testes;

3. Abrir as válvulas de respiro das seções de testes, mantendo fechada a válvula de equalização de pressão que liga as duas seções de testes;

4. Ajustar o nível de água desejado na seção de testes. Caso o nível

preexistente seja maior que o desejado, então se deve abrir a 
válvula esfera localizada na parte inferior da ST1 e abrir também a válvula de esgotamento, fechando essas válvulas após o ajuste desejado. Caso o nível preexistente seja menor que o desejado, então devemos abrir a válvula esfera mencionada anteriormente e abrir também a válvula de água de alimentação das seções de testes, fechando-as após o ajuste de nível desejado. Durante este passo deve-se manter aberta a válvula de respiro para admissão ou descarga de ar;

5. Ligar as resistências do aquecedor de $9000 \mathrm{~W}$ (nominal) $(\mathrm{R} 1=$ 11,5 Ohms e R2 = 12,3 Ohms) que deve estar instalado na seção de testes em que se está realizando os testes;

6. Aguardar até que a temperatura da água atinja a condição de saturação, observando as temperaturas na tela do painel frontal do programa BETSNI prog.vi e também a saída de vapor pela linha de respiro da seção de testes. Esta operação serve para eliminar o ar (não condensável) da seção de testes, que dificulta o processo de condensação. Uma vez atingida a condição de saturação, fechar a válvula de respiro da seção de testes;

7. Ligar a vazão de água de resfriamento da sonda, ajustando o valor desejado;

8. Aguardar até que a nova condição de regime de estado estacionário seja atingida, observando o comportamento das temperaturas na tela do painel frontal do programa BETSNI prog.vi;

9. Ajustar outro valor de vazão de água de resfriamento;

10. Repetir o item 8; 
11. Repetir o item 9 até que todas as vazões de resfriamento desejadas sejam testadas;

12. Desligar as resistências e a vazão de água de resfriamento da sonda;

13. Retornar ao item 3, ajustando outro nível de água na seção de testes;

14. Repetir o procedimento até que todos os níveis desejados tenham sido testados.

Observação: Com intervalos de tempo aproximados de 10 minutos, medir a tensão de alimentação das resistências, corrigindo, caso necessário, seu valor no painel frontal do programa BETSNI prog.vi do SAD. 


\section{APÊNDICE F. Procedimento Experimental para testes de transiente de diminuição de nível em ST1 ou ST2}

O APÊNDICE F apresenta o procedimento experimental a ser seguido para realizar um teste de diminuição de nível de $3600 \mathrm{~mm}$ até 2400 mm nas seções de testes ST1 ou ST2. Os passos abaixo enumerados devem ser realizados.

1. Executar o procedimento para ligar o SAD e o PC apresentado no APÊNDICE D. No programa BETSNI prog.vi ajustar para gravar os dados desde o início do experimento;

2. Remover os manômetros instalados nos potes de condensação das seções de testes ST1 e ST2. Colocar água nos potes de condensação até o seu transbordamento, através das conexões onde são instalados os manômetros. Após esta operação, reinstalar os manômetros. Esta operação tem o objetivo de assegurar que a linha de baixa pressão dos TPD’s estejam sempre cheias com água. O excedente de água colocado nos potes de condensação irá escoar para o vaso da seção de testes, ficando o nível nos potes na linha inferior do tubo que liga cada pote aos vasos das seções de testes ST1 e ST2;

3. Abrir as válvulas de respiro das seções de testes ST1 e ST2, mantendo fechada a válvula de equalização de pressão que liga as duas seções de testes;

4. Para o caso de um transiente de diminuição de nível em ST2, se deve proceder da seguinte forma: Ajustar o nível da seção de testes ST1 em $1200 \mathrm{~mm}$. Caso o nível existente na ST1 seja maior que 1200 mm, então se deve abrir a válvula esfera localizada na parte inferior da ST1 e abrir também a válvula de esgotamento, fechando essas válvulas após o ajuste desejado. Caso o nível existente na ST1 seja inferior a 1200 mm, então 
devemos abrir a válvula esfera mencionada anteriormente e abrir também a válvula de água de alimentação das seções de testes, fechando-as após o ajuste de nível desejado;

5. Ajustar o nível da seção de testes ST2 em $3600 \mathrm{~mm}$. Caso o nível existente na ST2 seja maior que $3600 \mathrm{~mm}$, então se deve abrir a válvula agulha localizada na parte inferior da ST2 e abrir também a válvula de esgotamento, fechando essas válvulas após o ajuste desejado. Caso o nível existente na ST2 seja inferior a $3600 \mathrm{~mm}$, então devemos abrir a válvula esfera mencionada anteriormente e abrir também a válvula de água de alimentação das seções de testes, fechando-as após o ajuste de nível desejado;

6. Ligar as resistências R11=33,1 Ohms e R21=32,3 Ohms do aquecedor de $3000 \mathrm{~W}$ da seção de testes ST1; Ligar a resistência R12= 11,5 Ohms da seção de testes ST2;

7. Fechar a válvula de respiro da ST1 quando a água nela contida atingir a condição de saturação, percebida pela leitura das temperaturas na tela do painel frontal do programa do SAD e também pela observação de saída de vapor através da tubulação flexível (mangueira) acoplada à válvula de respiro da ST1;

8. Desligar as resistências R11=33,1 Ohms e R21=32,3 Ohms; e Ligar a resistência R22=12,3 Ohms, ficando agora R12 e R22 ligadas;

9. Fechar a válvula de respiro da ST2 quando a água nela contida atingir a condição de saturação, percebida pela leitura das temperaturas no programa do SAD e também pela observação de saída de vapor através da tubulação flexível (mangueira) acoplada à válvula de respiro da ST2;

Observação 1: Com intervalos de tempo aproximados de 10 minutos, medir a tensão de alimentação das resistências, corrigindo, caso necessário, seu valor no programa do SAD. 
Observação 2: Os procedimentos de 6,7 e 8 são necessários para assegurar que as misturas existentes dentro das seções de testes estejam isentas de ar (não condensável) que dificulta o processo de condensação do vapor.

10. Ligar a vazão de água de resfriamento da sonda de tubo $U$ instalada na ST2 com $100 \mathrm{l} / \mathrm{h}(0,028 \mathrm{~kg} / \mathrm{s})$ e aguardar até que uma nova condição de estado estacionário seja atingida. Isso pode ser verificado através do SAD, na tela de temperaturas;

11. Abrir a válvula de equalização de pressão entre ST1 e ST2 com apenas $1 / 4$ de volta. Esta operação serve para equalização das pressões nas regiões superiores das seções de testes. Testes realizados com aberturas maiores que $1 / 4$ na válvula de equalização mostraram que ocorre a passagem de fluido entre as seções de testes;

12. Iniciar o transiente abrindo totalmente a válvula esfera da parte inferior da ST1 e em seguida abrir a válvula agulha da parte inferior da ST2 com a quantidade de voltas desejada;

13. Aguardar a obtenção de nova condição de estado estacionário com os níveis entre ST1 e ST2 praticamente igualados em $2400 \mathrm{~mm}$, por efeito de vasos comunicantes;

14. Fim do transiente. Parar o programa de aquisição de dados; Desligar a vazão de água de resfriamento e também as resistências R12 e R22;

15. Retornar ao item 2 para a realização de novo experimento quando o SAD e PC já estiverem ligados ou retornar ao item 1 quando o SAD e PC estiverem desligados; e 
16. Para o caso de transientes de diminuição de nível na seção de testes ST1 se deve realizar o ajuste inicial de níveis nas seções de testes de forma inversa, ou seja, nível inicial em ST1=3600 mm e em ST2=1200 mm. A inversão dos aquecedores entre as seções de testes também deve ser feita, ficando o aquecedor de $9000 \mathrm{~W}$ em ST1 e o aquecedor de $3000 \mathrm{~W}$ em ST2. 


\section{REFERÊNCIAS BIBLIOGRÁFICAS}

AMERICAN NUCLEAR SOCIETY. The need for near-term deployment of new nuclear Power plants. Position Statements. Junho 2005. Disponível em: http://www.ans.org/pi/ps/docs/ps56.pdf. Acesso em 17 de janeiro de 2008.

ARA, K., TERMAAT, K. P., JOHNSON, T., KATAGIRI, M., MOSTERT, P., KNUDSEN, K. Design and experience with the Bicoth-type reactor water level gauge for the Dodewaard Power Plant. IEEE Transactions on Nuclear Science, v. 36, no.1, p. 12511255, fevereiro 1989.

ARA, K., TERMAAT, K. P., JOHNSON, T., WAKAYAMA, N., MOSTERT, P., KNUDSEN, K. Development of an in-vessel water level gauge for the Dodewaard nuclear power plant. In Core Instrumentation and Reactor Assessment Proceedings of a Specialists' Meeting. Cadarache, France, junho 1988.

ARA, K., WAKAYAMA, N. KOBAYASHI, K. Development of an in-vessel water level gauge for light water power reactors. NUREG/CP-0027 vol. 30, p. 1667-1680, 1982.

ARAVE, A. E. An ultrasonic liquid level detector using shear wave attenuation in bar. USAEC Report IN-1442, novembro 1970.

ARAVE, A. E. US Patent no.3744301, junho1973.

ARAVE, A. E. Ultrasonic densitometer development. Ultrasonics Symposium Proceedings, p. 370-375, 1979.

BAPTISTA FILHO, B. D. Programa Retro_05 - Perceptron de Multicamadas com Retropropagação. Programa desenvolvido para o curso de graduação de Redes Neurais Artificiais na Engenharia Nuclear oferecido pelo IPEN aos alunos da USP, 2005.

BAPTISTA FILHO, B. D. Apostilas do curso de Redes Neurais Artificiais na Engenharia Nuclear oferecido pelo IPEN aos alunos da USP, 2005.

BRAGA, A.P., LUDEMIR, T.B., CARVALHO, A. Redes Neurais Artificiais - Teoria e Aplicações. Livros Técnicos e Científicos. São Paulo, 2000.

DANTAS, V. Energia para os próximos 20 anos. Brasil Nuclear, no. 31, p. 22, 2007.

ENERGY INFORMATION ADMINISTRATION (EIA).- OFFICIAL ENERGY STATISTICS FROM U.S. GOVERNMENT. New reactors designs. Disponível em:

http://www.eia.doe.gov/cneaf/nuclear/page/analysis/nucenviss 2.html. Acesso em 18 de dezembro de 2007.

GAUTHIER, J. C. O renascimento da opção nuclear. Brasil Nuclear, no. 25, p. 38, 2002. 
GENERATION IV TECHNOLOGY ROADMAP. A technology roadmap for the Generation IV Nuclear Energy Systems. Disponível em: http://gif.inel.gov/roadmap/. Acesso em 17de janeiro de 2008.

HABIBIYAN, H., SETAYESHI, S., ARAB-ALIBEIK, H. A fuzzy-gain-scheduled neural controller for nuclear steam generators. Annals of Nuclear Energy, 31,p. 1765-1781, 2004

HAMPEL, R., TRAICHEL, A., FLEISCHER, S., KASTNER, R. Water level in boiling water reactors - measurements, modeling, diagnostic. Progress in Nuclear Energy, vol. 43, no. 1-4, p. 121-128, 2003.

HAYKIN, S. Neural Networks - A Comprehensive Foundation. Prentice Hall, 1999.

HEBB, D. O. The organization of behavior: a neuropsychological theory. New York, Wiley, 1949.

IBAMA - INSTITUTO BRASILEIRO DO MEIO AMBIENTE E DOS RECURSOS NATURAIS RENOVÁVEIS. LICENÇA PRÉVIA NO. 279/2008, julho de 2008.

International Project on Innovative Nuclear Reactors and Fuel Cycles (INPRO). Guidance for the evaluation of innovative nuclear reactors and fuel cycles. Report of Phase 1A of the, IEA-TECDOC-1362, 2003.

JIRSA, P. Algorithm for monitoring the height of flooding of the core. Annals of Nuclear Energy, vol. 24, no. 6, p. 505-508, 1997.

KIM, C. H., LEE, D. W., NO, H. C. Assessment of an ultrasonic sensor and a capacitance probe for measurement of two-phase mixture level. Journal of Nuclear Science and Technlogy, vol. 41, no. 12, p. 1187-1191, dezembro 2004.

KLEIN, S. A., ALVARADO, F. L. Engineering Equation Solver (EES), Professional Version - 6.352, Outubro 2001.

KODELI, I., BIGNAN, G. Water level monitoring after shutdown using neutron and gamma flux measurements in PWR. Annals of Nuclear Energy, vol. 24, no. 7, p. 563570, 1997.

KOHONEN, T. Self-Organization and Associative Memory. Springer-Verlag, Berlim, 1989.

KOVÁCS, Z. L. Redes Neurais Artificiais - Fundamentos e Aplicações. Edição Acadêmica São Paulo, 1996.

LEWIS, H. W. Water level indication. Nuclear Engineering and Design, 101, p. 193195, 1987. 
LYNNWORTH, L. C. Liquid level measurements using longitudinal, shear, extensional and torsional waves. Ultrasonic Symposium Proceedings, p. 376-379, 1979.

MAISSEU, A., O futuro é nuclear. Brasil Nuclear, no. 23, p. 4, 2001.

MANDL, R. M., UMMINGER, K. Water inventory determination using differential pressure cells. Nuclear Engineering and Design, 110, p. 55-59, 1988.

McCULLOCH, W. S., PITTS, W. A logical calculus of the ideas immanent in nervous activity. Bulletin of Mathematical Biophysics, v. 5, p. 115-133, 1943.

MELNIKOV, V. I., KHOKHLOV, V. N. Waveguide ultrasonic liquid level transducer for nuclear power plant steam generation. Nuclear Engineering and Design 176, p. 225 - 232, USA, 1997.

MELNIKOV, V. I., NIGMATULIN, B. I. The news two-phase flow control devices in LWR equipment based on ultrasonic and WAT - technology. Nuclear Engineering and Design 149, p. 349 - 355, 1994.

MILLER, G. N., ANDERSON, R. L., ROGERS, S. C., LYNNWORTH, L. C, STUDLEY, W. B., WADE, W. R. High temperature, high pressure water level sensor. Ultrasonics Symposium Proceedings, p. 877-881, 1980.

NA, M. G., NO, H. C. Design of an adaptive observer-based controller for the water level of steam generators. Nuclear Engineering and Design, 135, p. 379-394, 1992.

NATIONAL INSTRUMENTS. LabVIEW 7 Express - User Manual. USA, Abril 2003. http://www.ni.com/.

NATIONAL INSTRUMENTS. The Measurement and Automation - Catalog 2001, USA. http://www.ni.com/.

NEUSCHAEFER, C. H. A reactor vessel level monitoring system, an aid to the operators in assessing an approach to inadequate core cooling. IEEE Transactions on Nuclear Science, vol. NS-29, no. 1, fevereiro 1982.

NUCLEAR ENERGY RESEARCH ADVISORY COMMITTEE AND THE GENERATION IV INTERNATIONAL FORUM. A TECHNOLOGY FOR GENERATION IV NUCLEAR ENERGY SYSTEMS, Issued by the DOE, 2002.

OMEGA ENGINEERING INC. Temperature measurement handbook and encyclopedia. 1987.

PINHEIRO, O. Energia nuclear já é a segunda fonte de geração elétrica. Brasil Nuclear, no. 31, p. 4, 2007. 
ROSENBLATT, F. The Perceptron: A Probabilistic Model for Information Storage and Organization in the Brain, Cornell Aeronautical Laboratory, Psychological Review, v. 65 , no. 6, p. $386-408$.

SCHMIDT, H., REIMANN, H., KIEHNE, H. A new method of level measurement for the reactor pressure vessels of pressurized water reactors. VGB KRAFTWERKSTECHNIK 65, no. 7 , julho 1985.

TEIXEIRA, G. O novo ciclo da energia nuclear. Brasil Nuclear, no. 23, p. 10, 2001.

TERMAAT, K., KOPS, J., ARA, K., KATAGIRI, M., KOBAYASHI, K. Fabrication tests of Tricoth-type reactor water level sensor. IEEE Transactions on Nuclear Science, v. 37, no.2, p. 1024-1031, Abril 1990.

TORK, R. C., DERBIDGE, T. C., HEALZER, J. M. Water level measurement uncertainty during BWR instability. Nuclear Engineering and Design, 151, p. 173-184, 1994.

TSOUKALAS, L. H., UHRIG, R. E. Fuzzy and Neural Approaches in Engineering. Wiley-Interscience, 1997.

U.S. CLIMATE CHANGE TECHNOLOGY PROGRAM - Technology options for the near and long term, agosto de 2005, p.2.4-3 e 2.4-4. Disponível em: http://www.climatetechnology.gov/library/2005/tech-options/tor2005-242.pdf. Acesso em 17 de janeiro de 2008.

UNITED STATES NUCLEAR REGULATORY COMMISSION. Three Mile Island Accident , Fact Sheet, 2004, Disponível em: http://www.nrc.gov/reading-rm/doccollections/fact-sheets/. Acesso em 18 dezembro de 2007.

UNIVERSIDADE POLITÉCNICA DE MILÃO. Projeto IRIS.

http://www.hulk.cesnef.polimi.it, Itália, Abril, 2003. Acesso em 18 de novembro de 2006.

URANIUM INFORMATION CENTER. Generation IV Nuclear Reactors, 2007.Disponível em: http://www.uic.com.au/nip77.html. Acesso em 23 de agosto de 2007.

WENRAN, W., YUEYUAN, J., LIN, L., YALI, W. A novel encoding water level monitor system during and after LOCAs in a nuclear heating reactor. Nuclear Engineering and Design 179, p. 275 - 280, 1998.

WIDROW, B., HOFF, M. E. Adaptive switching circuits. Institute of Radio Engineers, Western Electronic Show and Convention, 1960.

WILLNER, S., EISENTRAUDT, M. Method and device for determining a liquid level with the aid of ultrasonic pulses. Experimental Thermal and Fluid Science 25 / Patents ALERT, p. 194, 2001. 
WORLD NUCLEAR ASSOCIATION. Generation IV Nuclear Reactors. UIC Briefing Paper \# 77, setembro 2007. Disponível em: http://www.world-nuclear.org/info/inf77.html. Acesso em 18 de dezembro de 2007.

WORLD NUCLEAR ASSOCIATION. World Nuclear Power Reactors 2007-08 and Uranium Requirementes. junho 2008. Disponível em: http://www.worldnuclear.org/info/reactors.html. Acesso em 8 de agosto de 2008.

TORRES, W.M., BAPTISTA FILHO, B. D., Technique for Water Level Measurement in Pressure Vessels using Thermal Probes and Artificial Neural Networks, Artigo submetido em 07/10/2008 para aprovação e posterior publicação na Revista Annals of Nuclear Energy da Editora Elsevier. 